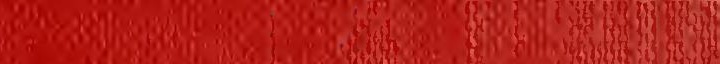

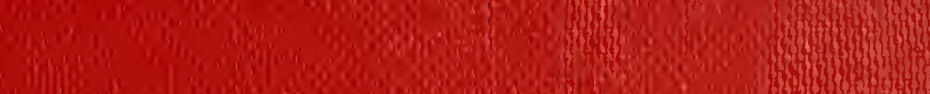

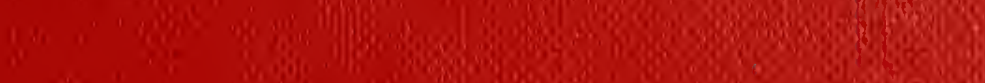

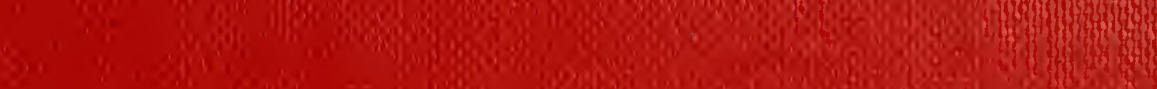

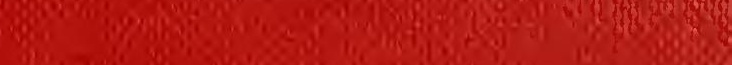

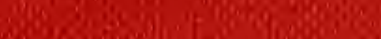

No6.

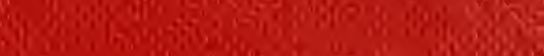

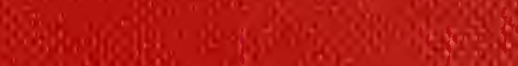

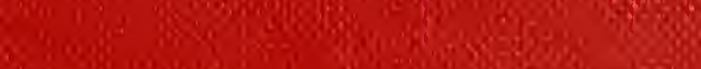

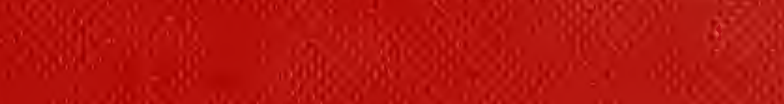

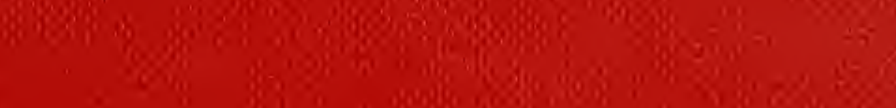
23.
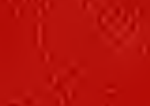

N.W. Wh

60.68

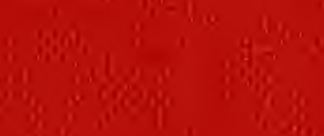

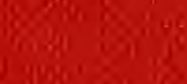

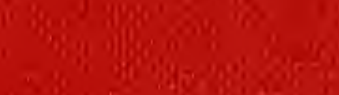

Q6.2.

$3, x^{2}$

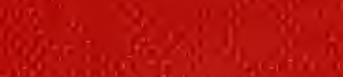

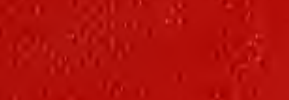

80909829

1.

a. The S.

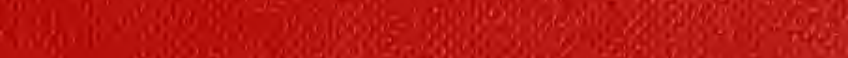

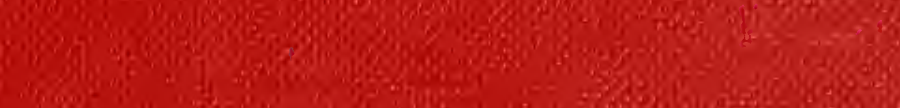

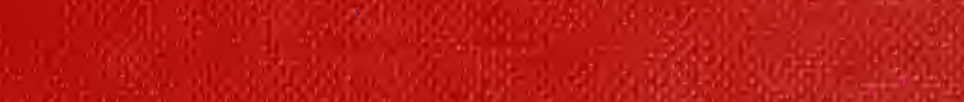
S.

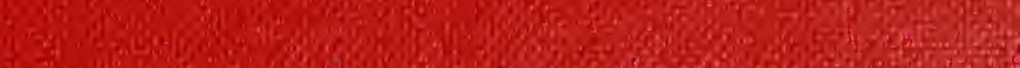
'Th,

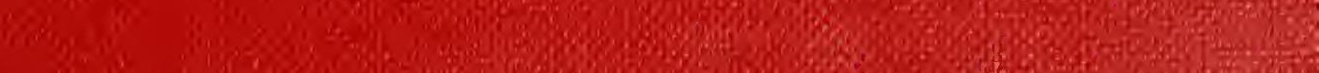

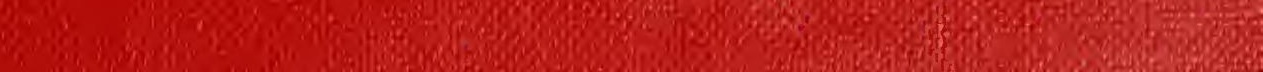

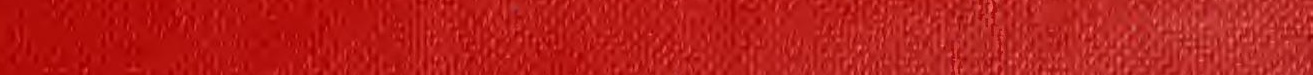
an

20 6.

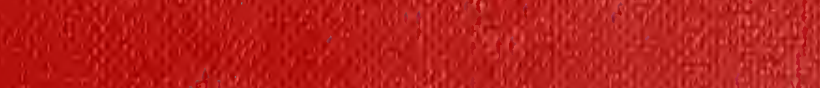


$=4(a)^{2}$

sufugirlses

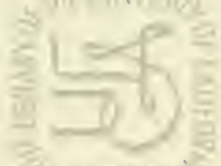

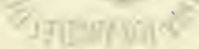

sul "wiyos

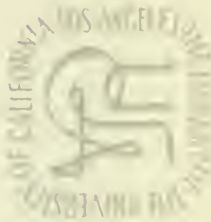

singariary

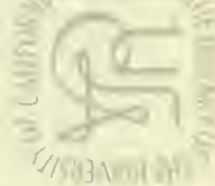

WEI WAYYos

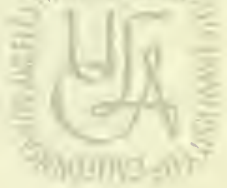

4of couraply

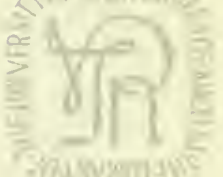

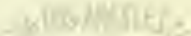

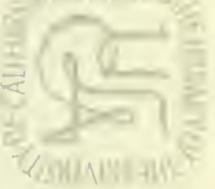

surfandizis,
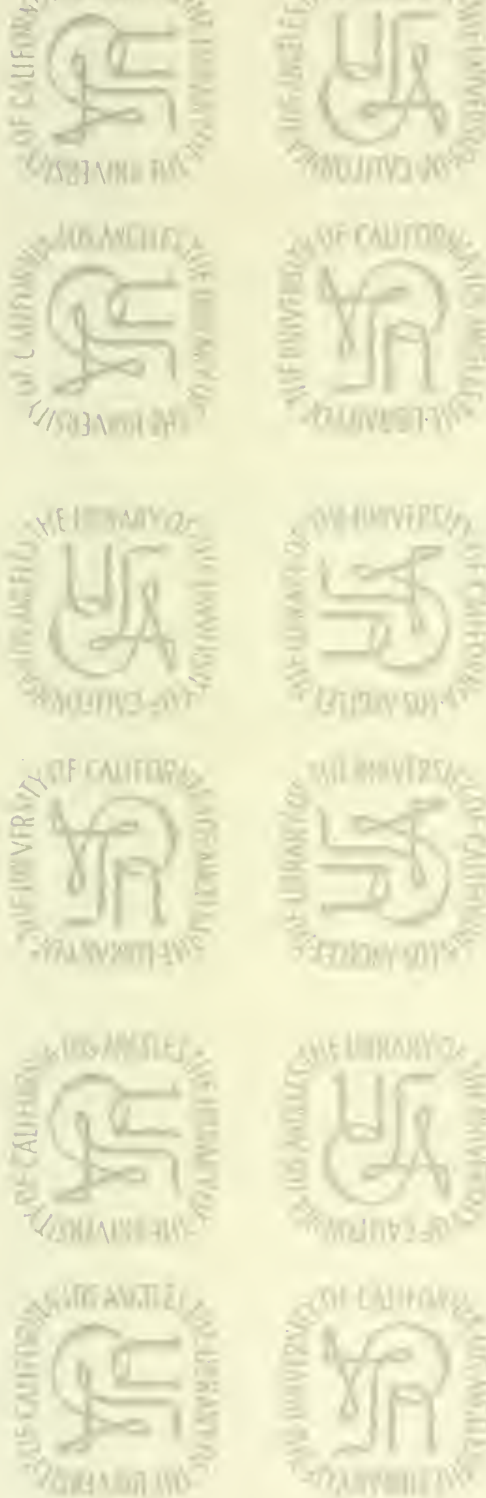

sure chumong.

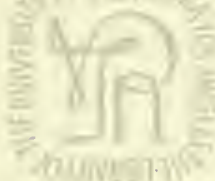

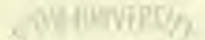

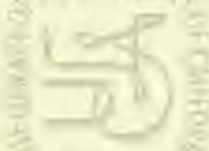

Primingy.
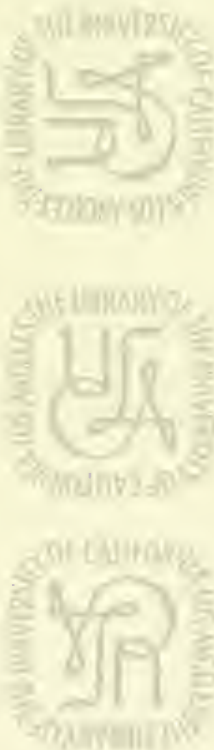

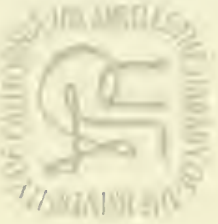

$\left.\frac{3}{2} \sqrt{\frac{3}{2}}\right)$

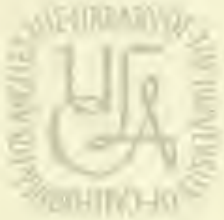
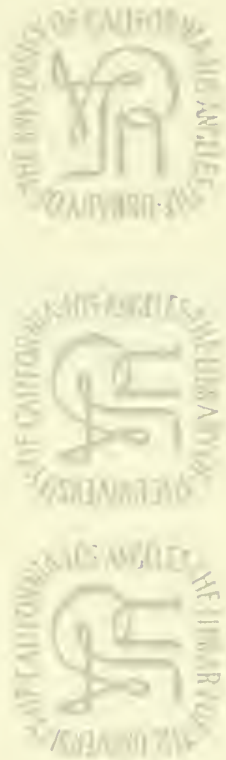

"6simaniso

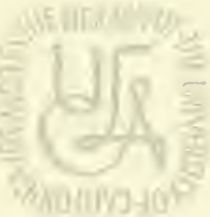

swothillye

3n)astol?

3) nivisus

$8]^{2}$
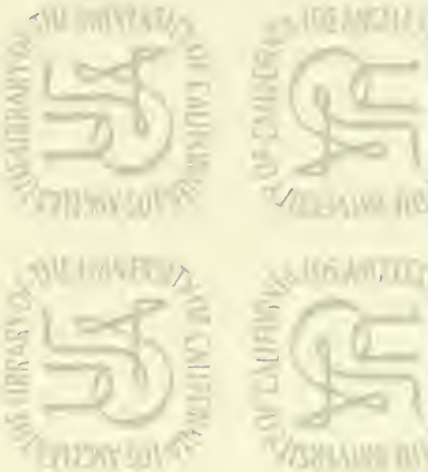

asilperpor

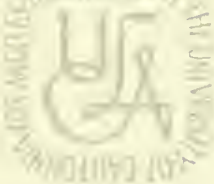

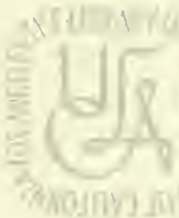

- ani Chulewes

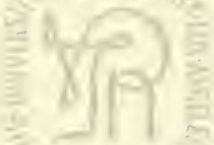

than iny ing

abliswion
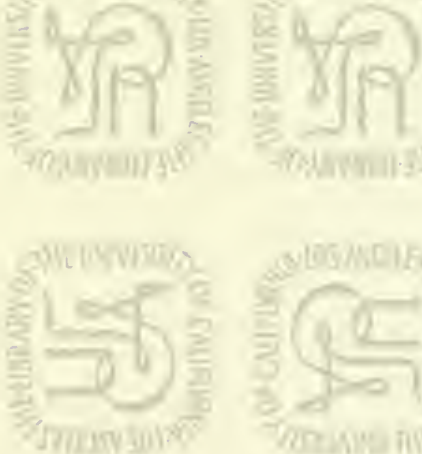

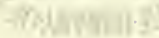

sLLGMDIF

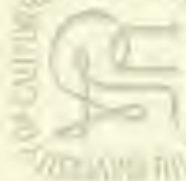

$\frac{40-50}{20}$ Tannyosto

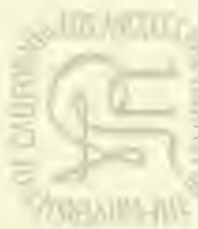





\section{IN THE ANDAMANS AND NICOBARS}






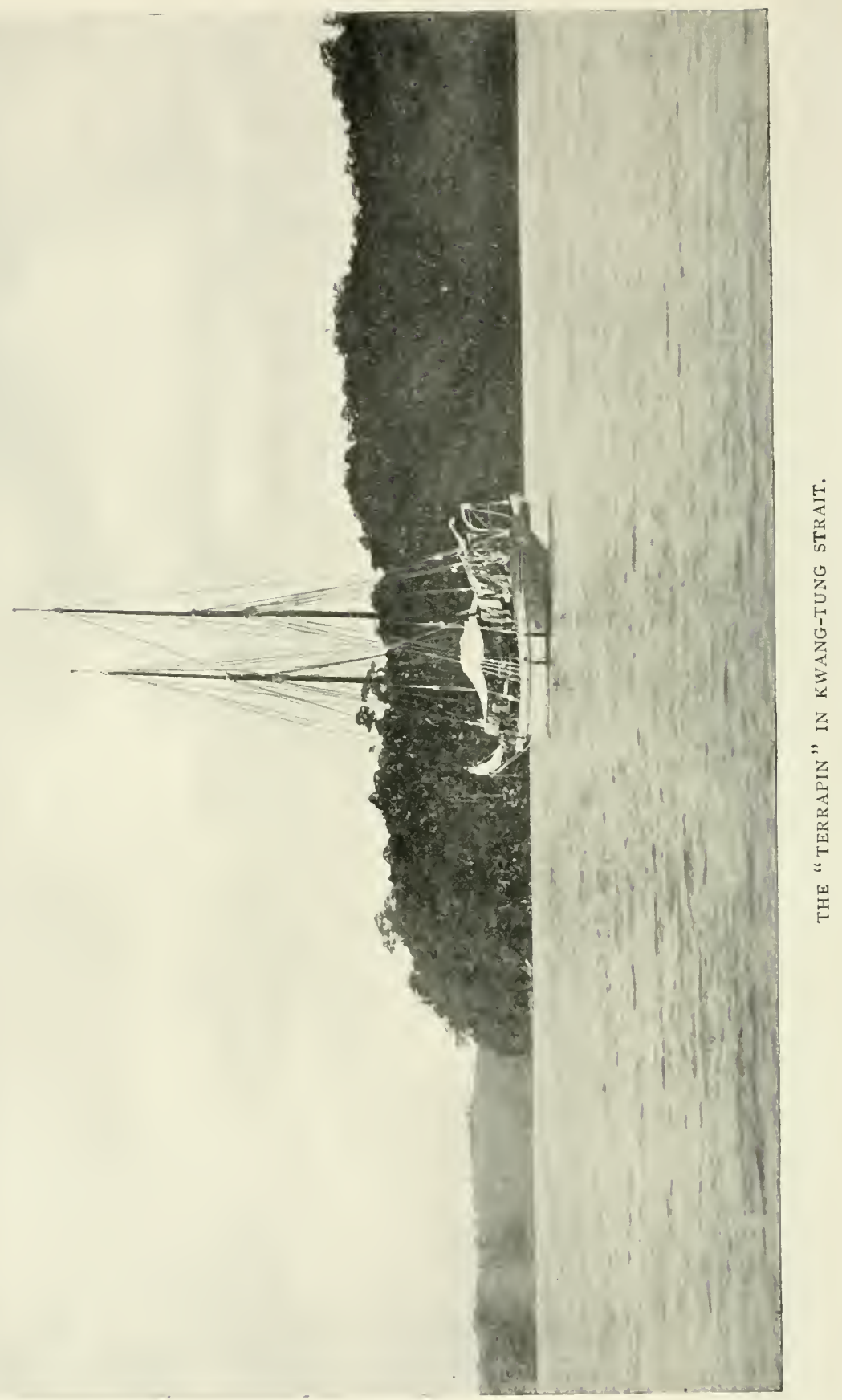

[Fontispiece. 


\title{
IN THE ANDAMANS AND NICOBARS
}

THE NARRATIVE OF A CRUISE IN THE SCHOONER "TERRAPIN," WITH NOTICES OF THE ISLANDS, THEIR FAUNA, ETHNOLOGY, ETC.

\section{By C. BODEN KLOSS}

\author{
" Where, beneath another sky, \\ Parrot islands anchored lie."
}

IVITH MAPS AND ILLUSTRATIONS

LONDON

JOHN MURray, Albemarle Street, IV. 1903 

OS
491
A5K69

To

WILLIAM LOUIS ABBOTT

IN FELLOWSHIP WITH WHOM I SPENT MANY ENJOYABLE MONTHS ON THIS AND FORMER CRUISES 



\section{PREF A C E}

THE following pages are the result of an attempt to record a cruise, in a schooner, to the Andaman and Nicobar Islands in the Bengal Sea, the main purpose of which was to obtain good representative collections (now in the National Museum, Washington, U.S.A.) of natural history and ethnological objects from the places visited. Special attention was given to the trapping of small mammals, which, comprising the least known section of the island fauna, were the most interesting subject for investigation. Sixteen new varieties were obtained in the Andamans and Nicobars together, thus raising the known mammalian fauna of those islands from twenty-four to forty individuals, while the collections also included ten hitherto undescribed species of birds. All the collecting and preparation was done by my companion, whose guest I was, and myself, for we were accompanied by no native assistants or hunters. Broadly speaking, one half of the day passed in obtaining specimens, the other in preserving them; and such observations as I have been able to chronicle were, for the greater part, made during the periods of actual collecting and the consequent going to and fro.

In order to give a certain completeness to the account, I have included a more or less general description of the two Archipelagoes, their inhabitants, etc.; the chapters of this nature are partly compiled from the writings of those who had had previous experience of the islands, and for the most part the references have been given.

I cannot but regard the illustrations, which are a selection from my series of photographs, as the most valuable part of this work, but I hope that my written record, in spite of its impervii 
fections, may stimulate some more competent observer and chronicler than myself to visit the latter islands-for the Andamans have already been described* in an admirable monograph by one who dwelt there for many years-before it is too late. Ethnically, much remains to be done, and every day that goes by produces some deterioration of native life and custom. To this end I have added many details about supplies, anchorages, etc., that might otherwise seem superfluous.

Of those who entertained and assisted us during the voyage, thanks are specially due to Mr P. Vaux of Port Blair, for his hospitality to us during our stay in that place; $\dagger$ and I am greatly indebted to Messrs O. T. Mason, G. S. Miller, and Dr C. W. Richmond, respectively, for the photographs of the Nicobarese pottery and skirt, for permission to include here much information from the report on the Andaman and Nicobar mammals, and for a list of the new species of birds obtained, which, however, up to the present, have not received specific designations. I have also to gratefully acknowledge the help rendered me by Mr E. H. Man, C.I.E., who, besides volunteering to read through the proof sheets, has given me much information, and corrected a number of inaccuracies. To my sister, for her superintendence of the book since my departure from England, and to my publishers for their kindness and assistance in many ways, I must not omit to offer my thanks.

* The Aboriginal Inhabitants of the Andaman Islands, by E. H. Man, 1884 .

+ On February 24th of this year Mr Vaux was killed while leading a punitive expedition against a section of the Jarawa tribe, who had recently murdered some wood-cutters. He rushed the last of several hostile camps by night, and took a number of prisoners; but, treading in the ashes of a smouldering fire at the moment of success, he caused it to blaze up, and being seen by a retreating native, was shot through the chest with an arrow, and died almost immediately.

October, 1902. 


\title{
C O N TEN'TS
}

\author{
PART I
}

\section{INTRODUCTION}

The Terrapin-Crew-Itinerary of the Cruise-Daily Routine-Provisions and Supplies-Collecting Apparatus-Guns-Shooting-Path-making -Clothing-Head-dress-A Scene in the Tropics-Native Indolence -Attractive Memories

\section{CHAPTER I}

Barren Island and the Archipelago .

Shipboard Monotony-Edible Sharks-Calm Nights-Squalls-Barren Island-Appearance-Anchorage-Landing-place-Hot Spring-Goats -The Eruptive Cone-Lava-Paths-Interior of the Crater-Volcanic Activity-Fauna-Fish-The Archipelago-Kwang-tung Strait-Pathmaking-The Jungle-Birds-Coral Reefs- Parrots-Two New Rats -Inhabitants.

\section{CHAPTER II}

PORT BLAIR

We enter the Harbour-Surveillance-Ross Island Pastimes-Visit the Chief Commissioner-The Harbour-Cellular Jail-Lime-kilns-Phœnix Bay - Hopetown-Murder of Lord Mayo-Chatham Island-Haddo and the Andamanese-Tea Gardens-Viper Island and Jail-The Convicts -Occupations-Punishments-Troops-Departure.

\section{CHAPTER III}

\section{Macpherson Strait-South Andaman and Rutland Island}

Gunboat Tours-South Andaman-Rutland Island-Navigation-Landingplace-Native Camp-Natives-Jungle-Birds-Appearance of the Natives - Our Guests - Native Women: Decorations and Absurd Appearance - Trials of Photography - The Village - Food - Bows, Arrows, and Utensils-Barter-Coiffure-Fauna-Water-New Species. ix 


\section{CHAPTER IV}

\section{The Cinoues and Little Andaman .}

Position of the Cinques-Anchorage-Clear Water-The Forest-Beach Formation-Native Hut-Little Andaman-Bumila Creek-NativesFlies-Personal Decoration-Dress and Modesty-Coats of MudCoiffure-Absence of Scarification-Elephantiasis-A Visit to the Village-Peculiar Huts-Canoe-Bows and Arrows-The Return Journey -A slight contretemps-Andamanese Pig-We leave the Andamans.

\section{CHAPTER V}

\section{KAR NICOBAR}

To the Nicobars-A Tide-race-A Change of Scene-Sáwi Bay-Geological Formation-V. Solomon-Mūs Village-Living-houses-Kitchens -Fruit-trees - The Natives-Headman Offandi-"Town-Halls"Death-house - Maternity Houses - Hospitals - Floods - "Babies" Houses "-Birds-Oil Press-Canoes-Offandi-" Friend of England" - "Frank Thomson" - "Little John" - Thirst for Information Natives' Nick-names-Mission School Boys' Work-A Truant-The Advantage of Canoes-A Spill-Our Method of Landing-Collecting Native Birds-A New Bat-Coconuts-V. Solomon-The Nicobarese and Christianity-Water-Area of Kar Nicobar-Geology-FloraSupplies.

\section{CHAPTER VI}

\section{TILANCHONG}

Batti Malv-Tilanchong-Novara Bay-Terrapin Bay-Form and Area of Tilanchong - Birds-Megapodes-A Swamp-Crocodile-Megapode Mound-Wreck and Death of Captain Owen, I 708-Leave Tilanchong -Foul Ground-Kamorta.

\section{CHAPTER VII}

\section{TRINKAT}

Beresford Channel-A Deserted Village-Jheel-Bird Life-Wild CattleScenery - Photographs - Port Registers - Tanamara-Population Customs-The Shom Pei-The Sequel to a Death-Interior of the Houses.

\section{CHAPTER VIII}

NANkaURI .

The Harbour Shores-A Village-Kanain-Canoe-Feeding the AnimalsCollecting-ground-Mangrove Creeks-Preparations for a FestivalBurial Customs-Malacca Village-Houses-Visit Tanamara-Furniture-Talismans and "Scare-devils"-Beliefs-Festivities-A DanceAn Educated Native-Tanamara and his Relations-CigarettesRefreshments - The Collections - Geology - Flora - Population Piracy. 


\section{CHAPTER IX}

KAMORTA

The Old Settlement-The Cemetery-F.H.de Röepstorff-Mortality-Birds -The Harbour-Appearance of Kamorta-Dring Harbour-Olta-möit - Buffalo-Spirit 'Traffic-Cookery-Ceremonial Dress-A Visit from Tanamara - Geology - Flora - Topography-Population-Hamilton's Description.

\section{CHAPTER X}

Kachal and Other Islands . . . .

Heavy Surf-Teressa-Bompoka-A Native Legend-Hamilton-Chaura - Wizardry-Pottery-Kachal typical of the Tropics-Nicoharese Dress-West Bay-Lagoon-Mangroves-Whimbrel-Formation of Kachal-Birds-Visitors to the Schooner-Fever-Chinese JunksThatch - Relics - The Reef - Megapodes - Monkeys - Full-dressed Natives-Medicine-A Death Ceremony-Talismans-Fish and Fishing-Geology.

\section{CHAPTER XI}

\section{Little Nicobar and Pulo Milo}

A Tide-rip-Islets-A Cetacean-Pulo Milo-Timidity of the NativesLittle Nicobar-Geology-Flora-Population-Site for a ColonyJungle Life-Banian Trees-The Houses and their Peculiarity-The Natives-Practices and Beliefs-The Shom Pen-The Harbour-We ascend a River-Kingfishers-Water-Caves-Bats and SwallowsNests-A Jungle Path-Menchál Island-Collections-MonkeysCrabs.

\section{CHAPTER XII}

\section{Kondul and Great Nicobar}

The Anchorage-The Island-Villages-We leave Kondul-Great Nicobar -Anchorage-Collecting-Up the Creek-A Bat Camp-Young Bats -Traces of the Shom Pen-Bird Life-Fish-Ganges Harbour-Land Subsidence-Tupais-IVe Explore the Harbour-A Jungle Pig"Jubilee" River-Chinese Navigation-Rainy Weather-Kondul Boys -Coconuts-Chinese Rowing.

\section{CHAPTER XIII}

\section{Great Nicobar-IVest COAST .}

Pulo Kunyi-Area of Great Nicobar-Mountains-Rivers-The VillageThe Shom Pen-Casuarina Bay-An Ingenious "Dog-hobble"-In the Jungle-A Shom Pen Village-Men of the Shom Pen-A Lazy Morning-The Shom Pen again-Their Similarity to the NicobareseFood-Implements-Cooking-vessel-The Dagmar River-Casuarina Bay-Pulo Nyur-Water-A Boat Expedition-The Alexandra River -Shom Peń Villages-Kópenhéat_More Shom Per_-ElephantiasisPet Monkeys-Anchorage. 


\section{CHAPTER XIV \\ Great Nicobar-West and South Coasts \\ "Domeat"-Malay Traders-Trade Prices-The Shom Pen Language- Place Names-Pulo Bábi-The Growth of Land-Climbing a Palm Tree-Servitude-Population-Views on Marriage with the Aborigines -Towards the Interior-A Shom Peir Village-The Inhabitants- Canoe-building-Barter-The West Coast-South Bay-Walker Island -Chang-ngeh-Up the Galathea River-Water-We leave the Nico- bars and sail to Sumatra.}

PAGE

\section{PART II}

\section{CHAPTER I}

\section{The ANdanan Islands and their Inhabitants}

Position - Soundings - Relationship - Islands - Area - Great Andaman Mountains-Little Andaman-Rivers-Coral Banks-Scenery-Harbours - Timber - Flora - Climate-Cyclones-Geology-MineralsSubsidence - Earthquakes - History - Aborigines - Convicts and the Penal System-Growth and Resources of the Settlement-Products and Manufactures.

\section{CHAPTER II}

The Nicobar Islands and Their AbORIGINes . .

The Nicobar Islands and their Aborigines-The Islands-Coral BanksNankauri Harbour-Population-Geology-Earthquakes-ClimateFlora - History - The Shom Pein : their Derivation, Appearance, Houses, Gardens, Cooking-vessel, Domestic Animals, Manufactures, Trade, Clothing, Headmen, Position of Women, Disposition, Diseases.

\section{CHAPTER III}

The Nicobarese .

The Evolution of the Nicobarese-Description-Character-LanguageLegends of Origin-Origin of Coco Palms-Invention of Punishments Superstitious Beliefs-Diseases - Medicines - Marriage - Matriarchal System - Divorce - Polygamy - Courtship - Property - Takoia HIeadmen-Social State-Position of Women and Children-Domestic Animals - Weapons - Tools - Fishing-Turtle-Food-BeveragesNarcotics and Stimulants-Cleanliness-Clothing-Ornaments-Coiffure - Amusements - Arts and Industries - Cultivation - Produce Traders and Commerce.

\section{CHAPTER IV}

Dampieir's Sojourn in Great Nicobar, and Voyage thence to Acheex in a Cayoe 


\section{CHAPTER V}

An Old Account of Kar Nicobar

\section{CHAPTER VI}

Some Customs of the Kar Nicobarese

The Feast of Exhumation-A Scene in the Graveyard-"Katap-hang""Kiala"-"Enwan-n'gi"-Fish Charms-Canoe Offerings-"Ramal" - "Gnunota"-Converse with the Dead-"Kewi-apa"_"Maya"-

"Yintouná Siya"-Exorcism-"Tanangla"-Other Ceremonies-The "Sano-kuv"-The "Mafai"-The "Tamiluana"-Mafai Ceremonies - Burial-Mourning-Burial Scenes-The Origin of Village Gardens -Destruction of Gardens-Eclipses-Canoe-buying-Dances-Quarrels - "Amok"-Wizardry-Wizard Murders-Suicides-Land Sale and Tenure-Dislike to Strangers-Cross-bow Accidents-Canoe VoyagesCommercial Occupations-Tallies.

\section{CHAPTER VII}

The Fauna of the Andamans and Nicobars .

\section{APPENDICES}

A.-Average Wind and Weather in the Andamans . 335

B.-Principal Forest Trees of the Andamans . . 336

C.-Notes on the Produce of the Andaman Forests . 339

D.-Census, Andaman Islands, 1901 . . . 342

E.-Government Schools at Port Blair . . . 343

F.-Measurements of some Andamanese net at Rutland ISLAND . . . . . . . 344

G.-Principal Flora of the Nicobars . . . 345

H.-Census, Nicodar Islands, igoi and i 886 . . 350

I.-Trade Articles and their Value in the Nicobars • $35 \mathrm{I}$

J.-Presents and Barter in Demand during the Cruise OF THE TERRAPIN . . . . . . . 352

K.-Measurements of some Nicobarese and Shom Peì - 353

INDEX . 


\section{LIST OF ILLUSTRATIONS}

The "Terrapin" in Kwang-tung Strait .

Frontispicce

Andaman and Nicobar Islands

The Landing-place, Barren Island

The Eruptive Cone, Barren Island

Ross Island (northern extremity)

Andamanese Men

Andamanese Women

Andamanese Shelter

Öngé Hut, Little Andaman

In the Village of Mūs, Kar Nicobar

Kar Nicobarese Family and Dwelling-house, with Lounge beneath

A Kitchen House, Mũs Village (showing method of construction) .

Death House, Hospitals, Maternity Houses, and Burialground, Mūs Village . . . . . " " 50

"Talik N'gi" (The Place of the Baby), Mūs Village . . " " " 52

Kar Nicobarese .

"Friend of England"

Mission Boys and Burmese Teacher, Kar Nicobar . . " " " 60

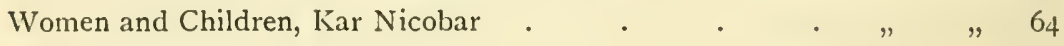

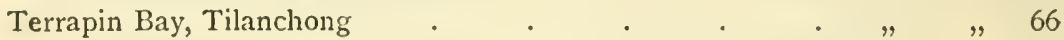

A Megapode

A Megapode Mound

Inúanga Village, Nankauri Harbuor

Nankauri Canoe, with Festival Decorations

Kitchen and Dwelling-house, with Festival Tree, Nankauri .

Tanamara's "Kareau"

Nankauri Man with Dancing Collar and Painted Nose

Group of Dancers, Nankauri Harbour .

Nankauri Man with Silver Necklace .

Objects from Nankauri Harbour xiv 
Dwelling-houses, Dring Harbour, Kamorta (partially constructed, and complete) .

To face page 98

Fig Tree with Aëreal Roots, Little Nicobar . . . " " " 122

Houses, Pulo Milo

Jungle Vegetation, Little Nicobar

Man with Pandanus Fruit, Kondul

Boys of Kondul .

IVest Coast of Great Nicobar

Man and Woman of the Shom Pen, and a Nicobarese

A Village of the Shom Pen

Women and Girls of the Shom Pen

Men of the Shom Pen

Men of the Shom Pen (in profile)

Hut of the Shom Pen

Canoe at Pulo Nyur, Great Nicobar

Huts of the Shom Pein

Men and a Boy of Great Nicobar .

On the Galathea River, Great Nicobar

Galathea River (highest point reached)

Hydrographical Chart of the Andaman and Nicobar Islands .

Öngé Man, Little Andaman

Andamanese Objects

Öngé Visitor at Rutland Island

Andamanese Bamboo Buckets and Cane Baskets (conical); also Nicobarese Cane Baskets (5), with Tray and Bucket of Spathe

Men of the Shom Pen ; Men of the Shom Pen (in profile).

Women of the Shom Peri ; Women of the Shom Pen (in profile)

Women of the Shom Pen; Women of the Shom Pen (in profile)

Huts of the Shom Pen .

Man of Nankauri; A Headman of the Shom Pen

"Tanamara" of Nankauri; "Tanamara" of Nankauri (in profile); A Headman of the Shom Pen : Headman of the Shom Pen (in profile)

124

, 126

, 132

, 138

, 140

142

$" 144$

, 146

, 148

, 150

, 152

, 154

, 158

, 160

"162

, 164

, 166

,$\quad 186$

1) $\mathbf{1} 88$

, I 90

200

, 214

216

, 218

, 220

, 222

of Kar Nicobar; Woman of Kar Nicobar ; Kar Nicobar

Boy (showing Epicanthus); Kar Nicobar Boy (in pro-

file, showing Prognathism)

Woman and Man Wearing the "Tá-Chökla," Kar Nicobar

Man and Woman of Kar Nicobar (in profile) .

Specimens of "Hentá-kói," made and first used in times of sickness to frighten away the offending evil spirits 
A "Hentá," painted and first suspended inside hut in time of sickness, to gratify good spirits and scare away demons. (Specimen from Nankauri)

To face page 234

Old Nicobarese Skirt, "Ngong"

Baskets, Troughs, and Areca Spathe Feeding-dish, Nicobar Islands

Group of Kar Nicobarese

, 248

\section{ILLUSTRATIONS IN TEXT}

Little Andaman Canoe .

PAGE

"Scare-devil," or device for exorcising evil spirits .

Oil Press (Kar Nicobar) . $\quad$. $\quad . \quad$. $\quad . \quad$. 53

"Scare-devil," or device for exorcising evil spirits . . . . . 78

Chaura Pottery . . . . . . . . . . 108

Shom Peń Cooking-vessel (Great Nicobar) . . . . 148

Iron Buffalo and Pig Spears . . . . . . . $22 \mathrm{I}$

"Scare-devil," or device for exorcising evil spirits (Kachal) . . . $23 \mathrm{I}$

Nicobarese Talisman . . . . . . . . . 232

"Scare-devil," or device for exorcising evil spirits (Kachal) . . 232

Female Talisman (Kachal) ; Female Talisman, "Kario" (Nankauri) 234

I, Shom Pen Spear (Great Nicobar). 2 and 3, "Hanoi cha," Canoe Decorations for bow, stern, and outrigger (Kar Nicobar). 4, Turtle Spear. 5 and 6, Wooden Fishing Spears. 7, Ornamental Canoe Stern-piece, "Misoka ap" (Kar Nicobar). 8, 9, and Io, Iron Fishing Spears 


\section{IN THE ANDAMANS AND NICOBARS}

\section{PART I}

\section{INTRODUCTION}

The Terrapin-Crew-Itinerary of the Cruise-Daily Routine-Provisions and Supplies-Collecting Apparatus-Guns-Shooting-Path-makingClothing-Head-dress-A Scene in the Tropics-Native IndolenceAttractive Memories.

THE Terrapin, captain and owner Dr W. L. Abbott, is a Singapore-built teak schooner of 40 tons register and 67 tons yacht measurement. She is 65 feet long on the water-line, and 16 feet broad, and has been given an almost box-shaped midship section, partly to afford sufficient inside space for the ballast (iron), but principally with the idea that when she takes the ground she may not heel to any uncomfortable extent. The draught is $7 \frac{1}{2}$ feet, but two years' experience has proved that this is too much for the class of cruising she is engaged in. The crew are berthed forward, and aft is a large hold where tanks containing about 3 tons of water, supplies, cables, etc., are stored. A large raised trunk hatch about $2 \frac{1}{2}$ feet high covers the central third of the boat, leaving 3 -feet gangways on either side. This structure affords ample head-room below, and gives coolness and abundant ventilation by means of windows which open all round it. Sailing in the tropics, with the thermometer constantly standing at $84^{\circ}$ or so in the shade, necessitates for any comfort a very different arrangement from what would be fitting at home. Whenever possible, the boat, while 
anchored, is covered with awnings from stem to stern. Under the hatch are a large saloon, two cabins, pantry, etc.

The crew-five ordinary seamen, a serang (boatswain), and sailing-master-are Malays; for natives are far more satisfactory in nearly every way on a small boat in the tropics than white men, even if the latter could be obtained. They can put up with more restricted quarters, are less inclined to grumble under the peculiar circumstances, or be disobedient, are more at home in every way in the surroundings and with the people one meets, are little trouble to cater for, and, most important of all, keep in good health and can stand the sun. A Chinese "boy" and cook are also carried.

Forward on deck there is a small iron galley for the preparation of meals, and aft repose two boats-an I8-feet doubleender for four oars, and a beamy Io-feet dinghy that best carries a crew of three. The schooner steers with a wheel.

The Terrapin left Singapore in October 1900 and, subsequent to calling at Penang, cruised off the coast of Tenasserim and among the islands of the Mergui Archipelago until I joined her late in December. A few days were then spent in the peninsula, where several deer and wild pig were obtained; then visiting High Island-where an unsuccessful search was made for Sellung* skeletons, and a number of birds and small mammals added to the collection-she left for the Andamans.

On the return voyage from the Nicobars we called at Olehleh, the port for Kota Rajah, Dutch capital of Acheen. Even a dissociation from them of only three months made the pinkwhite skins of the Europeans - sun-avoiding Dutch - seem strange and unhealthy.

Having spent a day or two at this place, where we first heard of the accession of King Edward VII., we skirted the north coast of Sumatra, with its park-like stretches of grass and forest, drifting

* The Sellungs are a primitive and timid tribe, who wander in canoes among the Mergui Islands during the fine weather, and make temporary settlements on lee-shores in the south-west monsoon. They number between two and three thousand. 
along almost in the shadow of its great volcanic mountains, and then, crossing the northern entrance of the Malacca Straits, anchored once more in the harbour of Penang.

At Klang, in Selangor, we stopped a night to visit the museum at Kwala Lumpor, and were passed by the Ophir and her consorts as they steamed to Singapore; which place we ourselves reached, after a slow passage down the coast, on the 27 th of April I90I, thus bringing the cruise to an end.

The day's programme during the voyage was simple. We rose before 5 A.M.; and after a hurried chota hazri, rowed ashore the moment it grew at all light. The next five hours were passed collecting in the jungle; and then returning on board, after a bath, change, and breakfast, the preservation of specimens went on until two o'clock; next came tea, then more work until about 3 P.M., when we once more rowed ashore and sought for fresh material until darkness set in. Then after another bath and change came dinner, and by the time the second batch of specimens was disposed of, we were quite ready for mattress and pillow on deck; for unless it rained we never slept below. The development of photographs often kept me up till midnight, since they had to be manipulated in a small pantry which could only be thoroughly darkened after sunset. I have seldom been in a warmer place.

Some consideration should be given to the provisioning of a boat when cruising away from regular supplies for health is largely dependent on this point.

For so long as flour will keep good it is pleasant to have fresh bread, but experience on this and other cruises is that it gets full of weevils after three months in a small boat. While tinned provisions and bottled fruits are very well for a time, one rapidly tires of them, and then there is nothing like the old stand-bys of salt beef and pork, ship's biscuits, rice, etc. Potatoes and onions will keep well for six months, and "sauerkraut," or Chinese preserved greens, are useful articles. Many of the birds shot for specimens-on this cruise, megapodes, pigeons, and whimbrelform welcome additions to the table, and one gets occasionally wild pig and deer; while even of such unorthodox animals as 
squirrels, the larger kinds-Sciurus bicolor attains almost the size of a hare, which it much resembles in flavour-are by no means despicable. When we were under sail, there were always lines towing astern of the vessel, which often produced bonito, dolphin, barracouta, edible shark, and other varieties, and we carried a seine, which, when stretched across the mouth of a tidal creek, was nearly always certain to entangle some kind of fish in its meshes, while with a casting-net catches of what one might call "whitebait" were often made.

One is rarely able to obtain much else than fowls from natives, and except in towns and large villages, where there are regular bazaars and markets, even fruit other than coconuts and bananas is scarce. Tinned and bottled preserves soon become insipid to the palate, but dried fruit, such as apples, apricots and prunes, we found far more attractive, and they should always be carried when native supplies are uncertain. In fact, beyond a few necessaries such as milk, butter, jam, tea, coffee, sugar, cheese and curry stuffs, and a few more luxurious articles, like soups, pickles-but those who have tried a well-seasoned piece of salt junk will admit that these and mustard are almost absolute necessities-sauces, etc., the fewer tinned provisions there are the better, so far as health in the tropics is concerned. When one can keep the hen-coop well stocked, and there is plenty of rice on board, one never feels like grumbling while there is any amount of work to be done.

In the matter of collecting apparatus, the newer powders are preferable, as with them there is less chance, through absence of smoke, of losing sight of the specimen as it falls, which is often the case otherwise. It is well to have cartridge cases of different colours for ease in selection, and the sizes of shot most useful seem to be:-SSG for pigs, deer, and large monkeys; AA and II for monkeys, eagles, and other large birds; $\mathrm{V}$ for pigeons, and others of similar size in high tree tops; VIII for the same at moderate range, and for smaller birds and squirrels, etc., when distant; while 2 drams of powder and $\frac{1}{2}$ ounce of XI shot-the cartridge filled out by several wads between the two-is most useful for small 
birds and animals up to 20 yards, and for others at proportionate distances. For such little things as sunbirds, and for snakes, lizards, or for point-blank shots, we carried auxiliary barrels, about 9 inches long, that can be slipped in and out of the gun like an ordinary cartridge, and which fired an extra long .32 calibre brass cartridge loaded with a pinch of dust shot (No. XIII). These were invaluable for obtaining the smaller specimens without smashing, and had a killing range of about $\mathbf{I} 2$ yards.

There is no more perfect weapon for the collecting naturalist than the three-barrelled guns that we used-shot barrels fully choked, and the third, placed beneath the others, rifled for long .380 cartridges. With one of these, the auxiliary barrel, and a. proper selection of cartridges, one is ready for anything that may turn up other than the larger "big game," for the equipment is so portable that there is no temptation ever to leave part of it behind.

The only drawback to such an outfit lies in the time lost in selecting a suitable cartridge for each shot, but the perfect specimens obtained by this method are ample compensation for the extra trouble involved. Even in this way accidents sometimes happen however, as when on one occasion, while walking through some grass, a tiny button-quail sprang up, and was knocked over at close range with what was thought to be a small charge of No. $\mathrm{XI}$ shot. The specimen was not found at once, but as it was the first of the kind obtained (and has since proved to be of a new species), the search was persisted in until after a quarter of an hour a little purple pulp attached to a wing was discovered. The collector had forgotten which barrel contained the smaller cartridge, and, pulling the wrong trigger, had fired a full charge of No. VIII from about that distance in yards, at a wretched little bird about the size of a sparrow!

To fire at flying birds in the jungle is both wasteful and unprofitable, for while a bird is only to be seen for a moment as it flashes between the branches, even if hit, it infallibly becomes lost in the dense luxuriance of vegetation. The chances in the favour of the quarry are, however, largely increased by a careful 
selection of the smallest cartridge possible on each occasion, often a tiresome stalk, and a large amount of dodging about to get a clean shot through the leaves and branches, so that the event is by no means a more foregone conclusion than sport in the open.

Besides bags for cartridges and specimens, with extractor, knife, string, cotton-wool, and wrapping paper, it is absolutely essential, if it is intended to penetrate the jungle at all, that one should carry some sort of implement-cutlass, parang, or macheté - to hew a way through the tangled undergrowth.

It is far the best plan, when shooting in the tropics, not to indulge in a too elaborate outfit. The most suitable and commonsense clothing consists of a stout cotton suit of pyjamas, grey or brown in colour for preference, with pockets; the ends of the trousers should be tied round the ankles with string, to keep out the ants and leeches, and only when these and thorns are very bad need stronger trousers and puttees be worn. Such clothes are easily put on and off, are comfortable, and are not heavy when soaked with water, rain, and perspiration.

On board ship, when away from civilisation, we invariably wore a similar dress, or the national garment of Malaya, the sarong, than which nothing is more comfortable in a hot climate, unless it be the exceedingly sensible dress of the tropic-divelling Chinese.

For head-dress there is no better gear than an old felt hat (terai), which can be rolled up and put away in the game-bag when one is in the shade of the forest. In one of the most delightful books that has been written about the East, the following lines occur: " Given a thick jungle, trees 200 feet high, and a mushroom-helmeted sportsman, it will be seen that comfort and a large bag are incompatible. A long training in the Sistine Chapel is necessary for this work. Absurd as it may seem, my spine in the region of the neck eventually became so sore that I was on more than one occasion compelled to give myself a rest." IVith the latter part of the passage I perfectly concur, for one often stands

* The Cruise of the Marchesa, by F. H. II. Guillemard, second edition, London, 1889. 
for minutes at a time staring vainly upwards, to where, right overhead, the specimen that one knows is there, is vocally proclaiming its presence, and the effect on the back of the neck is, after a time, often one of excruciating agony. Strangely enough, large birds like parrots and pigeons are often the most difficult to see.

But why the helmet in the shade of the forest? We ourselves never wore hats except when out in the open or going to and fro between the schooner and the shore, while the sun was high, and experienced no ill effects from being without them at other times, although one of us made it a practice to keep his head shaved for the sake of coolness. Though they perhaps lay me open to an accusation of thick-headedness, I mention these facts to show that it is not necessary to burden oneself with an awkward sola topee with the idea of evading danger from the sun in such circumstances.

A cloudless sky and a blazing sun; a long stretch of yellow beach lapped by a calm sea of brilliant green above the reef, verging into an intense sapphire in the distance. Inland, swelling hills clothed in densest jungle - the topmost ridge capped by a delicate tracery of foliage that stands out clear cut in the pure atmosphere. Adjoining the sandy shore a grass-grown level expanse, with a grove of stately palm trees, through which runs a rippling brook, and lastly, two or three native huts and their occupants, so that one can lie, pyjama-clad, in the shade, and consume young coconuts without first having to climb for them.

"Only to hear and see the far-off brine,

Only to hear were sweet, stretched out beneath the pine."

Is it fair that we should call the native of the tropics lazy because in some parts of his domain the labour of an hour supplies his daily wants? The working man of colder climates, by eight and even twelve hours' occupation, obtains no more, and often less. The others are the true lotos-eaters, and when one is 
amongst them one often feels, as doubtless they do themselves, could they formulate their sensations :

"... Why should we toil alone,

We only toil who are the first of things,

And make perpetual moan,

Still from one sorrow to another thrown :

"There is no joy but calm !'

Why should we only toil, the roof and crown of things?"

These are one's thoughts, while captivated by the charm of the islands, and if feelings change when analysed in more virile countries, the transformation of ideas only goes to show how relative to circumstances are such things as industry and idleness.

The foregoing are a few prosaic items about a form of life which, although when indulged in too long, it perhaps causes now and again a desire for the amenities of civilisation and a shirt-front, yet when it is over, always leaves a longing for further experiences whenever one is haunted by thoughts of the palms, the sunlight, and the sea; wanderings in the jungle; strange birds, animals, and vegetation, and pleasant memories of easy-going islanders. 


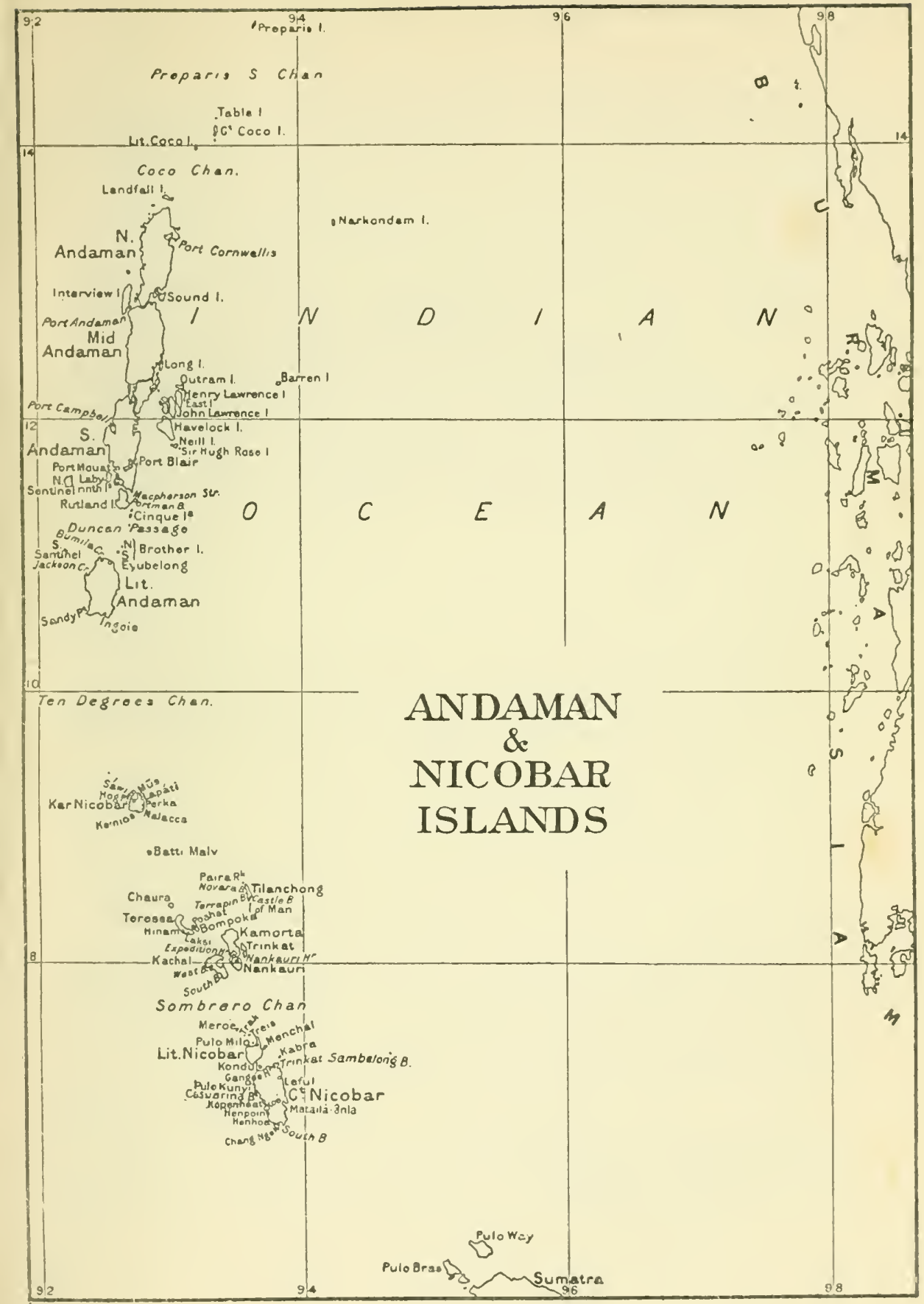

[To fice prege s. 



\section{CHAPTER I \\ BARREN ISLAND AND THE ARCHIPELAGO}

Shipboard Monotony-Edible Sharks-Calm Nights-Squalls-Barren Island -Appearance-Anchorage-Landing - place-Hot Spring-Goats-The Eruptive Cone-Lava-Paths-Interior of the Crater-Volcanic ActivityFauna-Fish-The Archipelago-Kwang-tung Strait-Path-making-The Jungle-Birds-Coral Reefs-Parrots-Two New Rats-Inhabitants.

WE were six days out from land before Barren Island hove in sight. Since New Year's Day, when we got up anchor amongst the islands of the Mergui Archipelago, the schooner had been carried by the lightest of breezes towards the Andamans. The days slipped by, each one as monotonous as its predecessor; there was no change in the wind, save when it fell calm for a space, and the sun was so hot that we gladly sought shelter in the cabin, where occupation might be found with a book. Once we harpooned a porpoise, but he broke away from the iron, and now and again, on a line trailing astern, we caught a small shark, immediately claimed by the cook, to appear later on the table; for although the name seems instinctively to prejudice one against them, all sharks are edible, and the smaller species, which can scarcely include human material in their dietary scale, are by no means to be despised when fresh provisions are unobtainable, in spite of being often somewhat dry and flavourless.

But the nights were ample compensation for any possible discomfort by day. Around was the calm flat sea, and overhead a pale blue sky, across which swung the tropic moon, 
so bright that all but the larger stars were drowned in light. Then, when the heat of day was over, we would take our pillows on deck and-in a perfect silence but for the creaking booms and the water gurgling in the scupper-pipes - watch mast and stars swing slowly to and fro until sleep brought unconsciousness of the night and its beauty.

But it is not always so even in the tropics, and the contrary, and not infrequent, experience, without going to extremes, is the squall of a moonless night.

As the dense clouds rapidly advance from the horizon and blot out the stars, one is left in inky darkness broken only by the glimmer of the lamps in the binnacle. Soon the wind comes tearing down and whistles loudly in the rigging, while with lowered sail, the vessel seems to fly through the waterjudging by the rolling wings of foam that stream from her shoulders and gleam weirdly in the green and red rays of the sidelights. Presently the rain falls in a stinging chilly torrent, killing the breeze and leaving the boat rolling uncomfort. ably on the surface; and when the furious downpour is over, and the night is quiet once more, all that remains to show the past disturbance is sodden canvas, stiffened cordage, and the uneasy heave of the wind-ivhipped sea.

So the squall passes - generally leaving a calm behind it -having in a little space squandered enough unavailing breeze to have helped the vessel on her course for hours to come.

At last, one evening, we saw Narkondam from the masthead, about sixty miles away; and next morning Barren Island had risen above the horizon. These two little islands, eastern outliers of the Andamans, and connecting links between the eruptive regions of Burma and Sumatra, are both of volcanic origin, though the former is now extinct.

Barren Island, about two miles in diameter, is merely the crater of a volcano rising abruptly from the sea, which, a quarter of a mile from shore, is nearly everywhere 150 fathoms or more in depth.

Approaching from the east, we caught a glimpse, while still 


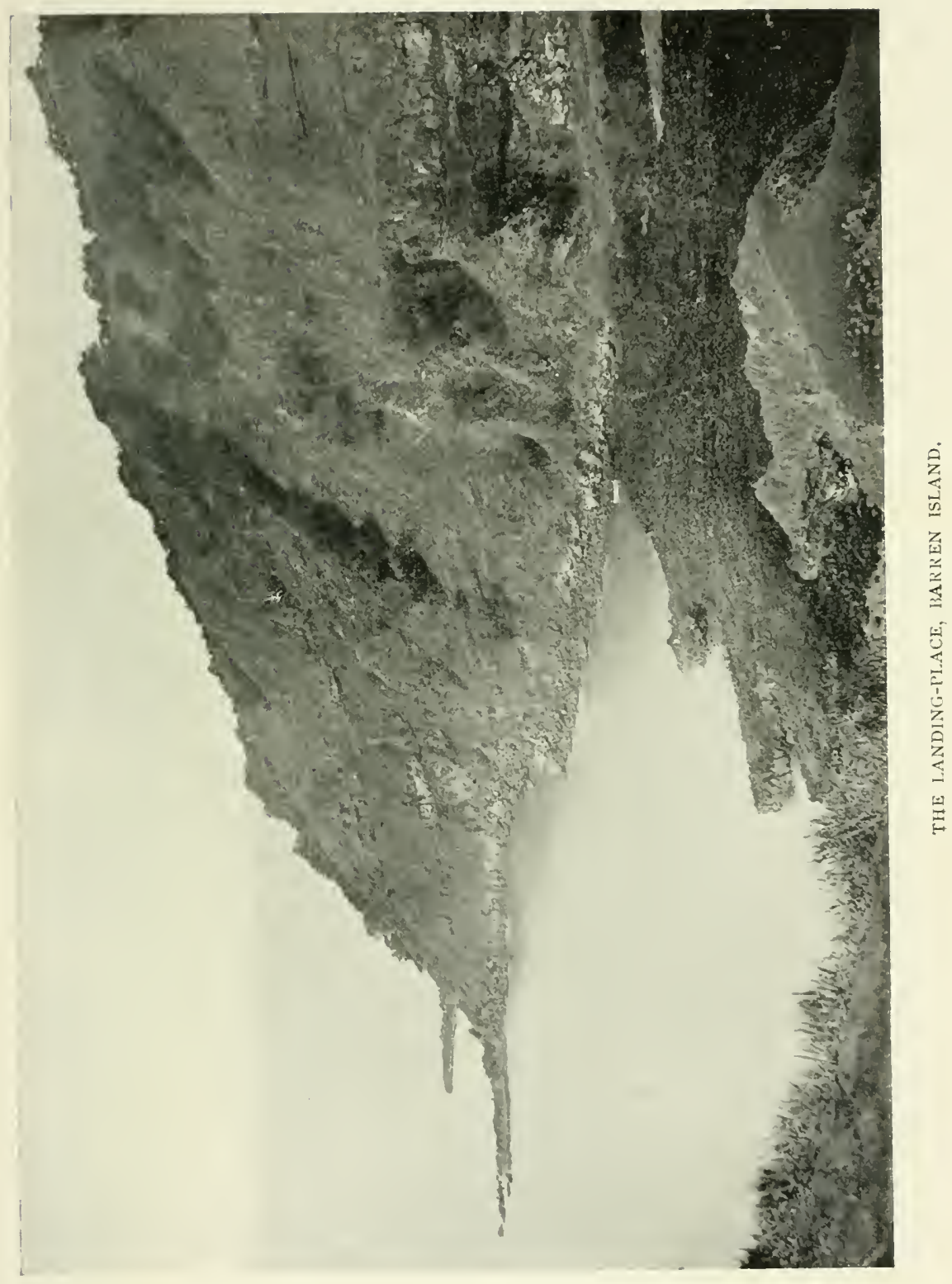

[To fuce prage 10. 

some distance off, of the black tip of an eruptive cone, showing above the rim of the crater, which at a nearer view proved to be of igneous basalt, clothed on the outer slopes with a growth of creepers, bushes, and of trees 50 to 60 feet high, frequented by numbers of fruit pigeons.

On the north-west side of the island the wall of the old crater has been broken down, and a large gap about a hundred yards wide at the base affords an easy means of access to the interior. It is through this opening that the best view of the cone is obtained from seawards.

As we sailed past the gap that afternoon the scene was one of striking beauty. Against a background of bright blue sky the little island rose from a sea of lapis-lazuli, which ceaselessly dashed white breakers on the rocky shores. The steep brown slopes, part clothed in brilliant green, framed in the cone-a black and solid mass, round which a pair of eagles circled slowly.

Fortunately for those vessels which may visit the island, there is one place off-shore where soundings can be obtained with the handline, and there we came to anchor in 15 fathoms, a little beach and clump of coconut palms bearing N.N.E., a quarter of a mile away.

Sails were soon stowed and we rowed off to reconnoitre the gap, which is the only practicable landing-place; everywhere else the land slopes steeply to the sea. To the south a heavy swell was breaking on the shore, but in the little cove formed here the sea was perfectly calm, and so clear that as we passed into shallower water the coral bottom, Io fathoms down, was plainly visible.

A rough wall of lava about a dozen feet high stretches across the opening, and to the left of this, among the stones and boulders of the shore, we found, below high-water mark, a little stream of fresh water trickling to the sea; it is the only water on the island, and at that time was at a temperature of $97.5^{\circ} \mathrm{F}$.

* Temperature in $1891=103.5$. Hume visited the island in 1873 and noted $140^{\circ}$, while in 1866 the Andaman Committee found the temperature to be between $158^{\circ}$ and $163^{\circ}$. In 1857 Dr Mouat landed, and writes of "a natural boiling spring, the waters so extremely hot that they rendered the sea in the immediate neighbourhood warm enough to roast crabs in their shells," and about 
The only inhabitants of any size that the island can boast of are a large herd of goats, whose well-worn tracks show plainly on every slope and cliff. A score of these animals, left in I 89 I by the station steamer from Port Blair, have so thriven that their descendants must now be numbered in hundreds, and are so free from fear, and unsuspicious, that had we needed them we could have butchered any quantity.

From the landing-place the ground slopes gently upward to the floor of the crater, which is about 50 feet above sea level. In the centre of this rises the little cone of slightly truncated form. Symmetrical in outline, I000 feet high and perhaps 2000 feet in diameter at the base, there is nothing it reminds one of more closely than a huge heap of purplish-black coal-dust, with patches and streaks of brown on the top.

To right and left of the base, and thence towards the sea, flows a broad black stream of clinkery lava, the masses of which it is composed varying in dimensions from rugged blocks of scoriæ a ton or more in weight to pieces the size of one's fist. The journey across it would be one of some difficulty, were it not that the goats, coming from all parts of the island in their need for water, by constantly travelling to and fro in the same line, have worn a smooth and deep path from side to side, some 200 yards distant from the sea.

The level ground at the base of the cone, widest on the southern side, is covered with tall bamboo grass and various kinds of low bushes. On the inner slopes of the crater, the south and east sides, which are of rocky formation, support a certain amount of small forest, in which we quickly noticed the absence of such tropical forms as palms, rattans and lianas, and of trees more than 60 or 70 feet high and 4 or 5 feet in diameter; *

the same date Dr von Liebig records a broad but thin sheet of nearly boiling water issuing from beneath the lava, and the sea warm for many yards to a depth of more than 8 feet. Earlier still, in 1831, we have Dr Adam's account, which states that 100 yards from shore the water was nearly boiling; the stones and rocks on shore exposed at low tide were smoking and hissing, and the water was boiling all round them.

*In 1789 only withered shrubs and blasted trees were to be seen on parts 


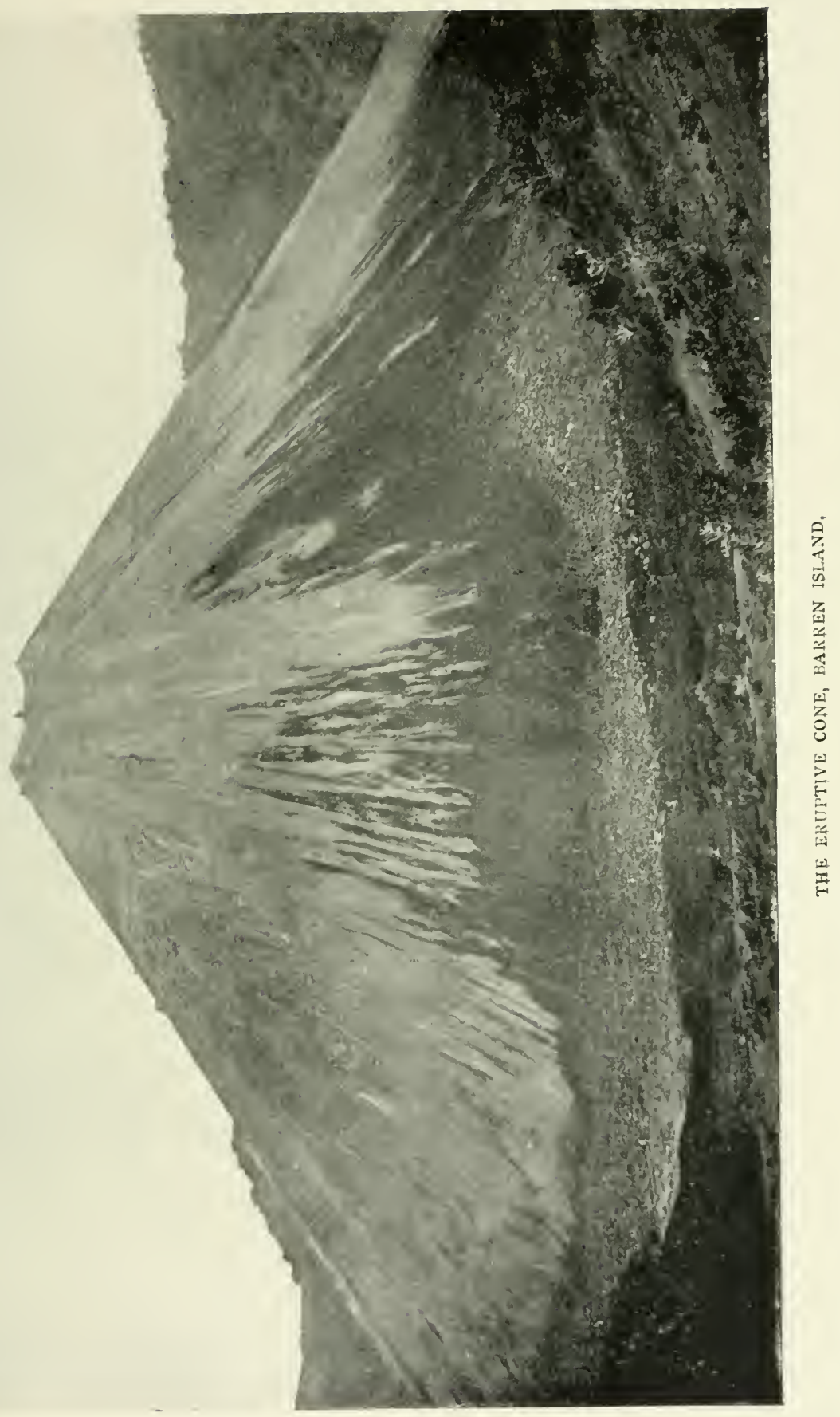

[To face page 12. 

the remaining sides, composed mainly of volcanic ash, afford foothold only to a coarse tussocky plant growing in clumps on the loose black dust. We found these latter slopes not at all an attractive scene of operations, for the feet sank and slipped at every step, and raised at the same time clouds of fine black dust.

During the day the heat in the interior was extreme, for the sun's rays beat down upon, and were reflected from, the dark slopes, while the wall of the crater completely cut off any sea breeze. IVe did not ascend the cone, for our stay was to be short, and we wished to investigate the fauna as fully as possible; but from reports of the visits paid to the island once every three or four years from Port Blair, it would seem that the slight signs of activity still existent consist of an issue of steam and the continued sublimation of sulphur; while of the two cones which form the top, one is cold, and already bamboo grass and ferns are beginning to clothe the entire summit. There is ample proof in those details which have been recorded of the island during the last century that the volcano is rapidly becoming quiescent, and is indeed, perhaps verging on a condition of extinction, as has long been the case with Narkondam.

Captain Blair, who passed near in 1795 , writes of enormous volumes of smoke and frequent showers of red-hot stones. "Some were of a size to weigh three or four tons, and had been thrown some hundred yards past the foot of the cone. There were two or three eruptions while we were close to it; several of the red-hot stones rolled down the sides of the cone and bounded a considerable way beyond us. . . Those parts of the island that are distant from the volcano are thinly covered with withered shrubs and blasted trees."

A few years later Horsburgh records an explosion every ten minutes, and a fire of considerable extent burning on the eastern side of the crater. In the next thirty years, the

remote from the cone (Blair): while as late as 1866 there were no trees of any height, but on the slopes and ridges abundance of bushes, some rising 20 feet (Report of the Andaman Committee). 
subterranean forces had considerably diminished in activity, and at the end of that period only volumes of white smoke with no flame were to be seen. Drs Mouat and Liebig, who visited the island within a few months of each other in 1857 , write respectively of volumes of dark smoke, and clouds of hot, watery vapour. In I866, a whitish vapour was emitted from several deep fissures, and about I\$90, steam was seen to be issuing at the top from a sulphur-bed, which was liquid and pasty, and a new jet was coming from a lump on the sloping side of the cone; while the sole evidence of activity now to be observed is the deposition of sulphur, and an escape of steam that often condenses on the surface rocks.

Concerning the fauna of the island, birds-inside the crater - were not numerous: commonest were a little white-eye (Zosterops palpebrosa), and the Indian cuckoo, which swarmed everywhere, its loud cries, "ko-el, ko-el," resounding in all directions. The only mammals other than the goats were rats, which, while of one species (Mus atratus, sp. nov.), afford a rather curious example of range of colouring, for while many were of the usual brown shade, a great number were of a glossy coal-black, much resembling in tint the lava and volcanic dust in which they made their homes. The island is everywhere riddled with their holes, but though so numerous, the landcrabs may fairly claim to divide the place with them. Trapping for rats was a failure, for no sooner was one caught than it would be torn to pieces by the crabs, who in other instances would spring the trap long before the others were attracted by the bait.

Altogether we landed four times, but soon found that very little variety was to be obtained: the sea, however, swarmed with fish, and many fine catches of rock-cod, trigger-fish, and mullet, 20 to $70 \mathrm{lbs}$. in weight, were made by the crew.

Late one evening we left Barren Island, and with a fair though moderate breeze, which, however, soon drew round against us, covered the 36 miles to the Andamans proper, 
and anchored before noon next day in the Kwang-tung Juru.

From a distance, all the islands of the Archipelago appear to rise to about the same height,-between 500 and 600 feet-presenting a fairly level sky-line from north to south, and with the exception of East Island, which shows a white sandy beach, all seem fringed with thickets of mangroves.

The strait, which is about a mile wide, separates the islands of John and Henry Lawrence, and with its smooth water and low banks, on which the veil of mangrove and jungle, extending to the water's edge, is broken at short intervals by small bluffs of pale clay shale, might easily, but for its brilliant blue colour, be mistaken for a quiet river.

We landed in the afternoon on the eastern shore, and at once set to work cutting a path, for here was the densest kind of Andaman jungle, and although within it one comes across little patches where the bush is fairly open, it is, on the whole, a wild tangled mass of trunks and branches, bound together by countless ropes of creeping bambon and thorny rattan.

Cutting right and left, avoiding a thick bush here and a hanging screen of creepers there, perspiring at every step, we forced a sinuous way in from the beach, until, coming upon a well-trodden pig-track, we found progress so much easier, that, with a little chopping now and again, we were able to move about with some degree of freedom, and along the path so slowly made, a long line of traps was set and baited in readiness for night.

Such a performance is one that regularly occurs during the first visit to each fresh locality in which one collects, and on these occasions the noise caused by chopping away branches and crashing through the bushes very naturally makes the denizens of the jungle conspicuous by their absence.

Afterwards, however, as you move quietly along the path, with all the faculties freely given to the detection of those various objects to the desire for possession of which your presence is due, the jungle seems a much less lonely place, and after days spent in wandering in its shade, during which a bit more path 
has been cut here, and a few more yards of open space added there, you find that you can take quite a long walk, entirely uninterrupted by use of the parang hanging at your side.

Among the few birds shot that first afternoon were the beautiful Andamanese oriole, with gorgeous plumage of black and yellow, and a peculiar cuckoo-Centropus andamanensis-soberly clad in brown and grey. This bird was a source of much disappointment on one occasion. There are no squirrels known to the Andamans, and seeing what I took for one, without waiting, in the momentary excitement of an apparently fresh discovery, to look more closely, I made a rapid snap-shot, and down tumbled a cuckoo; my consequent disgust may be imagined. The bird, however, can easily be mistaken for a small mammal, for besides resembling one, with its dark brown plumage and fairly long tail, its habit is to spring from bough to bough and creep along the branches in a very rodent-like manner.

Warned by the fading daylight, we returned to the shore, and found a quarter of a mile of dry coral between ourselves and the water, with the dinghy high and dry, so, after making it fast to the mangroves, we picked a way across the reef and hailed the schooner for another boat.

These coral-reefs, although their beauty of form and colouran endless change of myriad shapes and tints-when seen through the clear water from a boat above is quite beyond description, awaken far less admiration when they have to be crossed on foot while the tide is low. It is impossible for even natives to cross them barefooted. Nearest the shore comes first a belt of mud and coral débris that is easily traversed; next lies a broad strip of sharp and brittle madrepores which break and crumble beneath one's weight; while, seaward, rise from deep water the Astræasgreat solid masses of which the reefs are mostly built; and as one jumps from mound to mound, one vaguely wonders at which of those in front a slip may occur, and as the least result plunge one head over heels into the pools around. With a small boat, however, shallow and quick-turning, it is generally possible to pass through these latter and reach a point, where, protected by boots, 
the shore may be attained at the slight expense of a wetting below the knees.

To escape this unpleasant little journey, we moved a day or two later farther up the strait to where the shore was free from coral, and therefore more accessible, although having reached it, we were confronted by a precipitous cliff of crumbling earth, but when the top was gained, after a zigzag climb, we moved on level ground covered with heavy jungle.

The smaller species of birds were very rare here, but we got almost immediately the first specimen of the island parrotsthe brilliant green Palcornis magnirostris. This bird is the local representative of a continental form, from which it differs only in the enormous size of the bill, which in the male is of bright scarlet.

It is a somewhat callous thing to attempt to do, but should one succeed in only severely wounding a parrot, others of the species are sure to be obtained. The cries of the injured bird so attract its companions that they will gather near from all parts within hearing, and seem so possessed with curiosity to know what is wrong, as to be, for the time, perfectly oblivious of the collector and his gun, while they sit around or fly nearer and nearer to their wounded companion and answer its loud croaking notes with others equally harsh.

Parrots of three species were very numerous, and perhaps the most frequent noise in the jungle was their shrill scream, uttered as they flew from tree to tree. Many big black crows, too, flopped-a word which exactly describes their movement -noisily about, and, when hidden by a screen of leaves, we mimicked their cawing notes, more bewildered birds it would be difficult to find. In these woods the larger birds were fairly common, and the traps obtained for us numerous rats of two varieties, one of which squealed pitifully when approached (Mus stoicus, sp. nov, and $M$. flebilis, sp. nov.).

The Archipelago is inhabited by a tribe known as AkaBalawa, now on the verge of extinction, as it numbers only 
twenty individuals; but the sole traces of occupation we came across were the decayed remains of a canoe, lying up one of the mangrove creeks that branch off from the strait.

We remained here three days, all that could be spared from the time given to the cruise, and early on January I Ith left for Port Blair. 


\section{CHAPTER II}

\section{PORT BLAIR}

We enter the Harbour-Surveillance-Ross Island Pastimes-Visit the Chief Commissioner-The Harbour-Cellular Jail-Lime Kilns-Phœnix BayHopetown-Murder of Lord Mayo-Chatham Island-Haddo and the Andamanese-Tea Gardens - Viper Island and Jail-The ConvictsOccupations-Punishments-Troops-Departure.

A FRESH breeze from the north raised an army of dancing white-caps on the sea, as, rolling along with the wind astern, we made the run to Port Blair in about seven hours.

Easily picking up the Settlement while some distance off, on account of its proximity to Mount Harriet-a pointed hill rising about I 200 feet-we came to anchor to the south of the jetty inside Ross Island, and were immediately boarded by one of the native police-a representative of which body was always on board during the day throughout our stay. This measure is taken to see that the crews of vessels in the harbour hold no communication with the convicts, and also for the prevention of smuggling.

Soon afterwards the doctor and port officer came aboard: both these gentlemen seemed at first to regard us with some suspicion, and indeed by this time, more than two months out from port, we were certainly a rather ruffianly looking party.

The island of Ross is situated at the mouth of the harbour, and tends greatly towards its protection. It is hilly, about 200 acres in area, and is divided into two almost equal parts by a wall running east and west across it; the southern portion is occupied by the barracks of the convicts, and the other contains the headquarters of the Settlement. 
On the summit stands the pleasant-looking residence of the Chief Commissioner; the church, and the barracks (architecturally modelled on Windsor Castle) for European troops; both the latter built of a handsome brown stone quarried on the mainland. Below these come the mess, containing a fine library and some beautiful examples of wood-carving executed by Burmese convicts; then the brown-roofed bungalows of the Settlement officers, all bowered in tropic foliage, amongst which graceful palms and traveller's trees stand prominently forth; and lower still, near the sea, are the treasury, commissariat stores, and other Government buildings. The whole place-in itself of much natural beauty-is kept in most perfect condition by a practically unlimited supply of convict labour.

At first sight, it seemed an altogether delightful spot to find in such an isolated corner of the earth; but its melancholy aspect is quickly and forcibly brought home to one by a visit to the jail on Viper Island, and by the continuous presence of the convicts, who are rendered conspicuous by their fetters, or neck-rings, supporting the numbered badges by which the wearers are distinguished.

As usual with our countrymen, "when two or three are gathered together " in distant portions of the world, plentiful facilities for outdoor amusements have come into being. There are cricket and tennis grounds-the latter both concrete and grass-near which a band of convicts discourses very fair music several times a week. There is a sailing club too, and nearly every Saturday throughout the year races for a challenge cup are held in the breezy harbour, at which a score of various craft are often found competing; and the Volunteer Rifle Corps has some thirty members, who compete with gun and revolver for a numerous list of prizes and trophies. Good salt-water fishing is to be had with the rod, for fish in great variety are everywhere abundant; and on the mainland, near Aberdeen, golf and hockey are played.

With all this, it is probable that the gentler sex find things somewhat dull at times, for shopping, in the feminine sense of 


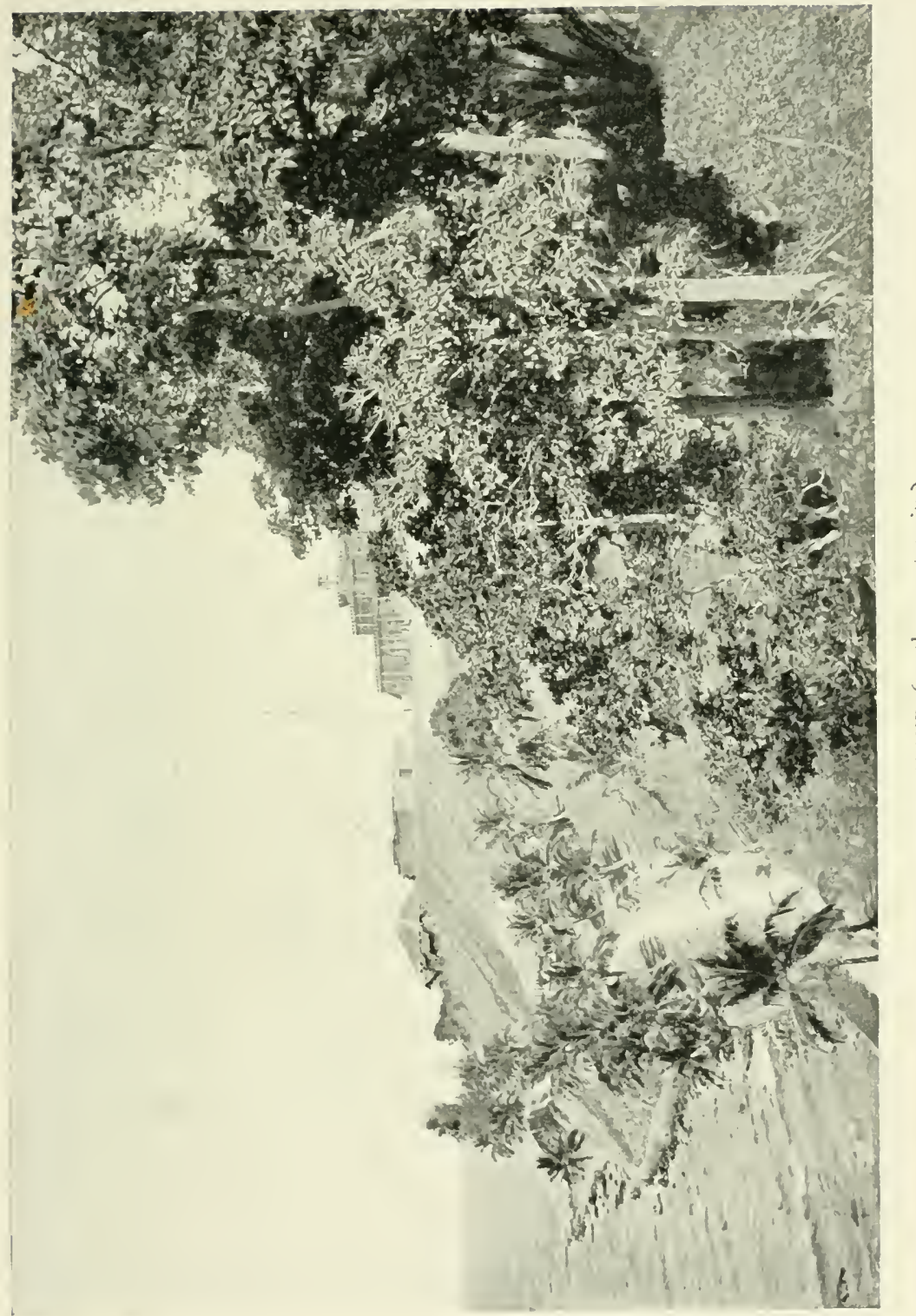

[To fuce page 20 . 

the word, is impossible. There are no shops, and the wants of the community are supplied by a co-operative store, at which, it is reported, in more than one year recently, articles have been sold at a price considerably under cost. Besides this, there is only the native bazaar, which is, of course, ubiquitous in the East.

Before visiting the Nicobars, it is necessary for all vessels to obtain a permit, so, in duty bound, we called one morning on the Chief Commissioner, and to him we are indebted for much information that became valuable in the next few months.

Colonel Temple, who takes much interest in the natives of his district, particularly from a philological standpoint, possesses a very complete ethnological collection of Andamanese and Nicobarese articles, and an aviary containing a great number of the birds inhabiting the two groups of islands. All these objects we were fortunate enough to see, and so gained at the outset a very good idea of those things we were so anxious to obtain specimens of for ourselves.

One morning, in the company of Mr P. Vaux, acting port officer, we made a delightful tour round the harbour in one of the Government launches.

Port Blair is a long, ragged indentation, about seven miles from head to mouth, broken and diversified by numerous little bays and promontories. The shores-intersected by numerous roads - are almost entirely cleared from jungle, and since they have been in this condition, fever has been practically unknown amongst the European community.

Passing first close by the suburb of Aberdeen, which is on the mainland just opposite Ross, we obtained a good view of the Cellular Jail, a huge building of red-brown bricks, with long arms-three storeys in height-stretching from a common centre like the rays of a starfish. It has been built almost entirely from local resources, and with local establishment and labour, and holds 663 cells and the accompanying jail buildings. Here each newcomer is incarcerated in solitude for six months, with the double intention of such confinement acting both as a 
moral sedative and a warning of what may happen again if his behaviour is not satisfactory in future.

We steamed along past the brickfields; the kilns, where, from the raw coral, lime is manufactured; but as the salt cannot be thoroughly washed out, and subsequently effloresces from the mortar, the result is a rather inferior quality.

At Phœnix Bay, a little farther up the harbour, where we landed to inspect the shipyard and workshops, are sheds fitted up with apparatus for blacksmiths and latheworkers, carpenters and woodcarvers, where occupation is provided for more than 600 skilled workmen. The numerous boats one sees passing to and fro in the harbour are built here, for the shipyard can undertake anything from a 250-ton lighter or 70-feet steamlaunch down to a half-rater or the smallest dinghy. The materials for construction are close to hand, since the woods used (padouk for the planking and pyimma for frames) are obtained from the neighbouring forests.

Some years ago Phœnix Bay was a swamp, but now large, brick, steam workshops and wooden sheds of the marine yard, in which the lighters and launches are constructed and repaired, stand on the land reclaimed; and connected with these is a slipway, one of the largest in India, that is entirely of local construction-the whole of the ironwork of the carriage, rails, wheels, and ratchet, having been cast on the spot.

Almost opposite Phœnix Bay, the station of Hopetown, conspicuous by its aqueduct, stands on the northern shore. It was here that in 1872 Lord Mayo, the most popular of Indian Viceroys, was murdered by a fanatical prisoner.

The Viceroy had visited Mount Harriet in order to judge of its suitability as a sanatorium, and had just finished the descent. ". . . The ships' bells had just rung seven; the launch, with steam up, was whizzing at the jetty stairs; a group of her seamen were chatting on the pierhead. It was now quite dark, and the black line of the jungle seemed to touch the water's edge. The party passed some large loose stones to the left of the head of the pier, and advanced along the jetty, 


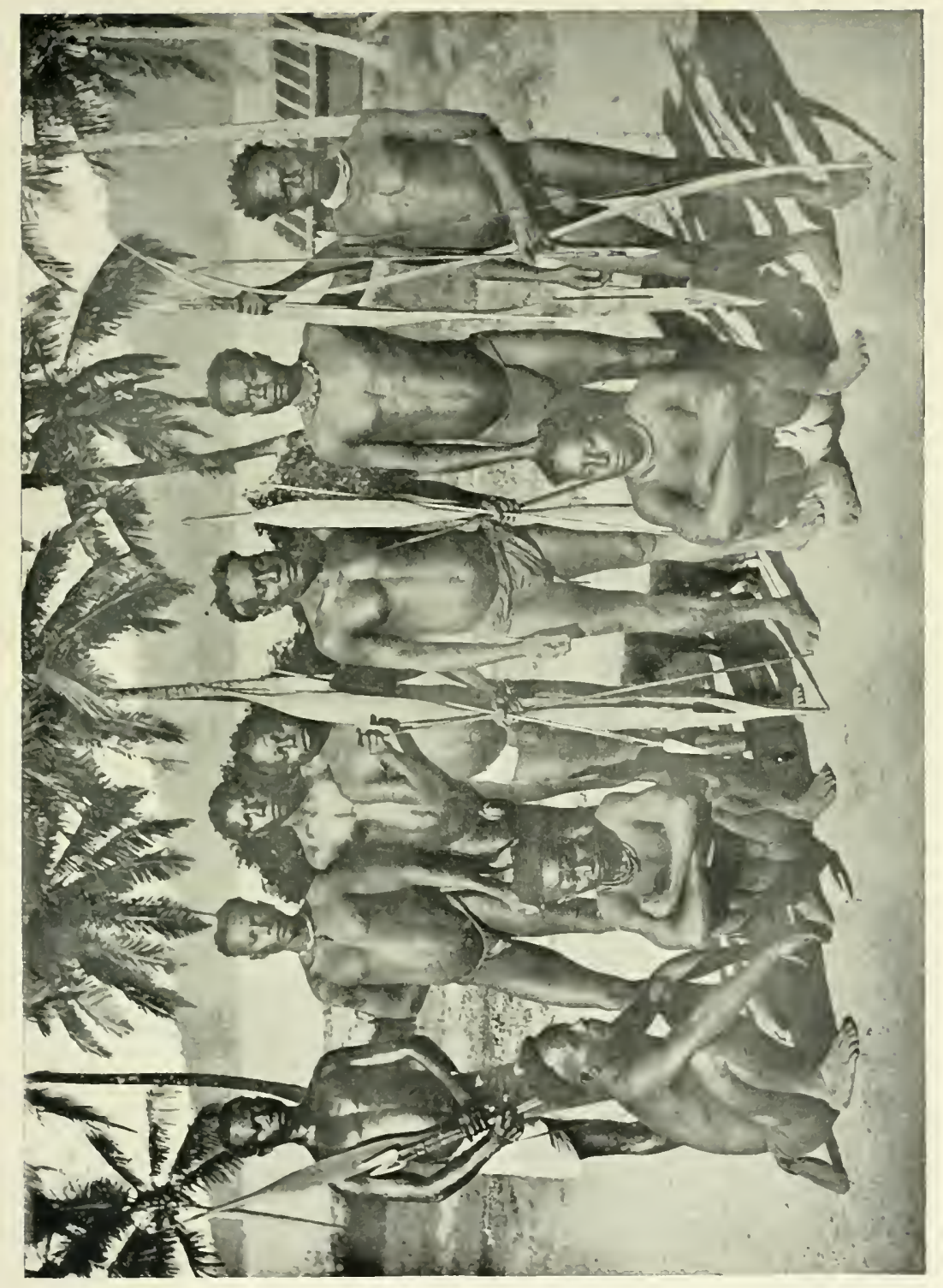



two torchbearers in front ... and the Viceroy stepped quickly forward before the rest to descend the stairs to the launch. The next moment the people in the rear heard a noise, as of 'the rush of some animal,' from behind the loose stones; one or two saw a hand and a knife suddenly descend in the torchlight. The private secretary heard a thud, and instantly turning round, found a man 'fastened like a tiger' on the back of the Viceroy. In a second, twelve men were on the assassin; an English officer was pulling them off, and with his sword hilt keeping back the native guards, who would have killed the assailant on the spot. The torches had gone out; but the Viceroy, who had staggered over the pier side, was dimly seen rising up in the knee-deep water and clearing the hair off his brow with his hand, as if recovering himself. His private secretary was instantly by his side in the surf, helping him up up the bank. 'Burne,' he said quietly, 'they've hit me.' Then in a louder voice, which was heard on the pier-'I'm all right, I don't think I'm much hurt,' or words to that effect. In another minute he was sitting under the smoky glare of the re-lit torches, on a rude native cart at the side of the jetty, his legs hanging loosely down. Then they lifted him bodily out of the cart, and saw a great dark patch on the back of his light coat. The blood came streaming out, and the men tried to stanch it with their handkerchiefs. For a moment or two he sat up in the cart, then he fell heavily backwards. 'Lift up my head,' he said faintly; and said no more." *

Leaving Phœnix Bay, we steamed past Chatham Island, where the sawmills are situated, and where a number of hospital convalescents are kept busy with the easy task of manufacturing rope and mats from the coir prepared in Viper Jail. On the approach of a hurricane, vessels in port proceed up harbour and anchor above this island, where they are secure from all danger.

Our next stopping-place was at Haddo, where we visited the Andamanese in their Homes, and out on the water saw a number of natives fishing from canoes.

* Rulers of India Series-The Earl of Mayo, by Sir W. W. Hunter. 
The sheds in which the aborigines are domiciled are substantial structures of attap, standing near the sea in the shade of coco palms. We found present eight or nine women, and twice that number of men and boys, who, on catching sight of our advance, ran out of doors to meet us. Two or three babies present were carried by the mothers in a broad band suspended from forehead or shoulder. The first thought that flashed into one's mind on perceiving them, with their small stature, sooty skins, and frizzly hair, was that here were a number of juvenile negroes ("niggers") : they are, however, far better-looking than that people, and some of the women might almost be called pretty, even when judged from a European standpoint.

For clothing, the men wore breech-clouts of red cotton, and strings of beads or small shells about the neck: the ornaments of the women consisted of similar necklaces, and several girdles of beads or bark, in the lowest of which a green leaf was inserted, by way of apron. The hair of the women was slightly shorter than the men's, but worn in a similar fashion-all but a circular patch on the top of the head, like a skull-cap, was shaved away, and this was often divided by a broad band of bare skin running from back to front. Chest and back were covered with skin decoration of the cicatrice type, which, healing without any tendency to keloid, left a smooth mark, distinguished by its lustre only from the normal surface. Many had smeared themselves with fat, which gave the skin a very shiny appearance.

The bows carried were of the recurved paddle type that attains its greatest development in the Andamans, ${ }^{*}$ and the arrows were armed with formidable iron points and barbs: the heads of these are detachable, and are connected with a shaft by a short cord of fibre, which is wound about the arrow by twisting the head in its

\footnotetext{
* A somewhat similar weapon to this remarkable bow is found among the Oregon Indians, and also seen in the composite bow of the Eskimos, while a thircl, still more closely approaching it in appearance and principle, is found in New Ireland and the New Hebrides.

An interesting account of the Andamanese bow, with a series of photographs showing the various stages of construction, has been contributed by Mr M. V. Portman to the Archery volume of the Badminton Library.
} 


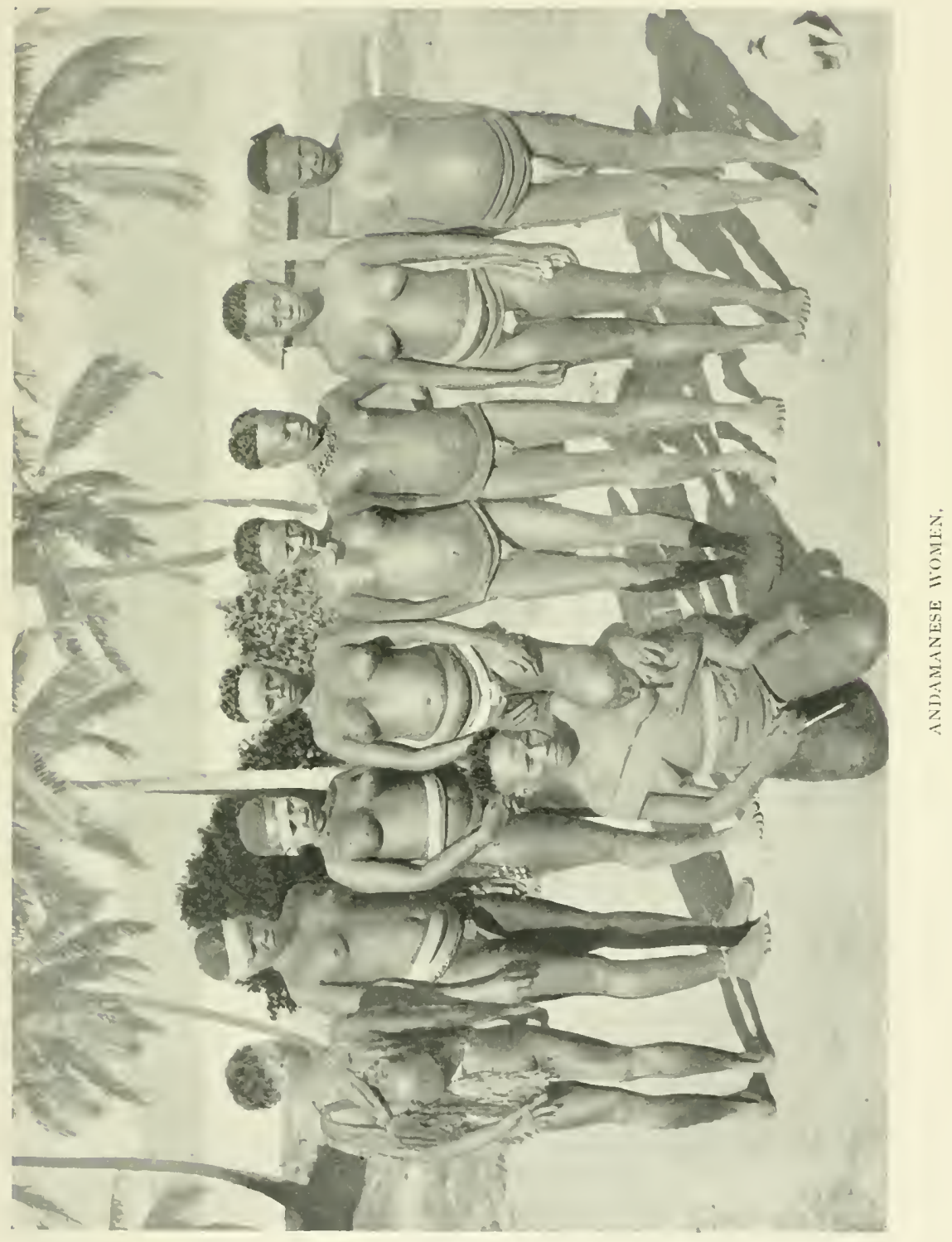



socket. These arrows are used in shooting pig, and of course much impede the escape of any animal, by the shaft disengaging from the head and catching in the undergrowth of the jungle. The bows were constructed of white wood, and handled with the recurved end downward.

The foreheads of some of the women were daubed with white clay, and one, in addition to a quantity of coral ornaments, wore suspended from her neck a human skull daubed with red earth. This, however, is not, as was long supposed, a sign of conjugal mourning, for any of the relatives or intimate friends of a deceased person are qualified to wear his disinterred bones, and the skull often passes round amongst a considerable number of people.

We were agreeably surprised at the appearance of the natives, as they were clean, pleasant-looking, and merry, apparently somewhat childish in disposition, and much given to chatter and laughter.

On leaving, we flung a number of small coins amongst them, and these were scrambled for with great noise and excitement.

The Homes are occupied from time to time only by the natives, who are allowed to go and come as they please, and while dwelling in them are supplied with provisions. Love of the jungle, and the life to which they are born, is so deeply rooted in the aborigines, that although they occupy the sheds intermittently for varying periods, few have been found who are sufficiently attracted by the neighbouring civilisation to become permanent residents.

As we proceeded up the harbour we caught a glimpse, at the head of Navy Bay, of the tea gardens which have for some time been established there. The product is very coarse and strong, and finds favour with the European troops in India, and with the Madras Army.

Lastly we came to Viper Island, which has been not inappropriately christened "Hell," for in Viper Jail are kept the very worst of the prisoners in the Settlement, and it must not be forgotten that here are collected the scum of the whole immense Indian Empire and of Burma as well. No one is 
sent to the islands who has less than seven years to serve, and many here, perhaps, are those, who, but for some flaw in the evidence which convicted them, might long ago have paid the last penalty for their crimes.

Viper Island is elevated in parts with a somewhat broken surface, and the Jail, with its grey-and-white walls, standing among a group of trees, shows picturesquely from the summit of a hill. A number of convicts are confined to the island, besides those in the prison, and to accommodate them barracks have been erected in various spots.

We landed on a jetty, and, passing by the guardhouse at its foot, soon climbed the little hill, on the top of which the prison is situated. First, and grimmest sight of all, came the condemned cells and the gallows, and then we passed-accompanied by a guard of police-through room after room full of men reclining on slabs of masonry. The shackled inmates of these wards, who rose unwillingly with clanking irons at the word of command, are under the control of promoted convicts made responsible for their behaviour. The effect of our entrance varied with different individuals; some, apparently apathetic and sullen, took no notice whatever, while others seemed to evince the liveliest curiosity.

As the day of our visit was a Sunday, no work was being done: all the inmates were undisturbed, save a few whose heads were being cropped, and some convalescents receiving their midday ration-a chapáti, and an ample portion of coarse boiled rice.

The scope allowed for employment in the prison is somewhat limited, for, while the work must be of sufficient severity to act as a punishment, it must of necessity be of such a nature that the tools accessory to it are not of a kind that can be used by those handling them in an attack on jailers or fellow-prisoners. Among the tasks set are coir-pounding, in which a certain quantity must be produced and made into bundles every day: the heavy mallets used are fastened, for safety, by a short lanyard to the beam on which the husk is broken up. Again, 
oil has to be expressed from a given weight of copra by pounding the material in iron mortars with unwieldy wooden pestles. Wool-teasing is yet another form of occupation.

Besides the wards, there are a number of cells for solitary confinement; some of these were occupied by prisoners suspected of malingering, others by those awaiting punishment.

This last, of course, takes various forms, from-for instancethe dark cell, where an offender may be incarcerated for twentyfour hours, to castigation with a rattan, in which, it is said, the maximum sentence of thirty strokes can be applied so severely as to be fatal to the recipient. Lastly, of course, comes execution by hanging, which is inflicted in the case of those prisoners, who, being already under severe sentence, attempt the lives of their fellows, their warders, or the officials of the Settlement.

The transportation of European offenders is now discontinued, but a large number of female convicts are engaged mainly in turning the wool prepared in Viper Jail into blankets.

Caste-a most important point in connection with people of India-is carefully respected, and the Brahmin prisoners are nearly all employed as cooks.

The majority of the convicts are from the Indian Peninsula, and are resident for life. Of the Burmese, however, the greater part are serving sentences of ten years, for engaging too recklessly in the national pastime of dacoity, and many of them are employed in the jungle and as boatmen.

To maintain discipline, and for the protection of the Settlement, a military force of about 440 men is stationed at Aberdeen, Ross, and Viper - two companies of European and four of native troops-and a battalion of military police.

After leaving Viper Island we returned to the headquarters of the Settlement, where next day we left behind the last post of civilisation met with, until three months later we reached Olehleh, the most northerly of the Dutch colonies in Acheen. 


\section{CHAPTER III}

\section{MACPHERSON STRAIT-SOUTH ANDAMAN AND RUTLAND ISLAND}

Gunboat Tours-South Andaman-Rutland Island-Navigation-Landingplace - Native Camp-Natives - Jungle - Birds - Appearance of the Natives-Our Guests-Native Women: Decorations and Absurd Appearance-Trials of Photography-The Village-Food-Bows, Arrows, and Utensils-Barter-Coiffure-Fauna-Water-New Species.

AfTER leaving Port Blair, where we got up anchor at half-past three in the morning to make the most of a light breeze, we sailed slowly along the coast of South Andaman, until, rounding the point of the south-east corner, we came to anchor in Macpherson Strait.

Just outside the port we met the R.I.M.S. Elphinstone returning from a census-taking visit to the Nicobars; three or four times a year she makes a ten days' trip round the group, stopping at a few of the more important places; and these cruises are almost the only thing that brings home to the natives the fact that they are under the British raj.

For some distance south of the Settlement the land consists of undulating grassy hills, dotted with coco palms, and streaked by gullies, in which dark clumps of jungle still remain. It is an ideal country for game, and some years ago hog-deer were introduced; but, although they have multiplied, they are very rarely seen, and have afforded but little sport.

Nearer the strait, the hills by the coast are still covered with forest; and between the stretches of sandy shore at their feet grow luxuriant thickets of mangroves. 


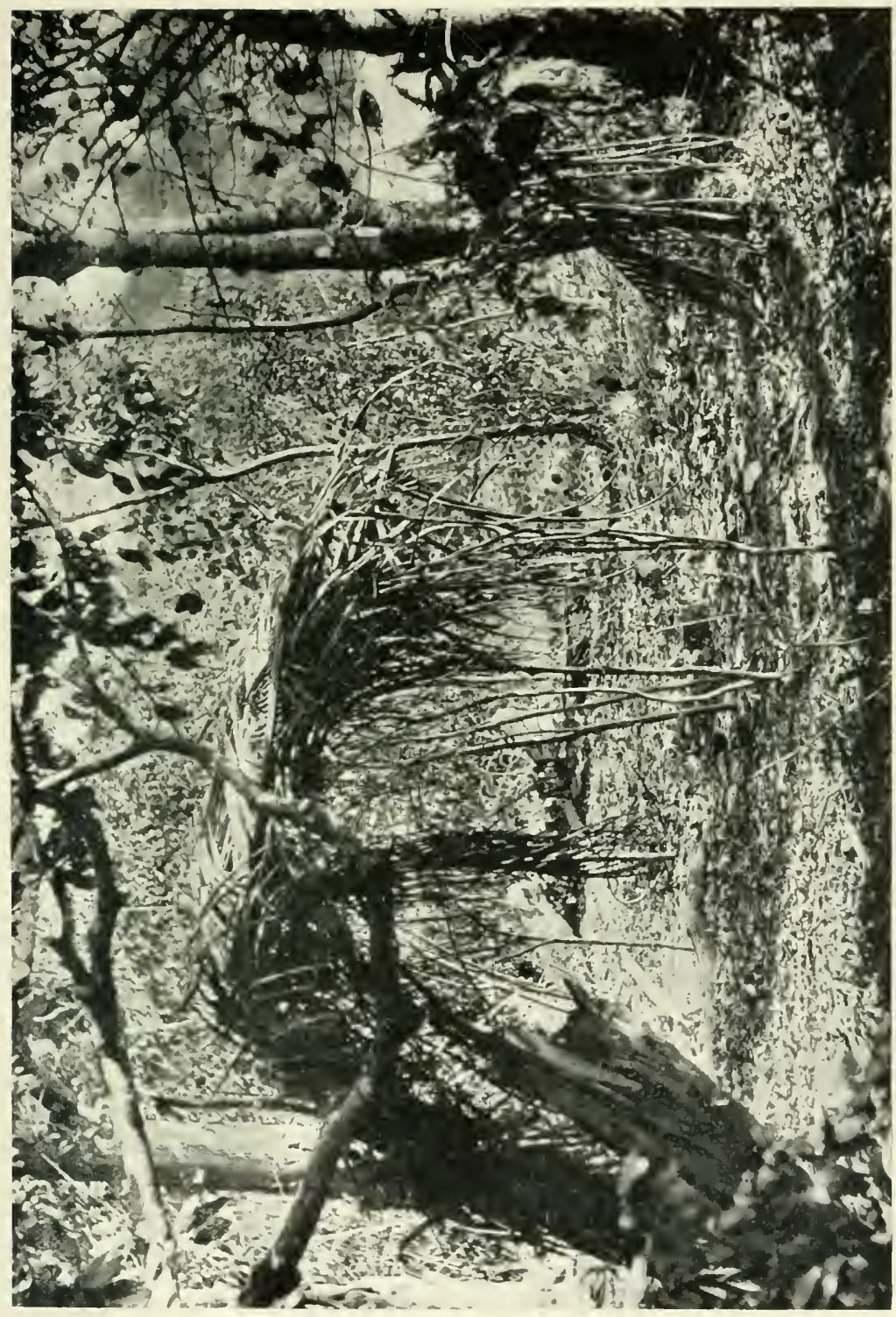



Rutland Island, rising on the east in tall precipitous cliffs, on the north slopes gently to the strait, which on both sides is bordered by alternate tracts of yellow beach and bright green mangrove.

We hauled round Bird's Nest Cape-a bare rocky headland of serpentine, still producing those edible delicacies which are responsible for the name-and, with a man aloft to con a passage along the coral-reef, carefully avoided a rock near midchannel, and took up a berth in quiet waters about a mile from the entrance of the strait.

When sailing along little known shores, especially in the tropics, a look-out man should always be stationed at the masthead, for from that place dangers of reef and rock unnoticed from the deck are plainly visible. Year by year coral-reefs increase, and banks alter so greatly that entire reliance cannot be placed on the chart, even though it be of comparatively recent date.

We landed on South Andaman in a little bay, whose waters lapped a beach of golden sand. It was, as usual, nearly filled with coral, but fortunately the tide was never so low that we could not land directly on the shore. To left and right the land rose in gentle hills, on the one hand forest, and on the other grass-clothed, but beyond the centre, where it was flat, lay an expanse of tangled swamp.

Although their tracks, made since the last high tide, ran all along the beach, we saw no natives then or later; but just within the bush we found an old camping-place-cold ashes, heaps of broken shells, and a dilapidated hut about 6 feet square and high, made of light branches stuck in the ground, with tops drawn together and covered with a few palm leaves laid stem downwards.

That night a fire shone brightly on the beach of Rutland Island; and so next morning, while Abbott in the dinghy went north to make the round of the traps, I, with a crew in the whaleboat, rowed across the strait, and when we were within two or three hundred yards of the shore, a tall native ran down the 
beach and commenced waving a flag on the end of a long pole.

As the sea was pounding heavily on the reef, a couple of men were left in the boat to keep it off shore, and the rest of us, jumping overboard, waded to the beach. Two or three other natives now arrived, and we showed our good intentions by slapping them on their backs, with broad grins, to the latter part of which process they responded most heartily.

It was too early in the day to get to work with the camera, so, after fetching my gun from the boat, I struck into the jungle and spent an hour with the more clothed of its inhabitants.

The jungle was of the kind that may perhaps be best described as forest: that is to say, it was fairly free from the usual superabundance of rattans, lianas, and all those creeping growths which close the intervals among the trees with a thorny network of vegetation, and compel the intruder to go where he can and not where he will. Mighty trees towered upwards, branches interlacing and shutting out the sun, while down below, in the aisles of tree-trunks, stood the smaller brethren and the saplings, waiting the fall of some neighbouring giant to give them in turn room to lift their branches towards the light.

Little blue fly-catchers, utterly fearless, flitted about in the lower bushes, and, higher up, golden-billed grackles hopped or flew from branch to branch, their loud clear whistles resounding through the forest, whilst from the tops of the biggest trees came the deep "boom, boom," of the great fruit-pigeons. However, although birds were fairly numerous, I got but few prizesbest among them, perhaps, a pretty little olive-green and yellow minivet (Pericrocrotus andamanensis), and a black racquet-tailed drongo (Dissemuroides andamanensis), a bird whose flight, as its long tail feathers stretch out behind, is extremely graceful, and who possessed one of the sweetest combination of notes heard in the jungle.

With such specimens in my bag, I presently came on a 
little stream, and after following its course to the sea, tramped along the shore, and so came back once more to the boat.

A large fire had been made on the beach, and near it, in spite of the hot sun, the men sat fraternising with the members of the native party-five men and boys, three women, and three children.

In this little company there proved to be the three biggest men we saw among the Andamanese; in height they stood 5 feet $4_{\frac{3}{4}}^{\frac{3}{4}}$ inches, 5 feet $3 \frac{1}{4}$ inches, and 5 feet 2 inches respectively.* Although possibly a little weak proportionately in the legs, where the skin covering the knee was so thickened and corrugated as to almost resemble callosities, the members of the party were well built and not ungraceful, but spoilt in most cases by a varying degree of distension of the abdomen: this state of things is caused by the immense amount of food they will, when possible, consume at a sitting; but the striking appearance of the eldest matron of the tribe was a more or less temporary feature, principally due to the interesting condition in which she was.

It was a pleasure to photograph these people, for they submitted to the operation most docilely; and when, after taking a series of pictures, I gave a graphic invitation to breakfastpointing to my mouth, and rubbing that portion of the figure situated in the middle front-the men of the party all accepted the offer, and, reinforced by them, we returned to the Terrapin.

Arrived on board, they were at first rather inquisitive, but after inspecting the schooner and spending a little time below watching us at work, they went forward, and seemed quite comfortable amongst the men. As soon as it could be prepared, a large pailful of boiled rice was placed before them, and this was finished without any sign of flagging being shown. What a convenience the absence of tight clothing must be at such times!

The next few hours were passed by them lying on deck in the sun, where, out of regard for their feelings, we left them

\section{* See Appendix F.}


undisturbed, except for the few moments during which they were measured. To a second bucket of rice, offered before they left, they failed to do proper justice, but took what remained ashore, where the women probably had their share.

We ran across the strait under canvas, before a light breeze, and the sail was a source of huge amusement to all but the youngest of the party, who was intermittently busied in returning to daylight all the food he had previously consumed.

Following what seems a wide-spread custom, the ladies ashore, had, to some extent, got themselves up for the reception of visitors. Although the previous dress-a small bunch of grass slung from the waist by a cord-fulfilled all requirements, they were now further decorated with an almost complete coating of ochreous clay, through which black eyes, nose, and lips showed below a bald pate with ludicrous effect. The babies, too, had been glorified in the same manner, and we felt quite bashful and shabby in our old pyjamas.

So absurdly comical did they appear, that it was only by much perseverance I was able to photograph them again, for whenever I attempted to adjust the focus, the picture on the screen gave rise to such fits of laughter that the camera was in danger of being upset. Even the boat's crew, unemotional Malays as they were, lay about, doubled up in paroxysms of laughter, which, increased by the looks of wonder and the ingenuous smiles with which my subjects persisted in regarding us, continued until the point of sheer exhaustion was reached. The old lady of the party and myself became great friends, and when on our departure I presented her with my handkerchief (all that I then had left) as a souvenir of our visit-as I gravely tied it about her head, I am sure we made an impressive picture.

The huts, or chang, were four in number, and stood side by side just within the jungle, with the fronts facing inland. On a sloping framework of thin branches, raised about 4 feet at the upper edge, and covering a piece of ground 6 feet square, 
were laid sufficient palm leaves to make a rain-proof shelter. The front and sides were left completely unprotected, the earth below was covered with more palm leaves, and a small fire was burning on the ground below an upper corner of each roof.

The only food they appeared to be supplied with was obtained from the large trees beneath which the camp stooda small round fruit with a green skin, and a pleasantly-flavoured pulpy flesh; a large quantity of dark-coloured beeswax was lying about, so honey was probably plentiful and easily obtained.

By signs, we gave the men to understand that we wished to purchase bows and arrows, and while these were being produced from some hiding-place in the jungle, whither the natives requested us not to accompany them, the women and children regaled themselves with a parcel of sugar which had been brought for their special benefit.

We eagerly bought up all visible belongings that could be carried off. Among these were small pots made from the joints of the giant bamboo, conical baskets of rattan fibre, and large buckets carved from solid wood, any cracks being sewn up with rattan and luted with wax; all these were furnished with slings for ease in carrying.

The bows were not of the kind regarded as typical of the Andamanese, but are fashioned in the style to which we are accustomed at home, with this peculiarity-that instead of the rounded side or "belly" being nearest the string, it is away from the archer when the weapon is held ready for use. They are about 5 feet long, and of a material resembling rosewood; the tips are cut away, so as to leave a shoulder for the string to rest on, and below these points the bow is whipped for an inch with fine cord. The string is of twisted fibre, with a loop at either end, made by taking a half-hitch and then twisting in the loose end for a short distance.

Arrows have the shaft of bamboo, to which is attached a long point of hard wood, and the joint is whipped. Some 
of the arrows used for fishing are triple-headed. A fairly deep notch is made to receive the bowstring, and the butt of the arrow is tightly scored transversely, with the idea of affording a better grip. The lengths varied from 45 to 66 inches.

While being strung, the bow is held almost vertically, with one end resting on the ground. A foot is then placed on the centre, and the upper end drawn towards the operator until the loop can be slipped over it.

The pull used may be anything between 50 and 60 lbs., and though in the jungle, with their silent step and quality of remaining unseen, the Andamanese are dangerous as enemies, in the open they would be less formidable, for it is doubtful whether their arrows will carry more than a hundred yards, and certainly their shooting, as we ourselves saw, possessed little accuracy at more than a quarter of that distance.

In return for the various articles obtained, we gave an axe, a parang, a file, a number of long French nails, and a quantity of red cotton, with which things they seemed very satisfied; and we left behind, as a parting gift, a good supply of rice and leaf tobacco.

The dress of the women I have already described: their heads were bald, entirely shaved of hair. The men were only partially cropped, and what hair was left was short, and had much the appearance of a small skull-cap. Those who were ornamented with clay had applied it in long stripes down arms and body, and across the face, while for further decoration some wore a cord about the waist, or armlets of fibre tightly fastened round the biceps.

We found the shores of South Andaman a splendid locality for collecting. One morning in particular I remember. On landing we saw all about the beach the tracks of numerous pigs that had come down in the night to obtain a meal of the trepang, crabs, and molluscs left exposed by the ebb tide; and I had not been five minutes ashore before I knocked over an equal number of beautiful parrots ( $P$. faciatus), a species we found everywhere very common throughout the Andamans. 
A little group of coco palms, in a corner of the bay, marks a spring from which we obtained good water, and adjacent stood a small leafless tree, whose branches, however, bore quantities of a brilliant red blossom (Ixora, sp. ?). To this came birds in such numbers that I remained beneath it all the morning. Here I obtained our first specimens of the Andaman sun-bird, a tiny thing with olive back, blue throat, and yellow breast, and also one of the most beautiful of kingfishers (Halcyon saturatior), a glorious combination of bright chestnut, white, and vivid blues that one could never tire of admiring. Common was the little crested bulbul, clothed in black and white, with crimson ear-coverts, and equally so the brilliant-plumaged oriole, while the sleek-looking Andaman myna, soberly feathered in black and white, occurred in no small numbers. Indeed, birds came and went so quickly, that I was often hard put to it to select the proper cartridge, and frequently three or four specimens at a time lay waiting to be stowed away in the game bag.

Time and place combined to make a naturalist's paradise, and I did not desist from collecting until my stock of wool, paper, and ammunition were exhausted. It must not be thought, however, that such an experience is in any way common, for it is seldom that the work is so easy or the harvest so large.

Amongst the birds obtained on South Andaman was a pigeon that has since proved to be new (Osmotreron, sp. nov.); while, as far as mammals were concerned, rats of two speciesone hitherto unrecorded, Mus taciturmus, sp. nov., and $M$. andamanensis - were fairly common; and we were fortunate in obtaining a palm-civet, of the species peculiar to the islands, which for several nights had been committing depredations along the line of traps; and also a single example of a new shrew (Crocidura andimanensis). 


\section{CHAPTER IV}

THE CINQUES AND LITTLE ANDAMAN

Position of the Cinques - Anchorage - Clear Water - The Forest - Beach

Formation-Native Hut-Little Andaman-Bumila Creek-Natives-Flies

-Personal Decoration-Dress and Modesty-Coats of Mud-Coiffure-

Absence of Scarification-Elephantiasis-A Visit to the Village-Peculiar Huts-Canoe-Bows and Arrows-The Return Journey-A Slight contretemps-Andamanese Pig-We leave the Andamans.

THE channel that separates Rutland Island from Little Andaman is about 28 miles wide, and is everywhere less than 50 fathoms in depth. Several small wooded islets rise above its shallow waters, leaving in the centre, however, a clear stretch of sea - the Duncan Passage - which is sometimes traversed by ships passing through the Archipelago.

At the northernmost group of these islets, the Cinques, we spent a day, before visiting the coast of Little Andaman. The two islands, which are narrow and hilly, stretch for about 6 miles in an almost $\mathrm{N}$. and S. direction, and are almost joined by a reef of rocks awash at high tide; they are only 3 miles distant from the south-east end of Rutland Island, and 9 miles from Macpherson Strait. We anchored between the islands, in a little bay in the shore of the northernmost, with the reef of rocks to the eastward.

Here, as in all such islands where there are no streams or mangrove swamps, the water was excessively clear-so clear that we could perceive fish swimming amongst the coral, and the anchor lying on the bottom io fathoms below.

The forest on the southern and western shores presents a 
striking contrast to the jungle of the other islands, and bears witness to the strength of the south-west monsoon. The slopes of the hills are scantily covered with grass, and on the lower ground, amongst the starved and twisted trees, numerous dead branches show white against the scanty foliage of the other wind-warped limbs. Below, the effect is stranger still, for the shrubs and bushes grow in rows running inland from the beach, so that one can walk up and down between them as in the lines of an artificial plantation.

The beach on which we landed was composed entirely of white coral sand, and upon it we found graceful branches of a brown and white coralline (Isis hippurus), and numbers of pearly-chambered spirulas. After forcing a way through the matted foliage, we reached the more protected parts of the island, where the jungle was of a more luxuriant description; but animal life was very scarce everywhere, and our list of the avifauna contains the names of ten species only.

There are no permanent inhabitants, but the Cinques are occasionally risited by the natives (Öngés of Little Andaman and natives from Port Blair), who probably find it a good locality for turtle and fish. We picked up in the jungle an arrow of a kind afterwards obtained at Little Andaman, and discovered a path that ran from south to north, where, on the shore of a little sandy cove, stood a hut similar to those already seen, save that sides had been added, thus making a semicircular shelter, and a small platform of sticks erected above the fircplace. A number of baskets hung from the roof, and for flooring, instead of palm leaves, there was an old teak grating and some planks-flotsam, perhaps, from a shipwrecked vessel.

At midnight a fair breeze sprang up and we made sail, crawling slowly southward by its help, until, twelve hours later, we dropped anchor off the coast of Little Andaman.

Eyubelong, as it is called by its inhabitants, the Öngés-a tribe, who, by their bows, absence of scarification, and other indications, seem to be closely akin to the Jarawas-is in shape an irregular ellipse, with an area of rather more than 250 square 
miles, and a level verdure-clad surface that rises gradually to a height of 600 feet in the interior towards the south. It has no harbour on its coasts, but on the northern shores two or three creeks run inland for short distances. We brought up off the northern of these, by name Bumila, which seemed to offer a well-protected anchorage; but when the boat was sent off with a sounding-line to make observations, we found that coral reefs, stretching from either side, so narrowed and complicated the entrance that it would be a task of some difficulty to take the schooner in, and one still more so to get her out, against the prevailing breeze. The lead, too, at low tide, gave the greatest depth as 8 feet, and even in the channel large coral heads rose irregularly from the bottom: it was, therefore, decided that we should make a short stay only, and that during it the Terrapin should remain outside.

Already a group of natives had gathered on the beach, all waving bunches of leaves, and since we had been warned that all the tribes but those at the north end were still hostile, we concluded that this particular band were displaying that token of friendship common to nearly all savages-the green branch of a tree. Very soon, however, we found that the waving leaves were for a far more practical purpose, and that the creek thoroughly deserved its name. Bumila is S. Andamanese for "fly," and I don't think I ever saw so many of those pestiferous insects together at one time. They swarmed round the natives and settled on their naked bodies in hundreds, and no sooner had we landed than we were assailed in so impartial a fashion that we quickly followed the example of the inhabitants and supplied ourselves with defensive branches.

The Andamanese were quite friendly-although they are said to be treacherous and scarcely to be trusted in the southwestern portion of the island-so, after a short survey of the creck, we returned to the Terrapin, accompanied by a legion of flics, together with as many natives as the boat would hold, and the latter were soon at work on as hearty a meal as that made by their countrymen at Rutland Island. The party met 
at Rutland Island were also Öngés and were merely visiting Rutland Island on their way to or from Port Blair.

By the time we landed again in the afternoon, the number of waiting natives had increased to about thirty, and they continued to arrive until between sixty and seventy were present, of all ages and both sexes.

One of our party, who stands some inches over 6 feet in his socks, and is proportionately built, was a contrast to a group of natives, none of whom were more than 5 feet in height; and nothing impressed my mind more forcibly than this sight with the racial diminutiveness of the Negrito race.

By way of ornament, the men rang the changes on chaplets and armlets made from the inner bark of a tree, and necklaces and girdles of cord, in which was twisted some bright yellow material of a straw-like nature. Similar ornaments were worn by the women, who, in addition, wore for dress an apron, or bunch of a fibre resembling bass, suspended in front from the centre of the girdle. Everything but the aprons was freely parted with, but the modesty of the women was so strongalthough the men go completely unclad - that we could not obtain them until we thought of tendering sufficient cloth beforehand to serve as a skirt, and then, after draping this about themselves, they were able to remove the girdle without doing violence to their praiseworthy scruples. Both sexes wore also about the neck a small reticule or purse, of netted twine, which served as a hold-all, and often contained tobacco, pipes, and fruit.

Both men and women cover themselves with a thick wash of reddish clay, which, when fresh, gives them a very striking appearance. On one of the men thus ornamented, the coating was applied in this wise :-On the face a circular patch extending from brow to chin, but leaving nose and lips black; on the front and back of the body large elliptical patches, through which, while wet, the fingers were evidently drawn, leaving broad bands of four black stripes; the arms were covered to half-way 
down the forearm, and the wash was applied to the legs from mid-thigh to shin. Several natives, besides this simple adornment, were daubed on head and shoulders with a greasy mixture of red pigment and fat.

The heads of both sexes were in various stages between baldness and a covering of hair of fair thickness: they shave, however, before the tufts reach the spiral state seen in the natives frequenting Port Blair, and the hair is never allowed to attain any length on temples and nape. Like those seen at Rutland Island, their bodies were free from the tattooing or scarification so noticeable on the South Andamanese. The man who seemed to be chief of the tribe provided the only case of elephantiasis remarked among these islands: it occurred with him in a very mild form-merely a slight swelling of the left leg.*

Having taken a series of photographs, during which operation the women were the cause of much laughter, as they stood in a row before the camera, we started off westwards along the beach to visit the village and obtain more curiosities. We set a rattling pace along the hot sand, to see what the little people could do; but when, after travelling nearly four miles, we reached the huts they occupied, those who had started with us were still up, although they had to break into a jog trot now and then to keep their position. They moved with a very springy action, and a swing of the body from the hips.

The huts stand singly, at distances of several hundred yards from each other, just within the shade of the jungle where it comes down to the beach, and are very different in style and construction from the majority of those of the northern islands. They are built to the shape of a somewhat flattened cone, about I 3 feet high, and 30 feet in diameter. On a framework of light sticks,

* Scurvy is more prevalent on Little than on Great Andaman, perhaps owing to the low-lying swampy formation of the larger portion of the island. Hereditary syphilis is believed to be common among the Öngés, having been possibly introduced at some remote period prior to the occupation of 1858 . Whether it is to be traced to Malay pirates, or through the Jarawa tribes to the Settlement of 1789 , will never be ascertained, but, in coming to a conclusion, the Nicobarese must also be considered as a factor in the case. 


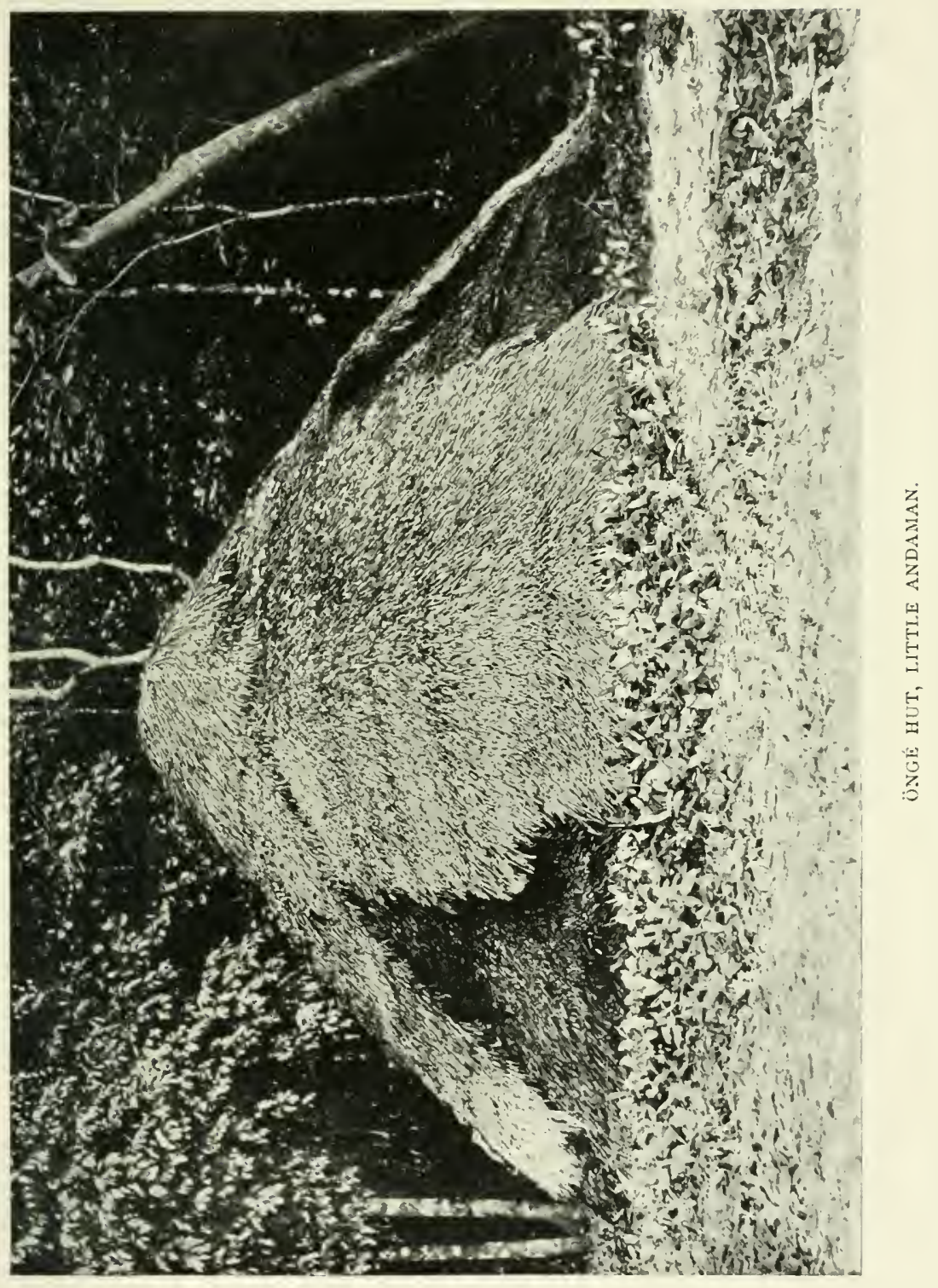



supported by twenty or more upright poles planted irregularly about the interior, a thick covering of large mats is laid. The mats are made by fastening the stripped mid-ribs of a species of fern-palm side by side with a rattan lashing after the style of a "chick," and then securing at right angles to the foundation thus constructed a thick layer of the pinne of the same plant. For doors, several of the lower mats are arranged to roll up, and leave an opening about 4 feet square. Sleeping platforms are formed by laying split bamboos lengthwise on a framework, measuring about 5 feet by 4 feet, which is raised above the ground on legs 6 to i 8 inches high. Each hut contains a number of such bed-places, and beside each of them were the ashes of a small fire.*

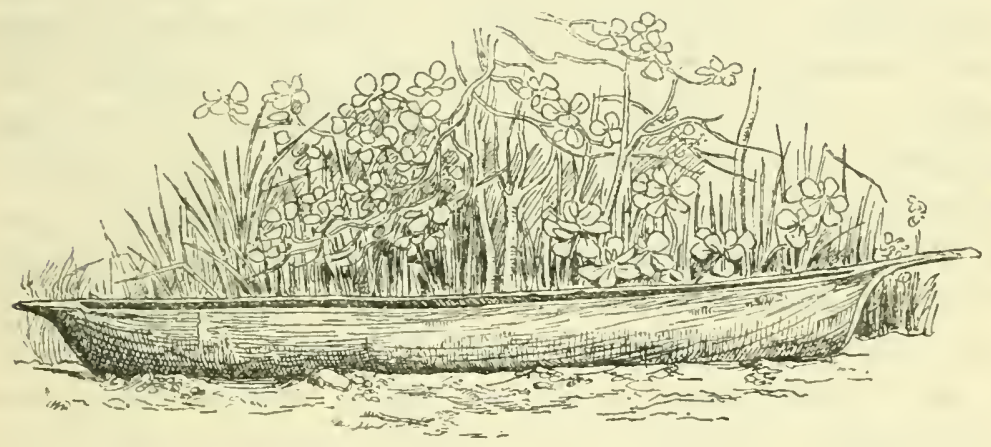

Little Andaman Canoe.

Near the hut lay a nearly completed dug-out canoe (of the wood of Sterculia campanulata), about 28 feet long by 3 feet wide and deep, of the usual Andamanese form, with sawedoff ends, and projecting platforms at bow and stern, forming convenient places to stand on when spearing turtle and fish. The sides were left about $\mathrm{I} \frac{1}{4}$ inches thick; and although the canoe was constructed from soft wood, even now, when they

* "The hut was of the usual type of Little Andaman dwellings, having raised platforms for the married people to sleep on; several large baskets were slung up to the roof, and two rows of pigs' skulls ornamented the walls, showing from their numbers (about 500) that there was no lack of food."-M. V. Portman. 
possess a few iron tools, such as small axes and files, the work must be one of painful slowness.*

Their bows and arrows were like those from Rutland Island: many of the former, however, were only 5 feet in length, while of the latter some, in addition to the hardwood tip, had a bent nail lashed on in such a way as to form both point and barb, and the butts of all were left smooth.

By the time we had finished at the encampment, night was drawing near, but fifteen or twenty men accompanied us when returning. In the growing darkness the journey back was far from easy: now we were ploughing through loose sand and climbing over fallen trees, now dodging among mangrove roots, or splashing thigh-deep through the water, which had risen with the incoming tide. In such circumstances the natives showed their superiority to ourselves by their agility in making a way amongst roots and fallen trees, and by either their better eyesight in the dark or familiarity with the path. Evidently they had come with the intention of accompanying us on board; for when the boat was reached, all got into it, and we had some trouble in persuading them to leave. The coral bottom at the anchorage was very bad holding-ground, and had it come on to blow, we might have been compelled to put to sea, in which case we did not wish to return. The natives were perfectly harmless, as they had no weapons; but we had no desire to leave an unpleasant impression for the benefit of future visitors, so had recourse to gentle measures only. All, however, clung to the sides and thwarts of the boat, and gave vent to a chorus of refusal, "Nai, nai," and the childish behaviour continued, until one, more hardly pressed than the

* The canoes are sometimes fitted with an outrigger, and it has been supposed that this has been adopted from some Point de Galle fishing-boat wrecked on the islands, for early writers never mention its existence (Sir H. Yule, Encyclopadia liritannica); but it is much simpler to conjecture it to be a copy of the same feature from the Nicobarese canoc. On the other hand, there is no argument against it being original, for the aborigines of New South Wales and Queensland have a canoe that is in every way almost the exact counterpart of the Andamanese vessel. 
others, jumped overboard with a yell of rage, when the rest immediately followed suit. We then found that a rowlock had been carried off; but when we turned towards the shore with the momentary idea of recovering it, the natives all disappeared into the jungle, so we rowed off with three oars, and reached the schooner about 7.30 I'.M.

Next morning, on landing to shoot, we found the little contretemps of the night before entirely ignored, for a party of natives was waiting for us at the creek.

Although, probably, not collected on before, the island, during the few hours we spent on it, produced nothing fresh in the way of birds. Abbott, however, bagged the pig peculiar to the group (Sus andamanensis), which, like the human inhabitants, is diminutive in stature. Our specimen, although a fullgrown boar, stood only 20 inches high at the shoulder, and was just double that in length of head and body. He was skinned on the spot, and the carcase, together with a viviparous shark we had caught during the night, and a quantity of red cotton, we presented to the natives as a parting gift, and then, shaking hands with them all round, we said farewell to the Andamans and put to sea. 


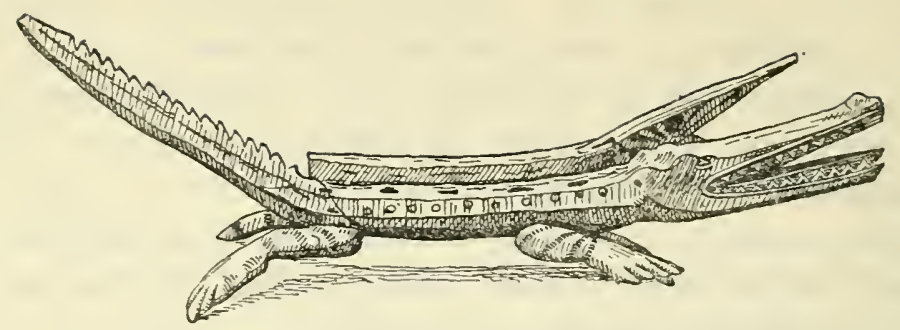

"Scare-deril," or device for exorcising evil spirits.

\section{CHAPTER V}

\section{KAR NICOBAR}

To the Nicobars-A Tide-Race-A Change of Scene-Sáwi Bay-Geological Formation-V. Solomon-Mūs Village-Living-Houses-Kitchens-FruitTrees-The Natives-Headman Offandi-"Town-Halls"-Death-HouseMaternity Houses-Hospitals-Floods-"Babies" Houses"-Birds-Oil Press-Canoes-Offandi-"Friend of England"- "Frank Thompson""Little John"-Thirst for Information-Natives" Nick-names-Mission School Boys' Work-A Truant-The Advantage of Canoes-A SpillOur Method of Landing-Collecting Native Birds-A new BatCoconuts-V. Solomon-The Nicobarese and Christianity-WaterArea of Kar Nicobar-Geology-Flora-Supplies.

" 2 Ist January" 1901.-The American yacht Terrapin anchored at Sáwi Bay about 7 P.M. I sent men to inquire about the vessel, and the gentlemen on board informed me that they had come via Port Blair, and would land early next morning.

"22nd January I90I.-Early this morning Dr Abbott and Mr Kloss landed and came to 'Temple Villa,' and gave me to understand the object of their visit. They remained here till the 27 th inst., and I gave them every possible help. They left the island well pleased with their visit. Many Nicobarese came from other villages with articles in the hope of purchasing rum, but they were sadly disappointed: as I had begged the gentlemen not to encourage the people with spirits, and they complied with my request."-From the diary of Catcchist $V$. Solomon. 


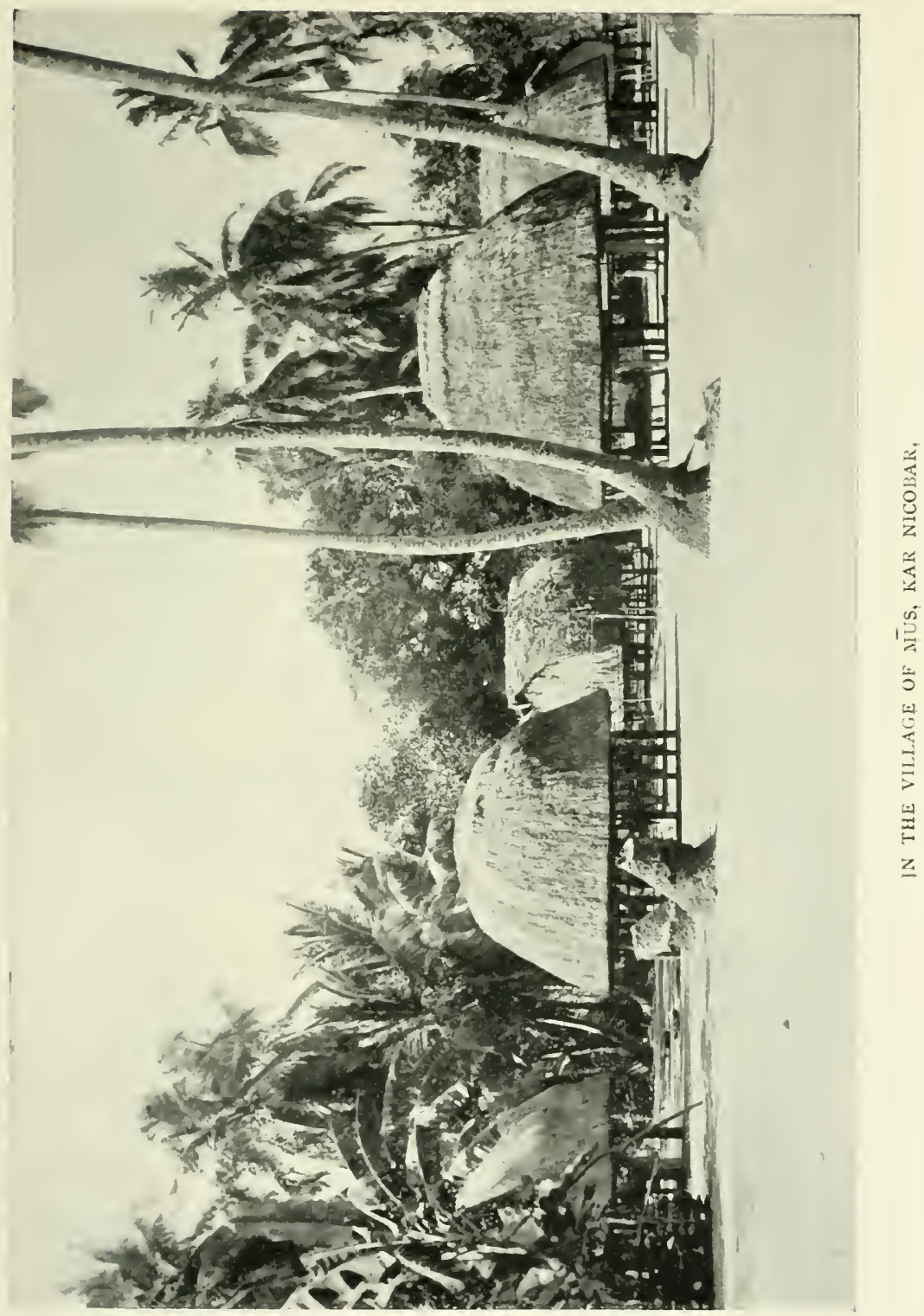

[To face page it. 

The wind was fair, but light, as, on 20th January I90I, we left Bumila Creek for the Nicobars, and we sailed slowly along the western coast of Little Andaman with the shore in full view. A sandy beach ran all along, with here and there a crop of rock breaking out, and behind it, stretching right across the island, spread dense unbroken jungle.

At distant intervals along the shore stood several of the peculiar conical huts, and as we proceeded southward the forest gradually assumed the grey and twisted look due to the force of the south-west winds.

Now, however, all was calm and still, and the Terrapin sailed on such a steady upright keel, that photographs taken the day before were developed without spilling any of the solution used from the shallow dishes. Heavy rain, with which we filled the tanks, fell during the night, and at noon next day we sighted the low island of Kar Nicobar, lying some 22 miles away.

As we neared the north-west part, after an 80 miles' sail, a large village of beehive huts on posts came into view, and the immense number of coconut palms along the eastern shore was very striking.

West of the point, we sailed into a strong tide-race, the current running against the wind at a rate of 4 to 5 knots, and knocking up a heavy, broken sea, in which the schooner yawed and rolled about, taking water on board from every direction. Although the wind was dead aft, it was long before we made any way. With the fore-topsail down, we remained stationary; with it up, we gradually moved ahead. After a time, however, the tide slackened, and we sailed slowly into Sáwi Bay, where we found a Moulmein brig, the Princess of IVales, loaded to her bulwark rail with coconuts, and passing close by we anchored inshore of her, in 7 fathoms, just as night fell.**

* Such tide-races are not uncommon among the Nicobar Islands, and later we met with several others, though none so severe as this first. The tides round Kar Nicobar run with great velocity; a rate of 7 knots has been noted to the eastward of the island. 
An hour or two later, a large outrigger canoe brought alongside a party of men-some of whom spoke English fairlyto ascertain what we were; and by the rays of a lantern, we obtained our first glimpse of the Nicobarese, who appeared, with yellow-brown skin, straightish hair, and medium stature, to be somewhat akin to Malays.

Here was a change indeed, both in place and people. From islands densely jungle-covered to open stretches of grass-land and groves of coco palms: from a little, black-skinned, frizzlyhaired race, in an exceedingly low plane of existence, to a browncomplexioned, lank-haired people, of fair height, who are almost semi-civilised, live in good dwellings, cultivate food products, and possess domesticated animals.

The houses alone were typical of the change of race: those of the Negro peoples-the stock to which the Andamanese belong-are built directly on the ground, while here, among a group of (practically) the Malayan race, the dwellings were universally raised on piles.*

We landed next morning by wading through the surf, for the sea, though smooth off-shore, was breaking on the beach.

The shores of the bay rose precipitously from a beach of sand to an average height of 30 feet, and showed plainly the island formation of grey clay, sandstone, and overlying beds of upheaved coral. Here and there, buttresses of sandstone stood out boldly from the softer cliff, which had crumbled away between them. Above, the land ran inward in a level, unbroken stretch.

We were met almost immediately by $\mathrm{Mr} \mathrm{V}$. Solomon, a Christian Madrassi, who fills the positions of meteorological observer, port officer, schoolmaster, and catechist, and acts unofficially as magistrate and amateur doctor. When we had satisfied him that we were not the proverbial filibustering

* The Scmangrs, a group of Negritoes in the Malay Peninsula, surrounded by dominant peoples dwelling in pile-buildings, still retain their practice of building huts akin to those of the Andamanese. 


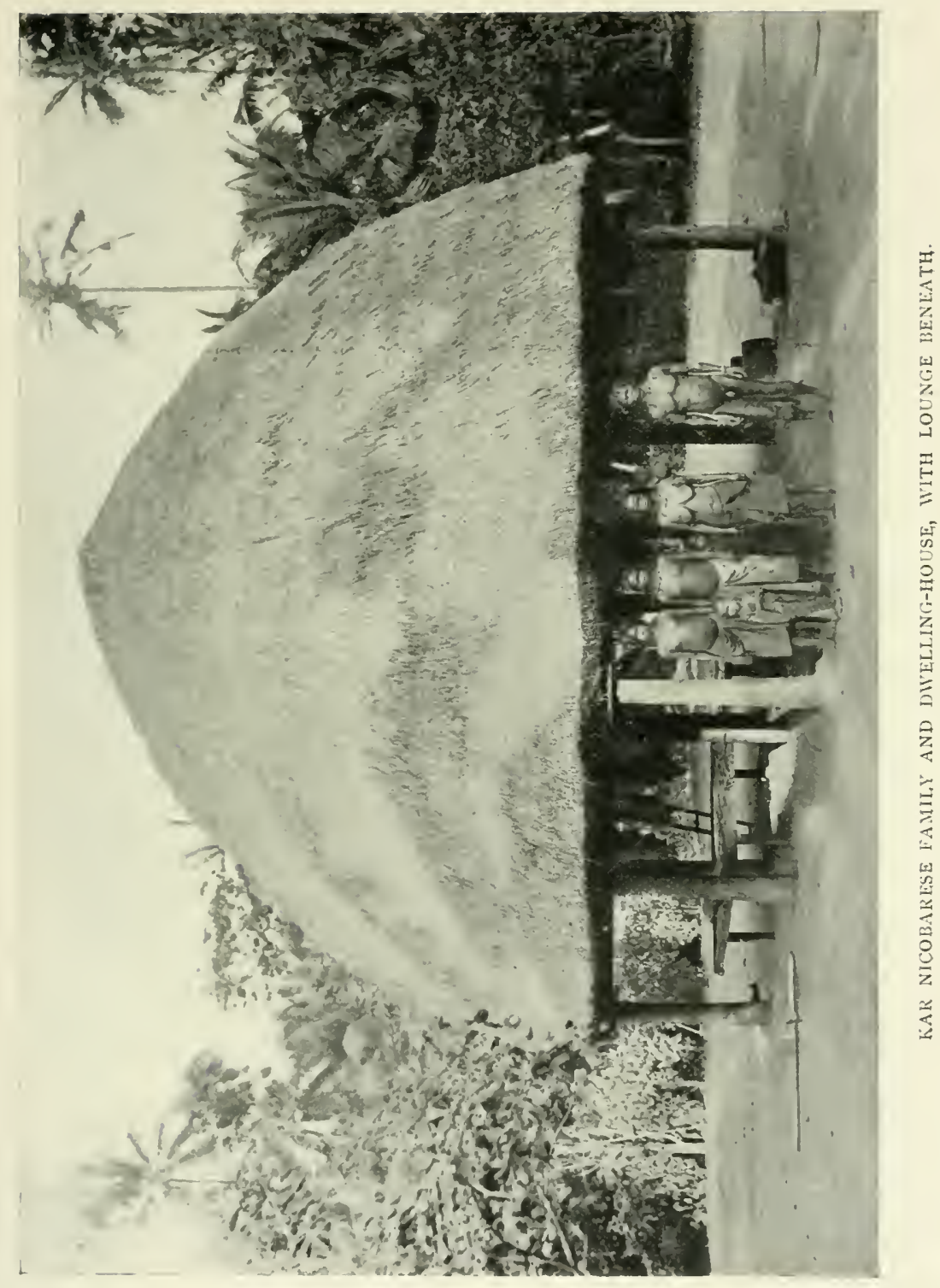

[To fere page 46. 

American schooner-or still more heinous, laden with a cargo of spirits-he offered every assistance in his power, and put the schoolhouse at our disposal, should we care to live ashore.

A flight of broad stairs, built against the cliff, led to its top, and then, after traversing two or three hundred yards of broad road, the agent's bungalow - "Temple Villa" - and the schoolhouse, both standing on an open piece of land purchased from the natives, were reached.

In the clearing were sheds for the meteorological instruments, a very deep well, the only one in Kar Nicobar, and enclosures for several Indian cows that were kept by the agent. The Nicobarese do not use milk, and a herd of cattle given to them when the settlement at Nankauri was abolished, are now roaming over Trinkat in a semi-wild state, very occasionally losing one or two of their numbers by the spears of the natives, to whom, at times, they afford a welcome supply of food. The common pigeon was introduced into Kar Nicobar in 1898 , and numbers of them were to be seen in the vicinity of the bungalow.

The village lay just beyond, on the eastern shore, for this part of the island is merely a narrow arm projecting from the main portion in a northern direction.

Mūs has a population of 530 , and covers about half a square mile of ground, the various groups of houses being scattered irregularly about in picturesque disorder amongst thickets of fruit-trees and fenced-in gardens.

All the buildings stand on thick piles, * about 7 feet high, but vary in architectural type. The living-houses (pati), roughly about 20 feet in diameter, and $15-20$ feet in height from floor to apex, are in shape something between an inverted basin and a pie-dish, covered with a heavy thatch of lallang grass. Without windows or visible entrance, the interior is reached by a neatly-made ladder of bamboo, or notched pole, through a trapdoor in the floor, which works on hinges and * Of Barringtonia speciosa, Eugenia javanica, and Calophyllum inophyllum. 
has an alarum attached, so that any nocturnal intruder will make his presence known.

The top of each pile is fitted with a large, circular, wooden disc, to prevent the entry of rats and reptiles,* and beneath the house, in the shade, there is generally a swing, and also a platform of springy cane that serves the native for a lounge. Baskets, bag-shaped and wide-meshed, hang from the piles, and in these the hens are put when it is laying-time.

Inside, the walls are generally neatly lined with thin battens of areca palm attached horizontally; up in the roof, a kind of attic is formed, by means of a light shelving of areca or other palm wood, having a square aperture left in the centre for entrance. On the floor, which is also grated, are the wooden clothes-chests that contain the family possessions, betel-boxes, the mats of areca palm leaf, and the wooden head-rests which are used when sleeping; and from the walls hang baskets, spears, crossbows, suspensory contrivances made from small branches with part of the twigs left on, and also some tobacco, coconuts, and a piece of pork-the offering to the spirits.

The other type of building (kamun tclika) is used as a kitchen; it has a ridged but curved roof, an oblong floor, rounded at the back and in front, and a platform, and a semicircular projection of the roof to shade the doorway.

At the further end the fireplace is situated. A flat block of wood is hollowed out and covered with sand or clay, and huge clay pots-often with a capacity of many gallons-stand above it, on pieces of stone, raising them clear of the coconut husks which are the principal fuel. Around lie pandanus fruit, the boards and shells with which it is prepared for eating, and the thorn-armed leaf-stems of the rattan, which the natives use for grating up coconut. $\mathrm{Up}_{\mathrm{p}}$ in the roof, are stuck, between the thatch and the rafters, hollowed-out wooden troughs, in which the food of the pigs, dogs, and other animals is prepared; flat wooden dishes, provision baskets, and fans for blowing up the fire, made of the sheathing petiole of palm trees, while,

"The Dyaks of Bornco employ a similar protection in their rice granaries. 


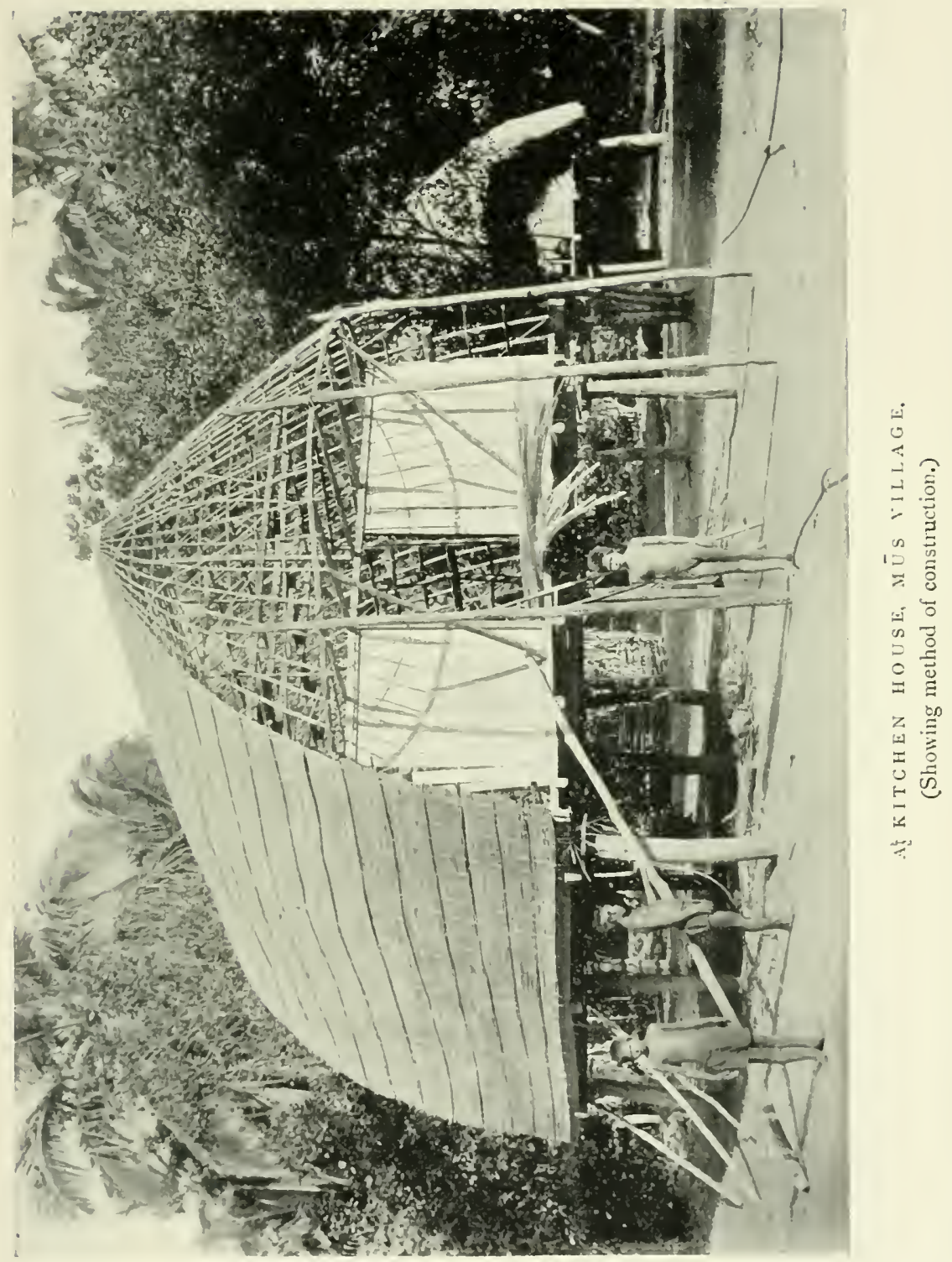



across the beams, are hung coconut shells-joined in pairs by a short rattan handle-which contain the day's supply of water.

The thatch of the houses - generally of lallang grass, but sometimes of palm leaf-is fastened to a framework, built with vertical rafters of the mid-ribs of the coco palm, joined crossways by battens of areca wood, of which material the grated floor is also made. Until recently, the whole structure was held together by careful mortising and lashings of cane, but now it is evident from the newer buildings that nails are coming into use among the natives of this island for such work.

The houses stand in groups, on open sandy ground, and interspersed with them are plantations $(y a)$ of bananas, melons, and sweet potatoes-protected from the numerous roving pigs by zigzag fences of rails piled horizontally between double posts-and clumps of fruit-trees of many varieties-coconut, orange, lime, shaddock, soursop, jack champada, tamarind and papaya.

Sturdy brown-skinned natives, clad in the scantiest kissáts* of red cotton, and wearing picturesque chaplets of white palm leaf with long projecting ends (tá-chökla), stared at us as we walked through the village; children and women, with a piece of cotton cloth hitched round the waist, disappeared in the houses as we approached. The teeth of all were stained by constant betel-chewing, and, since the blacker the colour the more beautiful is the owner according to local standard, to produce this effect the teeth are never cleaned.

The dwelling-place of the headman (mah), who is named Offandi, in no way differed from the others. We made our presence known from below. "Wait," came a voice, "wait till I've got my clothes on," and soon after the chief appeared in a rusty suit of black broadcloth, and a damaged, bowler hat. He was a short but exceedingly strong-looking man, with a thick neck and bullet head, and wore a very slight moustache.

* Kissát is the Kar Nicobarese name for the loin-cloth worn by males. In the Central and Southern Islands of the group this article of attire is styled neng. 
We shook hands all round, and commenced asking each other questions in English as we strolled through the village. Then, after ascertaining that we should be pleased to see him on board later, and provide spirituous refreshment, Offandi left us.

He was said to be very well off, possessing large numbers of coco palms, but the other staple of wealth (pigs) he has to buy.

We presently reached, near the shore, a group of buildings known as Elpanam (The Place).* Principal among these were two buildings, in which feasts and meetings take place. While of the same shape as the living-houses, they were much larger in every way. The roof and floor are built on the ground, and then, by the combined efforts of the whole village, are raised to the supports on which they rest. They were constructed inside of laths of areca, closely bound together, and fastened horizontally to a framework covered with grass thatch, a foot or more in thickness.

The floors were gratings of split palm wood, but a great portion was planked, and on this solid part a large fireplace was built of clay.

In the centre hung a rack, from which the joints of pork are suspended at feast-times, and beneath were placed boards to catch falling fat and grease.

Strings of pigs' jaws were hung across the upper part of the roof, and showed the number of animals consumed at the last feast-a ceremony that sometimes lasts a month.

The pigs, which are killed for these occasions by being speared through the heart, are doubtless an introduced species, for they attain immense proportions and are of many colours :black and white, brown, brown and white, etc. The young, however, are all striped when born.

Adjacent to these "Town Halls" $\dagger$ are the stores of the

* In contradistinction to the village, which is known as "panam."

+ These large buildings in Elpanam are equivalent to the "Balai" of the Malays, for in them visitors are installed, feasts are held, and general meetings take place. 


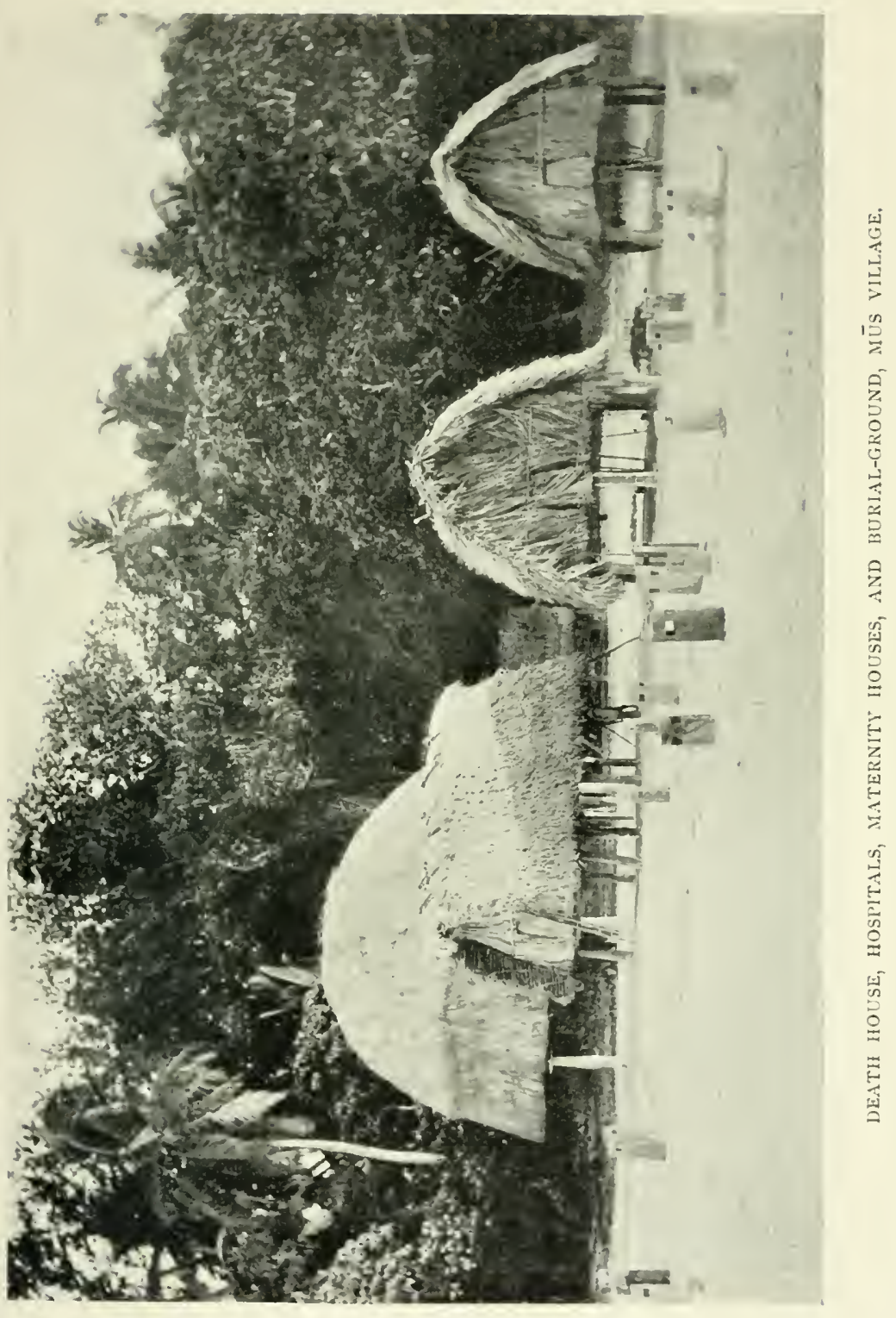

[To face puge 50. 

Burmese traders, some buildings which are equivalent to the hospital of civilisation, and several maternity houses, where women take up their residence shortly before confinement.*

The starting-point in life, and also the place of departure, is for the Nicobarese of this village one and the same, for next to the house appointed for his birth is another-the "House of Pollution"-to which he is carried to die; and yet a few paces further is the burial-field, with its group of grave-posts, where his body will be bestowed for a time. Not for long will it rest even there, for in a few years the skeleton will be disinterred and cast into the jungle-the skull alone, if he has been a man of some importance in life, being allowed to find in the grave an abiding place.

The shores of Kar Nicobar are in places very low, and during bad weather the waves have been known to roll up the beach and flood Elpanam a foot in depth, carrying away canoes, etc. To subdue the sea on these occasions, tamiluanas (medicine-men) and their followers, adorned with garlands, walk in procession along the beach, with devil-destroying rods and leaves, with which they strike the water, and then surround Elpanam with palm leaves, and perform other ceremonies.

On the outskirts of the village, we saw here and there small huts called Talik n'gi-the place of the baby. To these, mothers come from Elpanam with the newborn child, and spend several months in solitude, attended only by their husbands, before returning to the village-a very sensible proceeding, and one worthy of imitation in more civilised communities. It seems only common justice that any unpleasantness caused by ourselves in our earliest moments should be confined to those most responsible for our appearance. So the Kar Nicobarese appear to think, and have accordingly taken measures to prevent new arrivals becoming a nuisance to their future com-

* At delivery a recumbent position is assumed, and the mother is attended by the nearest neighbours, who assist by pressing and kneading the abdomen. 
panions, for many of the houses in the village contained perhaps twenty inmates; doubtless, also, it is well for babies not to be subjected to too much companionship and attention.*

Again in the village we made the acquaintance of the oldest inhabitant, yclept "Friend of England," who, judging from the number of his chits, is a man of some note and many acquaintances.

Clothed at first in an infinitesimal native garment, he retired for a few moments, and then appeared in white jacket, knickerbockers, and top hat, carefully brushed in the wrong direction. $\mathrm{He}$, too, would pay us a visit on board, provided that liquid sustenance were afforded; and having satisfied himself on this point, he intimated that we might count on his appearance that afternoon.

Our attention was attracted by a somewhat rude mechanical contrivance, beneath a tree, which we were told was a press for extracting oil from coconuts. Two large blocks of wood, one above the other, were placed closely against the trunk. In the upper surface of the topmost $\log$ a shallow depression had been made, and from this a channel ran to one edge, which ended in a kind of lip. In the trunk itself a hole had been scooped, to receive the end of a long beam of wood.

A quantity of coconut kernel having been placed in the basin, the beam is inserted in the tree, and a native standing on the outer end, by jumping up and down exerts so much pressure on the coconut that the oil oozes out, and running down the channel, drips from the lip into an earthenware pot placed beneath.

Here and there about the houses stood a kind of benchseat, that was merely the $\operatorname{limb}$ of a tree with several of the

" Cf. Dyak custom, "When an interesting event is about to happen, the lady is secluded in a small house, where she remains for several months, during which no stranger is allowed to enter the hut."-The Head-hunters of Borneo, by Carl Bock.

The practice of couvade is said to exist among the Nicobarese, but we heard nothing of it during our visit. 


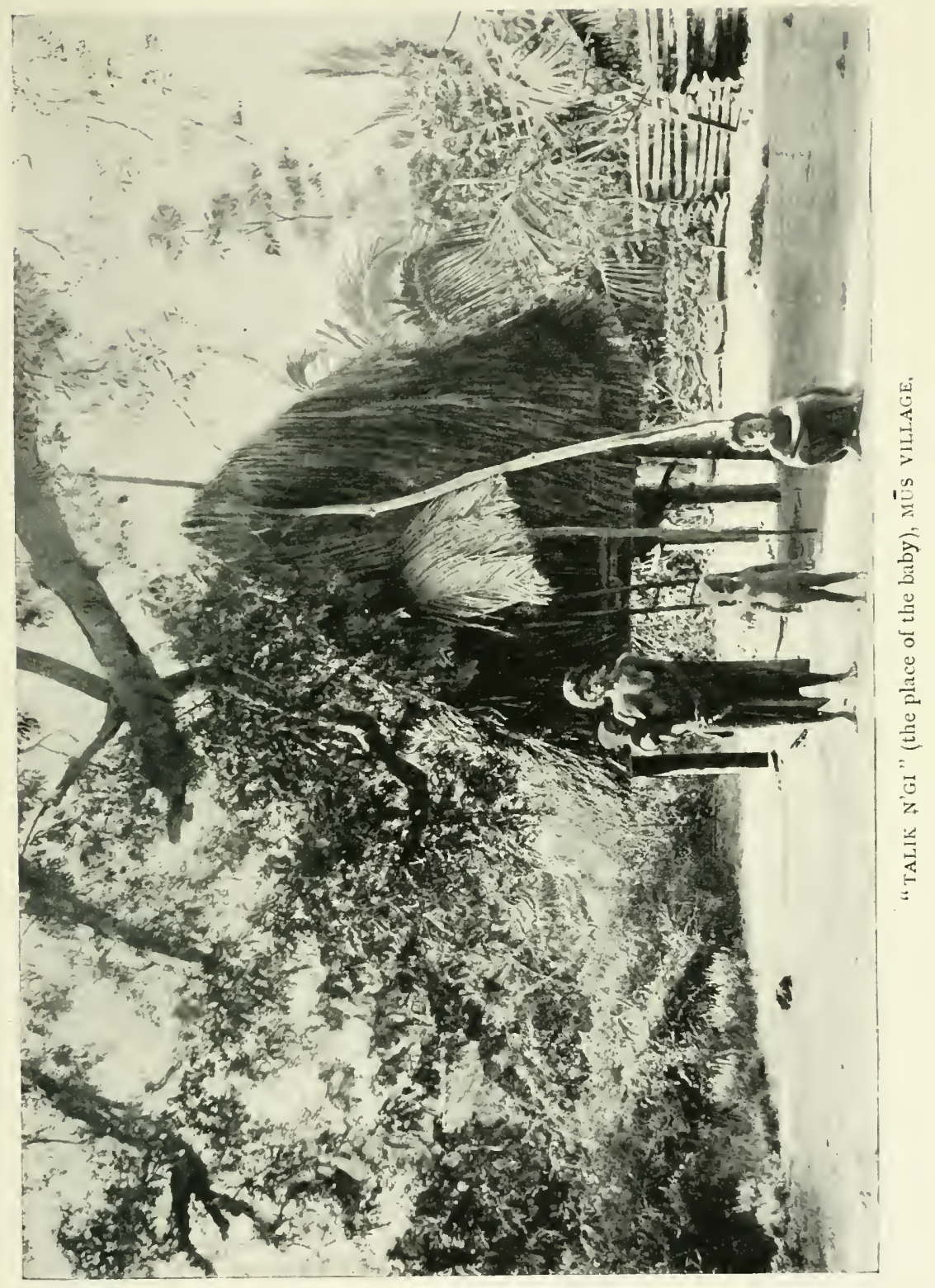

[To fuce prage 5:. 

branches left projecting, and trimmed in such a way that the whole piece would balance firmly.

We obtained a number of birds in the trees about the village; one in particular (Ixora, sp.?), whose leafless branches bore a quantity of large red flowers, was frequented by flocks of white-eyes (Zosterops (?), sp. nov.), munias, and sunbirds, (Arachnechthra (?), sp. nov.), and by the chestnut-rumped myna (Sturnia erythropygia), a bird only known from this island, although we later collected on Kachal a new species that closely resembles it.

The canoes $(a p)$ belonging to the village were drawn up on the shore of Sáwi Bay, for the other beach is fully exposed to the monsoon, and also fronted by an awkward reef. These vessels_all dug-outs_constructed from a single trunk (Calophyllum

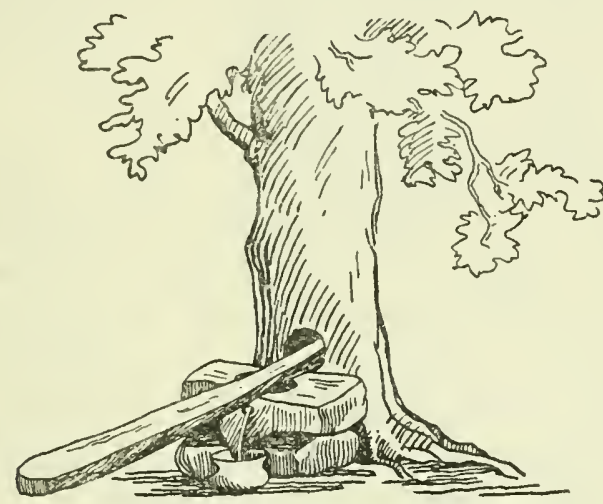

Oil Press (Kar Nicobar).

spectabile), ${ }^{*}$ are very narrow in proportion to their length, and of graceful shape. After the canoe is hollowed, it is somewhat spread out by cross-pieces of wood, which are lashed from gunwale to gunwale, at intervals of about a foot. To give the requisite stability, an outrigger is attached:-To two projecting spars or wings lashed to the canoe, a log of very light

* This tree is found only in the southern islands, whence the large sea-going canoes are obtained through the natives of Chaura, who act as middlemen. 
wood (Sterculia alata), about three-quarters the length of the hull, and sharp at either end, is fastened, and the correct level of this float is maintained by each wing being bound to, and resting in, the angle made by three intersecting pairs of hardwood pegs, which are driven into the outrigger. The vessels are further provided with ornamental projecting stem- and stern-pieces (C. inophyllum), carved in a variety of designs, and sometimes painted red. No paint or wood-oil is used on the canoes, but the outer surface of the hull is charred all over, with the idea of protecting it from the effects of the water.

The paddles are about 4 feet long, very light and thin, made of a hard red-brown wood (Garcinia speciosa), with lancetshaped blades, and handles without any form of cross-piece, but flattened at the top.

In the afternoon, Offandi came on board, and after drinking a glass of rum, begged for a bottleful to take ashore. As this request was not complied with, he cried threateningly in a menacing tone, "What, you refuse me then?" but calmed down on learning, that, although we were not at liberty to supply him with spirits "for consumption off the premises," he could have what he wanted whenever he liked to come aboard. A bottle of Eno fully restored his good humour, and drew forth expressions of friendship: "You good man, I love you; you do me good turn, I make return." This reciprocity is the basis of Kar Nicobarese relations with strangers-value for value, and no gifts; although Offandi once presented us with an edible bird's-nest without asking for an equivalent.

One man, "Sweet William" of Lapáti, carried this trait so far, that he wanted a steamer to take him to England, in order that he might there build a house for himself, and occupy a piece of land in lieu of the plot at Mūs that has been purchased by the Indian Government.

The headman was, for a Nicobarese, a very travelled individual, for he had spent a month in Calcutta, ten days in Penang, and various periods at Port Blair; and as a result, had a really working knowledge of several languages. English, 


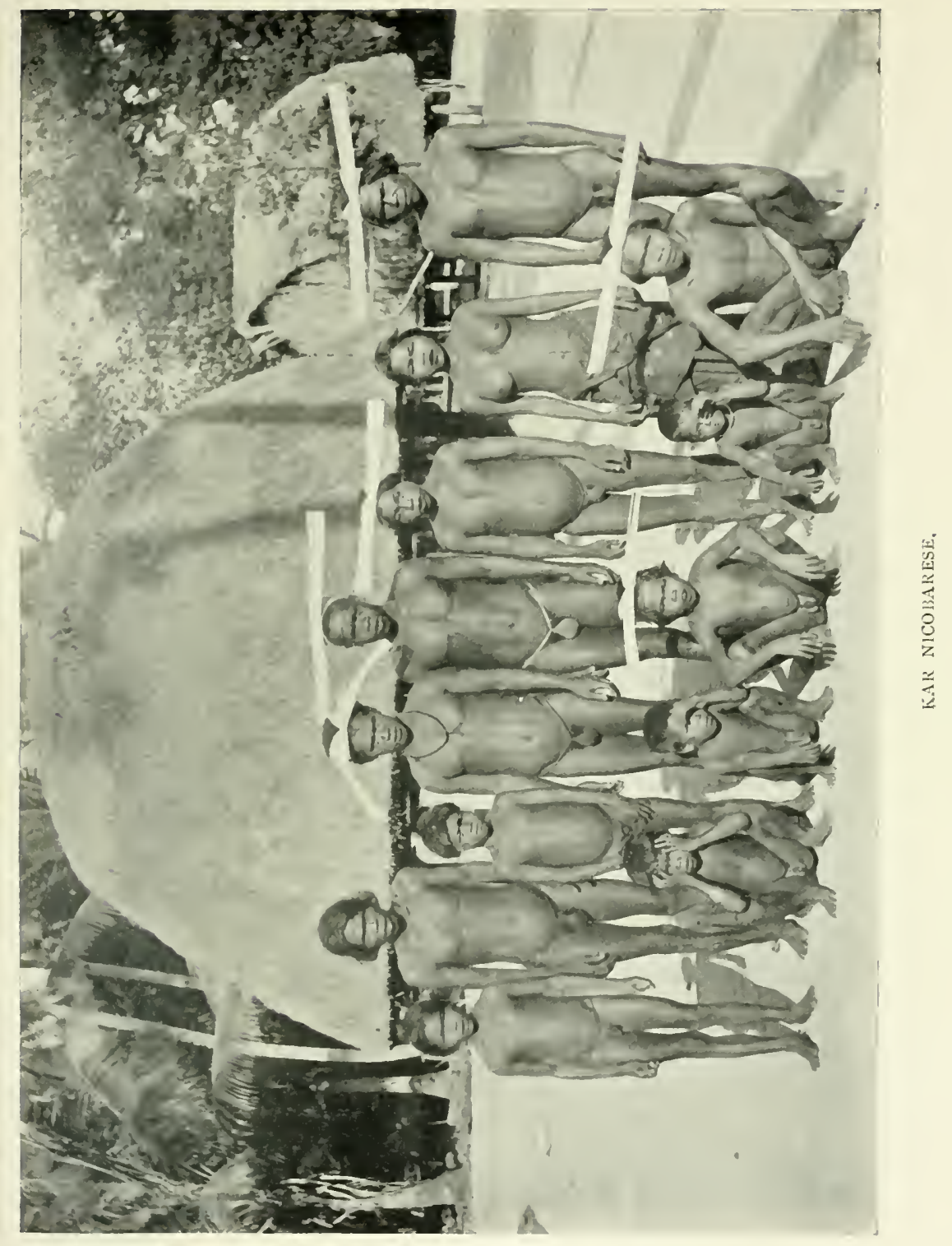



Hindustani, and Kamortan, he speaks well, and has some acquaintance with Malay and Burmese.*

Visits to the Terrapin occurred frequently during our stay, but none were of long duration, for a growing squeamishness on the part of our guests generally cut them short.

Although accustomed to travel in canoes, they could not withstand the motion of the schooner. Indeed, for the whole time we lay in Sáwi Bay, the Terrapin, on account of the swell that set into the bay, so rocked and rolled at her anchor that life on board was scarcely comfortable. The fiddle was always on the table, the preparation of our specimens went on under difficulties, and at night sleep was almost impossible unless we wedged ourselves on our mattresses by means of extra cushions and pillows. The vessel frequently took water over her sides, until at times it almost seemed that she would roll her masts out. We generally had to exercise the greatest care in leaving or boarding the ship, and yet with it all the sea was quite unbroken save for the line of surf along the beach. The bigger trading - vessels - brigs and barquentines - anchored more off shore, and, because of their greater size, were scarcely affected by the motion.

Whenever the tide was low, the reef-bordered portions of the coast were always frequented by various parties of natives, busily occupied in searching in the pools and under the coral boulders for fish, crabs, and molluscs; at night, when the sea was calm, bright fires blazed on the water and the shore, and marked where fish-spearing was going on from sheltered ledges of rock or slowly-moving canoes.

Of all the people, "Friend of England" was perhaps the most amusing. He was infected with the garrulity of old age, and made the most of his opportunities by unblushing mendicancy.

As he came alongside, sitting - a very dignified figure in top-hat and white knickerbockers - upright and motionless in his canoe, which was manned by juvenile paddlers, he always,

* "A century ago, all the natives of Kar Nicobar spoke the Portuguese of the Indian Eurasians."-Hamilton, Asiatic Researches, vol. ii. 
as he neared the schooner, took from his pocket an old silk cravat and arranged it round his neck.

After a few coconuts or oranges had been handed up, the old man would come below and shake hands all round. "I want smoke cigar, I want drink rum," was followed by a prompt refusal of anything smaller than a tumbler. Then would come the invariable preamble: "You my friend, I your friend; we give presents and make return," - with reference to the coconuts; followed by demands for medicine, turpentine, camphor, quinine, scent, and Eno; and as all his wants could not be satisfied, he professed he could not understand why on earth we had come without these things. When we came again we were to bring all of them, and we should then be great friends. He desired that we would convey the following to every one at home-foreigners he did not like:- "You go tell all men-Come here, come here, come here. I Friend of England, I good man. You bring much medicine, you give me-we be great friends, I make return. I plenty good man; I speak true, I no lie!"

He carried a large number of chits from officers of ships that had called here during many years past, and was very anxious that we should add to the number.*

* Letters of recommendation :-

(a) "The bearer of this, Friend of England, is a very worthy young man. He supplied me with a great quantity of nuts last voyage, and he can be trusted to any amount under 6000 pairs. Ioth March 1853 ,

Off Lapáti Village, Car Nicobar.

(Sd.) R. Middleton, Commander. Barque Colonel Brown."

(b) "This is to certify that I have traded with Friend of England, a native of this island, in coconuts, fruits, etc. Since I have found him to be trusty, honest to his agreements, therefore, I feel pleasure in saying that you can trust him with the truth before heaven.

North-West Bay, Island of Car Nicobar, Barque Rochester of London. March 3rd, 1857.

(Sd.) W. J. GreEN, Master of the above-named ship."

(c) "On our visit to the north side of Car Nicobar, I found the bearer, Friend of England, an honest, inoffensive man, and very willing to afford all the assistance in his power to us during our stay.

H.M. Steamer Undaunted, (Sd.) W. L. C. Beresford, Commander. January $1873 . "$ 


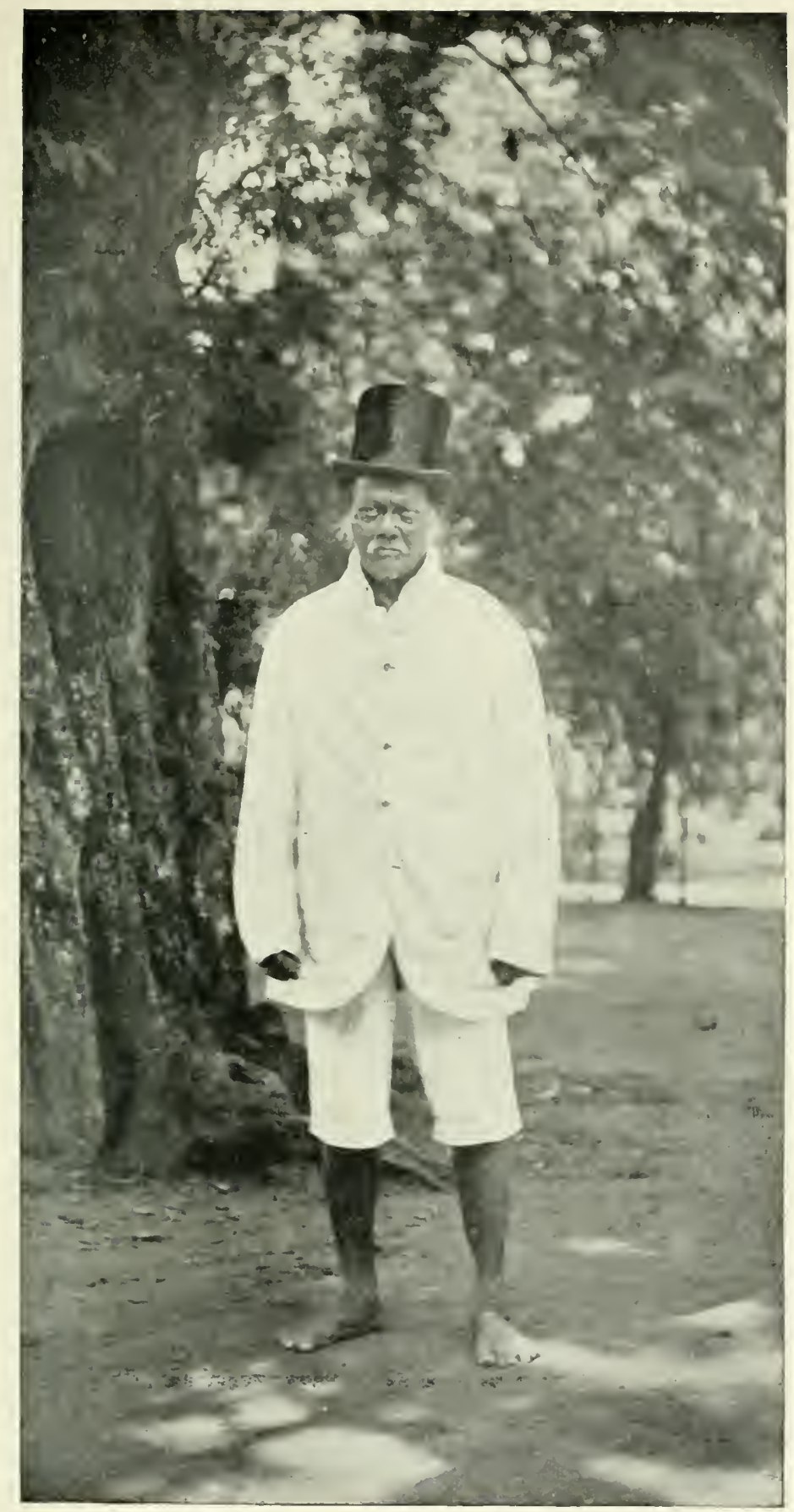

"FRIEND OF ENGIAND." 

Poor old "Friend of England"! his lines are no longer cast in pleasant places. His last wife, the widow of a friend, became blind, and he can no longer obtain another on account of his old age; he has become estranged from his son because of his too amorous conduct towards the latter's wife, and has had to pay several fines on account of similar behaviour towards other neighbours.

Our last glimpse of him as he made for the shore, after having been assisted to his canoe, generally caught him in the act of undoing his cherished necktie and restoring it, carefully folded, to his pocket.

One day-when we had so far broken through our rule as to give him a bottle of rum and water to take ashore "for medicine after we had gone"-going a couple of hours later into the village, we found "Friend of England" tottering up a path, and tried to take his portrait. But the old scamp, who all his life had lived in the sun, refused on this occasion to come out of the shade, and was so afflicted with involuntary staggers, that the result of several exposures was a very qualified success, and lost much of the impressiveness of the original, through his unwillingness to don his necktie in the customary Byronic style.

One of our guides about the island was "Frank Thompson," one of Mr Solomon's "most promising pupils, and a sincere Christian"-a rather stupid-looking youth, who had spent some years at the Port Blair School. I fear that we regarded him with some contempt, for he seemed to have developed into nothing better than a hanger-on at the Agency, and although he spoke English fairly well, and could doubtless read and write a little, in the jungle he proved to be quite useless. Birds he could scarcely ever see; he did not know the way about, and after a few miles, he was blowing and panting, and groaning inquiries as to how much farther he was to go. Thompson however could beg as well as the rest, nor was he out of his element when the rum and cigars were being passed round. 
A very different character was my shikari "Little John," native name unknown. This man was perhaps, on the whole, the best specimen physically of a Nicobarese that we came across. A handsome, rather scornful, face, with aquiline nose, was only spoiled by the occurrence of the Mongolian fold in the inner corner of the eyelids. His curly black hair was worn long, in a thick bushy mass, as far as his shoulders, where it was cut off straight across. Though only 5 feet 6 inches in height, he was splendidly built: was 40 inches round the chest, $13 \frac{1}{2}$ inches round the biceps, and 15 inches round the calf. The natives admitted that he was about the strongest man in the village of MĪss.*

He was awfully keen on collecting; could creep noiselessly through the jungle, and saw birds that I took long to distinguish, even after he had pointed them out. He was also a good "pot-shot," and nothing delighted him more than to carry the gun, and after having it loaded with cartridge suitable to the occasion, to fire at and bring down the specimen, when he would hand the weapon to me and dash away amongst the undergrowth to retrieve his booty, bringing it back with the greatest care.

He was an unwearying hunter, and would often creep about for ten minutes at a time, under some tree, in order to point out for my approval, and get a clear shot at, some bird whose presence he had discovered in the dense foliage.

He used to accompany us on board the schooner, and after having breakfasted with the crew, would sit in the cabin with a cigar, watching us as we worked at the skins, and improving his little English by constant inquiries: "How you call dis? What you call dat?"

The desire of the Nicobarese to learn words, and acquire the name of anything they do not know, is great, and their powers of memory are astonishing. The exercise of these linguistic abilities is most marked in the headmen, or "captains"

* His portrait is, unfortunately, a failure, as he seems to have moved slightly during the time of exposure. 
as they love to be called-a title inherited from the times when English skippers used to trade amongst these islands, and bestow by request their own names (and others less complimentary, but more pointed) on the natives they particularly favoured in their commercial transactions.

Nor were these our only acquaintances. "Sweet William" (who had a mouth and teeth like a shark's), W. L. Distant, Tom Noddy, Lady Clara, Sam Weller, and many others, came to see us. There was, too, $\mathrm{Mr}$ Corney Grain, who, many people may not be aware, is chief of a village in Sáwi Bay, and who dresses in two yards of pink ribbon.

In this way we were never at a loss for company, for when the above were engaged, there was always a reserve in the persons of Jack Robinson, Tom Tuson, Kingfisher, Young Edwin, James Snooks, Lorenzo, Lady-killer, and others.

$\mathrm{Mr}$ Solomon's efforts in education have received little support from the community; for by handing over their children to his discipline, the parents lose their assistance in the routine of daily work, no small portion of which falls to the younger generation, since almost all special work is done by small boys. These are very helpful in climbing the coco palms for the nuts required for barter, and they are of much assistance to the foreign traders also, who, to induce the boys to aid them, supply them with food, and give them presents of tobacco and other things. However, some fifteen or twenty boys, from 8 to 14 years of age, have now been given up to the mission school, ${ }^{*}$ to receive a little daily instruction and drill, on condition that the onus of feeding and clothing them shall not fall upon the parents.

Out of school hours these boys make themselves generally useful by fetching and carrying, preparing food, etc., and acting as crew of the agent's canoe.

That such a life is not universally pleasing to the youngsters themselves, is witnessed by the fact that a short time ago one

* This is partly supported by a small monthly subsidy from the Bishopric of Rangoon. 
of them ran away to the jungle, where he remained, and was able to support himself, until caught and brought back after a three months' disappearance.

He was a mischievous-looking boy, who found it hard to refrain from grinning while his portrait was being taken, for I secured his likeness as affording a marked example of the features of prognathism and epicanthus as occurring among the Nicobarese.

IVe found the services of these boys most welcome on several occasions. Frequently the surf in the bay was sufficient to promise at the least a thorough wetting when leaving shore for the schooner in our own boat. It was, as a rule, simple enough to land, but the reverse proceeding was a less simple matter. In such a case, we used one of the native canoes and a crew of mission lads.

After loading the light hull with our impedimenta, it was an easy business to place it at the water's edge, and, at a suitable opportunity, run it out into waist-deep water, jump on the almost uncapsizable hull, and with quickly-grasped paddles - no troublesome operation of shipping lengthy oars in rowlocks-force the slender craft beyond the breakers. Arrived at the schooner, a biscuit apiece seemed to be considered ample reward by our young friends (biscuits, stale bread, and old crusts are in great request among the Nicobarese), who, after disposing of them, would return to their canoe and disappear into the darkness with cheery farewell cries: "Good-night; goodnight, sar ; go-o-od-night."

Early in our visit, we one morning met with a mishap when landing in our stumpy dinghy through some more than usually heavy surf. The surroundings were scarcely such as one would connect our late Laureate with, but at the moment of catastrophe, some lines of his flashed into my mind:

\footnotetext{
"'Courage,' he said, and pointed to the land,

"This mounting wave will roll us shoreward soon,"'
}

and indeed it did. A big breaker rose under the stern, and 


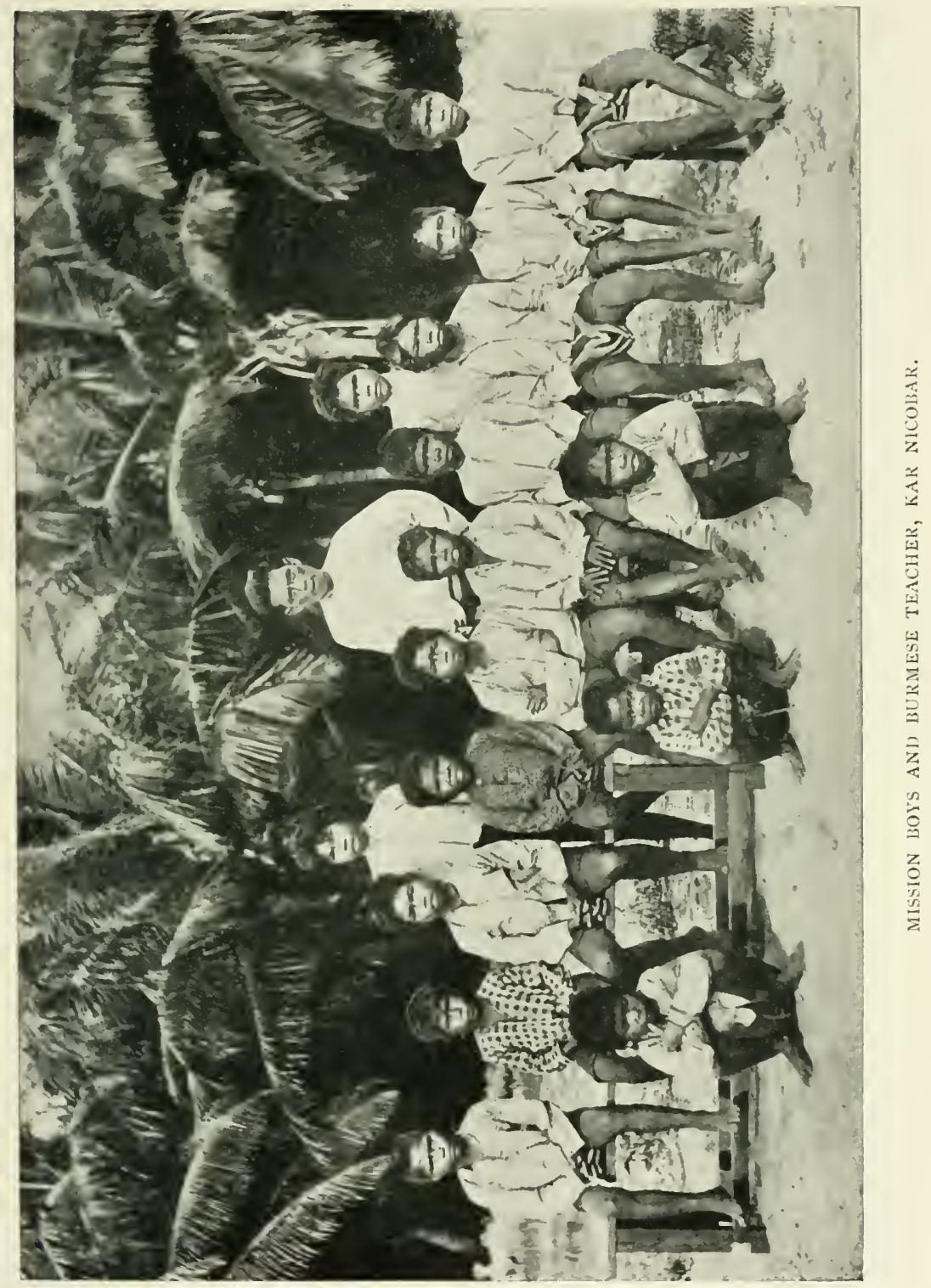



flung the boat, its contents, and ourselves, far up the beach. Fortunately our guns and cartridges were made up into bundles with waterproof canvas, so no harm was done beyond losing a rowlock.

From the incident we learned a lesson, and thereafter, had the proverbial New Zealander been on the beach in the early mornings, he might have seen a little boat approach the shore, with a blue-clad, brown-skinned Malay and a couple of white men in puris naturalibus. Outside the belt of surf, the latter would jump overboard, and, seizing favourable opportunities, wade to and fro with sundry bundles. Presently the dinghy would return, with a solitary occupant, to a schooner in the bay, while the others, after assuming a simple toilet and a peculiar sporting equipment, would disappear from his view, leaving the Antipodean observer alone on the shore. Although a little farther from the village, the best landing-place when the sea is rough is on the stretch of sand next to that adjacent to Mūs, and just to westward and inside the rocky point that separates the two strips of beach.

Sometimes we shot in the scrub and plantations surrounding the village, and sometimes we went a few miles along the bay towards Sáwi, now walking on the beach, now along the brow of the cliffs. The view from these last was very beautiful: on the one hand a forest of palms, pandanus and casuarina trees, on the other a line of waving grass; and below, the blue sea breaking in snowy rollers on a golden beach.

At times we met parties of natives proceeding from village to village in picturesque groups-the men carrying nothing but a dco, their warm-brown stalwart figures relieved only by the red kissat and white chaplet of pandanus with which their hair was bound; and the women draped in scarlet cotton, and adorned with chains of rupees and numerous silver bangles.

All would stare stolidly, and pass in silence; for in the Nicobars, where one man is as good as the next, and no degrees of rank are known, there are no words of greeting 
or graceful salutes such as one would meet with amongst strange Malays or natives of India.

The forest at Sáwi was open, and although of a heavy description, grew on land that seemed of very recent formation. It contained some of the finest specimens of urostigma trees we had ever seen, whose many aëreal roots, springing from a wide expanse of ground, met far overhead in support of immense masses of foliage.

In this heavy jungle we obtained specimens of Astur butleri, a little forest hawk with back and wings of a beautiful dark grey, allied species to which are found in several of the other islands. Here, too, we met with Carpophaga insularis, a variety of a widely-spread fruit-pigeon, C. anea, from which it differs only in having a plumage slightly less bright. We made acquaintance also with Palcornis erythrogenys, an exceedingly pretty parrot, and the only bird of its kind occurring in the Nicobars until $P$. caniceps is reached in the southern islands; but of the mound-building megapodes we had expected to find, there was no trace, although it was said they occurred in the middle of the island.

We obtained in the jungle one specimen of a hitherto unknown fruit-bat (Pteropus faumulus); but of rats, although they are probably numerous, one only was trapped (Mus burrulus, sp. nov.); crabs in nearly every instance making off with the baits.

As a rendezvous after our collecting excursions, we generally chose "Temple Villa," where we could sit and chat with the agent on the manners and customs of the natives among whom he lived, and drink the water of young coconuts freshly plucked from the trees surrounding the bungalow.

The coconut of the Nicobars, although small, is nowhere excelled for sweetness and flavour, and on reaching the schooner, drenched with perspiration after a morning's wandering in the forest, and perhaps a long row under the hot midday sun, we daily made appreciative trial of them the moment we stepped on board. 
The natives are very expert in opening them with the dáo. Holding the nut in the palm of the left hand, they slash off a portion of the husk, toss it round and remove another slice, until, with three or four cuts, the tender shell at the upper end is exposed, and only requires a slight tap to be broken through and allow the delicious water inside to reveal itself with a spurt.

The life of the Nicobarese is full of curious observances and ceremonies, of which, perhaps, no man knows more than $\mathrm{Mr}$ Solomon, who has spent five years among the people, and is engaged in the preparation of a vocabulary of their language.

In his capacity as catechist, he has not succeeded in converting any of his adult neighbours to Christianity, although one or two are occasionally present at his Sunday services. We met with one proselyte to Mohammedanism among them, but he, having been adopted by a trader when a boy, was taken to the Maldives and spent some years there. The natives as a body are still as averse to foreign influence on this point as they have been in the past, when missionary endeavourMoravian and Jesuit-time after time met with complete failure. In the second quarter of the last century they expelled two priests of the latter sect from the island, and Captain Gardner, in I85I, gives an account of the same fate befalling a pair of Moravians.* "Having converted a few natives, disputes arose between these and their heathen countrymen. They were of such a serious nature that it was determined to hold a general council of delegates from every village to consider a remedy for the evil. They came to the conclusion, that, as they had alvays lived in love and amity with each other before the arrival of the missionaries, with their strange story of the first woman stealing the orange, etc., the obvious remedy was to send them away. Accordingly, the missionaries were waited on, and told respectfully that they must leave at the first opportunity: that the natives were not to be joked with, and

* Singapore Reviezu, vol. ii. 
must be obeyed. The mission house was then burnt down, and a fence erected round the spot, inside which no native will step. It is unholy ground, they say, where the devil first landed; for, until the missionaries brought him with them, he had never been in the island, or knew where it was. I was told that a day is now set apart in the year when all the inhabitants assemble to drive the devil out of the island."

On the fourth morning of our visit our sympathy was due to $\mathrm{Mr}$ Solomon on the occasion of his wife's death-an event that occurred with some suddenness as the result of an apoplectic fit. One sequel to this was, that on the following night the entire village was engaged in expelling the spirit of the deceased from the neighbourhood with much ceremony and noise.

Kar Nicobar has an area of about 50 square miles, with a surface that is exceedingly level, as the highest point it attains is barely 200 feet above the sea-level; only in the north does the coast rise in low cliffs, and all round the shore is a fringe of coral-reef.

The geological formation consists of a foundation of serpentine, on which rest thick clay beds and layers of sandstone, exposed in parts, and in some places overlaid by upheaved coral banks, the whole having acquired a covering of sandy alluvium and drift, which was deposited before upheaval, with an additional layer of vegetable débris since accumulated.

With the exception of an indigenous coco palm zone, where coralline alluvium has formed, the beach forest of Casuarinas, Barringtonias, Ficus, Pandani, Hibiscus, Calophyllums, and other characteristic species, and irregular strips of inland forests, containing canebrake and bamboo, with Terminalias and Sterculias, the whole island appears to be covered with stretches of coarse lallang grass, dotted with tall screw-pines (Pandanus mellori), bearing the large globular fruit that supplies the inhabitants with their staple food; or with the natives' plantations of coconuts, betel, plantains, and yams. The nature of the forests depends entirely on the character of the soil and on the composition of the underlying rock. 


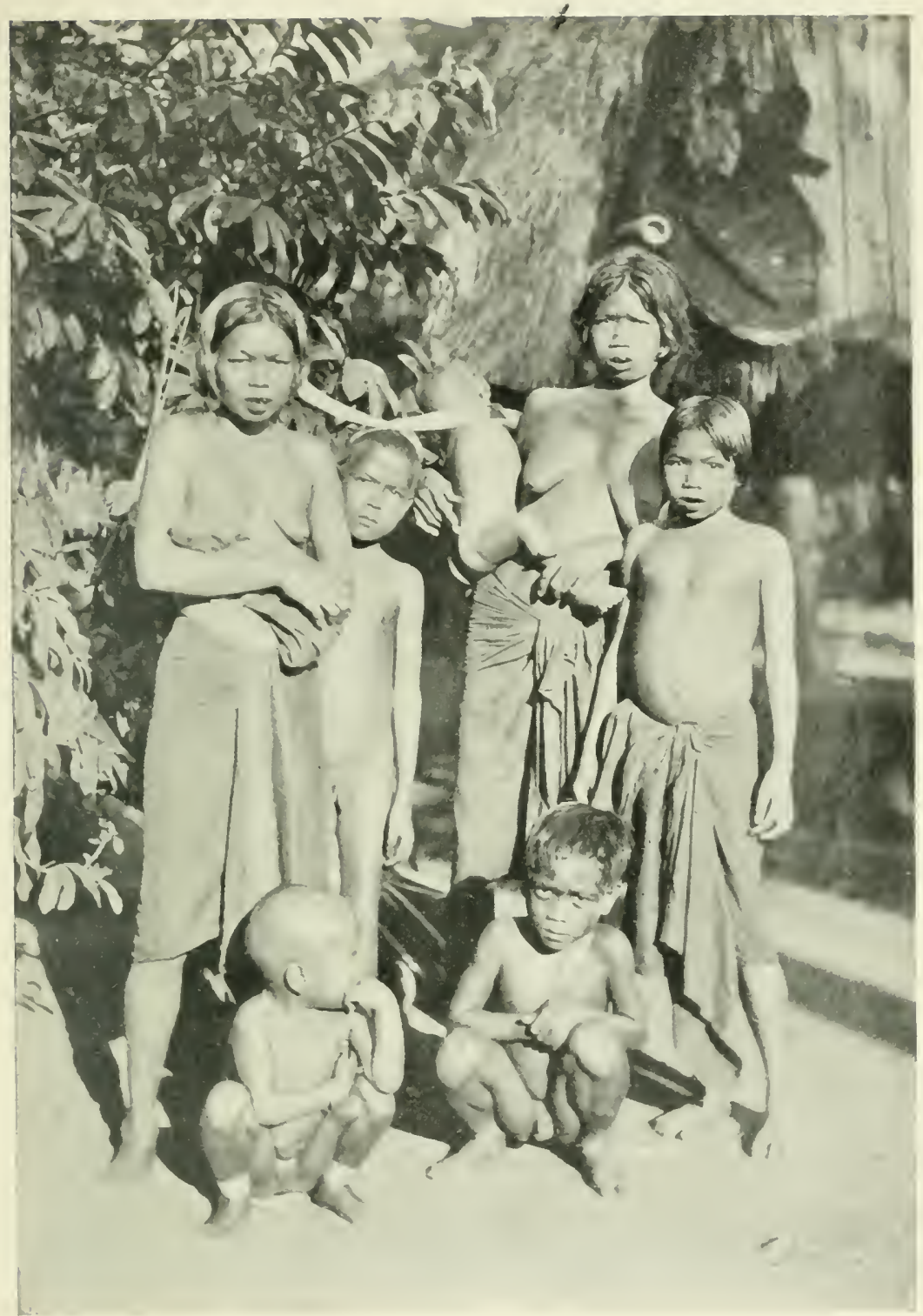

WOMEN AND CHILDREN, KAK NICOBAR. 

Although ranking only fourth or fifth in point of size, Kar Nicobar contains nearly three-fifths of the total population of the group; the number of its inhabitants has remained stationary for many years, and has lately been ascertained to stand at a trifle under 3500 .

"The people of Kar Nicobar ought to be among the most contented in the world. Everyone lives on terms of perfect equality with his neighbours. Beyond occasional illnesses, they have no cares or troubles, and there is absolutely no struggle for existence, coconuts and pandanus, their staple foods, being in such profusion that a child old enough to climb a tree could support himself without exertion." *

Our sojourn at Kar Nicobar lasted from the 2 ist to 27 th of January, and was spent in making a collection of the fauna (which was not entirely without result in the way of new species), and in obtaining as much information as possible about the natives during the opportunities open to us. Besides this, we secured, through the agent, a fairly representative series of such articles as are used by the islanders in their daily occupations and pursuits.

The well from which we filled our tanks was situated near the agent's house: no good water was to be obtained elsewhere in the bay. In this well the water rose and fell with the tides, the explanation of which is, not that the sea-water is filtered by the coral sand, but that fresh and salt water do not combine; the former rests on the latter, which is of course heavier, and the close and porous coral rock prevents the mixture of the two.

Having given all the time we could spare to Kar Nicobar, and found it a most interesting locality and one worthy of far more protracted attention, it was with feelings of regret that on the 26th we, as Dampier would say, "refreshed ourselves very well with hens, coconuts, and oranges, and the next day sailed from thence."

* A. L. Butler, Supp. And. and Nic. Gazette, Nov. 1897. 


\section{CHAPTER VI}

\section{TILANCHONG}

Batti Malv-Tilanchong-Novara Bay-Terrapin Bay-Form and Area of Tilanchong - Birds - Megapodes - A Swamp-Crocodile-Megapode Mound-Wreck and Death of Captain Owen, 1708-We leave Tilanchong

-Foul Ground-Kamorta.

ON our course to Tilanchong, we passed, after leaving the south end of Kar Nicobar, within a few miles of the little island of Batti Malv. It is scarcely more than a mile in length, and except towards the N.W., where it is somewhat flattened, falls steeply to the sea from a height of I50 feet. It is uninhabited, but the low jungle with which it is covered is the abode of countless numbers of pigeons-principally of the Nicobar variety - which are said to be so tame and fearless that they can be killed with sticke.

A little later Teressa hove in sight, a grey cloud on the horizon, and soon after we caught sight of our destination right ahead. It was midnight before the island was reached, and not caring to find an anchorage in the dark, we drifted gently northward under jib and mainsail, until at daybreak we were opposite the extreme point, where we turned and ran slowly south, keeping close inshore.

All the way along until the centre is reached, the island, 500 fcet high and nowhere more than a mile and a half broad, rises in almost precipitous cliffs of serpentine, with deep water at their feet, while the principal vegetation consists of thickets of pandanus in the gullies, and here and there, in spite of the rocky ground, 


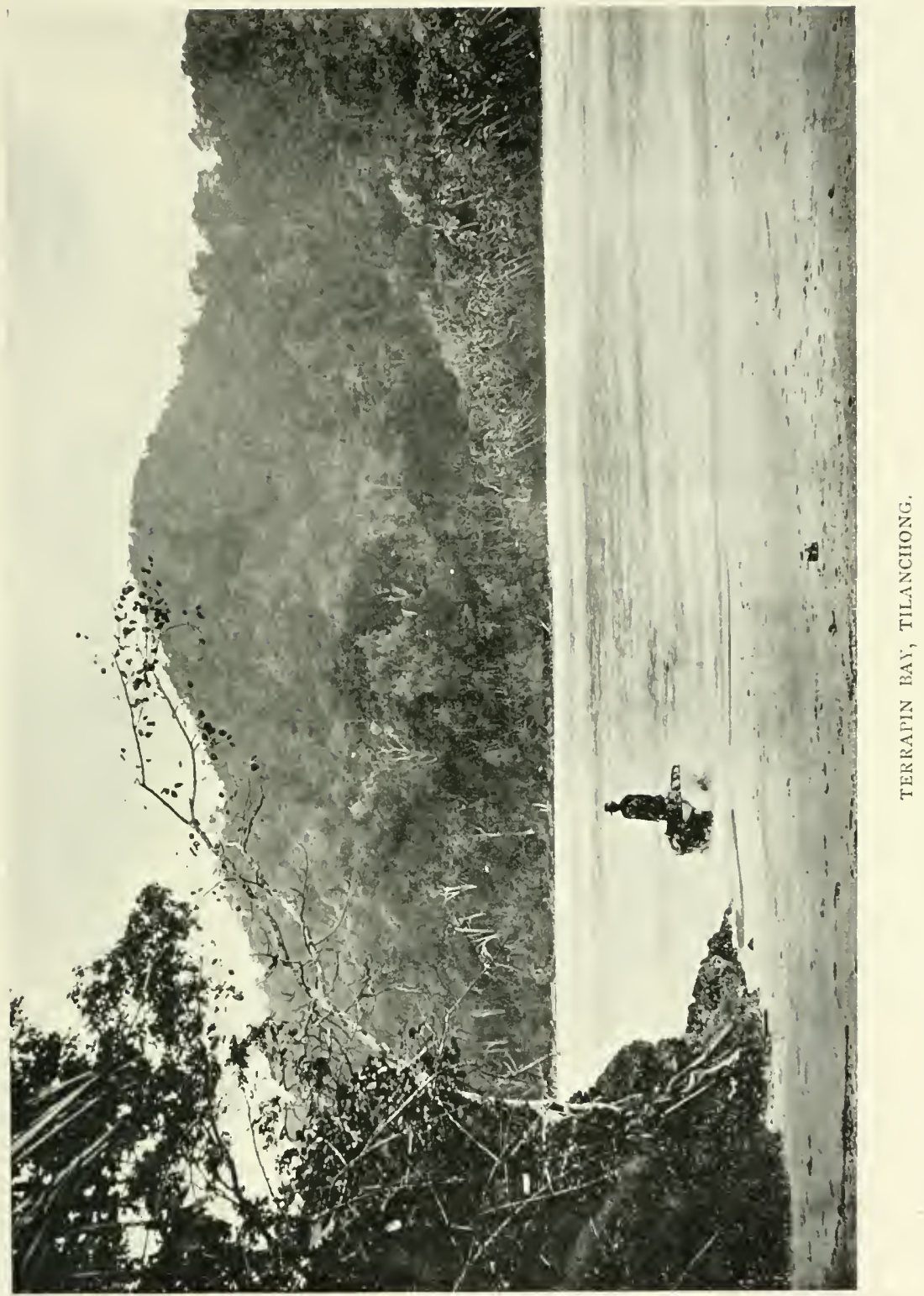

[To face rage 60. 

patches of luxuriant forest. We passed three small beaches, above which grew a few coco palms, and then came to Novara Bay, about 3 miles from the north end of the island, where the Austrian frigate anchored in 1858 . It was, however, on account of the steepness of the land, an impracticable place for collecting. South of this point the island is everywhere covered with dense jungle, and for the next 4 miles expands to a breadth of more than a mile, attaining in the centre its greatest elevation in Maharani Peak, a little over Iooo feet in height. A short distance further on, and opposite two rocky islets, each about 80 feet high, we found a good anchorage, which, being unnamed on the chart, was promptly christened "Terrapin Bay." It affords fair protection in the north-east monsoon, and shoals gradually from I 2 fathoms to the beach. The latter is about three-quarters of a mile long, and is divided by a huge mass of rocks covered with casuarina trees, behind which is a small stream of brackish water. Numerous coco palms shade the beach, and beyond them is a stretch of flat, jungle-covered land. Good water may be obtained at a little sandy spot beyond the rocks forming the northern point of the bay. There is also an anchorage on the other side of the island in Castle Bay.

Tilanchong is 9 miles long and $I_{4}^{\frac{1}{4}}$ miles broad at its widest point, and has an area of about 7 square miles. It is rocky, and everywhere covered with jungle, except in the north, and in shape resembles a flying bird with the north and south extremities as wings, and the broader part in the centre, head, and body.

Our landing at midday was a pleasant contrast to the experiences of Kar Nicobar; the sea was fairly calm, and damage to guns and ammunition was no longer to be feared. On entering the jungle, which at first was somewhat thin, we were immediately struck by the extreme fearlessness of the birds, and the immense number of lizards, of a species peculiar to this island (Gonyocephalus humeii), which abounded everywhere. Every tree-trunk in the forest was the resting-place of two or 
three of the latter, and as one moved along it was to an accompaniment of scurrying reptiles that dropped from the adjacent branches and darted off to a less immediate neighbourhood. Especially did they swarm in the jungle growing on the dry coral sand above the beach. Besides this small species we found a Varanus lizard, 5 to 6 feet long-very common. We frequently saw them, or heard their noisy rush through the bushes, as, disturbed by our approach, they galloped out of danger. Of the birds, the splendid fruit-pigeons (Carpophaga insularis), generally so wary and unapproachable, denizens of the highest tree-tops, were so unsuspicious that time after time we knocked them over with a pinch of dust shot, and parrots and Nicobar pigeons were obtained with almost equal ease. The latter, whose range extends from these islands eastward to the Solomons, are extremely beautiful birds. The feet are plum-coloured, and the stumpy tail, which is almost hidden by the wings, is snow-white. The head and neck are a delicate grey, while the long, flowing hackles and the rest of the plumage are of a glorious metallic green, iridescent in the sunlight, with shining tints of gold, purple, and blue.

We had not long separated before I caught sight of two megapodes scuttling through the bushes-dull-brown birds about the size of a six-months'-old chicken. They disappeared before I could shoot, but, close by to where they had been, I found one of their laying-places, a mound of fresh earth about 4 feet high and 12 feet in diameter, disturbed by recent working.

For a few hundred yards beyond the beach the soil is very light and friable, a mixture of vegetable loam and disintegrated coral; but behind this it becomes swampy, supporting a denselymatted growth, and while collecting amongst this, I lost my bearings and spent a warm half-hour cutting a way back to the more open forest in the vicinity of the boat.

"January 30. - This morning got my first megapode. Soon after landing, I saw a Nicobar pigeon on the ground, and while stalking it to get a close shot, noticed near by three birds, of 


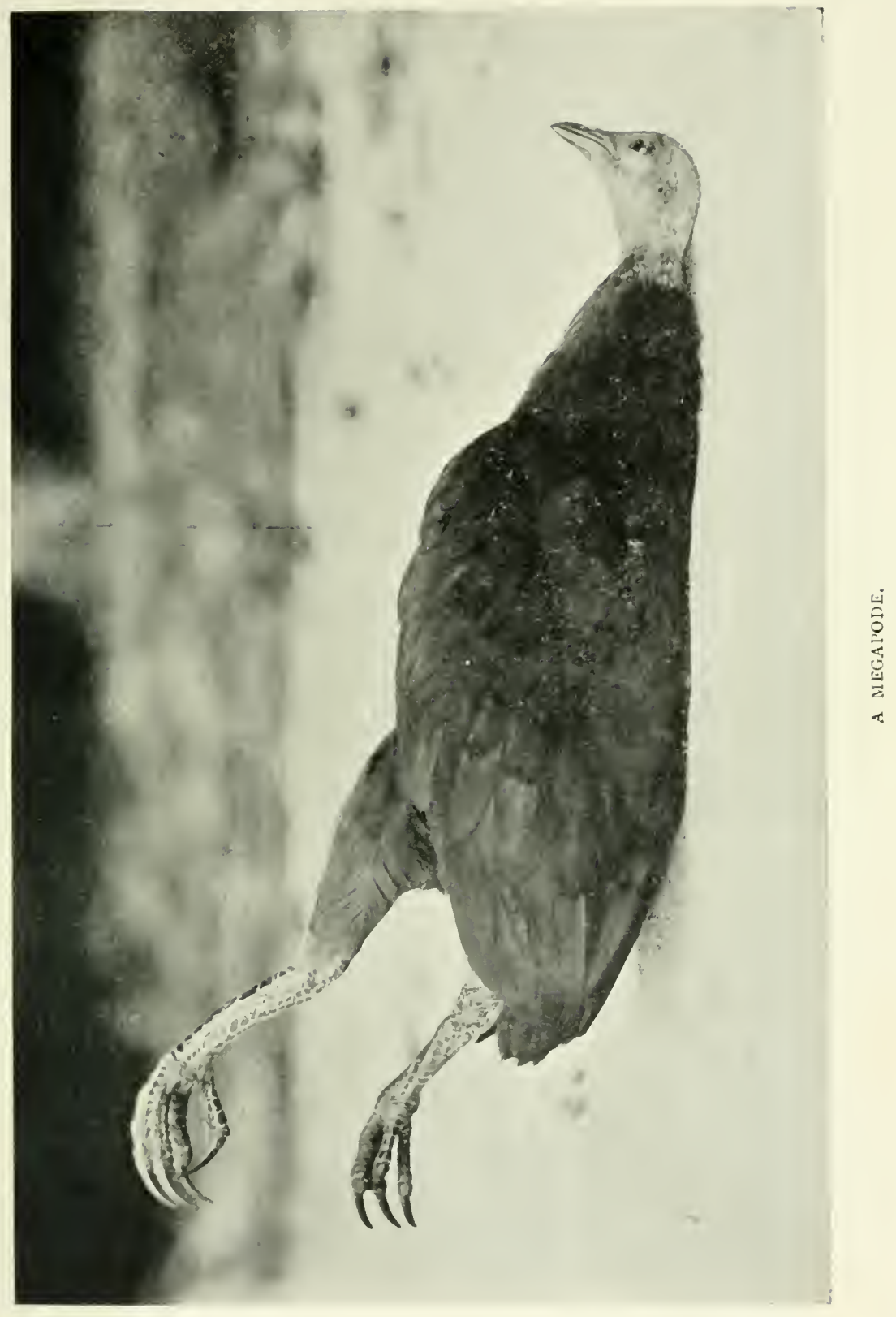

[To face page $6 \mathrm{~s}$. 

much the same size, dancing about amongst some bushes. They were out of sight most of the time, but I 'browned' the place with a heavy charge, and running up found a cock megapode lying dead. In appearance the bird is not unlike a partridge, though larger, and it has the same drooping tail; the feet, however, are out of all proportion, and are remarkable for their extraordinary strength and size; the plumage is olivebrown in colour, except on the head, which is thinly covered with pale greyish feathers, while the cheeks are naked and of a bright vermilion.

"Going further south than yesterday, I found beyond the rock, in the middle of the beach, what was probably once a fair-sized lagoon, but is now an open swamp nearly overgrown with grass and nipah palms. Several small water-birds and a couple of herons were flying about, and of the latter I obtained a white variety.

"We spent about an hour on shore in the afternoon and saw some more megapodes, but failed to get a shot at them: they frequent the open jungle directly bordering the shore, where the soil is so light that they can build their mounds with ease."

"Jamuary 3I.-On leaving the jheel this morning, as I walked over the rise of ground that separates it from the sea, l saw a crocodile lying half-in and half-out of the water, but before I could get near enough for a shot-cartridge to take effect he turned and swam off; as he rose and fell with the waves, he looked like a $\log$ of wood, but all the while made steadily seaward; he was about 10 feet long, and brilliantly marked with yellow.

"In the afternoon I took the camera ashore to get photos of a nest-mound. Just as I was entering the jungle by the mound, I noticed that earth was being thrown in a continuous shower from the top. Soon a bird ran out from a depression there; I shot it, and at the noise another jumped out for a moment and then went on digging, but appearing again a few seconds later, I got it also. It was about to lay, but the shot had unfortunately broken the egg: there is no external 
difference in the appearance of the sexes, but these were a pair, and it is therefore evident that when the hen is about to deposit the egg, the male assists in excavating the hole in which it is to be buried for incubation. The mound on which they were busy was between 7 and 8 feet high, and rather more than Ioo feet in circumference, and had a large coco palm growing through the centre. It would certainly be the work of a number of birds, and must have taken many years to build."

We got four more megapodes on February I, one of them containing an unbroken egg of a size remarkable for so small a bird; it measured $3 \frac{3}{8}$ inches by $2 \frac{3}{16}$ inches.* The shell is very thick, and when new of a pinkish colour, which changes in the earth to a dirty buff. The temperature of a nest-mound, which we dug into without success in a search for eggs, rapidly increased towards the centre: it was composed of light sandy soil, with apparently no addition of leaves or grass other than that lying about on the earth employed by the birds; the species does not seem purposely to include vegetable matter for causing heat by fermentation.

We failed, whilst here, to obtain a single specimen of a rat; the island is much cut up with holes, high and low, but they are those of crabs, who here also-as on Barren Island and in Kar Nicobar-made off with our baits, leaving behind in some of the traps a quarry we did not at all desire. The only mammal obtained was a large fruit-bat (Pteropus nicobaricus), of which Abbott found a camp up the stream and shot several for specimens. Tracks of pig were seen.

The island is uninhabited, and seems to have been in the same state for some time. In Hamilton's Voyrges some account is given of the adventures of a shipwrecked crew, whose vessel, commanded by a Captain Owen, was lost there in Iyo8. They found the place unpeopled, and, making fires in the night, were

* "I once weighed one of these birds and found it to be only six times greater than its own egg; whereas I found that a domestic hen weighs twentytwo times as much as its own egg."-E. H. Man. 


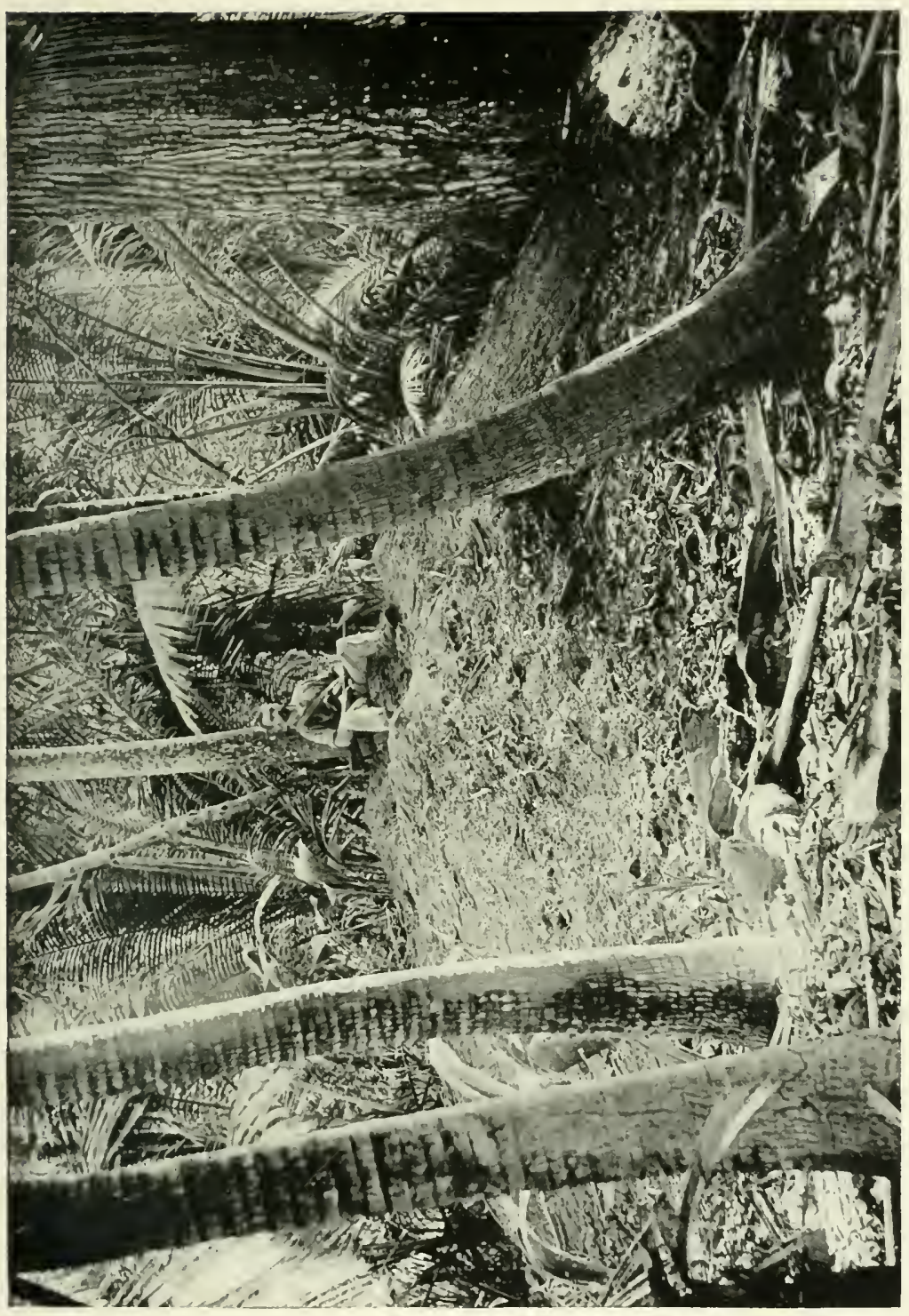

[To face page 70 . 



\section{WRECK AND DEATH OF CAP'TAIN OWEN 71}

taken off by several canoes that came across from the Nankauri group.

Their further adventures, although more properly appertaining to the history of the central islands of the Nicobars, may as well, for the sake of continuity, be given here.

"The natives," writes Hamilton, " . . . very courteously carried the shipwrecked men to their islands of Ning and Goury, with what little things they had saved of their apparel and other necessaries.

"The captain had saved a broken knife about four inches long in the blade, and he having laid it carelessly by, one of the natives made bold to take it, but did not offer to hide it. The captain, finding his knife in the poor native's hand, took it from him and bestowed some kicks and blows on him for his ill manners, which were taken very ill, for all in general showed they were dissatisfied with the action; and the shipwrecked men could observe contention arising among those who were their benefactors in bringing them to the island, and others who were not concerned in it : however, next day, as the captain was sitting under a tree at dinner, there came about a dozen of the natives towards him and saluted him with a shower of darts made of heavy wood, with their points hardened in the fire, and so he expired in a moment.

"How far they had a mind to pursue their resentment I know not, but the benefactors of the shipwrecked men kept guard about their house till next day, and then presented them with two canoes, and fitted them with outleagers to keep them from overturning, and put some water in pots, some coconuts and dry fish, and pointed to them to be immediately gone, which they did.

"Being six in company, they divided equally, and steered their course for Junkceylon, but in the way one of the boats lost her outleager and drowned all her crew. The rest arrived safely, and I carried them afterwards to Masulipatam."

People from Kamorta, from which it can be seen, and who own the plantations on it, come to the island from time to time for the sake of the coconuts, of which there are a fair quantity, and 
we found traces of visitors in the remains of two tumble-down huts and a liberal scattering of pigs' skulls.

IVe weighed anchor at 10 A.M., but it was an hour and a half later before we passed the two off-lying islets, for, every few seconds, flaws of wind, coming over the high land, so changed in force and direction that we could get no steerage way, but helplessly boxed the compass all over the bay before we caught a steady breeze. We found deep water between the islets close to the southernmost; everywhere else the ground seemed foul. With a 3 -knot breeze we sailed along the western shore, which at this end is much lower than the north, and densely wooded, presenting to view several white beaches and groves of coco palms, while not far from shore are numerous off-lying rocks that continue in a south-easterly direction for about 3 miles from the end of Tilanchong and terminate in a fair-sized islet, named Isle of Man.*

The island of Kamorta lies some 12 miles to the south, the adjacent part rising in low grass-covered hills, with occasional trees dotted about: along the coast runs a fringe of vegetation and coconut trees, while in the centre, where the island is about 450 feet high, it is more thickly covered with forest. Trinkat, closely adjoining it on the east, is very low, and from the sea, seems overgrown with jungle. Darkness had fallen before we reached the southern entrance of Beresford Channel, that runs between it and Kamorta, and proceeding inwards for a short distance, we anchored at 9.45 P.M.

* After Mr E. H. Man, by Col. Strahan, R.E., when surveying the Nicobars in 1886-7. 


\section{CHAPTER VII}

\section{TRINKAT}

Beresford Channel-A Deserted Village-Jheel-Bird Life-IVild CattleScenery-Photographs-Port Registers -Tanamara-Population-Customs - The Shom Pen-The Sequel to a Death-Interior of the Houses.

TrINkAT is a low, flat island about five miles long and one wide, separated from Kamorta by the narrow strait in which we anchored. This is much choked with coral-reefs, on which every now and then the sea breaks unexpectedly in low waves which run along their edges throwing up clouds of spray. Several villages, fronted by rows of streamer-decorated poles, were in sight on the western shores, and further up the channel a junk from Penang was anchored, the first we had seen. The island is nowhere higher than 80 or 90 feet, and is superficially of limestone formation-raised coral: the shores are fringed with jungle and coco palms, while the latter are frequent also in the patches of jungle occurring in the interior, * which, however, consists mainly of open undulating grassy land.

We landed, after crossing the reef, near a couple of huts, built of palm leaves and rough planks, that seemed deserted.

* This may possibly be one of the results of elevation. As the island grew, nuts drifted to its changing shores and took root, until, as more and more land appeared, those trees which at one time stood along the edge of the island would at length be situated in the interior. Kar Nicobar, another low island of similar formation, also possesses forests of indigenous coconuts.

"Trinkat, being flat, is divided amongst the inhabitants of the other two islands, where they have their plantations of coconuts and areca palms : these last being very abundant."-Fontana, Asiutic Researches, vol. iii., I778. 
A great number of pigs were roaming about in company with dogs, fowls, and a cat. The huts were surrounded for some distance by palm trees growing in thick scrub undergrowth. A little way along a path we arrived at a small jheel, on which were a diver and several whistling teal. Birds were numerous amongst the trees, where parrots ( $P$. erythrogenys) and pigeons dwelt in flocks, and on the ground megapodes ran about calling to each other, but were too well concealed, by the tall grass and bushes that grew everywhere, for successful collecting. We got here the Nicobar fly-catcher, in plumage of dark chestnut, with steely-black head, and Geocichla albigularis, a pretty grey, olive and cinnamon thrush, a shy bird that kept down on the ground or hid itself in low bushes. Out in the open, amongst the grass, we found numbers of small warblers (Cisticola cisticola), an occasional snipe or two, and flocks of little buttonquail (Excalfactoria (?), sp. nov.), while a herd of about fifty semi-wild cattle roamed about, most of them descendants of a number turned out here in ' 88 , when the settlement at Nankauri was given up. They suffer but little loss in numbers at the hands of the natives, for the Government allows no guns in the islands, and it is only very occasionally that a number of men will combine and slaughter a beast with spears.

From the interior the scene was very beautiful; rolling grassy downs were dotted with numerous dwarf pandanus trees $(P$. furcatus), amongst which the cattle, black, white, and brown, moved slowly. All around was thick jungle, through breaks in which the sea was visible on either hand, and in the west, the sun, shining from behind a dark cloud, painted the hills and harbour of Nankauri in tones of grey and gold. The photographs which I took of this scenery were spoilt, thanks to a liberty taken by the too inquisitive Chinese "boy," who privately satisfied his curiosity as to the appearance of the plates before they had been removed from the slides and developed.

In the evening the Government Agent, who is a native of India, came across from the harbour and brought the Port Register, in which we entered our arrival. These registers, bound in 
heavy brown leather, stamped with the arms of the Indian Government, we were often to meet with in future; one is in the possession of nearly every coast village except those of Great Nicobar, and some of the remarks in them are very interesting; others are equally amusing, as when some Nakodah, vain of his proficiency in English, tries to express himself in that language, to the utter bepuzzlement of any one who may come after and see what has been written.

In crossing the island next day, I stampeded the cattle, who are rather shy of any moving object, although later I was able to crawl to within five or six yards of the herd, thus learning how simple a matter it would be for the natives to exterminate it. In the interior there are several deep ditches of running water leading into small swamps where the cattle drink. The shore on the eastern side is formed in places by small bluffs of clay marl, above which can be traced the overlying beds of coral.

That afternoon, while preparing specimens, we received a visit from a swarthy gentleman in a suit of white drill-the trousers "a world too long," gracefully falling in concertina-like folds about his naked ankles. He saluted us gravely, and tendered a small pocket-book. "What is your name?" said we. "You will find it," said our dignified visitor, "in the book." So the book was referred to, and he stood revealed as Captain Tanamara, Headman of Malacca, recommended by $\mathrm{Mr} \mathrm{E}$. H. Man,* as intelligent and willing to be useful to whoever should stop at Nankauri Harbour. $\mathrm{He}$ is certainly more ingenious than the majority of the natives, and speaks English, Hindustani, a little Burmese, Kar Nicobarese, and Malay, which last indeed is known by most of the people from here southwards.

* The name of Mr Man is one to conjure with in the Nicobars. Everywhere we met with expressions of regret that he was about to retire after some thirty years' acquaintance with this group and the Andamans. Now and then we made rather unwarranted use of his reputation-did we want the portrait of a native who was rather nervous at the sight of the camera. "Here, come along, and don't be afraid, Mr Man does this," and it was all right. 
The population, he told us, was decreasing: formerly each house was occupied by a number of people, as is still the condition of things in Kar Nicobar, but now there are at most three or four to a hut.* He and many other men have no children, the usual number of which is but one or two in each family. Occasional polygamy and easy arrangements for divorce prevail here, and the custom of the husband residing at his wife's house is also in vogue, but in the case of an influential man, or a headman, it is otherwise. He was much interested in a kingfisher ( $H$. occiputalis) that was being skinned, and begged for the eyes, which, he said, formed a valuable specific in cases of sleeplessness!

One of the most attractive features of the Nicobars is the existence of a wild inland tribe-the Shom Pen† - in the interior of the southern island. These people are known by reputation all over the group, and seem to fill the part of a national "bogey man." From Tanamara, who has visited Great Nicobar in the station steamer, we obtained a few details. He had never seen them, and owned with much candour that he was "plenty 'fraid," and for that reason did not go on shore. He told us, however, that they are similar in appearance to the Nicobarese, but wear garments of rattan and bark only. They are friendly until they see any article belonging to the coast people which they may covet, and then a raid is made, and murder generally ensues in getting possession of it.+

The abandoned condition of the houses near which we landed was caused by a death which took place in one of them a short time previously. This was followed by immediate desertion, which, however, is only temporary. Everything going

* "The number of inhabitants on any one of the (central) islands does not exceed 700 or 800 . Ten or twelve huts form a village. Each village has its 'Captain.' A woman who bears three children is very fruitful; few hear more than four. No men seem older than forty or fifty; women live longer."-Fontana, Asiatic Researches, vol. iii., 1778.

+ Pronounced like pain (French).

* We were told on the west coast of Great Nicobar, that no valuables were kept in the village there for fear of the Shom Pen, but that all treasured possessions were stored in boxes, at Pulo Kondul. 
on seemed to have suddenly stopped; díos were lying on the floor, clothes hung from pegs in the walls, food, half-cooked, still stood in the pots. The animals wandered about uncaredfor, cats and dogs in a very famished condition.

Inside this house was quite a small museum: there were large figures, daubed with red and black paint, of men and women with eyes of pearl shell, Polynesian fashion, and drapings of palm leaf and cotton; smaller images and various grotesque heads, sharks, birds, and crocodiles, all carefully carved, and painted in red and blue; painted turtle skulls by the dozen. Spears, cross-bows, and water-vessels hung from the walls, with boards on which were human figures, pigs, fish, fowls, and palm trees, all very well drawn, and not conventionalised in design. On a shelf above the fireplace were piles of wooden plates, dishes, and food-baskets, and below them the big Chaura pots were standing on blocks of stone above the ashes.*

We only obtained one megapode on Trinkat, and it was found in a trap. They are probably numerous, for we saw several, and heard frequent calls. The undergrowth is very thick, and the ground covered with tall grass, and although to move about is easy, it is not easy to see these birds until one is almost upon them, when they disappear before one can get a shot. A few rats (Mus burme, sp. nov.) were caught in the traps, and we shot a few additional specimens, and this is the only island we visited in the Nicobars where they seemed other than extremely scarce.

* "To the middle portion of the roof frame an image of the household god is attached; from the walls are suspended human figures carved from wood, and enwreathed with bundles of grass or coconut leaflets, which are regarded as charms for the cure of diseases. Above the centre posts are hung up, strung to rattan, all the lower jawbones of hogs that have been slaughtered by the family: and their number furnishes a due estimate of the wealth of the owner of the house.... Wooden figures of men armed with sword and shield, and women in a dancing posture, with outstretched arms, are hung up in the rear and other parts of the building.""The People of Nias," The Races of Mankind, A. Featherman. 


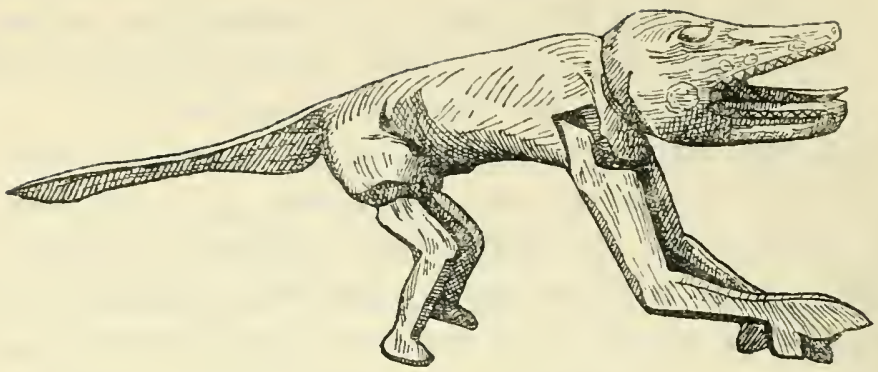

"Scare-devil," or derice for exorcising evil spirits.

\section{CHAPTER VIII}

\section{NANKAURI}

The Harbour Shores-A Village-Kanaia-Canoe-Feeding the AnimalsCollecting-ground-Mangrove Creeks-Preparations for a FestivalBurial Customs-Malacca Village-Houses-Visit Tanamara-Furniture -Talismans and "Scare-devils"-Beliefs-Festivities-A Dance-An Educated Native-Tanamara and his Relations-Cigarettes-Refreshments -The Collections- Geology-Flora-Population-Piracy.

ON the morning of the 5th we weighed anchor, and proceeded to Nankauri harbour. The entrance is about a quarter of a mile wide, and its northern coast, once the site of the Government settlement, is the only open grassy portion of the harbour shores. Just within the point stands the flag-staff, and above it, on the crest of a low hill, a little graveyard lies within the shade of casuarinas. A long jetty of coral blocks runs out from the shore, and near by is the house of the agent. Opposite, on either side of Mayo Point, are the villages of Malacca and Inúanga, and behind them the forest-clad slopes stretch to grassy uplands.

We sailed into Spiteful Bay, which lies just behind the southern point of the harbour entrance, and anchored in 12 fathoms, mud and sand, close to a little village of a dozen houses standing above the beach.* In front of these and planted in shallow water, rose a number of tall poles, each made of several 


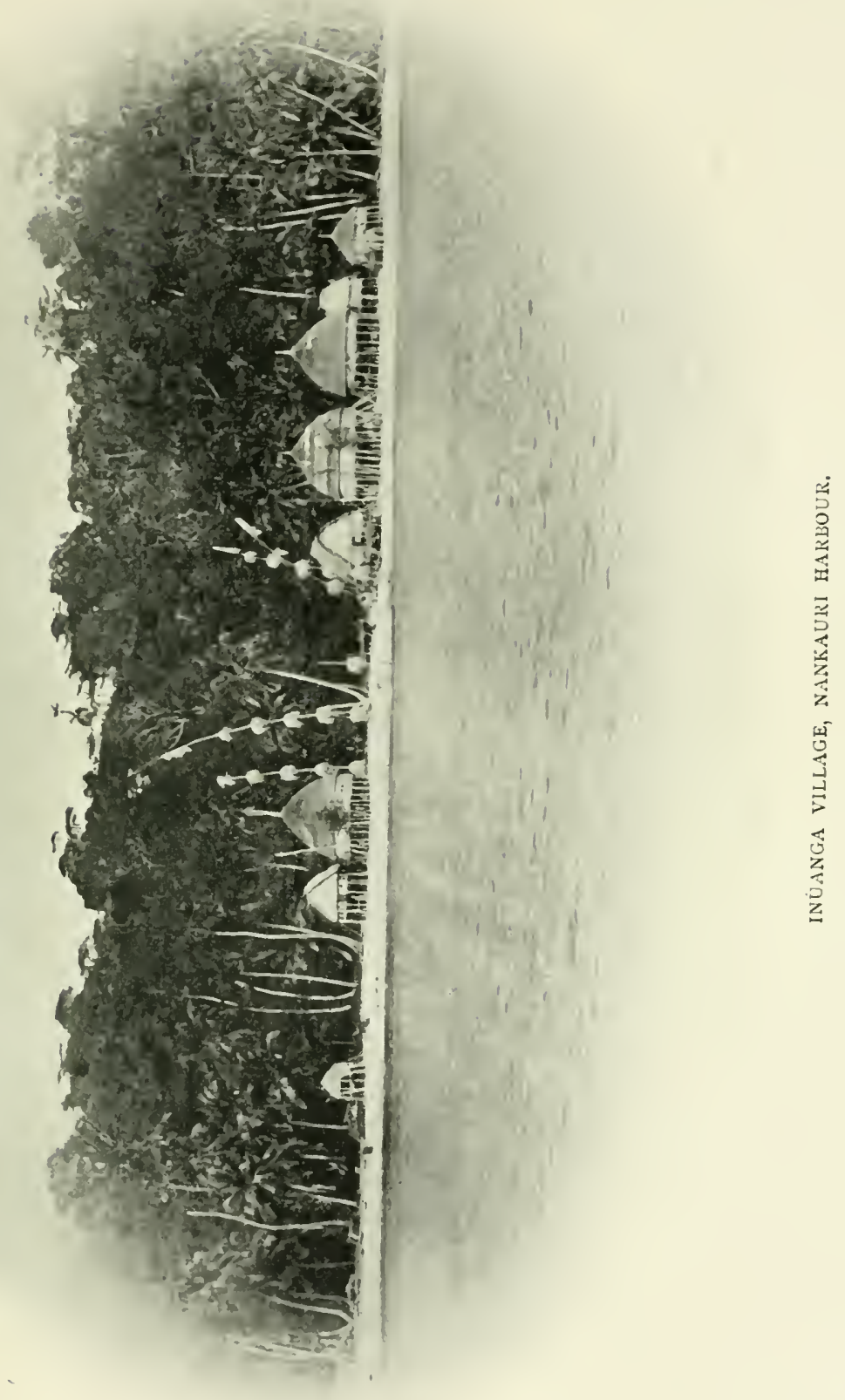

[To face page 78. 

spars bound end to end with rattan, and ornamented at intervals with bunches of palm leaves. These the natives call kanaia: they have, we were told repeatedly, no superstitious significance; one is put up for each inhabited house in the village, and renewed periodically.*

Landing at the village (matai) is easy, for below the waterlevel the sandy shore slopes downwards at an angle of $45^{\circ}$, a condition made possible by the tranquility of the harbour water. The houses, (n'gi) are less solidly built than those of Kar Nicobar, possess a small side-wall about 4 feet high, of boards, and a pointed finial crowning the conical roof; but do not have the protective discs on the supports: the door, too, and a number of small windows open in the sides, and the latter are all supplied with shutters that swing freely on a wooden hinge.

A new and very large canoe was lying on the beach, the dug-out portion, without additions, measuring 42 feet long by 3 feet wide and 3 feet deep. The hull was charred, and decorated by grooved bands running at short intervals from gunwale to gunwale round the outside. Canoes are fitted, according to size, with from one to four short bamboo masts, each supported by four wide-spreading stays of rattan, and on these are hoisted lateen sails with a short tack of about 12 inches, made of cotton or pandanus leaves. The masts are never stepped on the floor of the canoe, but always on one of the crossbars or thwarts.

The people about the village were feeding their dogs and pigs with a kind of gruel in wooden troughs, and as the animals

* Dr Scherzer (Cruise of the "Novara") states that they were used for frightening away the devil and driving him into the sea. $C f$., however, the Ma-ya-kuv-ka-ma-ka of the Kar Nicobarese (p. 295); and also an old Kar Nicobarese custom: "In every village there is a high pole erected, with long strings of rattan hanging from it, which it is said has virtue to keep the devil at a distance" (Hamilton, Asiatic Researches, vol. ii.). On the other hand, Colebrooke (Asiatic Researches, vol. iv.), writes: "In front of the villages, and a little advanced in the water, they plant beacons of a great height, which they adorn with tufts made of grass or the bark of some tree. These objects are discernible at a great distance, and are intended probably as landmarks; their houses, which are overshadowed by thick groves of coconut trees, seldom being visible from afar." 
were judged to have enough, each was smacked on the head and sent off; no greediness nor crowding was allowed, and the pigs were far better behaved than the generality of their species.

We found the jungle near the houses quite impracticable, both from its tangled nature and the steepness of the ground it covered. A walk along the shore produced only a whimbrel (Numenius phaopus), which, although not bad for the pot, is too wide-spread a species to be of much value ornithologically.

Experiences next day on the opposite side of the bay were little more encouraging. Scrambling up a steep hill, we found a small stretch of flat land on the top, where ran one or two faint paths, along which the traps were placed. Birds were very scarce, and as it began to rain, we returned to the dinghy, and rowed round the bay, looking for kingfishers. The boat was paddled up all the creeks in the thick belt of mangroves that fringe the shores, but there was no sign of the bird we were after-the large stork-billed Pelargopsis-and we had to be content with whimbrels. The creeks, which in many cases are only just broad enough to row in, often wind for long distances among the mangroves, and on a dull day are depressing places, with but little life in them. In the bay itself we saw many beautiful branching corals of kinds far too delicate to grow in the more disturbed water of the sea; much of the growth which spreads all over the bottom was, however, killed by the mud and fresh water that comes down through the mangroves.

Our arrival in the harbour was coincident with the beginning of a feast, which was to continue for a week or so. Two new canoes, decked with most gorgeous banners, flags, and streamers flying from small poles, * were launched on the first day, and, to an accompaniment of singing, rowed across to the northern shore to obtain young coconuts for the coming festivity. These joyous occasions the natives call, in imitation of our English custom, "making Christmas"; and over the door of those houses

* These flags are made by the natives, and some of them are a legacy from the Danish occupation - a white St George's cross on a red ground, with a double-ended fly. 


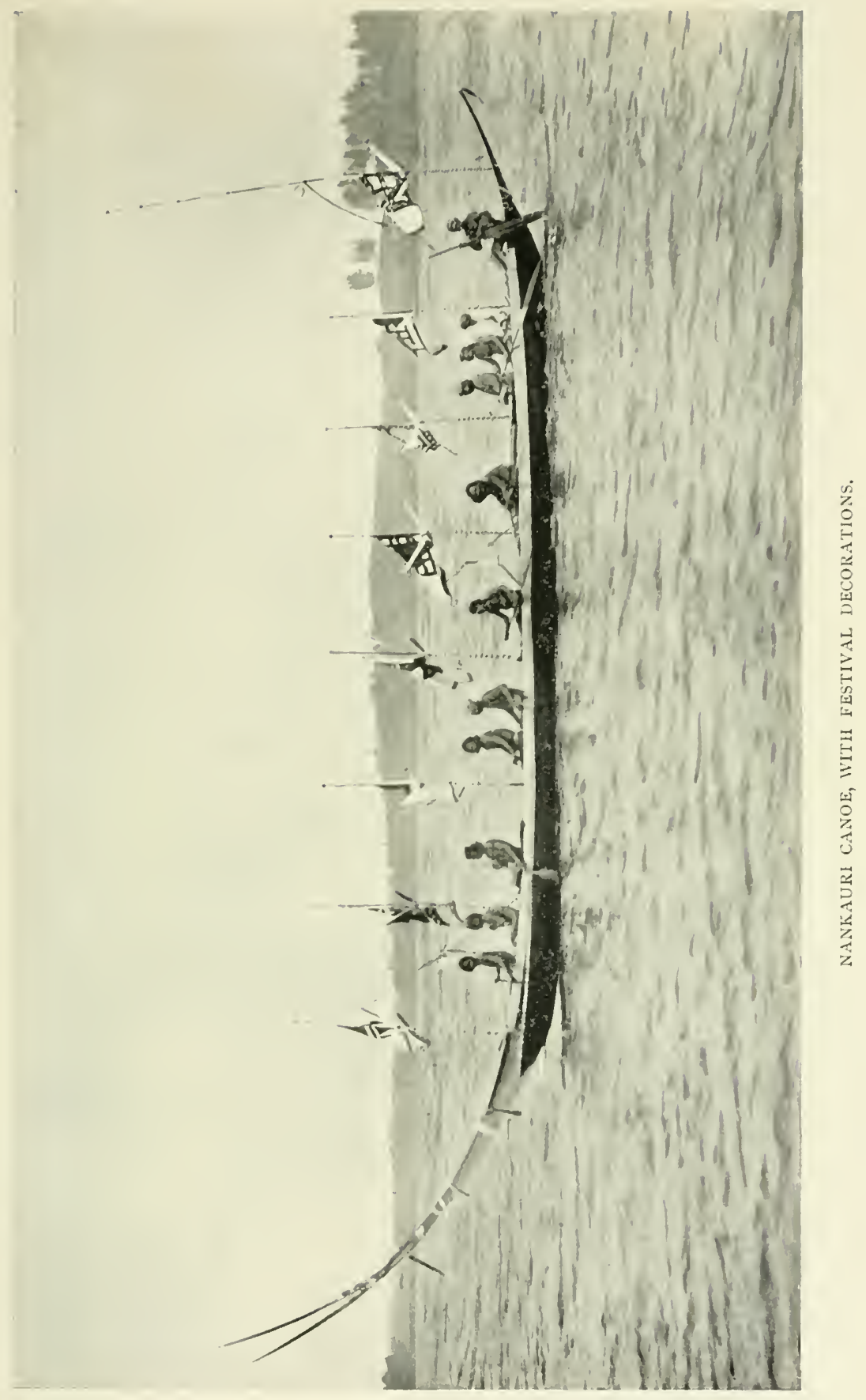

TTo fuce prege so. 

where the gatherings are held they fasten a number of branches.* We entered one of the houses thus decorated. Outside were large heaps of green coconuts, and inside other refreshment in the shape of several big jars of toddy; the interior was prepared for dancing. Immense quantities of cotton print, of every pattern and colour imaginable, were hung from rattans crossing the upper portion of the roof to within about 7 feet from the floor; the upper part was a nearly solid mass of cotton. On a framework in the centre of the floor, covered with alternate strips of red and white cotton, so that it seemed to be made of barbers' poles, were suspended a large number of spoons, forks, and soup-ladles. Everything else in the house was pushed back against the walls in order that the floor might be clear, and as the place was rather dark, it was illuminated by a lamp made from half a coconut-shell, containing melted pigs' fat and a strip of rag. The spoons and forks, in which the natives invest nearly all they obtain by the sale of their coconuts, are purchased from the Burmese and Indian traders. For soup-ladles they give 20 rupees; table-spoons ro rupees, and smaller sizes 5 rupees. They are of electro-plate and German metal, but the people apparently think them silver, and did not seem to believe us when we told them otherwise, so we did not press the point. Considering the large number they possess, the knowledge might be painful, and since they are destroyed at the owner's death, it perhaps does not matter much. "It's an ill wind that blows nobody good," and the traders ought to do very well at such prices.

The large public dances of the northern island are not held here, but two or three private houses are prepared for the occasion as above described.

The people of these islands employ in everyday life far more clothing than the Kar Nicobarese, and a great proportion of them wear some other garment-trousers or jacket-in addition to their national apparel. Formerly, they wore the white palm-

* Fontana mentions the palm leaves and other branches decorating the hut doors at festivals, 1778 . 
leaf head-dress, but it was given up when imported garments became common.

A custom of partially exhuming the bodies of the dead exists here, and whenever celebrated is the occasion of a special feast (Koruak). In the Northern Islands the entire remains are disinterred, carefully cleaned, wrapped up once more, and reburied; here, the skull and jawbone only are retained.

The local population greatly deprecates the method of their northern countrymen.

It would appear, by the way, that the present custom is no degradation of the past, for more than a century ago the head only was disinterred and cleansed.

"On the anniversary of the festival-if it can be so calledtheir houses are decorated with garlands of flowers, fruit, and branches of trees. The people of each village assemble, dressed in their best attire, at the principal house in the place, where they spend the day in a convivial manner. The men sitting apart from the women, smoke tobacco and intoxicate themselves, while the latter are nursing the children, and employed in preparation for the mournful business of the night. At a certain hour of the afternoon, announced by striking the goung (an instrument of brass somewhat like the gurry of Bengal-it sounds more hollow), the women set up the most dismal howls and lamentations, which they continue without intermission till about sunset, when the whole party gets up and walks in procession to the burying-ground. Arrived at the place, they form a circle round one of the graves, when a stake, planted exactly over the head of a corpse, is pulled up. The woman who is nearest of kin to the deceased steps out from the crowd, digs up the skull and draws it up in her hands. (The office is always performed by the women, whichever sex the skull belongs to. A man in a fantastic garb officiates as priest.) At sight of the bones her strength seems to fail her; she shrieks, she sobs, and tears of anguish abundantly fall on the mouldering object of her pious care. She cleans it from the earth, scrapes off the festering flesh, and laves it plentifully with the milk of fresh coconuts, supplied by the bystanders; after which, she rubs it over with an infusion of saffron, and 


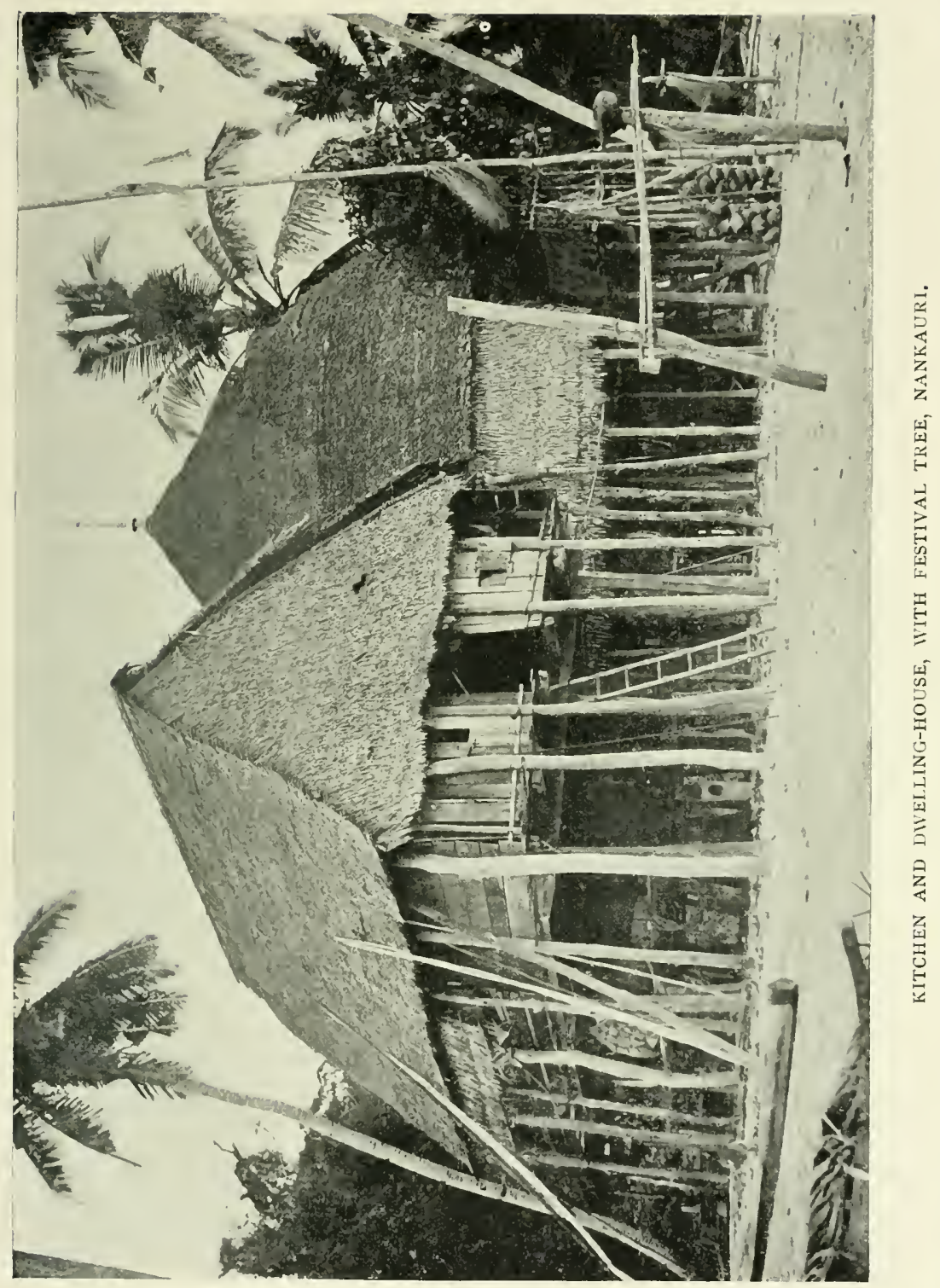



wraps it carefully up in a piece of new cloth. It is then deposited in the earth, and covered up; the stake is replanted, and hung with the various trappings and implements belonging to the deceased. They proceed then to the other graves; and the whole night is spent in repetitions of these dismal and disgustful rites.

"On the morning following, the ceremony is concluded by an offering of many fat swine, when the sacrifice made to the dead affords an ample feast to the living: they besmear themselves with the blood of the slaughtered hogs; and some, more voracious than others, eat the flesh raw." *

A few hundred yards from the houses in the bay, and on the seaward side of the same point, is situated the larger village where the headman resides; the path connecting the two crosses the site of one of the old Moravian mission establishments, where the brick foundations of some of the buildings once standing there may yet be seen. $\dagger$

This larger village + contains fifteen to twenty houses closely packed together, and fronted by a tall row of kanaia standing in the water. Bamboo posts, too, split at the upper end and spread out fanwise, are planted at intervals along the beach; they are put up yearly by every man in the village, to keep fever and devils (iwi) away; and several grotesque figures of crocodiles $(y e ́)$, placed in little shelters, raised on poles, prevent their living counterparts from attacking the villagers when they enter the water.

The houses are of two kinds, round and rectangular; the latter are used as kitchens and storerooms, but there is a fireplace in the others, where much of the cooking is done. The conical roofs are made of attaps of nipah palm, neatly fastened to a

* Colebrooke, Asiatic Researches, vol. iv.

† "The Danes have long maintained a small settlement at the place which stands on the northernmost point of Nankauri within the harbour. A sergeant and three or four soldiers, a few black slaves, and two rusty pieces of ordnance, compose the whole. They have here two houses, one of which, entirely built of wood, is their habitation; the other, formerly inhabited by the missionaries, serves now for a storehouse."-Colebrooke, Asiatic Researches, vol. iv.

+ Malacca. 
framework of thick rattan by lashings of cane, the sides and floor are generally of roughly-hewn boards; inside, about 3 feet from the wall, a circle of posts helps to support the roof, which, in some cases, is entirely lined with horizontal laths of wood. The apex is crowned outside by a high, carved finial. Access is obtained by means of a notched pole, and to permit the entrance of domestic animals, a tree trunk, split and hollowed out to form a trough, slopes gently up from the ground to door or window. Beneath the houses are platforms on which the natives keep their store of pandanus and coconuts, their spare pots and baskets, and peculiar bundles of wood. This latter is neatly cut into billets about I foot long, and packed into circular bundles, 2 or 3 feet in diameter, by means of a tight lashing of cane.*

One afternoon we paid a visit to Tanamara. $\mathrm{He}$ and his wife have no children, but have adopted a little girl from Chaura, whose parents are dead. This custom of adoption is, he says, not at all uncommon. Tanamara's father and mother live with him; the former, "England" by name, is an old, white-headed man, who is nearly eighty; he professes to know nothing about the piratical atrocities which formerly occurred in this group of islands, although many of them happened at a period sufficiently late in his life for him to have fully comprehended such events.

The interior and contents of the house were very similar to what we had already seen in Trinkat. Opposite the door stood the fireplace-a bed of clay on the floor-above which was a mantle-shelf or rack, where are kept pots, baskets, trays, etc. A grated floor formed a small chamber immediately under the

* "The large, neatly-made bundles of trimmed billets of wood, have always been mistaken for firewood, even by Pastor Rosen, who spent three or four years in the Harbour. They are, however, made merely to serve as offerings, and are rolled on to a grave of some relative or friend. They are supposed to represent a substantial token of affection and regard as they take much trouble to make. Their bundles of firewood are also cylindrical, but consist of dry scraps of wood picked up in the jungle and tied round with pieces of cane."E. H. Man. 


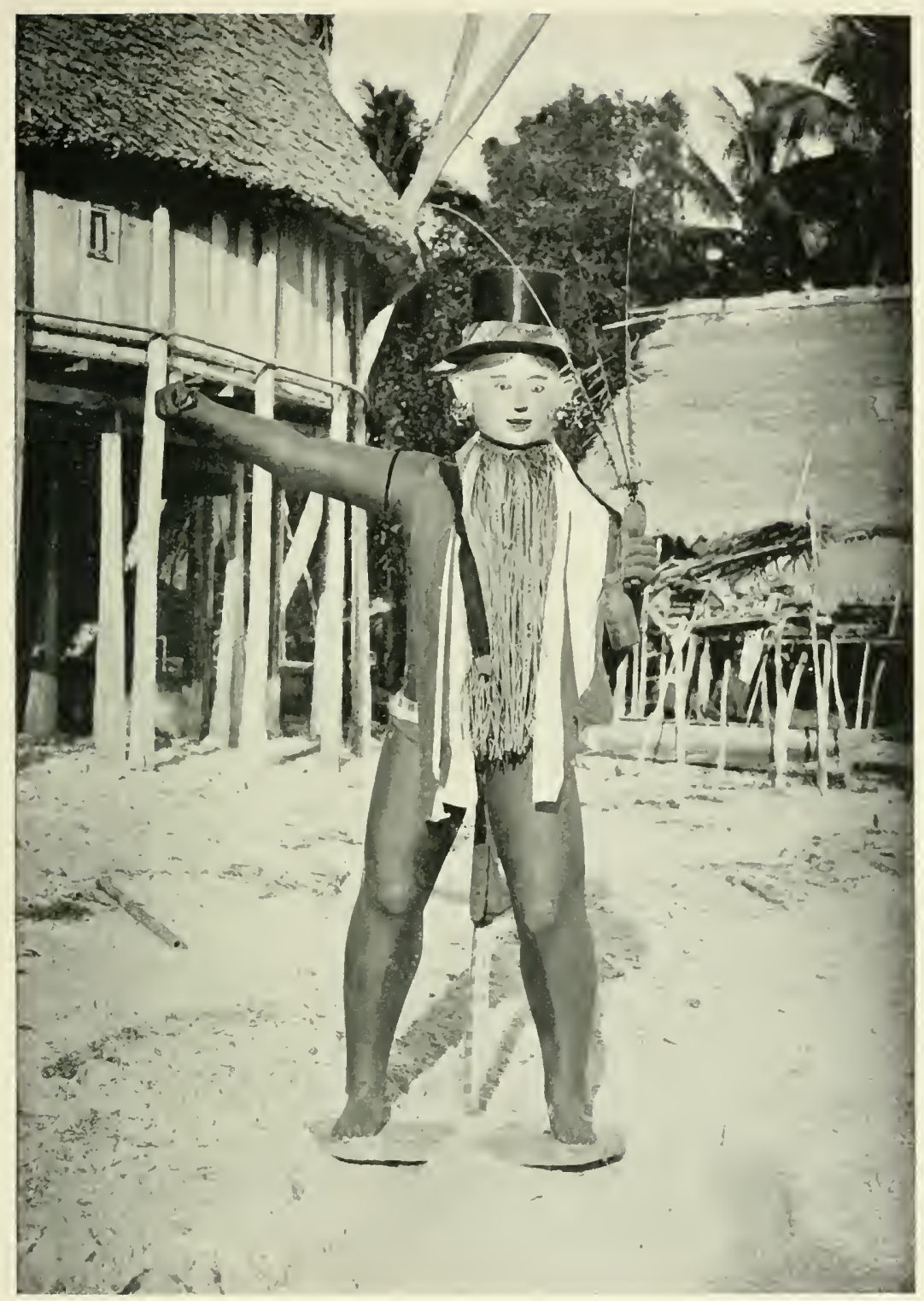

TANAMAKA'S "KAREAU." 

roof, where baskets and odds-and-ends are stowed away. Several boxes, packed with the family possessions of cotton and spoons, stood against the walls, on which hung various charms-small figures (kareau), carved scrolls, tassels of palm leaf, and pigs' skulls -all for scaring away devils. Hanging in the centre was a grass string, with a few small coconuts attached: these are for the purpose of feeding the house, and are periodically renewed: the object so nourished does not seem possessed of much acumen, however, for small green nuts, which have been blown down or have fallen from disease, seem quite good enough to sustain it. The house also contained some almost life-sized human figures (odiau), carved from wood, painted and clothed. These were not at all badly shaped, and show an appreciation of anatomical detail unusual among uncivilised people. The shape of the Nicobarese head, and the peculiar angle at which the teeth are set, were well noticed: the swelling muscles, the toes and fingers, even the sharpness of the shin-bone in front of the leg, and the form of the knee-cap, were faithfully copied. They were all supplied with a piece of rancid pork hung from the neck or placed in the mouth.*

Several pictures (hentá) drawn on slabs of wood were placed against the walls. These originate from an attack of fever. They are drawn by the village artist by order of the doctor (menliana), who tells him what he should make. The latter is paid in kind for his work. Of frequent occurrence are pigs, crocodiles and coconut trees, whilst almost always there appears a scene of men seated at a table and drinking rum from large glasses. If the patient make a good recovery, the picture is kept as a potent charm, since it has been successful in scaring away the spirits of illness; otherwise, it is thrown away. A bird (kaláng) $\dagger$ commonly made during fever will also produce recovery.

We could not persuade the people to part with any of these, neither would they sell one of the large figures. Tanamara has

* Canoes also are occasionally fed with chickens.

+ The white-bellied sea-eagle (Cuncuma leucogastor). 
a life-sized statue, painted black, with a white face, and although he was offered in exchange a dress-suit and a white sun-helmet, which he much coveted, he would not part with his double: its price was far above rupees. I was, however, permitted to photograph both pictures and figure; although, while the latter was being moved from the house to the beach, he was in an agony of apprehension, for he believes that if any accident should happen to it, illness on his part would follow, while, had we broken it or taken it away, he himself would certainly die. The object of these figures is to keep devils from working harm to their owners. Some people have none, while others sometimes possess two or more.

"February 7.-The people are far too occupied with their feasting to take much notice of our presence: on shore I found them so busy and excited that the photographs I had hoped for could not be obtained. Every day four large canoes go across to the other side of the harbour for coconuts, of which very few grow about the village: all the vessels are gaily decorated, and the paddlers are in holiday attire-collars of split banana leaf (fim ), beads, new cottons, and red paint on their noses.

"Tanamara came on board to tell us that the dance, at which by arrangement we are to be spectators, will be ready to-morrow morning; but that, to give a proper dance, the performers require to be jolly, and to be jolly needs a bottle of rum, which under the circumstances it was our duty to supply. He only stopped to beg for a glass of spirits, and then returned to the amusements on shore. Laughter, cheers, and singing have been going on in the village all the evening."

"February 8.-About nine o'clock this morning, taking with us a supply of liquid-half water, half rum-we landed at the village, and were received with a cordiality which doubtless owed its warmth partly to the presence of the bottles. In the banqueting-house we found dancing still in progress, that, judging from the noise made, had lasted throughout the night. All the cottons had been taken down, but the stand of spoons 


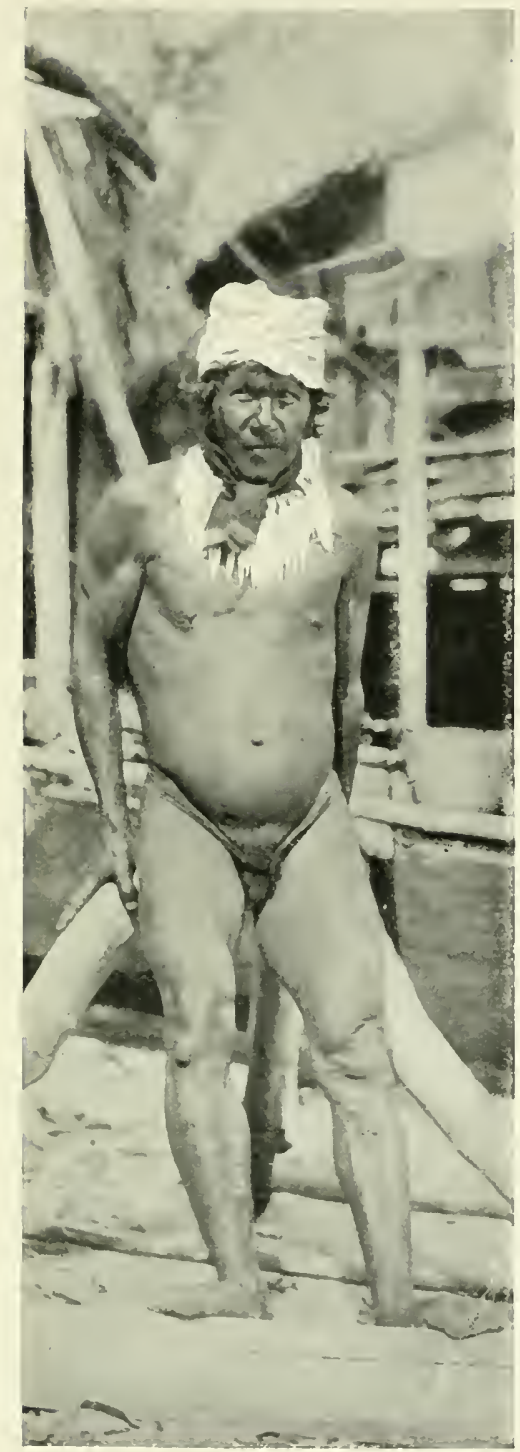

NANKALRI MAN WITH DANCING COLIAR AND I'AINTED NosF. 

still remained in the centre of the floor. Every one still on his legs was very hilarious; we were shown large jars which last evening were full of toddy. Lying about the sides of the floor people were sleeping, some from sheer weariness, some from intoxication. All were gaily dressed; bright cottons hung from the shoulders like a cloak, round the neck were strings of beads and collars of frilled banana-leaf, now faded; many wore ear-stretchers of red and white cotton made into rosettes, and the men were crowned with chaplets of twisted print: we saw several handsome belts, made of silver wire and rupees (almost the only use to which money is put), and some wore armlets of silver not unlike those brass-wire ornaments affected by Dyak women.

"In dancing, the people-men, women, and children-form a circle, or portion of a circle, round the spoons, and, with arms intertwined and hands on each others' shoulders, move slowly towards the right, with measured step, to the accompaniment of general chanting-to me it sounded like 'ah, ah, ah, ah, ah, ah, ah,' ad infinitum, only varied in tone and rhythm.* The regularity of the movement is broken at intervals by a step or two in the opposite direction, or a pause with a pirouette on one leg, and now and then a heavy stamp on the floor. One old woman, who danced most perseveringly, was so intoxicated, that, whenever her neighbours took away the support of their arms, she fell over, and was too helpless to rise unaided.

"Seated on boxes we watched the performance, and the doctor,

* The Whole of the Nicobarese Dance Music.

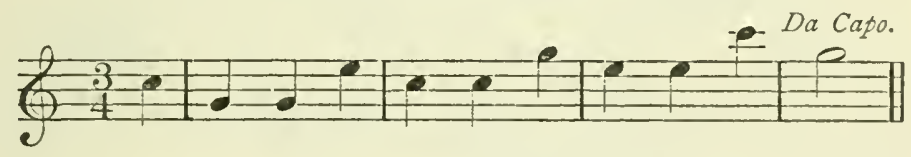

Fontana, Asiatic Researches, vol. iii.

It is extraordinary that people who are comparatively so far removed from savagedom, and so fond of dancing and singing, should have no musical instruments. They are acquainted with a kind of flute used by the Burmese, and a "guitar," but can show nothing of their own invention. Even the Andamanese, absolute savages as they are, possess a species of sounding-board, on which they beat time to their songs. 
presiding over the rum bottles, repeatedly filled a small glass, from which each imbibed, turn and turn about. At our feet squatted a number of half-drunken people, gabbling away in a mixture of Nicobarese, Malay, and English; not all so stupid, however, that some could not detect the water in the tipple.

"Tanamara, who was fairly clear-headed at first, received the finishing touch from the rum, and before we left embraced Abbott with fervent gratitude: 'You good man, I love you; you make us all nice and drunk. Oh, I feel so nice!'

"The dancing was very monotonous, and before long we were glad to get out to the open air: the hut was ventilated by a small doorway only, and the vitiated atmosphere in which people had been moving for the last twelve hours was by no means pleasant. Children and boys were present, but no young women; in fact, at all times we only caught sight of the latter as they bolted into the houses on our approach, and none were forthcoming for the camera."

"February 9.-Everything is quiet on shore to-day after the dissipation which left off yesterday. Tanamara came on board with a headache; he was sure it could be cured with rum, but got a heavy dose of Eno instead. We gave him a few ducks he was very anxious to possess. It is to be hoped there is a drake among them-a point that was somewhat doubtful-for then we shall have benefited the community to the extent at least of introducing a new domestic animal to the islands."

"February IO.-Gave Tanamara a watch this afternoon, to spur him to further efforts in collecting curiosities. His wife, whom he calls 'my Mary,' * desires to visit the schooner this evening; but although she is uninvited, and comes by her own wish, she has bargained for two fathoms of red cotton in payment for the honour done us.

"We met a man on shore who was for a time at the school formerly kept for natives at Port Blair. He lays claim to the name of William Brown, and speaks English very well; his

$$
\text { "I.c., "my marry"=my wife. }
$$




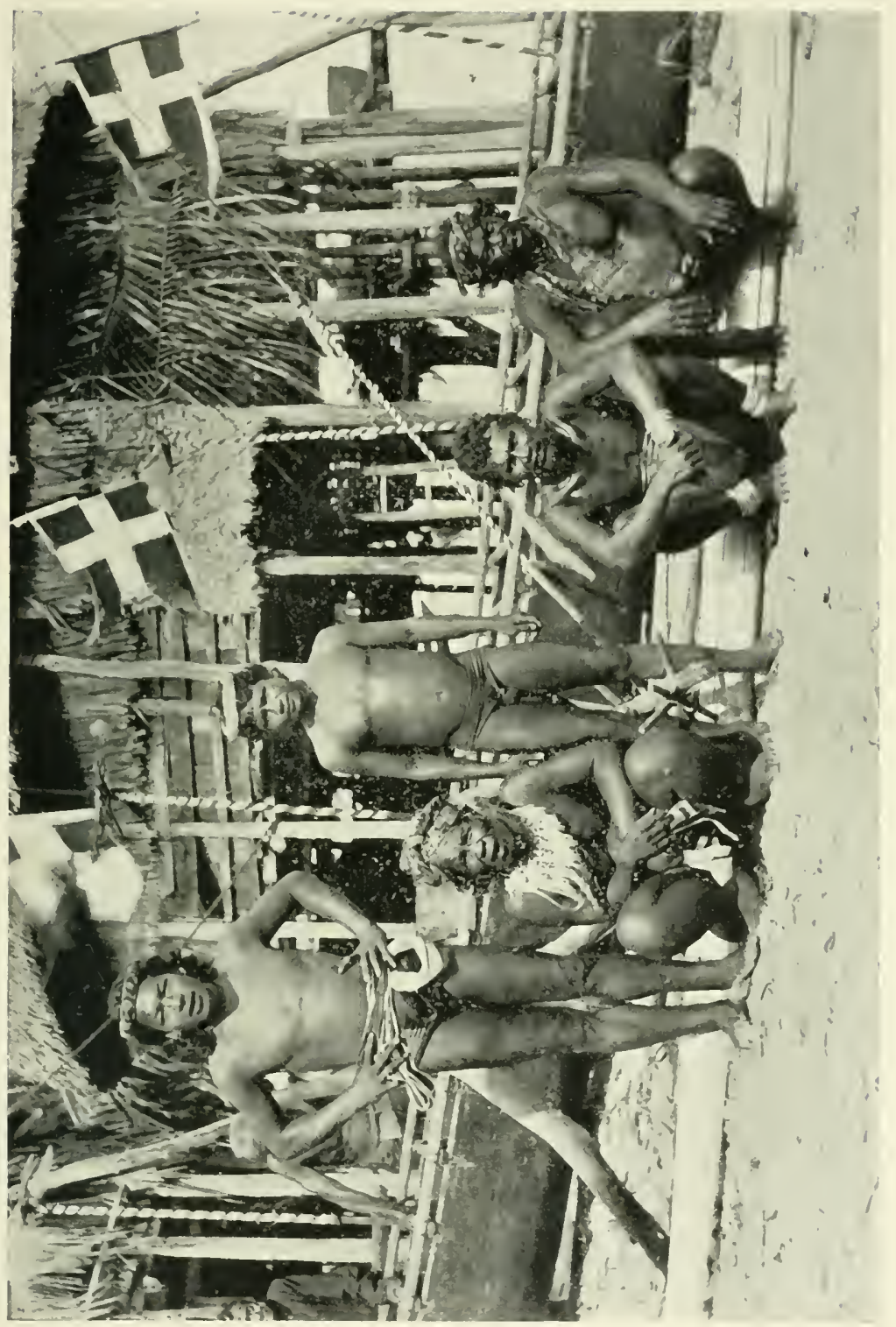



education otherwise has resulted in giving him a contempt for the native superstitions, of which he speaks with sneers, and meanwhile has replaced them by no other tenets. The train of events that brings such a condition of things about seems somewhat injudicious. A knowledge-a small knowledge-of the 'three R's' is of very little use to a native who has sooner or later to return to his national mode of existence. His experience may unsettle him, and is no suitable training for his future life, while it must leave him at a disadvantage among his countrymen, who have been bred to the conditions under which their existence will be passed."

"February I I.-Tanamara came on board last evening with his brother-in-law (Hamól) and nephew (Térrok). He was halfdrunk with toddy, and brought-it was quite a family partyhis wife (Helpak) and mother (Mert). A canoe-load of dishes, spears, and charms, which accompanied them, we purchased with old clothes, wire, and rice. The headman is as great a beggar as the others, perhaps more so, by virtue of his position and his English. Our conversation was continually interrupted by demands for one thing or another as he remembered them: things for his father, mother, wife, each request insinuatingly prefaced by the words 'my friend.' 'My friend, you give me-; My friend, I want-.' But for this fault, he is a fairly favourable specimen of a Nicobarese, and is certainly more intelligent than the rank and file; but, like many that we met, he is somewhat spoilt by contact with more civilised conditions.

"We had on board a quantity of American cigarettes, packed in cardboard boxes, each containing a dozen, and a coloured picture of a young woman in an evening gown! These packets were very useful as small presents, or as an answer to a request for a smoke. 'Oh, my dear!' exclaimed Tanamara, as he lovingly gazed at the picture from his packet. But he soon became dissatisfied, for she was a blonde and he likes brunettes, while what he was most anxious to obtain was the portrait of a Malay woman.

"Our small supply of spirits coming to an end, Abbott 
manufactured a new kind of cocktail from the medical storestincture of cardamoms, essence of ginger, sugar, and water, with a few spoonsful of rum to give the mixture a bouquet. This fiery liquid was received with some suspicion at first; but when I told them it was the favourite tipple of the C.C. at Port Blair (may I be forgiven), Tanamara and his brotherit was too stiff for the others-drank it down, although the tears stood in their eyes."

Of the fauna, we obtained from day to day little of interest : the jungle was without paths, and too thick even to see much in. No rats were trapped, but one specimen was brought us in a bottle by a native, and this has proved to be Mus alexandrinus, totally unrecorded until now from the Andamans or Nicobars. Pigeons were common, but megapodes scarce, and the only one obtained was caught in a trap. The vicinity of the harbour, though a somewhat unproductive hunting-ground for the ornithologist, for those interested in the natives, is, like Kar Nicobar, a most satisfactory locality.

Nankauri is a heart-shaped island, with an area of 19 square miles, and a maximum height of 534 feet. The bed rock consists of serpentinous magnesian, which is exposed in places. It is covered by a plastic white or yellowish clay and clay marl, with intervening beds of quartz sandstone, formed, like the clay, by the disintegration of the plutonic rock. The clay beds are similar to those which cover most of the northern islands, and contain silica, alumina, magnesia, and iron, but usually no lime, except in the form of gypsum, found in crevices. Portions of the clay cliffs exposed to the sun are covered with a fine efflorescence of sulphate of magnesia (Epsom salts). Professor Ehrenberg found in 1850 , on examining specimens sent him by $\operatorname{Dr}$ Rink (Galathea Expedition), that this formation is a polycistina clay similar to that of Barbadoes.

About one-third of the island is covered with grass: a belt of forest runs all round the coast, but in the interior is restricted to the valleys and more sheltered slopes. The most useful species are: Garcinias, Calophyllums, Myristica irya, which 


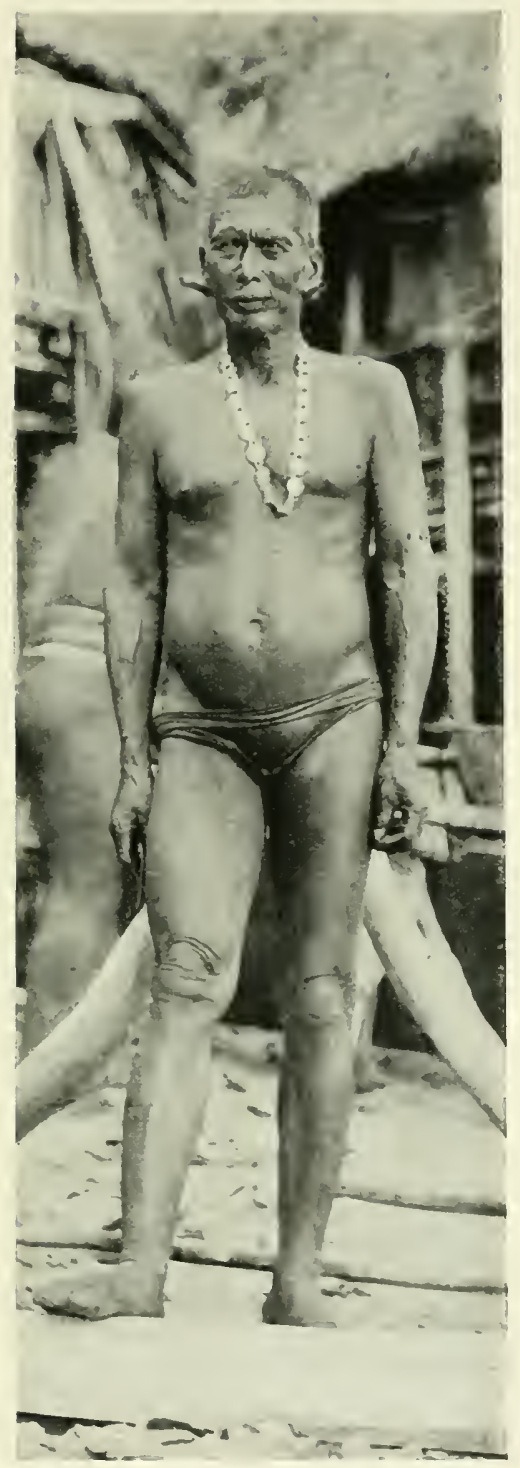

NANKALRF MAN WITH SILYER NECKLACE. 

yields good timber; Sterculia campanulata and Terminalia procera, which grow to immense sizes. The Nicobar and many other palms occur in numbers, and a wild species of cinnamon is common, as also is Amomum fonzlii, the leaves of which are used for cigarette wrappings, and the fruit much eaten by the natives.

But little fruit is grown about the villages: limes, guavas, and soursops are commonest. In the way of supplies, coconuts, pigs, and a few fowls might be obtained from the natives, and beef by shooting the wild cattle. Water in the harbour is very bad, and scarce.*

By a comparison of the census returns (I886 and I90I), the population would seem to have been stationary for many years: it now consists of 224 individuals.

The central group of islands was once notorious for the frequent disasters occurring to vessels calling there. It was for long thought that the numerous total losses that occurred in the Bengal Sea were due to storms and cyclones; but at length the discovery was made, that, from the beginning o the century until the British occupation, the vicinity of Nankauri Harbour was the habitat of a band of pirates, who cut off and murdered the crews of many vessels calling to trade and supply themselves with water or provisions. The headquarters of the band appear to have been in Expedition Harbour, and from there, whenever a vessel anchored at the islands, they sallied out, and either getting on board under the guise of peaceful natives, took the crews by surprise with a sudden attack, or else cut up landing-parties, and then captured the weakened vessel.

In this way, always by treachery and never in open warfare, they succeeded in capturing ship after ship.

There is some ground for belief that, for a time, the piratical goings-on were carried out under the leadership of an Englishman

* Mr E. H. Man writes, however:- "Water is plentiful in the numerous masonry wells and reservoir in the old Government station which is in the harbour. We used to boil and filter it by way of precaution, and then it was quite safe." 
named William Worthington. The dates given in the various accounts of him are contradictory; but it appears that, about I 808, Worthington deserted at Nankauri from the frigate Bucephalus, and that for some years subsequently the pirates were directed by a man who gave that name as his.

In I814, the Ceres was boarded by an Englishman, who stated that he had been left behind by a man-of-war. After inspecting the vessel, he left, and next day, as the anchor was being hove up, he arrived at the head of about thirty canoes, and made a futile attack on the ship.

A short time after, the brig Hope was cut off. An Englishman, who had previously stated he was IVorthington, deserter from the Bucephalus, murdered the captain and mate, and the natives despatched the crew, with the exception of two or three, who escaped in a boat and in some way arrived at Rangoon.

At length Worthington was either expelled from the harbour, or left with some home-going Bompokans; but be that as it may, a man of that name lived for some years on Teressa and Bompoka, where several captains met with, or received letters from, him. Their opinions of his character differed. He was last seen in December 1820 , when he reported that a ship from Bengal had been cut off and massacred at Nankauri, with several others previously, by natives led by Kafirs. He stated that after he deserted at Nankauri, he was unable to leave until he had paid a ransom to the natives. His death took place the same year, and the natives with whom he lived afterwards gave him the best of characters: that "John," as they called him, had long dwelt quietly and amicably amongst them. His seems to have thus been a case of "devil turned monk," and his career amongst the natives akin to the records of the better-known "beachcombers" of the early days in the Pacific.*

In a paper contributed to the Journal of the Indian Archipelago, I 847 , the missionary, Chopard, says that silver had a peculiar attraction for the natives, and was the chief article which induced them to butcher, by treachery always, crews of vessels calling at

* Vide Asiatic Journal, vols. xiii., xv., xvi. 
the harbour. He knew a Kamortan, thirty-five years of age, who recollected eight vessels which had been cut off there in that manner.

In 1833, a Cholia vessel was cut off in the false harbour of Nankauri (Expedition Harbour) and everyone murdered. In I844, Captain Ignatius Ventura, from Moulmein, commanding the Mary, anchored on the north side of Teressa at two o'clock, and an hour later he and his crew were murdered. In the same year, Captain Law met the same fate on Kamorta. In 1845, a vessel, having taken in part of her cargo at Kachal, sailed to the false harbour at Nankauri to complete, and all hands were murdered.*

"While I was at Kar Nicobar," Captain Gardner writes in I $857, \uparrow$ "two vessels were cut off at Nankauri, the crews massacred, and the ships plundered and scuttled." In I 840, the Pilot, South Sea whaler, was cut off there, and the captain, mates, and twentyfive men murdered; the third mate, surgeon, and seven men escaped to sea in a boat. ${ }_{+}^{+}$In $\mathbf{8} 84$, the cutter Emilic visited Nankauri, and her captain was murdered within an hour of landing, but the boat escaped.

Piracy in the Nicobars came to an end with the occupation of Nankauri Harbour by the Indian Government in 1869; but two years previous to that it had been necessary to send there a a British punitive expedition, on account of the atrocities committed by the natives. A notification of the event was made by Captain N. B. Bedingfield, who commanded the expedition, in the first of the Port Registers entrusted to the Nankauri natives.

\section{“TO ALL WHOM IT MAY CONCERN.}

"WHEREAS the natives of these islands have been guilty of several acts of piracy; the crews of no less than four vessels

* Père Barbe, Jour. Asiatic Soc. Bengal, vol. xv.

+ Singapore Review, vol. ii.

$\ddagger$ "Some Malays, who were at the Nicobars at the time, afterwards stated that the Pilot was attacked because the crew had tried to get hold of the native women; but those of the landing-party who escaped in the whaleboat, although attacked on shore simultaneously with the ship, tell a very different story." -Vide Asiatic Journal, I841. 
have been massacred; a white woman and two children have been kept prisoners for about two years and a half, and after being most cruelly treated, the poor woman, used for the very vilest purposes, was, with her children, first poisoned and afterwards knocked on the head: Her Majesty's ships Wasp and Satellite were sent to endeavour to liberate any captives that might still remain on the Islands, and to punish the natives for their crimes.

"Several towns implicated have been burnt, all the war canoes destroyed, and other punishments inflicted . . ." etc., etc.

Nor was this the only case of the kind, for although most of the vessels disposed of were native, the total included not a few European. There is another instance on record, in which a European woman was taken ashore and so brutally abused by the band of pirates that she died next day.

It is believed that the origination of these practices cannot be traced to the natives, but is due to the settlement of a body of Malays, who attracted a number of the inhabitants to themselves, and then formed a gang to plunder all vessels calling at the harbour, consequent upon a successful massacre of the crew. 


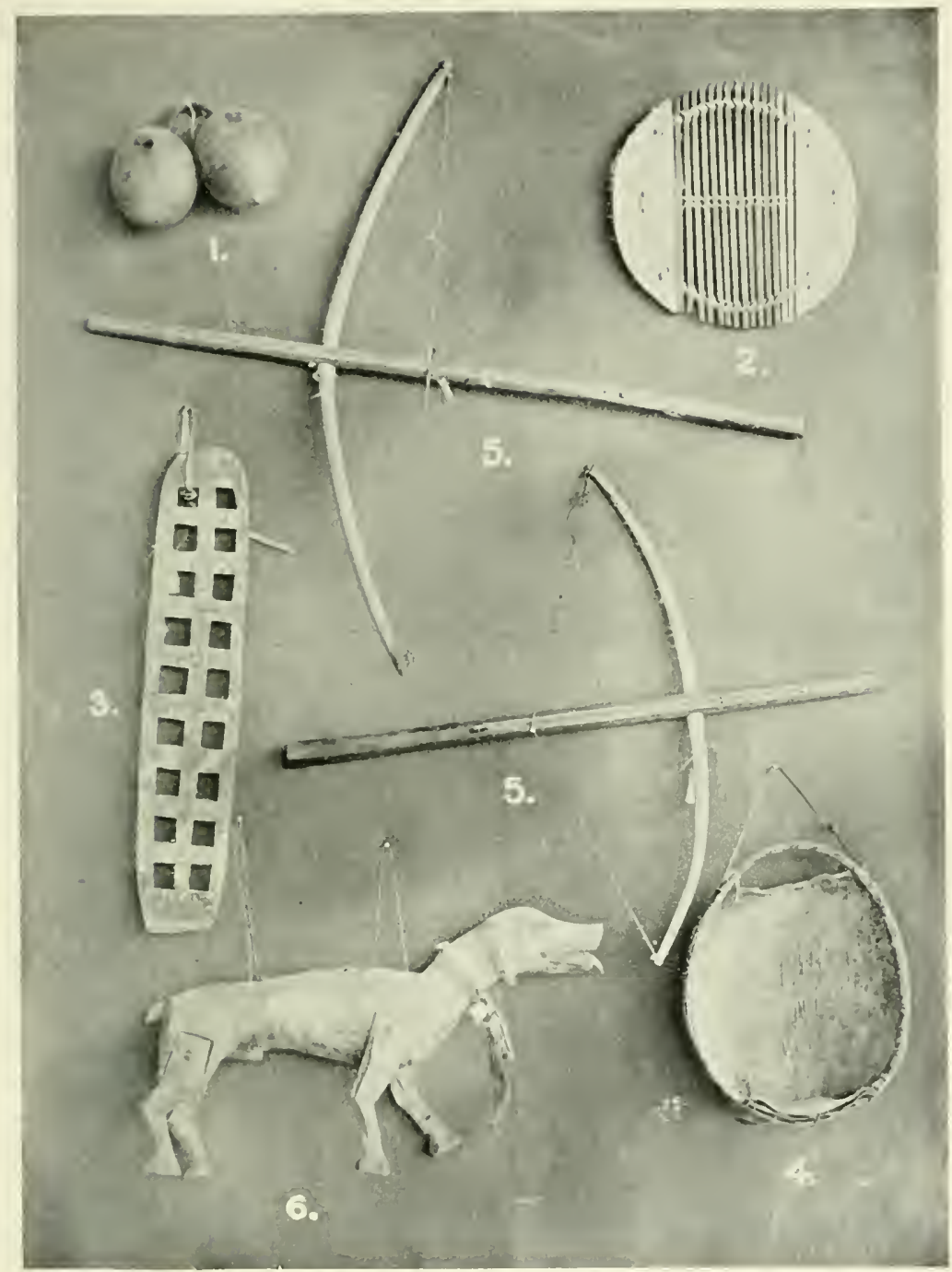

OBJECTS FROM NANKACRI HAKBOLR.

I. Coconut-shellwater-ressels (hishóra). 2. Wooden grating (hetpait) used in cooking.

3. Wooden grating (entina-momia) used in cooking.
1. Feeding-dish (dairuik or pakól).

5. Cross-bows (foin) for shooting birds.

6. Henti-köi (cf. plate fiacing $\mathrm{p}$. 232). 



\section{CHAPTER IX}

KAMORTA

The Old Settlement-The Cemetery-F. A. de Röepstorff-Mortality-Birds-

The Harbour-Appearance of Kamorta-Dring Harbour-Olta-möit-

Buffalo - Spirit Traffic-Cookery - Ceremonial Dress - A Visit from

Tanamara - Geology - Flora - Topography - Population - Hamilton's

Description.

ON several occasions we crossed the harbour and visited the locality of the convict settlement formerly established on Kamorta, but given up in 1888 , when the buildings were dismantled, and sepoys and prisoners withdrawn to Port Blair.

The jetty on which one lands is more than a hundred yards long, and although solidly constructed of coral blocks, is now in need of partial repair. To the right is a long sea-wall, and on the other hand a small boat harbour, both built of coral. Beyond the agent's house at the foot of the jetty, one walks along a grass-grown road shaded by an avenue of tall casuarinas, and passes several large wells of strong brickwork, and a large tank for rain water, with various other traces of past occupation, till on the hill-top one comes on the remains of the Government bungalow, of which only the foundations are now to be seen. A little farther on is the only building now standing-the old powder store-"where nothing's here that's worth defence, they leave a magazine!"

On another hill close by-from which are to be seen the whole stretch of the beautiful harbour, the distant forest-clad slopes of Kachal and the grassy interior of Kamorta-lies the little cemetery with its two occupants - Nicolas Shimmings,

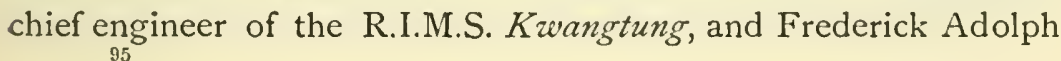


de Röepstorff, a Dane by nationality, and for some time superintendent of the settlement. Tanamara told us of his death, which occurred in I883. Complaint had been made that one of the sepoys of the small force stationed here was in the habit of stealing the natives' coconuts; him the superintendent reprimanded, and threatened to send to Port Blair for punishment. Next day the sepoy shot at and wounded de Röepstorff while the latter was in the act of mounting a horse. The injured man despatched a letter to the Andamans by a Burmese trader, but died before the arrival of a steamer, five days later. $\mathrm{He}$ was nursed and buried by the Nicobarese, who would not allow the Indian servants to approach him.* "He was," said Tanamara, "a good man, a very good man." He took much interest in all that surrounded him, and besides contributing accounts of the Andamans and Nicobars to the journals of the Asiatic Society of Bengal, he made large collections of lepidoptera for the Calcutta Museum, and compiled vocabularies of several of the local languages.

* A somewhat different, and more accurate, account of the incident is given in a volume of sketches by John Strange Winter, entitled $A$ Siege Baby. I have given here the unamended version of the natives as related to us by the headman.

Mr E. H. Man writes:- "The story given by Tanamara, regarding de Röepstorff's murder, is very incorrect. The murderer (a havildar of the Madras Infantry detachment then stationed at Nankauri) was under trial for having assaulted a convict. After recording a lot of contradictory evidence, de R. adjourned the case, whereupon the Madras Infantry jemadar pleaded on behalf of the havildar. The magistrate reproved him for his interference, whereupon the latter went and informed the havildar that he would probably receive a severe sentence which might result in his dismissal from the army. This so enraged the havildar that on de R. riding past the M. I. barracks a few hours later the same day, he shot him from his room. The havildar was the crack shot of the Madras army, having twice carried off Commander-in-Chief's prize. He shot himself on seeing that he had inflicted a mortal wound. De R. died within a minute or so. It was his wife who despatched news of the affair to Port Blair by a bagla, which had just arrived in Nankauri Harbour. In five days I arrived and held the inquiry. Mrs de Röepstorff during those five days had a natural horror of the M. I. sepoys, and she would not allow any of them to approach the house. Her Indian servants and others remained with her as before."

+ Vocabulary of the Dialects spoken in the Nicobars and Andamans, Port 
Nowadays, all that marks our possession of these islands is the Colonial Jack, presided over by a Hindu; all that shows our past occupation, fallen brickwork, grass-grown roads and graves: these things, and the result of our contact with the native inhabitants. In the north, some knowledge of the English speech, and the beginning of education; here the suppression of piracy.

The agent told us that in the group people were dying almost day by day ; the cause, from his description, ague and malaria.* Beyond two or three slight cases of elephantiasis, we ourselves noticed no symptoms of disease amongst the adults, but the children nearly all seemed to be suffering from yaws.

The country around the settlement is very undulating, and covered with long grass growing on a sterile clay. It was almost lifeless, for we saw little more than wagtails, pipits, and an occasional button-quail (Turnix albiventris and Excalfactoria, sp. nov.); but in one of the numerous gullies between the hills we found a little jheel where formerly paddy had been grown, and floating on its surface was a small flock of whistling teal (Dendrocygna javanica). A couple were dropped before they flew out of range, and next day we met in the same place a larger number, which all got off scot free; but a falcon $(F$. peregrimus), that like ourselves had just made an unsuccessful attack, was soon reposing in a game-bag, in company with a chestnut heron ( $A$. cinnomomea), and a redshank.

On February IIth, when we left our anchorage, the breeze was very light, and bore the schooner slowly through the calm waters of the harbour as we steered for the western exit.

Blair, 3s. Dictionary of Nancowry and Nicobarese Languages (both parts), Calcutta, 7s. 6d.

* This decline of population has been even more marked in the southern group than in the central, and has been found to be due to paucity of births and not to increased mortality. It has been attributed to injury done by the practice among the men of the Central and Southern Islands of fastening the neng or loin-cloth unduly tightly over the organs of generation, whereby these are in many cases rendered impotent. At Kar Nicobar, Teressa, and Bompoka, and Chaura the neng is worn less tightly. 
All around, the shores sloped downward, covered with dense forest, but now and again the inland hills rose grass-clad above the tree-tops; on either hand we passed small villages, Itoë (six houses), and Pachoak (five houses), placed just above the edge of the water.

The western opening is bold and rocky, but very narrow; and among the boulders of the shore are several blow-holes, from which, when the sea rolls on the beach, spouts of water fly upwards and break into showers of spray.

Outside, the wind was still light, and we tacked along the coast for some hours before it strengthened. Much of this side of Kamorta consists of low broken hills with pointed summits looking like volcanic cones-a grassy country, varied by occasional small patches of forest-while along the shore low bluffs and stretches of coco palms succeed each other.

Soon we passed the entrance of Expedition Harbour, a deep, land-locked bight, separated from Nankauri Harbour by a narrow strip of land; this was the reputed headquarters of the band of piratical savages who formerly committed so many depredations in this neighbourhood. Near by, Mount Edgecombe, of a very volcanic appearance, rises about 400 feet.

This shore seems but little inhabited, for until we reached our destination at 4 P.M., we saw only one small village of four or five houses.

The wind was off the land when we arrived at Dring Harbour, and since the entrance was narrowed by rocks and reefs projecting from either side, we lowered all sail and warped in.

The bay is about half a mile square, and the head, which is slightly wider than the mouth, is bordered by a long sandy beach, backed by a belt of scrub and palm trees, from a quarter to half a mile in depth. The other shores are partially formed by small cliffs, with a thin fringe of jungle, bounding grassy hills and downs.

The village of Olta-möit (fifteen to twenty houses), "Captain John," headman, lies along the beach, which abuts at the southern end upon a fair-sized creek leading to a mangrove swamp at 


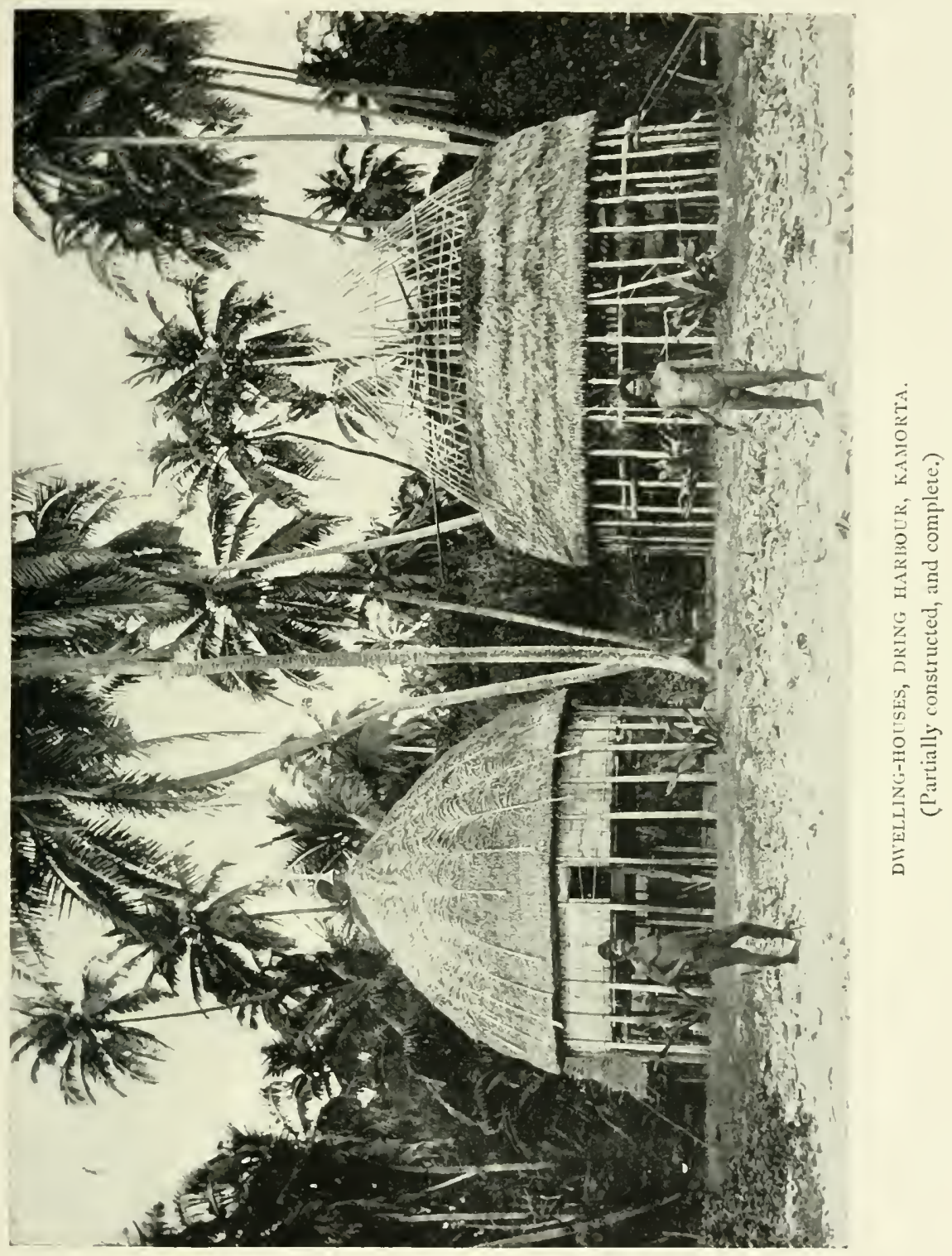



the back of the houses. Several natives came on board at once, in expectation of a feed; none spoke English, but all understood Malay.

The patch of jungle about the village is rather small, and to reach more necessitated a walk of some miles; we succeeded, however, in adding to our collection a diminutive serpent-eagle (Spilomis minimus), and caught sight in the denser jungle of a fresh variety of a little forest hawk. Specimens were also obtained of a small bat which has since been named Pipistrellus camorte.

The neighbourhood of the harbour has for long been frequented by descendants of buffaloes, turned loose by the Danes when they abandoned their settlement at Nankauri. Formerly it is said that large herds were to be met with in the neighbourhood; but we learnt, both from the inhabitants and from the Port Register, that the animals are now becoming very scarce, and only a few have recently been killed by visitors from the station gunboat.

I was out after them on two consecutive days. Both had been preceded by nights of rain, through which tracking was much facilitated. The country round is very undulating, often broken by deep gullies, and covered here and there with small patches of jungle, while everywhere are scattered pandanus trees, either in clumps or singly. On both occasions I picked up fresh tracks in the red clayey soil when some distance from the village, and after following them for several miles lost them in distant jungle. There seemed to be only two animals in the neighbourhood-one very large indeed, and the other of much smaller size. This decline in numbers is not due to the natives, who, with their spears only, could cause little destruction, and who evince no eagerness to pursue.

Tracks of pig were innumerable, and every now and then a bunch of little quail whirled away from beneath my feet. Although out by 5 A.M., I was not early enough; at three o'clock on a moonlight night one would probably be more fortunate. 
In I870, chital and sambhar were turned out on Kamorta, but nothing is now seen of them, except by the natives, who state that from time to time a few have been perceived here, and at Trinkat, which they reached by swimming the narrow channel intervening.

One afternoon was devoted to the exploration of the creek, which is rather deep at the mouth, and navigable by boat for several miles; all this distance it is bordered by the usual wearisome mangrove forest, in which, however, we saw numbers of parrots, whimbrel, and pigeons.

The proportion of old men among the people of the village seemed even greater than was the case at Malacca. On the headman, John, we met with the only case of tattooing found in the islands-probably the work of some Burmese trader, for neither Nicobarese nor Shom Pen tattoo or scarify themselves.

A second junk joined that already in the harbour the day after our arrival, and everybody on shore was soon drunk. The inference is obvious. The authorities at Port Blair prohibit the supply of intoxicants to the natives, and whenever they are found on board trading vessels, spirits are confiscated, and a small fine levied, in cash or articles of barter to the value of about a hundred dollars. This, however, is not always a sufficient deterrent, and on a second conviction, the Chinese skipper is awarded six months' rigorous imprisonment in the jail at Viper Island, Port Blair. The spirit is invaluable to the traders in their dealings with the natives, and is so inexpensive, that they can afford to risk its loss, since the chance of discovery is about one in a hundred.

A small feast was held during our visit, for which a number of pigs were prepared. Torches, made by binding immense palm leaves together, were set fire to, and the bristles singed off by fanning the flame on to the animals as they lay on the ground.

"Captain John" was resplendent for the occasion in a neng and dress-coat, and a friend of his looked very imposing in an officer's frogged and braided tunic. 
The day before we left we were surprised by the appearance of Tanamara, who arrived with one companion in a small canoe. He had declined to come up in the schooner, on the excuse that fever-devils and other evil spirits were very active in this locality. He was, he assured us, very sorry for us alone up here, and had had a dream which resulted in his setting out. (I am uncharitable enough to think that that dream had something to do with rum !) He did not wish to be seen by the shore people, of whom he seemed afraid, for he stayed aboard all day, and in the evening, when some of them came off to the ship, left for a time in his canoe. Next morning he departed at daybreak, that he might not be observed from the village.

We ourselves made sail a few hours later, with the intention of visiting Teressa. We took in water at Dring, but the only supplies obtained were coconuts.

Kamorta is 15 miles long, and of a general width of 4 miles : it attains in the extreme south-west a height of 735 feet, and in the centre rises 435 feet, but the average elevation is about 200 feet. It is of the same geological structure as Nankauri, but is covered with far less forest, and its extensive grassy downs are dotted with patches of scrub, bracken, and pandani. The presence of casuarinas high up in the middle of the island is peculiar. This species as a rule is found only on the coasts, but here they were planted by the Settlement authorities at the Government cattle-stations (between 1869-88), as it was found that this tree delights in the polycistina clay. The neighbourhood of Dring Harbour is extremely well watered, as nearly each one of the many gullies has either a stream or pond in it. A stratum of a sandy nature underlies the surface clay of this district, and by washing away, causes the latter to fall in, with the result that a number of curious hollows are formed on the tops of the rolling hills. This tendency leads to parts of the downs becoming terraced as if by artificial agency. Some thirty villages are scattered along its coasts, and the population, according to the census, has increased, principally by immigration 
from Chaura and other islands, from 359 in IS86 to 488 at the present day.

Of the central group of islands, Hamilton writes :-

"Ning and Goury are two fine, smooth islands, well inhabited, and plentifully furnished with several sorts of good fish, hogs, and poultry; but they have no horses, cows, sheep, nor goats, nor wild beasts of any sort but monkeys. They have no rice nor pulse, so that the kernels of coconuts, yams, and potatoes serve them for bread.

Along the north end of the easternmost of the two islands are good soundings, from 6 to 10 fathoms sand, about 2 miles offshore. The people come thronging on board in their canoes, and bring fowl, cocks; fish, fresh, salted, and dried; yams, the best I ever tasted; potatoes, parrots, and monkeys, to barter for old hatchets, sword-blades, and pieces of iron hoops, to make defensive weapons against their common disturbers and implacable enemies the Andamaners; and tobacco they are very greedy for; for a leaf, if pretty large, they will give a cock; for 3 feet of an iron hoop a large hog, and for I foot in length, a pig. They all speak a little broken Portuguese, but what religious worship they use I could not learn." *

* Hamilton's Account of the East Indies, Pinkerton's Collection of Travels. 


\section{CHAPTER $X$}

KACHAL AND OTHER ISLANDS

Heavy Surf-Teressa-Bompoka-A Native Legend-Hamilton-ChauraWizardry-Pottery-Kachal Typical of the Tropics-Nicobarese DressWest Bay-Lagoon-Mangroves-Whimbrel-Formation of KachalBirds - Visitors to the Schooner - Fever - Chinese Junks - ThatchRelics - The Reef - Megapodes - Monkeys - Full-dressed Natives Medicine-A Death Ceremony-Talismans-Fish and Fishing-Geology.

FOR some hours after we left Dring the breeze was very faint, but at midday a heavy squall with rain overtook us and carried us onward, so that we were soon sailing along the southern shore of Teressa.

The island of Bompoka, which lies but a short distance from its south-east end, is high, with a central tableland, whence the ground slopes gently downwards in every direction, and is covered with forest and grass.

Seen from a distance, Teressa looks like two islands, for it is elevated at either end: the northern part is covered with forest ; the southern end is all grass-land, save for a fringe of scrub and large coco-palm groves along the coast. This portion of the shore is very rocky in places, and numerous points of off-lying reefs project from the water.

A heavy swell was running from the south-west, and rank on rank of breakers-IO feet or so in height-were rolling shorewards, throwing up clouds of smoke-like foam. It would have been impossible to land without danger of losing guns, camera, etc., so we decided not to make the attempt, and therefore put about for Kachal, with the less regret in that the locality 
did not seem to hold out much promise as a collecting . ground.

There is no harbour on its coasts, for the shores of the island, which is crescent-shaped, are almost unbroken. We afterwards heard that, two or three months previously, a Chinese junk, whose crew all reached the shore, had been wrecked on the reefs fronting this part of the island.

In their customs, style of architecture, and in the more general absence of talismans and demon-exorcising regalia, the people of Teressa and Bompoka are said to resemble those of Kar Nicobar, but their language possesses great dialectical variation.

Teressa is 34 square miles in area, and rises in the north to nearly 900 feet. The bed rock is serpentine, covered with sandstone, and there is a fringe of recent coralline alluvium round the shore, while beds of coral on the high land of the interior indicate upheaval since the formation of the older alluvium.

The soil of the grass-lands is of an igneous clay formationmagnesian clay, formed by disintegration of the plutonic rocks, whose upheaval in two successive stages brought the Nicobars into existence. Overlying it in many places are the beds of coral, and to these formations the grassy downs of the island are confined-lallang, with occasional screw-pines, a bracken-like fern (Gleichenia dichotoma), delicate ground orchids, and various scrubby plants (Kydia calycina), which point to the occurrence of annual fires. The transition from grass-land to high forest, which appears on the sandstone, is very sudden.

The graceful Nicobar palm (Ptychoraphis augusta) is common in the jungle. Whole groves of this beautiful tree fill the moister ravines, and give a characteristic appearance to the forest. Nearly equally conspicuous are large numbers of Sterculic campanulata.

Fruit and vegetables are the same as are found on Kar Nicobar, with the addition of tobacco, of which several small fields have been raised from seed imported from the west coast of India. 
The census returns of 1901 give the population of Teressa as 624 , making the number of inhabitants 50 more than in 1886.

Bompoka, having the appearance of a truncated cone, and 634 feet high, is an oblong-shaped island, about 4 square miles in area, separated from Teressa by a channel 50 fathoms in depth, and scarcely more than 2 miles wide. Its inhabitants, who number less than a hundred, and the people of Teressa, have an interesting legend to account for the formation of the island. Once upon a time a vessel, having a prince for its captain, visited Teressa, where he, on landing, was murdered by the inhabitants. His wife was taken on shore and treated with the greatest respect; but, since the spot on which her husband's blood was shed was always before her eyes, she was very miserable. One night, however, she was advised in a dream, by her mother, to remove the bloody spot from Teressa if she would be happy. This she did, and Bompoka was thus separated from that island.*

The geological formation and the vegetation are similar to those of Teressa. The inhabitants have good plantations of fruit-trees-papaya, plantains, and limes-neatly fenced to keep out the pigs. At Poahat, on the west coast, good water is to be obtained from a stream at the back of the village.

These two islands, with perhaps Chaura, seem those referred to by Hamilton as the Somerera Islands, so called because "on the south end of the largest island is a hill that resembles the top of an umbrella or somerera. They are fine champaign ground, and, all but one, well inhabited. The island Somerera lies about 8 leagues to the northward of Ning and Goury (the Nankauri group), and is well inhabited for the number of villages that show themselves as we sail along the shores. The people, like those of Ning and Goury, are very courteous, and bring the product of their island aboard of ships to exchange for commodities. Silver nor gold they neither have nor care for, so the root of all evil can never send out branches of misery, or bear fruit to poison their happiness! The men's clothing is a bit of string round the middle, and about I f feet of cloth, * Vide Père Barbe, Jour. Asiatic Soc. Bengal, vol. xv. 
6 inches broad, tucked before and behind, within that line. The women have a petticoat from the navel to the knee, and their hair close shaved; but the men have their hair left on the upper part of the head and below the crown, but cut so short that it hardly comes to their ears."

Chaura, which lies 7 miles north-westward of Teressa, has an area of about 3 square miles only. It is generally low, and the only jungle it possesses is a little at the south end, where it rises almost perpendicularly in a rocky pinnacle to a height of about 350 feet, having the appearance, with the contiguous low portion, of a broad-brimmed hat. It was on this account termed Sombrero by the Portuguese navigators of the seventeenth and eighteenth centuries, who were probably the first Europeans to have any commercial dealings with the Nicobarese.

The people are very well off, on account of their trade in canoes and pottery: but to obtain the articles imported by the traders, canoe voyages are made to other islands, as the anchorage at Chaura is exceedingly precarious, and after the native requirements are provided for there are but few nuts to spare for trade, so that vessels are hardly ever known to call. The island is the best cultivated in the group, and besides abounding in oranges, limes, and other fruit, is covered with coconuts; and toddy being common, drunkenness is fairly prevalent. One of the institutions of the place is the door mat; for a large flat sponge, which is found in numbers on the reefs, is placed at the bottom of every house-ladder, for the natives to wipe their feet on!

Although the smallest, it is at the same time the most densely populated of the islands, for, in spite of decreasing numbers, which may perhaps be due to emigration, the people of Chaura number (January I9OI) some 522 in all; in 1886 the population fell only a few short of 700 . IVe were told that they are taller, more powerful, and darker-skinned than the other Nicobarese, and also dolichocephalic.

Through an exaggerated reputation for magic, they are greatly feared throughout the group, and have for this reason 
developed a most independent and overbearing demeanour. Various circumstances assist the cultivation of these traitsthe value in which their canoes* are held throughout the Archipelago, for one; but the most important of all is the monopoly $\dagger$ which the island of Chaura possesses in the manufacture of pottery.

Throughout the Nicobars there is an inherent belief that should anyone-other than a native of Chaura in Chauraattempt to make a vessel of clay, he is doomed to almost immediate destruction. This fate was formerly supposed to follow the act of even eating food cooked in any pottery other than manufactured on the island, but this part of the superstition is now losing force, and the Nicobarese freely provide themselves with pots made at Port Blair.

The women of Chaura-for the men take no part in the construction of the pots-cleanse and prepare the clay, by washing out the rougher particles and kneading it with fine sand. The operator seats herself on the ground by a slab of wood, on which she lays a ring of coco-palm pinnæ neatly bound together. Upon this ring she sets a shallow dish, neatly lined with a circular piece of plantain leaf. With a lump of clay, the bottom of the vessel to be constructed is moulded in the dish, and upon this basis, by means of ropes of clay, the work is built up, the operator turning the pot round and round, and shaping it with her eye and hand. The vessel is set aside on a platform under the hut for a day or so, to dry: only the

* These are all imported, many in order to sell to Kar Nicobarese.

+ Père Barbe (Jour. Asiatic Soc. Bengal, 1847) mentions other monopolies: lime might only be burnt at Kar Nicobar, boats built only at Nankauri, and to the same island was restricted the sowing of paddy. (The last a possible evidence of local Malay immigration.)

With reference to this note, Mr E. H. Man writes:-

"Lime (by burning certain sea-shells) can be made only in the southern group, Kachal, all villages inside Nankauri Harbour-except Ong-yúang, also the villages in Dring and Expedition harbours.

"Lime (made by burning coral) can be made only at Kar Nicobar.

"Canoes (large and small) are made in the central and southern groups where suitable trees are plentiful.

"Canoes (small) are made at Kar Nicobar, Teressa, and Bompoka." 
smallest kind can be prepared for the kiln without an interval of waiting.

The pot when dry is scraped with a shell, and then reversed, and all superfiuous material removed by means of a fine strip of bamboo moistened with water, while the fingers, also wet, are gently passed over the inner and outer surfaces in order to smooth them. The pot is then replaced on the platform for ten days more.

The kiln is prepared by sticking bits of broken pottery in the ground, a few inches apart, and on these the pot is set upside down. In the space beneath it, a layer of fine wood
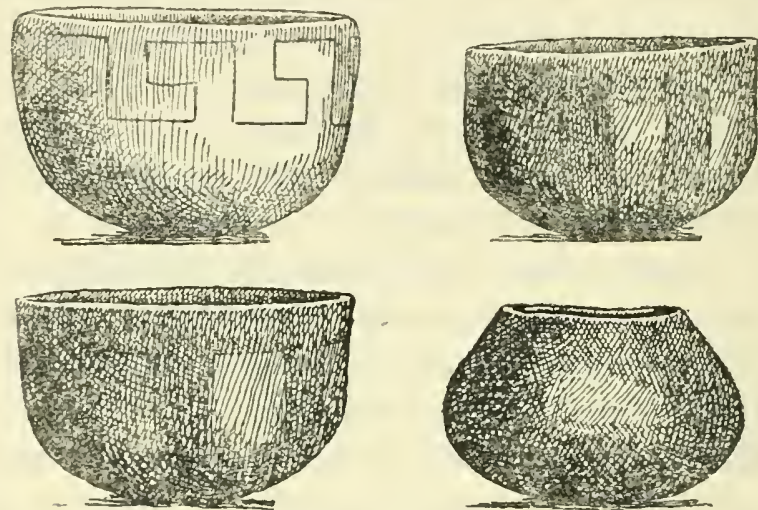

Chaura Pottery.

ash, and a quantity of coconut-shells and scraps of firewood, are heaped. A wheel-like object, larger in circumference than the pot, is placed on its upturned base, and against this rest sticks of firewood stood on end. When the fire is kindled, two or three women fan the flame, and with wooden pokers prop up and replace the fuel. When the vessel is baked, it is removed with the same implement and placed on dry sand.

Coloured stripes are laid on by means of strips of unripe coconut husk pressed against the vessel while hot-the acid juice turning black the moment it touches the heated surface. Finally a handful of moist husk is passed over the inner and outer sides, imparting a light-copper colour to the parts not 
stained by the deeper dye, and the vessels are stored for a time to season.**

The pots vary in size, from a capacity of half a pint to five gallons or morc, and also in shape, some having a perfectly straight plain lip, while in others the edge is turned out or rounded, but all are alike in having a more or less rounded base.

After leaving Teressa, we encountered fresh breezes and squally weather until we anchored in clarkness near the shore of Kachal. At daybreak next morning we weighed, and again started-with scarce a breath of wind-for the bay on the west coast where we intended to stay.

With Kachal we returned again to the tropical island of common type in these seas, for it is entirely jungle-covered, with no traces of grass-land visible.

On account of their geological structure, the Nicobars fall botanically into two divisions-the northern islands, including perhaps Nankauri, are largely covered with grass, with coco palms and pandani growing in the interior; while the southern group, consisting of Kachal, with Great and Little Nicobar, are entirely forest-covered. Tilanchong, although belonging to the others by position, should nevertheless be classed with the latter islands.

Several canoes from a small village on the north-west coast came off to inspect the schooner as we slowly drifted along. Their occupants seemed less prepossessing than those people we had just left, for they looked somewhat dirty in person and were dressed in discarded old clothes, or the cheap cottons and loose trousers supplied by the Chinese. The Nicobarese are not so partial to water as the Malays, and they by no means improve matters by unnecessarily clothing their bodies with cast-off garments and once gaudy cottons, which they never, or rarely, dream of washing.

We reached West Bay by midday, and anchored in $2 \frac{1}{2}$ fathoms. A junk was lying farther in, the fourth we had seen. From the southern shore, coral-reefs project for some distance, both

*Vide E. H. Man, Jour. Anthrop. Inst., 1893, vol, xxiii. 
into the bay and seaward, and at low tide the swell breaks upon them heavily; while, at the same time, two rocks project above water inside the harbour, near the north beach, and must be borne in mind when choosing an anchorage. Fifteen or sixteen houses, surrounded by coconuts, are scattered along half a mile of beach, and at its head the bay narrows and then extends inland among mangroves and their attendant swamps.

Our first expedition was up the bay, which we found opened out into a shallow lagoon nowhere more than 2 or 3 feet deep. The dinghy grounded often, and we were unable to reach firm land anywhere, so thick was the belt of mangroves. Rowing up some of the small creeks winding among them, we saw several flocks of herons (Sumatranus javanica), while sandpipers, curlew and whimbrel were common on the mud-banks, and pigeons and parrots in the taller trees.

In several places occur those stretches of dead mangroves only seen when the trees are large, and which are infallible evidence of the growth of land; for when such trees first took root, a certain amount of salt water must have been present, while, when they are found dead, the roots are nearly always silted up with solid matter, which first causes the water to become stagnant, and finally replaces it. Having served their purpose, they die, and stand white and gaunt until brought down by the wind or gradual decay.

At sunset, large flocks of whimbrel, travelling seaward down the mouth of the lagoon, afforded some fair shooting, for they were very wild, and flew past us at an amazing pace as we fired at them from the boat hidden in the mangroves.

On the northern side of the bay, where much of our collecting was done, we found, behind the houses, a number of paths leading among coconut and pandanus palms, tangled grass, and bushes. Beyond this scrub, in which gaudy-leaved crotons were not uncommon,* was the jungle, fairly open, but without any large trees.

* Probably obtained from the deserted Government establishment at Nankauri Harbour. 
The land in the neighbourhood of this coast, and probably as far as the hills inland and on the eastern side, which rise 800 feet, is of very recent formation, and consists of almost undecayed coral débris mixed with sand and vegetable loam, a compound scarcely sufficiently fertile to support a heavy forest at present.

Pigeons and glossy starlings were common, and we obtained specimens of a small forest hawk which had not been met with on the more open island (Astur, sp. nov.): we shot also a new chestnut myna (Sturnia, sp. nov.), somewhat similar to that met with on Kar Nicobar. Grackles (Eulabes intermedia), of which only one specimen on Nankauri had yet been seen, were fairly numerous, and the presence of a drongo, the first of its kind observed since leaving the Andamans, was recorded.

Numbers of Blyth's dove (Macropygia mipennis) frequented the scrub near the village. We were astonished to find the crops of all those shot completely filled with large red chillies only. It is almost impossible to conceive anything more pungent than a red pepper, and the bird must have an extraordinary interior to patronise such a diet exclusively. This unusual food had no effect on the flesh, for its flavour in no way differed from more rationally feeding members of the same species.

Now and again we would have visitors on the schooner, for in the evening people often came on board to watch us as we sat preparing specimens, and although on these occasions we generally obtained information from the natives concerning the locality and their customs, they were, as a rule, more bent on satisfying their own curiosity than our desire for knowledge.

One man showed us a ring, about $\mathrm{I} \frac{1}{2}$ inches in diameter, of a bone-like substance, and related a story about it of some large jungle-dwelling animal, from whose eye, or eye-socket, it was made. "This animal," he said, "was bigger than a pig, and very scarce"; further than that he was not intelligent enough to give a description!

Another native, "Yassan" by name, brought a letter originally 
belonging to his father, and written by de Röepstorff, who is now almost forgotten. Yassan was more intelligent than his companions, and we made arrangements with him to obtain for us a collection of charms and curiosities.

He was a man of some standing locally, was thrice-wedded, kept each of his "better-halves" in a separate house, and was at the time blessed with three children, all the offspring of one proud mother. Our conversation was carried on in Malay; but on one occasion, when we were at fault as to his meaning, he was asked to explain himself in Hindustani. He smiled rather wickedly, and immediately surpassed a Kling in volubility. Thereafter we stuck to the easier language, and guessed what we did not understand. These natives undoubtedly include some wonderful linguists among their number.

Once or twice the chinchews * of the junks brought for treatment Chinese suffering from malaria; the crews, they said, always contracted fever when visiting the Nicobars, and even if they do not suffer from it on the spot, it invariably occurs before reaching Penang. These particular vessels had been only a month at Great Nicobar, and a fortnight at this place, obtaining copra and rattan, but already several members of the crews were incapacitated from hard work.

Those junks trading at the Nicobars-where they remain during the greater portion of the north-east monsoon-that come immediately from Singapore, but originally from China, make the voyage and return between the last-named two places in the other (south-west) monsoon, which is the bad weather season in these waters, but the contrary in the China Sea.

The houses in the village were very similar in appearance to those we had just left, but were roofed with attaps of pandanus leaf. The process of thatching cannot be an enjoyable occupation, for either edge of the pandanus leaf is armed with a row of thorns, while the lower side of the mid-rib is provided with a third row set in the reverse direction; thus in brushing against a clump of young pandanus one is not * Supercargoes. 
only pricked when approaching, but scratched while getting away.*

Behind the village we found a fairly recent grave, around which the possessions of the deceased had been deposited-a wooden chest with the lid wrenched off, clothing, spoons, forks, tools, axes, dios, and other things, forming a miscellaneous collection that was rapidly rotting away. There they would stay until destroyed by the exposure, for no one would venture to help himself, however valuable or useful the articles might be.

In front of one house was a solitary example of kanaia, set up on land, however, instead of in the water: possibly the south-west monsoon blows too strongly on this coast for their general erection. The name of this village is Ol-kolo-kwak.

To reach land on the southern side of the bay we had to cross a broad reef of coral and coral sand, thickly overgrown with grass and corallines, and dotted with various species of holothurians. The forest on shore came right down to the water; and once inside it, we found ourselves in very truth in the home of the megapode.

No sooner were we under the trees than we immediately saw the birds-for the jungle is very open-running about, singly or in parties of twos or threes. From all round came their cries, perhaps best described as loud, ringing calls ending in a rapid cackle, to the sound of which the following syllables bear some resemblance- " ürr-rak, ūrr-rak, ur-r-rak, rak, rak, rak, rak!" The megapode hardly ever takes to flight when startled, but runs quickly away among the bushes; the only occasion on which I ever saw these birds use their wings was when once I suddenly walked into a party of four, scratching at the foot of a large tree. Two ran off, but the others rose clumsily in the air, and after flying a short distance, attempted to settle on a low branch, on which they alighted very awkwardly, and immedi-

* A legend illustrative of the unpleasant qualities of the pandanus, recorded by Mr F. C. Christian in The Caroline Islands, runs: that the Thunder-god, descending to earth, alighted in a pandanus bush, and found the situation so painful that he bestowed the art of making fire and moulding-pots upon the woman who released him from his predicament! 
atcly lost their balance and fell off. The feet, although very large and strong, are not adapted for grasping, and the tail is far too short to be of any use as a balance.

Sereral birds seem to occur somewhat locally: it was on this side of the bay only that we obtained Spilornis minimus, while the little forest hawk seemed confined to the northern shore.

We were unable to reach the hills in the centre of the island from the harbour, as the swamp at its head stretches out long arms to right and left, cutting off the land bordering the coast from the interior.

Kachal is the most northerly of the Nicobars in which monkeys are present, and, taking into account the scarcity of other mammalian fauna and the absence of this genus from the Andamans, it seems certain that they have been introduced. Their non-occurrence in Tilanchong - an island eminently suited to their requirements-goes to bear out this statement; for, so far as we know, it has never been permanently inhabited, and thus, unlike the other islands, offers no reason for monkeys being brought there.

The people of Ol-kolo-kwák told us these animals were very numerous in the jungle round the village, but several days passed before we met with them. On the first occasion, we each obtained a specimen from the same herd. They turned out to be macaques-one was a fine old male, weighing 2 I lbs., an unusually large size-with fur so dark as to be almost black, but greyish-white on the under parts. Having regard to the colour, the species has since been named Macacus umbrosus.

We saw them only once again, and then I found myself within a few yards of an immense male who was on the ground. My cartridge missed fire, and, immediately the click of the falling hammer caught his ear, he bolted. This proved to be our last chance of obtaining another example from Kachal. That one always loses the best specimens, is proverbial: this monkey was the biggest macaque I had ever seen. 
Such mishaps during one's earlier opportunities are always most vexatious; later we found monkeys very numerous in the other islands.

On 22nd February a Chinese junk passed northward, and the same day another arrived, and anchored in the harbour; that night there was carousal in the village and the noise of much singing.

Visitors to the Terrapin were fairly continuous during our stay here, and the appearance of some of them was as ludicrous as it was striking.

One man, who wore a battered "billycock" on his head, had encased his feet and legs in a pair of rubber jackboots; between these extremities he sported a sailor's jersey, and the usual $T$ bandage.

But, impressive as was this man's apparel, it was quite put out of the running by the grande parture of a fellow-dandy who arrived later. A top-hat worn sideways, and draped with a spotted cotton handkerchief where a mourning band might be, a gunner's jacket, thickly laced with yellow braid, and a light-blue pair of Chinese breeches, combined harmoniously (!) with heavy bead necklaces, and a face profusely bedaubed with red oil-paint. This gentleman's idea of refreshment was brandy, and to obtain it he had furnished himself with a supply of forvls, with which he was prepared to purchase it at the rate of a chicken a drink.

When not arrayed in these exotic costumes, everyone wore merely the neng, and perhaps a fillet of twisted cotton about the head.

A man who came to be doctored was treated with a glass of Eno, and an aloes pill, which he slowly sucked! This latter is the sort of medicine natives like, and as the awful bitterness of the drug became evident to his palate, the fellow doubtless thought it very effective treatment indeed. Give a native ro grains of quinine in sugar-coated tabloids, and he probably holds you a very poor sort of doctor; but dissolve that same quinine in a large glass of water, and make him drink the solution slowly 
-he will perchance recover on the spot! Faith and imagination, both in savagedom and civilisation, have a lot to do with these matters.

The women of the village were very shy and timid, but we now and again saw one or two going about their daily business; the children, however, could not get used to us, and fled screaming whenever we appeared.

A few days before we arrived at the village a woman had died there, and during our stay a performance for ridding the place of the ghost was gone through.

A large catamaran was constructed and rigged like a schooner, with sails made of green coco-palm leaves. The local doctor or bobo* then went through certain ceremonies, at which we were not present, and finally seized the ghost or devil and threw it into the boat, which was pushed off, and drifting away, was carried out to sea, where it disappeared.

The Malays have an almost similar custom to this, in the employment of the kapal hantu (ghost ship). This they use during times of pestilence, or in cases of individual sickness; but instead of forcing the evil spirits into it, they are attracted by a show of coloured rice, etc. Once they are cajoled on board, the vessel is pushed off, and carries the illness to whatever fresh locality it may reach.

The day before we left, Yassan, who had promised to collect, brought in a number of charms-figures of crocodiles, birds, women, men, and some fever pictures, called here déüshi (derived from the Portuguese for God, and is applied to the representations of the Deity in the pictures on boards and spathes). The people had but few scruples with regard to parting with such things. After being paid, he asked for a chit and a bottle of rum, "to use, mixed with eggs, as a medicine for his stomach!"

In the waters of the bay we caught quantities of small fish, which, although easily obtained by us with the seine, cannot be

* The Nicobarese equivalent is menliana ("medicine man," or shaman).

+ The belief that evil spirits cannot cross water scems to be of world-wide prevalence, $c f$. Burns' "Tam o' Shanter." 
a staple of diet in the case of the natives, who have no nets. I once observed a native in a canoe following a shoal, and making casts with a many-pronged fish-spear; he continually threw his weapon, but during the ten minutes I watched him, he caught nothing at all.

There is no good water here, and to fill our tanks we dug holes just above high-water mark; the liquid that filtered in was slightly brackish, and gave a heavy deposit of earthy matter.

Any quantity of coconuts may be obtained, with a few chickens and perhaps a pig or two.

Kachal is about 62 square miles in area, and reaches a height of 835 feet on the eastern side, which is composed of hills of calcareous sandstone and marbly slate, formed in deep seas during the Tertiary period. The western side, which is of very recent formation, consists of a flat shore plain of coralline alluvium, mixed with decayed vegetable matter and loam brought down from the hill. It is covered with dense forest throughout. The population is stated to be $2 \mathrm{SI}$-an increase of 100 in the last fifteen years. 


\section{CHAPTER XI}

\section{LITTLE NICOBAR AND PULO MILO}

A Tide-rip-Islets-A Cetacean-Pulo Milo-Timidity of the Natives-Little Nicobar-Geology-Flora-Population-Site for a Colony-Jungle LifeBanian Trees-The Houses and their Peculiarity-The Natives-Practices and Beliefs-The Shom Pein-The Harbour-We ascend a River-Kingfishers-Water-Caves-Bats and Swallows-Nests-A Jungle PathMenchál Island-Collections-Monkeys-Crabs.

SaIling across the Sombrero Channel, some 30 miles wide, between Kachal and Little Nicobar, we passed the islet of Meroë. It is low-lying, and about I mile in length. A yellow beach separates the dark crown of jungle and coconuts from the sea, except at the southern end, which is slightly elevated and rocky.

On its western side, a tide-rip-to which the chart ascribes a strength of 5 knots an hour at times-caught us, and we were in some danger of being carried inshore, but that the breeze was just strong enough to bear the schooner safely past. The tides in the channel set strongly, and are said to attain in parts a velocity of as much as 5 knots at springs.

South of Meroë are the islets of Trak and Treis, and from the deck the red sandstone cliffs of the latter could be seen with much distinctness. Little Nicobar, rising 1400 feet, showed broken and hilly, completely covered with dense jungle, and beyond it Great Nicobar loomed faintly above the horizon.

During the afternoon, when in the vicinity of Meroë, we were somewhat excited by a glimpse at what was perchance a 
specimen of the killer whale (Orca gladiator). The first hint we obtained of the presence of such an animal, was conveyed by the sight of a long black fin showing above the water immediately in the course of the schooner.

As we sailed over the spot where it had been, we perceived, while looking over the side, a stout, rotund body of a deep black colour, marked with large patches of a yellowish hue about the head and the posterior portion of the back. Only a momentary glance was obtained before it faded from sight in deep water, but we judged it to be some i 5 feet in length.

The dorsal fin distinctly differed in shape from that figured in descriptions of the killer; instead of being more or less triangular, it was sabre-like, long, narrow, and curved.*

We were all day journeying from Kachal to Little Nicobar, and had to anchor for the night somewhere west of Pulo Milo. As it became dark, immense flocks of pigeons left the forests of Little Nicobar for Trak and Treis, where they roosted for the night, and when day dawned we saw them passing back again. That morning, however, we made sail again, and reached our anchorage in a very short time.

The harbour is a fairly good one, and is formed by the coast of the island here bending to form a right angle, and by the island of Milo, which forms a protection on the west. Good shelter is afforded during the south-west monsoon-the most important consideration; and at other times only strong northerly winds need be feared.

We found 7 fathoms sand in the centre of the channel where we rounded to; and soon after the sails were down, three wild-looking fellows in black Chinese jackets came alongside, followed presently by a couple of old men clothed in red cotton.

For some unexplained reason, they seemed much afraid, and were with difficulty induced to believe that our intentions were nothing but good. From answers to questions, we learned that the people of Little Nicobar have nearly all died-a piece

* This cetacean is probably of the same species as that observed by MIr Holdsworth in the Indian Ocean, and described in the Hammals of India. 
of information that one seems to obtain everywhere but in Kar Nicobar and Chaura. The name of the island they gave as Pulo Panjang (Malay=Long Island); it is called "Ong" in their own language; among themselves the Nicobarese do not employ the names familiar to us.*

Little Nicobar, the second largest island of the Archipelago, has an area of 58 square miles. It is broken up into hilly ranges, the highest summits being Mount Deoban, 1428 feet, near the centre of the island, and Empress Peak, I 420 feet, at the north-east corner.

The bed rock is a calcareous sandstone, easily disintegrated, and overlaid by a deep soil capable of sustaining a rich and varied vegetation. The hills are thickly wooded from base to summit, and there are no grassy spaces like those found on the northern islands.

The nature of the forest varies according to position and soil. In the beach forest, Pandamus larum and P. odoratissimus, Hibiscus tiliaceus, Barringtonia speciosa, Terminalia catappa, and Calophyllum inophyllum, are extremely plentiful; in the littoral forest of the level inlets, Mimusops littoralis, Calophyllum spectabile (canoe wood), and Eugenias, are the best represented species; while palms (Ptychoraphis augusta and Areca catechu) and cane-brakes are common in the moister parts. The high forest of the hills contains fine specimens of Terminalia procera, C. spectabile, Myristica irya, Artocarpus lakoocha, and Garcinia speciosa. No Dipterocarpus trees occur.

The population of Little Nicobar and Pulo Milo is 67 : in

* Map Neme.
Kar Nicobar
Batti Malv
Chaura
Tilanchong
Teressa
Bompoka
Kamorta
Nankauri
Trinkat
Kachal

Native Nume.
Pu
Et
Tatat
Láök
Taihlong
Poähat
Nankauri
Nankauri
Laful (East Id.)
Tehnyu

Map Name.

Meroë

Trak

Treis

Menchal

Little Nicobar

Pulo Milo

Great Nicobar

Kondul

Kabra
Native Name.

Miroë

Fuya

Ta-añ

Menchál

Ong

Miloh

Lo-öng

Lamongshe

Konwaña 
fact, with the exception of Kondul, the inhabitants are fewer than those of any other island of the group. Its people speak, with some variations, the dialect of Nankauri: only for certain objects, and these, singular to say, of first necessitycoconuts, palms, pandanus, etc--do they employ different expressions.* The same language is spoken by the people of Great Nicobar. According to Hamilton, they all partook, two hundred years ago, of the unpolished nature of their mountainous islands, and were more uncivil and surly than those of the northward!

Should the group again receive a European settlement, I know of no spot more suited to the purpose than this: in accommodation for shipping only is it excelled by the splendid harbour at Nankauri; in all else it is far superior-in the formation and greater area of ground, in fertility of soil, and in the presence of water.

We landed first on Little Nicobar near some ruined huts which once formed the village of Makachian, deserted since I 898 , when the few remaining people either died or removed elsewhere; and after passing through a belt of coco palms, found ourselves in the jungle.

Much of the surface was level; but here and there little chains of sandstone hills, rising two or three hundred feet, wound about. The trees were of immense height, and in many places beneath them one moved about as freely as in an English forest.

Although this open vegetation is much more pleasant to traverse, it is not half so satisfactory for collecting purposes as the denser jungle, for it contains far less, both in variety and numbers, of birds and animals.

Megapodes, singly, in pairs, or in little flocks, ran about and sought busily for food, calling to each other meanwhile, until, alarmed by the sight of such unwonted intruders as white men, they scurried swiftly away. Overhead, so high as to be almost out of shot, pigeons, grackles, and parrots fluttered and 
cried, while, running up and down the branches, we saw, for the first time, the Nicobar tupai or tree-shrew, a little insectivorous animal, which, at a casual glance, might be taken for a squirrel. They were very common; but, unlike their representatives in the Malay Peninsula, etc., which are ground animals, we saw them only in the trees.*

It was soon evident that we had no cause to regret not having obtained more monkeys at Kachal, for here they abounded; and after discovering how common they were we would cold-bloodedly arrange every morning as to who should murder the specimen for the day.

Here a new bird was added to the islands' fauna (and to science) in the shape of a little Rhinomyias, quietly clothed in dull-brown plumage, which frequented the undergrowth of dense jungle and possessed a rather sweet note.

A momentary glance of a pitta gave for a few days (until we obtained a series of specimens) a fresh zest to collecting; this bird also was hitherto unrecorded from the locality, and proved to be a new species, although closely resembling $P$. cucullata.

A short distance from the shore, some immense banian trees grew so high that the pigeons and parrots which swarmed in their branches for the fruit were often completely beyond reach of the gun. The trees possessed, moreover, some wonderful aëreal roots (7o feet high), and, standing on the edge of an open space within the jungle, offered an opportunity for photography too good to be passed by. While the plate was being exposed-an operation of some minutes-a diminutive pig, bearing a striking resemblance to the Andaman species, trotted out from the surrounding foliage and leisurely inspected the camera. It was the first of the kind we had seen, and I had to reproach myself with leaving my gun at the boat.

* The tupai of Little Nicobar, which differs somewhat from that of Great Nicobar-principally the light areas of the pelage are less yellow and less contrasted with dark areas-is considered a sub-species by $\mathrm{Mr}$ Gerrit D. Miller, who has named it Tutraic nicobarica surda. 


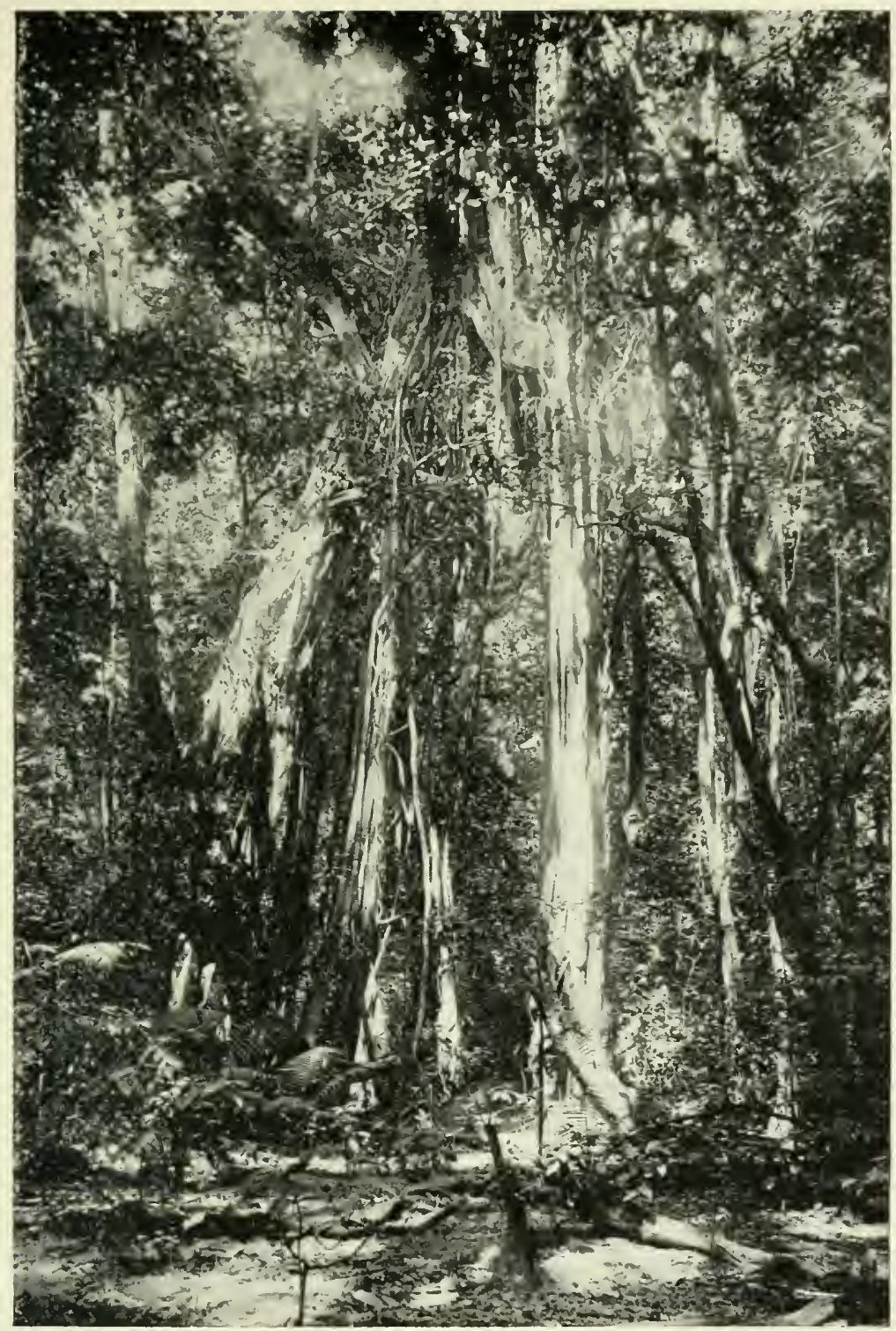

FIG TREE WITH AËREAL ROOTS, LITTLE NICOBAR. 

Pulo Milo is only about half a square mile in area, but is thickly covered with a growth of pandanus and coconut trees and jungle, above which hundreds of tall slim palms have forced their heads.

The little village of four houses lies on its eastern shore, fronted by a coral-reef that offers but little impediment to a landing-party: one tall pole, with bunches of palm leaf, stood on the beach-the last we met with.

The houses were all of quadrangular form, but with a peculiar feature about the roofs; for the slope from apex to eaves, instead of being straight, was in some markedly rounded, and in others the curve ran unbrokenly across the top from edge to edge. They were thatched with the leaves of the nipah palm, and the side walls, 2 to 4 feet in height, were built of rough-hewn planks laid horizontally, or of slabs of bamboo split and flattened out. The doors were closed by chicks of palm leaf, which in the daytime were propped out to shade the interior from the sun.

The natives soon overcame their distrust of us, and one evening "Shongshire," the headman, and others from the village, came on board. The former was a stately old gentleman, in spite of his top-hat, and somewhat resembled our old acquaintance, "Friend of England." With him was another old man of a most vivacious temperament, who gave us information in a very graphic manner as we all sprawled, chatting, on the cabin roof.

"There were only about a dozen people in the harbour," he said, "although in his boyhood many lived there; all however, were now dead from sickness and the 'orang bubu.' The former, he believed, was caused by eating turtle, and a kind of large fish that appeared near the shore at that period. The latter (apparently) were evil spirits that eat men, and are let loose by a wizard." *

Although the belief in evil spirits is quite as strong as in

* About this fact I am not certain, for the Malay in which our informant expressed himself was a thing quite sui generis. 
the central group, there is a great falling-off both in the elaboration and in the abundance of the instruments employed in exorcising them. In none of the houses was there either a large figure or a picture, or more than one or two of those minor charms which are met with in such abundance at Nankauri, while outside the dwellings the only representative of the signs and warnings to demon trespassers to "Keep off the grass," so numerous in that place, was a rudely-carved post daubed with paint.

The dead here, once buried, are left to rest in peace, and the somewhat loathsome process of digging up and cleaning the bones is not gone through.

It is probable that all this is a case of desuetude rather than the original absence of custom, and that such decay of ceremonial is due to the little value of public opinion, which is of no weight now that the population is so small. Taking into account that such religious accessories as they do possess, and that similar articles in Great Nicobar, together with the architectural type, etc., occur also at Nankauri, it is to be inferred that there was a time when these people in no way differed in observances from the inhabitants of that locality, who still retain in full the paraphernalia by which they outwardly mark the practice and maintenance of their superstitions.

Concerning the Shom Pen, we heard that though resembling the Nicobarese in appearance, they use a different language.

They are fairly numerous, and those living near the shore are on friendly terms with the coast people, bartering jungle produce and rattans. It is not wise, however, to go into the interior of Great Nicobar, as the wild men (orang utan) will murder strangers for the sake of their clothes and ornaments. They themselves are clothed in bark apparel. Their houses are either light shelters, the materials of which they carry about in their journeys, fitted with bunks one above the other, beneath the lowest of which a small fire smoulders; or are of a more substantial construction, with a fence* surrounding each house cluster.

* These fences were met with by de Röepstorff on the east coast (Jour. Asiatic 


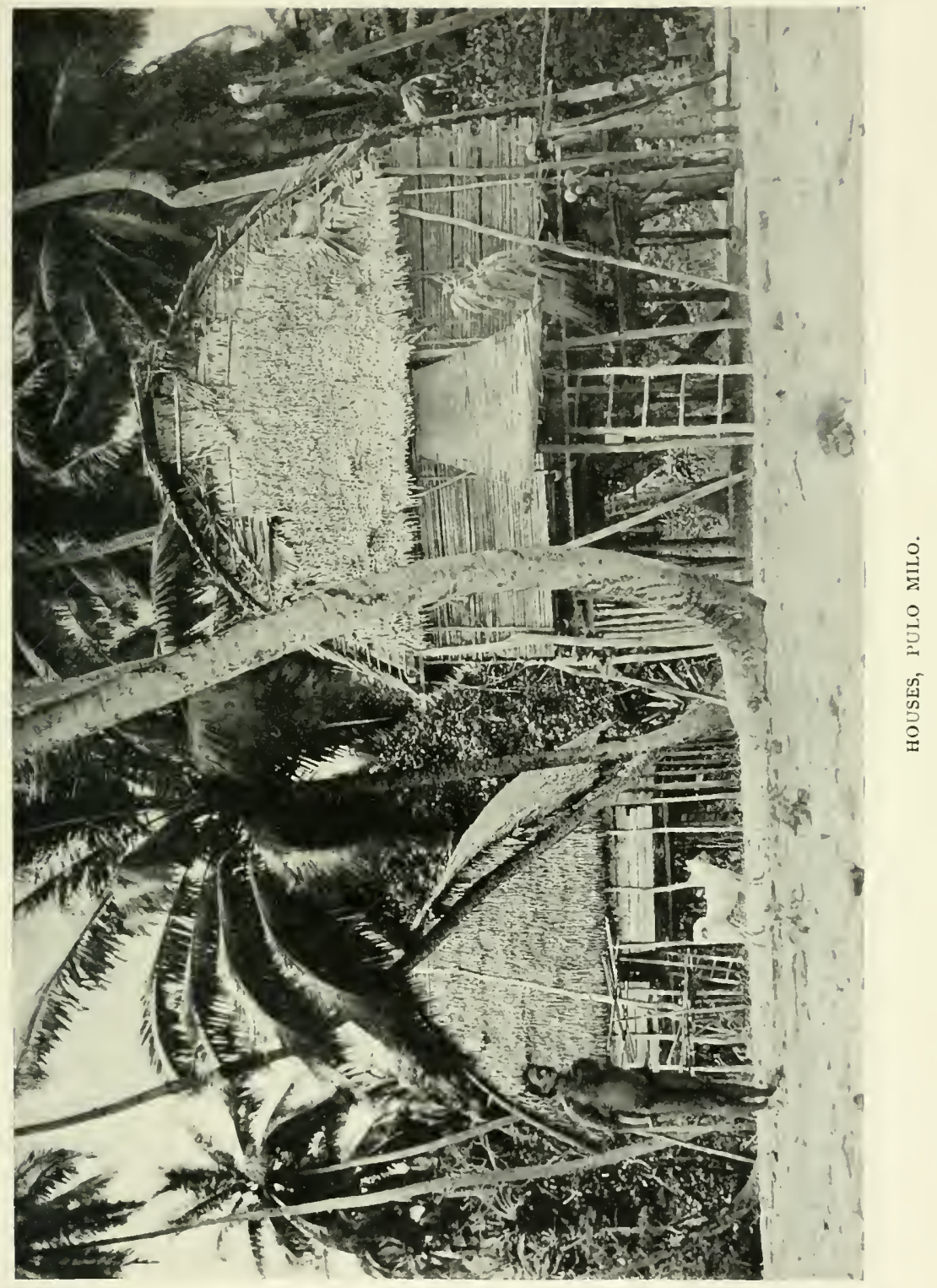

[To face rage 124. 

In shape, Pulo Panjang is roughly a parallelogram, but its north - west side is somewhat eaten away; and the bay thus formed makes, together with Pulo Milo, a most effective harbour.

At the apex of this is a small secondary bay, where a little river, rising in the hills inland, debouches through a broad belt of mangroves. The salt-water basin, although partially choked with coral, would, in the event of settlement, serve well as a small boat harbour.

We ascended the stream several times in search of the big storkbilled kingfisher (Pelargopsis lencoceplaala), which, strangely, occurs again in Borneo, and at no spot between that island and the Nicobars; the case of the megapode is exactly parallel.

The river at first ran through a forest of young, but lofty, mangroves (Bruguiera gymnorhiza), whose straight stems, leaning towards each other across the stream, bore a certain resemblance to an assemblage of scaffold-poles. At length, when the land became less swampy, they gave place to a fringe of nipah or attap palms, the fruit of which looks like an exaggerated pine cone, and is sometimes eaten by Malays, while from the tender inner shoot, the same people obtain a wrapper for their cigarettes. ${ }^{*}$

Finally, where the banks became dry and solid, they were overgrown by luxuriant jungle-a mixture of forest trees, bamboos, palms and rattans, with here and there bordering the stream, a many-footed, white-skinned pandanus, and often a beautiful tree fern (Alsoplitila albasetecea), that immediately brought to my mind the blue hills and equally lovely valleys of New Zealand.

The stream, although maintaining a depth of 5 to 10 feet, at length became very narrow, and we were compelled, in order

Soc. Bengal), and by the members of the Galathea Expedition up the Galathea River in Great Nicobar (Corvetten Galathea's Jordourseiling, Steen Bille, Kjöbenhaven, 1852).

* The Malay roko is an affair of much wrapper and little tobacco, whose flavour would seem so bonfire-like as to be akin to the brown paper or stump. of cane smoked by precocious and naughty little boys at home : 
to proceed, to chop away the network of vegetation that overhung the water. Now and again it ran through open spaces covered with tall and matted grass, and then between banks a dozen feet high ; but when we were forced to stop, unable to proceed further, the water was still brackish, although we had almost reached the hills in which it takes its source. The banks were frequented by herons, redshanks and other waders, and kingfishers (both $P$. leucocephala, with sandy head and body and blue wings, and the tiny bengalensis, the counterpart of our English bird). Several beautiful butterflies were seen, a rather common species, with velvety black wings, blotched with turquoise, constantly flitting up and down the course of the stream.

We obtained good water in the harbour; slightly to the west of the little bay, a rocky hill makes an angle with a little beach of bright sand, and at the point of junction a path leads to the spring a few yards inland, where, in the jungle, the trickling water runs down a face of black rock, and collects in a stony basin. By forming a slight dam at the foot of the rock, any quantity can be collected.

In the rocky hill just mentioned, we discovered several caves, which run inwards from mouths situated at the water's level. These are the homes of thousands of tiny leaf-nosed bats (Hipposideros nicobarula, sp. nov.), and immense numbers of the bird's-nest swift (Collocalia linchii).

The largest of these caves is about 50 feet deep, and 20 feet high at the entrance; but at the back the accumulation of guano is so great that there is barely room to stand. As we entered with a lantern, our feet sinking ankle-deep into the soft chocolatecoloured floor, there was a continual rush of little bats and birds overhead as they sought to escape, and with a leafy branch we knocked over a number of each kind before going to the end.

The rock at the back was covered with countless numbers of the shallow cup-shaped nests of saliva-gummed moss: so closely were they built, that in many cases one could not place a fingertip on the rock between them, and often they were constructed one on the side of the other. Nearly every one contained two 


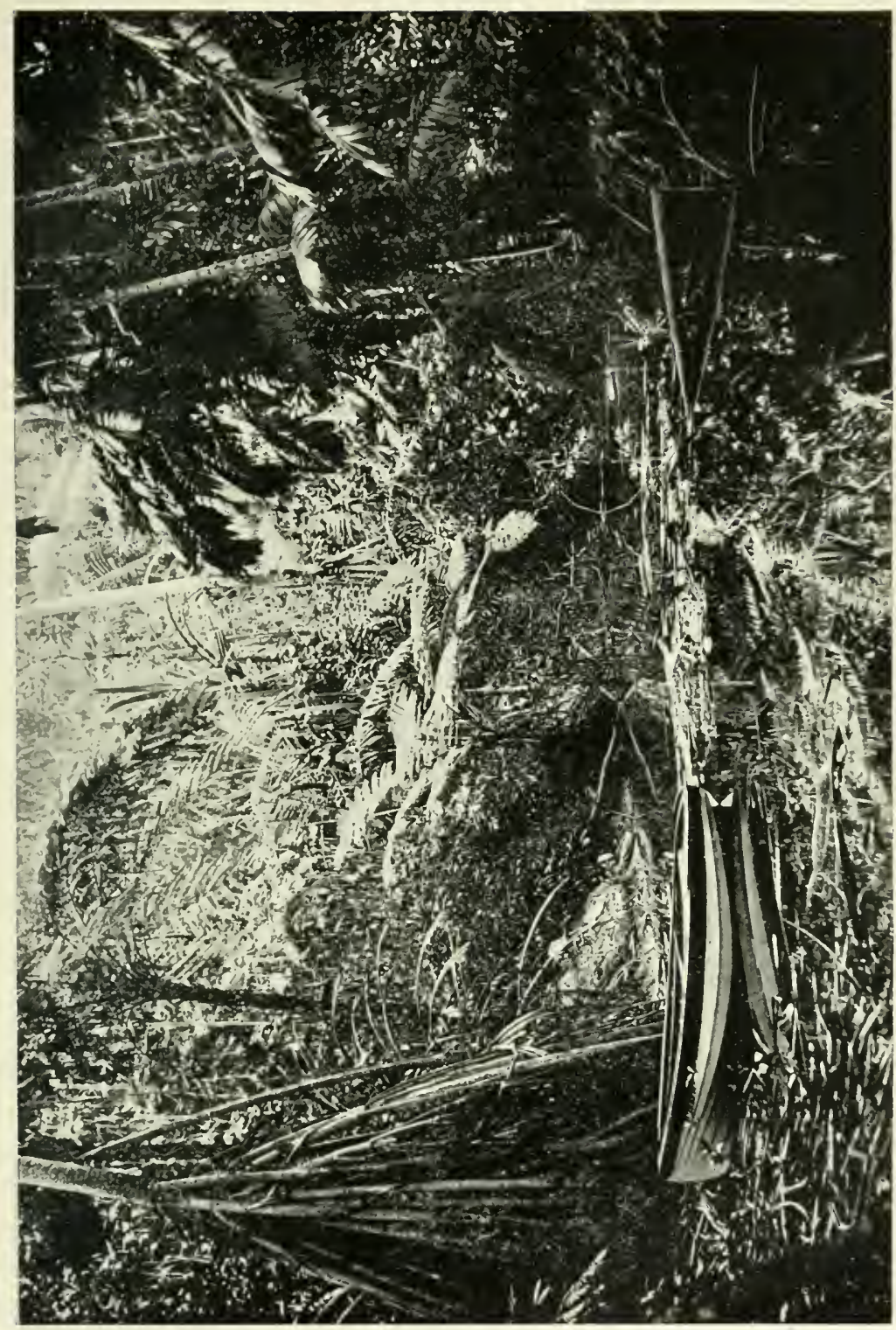



comparatively large, white eggs, or ugly, unflectged nestlings. Fortunately for the birds, they are builders of the green variety of nest; for had these been white, they would not long have remained undisturbed by the Chinese.

Swifts and bats-the one as graceful as the other is hideouswould seem queer neighbours, although there is a certain affinity between the two, for both enjoy the same food-flies and other insects-and obtain it on the wing without mutual interference; for the first hunt by day, and the others are nocturnal. In the cave, the swallows breed at the inner end, while the bats congregate near the mouth.

Another small cave was inhabited by bats only, and so thickly were they suspended from the walls, that one could kill a dozen at one blow. For long after we left the spot, clouds of swifts whirled about the entrance; but the bats, when disturbed, immediately disappeared in the jungle above.

The only path on Little Nicobar runs across its northern peninsula. It starts near a couple of dilapidated huts opposite Pulo Milo, and, running first through a belt of tangled scrub, crosses the little range of hills near the western coast, and then, traversing a stretch of rich flat soil, covered with splendid open forest, and great numbers of the Nicobar palm ( $P$. augusta), finally comes out on the east coast opposite the small island of Menchál, which lies a mile or so distant, and is only half a square mile in area. It is covered with forest, containing many coco palms and tree ferns, and also clumps of two species of giant bamboo (Bambusa brandisii and Gigantochloa macrostachya). It is of sandstone formation, covered with deep soil or sharply-worn coral. Somewhat farther down the coast is a small village, and the path has been made to connect this with Pulo Milo.

The forest through which the path ran was our favourite collecting ground. We met there for the first time the beautiful little sunbird Acthopyga nicobarica, with crown and tail dark shining blue, throat and breast scarlet, through which ran two moustachial streaks of brilliant blue, the remaining plumage olive 
grey, but further ornamented by patches of bright yellow beneath the wing and on the back. This is the male, for the hen bird, as in all sunbirds, is of very inconspicuous plumage. This species is very local in distribution, and does not occur in the northern islands.

Astur soloensis, the forest hawk, was not uncommon, but took pains to obtain, for it was very wary. Before beginning to call, one had to hide in a bush, or behind a tree trunk, and the chances were that when the bird did arrive it would perch behind you, and then, since its swooping flight is perfectly noiseless, one remained in ignorance of its proximity. Then, too, it might rest five yards away or fifty: in the former case, if you were not prepared with a suitable cartridge, the bird was lost, for there would be no time to reload; in the latter event, it was better to knock it over straightway than run risks in bringing it closer. Once they become frightened, or see what is making the call, they are off, not to return, "charm you never so wisely."

A parrot-Palcomis caniceps-restricted entirely to the two southern islands of the Nicobars, was very common about here, where its screams and chattering often broke the prevailing silence of the jungle. For such a bird, it was clad in sober colours; for, saving a grey head, across the front of which-like a pair of spectacles-there ran a patch of black feathers, the plumage was of green only. The whole scheme was somewhat relieved in the male by an upper mandible of scarlet.

Monkeys abounded, and on some days we might see as many as fifty or a hundred. They are so numerous that in both Little and Great Nicobar the coco palms, except in the neighbourhood of villages, are altogether unproductive, and this, according to the natives, is because the monkeys screw off every nut the moment it begins to form.*

They, too, are very timid in some ways, but one is able to get at them through their intense curiosity. The attempt to

* It is difficult to believe that this is the true reason of the trees' infertility; but it is a fact that no coco palms, except those about the houses, bear any nuts. 
stalk a herd of these animals is often a futile proceeding; but if, when you have seen them, you keep quite still, and attract their attention by some unusual noise, such as a continued tapping on your gun-barrel, you will generally have them all round you in a very short time.

The effect, on the monlicy, of man's appearance, is most interesting. The expression of their emotions is certainly almost human, as they sit and stare at him, coughing and snarling with anger and contempt, drawing back their heads and throwing the hand before the face with a gesture of abhorrence, and other movements indicative of shocked and outraged feelings. But predominant is the expression of absolute horror, which, coming from those we consider our still degraded cousins, is to our superiority very aggravating.

A troop of monkeys travelling through the forest and feeding as they move, is also worth watching. Their presence is plainly indicated, even when some distance off, by the crashing noise made as they leap from tree to tree. Having reached the extremity of one branch, the monkey, with a swing and a flying leap, conveys himself to another, not alighting as a rule on a bough of any size, but generally coming down on all fours amongst the small twigs, a bunch of which is immediately embraced.

In their manner of feeding they show a perpetual craving for change, the most fruitful tree not detaining them for many moments; while for each fruit from which a single bite is taken, half a dozen are plucked and thrown down.

Crabs swarmed nearly everywhere: scarlet hermits, that dragged about their variously-shaped domiciles in which they shut themselves up and lay inert when disturbed; and the hideous, purplish land-crabs, that scrambled away waving threatening claws at sight of a stranger. So numerous and rapacious were all these, that a week's assiduous trapping for mammals only produced one specimen, since the baits were always immediately discorered and deroured by the unwelcome and valueless crustacean. 
Before we left, a number of men from Great Nicobar arrived in a large canoe: they were proceeding to Nankauri on one of the expeditions undertaken by the Nicobarese when they desire to obtain the pottery manufactured only by the women of Chaura.

We weighed anchor at sunrise on March 4 th, having added a pitta, an owl, and the Rhinomyias-all new species-to the avifauna of the islands during a most satisfactory visit of seven days. 


\section{CHAPTER XII \\ KONDUL AND GREAT NICOBAR}

The Anchorage-The Island-Villages-IVe leave Kondul-Great NicobarAnchorage-Collecting-Up the Creek-A Bat Camp-Young Bats-Traces of the Shom Pen-Bird Life-Fish-Ganges Harbour-Land Subsidence-Tupais-We Explore the Harbour-A Jungle Pig"Jubilee" River-Chinese Navigation-Rainy Weather-Kondul BoysCoconuts-Chinese Rowing.

ON the same day, we anchored as night fell, close to the island of Kondul, having sailed down the west side of Little Nicobara coast of sand-beaches and steep jungle-covered hills-and crossed the St George's Channel, which divides the latter island from Great Nicobar.

Kondul is 2 miles in length, and half a mile wide, and, while running N.N.E. and S.S.W., lies too far from the larger island to form a harbour, although sheltered water is nearly always to be found on its lee-side.

We dropped anchor in 7 fathoms, opposite a little beach and some coconut palms on the western shore, and next morning rowed to the village on the other side, meeting on the way a strong tide-rip, off the south-east point, that for long kept us from making any progress.

The island is about 400 feet high, and its grey cliffs of slate and sandstone rise steep and bare until they meet the dense jungle with which the upper part is covered. Only on the east is there any flat land, and there, on a stretch of coral soil, are situated the houses and gardens of the natives, who now number some 38 individuals. 
We landed behind a projection of the reef which afforded shelter from the swell, and were met by the headman "Dang," who brought with him the shipping register.

Some of the buildings were round, others rectangular in shape, and supported by leaning-posts in addition to the piles; and here and there were erected a few slightly carved and painted stumps, draped with bunches of palm leaves.

The headman's house contained small figures of a man, woman, and child, and some painted nuts, also a large mirror in a gilt frame-a useless object probably obtained from the Chinese in return for some thousands of coconuts. We learned that there were many Shom Pen on the neighbouring coast, but that they were very nomadic, and badly disposed towards strangers.

Our talk over, we left the house and rambled about, behind the village, in a plantation of coco palms, bananas, and limes growing in rich alluvial soil; and then, proceeding along the shore, crossed a little stream, and making a détour round a mass of broken rocks, reached a further village of three houses. Here the people were rather nervous at first, especially when asked to stand for their photographs, and needed much reassuring before we got on satisfactory terms; but Jangan takot, kita orang baik (Don't be afraid, we are good men), and similar expressions, before long brought about more friendly relations.

After purchasing a supply of coconuts, limes, and as many chickens as could be obtained, we returned to the schooner and sailed for the north coast of Great Nicobar, known to the natives as "Sambelong," or "Lo-öng."

With the wind ahead, it was once more evening before we reached the little bay where we had decided to stop. Anchoring, at first temporarily, at the mouth, in 5 fathoms, the dinghy went off to sound, and ascertain whether we might enter. The bottom was sand and coral, and shoaled rapidly, until at the mouth we found a sandbar that almost dried at low tide. Of a village which we expected to see, since it was marked on the chart, there was no trace. 


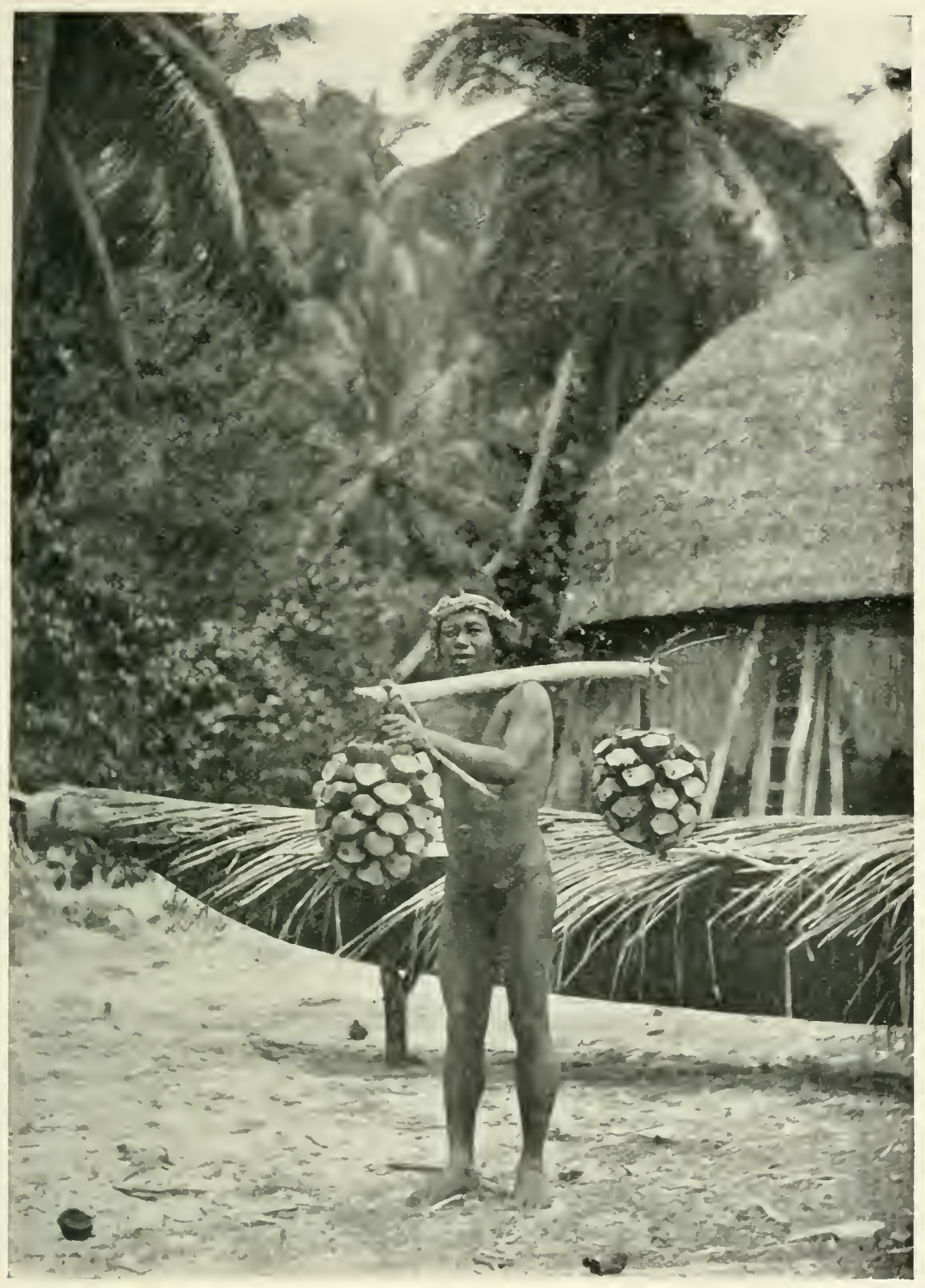

NAN WITH PANDANUS FRUIT, KONDEL. 

On the morning following our arrival, we set to work, on the right shore of the bay, to cut a path up the steep hills which rise immediately from the water. This caused so much noise, however, that nearly every animal and bird was*scared from the neighbourhood; and since we could only proceed along the summit of the hills, where such specimens as were shot were in danger of rolling down the steep sides and being lost, after setting a number of traps, we returned to the boat and set out to explore the bay.

The little basin at its head was surrounded by steep hills, but on the right a stream flowed through a gap in the latter. Beyond this the land sank, and opened out into a seemingly interminable mangrove swamp, through which the river wound deviously.

From the mangroves overhanging the stream we obtained several nests of a sunbird (Arachnechthra, sp. nov.). These in shape were something like an old-fashioned net purse, covered with lichen, and were suspended from the ends of branches. The entrance was in the side, and in each we found two pale-brown eggs mottled with a darker pigment.

Half-an-hour's row brought us to the end of navigation, and at that point we met with a vast colony of fruit-bats (Pteropus nicobaricus), occupying the mangroves on either side of the river.

At a small computation, several thousand animals must have been hanging head downwards from the branches, and the surrounding atmosphere was impregnated with the musty odour of their bodies. When we disturbed them, they gave vent to a continuous "skirling" noise, somewhat like the song of cicadas, but less shrill in tone.

By nature they are very fearless, and the majority merely stared inquisitively; a few spread their great wings and flapped heavily away for a short distance, and others crawled actively along the branches back downwards.

All the females carried, clinging to the breast, a young one of about one-third full growth; these the mothers hugged to themselves with a folded wing, but when unsupported, the young found no difficulty in maintaining its position, by means of its excessively 
sharp claws and its suction grip on the parent's teat. When the latter crawled about, the baby was supported in the membrane of the wing, which bagged slightly with the weight. I should imagine that it is not thoroughly weaned until the birth of a fresh offspring.

The action of these bats when climbing a vertical branch, is similar to a man's in shinning up a pole. The wings are first raised and a tight grip taken with the claw on the thumb, then the feet are drawn up, and, after they obtain a hold, the wings are once more lifted. When taking to flight, they swing to and fro once or twice, and then let go in a backward direction.

Several were obtained for specimens, and amongst them were two old females, which were shot without damage to the accompanying young. These latter I afterwards attempted to rear. At first they made no effort to escape, but clung tightly to the mother's teat. When they arrived on board, I put them into a box, fitted with a perch, from which they could suspend themselves, but I found they had barely strength to sustain their position by means of the hind feet only.

For food I gave them bananas mashed into a pulp, and a weak solution of condensed milk. The former, after masticating and extracting the juice, they would eject, but the milk was readily lapped up, or sucked from my finger tip.

The two did not agree well, but remained during the day in opposite corners of the box. At night they were very restless and noisy, continually uttering shrill cries, and often fighting. When I had owned them a few days, they escaped one night from their rough cage, and at daybreak were found high in the rigging. Later they escaped again and disappeared; reaching, I believe, the adjacent shore.

After exploring the neighbourhood, we found a good patch of flat jungle on the east shore of the bay, and near the sandbar across the mouth discovered a faint path leading inward. Following this across some damp ground, we saw numerous tracks of men and dogs, which certainly pointed to the presence of Shom Peri, as the Nicobarese said they themselves never went 
inland; but although we searched the locality thoroughly, we failed to obtain morc pronounced signs of occupation.

The forest abounded in life. Nearly every morning-generally the first bird obtained, and only seen thus early-a beautiful pitta was shot. Nicobar pigeons, sometimes in large flocks, every now and then rose with loud flight from the ground, where they were busy searching for food; for, unlike the big grey fruit-pigeons, with green-bronze back and wings (Carpophaga insularis), these birds are ground-feeders. The little brown Rhinomyias was very plentiful, as was the tiny kingfisher, Cey'x tridactyla, a most gorgeous bird, with coral-red feet and bill, and plumage of brilliant yellow, orange, blue, and lilac.

In a deep rocky ravine (that in the wet season must be filled with running water), arched over with tall jungle trees, and containing beautiful tree ferns, whose waving heads rose above the edge, I shot our first full-plumaged specimen of the Nicobar fly-catcher. Though not of brilliant colouration-for the slightlycrested head is of steely blue-black hue, and the remaining plumage of a silky-white (saving the large feathers of the wings, which are delicately pencilled with black, and the quills and edges of the tail feathers, the two central being several inches long, which are marked with the same colour), with blue bill and feet-this bird is to me perhaps the most beautiful of all the Nicobar avifauna; and while there are many of far more gorgeous plumage, none can approach it in delicacy, and the quiet beauty of its colouring.

Tracks of pig were very numerous in the low ground, and we often met with herds of monkeys making their way through the jungle; no rats, however, were trapped in this place, although crabs were scarcer than usual.

Water we obtained on the east side of the basin, just within the sandbar, but we had some difficulty in discovering it. The skipper, while engaged in the search, reported having found a number of spiked stakes planted in the jungle, similar to the ranjows of the Dyaks.

An old man, named Barawang, arrived one day in a canoe. 
He spoke English fairly, and said he was headman for the west coast, producing a Port Register in support of his statement. He formerly lived at Pulo Pét, but fled thence with his family to Kondul to escape a raiding party of Shom Pen.

The waters of the bay swarmed with shoals of little fish, which were much preyed upon by the ikan parang; * a long, thin, sabre-shaped fish with a formidable set of teeth; it is often seen darting along above the surface of the water, which it just flicks with its tail. Of the small fry we caught immense quantities with a casting-net, and obtained larger varieties with the seine, by fixing it on stakes across the mouth of the creek at high water; by the time the tide had fallen, several fish had invariably become entangled in the meshes.

On the roth we made sail, and proceeded a little further along the coast to Ganges Harbour, anchoring just within its eastern point. If the chart is correct, changes have taken place on the coast since the last survey. We lay opposite a small stretch of flat land, and where the plan gives the coast-line nearly straight, a little bay now exists, where stand stumps of dead trees, about which the low tides expose a broad expanse of black mud.

After wading through the mud to reach the shore, we found that much of the low-lying ground was merely swamp. Part however, was covered with tall, open jungle, in which were numbers of pigeon and parrots. There were no monkeys, but tupais (Tupaia nicobarica) were plentiful. These appear to be entirely arboreal in habits, and are quite as active as squirrels in running along branches, or climbing about amongst smaller twigs in search of insects. Their cry is a sort of trilling squeak, which is easily confounded with the call of a bird.

In crossing to the further side we found plentiful traces of Shom Pen-a faint path, a ruined hut, heaps of shells, and split seed-cases of the Barringtonia speciosa. The edge of the land was rapidly being eroded, and many tall casuarina trees, with roots undermined by the water, lying prostrate in the sea.

* The ikan parang is known to us as the "garfish." 
At either end, this disappearing beach was hemmed in by rising ground and rocks, which at its eastern termination contained a little stream and basin of good water.

On the 12 th we rowed about the shores of the harbour, landing every now and then to search for the aborigines. The only signs of man's presence discovered, however, were rows of stakes set up across the creeks in the mangroves. One of these rows we utilised to hang our own net on, and obtained there such an abundant catch of small fish that we returned the greater part to the sea.

The shore-line is much more indented than the outline given on the chart, and in the shallow water and mud of a little bay, rows of tree trunks still stood, two or three hundred yards from the land. This subsidence, however, is local in its occurrence, for everywhere else in the Archipelago signs of elevation are markedly present, and it is to be attributed to seismic agencyearthquakes having several times been experienced in the group -and not to a general depression of the land.

The following day we went still farther afield, and crossed the harbour to a beach where stood a grove of coconut trces and a small hut. The trees were without fruit, and the house, though deserted, contained a number of bundles of split rattan, such as a small section of the Shom Pen trade in with the coast people. The plantation was surrounded by hilly country, covered with tall, open jungle: birds were scarce, and a hawk and a megapode were all we obtained in the way of feathered booty; but, immediately on landing, Abbott caught sight of a couple of pigs, and knocked over the boar with a bullet. Though very similar to the Andamanese pig in size and appearance, it had patches of white on the feet. From it a new species has been described, under the name of Sus nicobaricus.

While rowing back to the Terrapin, we were overtaken by a blinding squall of wind and rain, which half-filled the boat and made the men (who sat with their feet on the thwarts) very uneasy, lest they should be polluted by contact with the blood and water that swished about in the bottom. 
Next day we extended our search still farther, and ascended a little river, to which the name of "Jubilee" has been given by the surveyors. We rowed up several arms of this stream that wound to and fro in the mangroves, but only found a small fishing weir constructed of rattans. The muddy shores swarmed with water-birds-herons, whimbrel, redshanks, and others-and we surprised a monstrous crocodile, little less than 20 feet long, who rushed into the stream long before our guns were ready. Returning to the mouth, we landed and walked for a couple of miles along the beach; but the shore was everywhere covered with dense tangled scrub, behind which lay the swamps of the river.

On the last day of our stay, a junk arrived from Dring, where it had taken in a cargo of coconuts. It was handled very clumsily, and nearly ran on the reef before the anchor was down, eventually having to make sail again and beat up to a more suitable place. Considering the happy-go-lucky manner in which these junks are navigated, it must be admitted that they have good fortune-they have a compass, indeed, but all those we met were totally unprovided with charts.

Our mornings in this place were spent in searching for Shom Pen; the afternoons were passed in adding to the collections. The traps produced a couple of rats only ; but we obtained several specimens of the storkbilled kingfisher, which was common about the shores of the bay. Several turtle were observed on the sea, but the harpoon never being at hand when requisite, they always escaped unmolested.

Possibly because of the proximity of high land-for Mount Thuillier, 2100 feet, the highest point of the Nicobars, rises near the northern end of the island-a good deal of rain fell every day, and somewhat spoiled the enjoyment of wandering in the jungle. At night when we lay in Ganges Harbour, it was nearly always calm, and many mosquitoes came from shore to plague us.

Traps were set on the shore throughout our stay, and we thus obtained a specimen of a new shrew (Crocidura nicobarica), the largest known Oriental member of the sub-genus; while two rats 


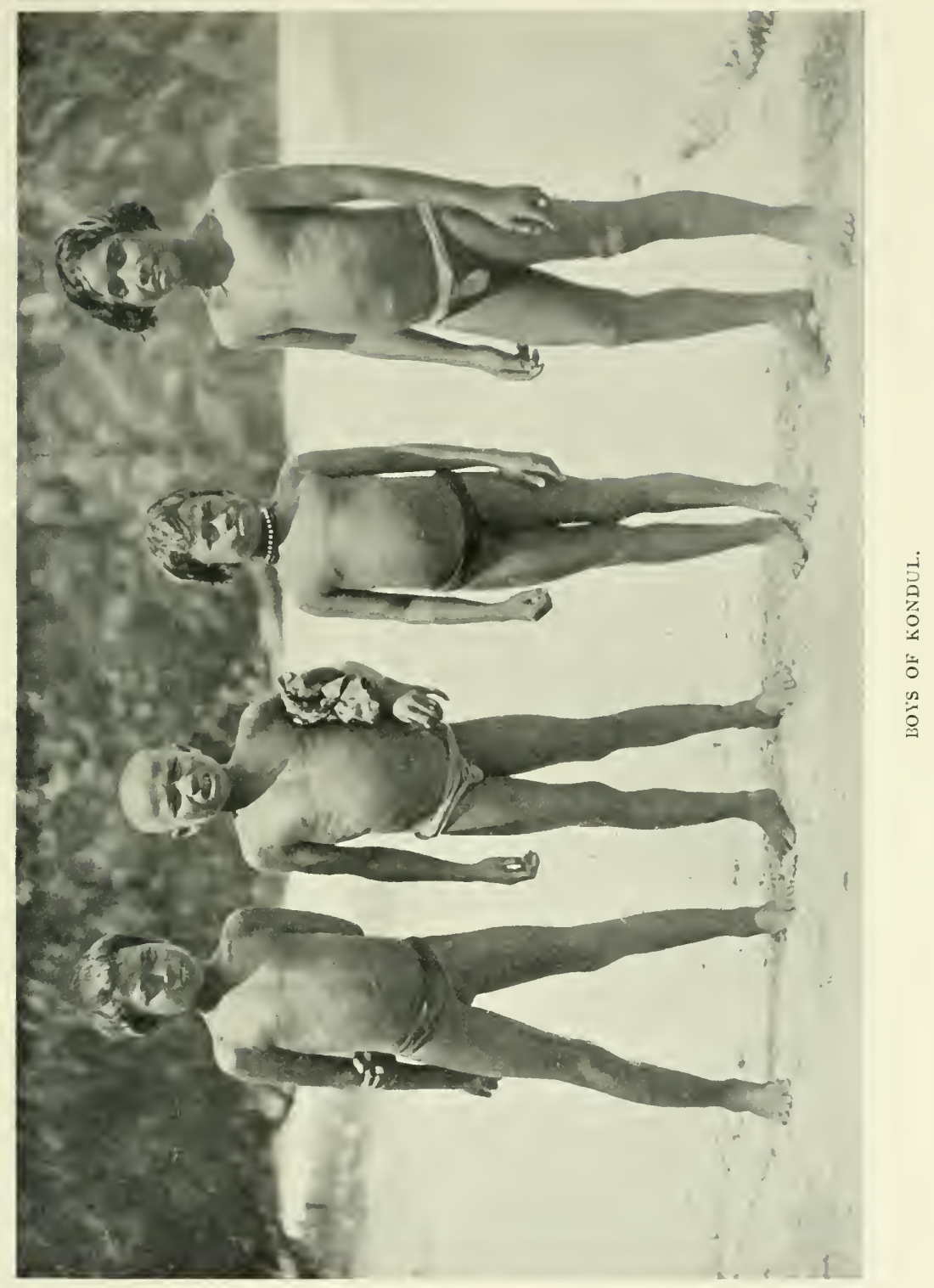



-all that were caught-were both undescribed varieties, and have been named Mus pulliventer, and Mus burrescens.

Having filled up with water-obtained from a little stream trickling down a cool rocky ravine at the inner corner of the baywe made sail early on the 16 th, and returned to Kondul.

Two hours' run before the wind brought the schooner to our former anchorage, where we were immediately joined by a junk from the north, and shortly afterwards by our companion of Ganges Harbour. After breakfast we reached the village, subsequent to a hard pull in the whaleboat against wind and tide, and found the junks' crews busily loading their boats with bundles of rattan; and by a chat with one of the skippers, supplemented the scanty information of the Sailing Directory anent the west coast of Great Nicobar.

Very few people were about, and the headman, suffering from an attack of inflammation of the eyes, had wisely confined himself to the shade of his house. Four jolly little boys, however, bestirred themselves to get us a supply of coconuts. One, after putting a loop of fibre round his ankles, climbed a palm tree and hacked off all the fruit, and then we all set to and carried the plunder down to the boat-a very awkward task, unless one knows the correct method, for the coconut is both heavy and bulky. With a dro a notch is made in the husk and a strip of fibre pulled out, with which the nuts are tied together two by two, and slung across a pole, to be comfortably balanced on the shoulders. To the owner of the tree we gave a bucket of rice, and to our juvenile assistants a length of bright cotton, which one, a bald-headed youngster, immediately annexed and wrapped round his shaven pate.

Towards evening they came to the schooner with an old man, bringing some more nuts and a few fowls; they joined the crew at the evening meal, but were very nervous, and one boy; whom the men wickedly pressed to stay, eventually took refuge in his canoe.

That night quite a small fleet-the two junks and ourselveslay in the quiet anchorage. The cook and boy, smartly attired in black oiled calico, went off in the dinghy to visit their compatriots. 
The style of their garments must be held to excuse the absence of that quality in their rowing, for each man's stroke was a thing to itself, as he painstakingly illustrated the famous maxim of $\mathrm{Mr}$ Charles Bouncer, "Dig your oar in deep, and pull it out with a jerk!" Perseverance and a devious course brought them to their goal; but we retired to sleep with dubious opinions as to their safe return. 


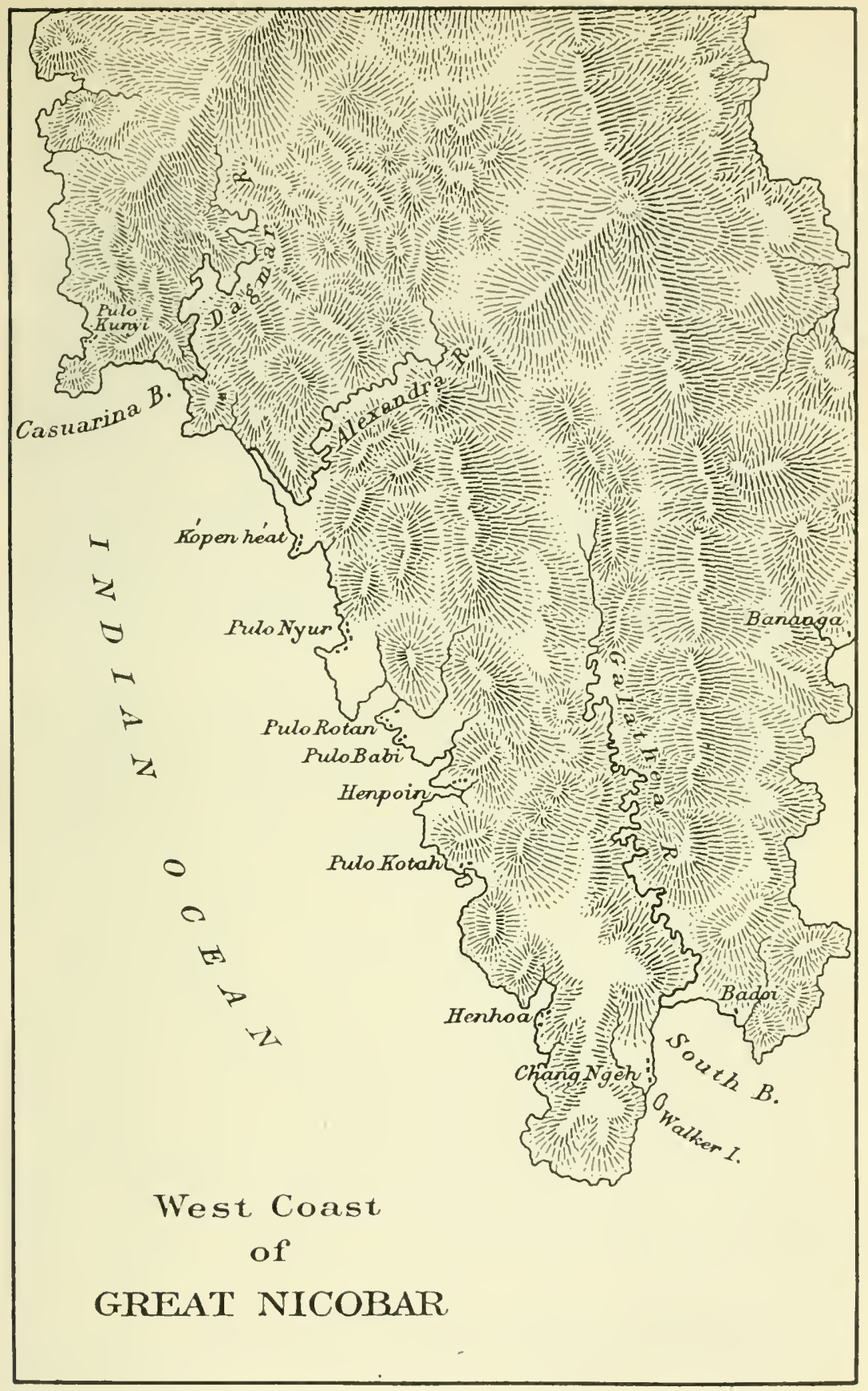

[To face prage 140. 



\section{CHAPTER XIII}

\section{GREAT NICOBAR-IVEST COAST}

Pulo Kunyi-Area of Great Nicobar-Mountains-Rivers-The Village-The Shom Pen-Casuarina Bay-An ingenious "Dog-hobble"-In the Jungle -A Shom Pen Village-Men of the Shom Pen-A lazy Morning-The Shom Pen again-Their Similarity to the Nicobarese-Food-Implements -Cooking-vessel-The Dagmar River-Casuarina Bay-Pulo NyurWater-A Boat Expedition-The Alexandra River-Shom Pen் VillagesKópenhéat-More Shom Peń-Elephantiasis-Pet Monkeys-Anchorage.

"March I7, I90I.-At 6.30 A.M. both junks left, and we followed half an hour later. The breeze was light, the sea smooth, and the Chinese kept ahead all the way: in fact, we only caught up the smaller just abreast of Pulo* Kunyi, our destination on the west coast, where we anchored shortly after the big junk about midday; the other boat did not stop, but sailed on for another village more to the south.

"Great Nicobar is the southernmost and the largest of the islands of the group, having a length of 30 miles north and south, and a breadth of from 7 to 14 miles, while the area is 334 square miles. The highest part of the island is that to the north, where Mount Thuillier attains an altitude of 2105 feet. A continuous range of hills runs down the east side of the island close to the coast, making the surface hilly; and near the centre a range 1333 feet high extends crossways in an E.N.E. direction. On the west side the hills are much more

* Pulo (Malay, island), on the west coast, is probably a mispronunciation of Telok (Malay, bay), for at only one of the small anchorages so designated is there an island at all. 
irregular in disposition, and there are broad alluvial plains between their bases and the sea.

"Both in vegetation and geological formation it resembles Little Nicobar, but is the only island of the group that possesses navigable rivers; for, when their bars are passable, the Dagmar and Alexandra rivers on the west, and the Galathea River in the south, can be ascended some distance towards the interior.

"The coastal population is barely two-thirds what it was computed at in I886, and now numbers 87 only. In the interior are the Shom Pen, who, liberally estimated, may number from 300 to 400 ; but, as a few friendly families alone are all with whom communication has been held, it is impossible to arrive at any definite conclusion.

"Great Nicobar is the least known of all the islands; the Government steamer seldom visits it, on account of its few inhabitants, the rough weather frequently met with on its coasts, and the absence of harbours near the populated districts.

"As we sailed along the north-west portion, we perceived it to be low and flat for some distance inland, but towards the south the land rose in irregular forest-clad hills.

"The village of Pulo Kunyi lies along the shore of a small bay, from either end of which two long reefs of coral stretch out seaward to form the harbour. This is further protected by a submerged coral bank which lies across the mouth, leaving only two narrow passages to north and south, of which the former is the more practicable.

"With a man in the cross-trees and a lead from the junk, we got in safely-finding 6 fathoms in the middle of the entranceand brought up in $3 \frac{1}{2}$ fathoms, in a well-sheltered anchorage where there was plenty of room for several small vessels to lie.

"As soon as all was shipshape on board, we went ashore with our guns. In the village, which consists of five buildings (sheds and houses), we met but two men-women and children had disappeared from fear of the Chinese and ourselves; but there are probably not more than ten inhabitants altogether.

"The Chinese were already at work, busily appropriating all 


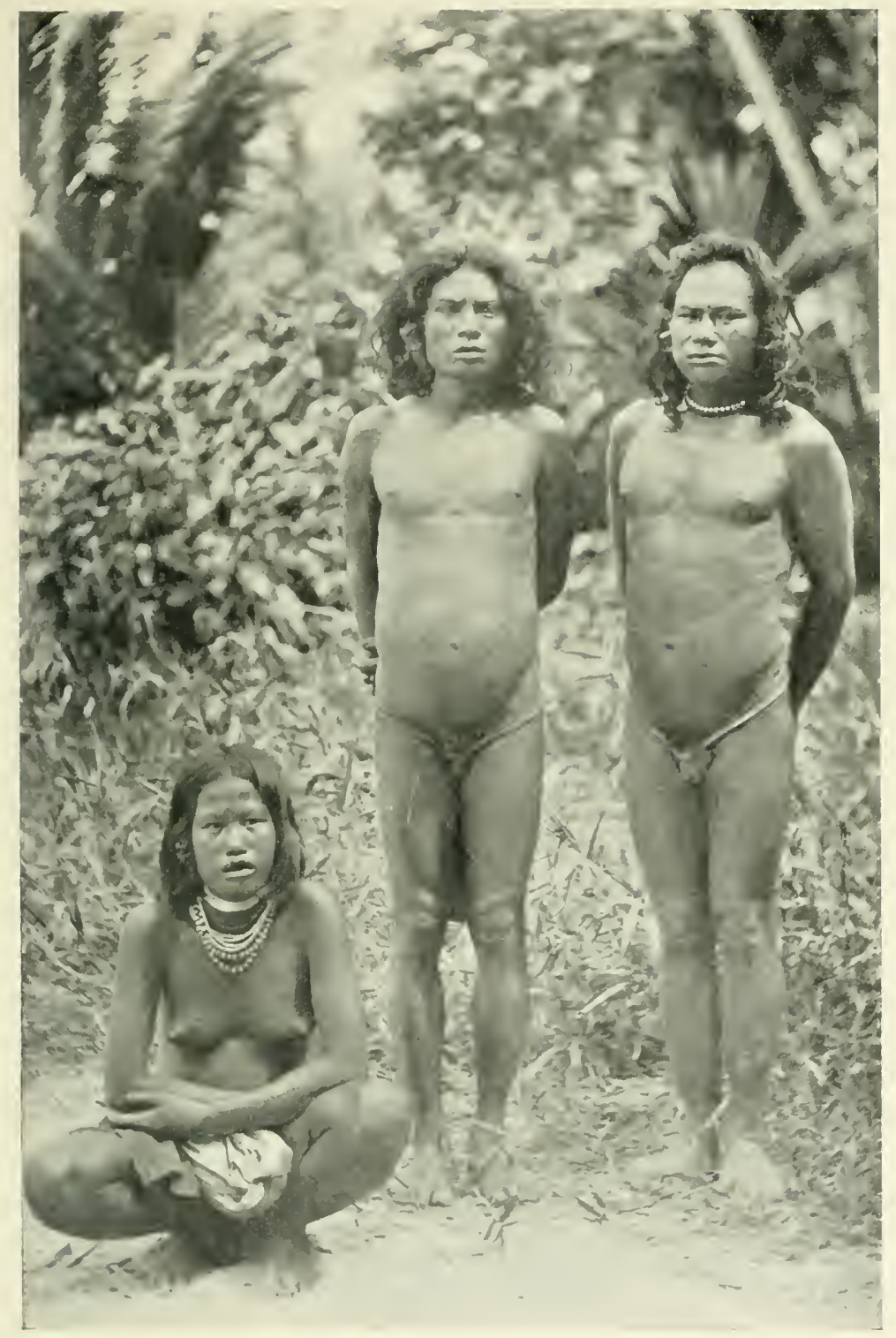

MAN ANI WOMAN OF THE SHOM PEN, AND A NICOBARESE. 

the coconuts that lay about. When purchasing these, they give a bag of ricc for 530 nuts, which sell at Singapore for \$1 5 . Barter worth $\$ I$ is given for half a dozen bundles of rattan, which fetch about $\$ 12$ in the same market. The trade of this island is mostly in canes, for very few more coconuts are produced than suffice for the wants of the inhabitants.

"The one beehive hut in the village was occupicd by an old man named Awang, with his wife and child. A large charm hung in the centre of the house-a frame about 8 feet by 6 feet, covered with palm leaves, across the top a row of birds, and at the foot a line of wooden men, each supplied with a ration of fat pork.

"Our persistent inquiries about the Shom Pen seemed to amuse Awang excessively; but we were delighted to find we had arrived in their neighbourhood at last. The aborigines live a short distance in the interior, and often come down to the coast; as they would do on the morrow, when we should have an opportunity of meeting them, since notice had been sent that the traders were waiting to purchase their stock of rattan.

"The inland tribe is split into two main divisions. The larger inhabits the interior proper, and is still hostile (there was a man in the village with some ugly open wounds beneath the shoulderblades, who had been speared by them close to the houses a year ago); the members of the other division, who form small settlements near the coast villages, are known as "mawas Shom Pen" (quiet, or tame Shom Pen), and are on intimate terms with the Nicobarese, fearing equally with them the wilder natives. When the latter are out on the warpath, the friendlies come down to the shore, and, with the coast people, leave the district by canoe until it is safe to return.

"The village is surrounded by open scrub and jungle, in which large numbers of screw-pines flourish. The little scarlet-breasted Aethopyga was common here, and numbers of them were flitting about the crowns of the coco palms, searching the fruit-stalks and bases of the leaves for insects.

"Good paths ran through the jungle, and following one to the 
southward, we reached the shore of Casuarina Bay, so named from the long grove of dark-foliaged trees that extends right along the coast. All round the head of the bay white surf rolled on the flat sandy beach, but there was a fair landing-place within the point, protected by a reef, and free from breakers.

"Before returning to the village we shot a number of tupais, some sunbirds, and a serpent-eagle. The local dogs all wore a large coconut slung loosely about the neck. This heavy burdening would hardly meet with the approval of the S.P.C.A.; but it prevents the dogs from chasing sows and their litters, and is a most effective hobble, as it hangs right between the fore-legs.

"Darkness was approaching as we passed through the village, and the fowls were all retiring to rest in the branches of the trees -a return to early habits that they may indulge in with security in these islands, where no mammal more dangerous than the monkey exists.

"The boat soon came off to fetch us in answer to a hail, and we returned to the schooner, where, after a bath and a dinner, we settled down to an evening's work."

"March I8.-Armed respectively with guns and camera, we struck inland, at sunrise, along a path running eastward through beautiful open forest. The ground was level, and our way lay for some time within sound of the breakers of Casuarina Bay. Picking up a bird now and again as we went along, we had proceeded some three or four miles when we heard the sound of voices in the bush. We stopped for a moment to listen, and then moved on. Presently the roof of a hut appeared between the trees. "Shom Pen!" we whispered, and, creeping down the path with the idea of getting among them before they could run, did they feel inclined, walked-oh, miserable swindle !-into a camp of Nicobarese rattan-gatherers; for the numerous bundles of canes hanging from the trees, and the heaps of scrapings, showed plainly what their occupation was.

"In a clearing about 30 yards across, surrounded by jungle, and standing in the shade of a few isolated trees, five huts stood along the bank of a little brook. 


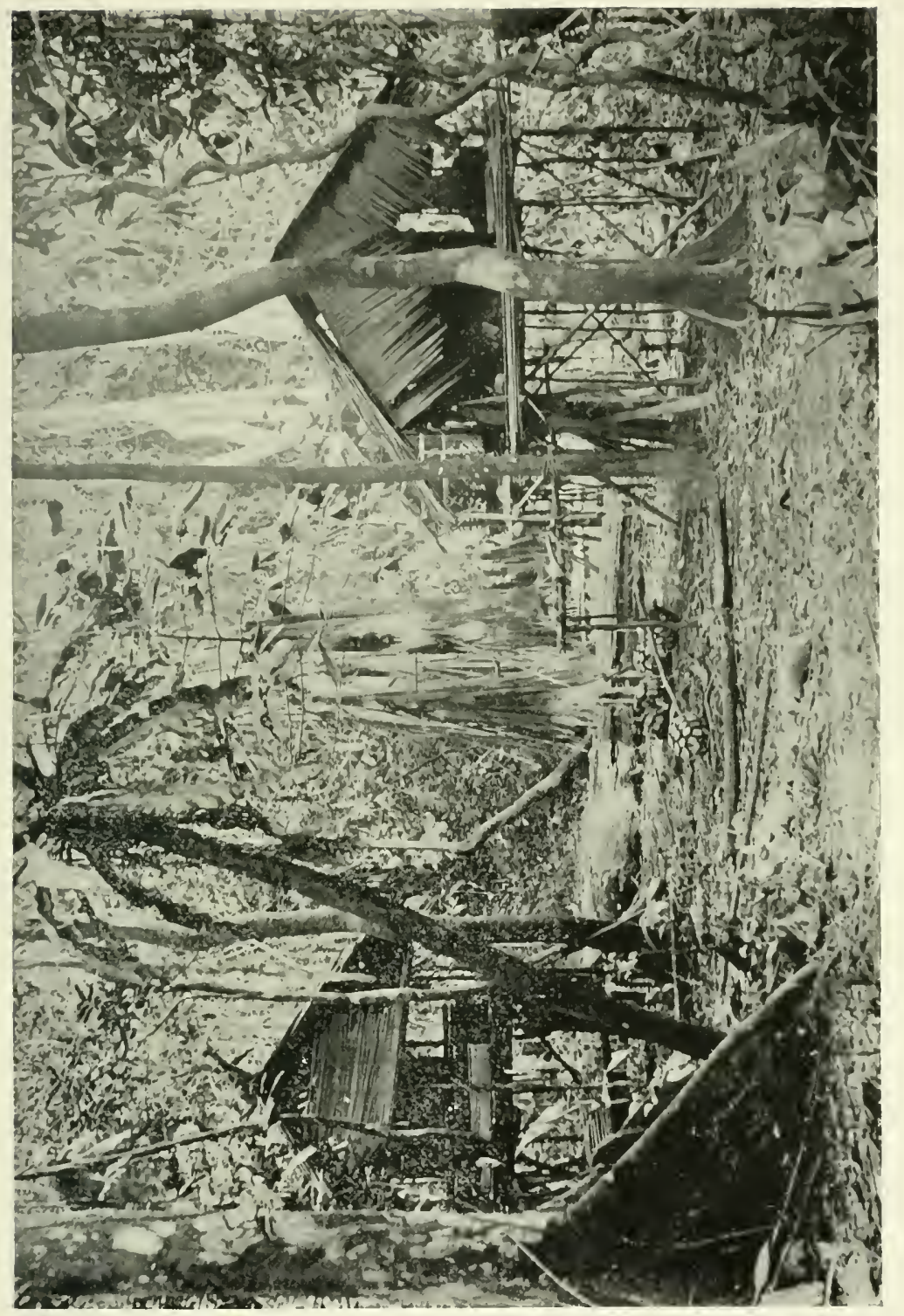



"Women and girls in waistcloths, busy preparing food from pandanus fruit, dropped their work when they caught sight of us, and rushed away for more clothes!

"Pigs, chickens, and dogs wandered about beneath the houses, and the only representative of the stronger sex was a young man, whose activity was much handicapped by a leg swollen with elephantiasis.

"The houses were small structures built on piles, 4 to 6 feet high, with open sides, and roofs of attaps.

"After taking photographs of the village, we returned to the shore, where consolation awaited us in the persons of three Shom Pen men, who had come in and were detained in Awang's house. Thither we proceeded, and took photographs and measurements of each. They were very docile, and stood like statues before the camera; neither did they object to being measured. We obtained from them a roll of coarse cloth-made from the inner bark of a tree, which is stripped from the trunk and pounded-and a rattan basket, giving in return an extra quantity of red cotton, in token of goodwill, for they had been inclined to bolt when they first heard we were coming.

"In general appearance these men resembled the Nicobarese, but were of slightly darker complexion-muddy-coloured-and physically of more slender build, and leaner: they wore cotton kissáts, and large wooden ear-distenders.

"Through Awang, who enacted the part of interpreter, we arranged with them to come down the next morning, and bring their whole party, baskets, spears, and more cloth."

"March 19.-We did not shoot for long this morning, for fear of frightening the Shom Pen; but though we waited about till Io o'clock, they had not appeared, and we then returned to the Terrapin.

"But for flies, which were rather numerous about the village, it was very pleasant lying in the shade of the palms, lazily watching the many butterflies which floated about, listening to the cries of oriole, calornis, and sunbird, and often catching 
glimpses of their brilliant plumage as they flew from tree to tree. In the clear waters of a little stream that flowed behind the village, we could see shoals of fish slowly drifting about, or poising themselves in the shade of the overhanging branches. The mouth of this stream is closed by the coral-reef, but a few small canoes are kept on its surface to carry the natives to the other bank. We were too lazy even to explore its course, but loafed drowsily beneath the coco palms, while

"All round the coast the languid air did swoon, Breathing like one that hath a weary dream,"

until, stirred by prosaic thoughts of breakfast, we returned to the schooner. Hardly had we done so when we caught sight of a string of people walking along the beach, whereupon, gathering together the necessary paraphernalia for an interview, we jumped into a boat and were soon on shore again.

"The party consisted of five men, three women, and three girls-there were no boys or babies in it. They had brought with them several rolls of new bark cloth-pieces about 4 feet by 6 feet-which, when fresh, is much lighter in colour than the old piece we got before; some rattan baskets of various shapes, ear-distenders, and a bundle of spears made of the hard wood of the nibong palm. These spears are about 8 feet long, and half an inch in diameter, tapering towards the butt. The makers have grasped the principle of the sail and surgeon's needle, for the points are triangular, with sharp edges; immediately below them, slight barbs, generally six in number, are carved on the shaft.*

"In physique, the men were less robust than the coast people, but at the same time were tough and wiry-looking-the lesser chest and arm development being probably accounted for by the absence of paddling exercise, for they own no canoes.

"In person they were somewhat dirty, more markedly in the

* An exact counterpart to this weapon has been observed among the "Alfurus" of Kau, Gilolo; vide plate in Kukenthal's Im Malayischen Archipel. 


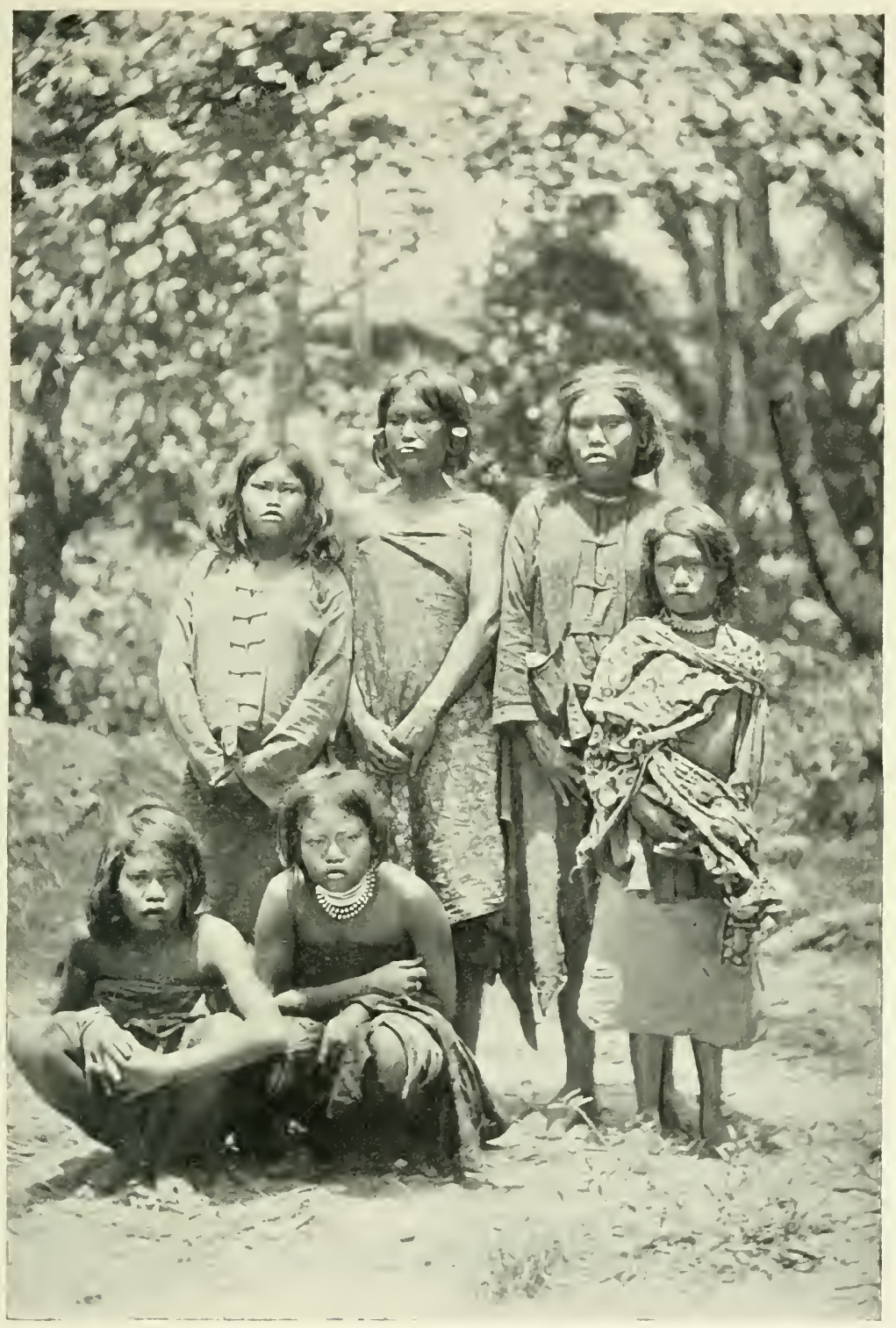

WOMEN AND GIRLS OF THE SHOM I'EX. 

case of the women, to whose clothes the odour of stale pandanusbread clung strongly. All chewed quids of betel, lime, and sireh leaves.

"The teeth of one woman presented a most extraordinary appearance, that at first sight appeared to be a case of macrodontism; the upper row projected outwards at an extreme angle, and, when closely examined, proved to be concreted together by a substance that was apparently a deposit of lime from the ever-renewed quid.

"Their hair, like that of the Nicobarese, varied from wavy to curly, and so slightly did they differ from the coast people that if one did not know who they were, they would pass, unless carefully examined, for ordinary Nicobarese, so far as appearance and mode of life are concerned.

"In proof of this statement it will suffice if I say that the settlement which-with minds primed by tales of bark-garments and triple-storied, fenced-in huts-we had thought to be a camp of the coast people gathering rattan, was, in truth, the village of this identical party.

"Such a mistake was, under the circumstances, almost justifiable - their food, utensils for its preparation, cooking-pots, clothing, and domestic animals, were all exactly similar to those of the Nicobarese.

"It would appear, that, from constant intercourse with the shore people, the Shom Pen have adopted many of their customs, and become possessed of similar property. The leader of this party even spoke a few words of Malay.

"All of them willingly submitted to be photographed and measured, especially when they saw that after the process there was a reward of red cotton, or brass cartridge cases, to be used as ear-plugs. Such things as they received in this way, or in payment for baskets and other articles, were immediately handed over to the women.

"They seemed to indicate time by pointing to the sun, and by such a method we made them understand that we should pay another visit to their camp on the morrow." 
"March 20.-We reached the Shom Pen village early in the morning, and found its occupants variously engaged-some sitting listlessly about, and others busied in splitting and cleaning the rattan which they trade with the coast people.

"The community was well supplied with food, in the shape of coconuts, bananas, and various tubers, besides possessing a plentiful store of pandanus fruit. Several young pigs, all obtained from the litters of wild sows, which are chased with a view to capture, were domiciled in cages within the houses.

"Principal amongst the articles in use were iron-pronged

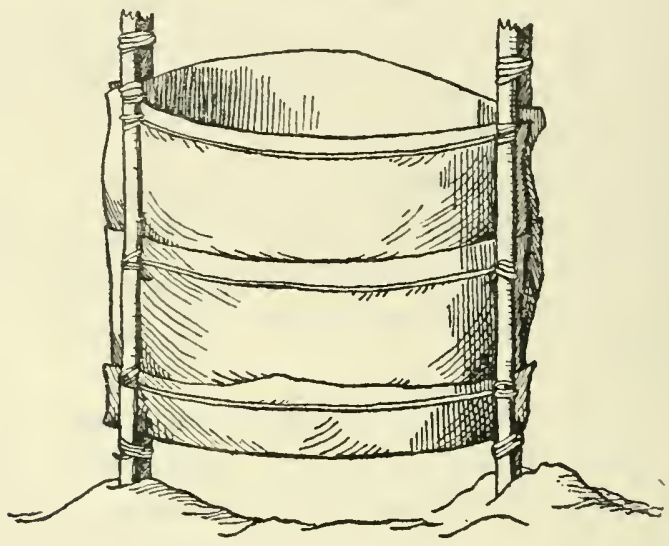

Shom Pen̉ Cooking-vessel (Great Nicobar).

fish-spears, axes, and dcos, with baskets, of which we purchased a selection; but the most interesting object visible, and one that had been overlooked during our former visit, was an apparatus for preparing the food of pandanus paste.

"Some 6 inches above a clay hearth on the floor of the huts, a receptacle, about 3 feet by 3 feet by 6 inches, was formed of five sheets of thin green bark. These, two on a side, and the fifth doubled at the bottom to form a trough, were inserted at either end between split stakes, which-bound tightly together with rattans-pressed the edges of the sheets against each other. The lower part was thickly luted with clay, and where the edges of the bark overlapped, a strip of cane was stretched from 


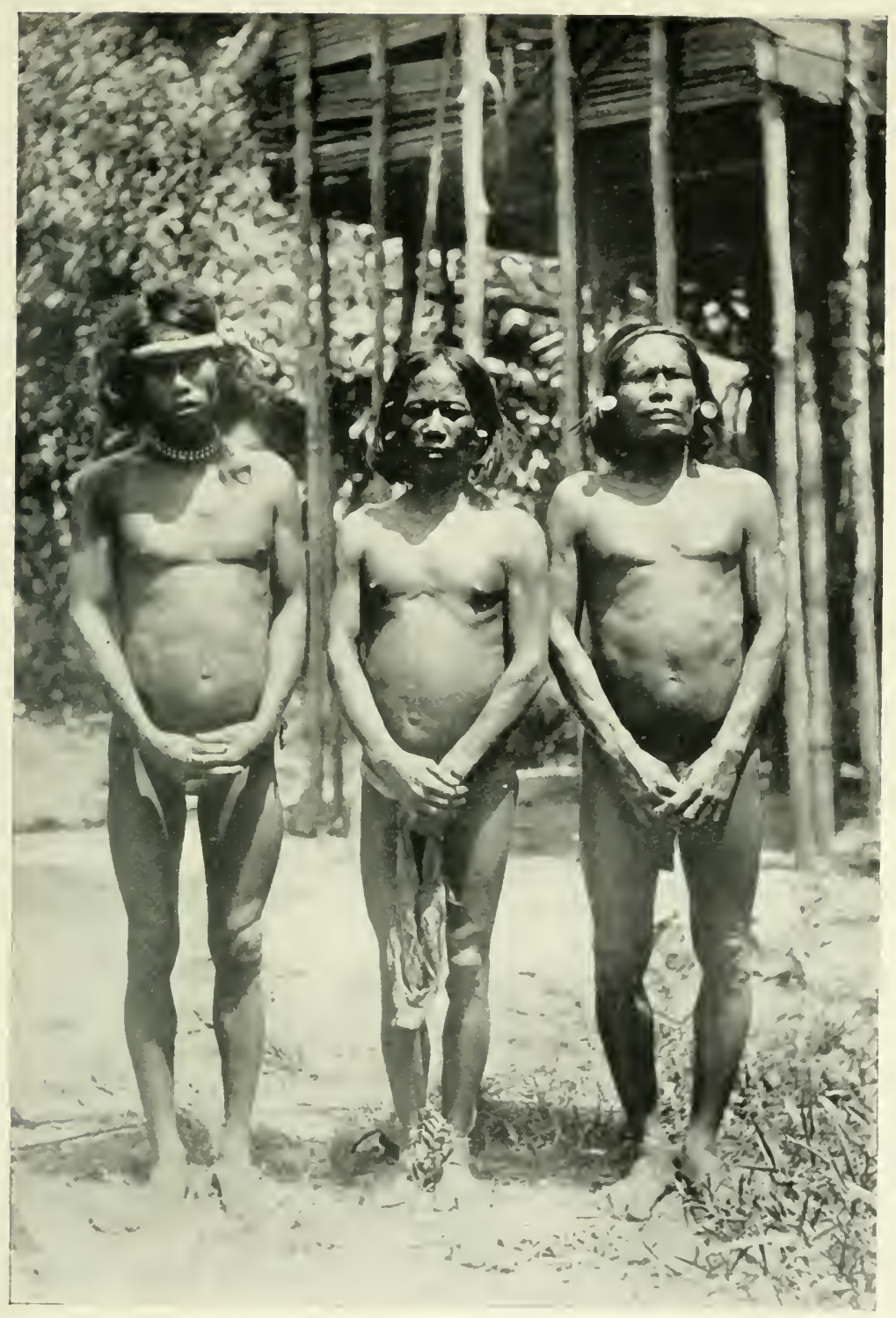

MEN OF THE SHOM PEX. 
IJs 
stake to stake to compress the join. This ingenious vessel was narrow at the bottom but gaped widely at the mouth.

"In cooking the pandanus, a little water is first poured in, and the fruit piled above it and steamed; when sufficiently done, the bread is prepared by the same method as practised on the coast.

"Several paths led beyond the camp; and following one, we crossed a small stream by a tree bridge (a couple of saplings laid side by side), 300 or 400 yards beyond which we arrived at the bank of the Dagmar River, here a stream about 40 yards wide flowing between low jungle-covered banks.

"Once more by the sea we photographed Awang and his family, bought some of his belongings, and also took possession of about twenty megapodes' eggs which he had collected for us.

"The Shom Pen we had seen, he informed us, were all there were in the neighbourhood, although far back in the interior were other, but unfriendly, groups. The only child in the village was his own son, and the same old story was repeatedthat where formerly there were two or three men with their families in each house, now there was only one.

"In the afternoon we walked along the shore of Casuarina Bay to the mouth of the Dagmar. Fortunately the tide was low, and exposed a broad strip of hard wet sand, which made the tramp very pleasant, in spite of the hot sun. On the way, we passed the half-dry bed of a small stream, crammed with thousands of a little black red-bellied mud-fish, so crowded together that numbers had died.

"The Dagmar River emerges suddenly from jungle, with banks almost free from mangrove and nipah, and makes its way to the sea through a curving channel in the sand, where at low tide it is very shallow.

"Bundles of rá an hung from several trees, and a small hut full of the same material stood near a path that evidently led to the Shom Pen village. More cane was to be seen across the river, and a canoe lay on the bank.

"So much we discovered by a little exploring; then, after 
climbing a palm and refreshing ourselves with stolen coconuts, we set out on the return walk, in order to avoid being overtaken by darkness."

"March 21.-A light breeze set in shortly after 8 A.M., and we weighed anchor. It soon freshened somewhat, and we worked down the coast, tacking on and off. First we passed the point forming the north extremity of Casuarina Bay, distinguished by a single palm tree which rises high above the jungle, and next came abreast of Kópenhéat, marked by a grove of palms and a hut, finally bringing up at I.I 5 P.M. in 9 fathoms, at a spot well protected by a reef from the S.W. swell, with a conspicuous round house bearing $\mathrm{E}$. This anchorage was a little bay formed by the shore running roughly $\mathrm{N}$. and $W$, and we were in an indentation of the reef, which, when the latter dries at low tide, is about 300 yards wide.

"The village here is called Pulo Nyur (Malay=Coconut Island), seven houses in all, and lies in the shade of palm trees broken into groups by intervening stretches of jungle.

"Going ashore in the afternoon we met in the largest house several men and boys from Pulo Bábi, the next village southward. Of the other buildings, four or five are uninhabited and falling to pieces. There was only one regular inhabitant in the place-a man whose father, brother, and wife had all died six months previously, and who, unless he could get another wife shortly, intended to leave the spot, which will probably soon be deserted, for his female acquaintances-not unnaturally-objected to such a lonely life.

"A year ago a man was killed by the Shom Pen on the outskirts of the village, and at the same time the man we saw at Pulo Kunyi barely escaped with his life.

"Several paths lead towards the interior, but the village has no (friendly) relations with the aborigines.

"Behind, and to one side, lay a large stretch of grass-covered swamp, on which a herd of monkeys was playing until we appeared, while numbers of herons, big and little, were perched in the surrounding trees. The morass was composed of a sort of 


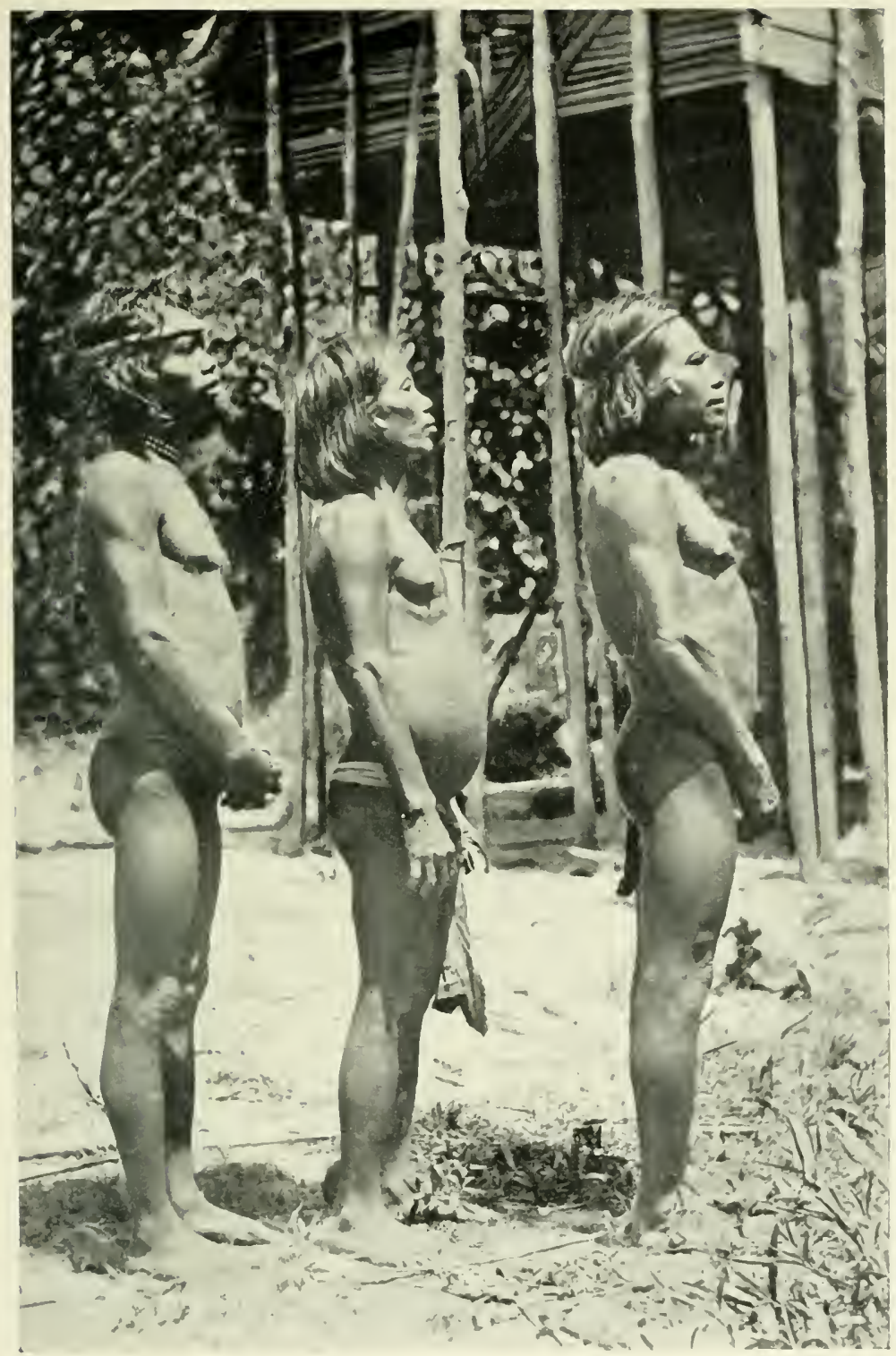

MEN OF THE SHOM PEN (in profile). 

sawdust-like paste, into which one sank up to the knees, yet the feet, when withdrawn, were not in the least soiled. In the jungle we got Nicobar pigeons, and a serpent-eagle that seemed to differ from the variety of Little Nicobar and Kachal (Spilornis, sp. nov.).

"A path from the beach led to a water-hole, which only required clearing out to afford a plentiful supply; the men set to work at this, and when they had got rid of the water, took from the hole a pailful of mudfish and eels.

"Learning in the evening, from people who came on board, that there were Shom Pen on the Alexandra River and at Kópenhéat, we determined on an expedition in search of them next day."

"March 22.-At sunrise we put off in the whaleboat, and now rowing and now sailing, as the wind served, and all the time keeping well out from shore, to clear the rollers that occurred at irregular intervals in most unexpected places, reached Casuarina Bay (about 6 miles) at 8 A.M.

"The breakers at the mouth of the Dagmar were too big for us to enter the river without an almost certain wetting, to avoid which we pulled back to the south end of the bay, and first wading ashore with the contents, ran the boat through the surf and quickly beached her. Almost at once we perceived within the jungle a deserted Shom Pen village of three huts, of a kind similar to those beyond Pulo Kunyi. In the camp were two or three platforms or lounges, roughly shaded by a few palm leaves, and some odds and ends were lying about; a small pig cage, food baskets made from the butt of a palm leaf, and a rude lamp-a shell, in which lay a bit of greasy rag supported on half a coconut.

"Several paths converged at the village, and these we followed up until each gradually came to an end-bundles and strips of rattan lying along them, showing plainly their raison d'être.

"One path, however, led past a second camp. Some of the huts were merely rough platforms built against the trunk of a tree; but others were evidently of the kind we had been told 
about at Pulo Milo-one platform above the other, respectively 3 and 7 feet above the ground, both partially protected by a number of long palm leaves leaning butt downwards against the structure. Continuing onward beyond this village we reached the Dagmar River, and searched along the bank for further paths without success.

"By midday, having thoroughly explored the locality, we returned to a tiffin of biscuits and sardines, with unlimited numbers of young coconuts, which one of the men quickly obtained from an adjacent tree. Then the boat was launched and loaded, and with the wind helping for part of the distance we travelled back to the Terrapin.

"As we passed Kópenhéat two men put out in a canoe with palm-leaf sails to inform us that a party of Shom Pen was then at their house. But it was now getting late, and the plates for the camera had all been exposed, so, after arranging for the aborigines to remain until next day, we parted from the canoe and proceeded to the schooner."

"March 22.--Off again by boat in the morning to Kópenhéat and met the Shom Pen, who had remained overnight; they having come a distance variously estimated at from half a day to two days' journey(!) down the Alexandra River in small canoes of Nicobarese construction.

"The headman, who was of the darkest complexion yet met with-a dull chocolate-spoke a little Malay. All were clothed-. in far more garments than the Nicobarese-and generally very dirty.

"Most of these people were afflicted with elephantiasis in various stages-none seriously, however. Nicobar water is reported to be bad; but, considering the state of the water-holes that the Shom Pen paths lead to, no surprise can be felt that those who use such a supply should be suffering from this disease. Often the water of the coast natives is unsatisfactory enough in quality, but having plenty of coconuts, they hardly ever use it for drinking purposes.

"After we had finished with the people we gave them 


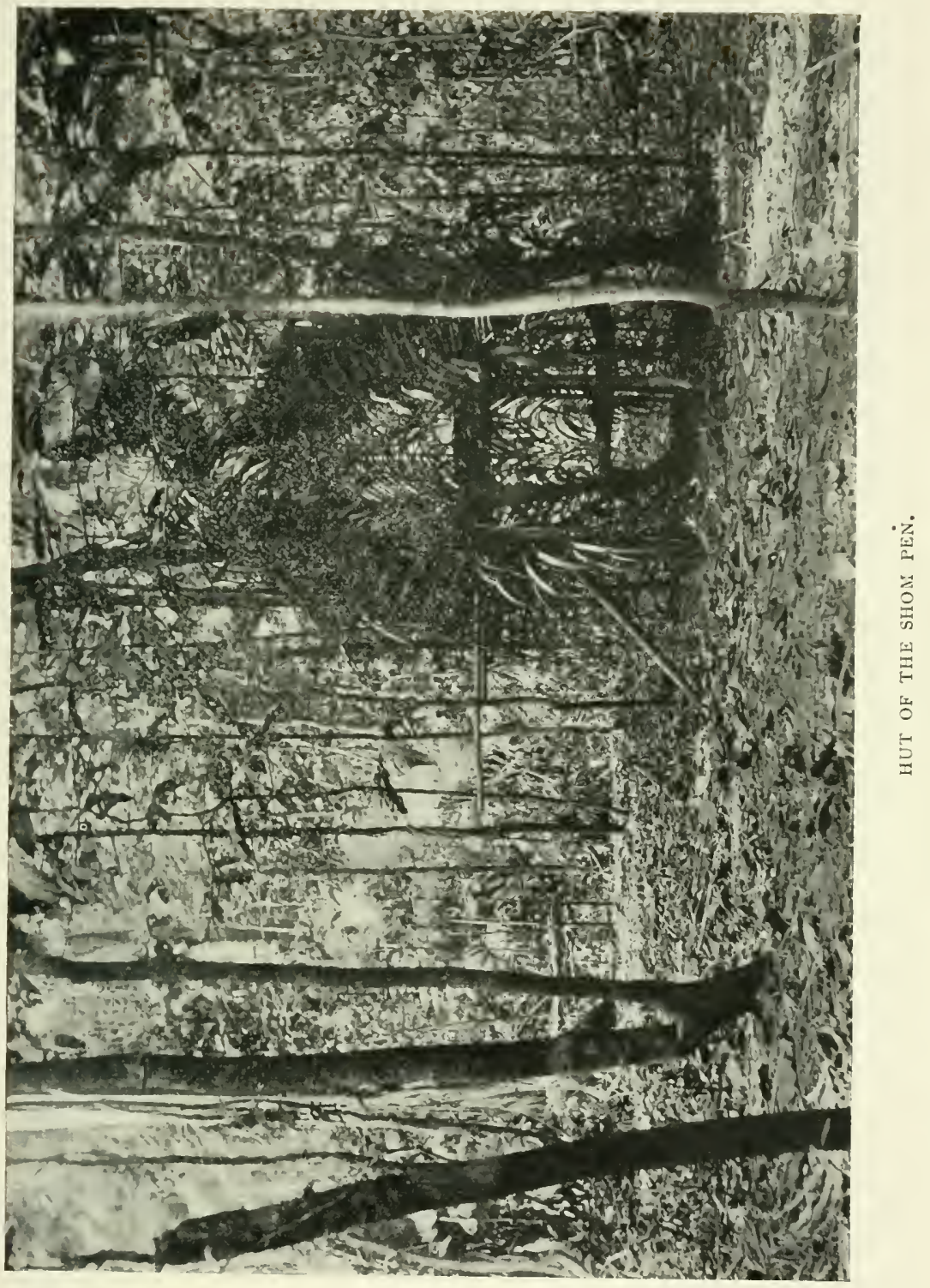



presents of cotton and sheath-knives, and then followed a path leading to the Dagmar through forest of a very open character. A walk of half a mile brought us to the bank of the river, here about 30 to 35 yards wide. There was very little current, owing to a sandbar across the mouth, which the natives say is dry at half-tide. The banks were jungle covered, and free from mangroves.

"Before leaving the village we bought some fowls, and a pair of young monkeys, said to be only three or four months old. They were imprisoned in a pig cage, and seemed half-starved, and were certainly very frightened as they sat clinging convulsively to each other.

"There is clear water, 300 or 400 yards wide, before Kópenhéat, with a reef on either side where the sea breaks heavily at high tide, but the anchorage is not so good as at Kunyi or Nyur." 


\section{CHAPTER XIV}

GREAT NICOBAR-IVEST AND SOUTH COASTS

"Domeat"-Malay Traders-Trade Prices-The Shom Pen Language-Place Names-Pulo Bábi-The growth of Land-Climbing a Palm TreeServitude-Population-Views on Marriage with the Aborigines-Towards the Interior-A Shom Pen Village-The Inhabitants-Canoe-buildingBarter-The West Coast-South Bay-Walker Island-Chang-ngehUp the Galathea River-Water-We leave the Nicobars and sail to Sumatra.

WE hove up anchor at 8 A.M. - the hour at which a breeze usually sprang up-and sailed for Pulo Bábi, a few miles down the coast, taking as passenger an old man named Domeat who had been staying at Kópenhéat.

He produced a number of chits for our perusal, and from one we learned that it was Domeat-now a toothless, but sturdy old gentleman, with nutcracker jaws and a benevolent expressionwho brought news of the recovery of the body of Captain Elton, commander of the station gunboat, who was drowned in the surf while attempting to land at Trinkat Sambelong* village, on the east coast, in March I88 I.

Most of the letters were written by Asiatics, and from them it seemed that the last Malay vessel to call at the islands arrived in 1877. Many formerly came to purchase coconuts, but this people, like our own nation, has been ousted from the trade by the inhabitants of China and the Indian Empire.

According to our informant, the Chinese pay the coast natives one packet of tobacco (value $2 \frac{1}{2} \mathrm{~d}$.) for three bundles of rattan, while the Nicobarese, who act merely as middlemen, and have 


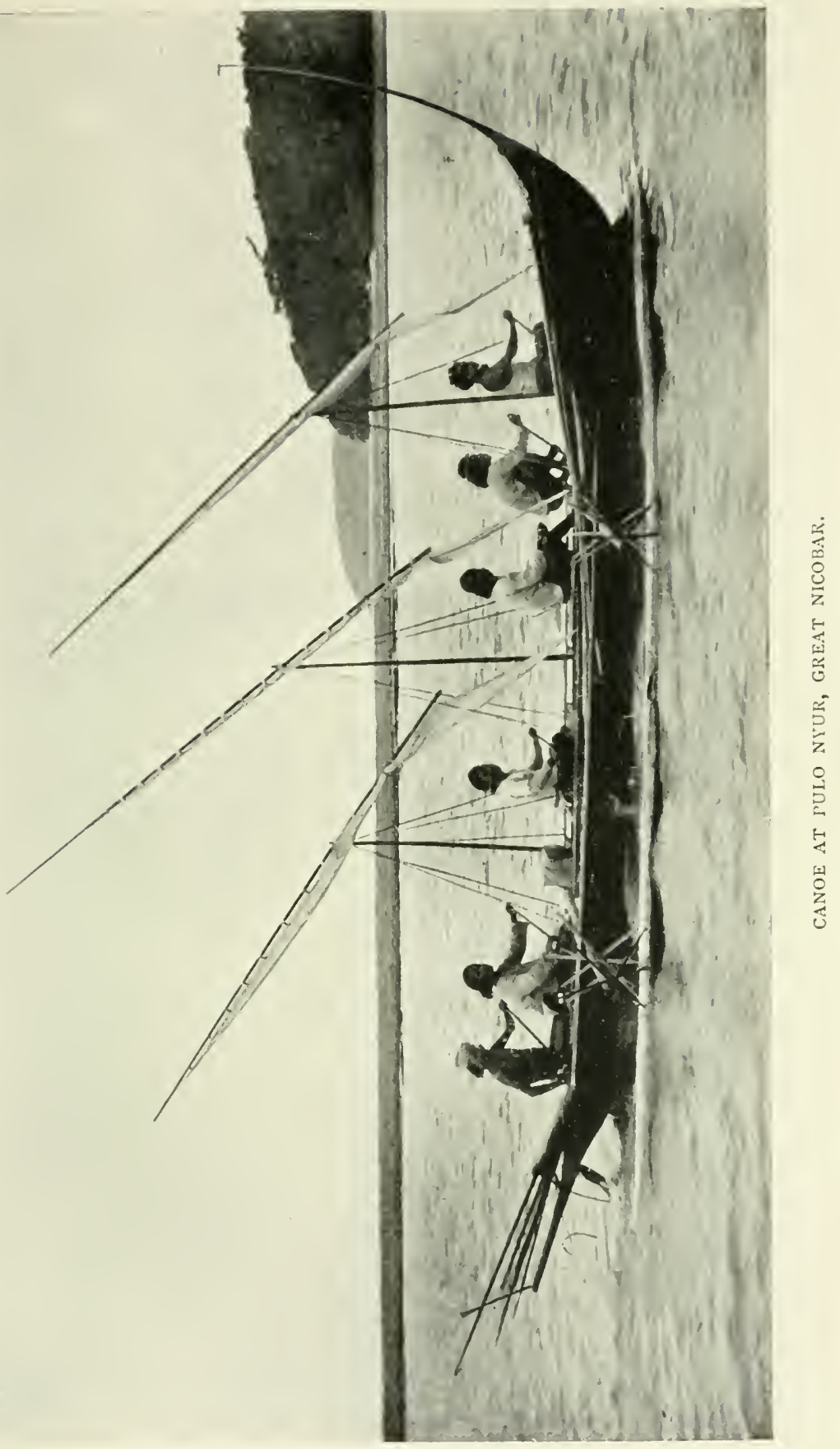

[To face page 154 . 

the export trade in their hands, only give the Shom Pein one packet for six bundles! The bush aborigines have no settled dwelling-places, but wander about, although they have good gardens established in various localities. Their language is quite distinct from the Nicobarese, ${ }^{*}$ but each knows enough of the others' speech to make themselves mutually understood. Asked, however, whether further south we could get a man who knew the Shom Pen language, Domeat replied: "When one of us sees a Shom Pen he runs away, and when a Shom Pen sees a Nicobar man he spears him!" $\dagger$

Misunderstandings frequently occurred when we talked to him about the various places on the coast. The name given on the chart is often not known to the natives: the Chinese have another name, which is not given on the chart, and the natives have a third, but are generally familiar with that used by the traders.

I believe the following to be correct :-

$\begin{array}{lll}\begin{array}{l}\text { Chart. } \\ \text { Pulo Kunyi, }\end{array} & \begin{array}{c}\text { Trade Name. } \\ \text { Casuarina Bay, }\end{array} & \begin{array}{l}\text { Native Name. } \\ \text { Pulo Kunyi. } \\ \text { Dagmar R., }\end{array} \\ \begin{array}{l}\text { Kópenhéat, } \\ \text { Táeangha, }\end{array} & \text { Telok Bintang, } & \begin{array}{l}\text { Ta-tí-al. } \\ \text { Kópenhéat. }\end{array} \\ \text { Koé, } & \text { Pulo Nyur, } & \text { Kassandun. } \\ \text { Henpoin, } & \text { Pulo Rotan, } & \text { Koé. } \\ \text { Megapode Island, } & \text { Pulo Bábi, } & \text { Kánal. } \\ \text { Henhóaha, } & \text { Pulo Bharu, } & \text { Henpoin. } \\ \text { Chang-ngeh, } & \text { Pulo Kotah, } & - \\ \text { Galathea R., } & \text { Pulo Chaura, } & \text { Henhóa. } \\ - & - & \text { Chang-ngell. } \\ & - & \text { Sakheer. } \\ \end{array}$

$\begin{array}{lc}\text { Spear, } & \text { Nicobarese. } \\ \text { Finger, } & \text { nuit, } \\ \text { Pandanus fruit, } & \text { bewait, } \\ \text { larūn, }\end{array}$

Shom Peri.

allai.

noité.

munkuang.

+ "The coast natives, man for man, are superior to the Shom Pen, and regard themselves so both physically and mentally. I have known of a lot of the latter (estimated at about 20) attacking a coast hut in which there were only two men. On these showing resistance and wounding a couple of the Shom Peil with wooden spears, thrown from inside the hut, the latter fled, carrying away 
We arrived off the village at II A.M., and worked in to an anchorage against a land breeze. The junks in whose company we had been at Kondul were already in the harbour-a square indentation, fringed with coral. With a look-out at the mast-head we got in without accident, and anchored in a fairly sheltered position, but some distance outside the other vessels. Small streams debouch in either corner of the bay; but the village, which consists of a dozen or more houses, and is the largest on the west coast, lies to the south of the harbour, with the usual accompaniment of numerous coco palms.

As a heavy surf was breaking on the reef fronting the houses, we rowed up the bay and landed by a small hut, beside which was a well of good water, and from thence reached the village by a path leading through scrub and many screw-pines.

Interviewing the headman, we learnt that a Shom Pen settlement lay half a day's journey in the interior, and having arranged with Nyam (the headman) to guide us on the morrow, we set out, accompanied by his brother Puchree, on a stroll through the village.

This really consists of two settlements-that nearest the bay, Pulo Rotan or Koé, and the other to the south, which at high tide is cut off from the mainland by a marshy channel-Pulo Bábi or Kanal. There are more houses, both round and square, than appear from seawards, but several are uninhabited and falling to pieces. Graves, placed between the houses, were marked by peeled sticks and young saplings, on which a foot or so of the branches had been left.

The land on which the village stood was of very recent formation, consisting entirely of sand, coral blocks, and débris of the roughest kind.

It would seem that the Nicobars are not only an area of elevation (as shown in Kar Nicobar, Trinkat, etc.), but also one of growth, as appears to be the case in the islands where there

the two wounded men. I have never heard of Shom Pen venturing to attack the coast people unless they were in superior numbers and could take them by surprise,"-writes Mr E. H. Man, however. 
is a central mountain mass with radiating arms and shore plains; in these the central high land was first elevated, and formed a core for the extension of land by the agency of fringing reefs where the surrounding sea-bottom has only a slight inclination.

Of this latter phenomenon Pulo Bábi appears to be an example, since, for some distance inland the shore is flat, and composed of coral sand and díbris, with a substratum of freshlooking coral rock. The bay is becoming choked with coral, and between living reef and shore are broad belts of slimy mud, a little lower than some of the coral heads beyond, where the reef, having reached low-water level, has stopped in its growth and died. Meanwhile it is extending outward on its own talus, and at the same time débris and sand are cast continually shoreward, and, with the help of smaller coralline growths, fill up the interstices of the shore coral until a solid bank is formed, which, by further aid from the waves of the sea, and from the land and its vegetation, is raised above high water and in time becomes dry land.

Such action depends on the tides, slope of the sea-bottom, and the relation of one part of the shore to another in regard to contour and position, but particularly on the currents, which in some places would accumulate material and in others remove it.

The crowns of the palm trees were frequented by flocks of the black and white nutmeg-pigeon (Carpophaga bicolor), an uncommon bird in such a situation. Of those we shot, several lodged in the trees and were fetched down by the natives, who climbed with the ankles joined by a belt or piece of rattan, and who, when lifting the feet, did not clasp the trunk with the arms as we should, but placing one round it, pressed against it with the other hand.

We found two Shom Pen youths in the village, who seemed to be in a state of easy servitude, and were used for such work as carrying nuts or fetching water.

There were between twenty and thirty men and boys dwelling here, and the skipper (with whom the people were 
more communicative than with us) said, only four women! Although, by going to Naukauri Harbour, said Puchree, they could obtain wives,-who, however, refused to leave their own homes,- he lamented the almost total impotence of himself and neighbours in the way of offspring. Asked if they ever married Shom Pen women, he said, "No, they didn't like them; they were dirty and didn't wash"; and when we suggested that he should catch (tangkap) a young one, and first train her for a year or two, and teach her manners- "Too much trouble."

"March 25.-We met Nyam and a companion at his house about six o'clock, and after a walk of half a mile reached the bank of a little river some 30 feet wide. Here lay a canoe, and paddles being produced we travelled up-stream, wading now and again over the shallows, until, having progressed a mile or so, we landed on the same bank at a spot where a second path commenced. This we followed for 2 miles in a northerly direction, crossing by the way the stream itself and a little tributary by bridges of sapling, and so arrived at the Shom Peń village.

"We had already seen two kinds of buildings amongst these people; here we met with a third.

"The houses-five in number, and recently constructed-stood on piles about I 2 feet high; in several cases a live tree being built in. These supports were strengthened by diagonal strutsa most uncommon form of scaffolding among savages. The floors were made of saplings placed side by side, and the side walls, about 3 feet high, of split nibong palm; while the roofs, which just afforded head-room at the apex, were roughly thatched with whole palm leaves, piled on butt downwards.

"Each house was about $S$ feet square, and at one end of each a small platform was attached, on which was the fireplace, with cooking apparatus of bark sheets covered with large green lcaves, to prevent charring. In a corner of each hut was a shelf of split sticks, and a long trough of split and hollowed palm trunk sloped from ground to floor for the dogs and other animals to mount by. The ladders for human use were 


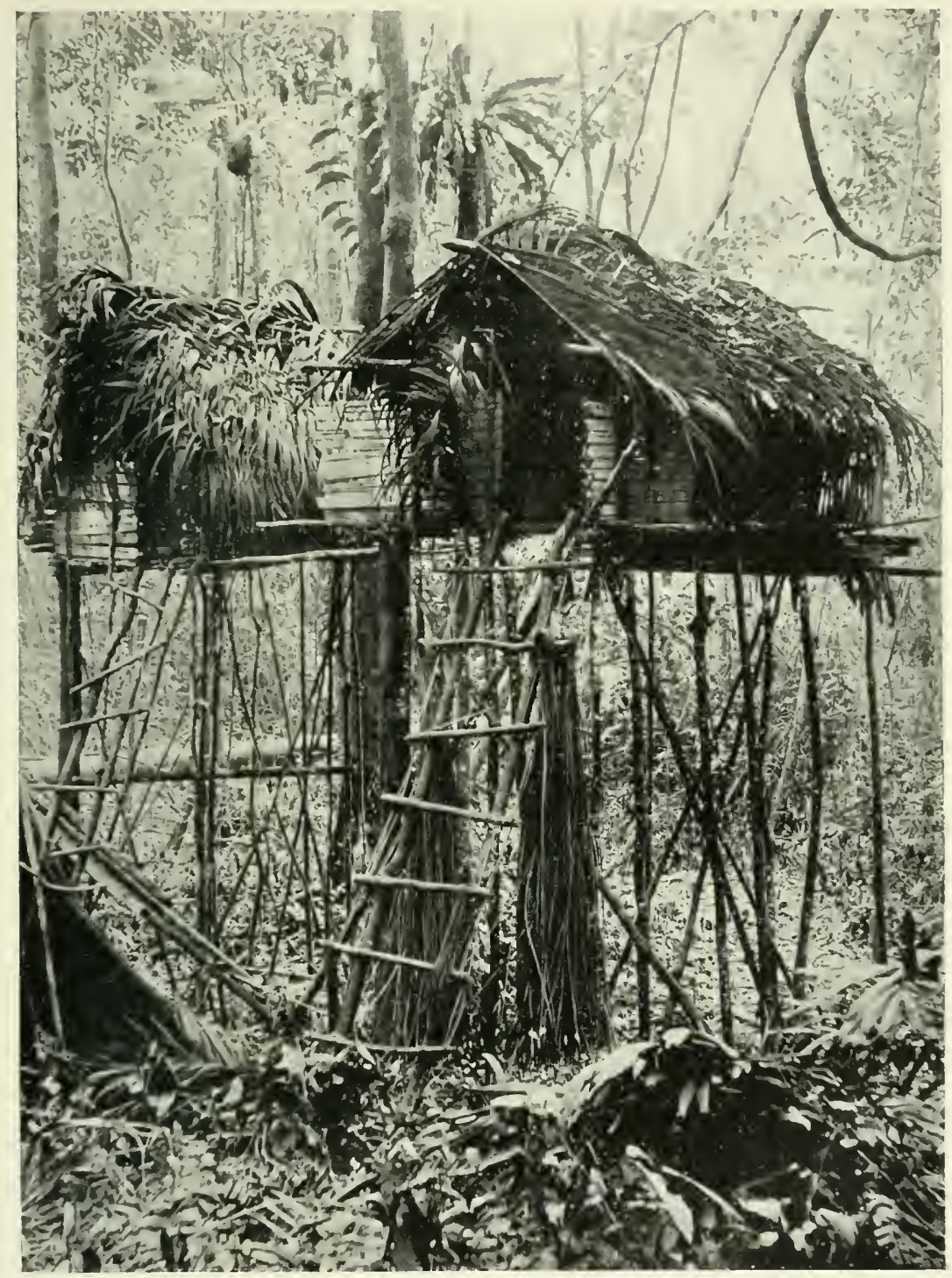

HITS OF THE SHON PEN. 

about 18 inches wide, with cross-pieces fastened on by rattan bindings.

"The village lay at the foot of a hill, above which the sun appeared between nine and ten o'clock, and was bounded on the other side by the bed of a stagnant brook. The trees about the houses were festooned with bundles of rattan, and the ground round them was littered deeply with the refuse scrapings. A few chickens and a miserable pariah cur or two wandered about, and several little pigs were caged in the huts.

"This party seemed less well-to-do than the others we had seen, for their only dress was cotton kissáts and waistcloths, and while possessing several pieces of bark cloth, in which they wrapped themselves at night, they had apparently no further clothing. Strings of coloured beads were worn about the neck, and their ear-lobes were distended by wooden plugs from I to 2 inches in diameter.

"They were of a most apathetic disposition. A few words were exchanged with our guides, whom the women immediately supplied with lime and sireh, and then, renewing their own quids, sat crouching in the doorways of the huts, or perhaps attended by request to the head of a neighbour who might be troubled with a parasitical itching. Although free from elephantiasis, the body of each individual was covered with the scaly symptoms of ringworm-tinea circinata tropica.

"After we had measured the whole party, there was sufficient light to photograph the village, to which, in the dark shade of the jungle, I gave an exposure of ten minutes. The portraits of the natives were taken under difficulties, for the only rays of sunlight that filtered through the branches shifted slowly with the rays of the sun, so that by the time the subject was posed and focussed, he was generally outside the patch of sunshine.

" VVe bought all the little property visible, and then returned to the schooner by path and canoe, having found that the so-called 'half-day's' journey resolved itself into a matter of little more than an hour. 
"Later in the day we strolled through the coast village to watch the progress towards completion of a partially-finished canoe we had purchased. With a little supervision it was only a short afternoon's work for three or four men to cut and fit, by means of their dáos, the stem and stern, crosspieces, outriggers, and float, and quickly do all the fastening required with tough strips of rattan.

"Our guides of the morning were rewarded with a sarong apiece and we purchased with rupees a pair of captive nutmegpigeons-somewhat uncommon pets-and a couple of greyheaded parrots ( $P$. caniceps) that had been obtained as fledglings by the villagers.

"Once again on board we found canoes arriving with loads of coconuts and numbers of fowls. Old shoes were the principal articles demanded, but the skipper got six chickens for a white linen coat. Our estimable captain is actuated by a commercial spirit; his invariable greeting to a new arrival is 'Ah, hang sudah datang! apa hang bazva?'-'Ah, you've come! what are you bringing?'"

"March 26.-Spent an hour on shore, and then left with the breeze at 7 A.M. Sailing slowly down the coast we passed Henpoin, Pulo Kotah, and Henhóa, at all of which places are many coco palms, with one or two houses visible. Two or three miles inland a range of hills runs down the coast, and must form the eastern slope of the Galathea Valley; until their foot is reached, the country is low and level.

"Off South Point the wind became very light at midday, and subsequently we worked up and down against a strong northwesterly tide, barely maintaining our position. After a small advance, at Io P.M. we were back again where we had been at noon, so, getting soundings of 9 fathoms, we anchored for the night." "March 27.-At daybreak the current was running S.S.W., at 2 knots. This slackened at nine o'clock, and with a light breeze from the N.E. we gradually made our way towards South Bay, until, the wind becoming more easterly, we tacked up it, and anchored towards the top in $7 \frac{1}{2}$ fathoms. 


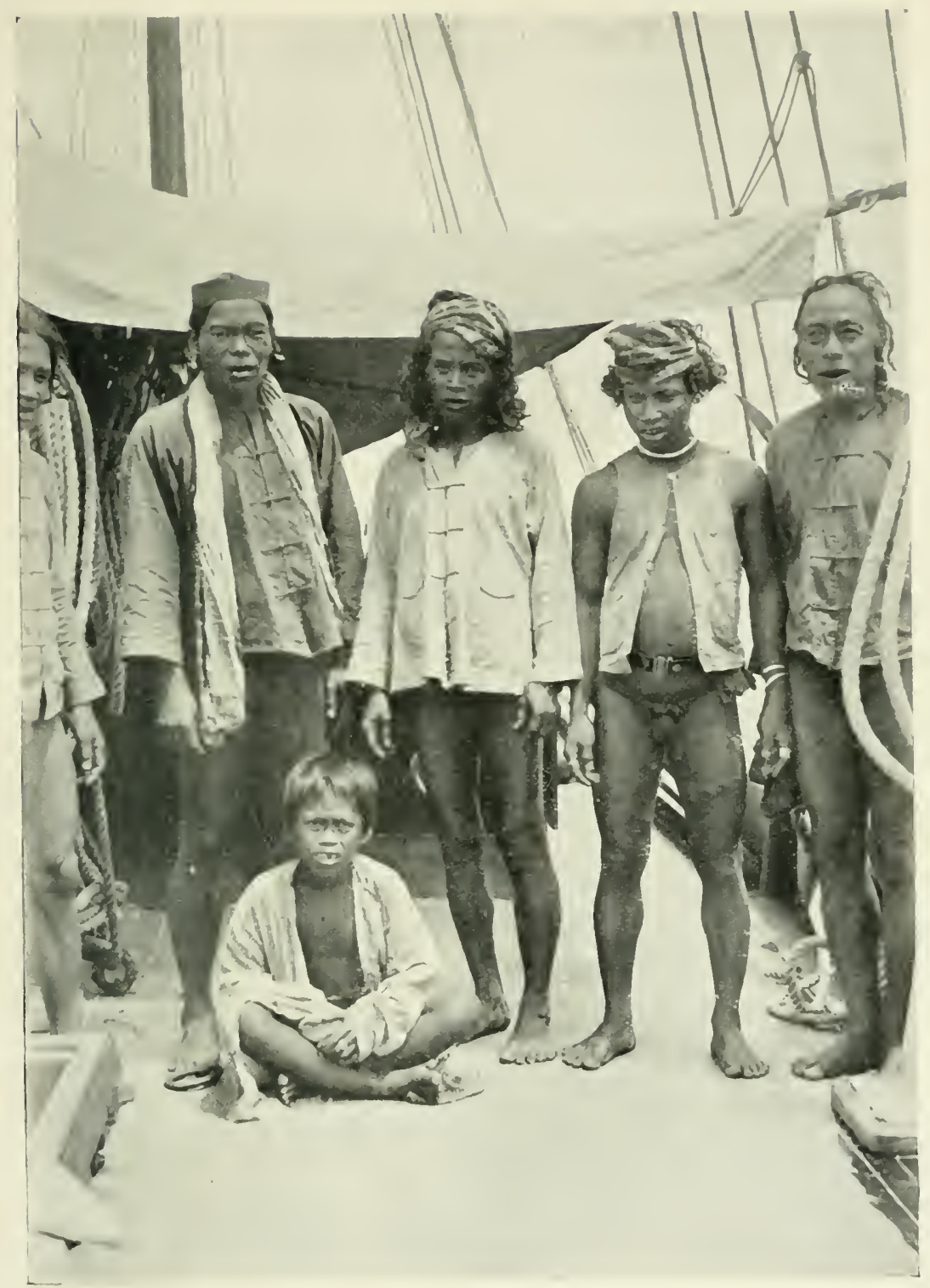

MEN AND A BOY" OF GKEAT NICOBAR. 

"The head, where the Galathea River debouches, is low and flat, but on either side the shores are a continuation of the hills, containing the river. The eastern cape is hilly and broken, but the western extremity tails off in a low stretch of flat land.

"Close to the western shore is Walker Island, a small grey block of rock that has been likened to a fort with sentries-the latter represented by columns of stone protected from detrition by boulders of harder formation, which once, of course, rested on the surface of the islet.

"Coconut trees grow all round the bay, and on the starboard hand we saw a dozen houses forming the village of Chang-ngeh, from which a canoe put off with two men. They, and two others far advanced in decrepitude, are the sole inhabitants of this portion of the island. Formerly there was on the eastern shore a village called Badói, but after some of its inhabitants had been killed by Shom Pen, it was deserted.

"We got ashore near the village at a spot sheltered from surf by a projecting reef. Close inspection showed that the houses were far more dilapidated than they appeared to be from the sea.

"Having obtained megapodes, dongos, and sunbirds by a short excursion into the jungle, we walked along the beach to examine the river mouth, in view of a journey up-stream next day.

"Coming from the right, where it runs for some distance parallel to the shore, the river turns suddenly and makes its way to the sea through a stretch of sand, leaving on the left a quiet backwater into which the current swirls. A continuous line of surf broke across the entrance, which was very narrow." "March 28.-At sunrise, having made all preparations overnight, we loaded the boat with food and bedding, mosquito nets, and collecting apparatus, and put off for the expedition up-river.

"First we pulled ashore and landed some of the cargo, for with it all on board and a crew of five, the boat was too heavy to negotiate the breakers safely. Then we lay off the river's mouth watching the sea; swell after swell came sliding in, until one larger than the rest swung by, leapt up, and with the white 
foam rippling along its summit, fell over with a thunderous crash. Pulling hard all, we swept along on its top, then passed through the surf, and lay a few moments later on the quiet surface of the river without having shipped a drop of water. When the things landed had been fetched, we reloaded and pulled up-stream; the last glimpse of the sea showing a Chinese junk rounding the eastern extremity of the bay.

"At first the river was about 30 yards wide and ran between low banks covered with stretches of mangroves and forest alternating, both fronted by a border of nipah palms. About 2 miles onward the shores rose a little, and the vegetation changed to a tangle of jungle, with a network of climbing bamboo, rattans, and various kinds of creepers. The course of the stream ran through no heavy forest, and in many places the banks were fairly open, covered with scrub and patches of thick grassy vegetation.

"Never was such a river for twisting and turning, and often as we steered round its $\mathrm{S}$-shaped bends we seemed to swing the sun right round us.

"We rowed along steadily for a couple of hours, and then seeing a lime tree overhanging the stream, stopped to gather a hatful of fruit. A few yards further on-the bank about I2 feet high-one of the men spied a rough hut, a mere platform with a shade of palm leaves; but when we landed, although odds and ends of rattan lay about the ground, it was evident that it had been unoccupied for some time.

"Now and again along the river we saw coco palms and bananas, while kaladies or yams grew plentifully at the water's edge. The banks were covered here with jungle and there with stretches of reeds, looking not unlike clumps of Indian corn.

"Flocks of parrots flew screaming overhead, herons flapped lazily away in front, and now and then a monkey, startled by the unusual sight, cursed us vigorously from a tree. Often a tiny ceyx - a flash of lilac and orange-darted across the stream, and oftener still the little blue bengalensis flitted away before us.*

* Halcyon pileata, conspicuous by its white-tipped wings, was very common 

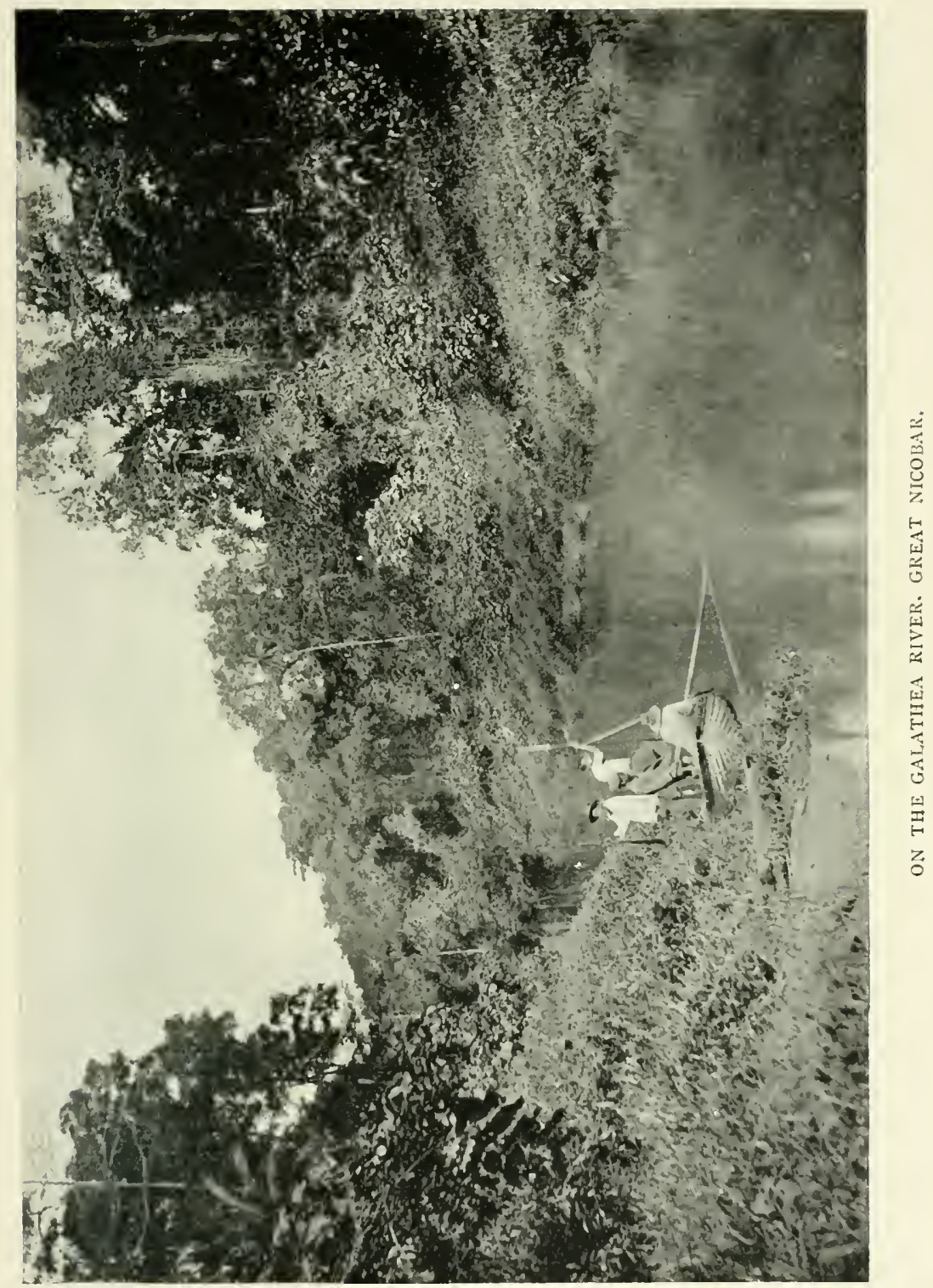

"Once we ran aground on some rocks, and twice had to scramble on fallen tree-trunks spanning the river, and force the boat beneath them. But for such incidents we progressed steadily upwards until eleven o'clock, when we pulled to one of the banks, here only some I 5 yards apart, and tying up the boat, proceeded to camp during the heat of midday.

"Then, after breakfast had been disposed of, it was delightful to lie on one's back in the shade of the jungle and watch the waving leaves against the sky; to search with the eyes for graceful ferns and orchids drooping from the branches overhead, and in a dreamy semi-slumber to listen to the calls of the birds, and the faint voices of the men as they rambled about in the forest. Presently, as the sun reached its highest point, all became quiet, and we dozed an hour away, to wake up, and-after boiling the kettle for some tea-start off once more.

"Gradually narrowing, the river maintained the same character, save that the banks became more open. At one fallen tree we had to unload the boat and haul it bodily over; several times we got round or under such obstacles with difficulty; and so, rowing and poling as the stream lessened, we went on, until at about five o'clock, the river, now only 25 feet wide, became so shallow and obstructed by fallen branches that we were forced to cease all attempt at further progress, and so made camp at a spot about 16 miles up-stream, almost in the latitude of Pulo Bábi. In the rainy season it would perhaps be possible to ascend a few miles higher.

"While daylight lasted, the boat was partly unloaded, sticks cut to support the mosquito nets, and supper prepared-heapedup plates of snowy rice, eled out by various tinned commodities. Then after re-charging the dark slides beneath a rug, and covering the baggage with a tarpaulin in case of rain, we turned in.

"It was a glorious moonlight night and the cicadas sang us to

on the river, and the calls of one or two birds not elsewhere obtained, were distinguished. Numbers of fish were seen in the shallows, and sometimes a snake swimming from bank to bank was to be observed. 
sleep from the trees, while the mosquitoes hummed away vainly and viciously outside the net.

"Now and again, for a time, came the cry of some startled bird and the croaking of the tree-frogs; but when these died away the prevailing silence was broken only by the sound of the dew dripping from the trees, and the occasional fall of dead leaves or rotten branches."

"March 29.-We turned out at daybreak while the river was shrouded in mist, and after chota hasri, started down-stream.

"The water had fallen a foot during the night, and for some distance we could only use the oars to pole with. Presently, however, we were paddling quickly down the river, until we came to the fallen tree, where it was again necessary to unload.

"All the contents were stacked on the bank, and then, while the boat was on the trunk, I walked along the latter to take a snap-shot of the scene from the shore. Just as it was half-way across, our craft stuck fast; all, gathering themselves together, gave a mighty heave, and suddenly it slipped over, taking everyone by surprise. 'Din fell into the water, 'Dul fell into the boat, Mat straddled the tree, and Abbott, by a display of flying, gibbon-like agility, succeeded in landing safely in the stern. It was all very amusing to see from the shore; far too funny, indeed, at the time for me to get my photograph.

"This was the only obstacle, for, thanks to the low tide, we found no difficulty in passing beneath the other fallen trunks. About ten o'clock we were back at the hut and lime-tree, and stopped there for breakfast; then, after gathering a bucketful of fruit, werè off again.

"With the sun almost overhead, it now became very hot on the water; but, pushing on, we reached the river-mouth soon after one o'clock and unloaded the boat once more before taking it through the breakers. From inshore they seemed much more formidable than from seaward, whence their height and the curl of falling water were hidden. We lay a short distance from the long, white lines that travelled across the bay, and watched them, backing and pulling to keep our place. 


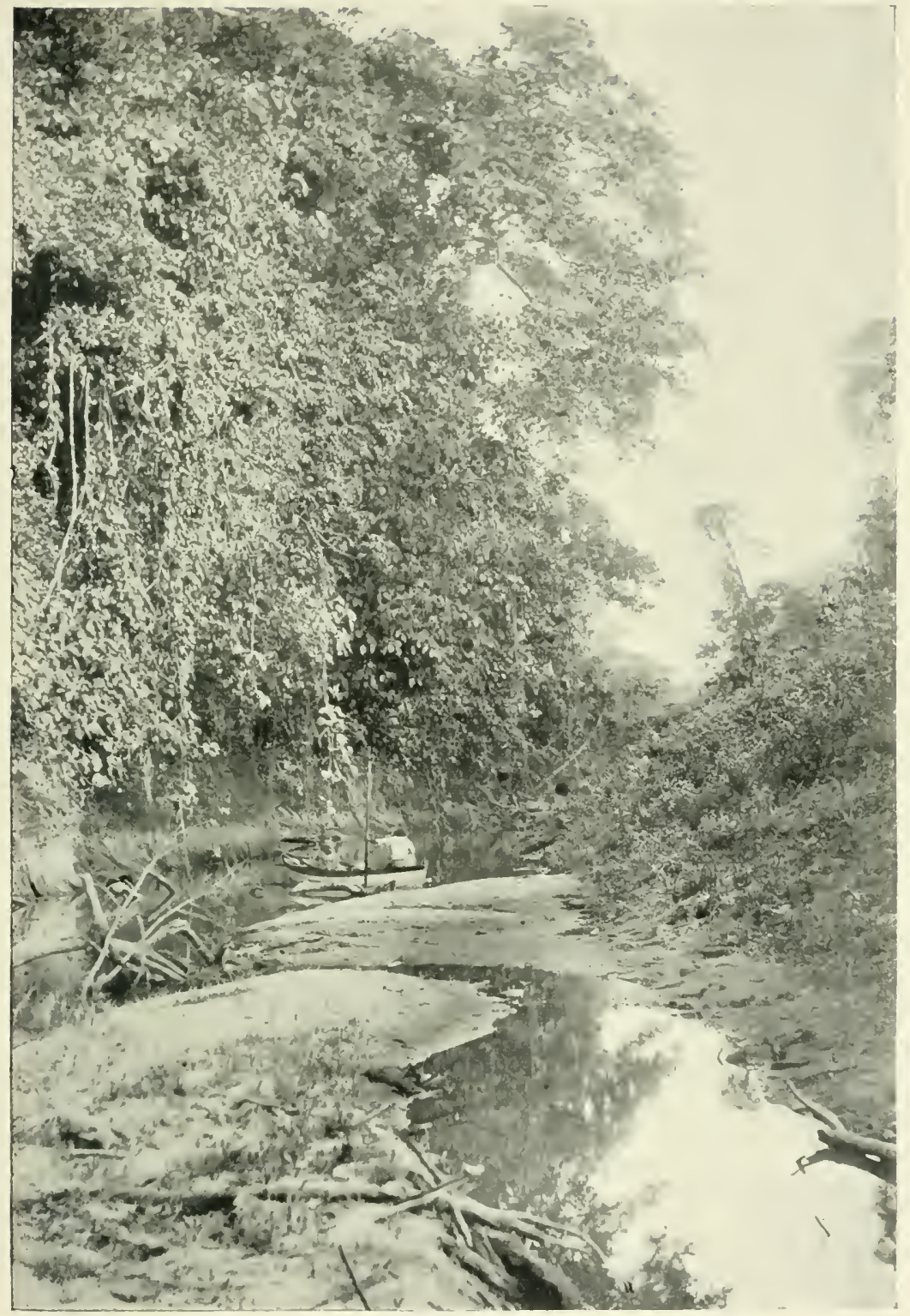

GALATHEA RIVER (highest point reached). 

"A series of breakers fell, then in rolled a monster, and as it broke before us, we dashed in the waiting oars and sped forward at the next. Up went the prow, and we were over and in the hollow before a second; then over that and yet another, and we lay on the gently-heaving surface of the bay.

"Back once more beneath the schooner's awnings, we found a welcome supply of thirst-quenching coconuts, brought freshly from the village.

"The junk, after taking in a supply of water, had left the day before. It is customary for these vessels, after their business on the west coast is over, to sail round the north end of the island when leaving for Acheen, in order to make a slight gain to windward; but this one, having learned that we were going direct, decided to take a similar course."

On March 30 we went ashore for the last time and found a good supply of water at Badói, about 100 yards inside the jungle. The stream dies away before reaching the sea, but above the watering-place it can be followed for some distance by wading up the rocky bed.

We were now full up with wood and water, and having obtained a good supply of forvls and coconuts from the village, were ready to put to sea, so left at ten o'clock in the evening, with a light wind, and a tide running S.W.

"March 3I.-At 9 A.M. the point below Mataita-ânla bore W. about 7 miles. Squalls of wind and rain occurred, and a succession of waterspouts travelled across the horizon; betweentimes and for the rest of the day, we experienced a dead calm, and rolled about on the swell. Position at 4.30 P.M., 8 miles east of Campbell Bay."

"April I.-There has been scarcely any wind, and we drifted $\mathrm{N}$. by $\mathrm{E}$. until Menchal and Kabra hove in sight. A school of sharks visited the schooner, and one about 7 feet long that was hooked, was given his quietus with a revolver bullet when hauled to the surface.

"Our live stock is flourishing. The three sober-looking parrots down in the cabin are becoming tamer day by day, 
and the pair of nutmeg pigeons will already eat chopped coconut from our hands.

"The monkeys, however, are of most interest, and are given daily exercise on deck. The male is an adept at the most horrible grimaces, but is an arrant coward, and, when startled, rushes to his companion, and, although the heavier of the two, puts his arms around her and is carried back downwards all over the place. When it is time to re-cage them, we have only to drive them together and they run into each other's arms, clasp convulsively, and incontinently roll over, when, as they lie squealing and grimacing on deck, they may be picked up and put back in their box. On one occasion this manœuvre was executed on the rail, and they fell overboard, sinking without a struggle, locked in a close embrace.

"Fortunately for them, the Terrapin was becalmed at the time, and they were recovered, to be very subdued for a time after the rescue, but none the worse for their experience.

"At 6 P.M. a light breeze sprang up, with signs of a squall from the north, and carried us along at a 2 to 3 knot pace through the night. A porpoise was harpooned under the bow, but broke away before it could be secured.

"On the 2nd the wind was light all day, save for a squall that compelled us to lower the foresail. Towards evening, Mount Thuillier, bearing W. by N., was just visible 50 miles away. The breeze freshened, and with darkness the last sign of the Nicobars dropped below the horizon, while daybreak revealed ahead of us the rounded summit of Pulo Bras." 
HYDROGRAPHICAL CHART OF THE ANDAMAN \& NICOBAR ISLANDS.

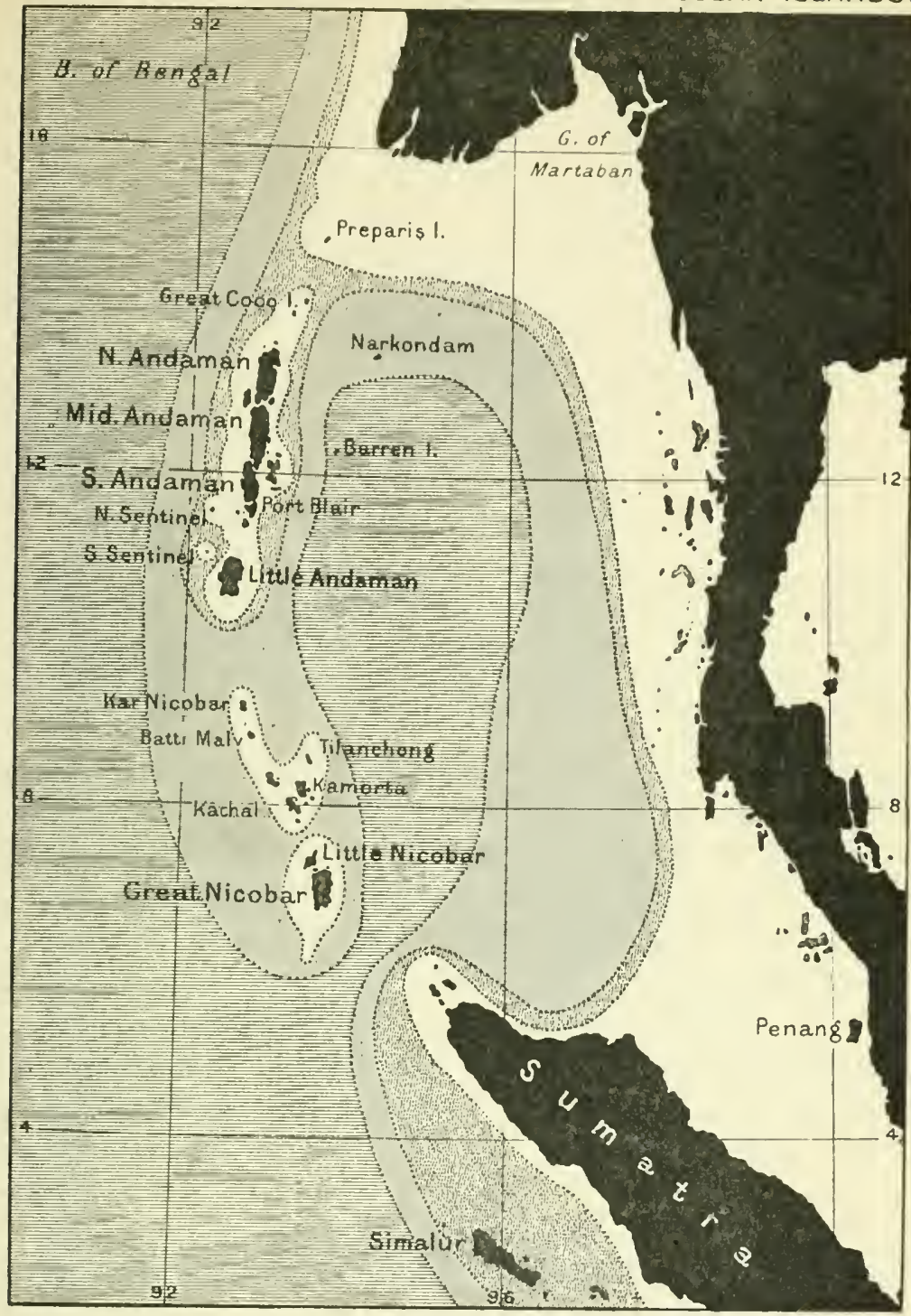

Depth of Sea less than 100 fathoms

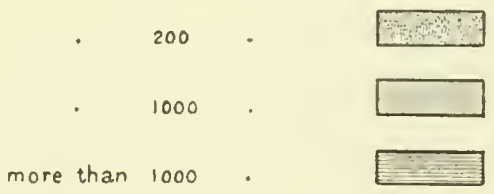





\section{PART II}

\section{CHAPTER I}

THE ANDAMAN ISLANDS AND THEIR INHABITANTS

Position - Soundings - Relationship - Islands - Area - Great Andaman Mountains-Little Andaman-Rivers-Coral Banks-Scenery-Harbours -Timber-Flora-Climate - Cyclones-Geology-Minerals - Subsidence -Earthquakes-History-Aborigines-Convicts and the Penal SystemGrowth and Resources of the Settlement-Products and Manufactures.

Tine Andamans, which together with the Nicobars form one of the minor dependencies of our Indian Empire, are situated in the Bengal Sea, between the parallels of $10^{\circ} 30^{\prime}$ and $14^{\circ} 15^{\prime}$ $\mathrm{N}$. latitude, and the meridians $92^{\circ} \mathrm{IO} \mathrm{O}^{\prime}$ and $93^{\circ} 30^{\prime} \mathrm{E}$. longitude, where they lie in a $\mathrm{N}$. by E. direction. To the west the coast of Madras is some 700 miles distant, and eastward Tenasserim, bordered by the islands of the Mergui Archipelago, lies about 320 miles away. Intervening between them and Sumatra to the south lies the Nicobar group, and before Cape Negrais in Burma is reached the little island of Preparis must be passed.

Close to Cape Negrais terminate the Arakan Hills, one of a series of ranges that run down from the Eastern Himalayas; and just south of Acheen Head we have the Gunong Mas, Batu Mukuruh, and other mountains; therefore, looking at a map of the district, it seems difficult to avoid the conclusion that the whole of the islands last enumerated are nothing less than a continuation southward of the Arakan Hills. But although they form a chain that seems to indicate a 
past union of Sumatra and Burma, investigation proves that this is far from being the case. For soundings in this part of the ocean show that between the Nicobars and the group of islands adjacent to the north-east point of Sumatra-entering from the open sea to the west, and thence trending north between the Andamans and Malay Peninsula almost as far as the latitude of Narkondam - there runs a long tongue of depressed ocean bed with depths everywhere over 1000 fathoms. This fact, together with the shallowness of the sea-bottom around and connecting the Andamans with the Arakan Yoma Peninsula, suggests the inference that the former were at one time past the termination of a seaward extension from Cape Negrais of the Arakan Yoma Range - a conclusion that is in some degree emphasized by the zoological and botanical conditions common to the two.

The principal islands are, Great and Little Andaman, Rutland and the Labyrinths, the Archipelago, North Sentinel, Interview Island, Landfall Island, and the Cocos, but there are many smaller adjacent, while to the eastward are the off-lying volcanic islets of Narkondam and Barren Island. The total area of the group is 2508 square miles.*

Great Andaman-in which may be included Landfall and Rutland Islands, for the whole land mass is so compact and divided up by such narrow shallow straits that it appears to be one single island that has been broken up by subsidence and adjoining volcanic action-is 142 miles long, and 17 miles broad at its widest point.

There are generally stated to be two straits, but as one of them bifurcates, the Great Andaman proper is really cut into four parts.

Austin Strait, which divides North from Middle Andaman, is very narrow and intricate, and not to be traversed by boats at low tide; but the Andaman Strait,- - generally 2 to 3 cables wide-which separates South from Middle Andaman at a spot where the hills are lower than elsewhere, although intricate, and possessing a bar at its eastern mouth with a depth of 9 or 10

* This was the estimated area before Col. Hobday's survey of $1883-5$. 
feet at low water, has depths from IO to 14 fathoms throughout the narrower part, and nowhere less than 3 fathoms at low water. The stream is never strong, and the R.I.M.S. Investigator passed through three times while surveying the islands in I 888 .

Homfray Strait cuts off Báratáng Island from Middle Andaman, and joins the Andaman at its western mouth. It is intricate and rocky, but has good depths, except at the eastern entrance, where there is a broad bar of 8 feet. The tidal stream is weak, and the narrowest part is 60 yards across.

The surface of Great Andaman is extremely irregular, and a central range of mountains runs from north to south, with an escarped face on the east, and a sloping declivity on the west, where marshy localities abound.

The highest point is Saddle Hill (2400 feet) in North Andaman: Mount Harriet (1200 feet) stands on the north shore of Port Blair; and Ford's Peak, in Rutland Island, rises I 400 feet ; while there are half a dozen unnamed summits with heights between 1000 feet and I 700 feet.

Narkondam rises 2330 feet, from an oval-shaped base whose greatest diameter is 2 miles, and the crater walls of Barren Island, 2 square miles in area, attain an elevation of II58 feet.

Little Andaman, some 25 miles south of Rutland, 23 miles long and 17 miles wide, with an area of about 220 square miles, is, on the contrary, level throughout, and gradually rises to a height of 600 feet in the centre. None of the other islands save Rutland attain this elevation.

Owing to its shape and conformation, there are no rivers and but few streams on Great Andaman, and during the dry seasonJanuary to April-there is some scarcity of water. Several creeks, however, are of sufficient depth to allow passage of boats for some distance into the interior. In the South Andaman the greater part of the drainage runs into the creeks, which ultimately leads off to the eastern shore, and in the North and Middle Andaman the bulk of the drainage seems to flow through gaps in the eastern range. 


\section{ANDAMAN ISLANDS AND INHABITANTS}

Little Andaman is sivampy in many parts, and possesses a few small creeks.

On the western side, in which direction Great Andaman slopes gradually, banks of coral occur at distances of 20 and 25 miles from land. There are three of these, varying in length from 9 to 25 miles, all composed of dead coral and sand, with here and there single bunches of live coral I or 2 feet high. The water, which is so clear that on a calm day $S$ or 9 fathoms looks like 20 feet, varies in its least depths from $3^{\frac{3}{4}}$ to $\sigma$ fathoms, and, judged from the appearance of the bottom and the absence of reef-building coral, it seems probable that the surface débris of the banks is disturbed by the send of the sea, and that the rollers topple and break on the middle bank in the south-ivest monsoon, though they may not do so on the others.

This western coast is fully exposed to the south-west monsoon, and is by no means a desirable locality to be in at that season.

Dalrymple Bank, of the same nature, lies adjacent to Little Andaman, on the same side ; but Invisible Bank, to the eastward, has depths of 17 to 50 fathoms, with a rock awash in the centre. This is of bluish-grey sandstone, so that the Bank, taking into account its irregular surface and the rapidly-increasing depths around, may be considered a submerged mountain-range, of the same formation as the oldest part of the Andamans-of which, Flat Rock, an isolated peak, rises alone above the sea. All these banks probably formed islands, or part of the Andamans, when the latter stood at a higher elevation than they do to-day.

Throughout the Archipelago the scenery is of exceeding beauty. The picturesquely undulating surface is clad everywhere, save where artificial clearings have been made, with the most luxuriant jungle, for, situated within the tropics, with a fertile soil, and a climate that for two-thirds of the year is somewhat moist, the islands are covered from hill-top to seabeach with an unbroken mantle of dense vegetation, rendered almost impenetrable by cane-brakes and undergrowth of rattans and other creepers. All along the shores are either stretches of 
yellow sand or brilliant green mangroves, and the seas round the islands are of the clearest water imaginable.

The coast-line is everywhere deeply indented, and affords a number-most unusual for such a small group-of deep-water harbours and other anchorages, where complete shelter can be found for large ships in all weathers and seasons. The most known and the best-although Port Cornwallis is nearly as good, and has the advantage of being some twelve hours' steaming nearer to Calcutta and Rangoon-is Port Blair, where the Settlement has been placed; but on the same coast of Great Andaman are many others, the more important being, Macpherson's Straits, Shoal Bay, Port Meadows, Colebrooke Passage, and Stewart's Sound. On the west coast are situated, Port Andaman, Kwang-tung Harbour, Ports Campbell and Mouat, while in the Archipelago perfect anchorage is to be found either in Outram Harbour or in Charka-Juru, * Kwang-tung Strait, or Tadma-Juru.

These are well distributed all along the coasts, and were the Andamans situated in some position of greater political or commercial importance, they would form an invaluable possession for this reason. As it is, the islands are exploited merely as a convict establishment-an Indian Botany Bay-and the only industry of any magnitude appertaining to them is that of timber, for which indeed the harbours are very convenient, as the forests worked are all in the neighbourhood of the seashore, or are so placed that after the trees are felled the logs can be hauled by elephants to the many creeks, and floated down to where the vessels engaged in the business are anchored.

The geographical conditions, and more especially the Tertiary sandstone of which the large area of the islands consists, point to a former connection with Arakan, and, in accordance with these indications, it is found that the bulk of the flora is Burmese; but the forest trees are finer, being very lofty and straight, while not a few purely Malayan species find their northern limit in the Andamans. The flora is not related to 


\section{ANDAMAN ISLANDS AND INHABITANTS}

that of Hindustan and India proper-a coincidence which can be partly explained by the insular climate and difference of soil.

The forests produce valuable woods, which can be used for many trade purposes-furniture; ship, boat and house building; railway carriages and sleepers; paving blocks, boxes, guncarriages and stocks, pianos, etc.; and as profitable minor products, there are canes for furniture, rattans for walking-sticks, and gurjan oil. Some of the woods can be obtained in extremely large quantities; all possibly in sufficiency for any trade that may arise with the islands.

Palms abound; the banian and padouk, that resembles mahogany; marble-wood, of a black, mottled appearance; satinwood; and the iron tree, which turns the edge of an axe, are all found in the forests, in beautiful confusion with cotton-trees, screw-pines, and arborescent euphorbias, and with large clumps of bamboos, 30 and 40 feet high; while all round the coasts, mangroves, the most satisfactory of firewoods, give shelter to lovely orchids.

A very conspicuous feature of the forests is the distribution (apart from the strictly littoral vegetation) into evergreen forest, very full of large gurjan trees (Dipterocarpece), and a leaf-shedding forest, containing a large proportion of padouk (Pterocarpus dalbergioides), or into a mixture of these two types.

The great peculiarity of the Andaman flora is that, with the exception of the Cocos Islands, which are covered with them, and thence indeed derive their name, no coconut palms naturally propagated are found in the Archipelago.* This is the more strange when it is remembered that all the shores of the Bengal Sea are the home of this tree, and that it simply teems in all the islands of the Nicobar group to the south. During the past thirty-five years advantage has been taken of trips in the Station steamer (or by other means) to plant coconuts at suitable

* The absence of this tree has doubtless had as much to do with the isolation in which the aborigines have lived as the hostility of the latter, for the islands produce little else than rattans and trepang - which would necessitate arduous collecting - to induce native traders to visit them. 
localities* along the coasts of Great Andaman, and in recent years at Little Andaman. Great numbers of the nuts were consumed by the aborigines, or by wild pigs, but at several places fruit has been obtainable, for many years past, from trees which escaped destruction.

The climate of the Andamans is equatorial in its uniformity, and greatly resembles that of Tenasserim and Mergui. It is not generally healthy for Europeans, but improves from a hygienic point of view when the forest is cleared from any locality. During the first two months of the dry season strong winds blow from the north-east, causing sickness, and damage to vegetation.

As the islands are exposed to the full force of the south-ivest monsoon, only four months of fair weather (January to April) can be counted on. December and January are the coolest months, with a mean temperature of $79^{\circ}$ and a mean minimum of $75^{\circ}$, while March and April are the warmest, with means of $82^{\circ}$ and $83^{\circ}$ respectively, and a mean daily maximum of $92^{\circ}$ at Port Blair, where throughout the year the mean is $80^{\circ}$, the highest $96^{\circ}$, and the lowest $66^{\circ}$; so that the absolute range is $30^{\circ}$. The mean diurnal range is as much as $14^{\circ}$ to $15^{\circ}$ in February, March, and April, while between June and September it is only $8^{\circ}$ or $9^{\circ}$. The mean temperature throughout the year is about $80^{\circ}$.

The south-west monsoon sets in, accompanied by heavy rain, in the early part of May, but occasionally in April, and lasts till October. March is the driest month, and January and February somewhat less so; but the rainy season lasts from the middle of May till the middle of October, and what is called the moderate season, from October to January. During the latter the average monthly rainfall is about $S$ inches; in the rainy season it is 16 inches, with twenty-four rainy days per month; while, on the average, throughout the dry season rain falls on ten days to an extent of 5 inches. At Port Blair the mean humidity is 83 per cent., and the average annual rainfall is $1 \mathrm{I} 7$ inches; but elsewhere it varies from 100 to 155 inches, and there are about $\mathrm{I} \& \mathrm{O}$ wet days in the year.

\footnotetext{
* Comparatively few.
} 


\section{ANDAMAN ISLANDS AND INHABITANTS}

At the change of the monsoons stormy weather is common, and the neighbourhood of the Andamans is considered to be the birthplace of many of the violent cyclones that occasionally visit the Indian and Burmese coasts of the Bay of Bengal.

The hurricanes generally both originate either between Ceylon or the N.W. portion of the bay, and take various courses, according to the season; but, although situated near the cradle of these storms, the islands are not often traversed by them. In I 864 one is recorded as having visited the locality, and on the night of November Ist, IS9I, a violent cyclone passed over Port Blair, which, after travelling north-westward across the bay, did much further damage at the mouth of the Hugli and on the Orissa coast. The maximum velocity of the wind registered at Port Blair on the latter occasion was I I miles.

Concerning the geology of the islands, it is curious that in the valley of the Irrawadi hot springs and other evidence of volcanic action occur in the same relative position to the Arakan Hills as the two islands of Narkondam and Barren Island occupy in respect to the Andamans. There seems little doubt that these two islands-now respectively extinct and quiescentbelong to the great line of volcanic disturbance that appears in Lower Burma and extends right through Sumatra and Java and the further islands of the Malay Archipelago. Thus it would seem that the Andamans proper, possessed of no volcanoes themselves, lie just outside the line of activity, and, with the Nicobars, occupy the same position with regard to the volcanic track as do the chain of islands west of Sumatra.

Possibly the land now constituting the Andamans first appeared above the sea as an extension of Cape Negrais in the latter part of the Tertiary epoch, at which time occurred the elevation of the Arakan Yoma Hills, and later became isolated by subsidence due to neighbouring volcanic action. As $\operatorname{Mr}$ A. R. Wallace points out, the presence of active volcanoes produces subsidence of the surrounding area by the weight of every fresh deposit of materials ejected either in the sea or on 
land. "The subsidence such materials produce around them will, in time, make a sea if one does not already exist."

The Andamans are of Tertiary formation, and of similar geological structure to the Arakan Yoma Range, the line of elevation connecting them with which is represented by the Alguada Reef and Preparis Island. (The Cocos are an integral part of the Andamans.)

Two sedimentary formations have been distinguished up to the present, the one older, the other newer than the serpentine which intrudes in various localities. They have been called the Port Blair and Archipelago series respectively.*

The former, occurring in the south, consists of fine grey sandstone-the characteristic rock, generally non-calcareous-and beds of conglomerate and limestone as subsidiary members; red and green jasper also occur; possibly, however, of an older series than the sandstone in which they crop out. This series seems to be of early Tertiary or later age.

The second series,-Miocene, or even newer-of which the whole of the islands of the Archipelago are formed, consist typically of soft limestone, of coral and shell-sand, soft calcareous sandstones, and soft white clay, with occasionally a band of conglomerate, the pebbles of which seem to have been coral.

The intrusive rocks of the Andamans-similar to those of Manipur and Burma in the north, and the Nicobars to the south, and of later date than the Port Blair series-are of serpentine, often passing into crystalline diorite and gabbro.

The Archipelago series seem to cover a large area of the Andamans, while the Port Blair formation is restricted to the south. The greater part of Rutland Island is formed of serpentine, in which small layers of brown opal have been met with, and which throughout the group seems disseminated with minute crystals of chromium. The Cinques consist of intrusive rocks of serpentine, associated with metamorphosed, indurated, and sedimentary series, mostly calcareous. The rocks of Little

*Vide paper on the "Geology of the Andamans," by Dr R. D. Oldham, Proccedings, Geological Survey of India, vol. xviii. 
Andaman are chiefly lime and sandstone, with a good deal of actual coral rock on the east and south coasts; while occasionally occur outcrops of an igneous nature. At Entry Island and Port Meadows, beds of volcanic origin exist.

In view of the connection with them, the apparent barrenness of the Arakan Hills goes to show that little may be expected from the Andamans in the way of mineral products. Amongst others, however, discoveries have been made of lignite, and the ores of chromium, copper, iron, and sulphur, ${ }^{*}$ although not in quantities that would pay commercial development.

It is indubitable, as Kurz has shown, $\uparrow$ that the Andamans are now undergoing subsidence; but there is ample evidence, in the raised coral beaches that fringe the shores, to show that in the immediate past this has been exceeded by elevation.

The islands have been subjected to earthquakes from time to time. The first recorded took place in August 1868, the next in February I8So, and several slight shocks occurred until December ISSI, when a severe earthquake visited the group, made itself felt over a large area of the Bengal Sea and surrounding countries, did much damage to masonry at Port Blair, and raised waves 3 feet high, following each other at fifteenminute intervals for a period of twenty-one hours. Another slight shock was experienced in February ISS2.

The origin of the name Andaman appears to be somewhat doubtful, and it is, of course, a word unknown to the natives. It is, however, very old, and may-as Sir Henry Yule suggests in his Commentary on Marco Polo-perhaps be traced to Ptolemy (who flourished at Alexandria soon after the commencement of the Christian era), and if so, we have by him the first-known

* Still being deposited at Barren Island.

+ This conclusion, although in some ways difficult to conceive of - for the Arakan coast to the north, and the Nicobars to the south, are both fringed by raised coral beaches, which show they have recently been elevated - is based principally on the fact that stumps of trees, which grow only above high-water mark, and beyond the reach of salt water, are found in the mangrove swamps and on the seashore. 
reference to the Archipelago, for he mentions a group of islands

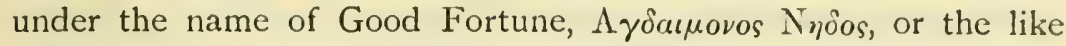
- "The Angdaman Islands" - whence have come the names Agdaman, Angdaman, Andaman. Even at this early date the inhabitants were said to be cannibals.

Doubtless the Chinese knew of the group in comparatively early times, for they have records of the neighbouring Nicobar Islands going back for more than a thousand years.

Skipping a long period, we next come to the ninth century, and there have the accounts of Arab travellers (A.D. 87I), which, although of an alarming description, are tolerably correct in some details. "The people eat human flesh quite raw; their complexion is black, their hair frizzled, their countenance and eyes frightful, their feet very large, and almost a cubit in length, and they go quite naked." Those ships, the story goes on to say, which have been set back by contrary winds, and compelled to anchor for the sake of water, commonly lose some of their men on these barbarous coasts, and it is fortunate that the natives have no ships or other vessels, otherwise they would seize and devour all the passengers.*

Reference to the Andamans in the thirteenth-century narrative of Marco Polo is very much of a traveller's tale. "Angamanain is a very large island. The people are without a king, and are idolaters, and no better than wild beasts. All the men of this island have heads like dogs, and teeth and eyes likewise; in fact, in face they are just like big mastiff dogs! They have a quantity of spices; but they are a most cruel generation, and eat everybody they can catch not of their own race. They live on flesh, and rice and milk, and have fruits different from ours." Colonel Yule suggests that Angamanain is an Arabic (oblique) dual, indicating "The two Andamans," viz., "The Great and the Little."

In 1563, Master Casar Frederike set out on his travels, and returning homeward three years later, passed near the Nicobars on his way from Malacca to Goa. "From Nicobar to Pegu is, * Pinkerton's Collection of Voyages. 
as it were, a row or chain of islands, an infinite number, of which many are inhabited with wild people; and they call those islands the Islands of Andemaon, and their people savage or wild, because they eat one another. Also, these islands have war one with another; for they have small barques, and with them they take one another, and eat one another: and if by evil chance any ship be lost on those islands, as many have been, there is not one man of those ships that escapeth uneaten or unslain. These people have not any acquaintance with any other people, neither have they trade with any, but live only on such fruits as the islands yield." *

An Italian doctor, John Francis Gemelli, who made a voyage round the world, touched at the Nicobars in 1695 , and refers incidentally to the neighbouring group. "Friday the 3 rd, we were in sight of the island of Nicobar. The island pays an annual tribute of a certain number of human bodies to the island of Andemaon, to be eaten by the natives of it. These brutes rather than men, use, when they have wounded an enemy, to run greedily to suck the blood that runs. The Dutch are witness of this cruelty of theirs; for they, going with fire-ships to subdue them, and landing 800 men, though they were well entrenched to defend themselves against those wild people, yet they were most of them killed, very few having the good fortune to fly to their ships. . . The chief motive of the Dutch to attempt the conquest of that island, was a report spread abroad that there was a well in that island whose water converted iron into gold, and was the true philosopher's stone. . . . No man in Europe or Asia can give any certain account of it, because those people have no commerce with any nation in the world." This vanished wonder was discovered by an English vessel that was driven to the islands; for a native who was carrying a shell of water accidentally spilt some of the contents on the anchor, and the part so wetted immediately turned into gold! The narrative goes on to say that the unhappy native,

* Extractes of Master Casar Frederike: his Eighteen Yeares' Indian Observations. Purchus: his Pilgrimes, London, 1625 ; vol. ii., p. 1710. 
who thus by his clumsiness revealed the priceless secret, was immediately killed, not by his countrymen, as might perhaps be expected, but by the strangers! There is no mention of torture; but the well was neither discovered then nor since.*

The next historian is an Englishman, for Captain Alexander Hamilton, in his Account of the East Indies, $\uparrow$ written about 1700, devotes some space to these islands. "The Andamans are surrounded by many dangerous rocks and banks, and they are all inhabited with cannibals, who are so fearless that they will swim off to a boat if she approach near the shore, and attack her with their wooden weapons, notwithstanding the superiority of numbers in the boat and the advantages of missive and defensive arms of iron, steel, and fire."

As an example of this, Hamilton tells of one, Captain Ferguson, whose ship, bound from Malacca to Bengal, in company with another, was driven by a strong current on some rocks, and lost. The second vessel was carried through a channel, and was completely powerless to aid those shipwrecked, "which," says our author, "gave ground to conjecture that they were all devoured by those savage cannibals."

This same chronicler met a native of the Andamans at Acheen in 1694, and says of the incident: "The Andamaners had a yearly custom to come to the Nicobar Islands with a great number of small praus, and kill and take prisoners as many Nicobarians as they could overcome." During one of these raids, however, the long-suffering Nicobarese armed themselves-it does not seem to have been their custom to resistand, gathering together, gave battle to the invaders, and utterly defeated them; and on this occasion the man under discussion, then a boy of ten or twelve years, who had accompanied his father, was taken prisoner, and, spared on account of his youth, was made a slave.

Some years went by, and he was sold to the Achinese, who,

* A Voyage Round the World by Dr John Francis Gemelli Careri. Churchills Collection of Voyages and Travels, vol. iv.

+ Pinkerton's Collection of Voyages. 
being Mohammedans, taught him their religion; and he remained in Sumatra, until, on the occasion of his master's death, he was manumitted.

He had now become very homesick, and so, obtaining a boat, he set out during the fine season from the islands of Gomus (Pulo Bras) and Pulo-weh. "From here the furthermost of the Nicobars may be seen, and so one island may be seen from another, from the southernmost of those to Chitty-Andeman (Little Andaman), which is southernmost of the Andamans, distant from Acheen about a hundred leagues." Once home, and made much of by his relatives, who recognised him although he had long been considered dead, he acquainted them with his knowledge of God, " and would have persuaded his countrymen to learn of him how to adore God and to obey His laws, but he could make no converts."

After a month or so of the old life, he returned to Acheen with a quantity of quicksilver, which, he said, abounded in some of the Andamans; and thereafter he made several other voyages, always returning with a similar cargo. "Some Mohammedan faquirs would have accompanied him, but he would not suffer them, because, he said, he could not engage for their safety among his countrymen. When I saw him he was in company of a seid, whom I carried as a passenger to Surat, and from whom I had this account of his adventures."

Trustworthy history of the islands now begins; for, at the close of the eighteenth century, the Honourable East India Company sent small expeditions, under Colonel Colebrooke and Captain Blair, to report on the possibilities of the group. Their accounts were so satisfactory, that, in 1789 , the latter was sent to establish a penal settlement in what was then called Port Cornwallis-now Port Blair.

All went well with Blair and his colony until I792, when orders were received from Calcutta to transfer the whole establishment to the harbour in North Andaman, which, in turn, was to be known as Port Cornwallis, The first place of that name was henceforth for a time dubbed Old Harbour. 
Colonel Syme, who was sent on a mission to Ava in I795, visited the establishment on his voyage out, and found there a population of 700 , including a company of sepoys. He estimated the aborigines at 2000 to 2500 , and gives a very unflattering description of them. They then used rafts of bamboo in addition to canoes.*

The new settlement proved so unhealthy, that, after an existence of four years, its abandonment was decided on: the prisoners were transferred to Penang, and the troops returned to Bengal. $\dagger$

For many years now, the group remained untenanted by a foreign element, and its isolation was broken only by the rendezvous at Port Cornwallis, in I824, of the fleet carrying the army of Sir Archibald Campbell to Rangoon for the first Burmese war; by the murder, while ascertaining the mineral possibilities of the islands, of Dr Helfer, a Russian scientist employed by the H.E.I.C.; and by the simultaneous wrecks in I844, on Sir John Lawrence Island, of the troopships Runnymede and Briton, which, in a hurricane one inky night, were flung, unknown to each other until morning dawned, right over the reef in among the trees of the jungle. Hardly a life was lost.

Before the Andamans again became the field of Government activity, the Cocos group, which lie 20 miles to the north of Great Andaman, were the scene of an unofficial attempt at colonisation. $\ddagger$ The first settlers were two men on their way to Australia, who, struck with the beauty of the Great Coco, with its shore covered with innumerable coco palms and other trees, gave up their original plan, and were left there in the early part of I849. There were no inhabitants; but the islands were frequented during the north-east monsoon by people from Tenasserim and Arakan, who came for the coconuts that were so plentiful. The only

* A Mission to Ava, by Col. Michael Syme, 3 vols.

+ The Indian Antiquary, monthly numbers, April 1900-June 1901, contains articles by Lieut.-Col. R. C. Temple on Blair's reports of his survey and settlement in the Andamans.

+ Vide "Our Monthly," June and July I $88_{3}$. Rangoon. 


\section{ANDAMAN ISLANDS AND INHABITANTS}

animals were rats; but the bays abounded with fish and turtle, and water was obtained by sinking wells in the beach.

In the middle of July, the Flying Fish-the ship that had landed the first settlers-brought a second batch from Moulmein, and the population then consisted of four men, two women, and four children, with a small number of Burmese and a few Lascars.

Some months passed, and the island remained unvisited; and the whole story of that time is one of incompetence, laziness, sickness, and starvation. Stores failed; while food procurable on the island only consisted of turtles, turtles' eggs, fish, and coconuts. The settlers were, besides, suffering from dysentery, fever, and other complaints, brought on by an unaccustomed mode of life, in dwellings that were mere hovels, and subjection to the inclemency of the rainy season. Their spirits became depressed, and despair succeeding discontent, they were more like an unfortunate shipwrecked party than immigrants who had landed to make a new home. Several of the colonists fell a prey to despondency, that in some cases amounted almost to mental derangement. Some of them died, and those who were rescued from that fate were brought away from the island in an utter state of destitution, emaciated in body and almost silly in intellect.

On October 29 the remaining settlers-of whom seven had died - were taken off, and reconveyed to Moulmein by the Company's ship Proserpine.*

In I855, measures were proposed at Calcutta - for the Andamans were then an appanage of the East India Company- for the repression of the outrages practised by the Andamanese on those crews shipwrecked on their shores, and two years later -on the conclusion of the Mutiny - it was determined that a penal settlement should once more be established in the group:

* Since I879, when the Cocos were transferred from the Commission of the Andamans to that of Burma, several settlements, less unfortunate, have been made in the same island for the purpose of trade in coconuts and timber. There is now a lighthouse on Table Island-the most northerly of the group-where many wild cattle (originally domestic) roam. 
thus combining a headquarters, from whence the pacification of the aborigines might be undertaken, with an abode of punishment for such mutineers and others whose offences had not merited the death penalty.

It was at this date that Dr F. J. Mouat, who has given an account of his visit in Adventures and Researches anong the Andaman Islanders, was sent, as head of a Commission, to examine the islands and select a suitable locality for the cstablishment of a penal settlement. The Commission spent about three weeks steaming about the coasts of the Archipelago, and finally decided on Old Harbour, to which they gave the name of Port Blair, in honour of its former resident.

A rather amusing incident occurred during the visit:- A nervous and imaginative member of an exploring party brought news of the proximity of a native village and a lurking body of aborigines. The doctor, without waiting for further information, or to be attacked, addressed his followers in a warlike speech, and gave the order to charge, which the company forthwith did with such vigour that two fiery spirits were knocked senseless by contact with burnt tree-stumps-a number of which the party had inistaken for natives. The expedition had, however, several serious conflicts with the aborigines, in which a few of the latter were killed.

On return of the Commission to Calcutta their advice was soon acted on, and the late General (then Captain) H. Man was sent to Port Blair to formally re-annex the Andamans and put matters in train, and following him a body of convicts arrived in charge of Dr J. P. Walker, who was appointed first Superintendent.

For some years the death-rate was excessive (averaging is per cent.), owing to the necessity of pushing forward clearing and building operations, and it was not until I\$68, soon after the appointment of Colonel Man as Superintendent, that it fell to a more normal level (average for ten years, 2.7 per cent.).

The pacification of the natives, by means of Homes, a school, and visits paid to the tribes by the Station gunboat, went 


\section{ANDAMAN ISLANDS AND INHABITANTS}

steadily on, until there now remain but two or three groups of Andamanese from whom any hostility is to be feared.

In 1872-3 the Andamans were formed in a Commissionership with the Nicobars, and a year later general attention was drawn to them by the death of Lord Mayo, Viceroy of India, at the hands of a convict.

The Andaman Islands are inhabited by people of pure Negrito blood, members of perhaps the most ancient race remaining on the earth, and standing closest to the primitive human type.

Geologically, the islands are connected with the opposite mainland, so that in remote times migration was probably possible ; and we find in the Malay Peninsula, and in the Philippines, which were at one time connected with it, aborigines who-known by various names, such as Semang, Jakun, etc., and Aeta-are the nearest existing relatives of the Andamanese.

There is no reason to consider the Andamanese any other than the aborigines of the islands, for we know from their kitchen-middens, which are found throughout the group, that they occupied it in very remote times.

From the examination of fragments of pottery, arrowheads, and other stone implements discovered in the shell-mounds, it is now believed that the locality was settled some time during the Pleistocene period, and certainly not later than the Neolithic age.

"In the Andaman kitchen-middens have been found shells, pig-bones, pottery (referred to a stone age-at least to the Neolithic period-and almost identical with the fragments found in the Danish kitchen-middens), and stone implements. Every second stone picked up showed indications of being used in some way; some as hammers, others fastened to wood as rude hatchets, knives, etc.: a beautiful polished celt was found, indistinguishable from European or Indian celts of the Neolithic period, also a typical arrow-head-all of Tertiary sandstone."-Stoliczlia.

The possession by the natives, in recent times, of implements and weapons manufactured from wood and shells only, is easily accounted for by their having found these equally suitable to their needs, and far easier to construct. 
It would be impossible to find anywhere a race of purer descent than the Andamanese, for ever since they peopled the islands in the Stone Age, they have remained secluded from the outer world, and to this isolation is due the uniformity so marked in their physical and mental characteristics.

In stature they are far below the average height; but although they have been called divarfs and pygmies, these words must not be understood to imply anything in the nature of a monstrosity. Their reputation for hideousness, like their poisoned arrows and cannibalism, has long been a fallacy, which, although widely popular, should now be exploded.

The average heights of Andamanese men and women, computed from a large series of measurements, are found to be 4 feet $10 \frac{3}{4}$ inches and 4 feet $7 \frac{1}{4}$ inches respectively, and their figures which are proportionately built, are very symmetrical and graceful. Although not to be described as muscular, they are of good development, the men being agile, yet sturdy, with broad chests and square shoulders.

The abdomens - although on the whole not to a greater extent than those of other savages-are sometimes protuberant, in the women more so than the men, and it is probably owing to this feature that they have been described as figureless, a statement by no means wholly correct.

In both sexes, the small of the back is very hollow and the buttocks prominent. The feet are rather large, and occasionally occurs a case of the great-toe being placed with relation to the others in an almost simian or thumb-like way. Hands are of moderate size and well shaped, with long thin fingers.

Viewed from a distance, the skin appears of a jetty colour, especially when shining from the fat with which it is often bedaubed: a close examination shows, however, that it is not absolutely black, although these pcople are amongst the darkest of mankind.* Soles, palms, and nails are pale pinkish-brown, and

* As one goes from South to North, the tribes become larger in stature and redder (less black).-M. V. Portman, Jour. Royal Asiatic Soc., I SSI. 
while the lips of some show a slight purplish tinge, those of the majority scarcely differ in tint from the skin of the face.

The hair, which is similar in colour to the skin, and lustreless, is woolly, and of what is known as "pepper-corn" type, for, when kept short, it assumes the form of little knobs with bare spaces between, giving to the head an appearance that has been rather aptly likened to that of an old worn-out shoe-brush. When long, the tufts take the form of a cone-shaped frizzly spiral. The body is glabrous, but there are traces of hair about the armpits and other parts, and adult males possess sometimes an excessively slight moustache, and about a dozen hairs on the tip of the chin.

The skull is mesocephalous, with an index of about 82 ; the forehead of good size, round and prominent; the face rather short, and often quadrilateral. The nose is somewhat broad, with rounded tip and nostrils, often short, and, when not straight, as is most common, is as frequently convex as concave. The eyes are large, horizontal, and placed widely apart, with black pupils and muddy yellow sclerotic; and the lips, which are wellformed and neither excessively prominent nor thick, are kept closed when at rest, and cover teeth strong though irregular and often stained from use of tobacco. The ears are of good shape, small, and lie close to the head.

Their speech is rapid and vivacious. Each tribe possesses a distinct dialect, traceable, however, to the same source.

"The Andamanese languages are one group, and have no affinities by which we might infer their connection with any other known group. They belong to the agglutinative stage of development, and are distinguished from other groups by the presence, in full development, of the principle of prefixed and affixed grammatical additions to the roots of words. Their form of speech is extremely intricate; for instance, the possessive pronouns have as many as sixteen possible variants according to the class of noun with which they are in agreement. There is also a distinct poetical dialect, and in their songs they subordinate to rhythm, not only the form of words, but even the grammatical construction of sentences." *

* Lieut.-Col. R. C. Temple, quoted in The Aboriginal Inhabitants of the 


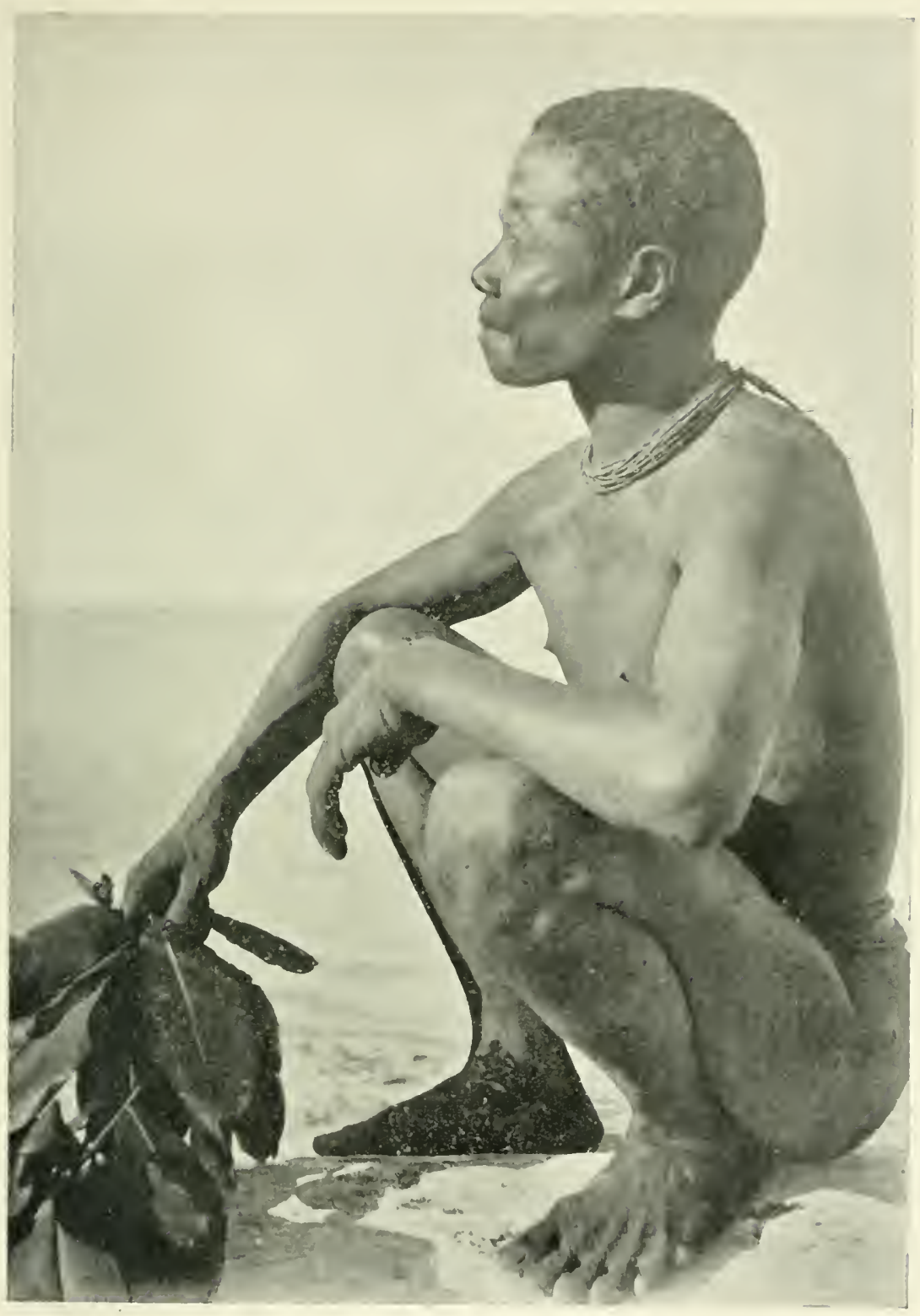

(i) NGE MAN, LITTIE ANIAAMAN.

[To face page 1st, 

They have words for the numerals "one" and "two" only, but can count to ten by tapping the nose with the finger-tips of both hands, uttering for each in turn the word $a n-k a=$ " and this," until, when the last is reached, the expression ardiru implies "all."

In disposition they are childish, but bright and merry, though petulant, quick-tempered, and restless, and not capable of much perseverance. Great affection is lavished on children and the young; old or helpless are held in high consideration. Women are well treated, and not used as drudges or slaves, but are assisted by the men, who assume a fair share of the day's work.

In the school that at one time existed at Port Blair for the Andamanese, it was found, that, as with all savages, the children, when educated were as proficient up to a certain age as the children of civilised peoples, but that point reached, they possessed no capacity for imbibing further knowledge.

As the natives gain by education in intelligence and tractability, they become fat and indolent, while their morals undergo much deterioration through contact with the convicts. The clearance of the jungle has been prejudicial to their health, and excessive tobacco-smoking among both sexes, which has been unrestricted, has seriously undermined their already enfeebled constitutions.

They possess very little vital power, and readily succumb to diseases, suffering much from febrile disorders, which give rise to pulmonary complaints-the chief cause of mortality among them. Very few reach the age of fifty, and the average duration of life is little over twenty years. Of the lesser ailments, skin diseases are very common.

Measles, to which over 20 per cent. of the population fell victims in 1877 , was followed by an outbreak of syphilis, both introduced by convicts. The latter disease has caused much

Andaman Islands, by E. H. Man-a work that deals in a most exhaustive manner with the subjects indicated in the title, but is now, unfortunately, out of print. 


\section{ANDAMAN ISLANDS AND INHABITANTS}

injury, and its spread has, it is believed, been greatly accelerated by the custom prevailing of the women suckling each other's children.

The "sense of shame" is but little developed, and the natives pay no attention to their own nudity, although by nature they are modest. Of the various objects worn, those only coming under the heading of clothing are the aprons or leaves worn with the girdle by the women, and always carefully adjusted.

Previous to marriage, which is not permitted to those between whom any degree of consanguinity can be traced, unchastity is the rule with both sexes. Births out of wedlock, however, are considered discreditable, and marriage generally follows on a girl becoming enceinte, in which case there seems no objection on the part of the lover to become the husband.

Once married, conjugal fidelity until death is the rule, and bigamy, polygamy, and divorce are unknown.

Restrictions from various tabooed articles of food, which begin at puberty and often last for years, are brought to a conclusion after a long series of initiatory ceremonies undergone by both sexes.

When a death occurs, the corpse is buried with a method and ceremonies differing somewhat according as to whether it be adult or child; * and after some months, during which the encampment in which the death took place is deserted, the body is exhumed, and the bones cleaned and made into souvenirs, which are distributed to relatives and friends.

Numerous superstitions are extant among them, and there is credence in wizardry.

No form of worship is to be found; but there exists a belief in a spiritual being, called Puluga, the Creator; and in evil spirits, Erem-chaugala, the spirit of the woods; and Jumuinda, the spirit of the sea, the first of whom causes sickness and earthquakes, the latter cramp; both are demoniacal. There are also

* "The dead are often disposed of on platforms erected in the fork of some suitable tree. Old people and infants are generally buried."-E. H. Man. 


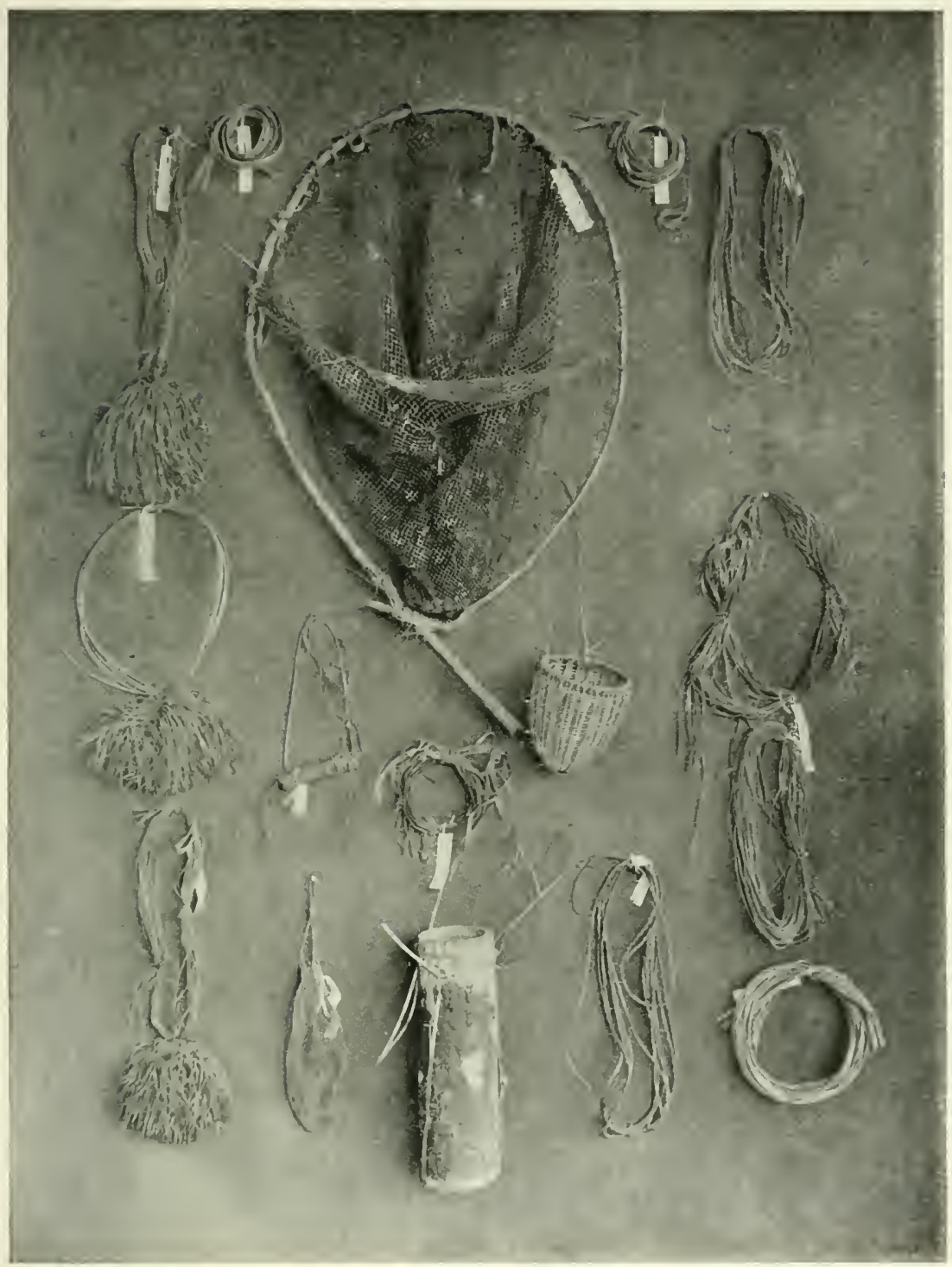

ANDAMANESE OBJECTS.

Aprons (3) worn by Öngé women (little Andaman).

Armlets, Necklets, and $\mathrm{IV}$ :iist-belts.
Hand Fishing-net. Child's Basket. Bamboo Water-holder.

Reticule for carrying small articles. 

WEAPONS, ORNAMEN'TS, UTENSILS, E'TC. 189

a host of minor devils, who are self-created; none of the demons are under the control of Puluga.*

They make no attempt at trading in the natural products of their islands, and manufacture nothing but the weapons, personal ornaments, implements, and utensils required for their own use. They have some knowledge of pottery, though not of the wheel, and make rude pots, which they ornament with patterns of wavy lines before baking.

No true musical instruments exist, but a rude soundingboard is constructed, on which they accompany songs by beating with the foot. $\dagger$

Tne weapons used in hunting and fishing are bows and spears,

* In the Jour. Royal Asiatic Soc., 1881, Mr M. V. Portman writes :"Although traditions of a Creation, a Fall, a Deluge, and a future state have been recorded as extant among the Andamanese, there is reason to believe that these accounts are merely the Christian religion as formerly taught in the Andaman orphanages, and distorted among the natives; for, while the southern tribes have a legend of a stone house where the Deity was born, the northern tribes, who have not been brought into contact with the Settlement, have no such tradition;" but Mr E. H. Man records traditions of a Creation, Fall, and Deluge, obtained from aborigines possessing no knowledge of what had been taught to the few small children at the Orphanage (chiefly reading and writing, sewing, basket work, etc.), and moreover, doubts whether any of the latter were capable of giving an intelligent-if any-account of the views held by Christians on these subjects.

"The Andamanese traditions do not resemble those of Christians. Savages in other parts of the world," writes Mr Man, "possessed traditions on the same subjects before missionaries or other Christians ever visited them."

t The pukuta yemnga, a shield-shaped piece of wood, placed with the narrow end in the ground. Andamanese songs are in solos and choruses, the latter invariably sung by both sexes if available, and are accompanied by a dance, which takes place in the evening and at night, in the jungle, when both men and women quite lose themselves in the excitement.

Specimens of Andamanese songs :-

(I) "From the country of the Yerewas the moon rose; it came near; it was very cold,-I sat down." Chorus._- "I sat down."

(2) "Maia Poro saw a big turtle in the water, and hit him in the eye. Poro laughed when he hit him in the eye." Chorus.- "Poro laughed when he hit him in the eye."

(3) "I am cutting the under-part of a canoe's prow. I am cutting a canoe." Chorus.-"I am cutting a canoe."

-Vide "Andamanese Music," by M. V. Portman, Jour. Royal Asiatic Soc., I 888. 
and there are both hand and large seine nets for taking fish. For food there are pigs, musang, dugong, porpoise, fish, turtle and their eggs, molluscs, larvæ (a delicacy), fruit, honey, and roots. Food is cooked and eaten as hot as possible: of the production of fire they, at least in modern times, have no knowledge : this accounts for the great care taken in preserving fire at their camping places, and when travelling.

The coast people are extremely expert swimmers and divers, but the interior tribes naturally not so, as their mode of life is somewhat different.

The natives are now known to be divided into twelve tribes, if groups that in many cases number at present less than fifty individuals can be so called. Beyond their speech there is little otherwise to distinguish them from each other, except in the case of the Öngés and Jarawas, who differ somewhat from the rest, but are in many ways both alike.

The enmity that the Andamanese had ever shown to all strangers was by some believed to have been greatly due to the treatment they had received from early Chinese and Malay traders, or bêche-de-mer collectors; but, prior to I $85 \mathrm{~S}$, extreme jealousy and distrust prevailed among adjacent tribes, and even amongst scattered communities of the same tribe, and it was not till 1879 that members of all the Andaman tribes (except Öngés and Jarawas) were able to meet on friendly terms at the Homes of the Settlement.

Friendly relations have lately been arrived at with most of the inhabitants of Little Andaman (i.e. the Öngés), but the Jarawas, who inhabit the North Sentinel, Rutland Island, and South Andaman, have proved to be quite irreconcilable, and their attitude often explains the total disappearance that sometimes follows escapes of the convicts.

They are generally feared by all their native neighbours and, with the boldness of ignorance, do not hesitate still to attack even superior numbers of Europeans, as an instance that occurred during the late census operations shows.

At Port Campbell a body of natives were seen who were 


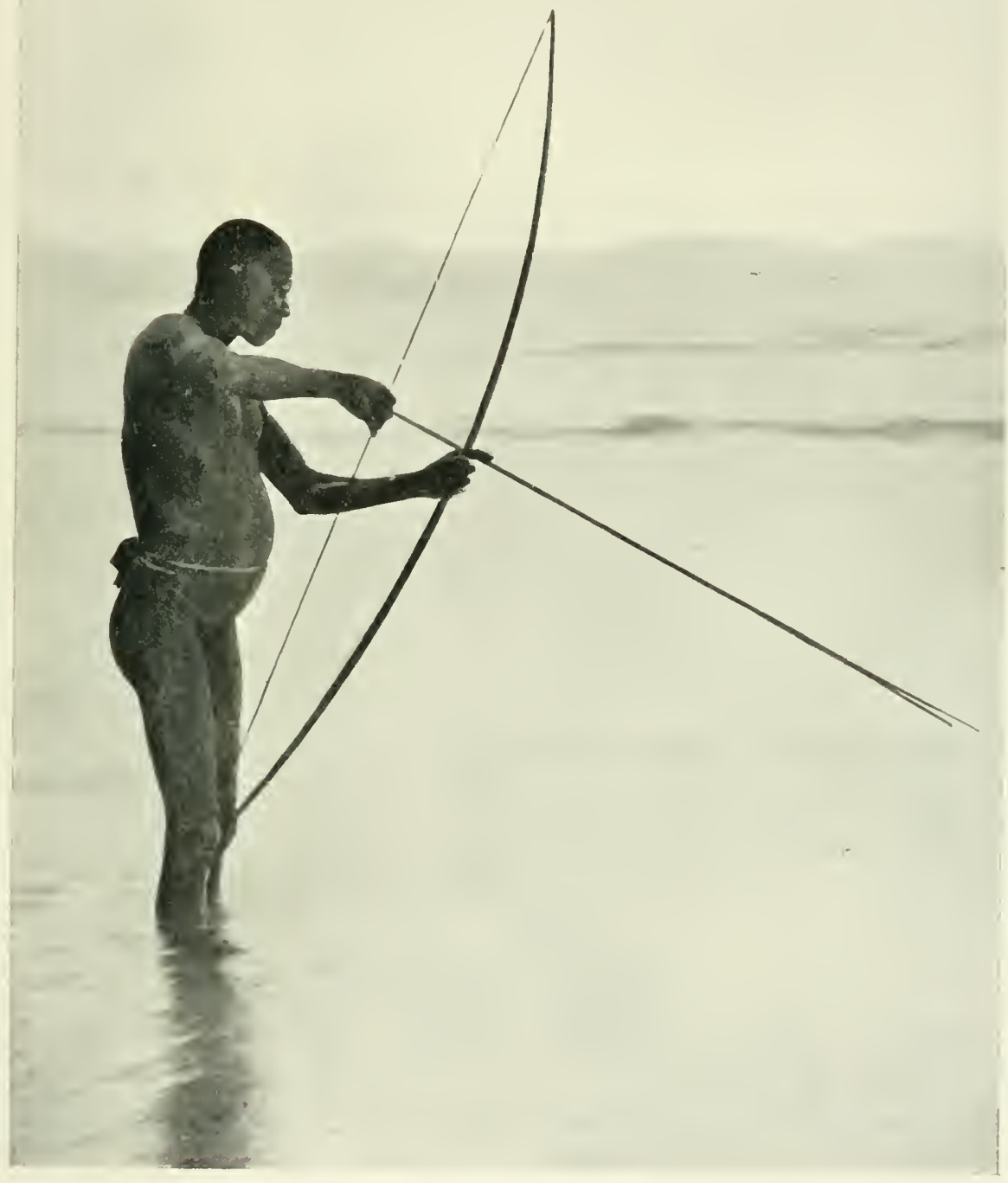

ÖNGÉ VISITUR AT RUTLAND ISLAND.

[To face page 190. 

pronounced to be Jarawas, and, as it was considered to be a suitable opportunity to attempt to establish friendly relations with them, the census party made for the shore, in a boat manned by Andamanese, taking with them a quantity of presents, a rifie, and some boards and cushions to serve as shields in case of hostilities, and an Andamanese woman, whose shrill cries it was hoped might prove to the savages pacific intentions. The crew, as usual, took their bows and arrows, but carefully concealed them, and, as the boat approached the shore, all waved handkerchiefs and large pieces of red cloth, much appreciated by the other Andamanese, while the woman loudly and unceasingly screamed friendly messages But it was soon apparent that the Jarawas meant fighting, for they sent their women and children away to a distance, and then three of the men, armed with bows and arrows, and with threatening cries and gestures, waded out towards the boat, Ioo yards distant, through the shallow water intervening. The three advanced in line, at intervals of about fifteen paces, and placed themselves so that the centre man could rake the boat and the others shoot into it from either side.

No arms were shown from the boat, but friendly signs persevered with, until the man on the right flank, who was the leader, when well within bow-shot, raised his weapon, and as it was seen that he was evidently in the act of discharging it, which would have been the signal for the others to follow suit, the rifle in the boat was fired at him, wounding him in the thigh. This caused him to spin round and make off towards the beach, followed by his supports. After running for a short distance, he fell, and, while his two companions pluckily picked him up and carried him into the jungle, some of the others, who had been looking on from the beach, yelled to the women, with the result that they were seen to return as hurriedly as possible. As the men on the beach evidently considered themselves in perfect safety, although only some 300 yards distant, a second bullet was fired into the sand near them, much to their astonishment and consternation, as they then and there 


\section{ANDAMAN ISLANDS AND INHABITANTS}

fled into the adjacent jungle with shouts of alarm. The party in the boat thereupon returned to the launch and steamed out of the harbour.

It was suspected that these same men were responsible for the unprovoked murder of a petty officer of an oil-collecting gang, which had recently taken place near one of the Jarawa districts.

The population of the islands has been computed from time to time-from the 6000 at the period of the founding of the Settlement-in variously diminishing numbers down to the present day, when it is placed at about 1900.*

The case affords a striking example of the effect of contact between civilised and savage man, for only those tribes of the Andamanese that are still hostile or who have little or no intercourse with the Government Settlement, have preserved any respectable number of individuals in their ranks.

Of these, the Jarawas, although not distantly located from the Settlement, receive all advances with inveterate implacability, while the Öngés of Little Andaman, who were until I884 almost totally unvisited, are further off, and enjoy an insular position.

These two tribes between them represent by estimation some 1250 of the total inhabitants of the islands. The numbers in the various other tribes are now very small, but possibly were never as large as those of the two mentioned.

Everywhere is noticeable an enormous disproportion between the numbers of adults and children-a feature, in view of the fewness of the former, that argues badly for a much longer continuance of the race. Concerning the fact, some of the natives say that it is not due to sickness, but that children are very seldom born; others state that the first, or first and second children are dead, and that the one present is the sole survivor. Undoubtedly, however, the infant mortality that exists is due to the presence of syphilis, which occurs in some of its most virulent forms amongst these people, and not to maternal 
neglect, as the mothers display the greatest affection for their children.

"The Andaman Penal System is the result of the constant attention of the Government which created it, and is the outcome of the measures of practical men, devised to meet the difficulties with which they have found themselves face to face, and reduced to order and rule by some of the keenest intellects that have worked in India for many years past. It is no paper constitution drawn up to suit any particular theories. There have always been the convicts in their thousands, and there have been the climate, and the necessity for treating the convicts in the way best calculated to benefit them, and for so employing them as to bring down their cost to the taxpayer to the lowest limits compatible with climatic conditions and beneficial treatment. Trusted agents of the Government have pondered these things on the spot in the light of an ever-increasing experience, and their ideas and suggestions have passed under the criticisms of highly experienced administrators, and have in the end produced the system which is now carried out.

"Repeatedly tinkered and patched and recast and remodelled though it has been, the Andaman System is still inchoate-still on itst rial as it were. It could not well be otherwise, for in dealing with the criminal we are attempting to solve a mighty problem as old as criminality itself, and are plunged, perforce, into a controversy as contentious now as it was centuries upon centuries ago.

"From the best estimates to hand, we may take it that the permanent convict strength of the Settlement may be placed at about 12,000 , of whom about 800 are women, and the rule is that only life convicts are sent from India, and life and long-term convicts from Burma. The people received, therefore, are the murderers who have for some reason escaped the death penalty, and the perpetrators of the more heinous offences against person and property - the men of brutal violence, the highwaymen, the robbers, the habitual thieves, and the receivers of stolen goods, the worst of the swindlers, forgers, cheats, coiners, and such like-in fact the most unrestrained temperaments of a continent. These considerations show the scale of the work, and the nature of the task. 
"The convict comes to the Andamans a creature who, by his life or his acts, has shown himself to be so unfitted for human society that he has been cast out of it for life, or for a long term of years. Received thus, he is first subjected for six months to a most severe discipline-hard, rigid, uncompromising. He is taught what it is like to be forced to bend his uncontrolled nature to the iron yoke of a réginne, not of hard toil, but of soul-crushing monotony. From the stern Cellular Jail he is next transferred to one of the associated jails, to the comparative blessing of hard labour, in company with others, but still under a strict discipline. He works and feeds with others in gangs, and there is a certain variety in the tasks demanded, but he still sleeps in his separate cell. Here he stays for a year and a half, and then for the next three years he is a slave, as the word is ordinarily understood, locked up with other slaves in barracks at night, but working in the open at any kind of task that the needs of the Settlement may require of him, according to his capacity-an unpaid, unrewarded labourer, but well fed, housed, clothed, and cared for, and always under watch and guard. During the following five years he is still a labouring convict, but the severity of his life is eased down a little for him. He is now eligible for the petty posts of supervision, and for the less irksome and less slave-like forms of labour, and he gets a little-a very little-allowance, to buy a few small luxuries, or to place in the Savings Bank against future necessities. Having thus served ten long probationary years, he is eligible, if he has any capacity, to take a ticket-of-leave and become what is locally known as a self-supporter.

"The convict is now in a sense 'free.' He earns his living in his own chosen way; he lives in a village, in his own house; he farms a little land; he keeps cattle; he can move about unwatched; he can send for his wife and children, or, the far more frequent course, he can marry a convict woman, who, under her own regulations, is eligible for marriage. He can thus become pater familias, with a little hoard of his own earning, and differing outwardly in no way from the ordinary villager or properly conducted member of human society. In reality, however, he differs so greatly, that he misses all those things that 'free' men prize so highly. He has no civil rights under the ordinary law, and all the affairs of his life are dealt with by the executive authority. He must live where he is told; and generally conduct his life as 
he is told; he may move about beyond his village and his fields by permission only; he cannot leave the Settlement; he may not be idle, under pain of a forced return to convict labour. In this state he remains ten or fifteen years, according to the crimes that have sent him here, until the happy day comes when the order for absolute release is placed in his hands and he goes free as other men.

"As in the other portions of his life in transportation, even in the condition of self-supporter the convict passes through two distinct stages. In the first stage he is assisted at the beginning with house, food, and tools, and then by exemption from rent, taxes, fees, and other cesses payable by the free towards the common benefit. In the second stage he receives no assistance whatever, but finds the whole of his means of livelihood, and is charged with every public payment which would be exacted from him in his own country.

"The women are dealt with on the same lines, but more gently, as becomes the gentler sex. For the first three years the convict woman works in the Female Jail as a mere slave, fed, housed, clothed, and cared for. Then for two years she is treated to the same casing down of severity as is granted to the men, and after a total of five years she is eligible for marriage and domestic service. Assuming that she marries, she joins her husband in his village, where she leads the ordinary life of an Indian woman, but subject to the same disabilities as her husband until she has completed fifteen years in transportation, when she may go free with him whithersoever he may go.

"Now through all this long education to useful citizenship there run continuous threads of practice in self-help and self-restraint, and of inducement to profit by the practice. The length of the convict's stay in the Cellular Jail depends entirely on his conduct in it, and so it remains throughout his career, up to the point of self-support. Efforts to behave well, and submission to control, mean promotion upwards from grade to grade in due course. Every serious lapse means the retarding of promotion, or actual retrogression. And when he has obtained his ticket-of-leave, it is to his own effort, his own thrift, his own steadiness, that he has solely to look for that little hoard which is to be so much to him when he goes back to his native land-no pauper, no mere jail-bird, no unwelcome burden on his relatives, but a self-respecting citizen, 


\section{ANDAMAN ISLANDS AND INHABITAN'TS}

with a little capital of his own earning, for years habituated to provide for himself in an orderly way, and thoroughly broken to harness as it were.

"It does not require much imagination to contrast the difference in the personality of the same human being as he reaches and leaves Port Blair. He that arrived an outcast, void of restraint, and unfit for association with his kind on equal terms, goes forth a useful citizen, broken to restraint, and not only fitted for human society, but well used to submit to the conventions by which alone that society can be maintained. And men so reformed are not sent back to India by ones and twos, but by scores every year. Every one of the life convicts sent home is such a man. The incorrigible are kept till death, and the slow to learn are kept until they mend their ways, while those only that have good in them, and are capable of reform, are returned to the society they once disgraced.

"The difference between transportation to Port Blair and imprisonment in a jail lies in this very matter. While the Port Blair returned convict is a man fitted to, and habituated to, support himself, the prisoner released from a jail is not only a pauper but has became pauperised. That is, he has become unaccustomed to find for himself, and this disability has grown upon him with the length of his imprisonment. On this important ground alone, one cannot help hoping that some day it may be found feasible to extend the Andaman System to long-term prisoners from India.

"Besides the direct personal cducation that the Port Blair convict receives, he is taught various lessons of general importance in indirect ways. There is the value of justice, for instance. For though his life is absolutely controlled by executive officers, everything that happens to him is the result of a quasi-judicial procedure. No punishment can be inflicted without a proceeding, without registration, or without record of the evidence on which it is awarded. There is a regular course of appeal, and a further untrammelled appeal to the Head of the Administration himself. Thus, though the punishments in such a place as Port Blair must on occasion assume a form of deterrent severity, there is as much security of justice in award as elsewhere.

"Then there is the system of local marriage. This is no concubinage, no temporary or irregular alliance. Every inquiry is 
made and every step is taken that is necessary to render convict marriages legal, according to the customary personal law of the contracting parties. Long is the waiting in many cases between proposal and completion, and many are the disappointments when the conditions are found to bar completion. Once married, the husband and wife are made to clearly realise their condition, and must depart together or not at all.

"The children, of course, are a very serious question, but the best is done for them,-their health is so well cared for, that in Port Blair, probably alone in all the East, it is the rule to successfully rear the whole of a young family; primary education is here compulsory, again probably alone in all the East; and technical training is free to all. Their inheritance of temperament and their early associations are the points of anxiety regarding them, but these matters may be fairly said to be beyond control.*

"The Savings Bank has already been mentioned as a factor in the education of the convict. How great has been the effect of this beneficent institution will be seen from the fact that it was started twenty-seven years ago with 54 accounts, and is now, and has for years past been, the largest local bank of the kind in India. It has now over 2300 open convict accounts, and has had 12,000 accounts opened during its existence. This means, that for years, more than one fourth of the whole body of the convicts have kept their savings in it, thus showing how well they have taken to heart the lessons of thrift and of faith in the honesty of the Government.

"But far be it from concealing the fact that there is a seamy side to life in Port Blair. It could not be otherwise; and it would be easy enough to paint a lurid picture of its inhabitants,-easy enough to preach a scathing condemnation of the envy, hatred, and malice, the uncharitableness, the evil-speaking, lying and slandering, the murder and the cruel death, of the amazing immorality, the callous depravity, the downright unabashed wickedness, that are so constantly forced upon the view. But such is not to the purpose. Human faults are easily seen and easily denounced, for such things lie on the surface. The difficult thing always is to perceive aright the good that there

* Vide Appendix E. 
is in bad men, and bring that out, and that is the object that the Government is aiming at in the system just explained.

"Any one observing the work of the English in the East may possibly be struck with the idea that the reason for the acknowledged capacity of the race for colonial enterprise and the maintenance of empire is the ability and the willingness of the average Englishman to put his hand to any kind of work that may come his way, without any special training, from framing suitable laws and regulations and creating suitable organisations to making roads and ditches, building houses, and clearing land and ploughing it. Here in Port Blair, the officers entrusted with the creation, organisation, and maintenance of the Penal Settlement, have, without any special training for the work, and without any special guidance and teaching, managed with the worst possible material to work upon-life and long-term convicts from every part of India and Burma - to create in little more than forty years, upon primeval forest and swamp, situated in an enervating, and until mastered, a deadly climate, a community supporting itself in regard to many of its complicated wants.

"They began with the dense forests, the fetid swamps, and the pestilential coral banks of tropical islands, and have made out of them many square miles of grass and arable lands, supporting over fifty villages besides convict stations. Miles upon miles of swamp have been reclaimed, the coral banks have been controlled, and a place with regard to which the words climate and pestilence were almost synonymous has been turned into one favourably spoken of as to its healthiness. The Settlement now grows its own vegetables, tea,* coffee, cocoa, tapioca, and arrowroot; some of its ordinary food grains, and most of its fodder. It supplies itself with the greater part of its animal food, and all its fuel and salt. In other lines of work, it makes its own boats, and provides from its own resources the bulk of the materials for its buildings, which are constructed and erected locally. Amongst the materials produced are all the timber, stone, bricks, lime, and mortar, and most of the iron and metal work are made up there from raw material. In the matter of convict clothing, all that is neccssary to be purchased elsewhere are the roughest of cotton hanks

* Orange Pekoe and Pekoe Souchong. 
and wool in the first and rawest condition, every other operation being performed on the spot. It provides much of its own leather.

"In achieving the results, the officers have had first to learn for themselves as best they could how to turn out the work to hand, and then to teach what they had learnt to the most unpromising pupils that can be imagined,-only about 3 per cent. of the convicts sent there having been previously employed on the work required of them in Port Blair. And they have been hampered all along by the necessities of convict discipline, by the constant release of their men, and their punishment for misconduct. It is under such conditions that the Corps of Artificers and the other convicts have had to be utilised. Nevertheless, the roads and drains, the buildings and boats, the embankments and reservoirs, are as good and durable as are the same class of structures elsewhere. The manufactures are sufficient for their purpose, and there are among the taught those who are now skilled in the use of many kinds of machinery. Cultivation is generally fair, and some of it very good. The general sanitation-but here there are peculiar advantages-is literally second to none." *

First of all the industries of the Andamans is that of timber, and to accelerate and increase it a Steam Tramway has been instituted, and there are now some 14 miles of line connecting the forests with the shores of Port Blair. As a further adjunct, Steam Saw-mills were erected in 1896 , and a Forest Department, that employs 500 to 600 men daily under its own officers, not only supplies the Settlement with the whole of its requirements in timber from the local forests, but also exports timber and forest produce to various places in India and Europe. Of these latter exports, rattans and gurjan oil are the chief; other natural products of the islands are trepang-bêche-de-mertortoiseshell and edible birds' nests, but they are only collected in small quantities.

* The foregoing information relating to the convict system and the progress of the Settlement is extracted from addresses by the Chief Commissioner (Lieutenant-Colonel R. C. Temple) to the Andaman Commission; vide Supplements, Andaman and Nicabar Gazette, July 1897, and February 190I. 
The principal cultivations in which convicts and ex-convicts are engaged are paddy, sugar-cane, Indian corn, and turmeric; coconuts have during the past thirty-five years been extensively planted, and besides the agricultural products previously mentioned, vegetables and fruits of various kinds are grown.

The larger industries in which the penal community is engaged in have already been alluded to, but there are many minor employments, the products from which also go towards making the Settlement self-supporting. Amongst these are to be found the manufacture of all kinds of furniture, cane chairs, baskets, many varieties of bamboo-work and ornamental woodcarving, woven articles, from serviettes to saddle-girths and blankets, pottery, rope and mats, silver, tin, brass and iron work, shoemaking, rickshaw and cart building, besides the production of such materials as lime, bricks, and tiles.

Port Blair is in communication three, and often four times a month, with Calcutta, Madras, and Rangoon, by the vessels of the Asiatic Steam Navigation Company. The distances between the Settlement and the ports named are 796,780 , and 387 miles respectively. 


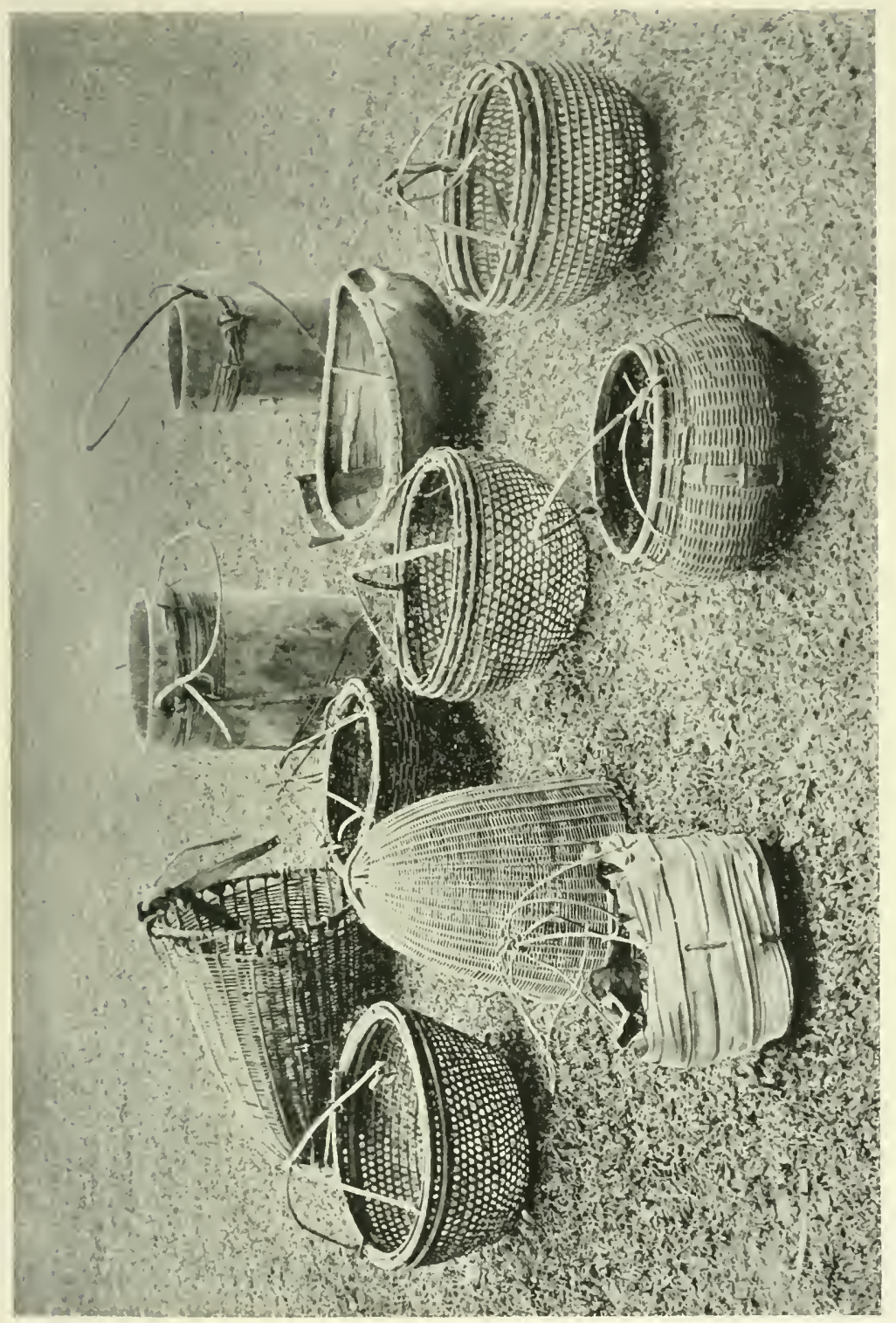

ำ 



\section{CHAPTER II}

THE NICOBAR ISLANDS AND THEIR ABORIGINES

The Nicobar Islands and their Aborigines-The Islands-Coral BanksNankauri Harbour-Population-Geology-Earthquakes-Climate-Flora - History - The Shom Pen : their Derivation, Appearance, Houses, Gardens, Cooking-vessel, Domestic Animals, Manufactures, Trade, Clothing, Headmen, Position of Women, Disposition, Diseases.

THE Nicobars lie 80 miles south of the Andaman group and I IO miles from Sumatra proper, and constitute a chain of islands 160 miles long, lying in a N.N.W. $\frac{1}{2}$ W. direction, with a branch forking out from their centre $N$. by $E$. The area of the group is about 600 square miles, and it consists of some twenty islands, of which the principal are, Kar Nicobar, Batti Malv, Tilanchong, Chaura, Teressa, Bompoka, Kamorta, Trinkat, Nankauri, Kachal, Little Nicobar, and Great Nicobar.

Besides these, there are several small satellite islands: Great Nicobar possesses Kondul and Kabra; Little Nicobar, Milo and Menchal, with Treis, Trak, and Meroë further off; and lastly, near the south extremity of Tilanchong, there is the rocky islet named "Isle of Man." * There are villages on Kondul and Milo, but Batti Malv and Tilanchong are uninhabited.

Two large isolated coral banks occur-one near Chaura, with only $I \frac{1}{2}$ fathoms of water; and another, far more extensive, in the Sombrero Channel, with I I fathoms of water above it.

Although the Nicobar Islands are scarcely ever heard of, the China Mail boats and other great ocean steamers pass almost in sight of them nearly every day, and they possess in 
the central group one of the finest harbours in the eastern seas. Nankauri Harbour has not only entrances on the east and west, that make it practicable for any sort of vessel in both monsoons, but these are further protected by the islands of Trinkat and Kachal respectively, which give sheltered anchorage outside the mouth of the harbour itself.

By any other nation than the British it would be highly valued at the present time as a coaling station, but, owing to its proximity to the Straits Settlements, and the failure of the small islands around to produce anything more valuable than coconuts, it is completely neglected by its possessors, from both commercial and strategical standpoints.

The natives of the group number at present a few short of 6000 (to which should be added a possible 300-400 Shom Peni), and there are generally some 200 foreigners resident in the north during the trading monsoon. The islands increase in size as they are passed towards the south, but the contrary is the case with regard to population, which decreases regularly, island by island, with one or two exceptions, from Kar Nicobar in the north with $345 \mathrm{I}$ inhabitants, to Great Nicobar with only 87 **

"The Nicobar Islands belong to an area of elevation which can be traced from the Bay of Bengal far into the southern seas, $\dagger$ and is characterised by two phenomena: first, the activity of the interior of the earth, showing itself in volcanic action; and secondly, the activity of the coralline animals, disclosing

* Vide Appendix H.

+ "All along this great line of volcanoes are to be found more or less palpable signs of upheaval and depression of land . . . ; upraised coral-rock, exactly corresponding to that now forming in adjacent seas ...; unaltered surfaces of the elevated reefs, with great masses of coral standing up in their natural position, and hundreds of shells, so fresh-looking that it was hard to believe that they had been more than a few years out of the water.

"The width of the volcanic belts is about 50 miles; but, for a space of 200 on each side of them, evidences of subterranean action are to be found in recently elevated coral rock or in barrier coral reefs, indicating recent submergence."-Cf. "Andamans," The Malay Archipclago, A. R. Wallace, pp. 5,6 . 
itself in the formation of that kind of coral reefs known as fringing or coast reefs. The islands occupy a gap without volcanoes between the volcanic ranges of Sumatra, and Barren and Narkondam Islands, and the occurrence of young volcanic rock in them is improbable. They are distinctly characterised as a portion of the chain of oceanic elevation which began in former geological periods and still continues, by the upheaved coral banks, and by the continuous formation of coral reefs. The synclinals and anticlinals in the gcological structure of the islands are coincident with the direction of the great geological line of elevation which connects the northern part of Sumatra with the Andamans.

"Among the geological formations of the Nicobars, three are the most important:-(I) An eruptive serpentine, with gabbro formation. (2) Marine deposits, probably of a younger Tertiary age, consisting of sandstone, slates, clay marls, and plastic clay.

(3) Recent coral-reef formations.

"The serpentine and gabbro formation is characteristically of an eruptive nature. The Tertiary sandstones, slates, and clay marls appear forcibly broken through; their strata is partly inclined, partly bent in flat, parallel, wave-like undulations. These rocks are accompanied by coarser and finer breccias, composed of angular fragments of these same rocks, and they can partly be regarded as friction breccias, partly as sedimentary tufas, in which beds of an argillaceous marl are interstratified. The eruption of these plutonic masses appears therefore to fall in a time when the formation of the marine deposits was partially completed, partially still in progress. They broke through on lines of fracture, of which the principal strike from S.S.E. to N.N.W. agrees with the longitudinal extension of the islands. On the middle islands the serpentine and gabbro attain their greatest development: on Tilanchong, Teressa, Bompoka, Kamorta, and Nankauri, they form bare hill ranges of $200-500$ feet, and their configuration often marvellously resembles that of younger volcanic formations. The elevatory power has, however, acted most strongly on the southern islands, and has here upheaved sandstones and slates to heights of I 500-2000 feet above sea-level; on the northern islands the same power was, on the contrary, weakest.

"The clay marls of the northern and central islands (Kar 


\section{NICOBAR ISLANDS AND ABORIGINES}

Nicobar, Teressa, Bompoka, Kamorta, Trinkat, and Nankauri) and the sandstones and slates of the southern (Kachal, Little and Great Nicobar) appear to be only petrologically different products of one and the same period of deposition. There are, at the same time, very few materials from which the age of the marine formation could be determined, as the only fossil remains which have been found in their strata are fragments of driftwood changed to brown coal, plants resembling Fucoids, Foraminifera, and Polycistince. All these indicate more or less distinctly a young Tertiary age.

"We find a repetition of the geological condition of the Nicobars on the southern coast of Java and the south-west coast of Sumatra.

"The third principal formation of the Nicobars are coral formations belonging to the most recent or the present period. Coral banks of great thickness are found on Kar Nicobar, Bompoka, Trinkat, and other islands. They consist partly of compact coral limestone, partly of a coral and shell conglomerate upheaved 30 or 40 feet above the present level of the sea. On all the islands the original area is to be observed enlarged by coral land which is only separated by the higher sand-dunes along the shores from the still continuing formation of the coral reefs surrounding all the islands in the character of fringing reefs. Although these raised coral banks are decided evidence of the long-continued upheaval of the islands-that, in connection with the eruption of the serpentines and gabbros-the formation of the flat coral lands elevated a few feet only above the sea, can, on the other hand, be explained by the accumulation of coral fragments, of sand and shells, by the waves and breakers on the shallow surface of the fringing reefs." *

Coal of a brown variety has been found in Little Nicobar, Treis, Milo, and Kondul, but everywhere in isolated masses and single fragments, showing traces of rolling, met with here and there without order, in sandstone and slate, and evidently derived from driftwood.

The only traces of minerals discovered have been ores of

*Vide paper on the "Geology of the Nicobars," by F. von Hochstetter, translated by Dr Stoliczka, Proc. Geol. Survey, India. 
copper and iron pyrites, finely disseminated through dioritic and serpentine rocks. The possibility of the occurrence of copper ores in the eruptive formation cannot be denied, but no discovery has yet been made which would indicate it. On the other hand, the islands are rich in useful building materials. The sandstone of the southern islands must give excellent working stones; the plastic clays of the north could, doubtless, be worked into bricks or pottery; the natives of Chaura largely employ it in their earthenware manufactures.

Although the islands are generally beyond the sphere of cyclonic disturbances, they have more than once experienced the effect of earthquakes. One of the most remarkable of these is said to have occurred from October 3 I to December 5, I847, when fire is reported to have been seen on one of the mountains of Great Nicobar. Part of the northern coast of the latter, especially in the vicinity of Ganges Harbour, sank beneath the sea, and for long the locality was deserted by the aborigines.*

On December I88I, an earthquake, felt also at the Andamans and throughout the Bengal Sea generally, caused extensive damage in Kar Nicobar to the coconut groves and huts of the natives. Vents were opened in the sandy soil; inland, trees were overthrown; sea-waves broke on the island, and at the village of Mūs, water rose into the houses of the Burmese traders, which stood on platforms $2 \frac{1}{2}$ feet high.

There was another earthquake at Kar Nicobar in November 1899, when strong, but not alarming, shocks, lasting ten minutes, were experienced. The last occurred on September 18, 1900, when two heavy and severe shocks, each lasting five minutes, were felt throughout the island, but caused no damage.

The climate of the Nicobars is more uniform than that of the Andamans, for it is less diversified by wet and dry seasons, heat and cold, and in this respect resembles that of the Malay Peninsula at the same latitude. The prevalence of malaria renders the group unhealthy alike for foreigners and, in certain localities, for the natives, and all the attempts at settlement

$$
\text { * Vide p. I37. }
$$


have resulted in great mortality from this cause, although where jungle exists an improvement is said to have taken place when the land has been cleared.

The average mean annual temperature is about $82.5^{\circ}$, the maximum in the shade between $93^{\circ}$ and $94^{\circ}$ and the minimum $73^{\circ}$. March and April are the hottest months, with means of $82^{\circ}$ and $83^{\circ}$ and a maximum of $89^{\circ}$, while August to Decemberwhen the mean temperature is $79^{\circ}$-is the coolest part of the year. The mean annual temperature at Nankauri is $80^{\circ}$, and while the highest reading recorded is $99^{\circ}$, the lowest is $70^{\circ}$. The mean diurnal range there varies between $9^{\circ}$ and II $^{\circ}$ only.

Although the seasons of the monsoons are the same, they are not so well defined among the Nicobars as on the coast of the Bay of Bengal generally; but heavy rains occur in May, June and July - when the south-west monsoon is at its heightand rains rarely cease until December. March is the driest month, and while from May to December there is an average monthly rainfall of 12 inches, with twenty wet days per month, for the rest of the year the monthly average is only 2.9 inches, with showers on twenty-six days only.

At Nankauri the mean humidity is 79 per cent., and the annual rainfall I 10 inches; while, as regards the southern group of islands, there is good ground for the belief that much more rain falls, probably not less than an average of 150 inches annually; this is doubtless attributable to the forest-clad mountains of Great and Little Nicobar.

The prevailing winds are the monsoons-the south-west from the beginning of May till mid-October, followed by variable winds to the end of the year; the north-east monsoon from January until April, with an interval of more variable winds before the other sets in. Hurricanes seldom visit the islands, but in March 1892 the central group was subjected to a cyclone which caused much destruction in the forest. During the southwest monsoon frequent thunderstorms and gales of wind occur, especially in the vicinity of Great Nicobar. The north-east 
monsoon brings fine weather, but sometimes blows with considerable strength.

A remarkable feature of the Nicobars is the manner in which the general botanical appearance of the islands coincides with the geological division, for, while the southern group (Great and Little Nicobar with Kachal) are wooded from beach to summit, the forests of the other islands are restricted to the plutonic rocks and the slopes and dells of the older alluvium, while the hilly plateaux and ridges are covered with park-like grass heaths.

The most prominent features of the flora are, perhaps, the quantities of Barringtonia speciosa, which, with their large shiny leaves and beautiful crimson-tipped tassel-like blossoms, grow all along the coasts; the tall screw-pines (Pandanus larum), bearing the immense fruits that provide the main food of the natives; and the graceful Nicobar palms (Ptychoraphis augusta), which occur in all the forests. Giant bamboos are extremely scarce, but the climbing species (Dinachloa) is common everywhere in the jungle, and beautiful tree ferns (Alsophila albo-setacea) grow in the forest and along the river banks of the south.

A mangosteen (Garcinia, sp.) and a cinnamon (Cinnamomum obtusifolium) grow wild, as do the pepper vine (Piper betel) that supplies the sireh leaf, and the betel palm (Areca catechu). These two are also cultivated, and it is said that the latter is not indigenous.

The large numbers of milky climbers leads to the hope that some rubber-yielding varieties may be discovered capable of supplying a sufficient quantity of raw material for export. The vanilla orchid occurs, and the southern forests produce quantities of rattan, both as a small variety that is exported, and a large cane two inches or so in diameter, which the natives use for the horizontal rafters in the circular framework of their houses.

Semecarpus heterophyllus, Morinda citrifolia, Artocarpus lakoocha, and A. chaplasha, Cordia mixa, Mallotus philipenensis, and Amomum fenzlii, may be mentioned specially as species capable of yielding commercial products; but their sparseness, 
coupled with the fact that it is easier and cheaper to cover the soil with coconuts and areca palms, puts out of the question the possibility of utilising the species to any profit.

The Nicobars produce few trees of any commercial value as timber, and those probably not in large quantities: the best of these are Myristica irya and Terminalia bialata, and of secondary value in this respect are Mimusops littoralis, Hopea odorata, Artocarpus chaplasha and lakoocha, Calophyllum spectabile, Terminalia procera and species of Garcinias.

Evergreen forest predominates, and mixed forest appears only occasionally, but pure leaf-shedding forest is not met with; and as regards species, there is a marked absence of Dipterocarpus trees.

It is in the writings of Ptolemy that we find the first probable reference to the Nicobars, for after the Andamans, the next group mentioned by him is the "Barussae," which seems to be the Lankha Báli's of the older Arab navigators, since these are certainly the Nicobars.* The islands were also known to the same voyagers under the names of Megabalu and Legabalu.

The Chinese, another race of great navigators in these seas, have records of the Nicobars for a thousand years and more.

The next reference of any importance is that of an Arab trader who came into contact with the group during a voyage to Southern China in $85 \mathrm{I}$ A.D. $†$ "Nagabalus, which are pretty well peopled: both the men and women there go naked, except that the women conceal their private parts with leaves of trees. When shipping is among these islands, the inhabitants come off in embarkations, and bring with them ambergris and coconuts, which they truck for iron, for they want no clothing, being free from the inconveniences of heat or cold."

Rashuddin writes of the islands in nearly the same terms,

* Sir Henry Yule.

+ Vide translation by the Abbé Renaudet, in Pinkerton's Collection of Travels, p. 183 . 
under the name of Lakvárem, opposite Lamuri (a kingdom of Sumatra), and the very imaginatively-minded author, Friar Oderic,* compiled a chapter on Nicoveran which is a mass of the wildest fable, utterly unworthy of credence, containing, as it does, details of people with faces like dogs, who are stout in battle (not a characteristic of the modern Nicobarese) and worshippers of the ox, while their king possessed strings of pearls, and the largest ruby in the world.

"Concerning the island of Necuveran, when you leave the island of Java the less (Sumatra) and the kingdom of Lambri, you sail north almost I 50 miles and then you come to two islands, one of which (Great Nicobar) is called Necuveran. In this island they have no king nor chief, but live like beasts. And I tell you they all go naked, both men and women, and do not use the slightest covering of any kind. They are idolaters. Their woods are all of noble and valuable kinds of trees; such as Red Sanders, and Indian-nut, and Cloves, and Brazil, and sundry other good spices. There is nothing else worth relating," says Marco Polo, who probably only passed near the islands in or about the year I293, but who gathered fairly accurate information about them.

After the Cape of Good Hope was doubled in 1497, the islands were frequented by voyagers, as expeditions to the East became more numerous.

"It was the Nicobar custom in 1566," says Master Casar Frederike, that "if any ship come near to that place or coast as they pass that way, as in my voyage it happened, as I came from Malacca through the channel of Sombrero, there came two of their barques near our ship, laden with fruit, as with monces (which we call Adam's apples, which fruit is like to our turnips, but is very sweet and good to eat). They would not come into the ship for anything we could do, neither would they take any money for their fruit, but they would truck for old shirts or old linen breeches. These rags we let down with a rope into their barque unto them, and look what they thought their things to be worth; so much fruit they would make fast to the rope, and let us hale it in: and

$$
\text { * "Travels, A.D. I31 j-1 330," Hakluyt Library. }
$$


it was told me that sometimes a man shall have for an old shirt a good piece of amber." *

In his East A frica and Malabar, $\uparrow$ Barbosa refers shortly to the Nicobars. "In front of Sumatra, across the Gulf of the Ganges, are five or six small islands, which have very good water and ports for ships: they are inhabited by Gentiles, poor people, they are called Niconbar; and they find in them very good amber, which they carry thence to Malacca and other ports."

Captain John Davis, of Arctic fame, the inventor of the "back-staff," the earliest form of quadrant, piloted a Dutch ship to the East Indies, and touched, in 1599 , at the Central Nicobars. He wrote that ". . . the people brought in great store of hens, oranges, lemons, and other fruit, and some ambergris which we bought for pieces of linen cloth and table napkins. These isles are pleasant and fruitful, lowland, and have good road for ships. The people are most base, only living upon fruits and fish, not manuring the ground, and therefore having no rice." +

During the reign of Elizabeth, Sir James Lancaster made several voyages to the East Indies, and touched at the Nicobars. Two of his officers, Barker and May, have chronicled a visit to the islands in 1592 , in a description that would apply more accurately to the Pulo Wai group. "The islands of Nicobar," says Barker, "we found inhabited with Moors, and after we came to an anchor, the people came aboard us in their canoes with hens, cocos, plantains, and other fruits, and in two days they brought to us royals of plate, giving us them for calicut cloth, which royals they find by diving for them in the sea, which were lost not long before by two Portugal ships which were bound for China and were cast away there. They call in their language the coco, calambe (Malay, klapa); the plantain, pison (Mal., pisang); a hen, iam (Mal., ayam); a fish, iccan (Mal., ikan); and a hog, babi (Mal., babi)"; and May, the other writer, says that the natives were in religion Mohammedans.

* Extractes of Master Casar Frederike: his Eighteen Yeeres Indian Observations. Purchas: his Pilgrimes, vol. ii., p. 1710.

+ Hakluyt Library.

$\ddagger$ Purchas: his Pilgrimes, vol. i., p. I23. 
Lancaster's own account of the "Islands of Nicobar" is more interesting, and is based on his experiences there in 1602. Of either Pulo Milo or Kondul he writes:-

"Here we had fresh water and some coconuts, other refreshing had we none. Yet the people came aboard our ships in long canoes which would hold twenty men in one of them, and brought gums to sell instead of amber, and therewithal deceived divers of our men: for these people of the east are wholly given to deceit. They brought us hens and coconuts to sell, but held them very dear, so that we bought few of them. We stayed here ten days. ...

"We were forced to go to the island of Sombrero (the Portuguese name for Chaura) some Io or 12 leagues to the northward of Little Nicobar. Here we lost an anchor, for the ground is foul and groweth full of counterfeit coral and some rocks, which cut our cable asunder.

"The people of these islands go naked, having only the privities bound up in a piece of linen cloth, which cometh about their middles like a girdle and so between their twist. They are all of a tawny colour, and anoint their faces with divers colours: they are well limbed, but very fearful: for none of them would come aboard our ships, or enter our boats.

"The General reported that he had seen some of their priests all apparelled, but close to their bodies, as if they had been sewed in it; and upon their heads a pair of horns turning backwards (tá-chökla), with their faces painted green, black, and yellow, and their horns also painted the same colour. And behind them, upon their buttocks, a tail hanging down very much like in the manner as in some painted clothes we paint the devil in our country. He demanding wherefore they went in that attire, answer was made him, that in such form the devil appeared to them in their sacrifices, and therefore the priests, his servants, were so apparelled. In this island grow trees which for their tallness, greatness, and straightness will serve the biggest ships in all our fleet for a mainmast, and the island is full of these trees." This description of the island cannot be said to be applicable at the present day.

"Here likewise we found upon the sand by the seaside a small twig (Virgularia mirabilis?) growing up to a grand tree, 
and offering to pluck the same, it shrunk down into the ground, and sinketh unless you hold very hard. And being plucked up, a great worm is at the root of it: and look how the tree groweth in greatness the worm diminisheth. Now as soon as the worm is wholly turned into the tree it rooteth in the ground, and so groweth to be great. This transformation is one of the strangest wonders I saw in all my travels. For the tree being plucked up little, the leaves stripped off, and the pill by that time it was dry, turned into an hard stone, much like to white coral; so that the worm was twice transformed with different natures: of these we gathered and brought home many." *

Towards the middle of the century, Koeping, a Swede, touched at one of the islands in a Dutch vessel and thought he perceived men with tails, "like those of cats, which they move in the same manner," but he was deceived by the peculiar clothing. He further credits the Nicobarese with cannibalism, for a boat's crew of five men that went ashore never returned, but next day their bones were found strewn over the beach! $\uparrow$ Next, Dampier was put ashore by the privateer he piloted on the N.W. coast of Great Nicobar, and after a short sojourn left with his companions in a native canoe, and succeeded in reaching Sumatra.

The first recorded murder of a European by the natives seems to be that of Captain Owen, who was wrecked on Tilanchong, and from thence taken to Nankauri, where he was put to death on account of his ill-judged behaviour towards the inhabitants. This incident is related by Hamilton in his account of his own experiences in the East Indies from 1688 to $1723, \ddagger$ where he gives a little information about the Nicobars.

The first attempt at a settlement on the islands was made by Jesuits on Kar Nicobar in I7II, but they succumbed to the climate, and the effects of such results as they had attained to soon disappeared. Hitherto no efforts had been made to

* Lancaster's "Three Voyages to the East Indies," Hakluyt Library.

† Koeping, Stockholm, 1743 .

$\ddagger$ Pinkerton's Collection of Voyages. 
convert the natives, although missionaries of the same denomination were well acquainted with the group.

In 1756 Tanck took possession of the Archipelago in the name of Denmark, and under the designation of "Frederiks Oerne," and founded a colony on the north coast of Great Nicobar, which in 1760 was transferred to Kamorta, and there came to an end owing to the unhealthy climate.

In I766 fourteen Moravians were installed on Nankauri, with a view to extending the influence of the Danish East India Company, but in a dozen years nearly every member of the settlement was dead. They are said to have made no conversions.

A Dane, named Koenig, who was a doctor of the same religious body, voyaging from India to Siam in 1778 , spent several hours on Kar Nicobar, and in his diary left some account of his visit; and almost contemporaneously a vessel under the Austrian flag, the Joseph and Theresa, Captain Bennet, anchored off the northern island: her voyage was made to obtain plantations and trading stations in the East for the Austrian Empire. This was the scheme of a Dutchman, named Bolts, who entered the Austrian service in 1775 , and who accompanied the ship, a chartered English vessel with an English crew. The expedition spent five months in the group: a fort was erected on the island, and ships purchased to trade between Madras, Pegu, and the Nicobars. War in Europe ruined the company, and it was suspended after an existence of seven years.

In 1779 two more Moravians settled on Nankauri, in an attempt to found a fresh Danish Mission, but eight years later this was abandoned, and the survivor returned to Europe.

With the commencement of the nineteenth century, English traders from India began to visit the islands for coconuts, and, through contact with their crews, the custom and life of the natives seems to have undergone much growth and alteration.

In I83r Denmark made a last attempt to colonise the group by missionary enterprise, and Pastor Rosen was sent out. He dwelt on Nankauri, in the middle of the north side of the 
harbour, and for a time also lived on Trinkat; but after three years he returned to Europe, and some time later published his experiences.

The year Rosen left, two Catholic missionaries arrived at Kar Nicobar from Malacca, and lived on Teressa and Kamorta, but after a time one of them, Borie, died of fever, and the survivor left. This was the last of the series of missionary endeavours to found a settlement and convert the inhabitants.

In I845, Mr Mackay, Danish Consul at Calcutta, chartered a schooner and made a voyage to the group in search of coal, which was prospected for without success.*

A year later the Danish corvette Galathea, $\dagger$ voyaging round the world, spent some months among the islands, and her commander, Steen Bille, took possession of the central group for Denmark, and invested two natives with the insignia of chief magistrates. Two years afterwards, however, the Valkyrien was sent to the islands to bring away the flags and bâtons, and the last of several ineffective annexations came to an end. The Galathea expedition surveyed much of the coasts, sought for coal and other minerals, and named the principal river the "Galathea."

In 1858 the Austrian frigate Novara spent a month in the group, during which, half the time was passed at sea. Many parts hitherto unsurveyed were charted by them, and valuable knowledge as to the ethnographical and geological conditions of the islands was obtained.

The islands were finally taken possession of by the Indian Government in I869-the British had officially annexed the group in I 807 , but not occupied it-and a settlement was formed at Nankauri Harbour to check the piratical proceedings of that place, and although this was given up in 1888, after it had served its purpose, the history of the Nicobars is now bound up with that of the Andamans, to which they are affiliated.

* H. Busch's Journal of a Cruise round the Nicobars.

+ Corvetten Galathea's Jordourseiling, Steen Bille, 2 vols., Kjöbenhaven, 1852.

† Voyage of the Novara, Dr Karl Scherzer, 3 vols., London, 1862. 


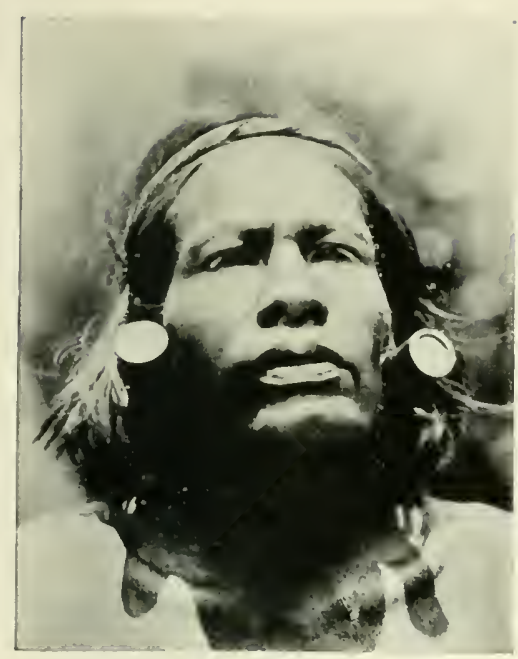

MAN OF THE SHOM PEN.

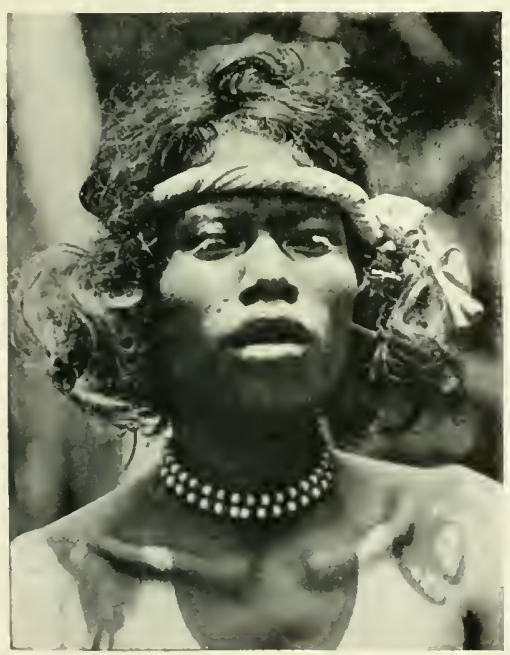

MAN OF THE SHOM PEX.

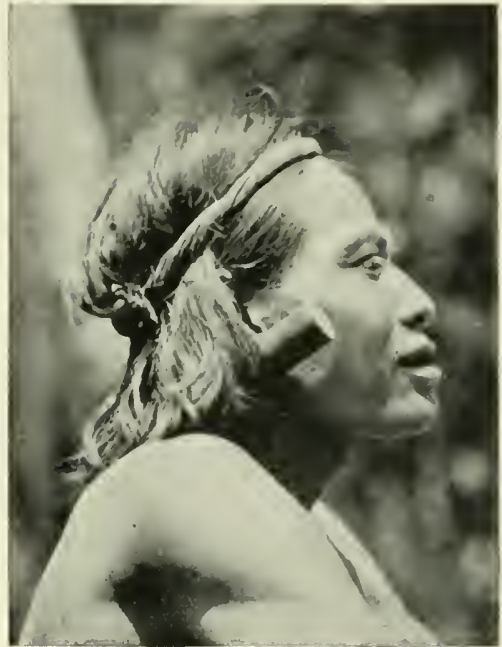

MAN OF THE SIIOM PEN (in profile).

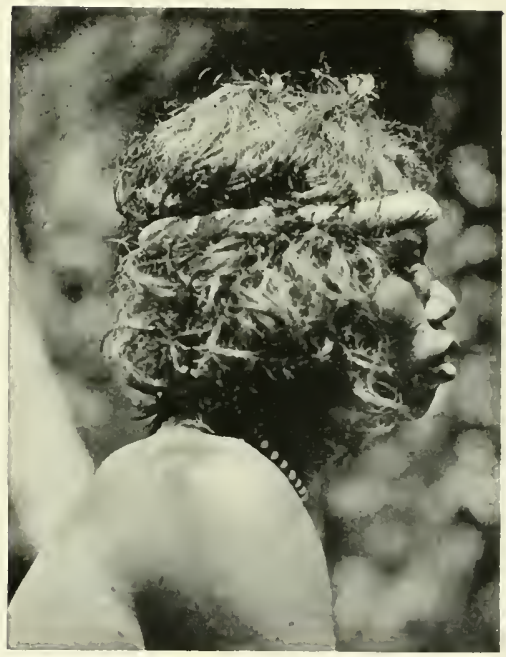

MAN OF THE SHOM IEN (in profile).

[To face page 214. 

Although the inhabitants of the Nicobar Islands were originally all of the same stock, various causes have contributed to bring about a distinction amongst them, and they are now separated into two distinct ethnical groups, - the Shom Pen of the interior of Great Nicobar, and the coast people, or Nicobarese, who are found in all the inhabited islands.

Of the Shom Pen but little is known, as, with the exception of a few families who have friendly intercourse with the coast villages, they have, as now constituted, always been persistently hostile to the Nicobarese, but it is probable that they number at most between 300 and 400 individuals.

It was for long believed that the interior of Great Nicobar was inhabited by a race of Negritoes akin to the Andamanese, but the Shom Pen are an isolated group of primitive Malayans, and although they must be regarded as the aborigines of the islands, many features amongst them point to the fact that they are no longer racially pure.

Not only does the facial appearance vary greatly, but the hair, which is universally regarded as an almost infallible indication of race amongst primitive peoples, occurs in all the grades between curly and straight.

To account for this latter difference, and for the dull brown colour of the skin-far darker than is usual amongst Malays-one may of course suggest remote Negrito admixture. Possibly the Andamanese, on one of the predatory voyages which it seems they were not unaccustomed to make in this direction,* may have reached the island, and for some reason unable to return, have intermixed with the inhabitants.

But I think it more probable that these peculiarities are due to a Dravidian strain, and that some mariners of this race, who, from before the time of Solomon, were accustomed to make trading voyages to the Eastern Archipelago, $\dagger$ became stranded

* "The people of Kar Nicobar have a tradition among them, that several canoes came from Andaman many years ago, and that the crews were all armed, and committed great depredations, and killed several of the Nico. barians."-Hamilton, Asiatic Researches, vol. ii.

+Achin, at the north-west extremity of the neighbouring island of Sumatra, 
on these islands, and incorporated themselves with the people they found there.

In this way, not only would the nature of the hair, colour of the skin, and occasional definiteness of feature, be accounted for, but the aborigines would be left as we now find them, unreduced in height, while mixture with the Andamanese would probably have the effect of lessening their stature.

Furthermore, I have, since my acquaintance with these people, occasionally met Tamils, whom, if I had seen similarly garbed in the forests of Great Nicobar, I believe I should have been unable to distinguish from Shom Pen.*

On the other hand, they much resemble, in appearance and mode of life, descriptions of many of the primitive Malayans who have intermixed with Negritoes. Of these the Kubus of Sumatra are an instance, $\dagger$ and of the Jakuns of Johore, who are believed to

appears to have been for ages before the arrival of Europeans the great mart for the Telingu traders, who, probably as early as 2000 B.C., carried from the Malay Peninsula the tin used by the Egyptians in making their bronze implements.

* "Commercial intercourse was maintained from a very early date between the South of India and the trading towns which formed the emporia of the spice islands, notably Johor, Singapore, and Malacca. When the Portuguese, at the commencement of the sixteenth century, first visited these places, they were amazed at the concourse of foreign vessels assembled there. When this intercourse began it is impossible to say, but it was probably much earlier than the above. Snouck-Hurgronje, writing of Acheh, says that the settlement of Klings from Southern lndia in that country is of great antiquity; and that the Tamils were the leaders in this commercial enterprise in Malaya is clearly shown by the pure Tamil words,-chiefly connected with commerce, though not altogether so,- -which have found their way into Malay. . . . The Malay for 'ship,' kapal, is pure Tamil ... the pure Tamil padagu, 'boat,' may reasonably be taken to be the parent of the Malay prahu. If this be so, it would seem as if the Tamils first introduced the Malays to even the most elementary navigation, and, as they gave them kapal, taught them to 'go down to the sea in ships.' . . . They do not seem to have settled down or intermixed with the Malays to any great extent,--not certainly so much as in Acheh, where considerable colonies of Tamils took up their abode. Their object being merely commerce, they went as they came, returning year by year as the monsoon favoured." "Southern India and the Straits," IV. A. O'Sullivan, Jour. Straits Branch Royal Asiatic Soc., No. 36, July 1901.

+ Vide pp. 235, 236, of $A$ Naturalists Wanderings in the Eastern Archipelago, by H. O. Forbes; London, Sampson Low, 1885. 


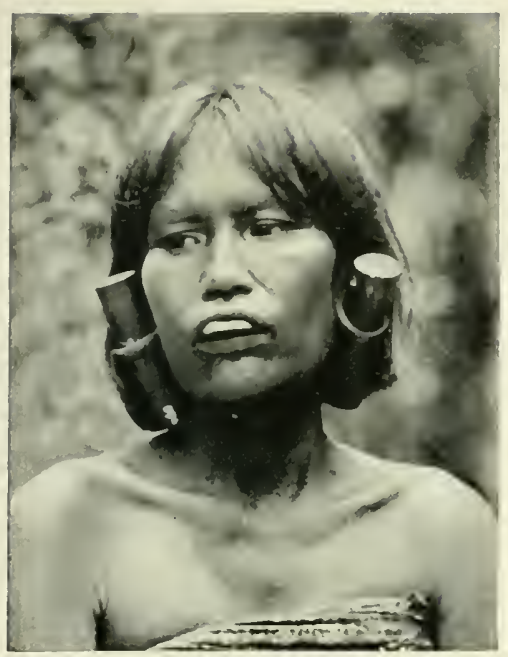

WOMAN OF THE SHOM PEN.

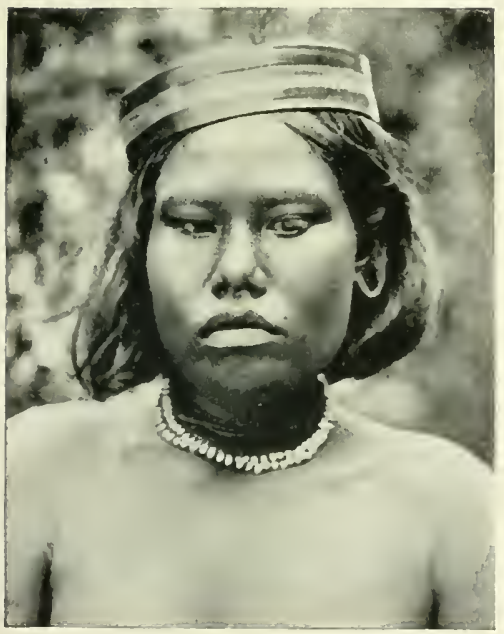

WOMAY OF THE SHOM PEN.

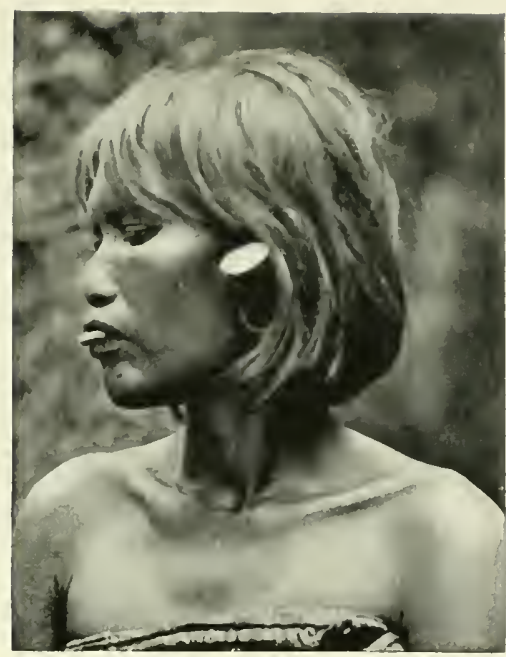

WOMAN OF THE SHOM PENं (in profile).

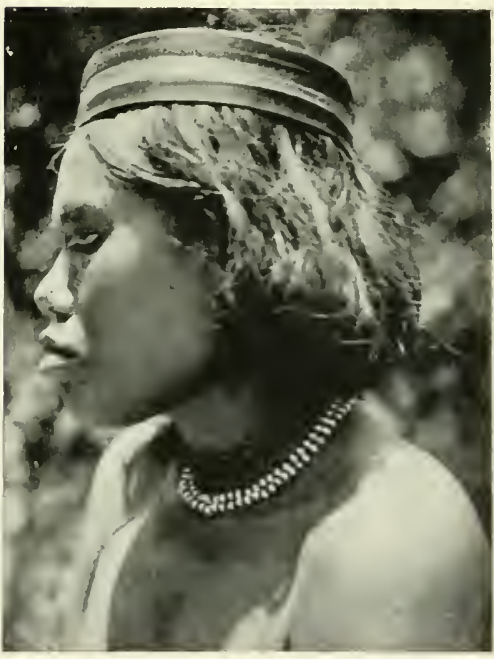

WOMAN OF TIE SIIOM PEN (in profile). 

be of Negrito origin, but much interbred with Malays. $\operatorname{Mr~} \mathrm{H}$. Lake* writes: "The true Jakun is of short stature, 5 feet 2 inches is a fair average height. They are much darker in colour than the Malay, and, as a rule, not so well set up. The hair, which in the pure Negrito curls closely, is here in most cases simply wavy, or even straight. They live in small communities, and subsist miserably on fruits, roots, etc. They seldom remain many weeks in the same spot, but wander from place to place, living under scanty shelters built on rickety poles at a considerable height from the ground. It is not uncommon to find a dozen in company, with a tame monkey or two, cats and dogs, living in perfect harmony under the same roof."

We may therefore consider the Shom Pen to be the aborigines of the group, who, although everywhere else either exterminated or absorbed by settlers from outside, have in Great Nicobar found a refuge in the forest depths, and by long-standing hostility to the intruders, arising from some unknown cause, have preserved to a great extent their natural traits and existence, although somewhat degenerated, both on account of the less favourable circumstances in which they live and of the interbreeding that the smallness of their numbers compels.

Although the Shom Pen are by measurement as tall in the average as the coast people, to the eye they appear smaller, and they are less robust, with lean though bony figures (average chest measurements, 35.2 inches), sinewy rather than muscular.

Fourteen measurements of adult males gave a maximum height of $67 \frac{3}{4}$ inches, a minimum of $62 \frac{1}{8}$ inches, and an average height of 64 inches. Of eight women measured, the tallest was $65 \frac{1}{4}$ inches in height, and the smallest $57 \frac{3}{8}$ inches, while the average stature of that number was found to be 60.8 inches.

The colour of the skin is a dark muddy-brown or bronze (several shades deeper than the coast natives), but it is liable to slight variation, and is generally a little paler in the women and girls, who resemble far more distinctly the coarse Malayan type than the men do.

* Jour. Royal Geog. Soc., I899, p. 288. 
The hair of the head is very luxuriant, and of all varieties between wavy and curly, but is not crisp or frizzly to any degree. No hair grows on the face, or on the body, save about the armpits, etc.

The outline of the face is an oblong rectangle, and the forehead is somewhat retreating, but occasionally high and rounded, though narrow; the supraciliary arch is prominent, but the eyebrows are light. The eyes, with black pupils, are both oblique and horizontal, and when the latter, are often accompanied by the Mongolian fold, which occurs most frequently among the women.

The nose is broad and flattened, with rounded tip and rather rounded nostrils, the plane of which is upward. It is generally of medium size and straight, but now and again has a pronounced bridge, or a slightly concave outline.

The cheekbones and zygomatic arch are prominent, and a degree of prognathism is prevalent. The teeth are large, irregular, and discoloured, and project outwards. The mouth is large, the lips thick, with the upper very curved from centre to ends; they are generally closed. The lower jaw is commonly large and heary; and the chin is pointed, as the bones converge directly from the basal angle. The ears lie close to the head, and are hidden by the hair, but the lobes are much distorted with plugs of wood.

The huts in which the Shom Pen dwell, although always built on piles, show considerable differences, and vary from a well-built floor with a carefully constructed roof of palm leaf attap, to a rough platform often placed against the side of a tree and sheltered by two or three palm branches fastened to the corners.*

They are said to possess gardens enclosed in zigzag fences, where they cultivate bananas, yams, and other tubers. The

* "Those that are of a permanent character sometimes partake of the same bee-hive form which commonly marks the dwellings of the coast people, being in like manner raised on posts 6 or 8 feet above the ground."-E. H. Man, Jour. Anthrop. Inst., vol. xv. 


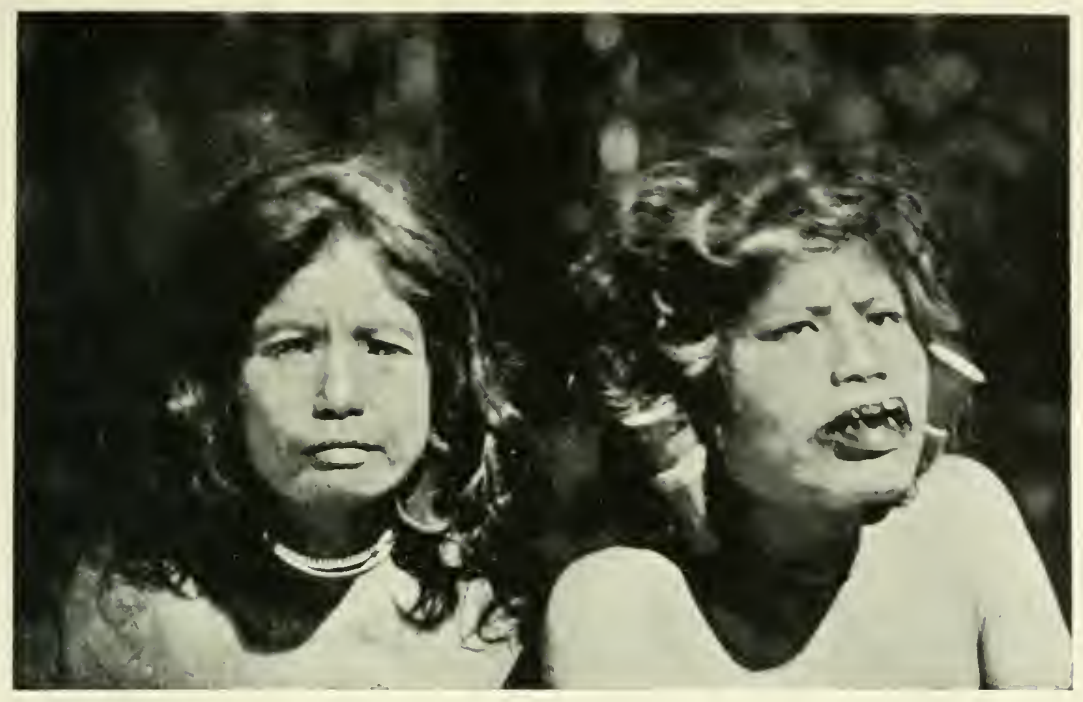

WOMEN OF THE SHOM PEN.

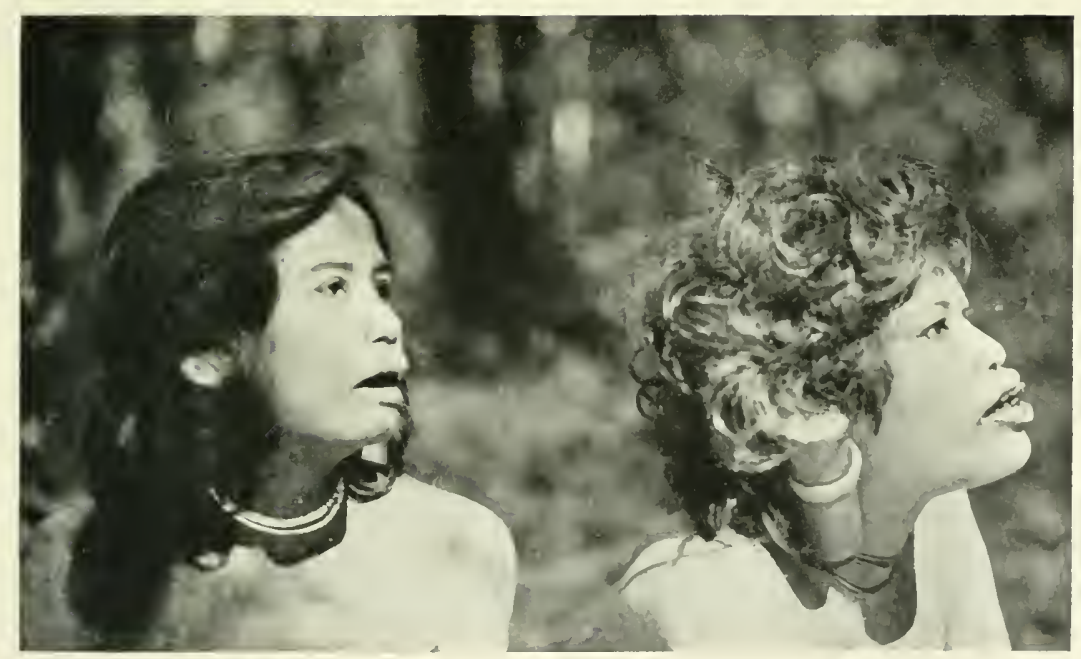

WOMEN OF THE SHOM PEX (in profile). 

pandanus fruit they cook in a well-made vessel of sheets of bark, carefully protected with green leaves and luted with clay, in which we can, perhaps, see one of the origins of pottery; for it is quite admissible that, in course of time, the leaves should be discarded, more clay added, and at length the effect of fire on the latter having been observed, the bark also would be done away with, or only used as a mould for a clay vessel, from which more suitable shapes would finally be evolved.

The domestic animals are dogs, cats, chickens, and pigs, which are generally caught when young in the jungle, and apparently not permitted to attain any respectable size. All find a refuge in the houses, up to which a sort of inclined plane is arranged for their convenience.

Their manufactures are very few. They make canoes; construct a spear out of a single piece of wood, baskets, both of rattan and palm spathe, and a rough cloth from the inner bark of a tree.*

The friendly Shom Pen are energetic collectors of rattan, which they trade with the Nicobarese, and so obtain garments, beads, knives, parangs, axes, and tobacco, which is smoked in the form of cigarettes. They are great consumers of betel-nut, in combination with lime and sireh.

Amongst these friendly families, the clothing worn is similar to that of the Nicobarese, with necklaces of beads, and they employ a large wooden ear-distender an inch and a half in diameter. $\uparrow$ The sheets of bark cloth are used as pillows and coverings at night, and amongst the hostile aborigines it is said the women wear short petticoats of this material, while the men go entirely clothesless.

Amongst those met with, there was generally one man in each party, who, by virtue possibly of superior intelligence or knowledge of the coast language, seemed to have some slight authority over the remainder.

* Ficus brevicuspis.

+ A similar ornament is worn in Sumatra, and also among the Dyaks and Punans in Borneo; vide Carl Bock's Headhunters, plates 10 and $2 \mathrm{I}$. 
They are monogamous, and, unlike the Nicobarese, marry for life. The position of the women is apparently a satisfactory one, for they are regarded as little or in no way inferior to the men. The men obtain the food, the women prepare it. Rattans are collected in the jungle by the men, and by them carried to market; both sexes together prepare it, by scraping and splitting, for sale. When bringing articles for barter, the men bore the spears, and the baskets and cloth were carried by the women, and generally such things as were obtained in exchange were immediately handed over to the latter.

All those met with seemed quiet, stolid, and timid in disposition; but a cupidity for the goods of their neighbours at times overcomes the latter characteristic amongst the less accessible of the aborigines, and many are the murderous attacks they are said to have made on the Nicobarese for the purpose of loot.

No infants or young children were seen, although surprise visits were paid to several of the villages, neither were any old people en evidence, but the ages were judged to vary between ten and forty-five years.

The language differs from all others in the islands, but here and there are individuals who know sufficient of the coast speech to hold converse with the Nicobarese.*

Their carelessness with regard to their water-supply-for any muddy pool or stagnant brook is made use of -is probably sufficient reason for the large number of cases of elephantiasis occurring among them; the only other affection besides this, that seems to be in anyway chronic, is the common body ringworm of the tropics.

* "Each community of the tribe appears to possess a dialect more or less distinct, but this is what might be expected when we consider the isolation of the several encampments and the difficulty of inter-communication, apart even from the hostile relations in which they stand towards one another."-E. H. Man, Jour. Anthrop. Inst., vol. xv. 


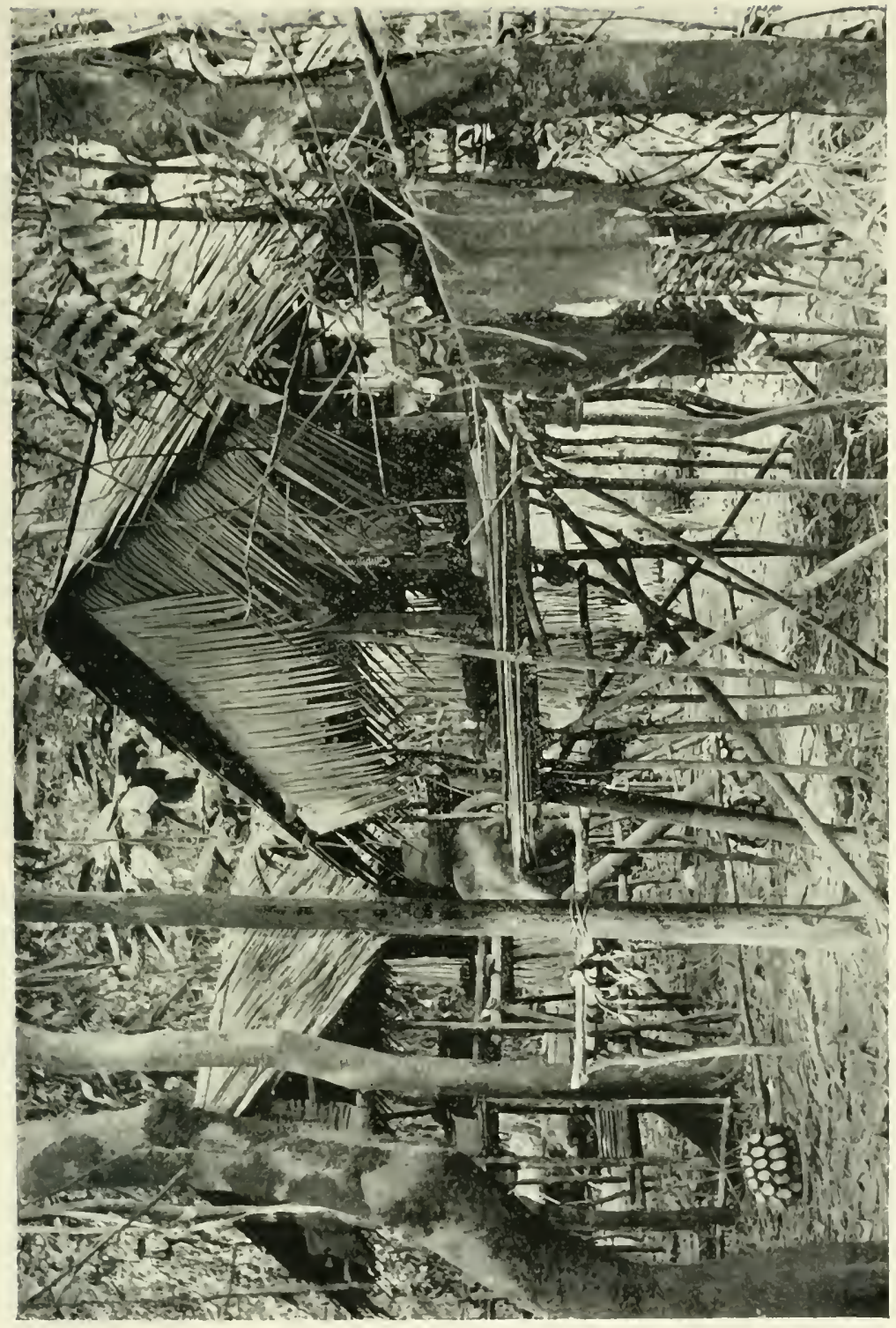





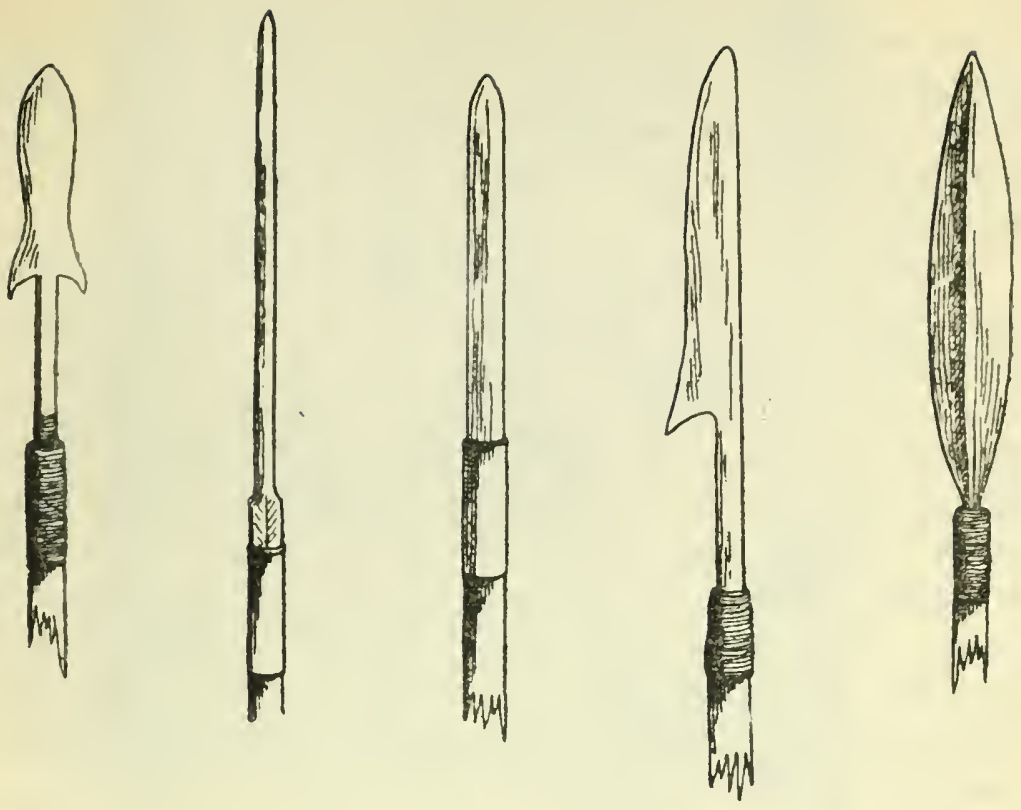

Iron Buffalo and Pig Spears.

\section{CHA P T E R III}

\section{THE NICOBARESE}

The Evolution of the Nicobarese-Description-Character-LanguageLegends of Origin-Origin of Coco Palms-Invention of PunishmentsSuperstitious Beliefs - Diseases - Medicines - Marriage - Matriarchal System - Divorce - Polygamy - Courtship - Property - Takoia-Headmen-Social State-Position of Women and Children-Domestic Animals -Weapons - Tools-Fishing-Turtle-Food-Beverages-Narcotics and Stimulants - Cleanliness - Clothing-Ornaments-Coiffure-Amusements -Arts and Industries-Cultivation-Produce-Traders and Commerce.

IF the Shom Pen are not racially pure, the Nicobarese or coastdwellers are still less so, and what components have gone to form them as they now exist is an interesting ethnical question.

To account for a certain similarity in all the people of the Archipelago, we may suppose that not all, but most, of the islands were occupied by groups of the aborigines, who every- 
where but in Great Nicobar-where, because of its size and forest-clad nature they could find a refuge-became either exterminated or absorbed by successive arrivals of colonists that have since made the presence of the former almost indistinguishable.

In spite of the partial likeness of type, it is doubtful whether all, or nearly all, the islands were occupied by the aborigines. Tilanchong, for instance, is uninhabited, and it is questionable whether such forestless islands as Kar Nicobar, Chaura, or Kamorta, etc., could be suitable habitats for such a primitive people. In Kachal, Nankauri, and Little Nicobar we have islands of a similar character to Great Nicobar, although in them no traces of a rude people are to be found. It is probably on account of the smallness of these areas that the immigrants succeeded in eradicating the first inhabitants, who, in the other island alone, hostile causes notwithstanding," have preserved for themselves a separate existence.

To account for such features as are common to both peoples everywhere, we may conclude, therefore, that while many of the latter aborigines survived separately, the others were absorbed by settlers on the coasts, who, by communication and intermarriage with islands not possessing an indigenous element, carried the Shom Pen strain throughout the Archipelago.

The arrival of numerous colonists from the eastward would account for the lighter complexion of the Nicobarese; for it is only natural to suppose that if a separate branch of the same people, the one living in the open on the coast would be darker in complexion than the other, instead of which the contrary is the case.

As to the component parts of the Nicobarese, various suggestions have been made. They are Malays modified by a Burmese element; $\dagger$ the descendants of Malays before Mahommedanism spread among them (close of thirteenth century), but separated

* Such hostility being now active on their side only.

+ Professor V. Ball, Jour. Asiatic Soc., Bengal. 

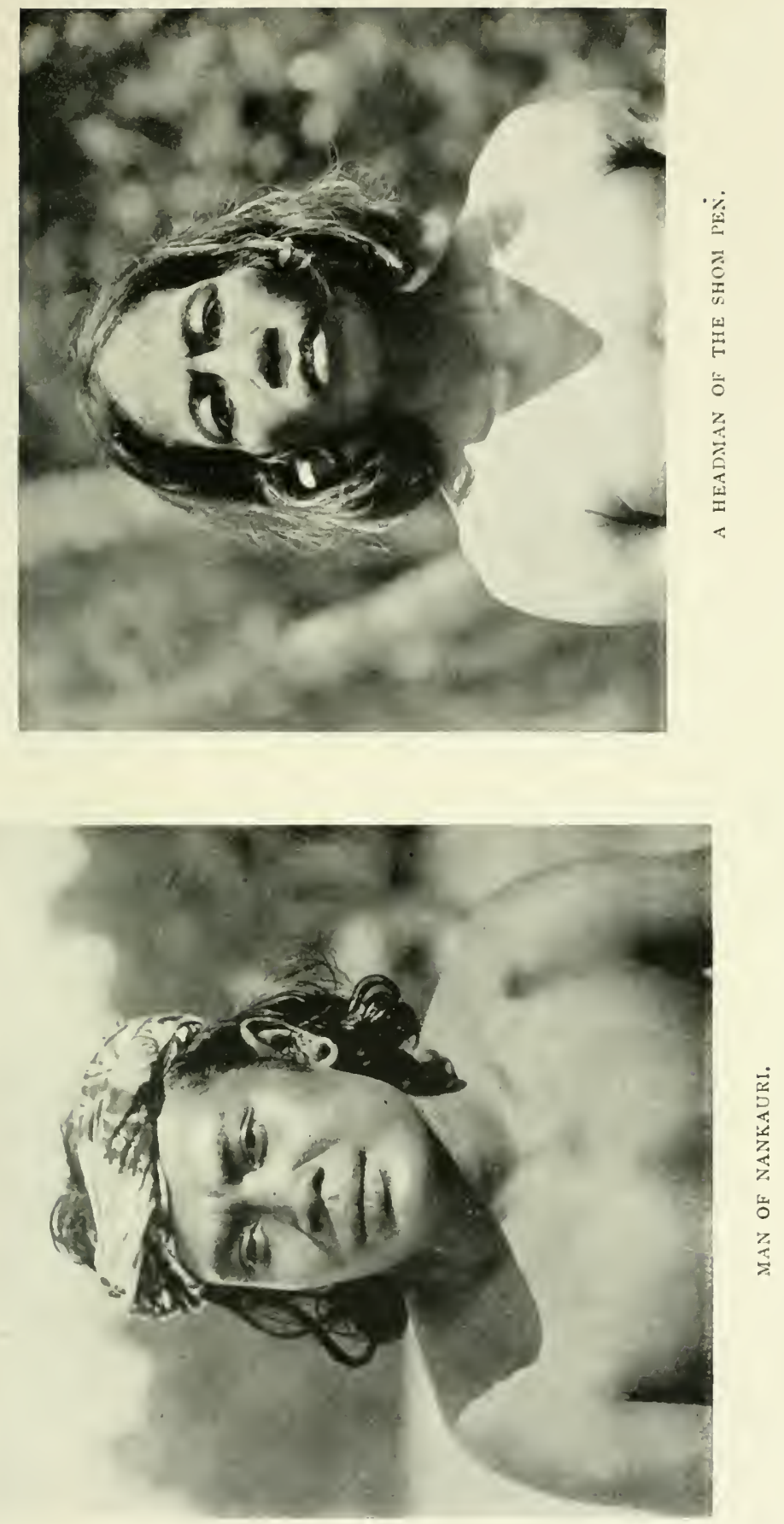

[To fuce pege 222. 

at a much earlier date; ${ }^{*}$ or, again, they are of the same race as the Battaks. $\dagger$

They are described as offshoots of the Malay race, being a people which, while possessing much in common with the IndoChinese stock, nevertheless, in their physical characteristics, hold a place midway between the Malays and the Burmese.+

It has also been said of them that they are "descended from a mongrel Malay stock, the crosses being probably in the majority of cases with the Burmese, and occasionally with natives of the opposite coast of Siam, and perchance also in remote times with such of the Shom Pen as may have settled in their midst." §

The natives of Teressa are probably not greatly wrong when they say that the inhabitants of Nankauri are Malays, who when out fishing lost their boats and settled there, and the Kar Nicobarese are descendants of the Burmese who, in a revolution that took place in their country, were obliged to leave the Tenasserim coast. \|

In the first case, it is not difficult to admit that fishing-boats belonging to Sumatra (90 miles distant), or to the Malay Peninsula (260 miles away), should be blown off-shore in a storm, and safely reaching Nankauri yet not care to face the voyage back.

Pegu is about 400 miles from the islands, and Tenasserim a little less. About 1000 A.D. the first historical conquest of the Lower Irrawadi was effected by the Burmese, and its inhabitants, the Mous, became known as "Talaings," or slaves. Their final defeat took place in 1757 .

* Dr Stoliczka, Jour. Asiatic Soc., Bengal.

+ Père Barbe, Jour. Asiatic Soc., Bengal.

† Dr Rink, Voyage of the Galathea.

$\S$ E. H. Man, Jour. Anthrop. Inst., I889.

II Père Barbe, Jour. Asiatic Soc., Bengal, vol. xv.

TI In 1897 , a Nalay vessel, on a voyage from Olehleh to Pulo Wai, was blown to sea and sunk. Her crew took to their boat and reached Trinkat, whence they were returned by the agent to Acheen in a Chinese junk. In earlier times these men would probably have settled amongst the natives, and so have been instrumental in the further diversifications of the race. 
Nothing is more possible than that, after one of their disasters, a small section of the Talaings fled from their home and established themselves in the Nicobars, which they had probably become cognisant of in the way of trade.* At present the only sea-going craft are a few score "kallu," small junks of $20-60$ tons, built in Tavoy, which, manned by five or six Talaings, venture as far as the Nicobars, where they ship coconuts in the fine monsoon. $\dagger$

Nor are these all, for the islanders are doubtless leavened by stray immigrants from India, +- which would account for the not infrequent occurrence of Caucasian features among them,-by Arabs, and even by Chinese.

Malays and Burmese-or rather Talaings-formed, however, the greater part of the intrusive element.

Although colonisation was very local-the reason possibly for so many distinct languages in the group-the islands now exhibit a state of transition, due to intercrossing. Individuals occur at the extremes of the Archipelago who bear a striking resemblance to each other, but nevertheless there is a marked, though vague, difference to be seen when the natives of several of the islands, or groups of islands, are compared with each other as a body.

"All things considered, it may be inferred that the Archi-

* "The Nicobar Islands were peopled from the opposite main and the coast of Pegu, in proof of which the Nicobar and Pegu languages are said, by those (Nicobarese?) acquainted with the latter, to have much resemblance."-Hamilton, Asiatic Researches, vol. ii.

+ Burmah, M. and B. Ferrars.

+ (a) In 1899 , thirty-five men from the Maldives arrived at Kar Nicobar in a ferry-boat, which resembled a lighter in appearance, and was built of coconut wood. They had gone to Maldive from Addo Atel to buy rice, and encountering a storm on the return journey, had missed their island, and after a two months' voyage (more than 1000 miles) reached Kar Nicobar, having thrown overboard most of their rice to keep their vessel afloat. As they feared to go back in their own boat, they were forwarded to Calcutta in various trading-vessels.

(b) "In almost all the villages (central group), Malabars or Bengalese are to be found. The natives encourage them to stay by grants of land, and after a certain number of years they are permitted to make choice of a female companion."-Nicholas Fontana, Asiatic Researches, vol. iii. 


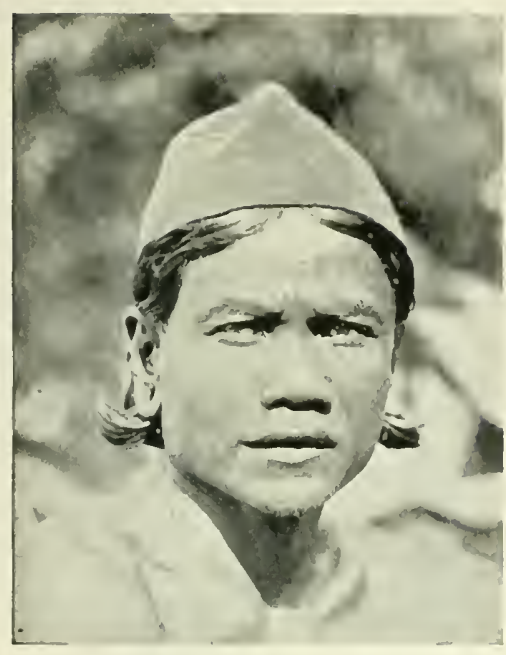

"TANAMARA" OF NANKAURI.

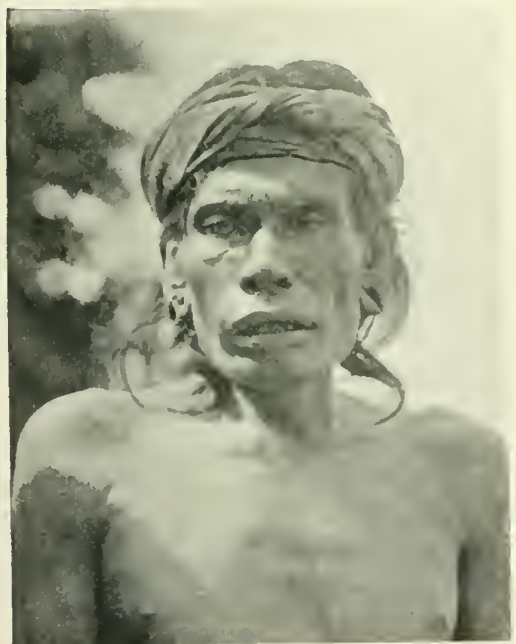

A HEADMAX OF THE SHOM PEX.

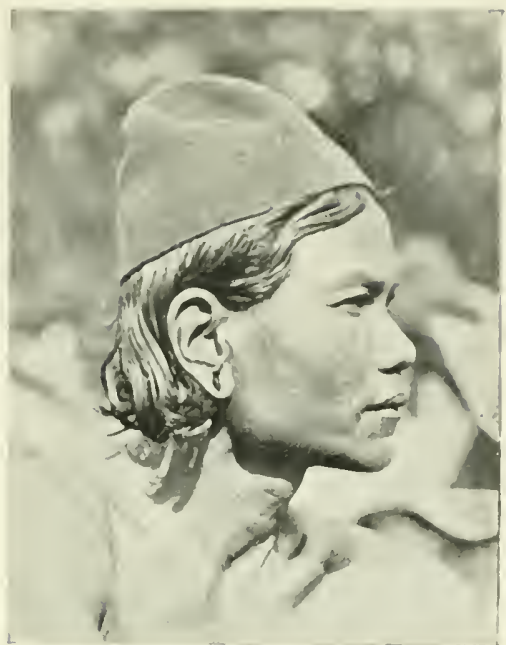

"TANAMARA," NANKAURI (in profile).

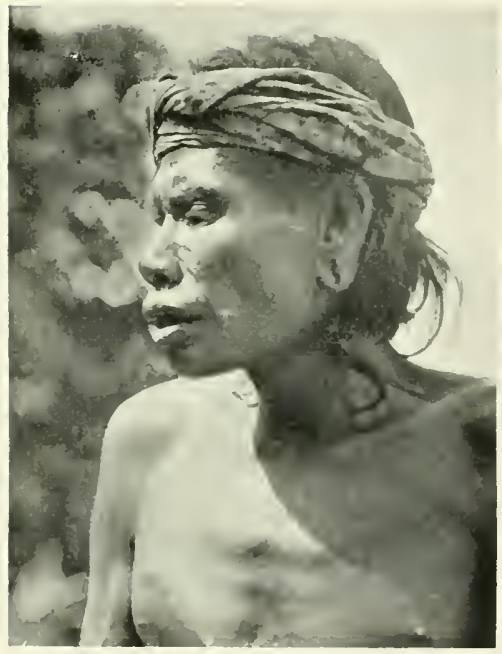

HE.ADMAN OF THE SHOM PE. (in profile). 

pelago was originally occupied by primitive peoples of Malayan stock, now represented by the Shom Pen of Great Nicobar, and was afterwards resettled on the coast-lands by Indo-Chinese and Malayan intruders, who intermingled, and either extirpated and absorbed, or else drove to the interior, the first occupants." *

It is difficult to picture a typical representative of this muchmixed people, as even in those islands that have a distinct speech of their own, and whose inhabitants might be supposed to be fairly homogenous, wide differences are met with, as above pointed out. The variations, however, are not sufficient on the whole to merit separate descriptions of the inhabitants of each island.

These variations occurring in size, features, and hair, show that the Nicobarese are a thoroughly mixed race, for the points do not coincide with each other; that is to say, curly hair does not always go with a prominent nose, or straight hair with Malayan features.

It is hardly possible to describe a representative specimen who combines all the prominent prevalent characteristics, but they seem capable of division into two classes, the smaller of which is superior in appearance to the other, and is often strikingly Caucasian, with oval face, straight eyes, aquiline nose, and thin lips. $\dagger$

The result of about forty measurements shows that the maximum height of an adult male Nicobarese is $70 \frac{3}{4}$ inches; the minimum, $59 \frac{1}{4}$ inches; and the average stature, 63.9 inches.+ While thus somewhat under middle height, they are well built (average chest measurement, 35.3 inches) and proportioned, muscular, and on the whole a sturdy-looking race. 1899 .

* Professor A. H. Keane, "Man, Past and Present," Camb. Geog. Series,

+ Comparing the group of Kar Nicobar boys (page 60) with those of Kondul (p. I38), it is not easy, at a glance, to perceive much racial resemblance. The first, scowling and flat-nosed, with prominent teeth and thick lips, and the others intelligent-looking, with almost European features. Yet the eldest of these latter exactly resembled in every way Little John, the man who was my shikari in Kar Nicobar.

\# Although the average is no more than with the Shom Pen, there is a much greater individual variation of stature. 
The colour of the skin is a brown much resembling in colour the tint of a sun-burnt, weather-beaten Malay, such as a sailor; it is darker than the ordinary native of that race, and has less of the olive or yellow about it.

The hair is of a rusty black, but generally glossy with oil : it is thick and luxuriant, and reaches to the shoulders, varying between a slight waviness and pronounced curls. It is somewhat coarse, and when kept short with boys, is almost bristly, and stands up stiffy all over the head. In about 5 per cent. of the men there are traces of moustache and beard, otherwise the faces are smooth, but the axillæ and elsewhere, and often legs and thighs, are profusely covered with hair.

The form of skull is brachycephalic, with an index of about So.5, and the back of the head, among the natives of the central and southern groups of islands (excepting the Shom Pein), is noticeably flat.* The face is broad, and, but for the cheek-bones, which are generally prominent and developed laterally, approaches the oval type. Often, however, it has a somewhat rectangular outline, owing to the squareness of the lower jaw in the rear. The features are somewhat flat. The forehead is slightly rounded and even well-formed, but it is often compressed at the temples, and falls away somewhat suddenly.

The supraciliary arch is prominent, and the eyebrows are generally fixed in a permanent scowl; the pupil is black, and the eyes often-though not as a rule-slightly oblique, with the Mongolian fold at the corner.

The nose is generally broad, and coarse in outline, is straight, and of medium length, depressed at the bridge, flattened, with

* This is due to the practice, observed and described by Mr Man, of flattening the occiput and forehead of infants by the mother, who gently exerts pressure by means of a small pillow, and the palms and outstretched fingers of both hands for an hour or so at a time.-Jour. Anthrop. Inst., Feb. 1894, p. 238.

"It is a custom with them to compress with their hands the occiput of the new-born child; by this method they say the hair remains close to the head as nature intended it, and the upper fore-teeth very prominent out of the mouth." - Nicholas Fontana, Asiatic Researches, vol. iii. 


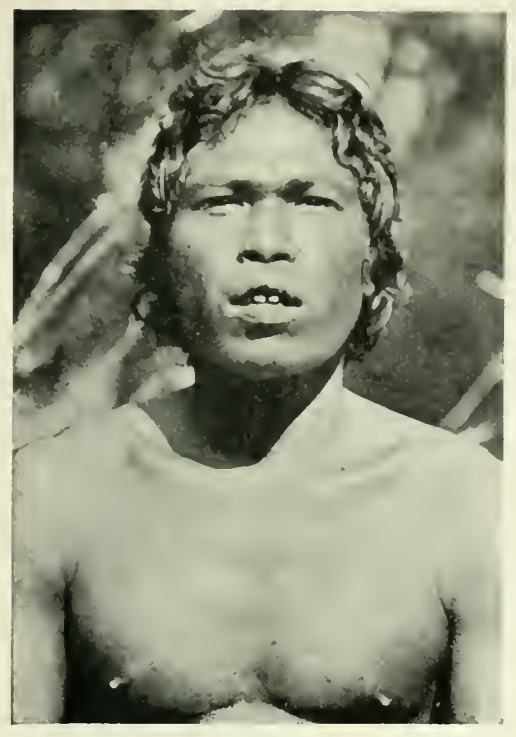

MAN OF KAR NICOBAR.

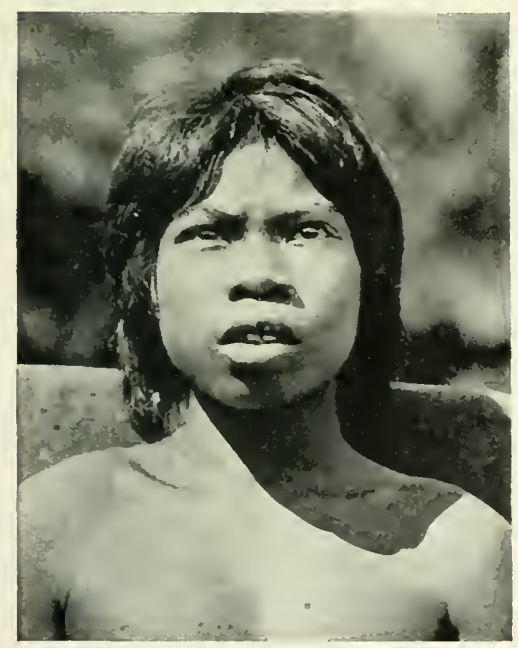

KAR NICOBAK BOY. Showing Epicanthus.

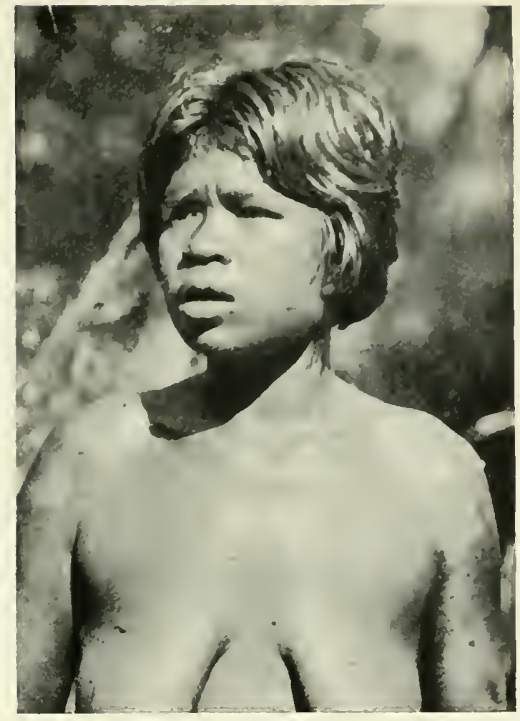

WOMAN OF KAR NICOBAR.

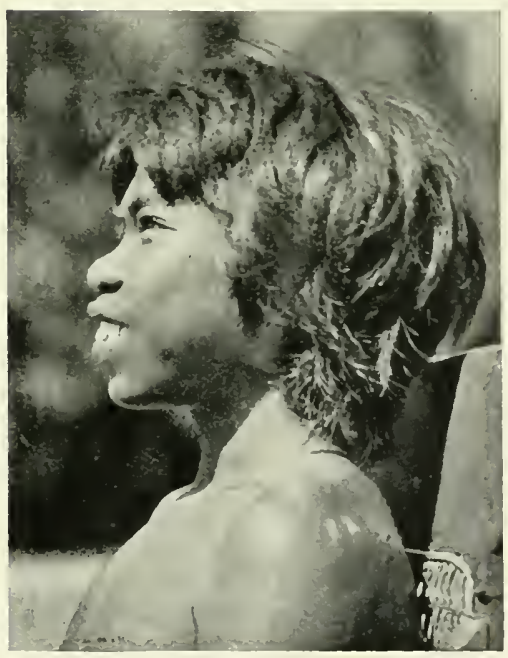

KAR NICOBAR BOY (in profile). Showing Prognathism.

[To face nage 220. 

rounded tip, has inflated alae nasi, and the plane of the nostrils directed upward.*

There is often marked prognathism of the dental variety, and the teeth are irregular and blackened, large and projectingfrequently growing outwards at an angle, like those of a rabbit.

The mouth is naturally large, and its shape is not improved by holding the betel-quid between the upper lip and teeth. The lips are moderately thick, and the lower is often pendulous and turned down, showing much of the mucous membrane. When at rest, the lips are kept apart.

The chin is usually rather retreating, small, with a rounded and pointed tip; but the jaw is somewhat heavily hung at the base, and the posterior angle is strongly marked.

The ears are well formed, moderately large, and lie close to the head, unless drawn out of shape by much use of ear-distenders.

The Nicobarese have not always been given a good character by their acquaintances. They have been called lazy, inactive, and drunken, cowardly and treacherous, but this last must be taken as applying more to those bands of pirates-with a probable large foreign element-who committed so many crimes during a long period; otherwise, they are harmless and good-tempered. The accusation of cowardice is made with more truth, and it is a quality they frankly own up to.

Lazy and inactive they may be from our point of view, but hardly otherwise. Food is abundant all round them, weapons are not necessary, and clothing they do not really need. They show plenty of application and care when making their canoes, building their houses-which in construction are models of neatness-and in gathering the toddy, that with betel-nut is, perhaps, their only native luxury. Drunken they certainly are on many occasions, but the state with them is one that, fortunately, does not give rise to troublesomeness.

They are honest in their commercial transactions, and are most indignant should their integrity be impugned, while the

* Besides the aquiline noses already mentioned, a distinctly Jewish or Papuan feature is occasionally to be met with. 
accusation of untruthfulness brings them up in arms immediately.

Somewhat absent in manner, unemotional and apathetic, the more intelligent are yet extremely inquisitive towards strangers, and ask endless questions of a personal kind.

Although not remarkable for courtesy, or possessing any forms of salutation, * they are very hospitable, and always ready with coconuts, cigarettes, etc., for a visitor. It is customary for natives, when travelling, to enter without remark any house on their path, help themselves to food and drink, and depart in silence. $\dagger$

They are exceedingly independent in manner and spirit, are of a somewhat commercial turn of mind, and are occasionally gifted with a distressing importunity, which is most common in those places where visits from Europeans have been most frequent.

Parents seem to possess great affection for their infants, and the number of men, especially, who may be seen about the villages carrying their children, or otherwise amusing them, is remarkable.

Six distinct dialects and languages are spoken in the Archipelago-one on Kar Nicobar, another on Chaura; Teressa and Bompoka together have one; the central islands of Kamorta, Nankauri, Trinkat, and Kachal speak a fourth; while Little and Great Nicobar with their adjacent islands have a fifth. Lastly, the Shom Pen of the interior of Great Nicobar employ a speech that is dissimilar to the others.

The language, which is somewhat harsh in sound, has, however, "an extraordinarily rich, phonetic system - as many as twenty-five

* "They have terms answering to 'How d'ye do?' and 'Good-bye.' The following are said in the Central Islands :-

A. Met chai-chacha-ka?-How d'ye do?

B. Pehiri (said in response).--The same to you.

A. Yashe me ra.-Good-bye (said by the person leaving).

B. Tazuitse me rakit.-Good-byc, lit., Thus you at present moment (said in response).

A. Pehdri.-The same to you.

At the other islands there are corresponding terms."-E. H. Man.

$+\mathrm{V}$. Solomon. 


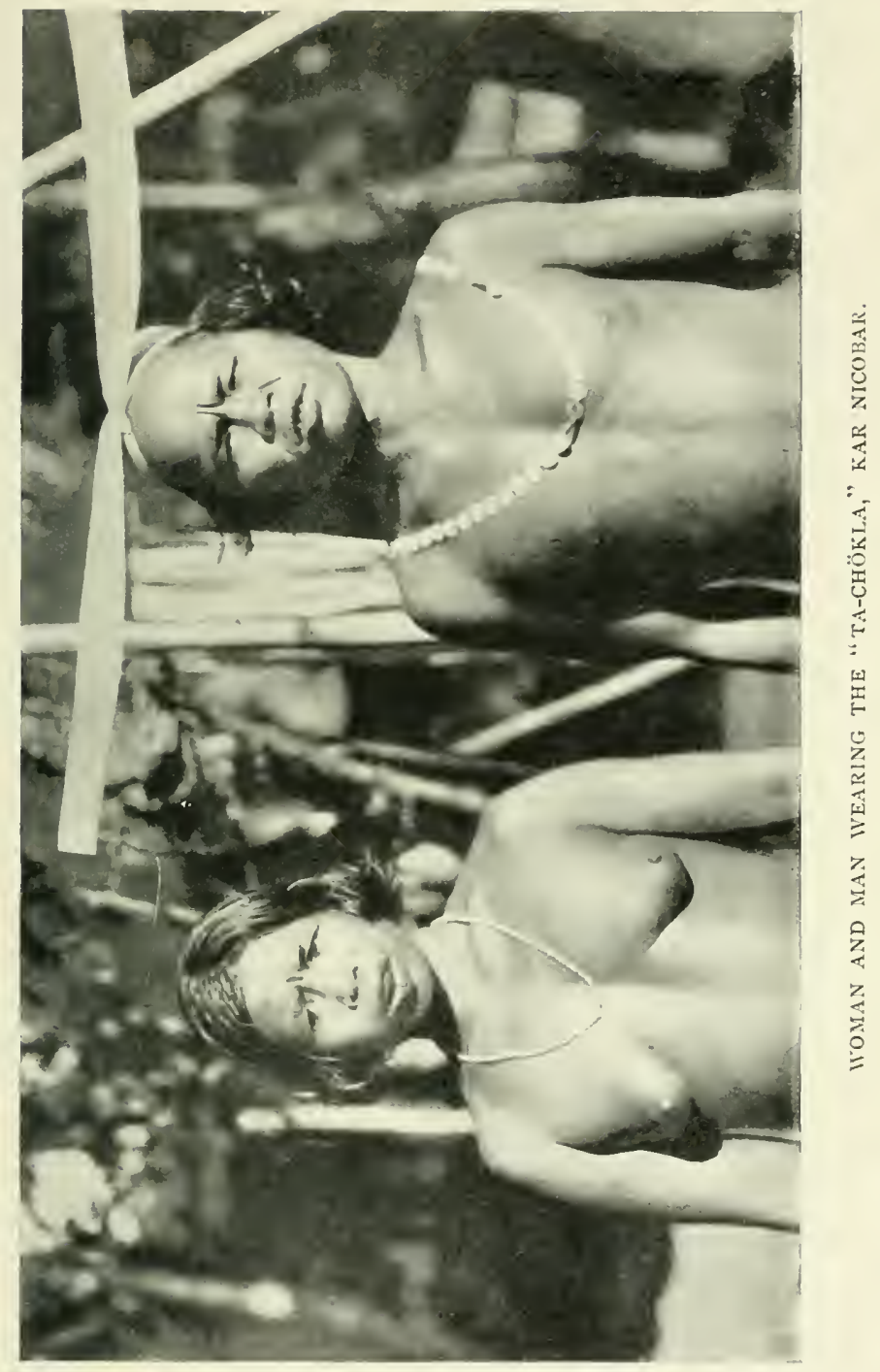

[To fue page $220 \mathrm{~s}$. 

consonantal and thirty-five vowel sounds (it possesses a peculiar double series of nasal vowels) - is polysyllabic, and untoned, like the Malayo-Polynesian, and the type seems to resemble the Oceanic more than the Continental Mongol subdivision." *

This is the theory of the Kar Nicobarese with regard to their origin :-

A certain man, from some unknown country, arrived at the Nicobars on a flat, with a pet female dog, and settled in Kar Nicobar. In course of time he espoused the bitch, and begot a son. When this son was grown up, he concealed his mother by covering her with a ngong, a kind of petticoat made of coco-palm leaves, and, after killing his father in the jungle, took his mother to wife. From such parents the Nicobarese believe they originated, and it is their progeny who now people the island.

The two-horned head-dress-tá-chökla-worn by all males, they consider symbolic of their mother's ears; the end of the loin-cloth that dangles behind, they call her tail; and the piece of cotton reaching to the women's knees only, they compare with the ngong petticoat, which was her first dress.

Until comparatively recently, this ngong-a thick fringe of palm leaf about 15 inches deep, inserted in a band-was in universal wear (see Koeping, Hamilton, Lancaster, and others) and, even now, it is worn sometimes by the women when working in the plantations. It is also worn at Teressa, and still more at Chaura. $\dagger$

Another version of the legend varies somewhat, making the father a dog and the mother a woman. It is owing to this belief that the natives say they are sons of a dog, and for this reason they treat their dogs very kindly, and never beat them: they quiet them by simply saying "Hush! hush!"

There is another tradition amongst the Nicobarese, to the effect that the first stranger who came to their islands, seeing something moving on the sand, perceived small people the size of

* Professor A. H. Keane, "Man, Past and Present," Camb. Geog. Series, 1899.

+ Vide plate facing 248 . 
an ant. He took care of them until they attained the common size of men-and this was the origin of the natives.*

To account for the coconut trees that grow in such abundance on the island, the Kar Nicobarese version runs thus:-

Once upon a time there was a scarcity of water, and a certain man then produced it from his elbow by means of magic arts. The people therefore considered him to be a devil-man-wizardand beheaded him. On the spot where the head fell there sprang up a tree, and after a time it became very big, and began to bear fruit, and the fruit resembled the head of the slain man.

For a long time the people were afraid to approach the tree or to taste the nuts, because they had grown out of a human head, and so, by the falling of the ripe fruit, there grew up a dense grove of coconut palms.

At last some wise men brought to the trees an old man who was dying, and made him taste of the nuts, to find out their qualities! The old man accordingly ate one, and found it to be very delicious, and from continually eating nuts he became very strong, and grew to look like a young man.

Thenceforth the people began to make use of the coconut!

In the old days it was the custom to kill men for any offence, grave or simple. But at length the elders, finding that the population had greatly diminished thereby, held a council, and introduced the system of killing pigs, burning houses, felling trees, breaking canoes, and destroying clothes, etc., and this method is continued at the present day side by side with the former.

The people seldom have open fighting among themselves, neither do they use their fists, or flog. In extreme cases only (witchcraft) do they commit murder.

The Nicobarese have no conception of a Supreme Being, or a future state, but there is a universal belief in evil spirits, who are in part ghosts of the wicked, and who can be propitiated by offerings and kept away by exorcisms.

* Père Barbe, Jour. Asiatic Soc., Bengal., vol. xv. 


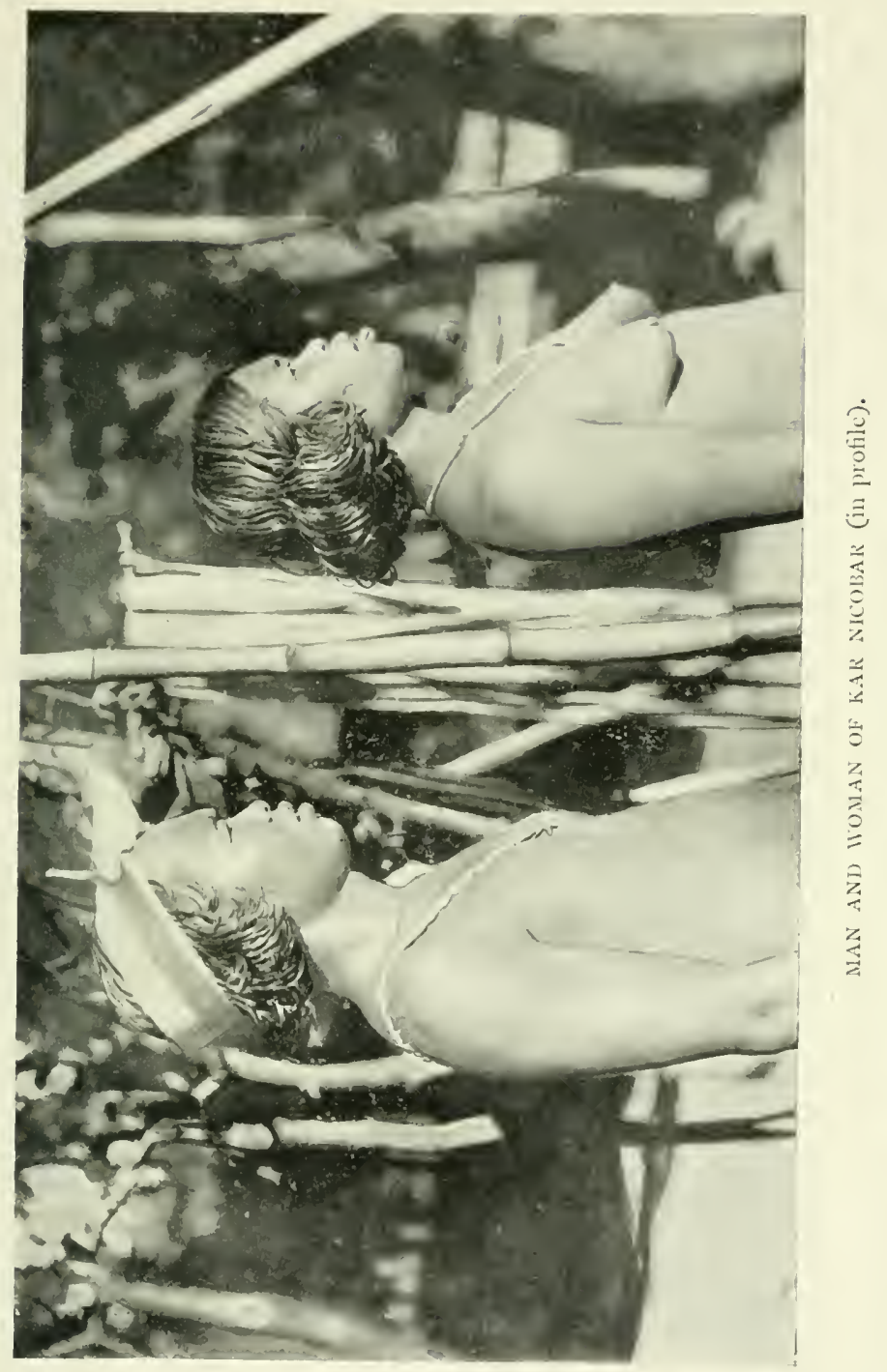



These creations of the imagination, who in the northern island are called Siyas, seem much akin to the Náts of IndoChina, but are far less localised, and, as a rule, have no particular tree, rock, or stream for their abode. They are the cause of every misfortune and disease that occurs to man, but death in the ordinary course of things is considered to be a natural event.

It would appear that in Kar Nicobar, Teressa, and Chaura, where the superstitious practices are nearly alike, some idea

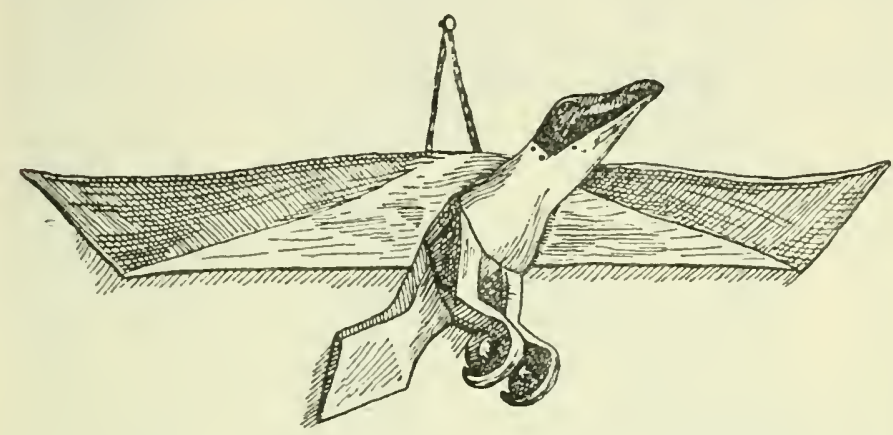

"Scare-devil," or device for exorcising evil spirits (Kachal).

is entertained of spirits not altogether inimical to mankind; but in the other islands, whose beliefs are all homogenous, the Iwis are all harmful to human beings, and are kept at a distance by a redundancy of charms and talismans that does not occur in the north.**

The latter, which include various objects, such as figures of men, women, animals, etc., pictures, banners, and so on, are none of them regarded as idols or worshipped, neither are they fetishes-the instruments of spirits, or themselves endowed with

* Tanamara, headman of Malacca, Nankauri, when questioned on this point, stated that the spirits were all evil :- "What, no got good devil-hantu baik? No, all bad; plenty fever-devil, plen-ty devil eat man." But, with reference to this assertion, Mr Man writes:- "The names of certain good spirits have often been given to me at Nankauri, and by Tanamara himself." One inference is, that the latter purposely denied their existence in order to be spared the trouble of answering further questions on the subject. 
life-although those of them representative of living objects are from time to time given such food as pork or coconuts. They merely act as "scare-devils," putting to flight the demons

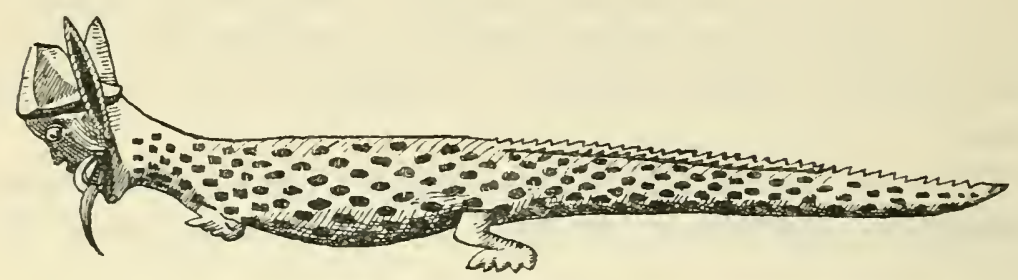

Nicobarese Talisman.

of sickness and guarding their constructors from any misfortune. They are effective only on behalf of those who make them, and at such person's death it is the custom to destroy or discard the talismans.

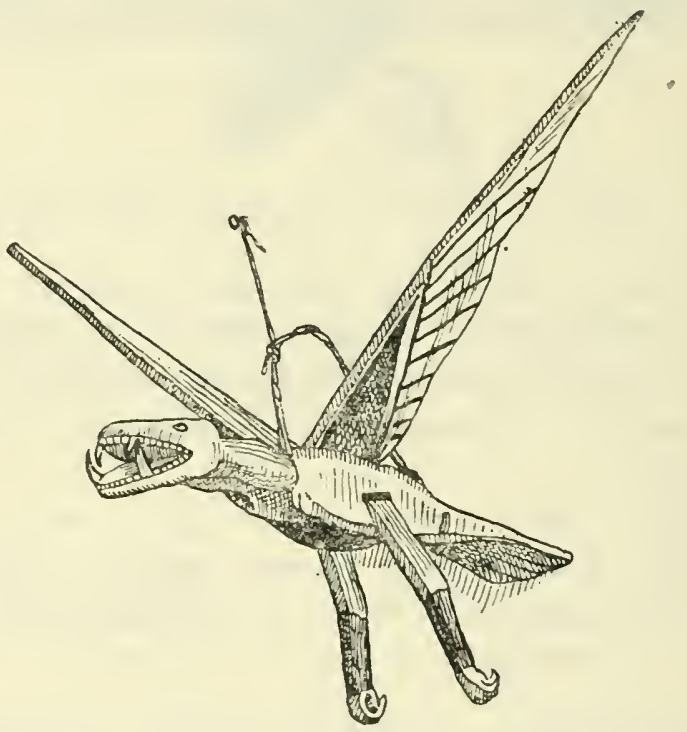

"Scare-devil," or device for exorcising evil spirits (Kachal).

The natives have no temples or any form of worship, but there have come into being shamans or priest-doctors, known as tamiluanas and menluanas, who have the power of com- 


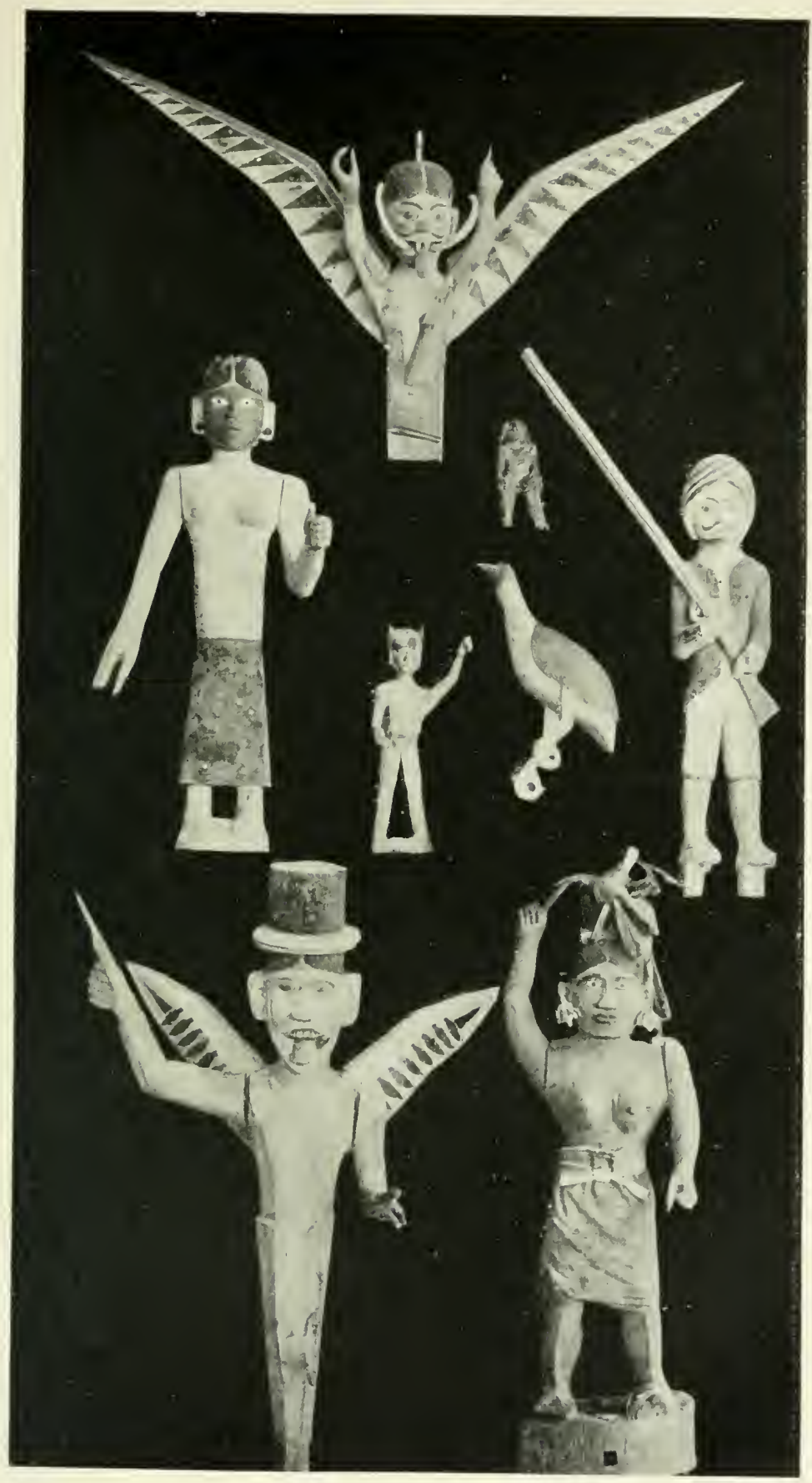

SPECIMENS OF "IIENTÁ-KÓL"

Made and first used in times of sickness to frighten away the offending evil spirits. 

municating with the spirits, and by means of certain ceremonies, in conjunction with the use of rods, particular leaves, and ashes, periodically, by open warfare and by magic, drive the malignant demons from such places in man's neighbourhood as they may have intruded into, or defeat them when prevailing disease or misfortune can be traced to their agency.

These practices and beliefs, which it would be incorrect to class together under the name of religion, are not accompanied by any moral element. Their code of ethics has no connection whatever with the form of malevolent spiritualism which they entertain, but is entirely an affair of public opinion and social convention.

The cult of the natives as it exists in the south, with its multiplicity of charms, "medicine," and demon-scaring figures and objects, is probably only an isolated case of a practice widely spread throughout the Malayan Archipelago-in Sumatra, Borneo, and other islands, and even amongst the Papuans still further east.*

* (a) "On the path, at no great distance from the (Dyak) village, rude wooden figures of a man and woman are placed, one on each side opposite to each other, with short wooden spears in their mouths. They are called Tebudo, and are said to be inhabited by friendly hantu (spirits) who keep the path clear of inimical spirits."-Chalmers.

(b) "The Bedājoē possess a multitude of large wooden idols called Hampatong, as well as other objects which cult or superstition has consecrated. Every habitation of this tribe, as well as those of the Dusuns, has several small wooden idols who are supposed to guard the habitation, protect the rice harvest, preserve the inhabitants against sickness, and to fulfil generally analogous functions. The Dyaks collect, with the same object, skulls of monkeys, bears, and wild cats, which they preserve in little boxes called kamontoha, and which they suspend in the houses."-S. Müller.

(c) "As far as we could learn, the only act of worship paid these images is that of offering them food once or twice a month, such as rice, pork, eggs, fowls. On no condition will they (Dyaks) consent to give them up, and the only reason assigned is that sickness will be the inevitable consequence."-Doty.

(d) "The inland tribes of Borneo are without any definite forms of religious worship; they make idols of wood, but I have never seen any offerings made to them, nor do they regard them apparently as anything more than scarecrows to frighten off evil spirits."-Folklore in Borneo, by W. H. Furness.

$(e)$ "These figures (tambatongs) are not exactly idols in the ordinary sense of the word, as they are not directly worshipped, although representing the 
On the other hand, it is not at all impossible, in view of the natives' acquisitiveness of foreign ideas, that most of their practices arise from a corrupted interpretation of the, in other respects, futile teachings of the numerous missionaries who have laboured in vain in the islands, complicated by an additional jumble of tenets adopted from other strangers with whom they have come into contact, while, in particular, the figures, pictures, and charms of many localities may be to some extent

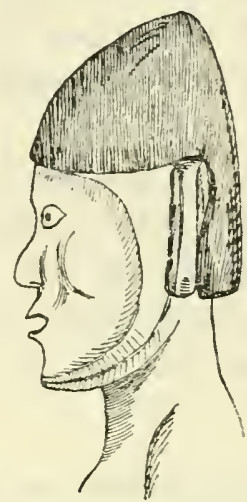

Female Talisman (Kachal).

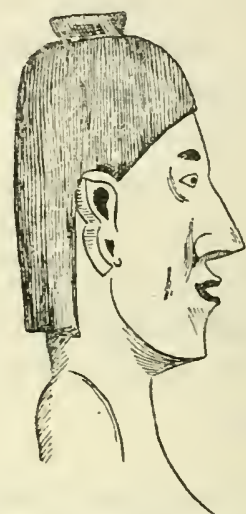

Female Talisman, "Kario" (Nankauri).

merely a degraded survival of the religious paraphernalia of the Jesuit missionaries.

religious beliefs of the Dyaks, and regarded with superstitious veneration; they should, perhaps, rather be called talismans, as they are looked upon as charms to keep away evil spirits and ill-luck."-P. 32, Headhunters of Borneo, by Carl Bock.

$(f)$ "Although I found in a house at Old Affara (a village on Vorkay, one of the southernmost of the Arrus) an image rudely formed of wood, together with a post on which different figures, such as snakes, lizards, crocodiles, and human forms, were carved, and which the owner stated to be intended for preserving the house from evil spirits (Swangi), yet it is evident that the Arafuras of Vorkay possess no religion whatsoever. . . . They certainly hold a feast at the time in which they have perceived that the Christians of Wamma hold one also, namely, at the commencement of the year, when they, in imitation of the Christians, celebrate the advent of the new year. ... Of the immortality of the soul they have not the least conception."-Koff's Voyage of the Dourga, p. I6I.

$(g)$ "The Battas believe in demonic agency called Begu for every species of malady. ... To drive out these demon monsters ... talismans and charms are employed."-Featherman's Social History of Mankind. 


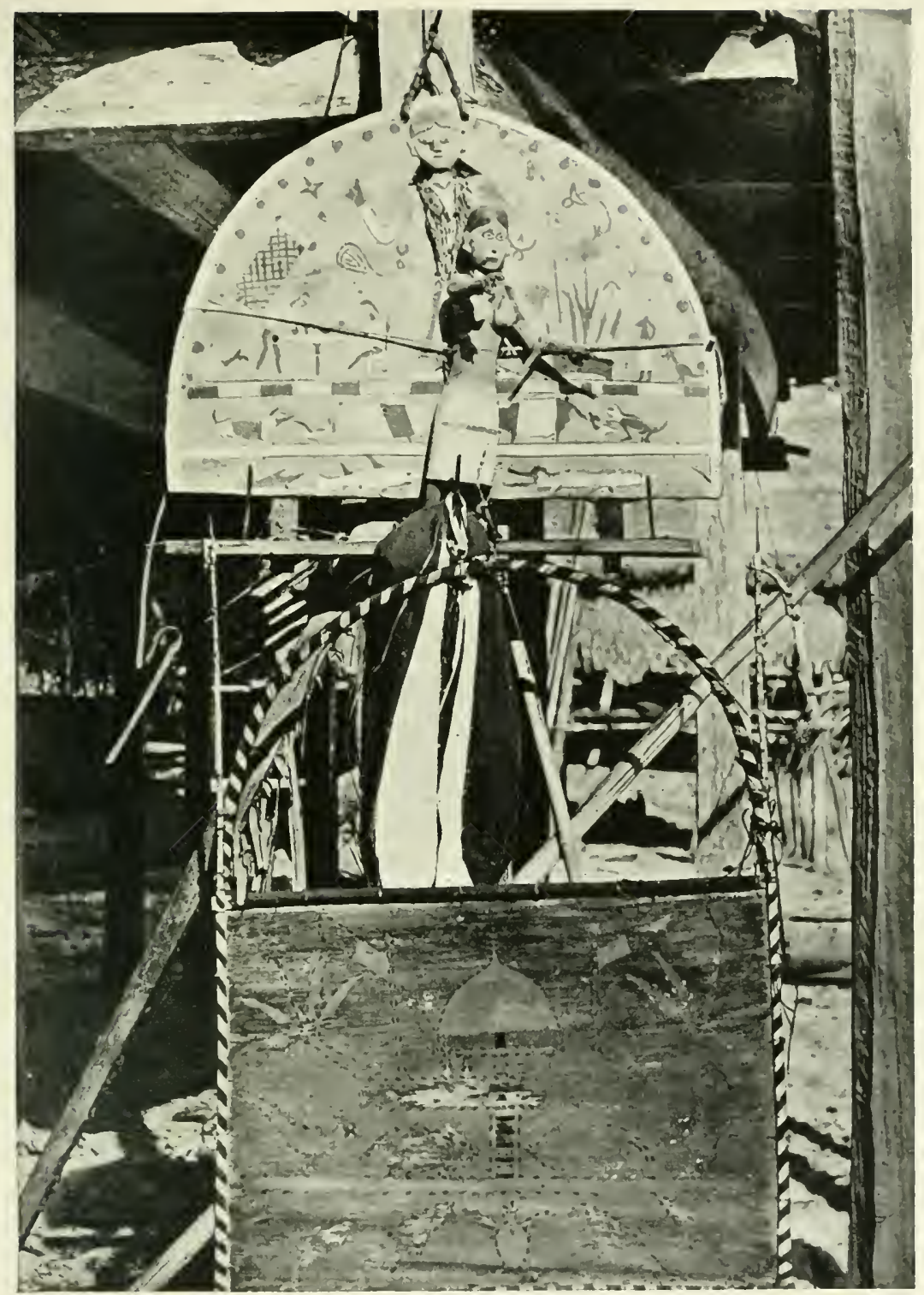

A "HENTÄ."

Painted and first suspended inside hut in time of sickness, to gratify good spirits and scare away demons. (Specimen from Nankauri.) 

One might adduce in support of this theory the fact that superstition and its accessories thrive most strongly in the places where the missionaries as a rule establish themselvesKar Nicobar and Nankauri Harbour.

Fever, colic, coughs, rheumatism, and sore and inflamed eyes, are not unfrequent ailments. Syphilis also occurs, and has probably been introduced by the traders, or by the Nicobarese who have visited Calcutta and Moulmein in their vessels.

Itch (tinea circinata tropica) is in some localities very prevalent among the natives, who are also liable to attacks of a mild form of elephantiasis throughout the Archipelago. It is said that in Chaura from one-third to one-half the population are so diseased in one way or the other. Cases of yaws occur from time to time among children.

Eno's fruit salt, camphor, castor-oil, turpentine, and quinine, are the principal features of the Nicobarese pharmacopœia.

Eno's fruit salt mixed with water, with a little powdered camphor and turpentine added, is given twice a day for colic. For fever, a little quinine is added to the same mixture.

Sandalwood and jessamine oil are held in great repute as aphrodisiacs, and are purchased from the Burmese traders in small quantities at a very high price.

Faith, however, is not always placed in the efficacy of mundane remedies. A woman who had been ill for a year, when asked if she would take medicine, replied, "The devil has caused this illness, and it cannot be cured by medicine. Only the tamiluanas can cure me by driving the devil out of me." She preferred sugar and biscuits to drugs.

Malaria, which is perhaps the indisposition by which they are most frequently attacked, is always attributed to demonic agency.

Marriage amongst the Nicobarese is of a class that is considered to be a modification of the matriarchal system, and 
that exists widely spread in this portion of the world amongst the Malayan and Indo-Chinese peoples.

Until he marries, a man considers himself a member of his father's household, but after that event he calls himself the son of his father-in-law, and becomes a member of his wife's family, leaving the house of his own parents, or even his village, if the woman dwell elsewhere.*

Only the chiefs, or wealthy men whose positions in the village are of influence, are exceptions to this law; they are permitted by custom to bring their wives to their own houses. $\dagger$

There is no law of exogamy amongst them-a man marries in his own village, village-group, or even house; for although connections between blood relatives are disapproved of, there is nothing to prevent such taking place, except public opinion, which may often be disregarded with impunity.

The woman on her marriage brings no special dower into

* (a) "Amongst the Dyaks . . newly-married couples do not go to live in a new house of their own, but a compartment is set apart for them in the house of the bride's parents."-Hickson's North Celebes, p. 286.

(b) "The marriage customs throughout the Sangir, Talant, and Sian Archipelago are based on the old matriarchal system-that is, when a man is married he becomes a member of his wife's family, and must leave his own and go to live in the village or the house of his wife's parents." -P. I97.

(c) "When a Dyak marries he enters the family of his wife, and lives in her parents' house till the couple set up for themselves, which is generally not for some time afterwards."-Denison.

(d) "If the suitor among the Battas is too poor to pay the price for a wife, he may contract the ambil anak marriage, which obliges him to become a member of the family of the bride's parents and live with them in the same dwelling: he is required to work for his father-in-law, and attend to the ordinary agricultural labour."-Social History of the Races of Mankind, A. Featherman.

(e) "New couples mostly start life in the young wife's home, the lad working for her parents, and as families come, the elder pairs are established in houses of their own."-Burmah, M. and B. Ferrars.

+Cf. A Naturalist in North Celebes, S. I. Hickson, p. I98.- "In the Sangir Islands the only persons who are free from the matriarchal system are the sons of the rajahs, who do as they please about following their wives." P. 286-"Among the Dyaks of Sarawak we find... that in some cases the man does not follow the woman; but if he is of higher rank, or the only support of aged parents, the woman is obliged to come and live in his family." 
the partnership, neither is there any custom by which the man is compelled to place a certain amount of property at the disposal of her parents. Each has a right to a certain proportion of their common household possessions, and their worldly status improves by inheritance and by their own efforts.

Those marriages are most successful from which children are numerous, for these make life easier by taking a large amount of the daily and special work upon themselves, and by acting as a support and provision to their parents in old age.

There is very little that is binding in the marriage state of these people, cohabitation with its duties being co-existent with mutual consent. So long as they like each other and are contented with their position, the couple remain together; but the absence of children, illness, old age, and many extremely trivial reasons are sufficient cause for separation.* The divorce is a matter for the two most concerned only; there are no public proceedings to take place, no ceremonies to undergo.†

Most of the adult members of the population have been married three or four times, a goodly number far more often. The children of the partnership, if young, go with the more

* (a) "A man may readily obtain a divorce without any better reason than that he has fixed his heart on another woman."- "Customs of the Minahassers," Hickson's North Celebes, p. 28 I.

(b) "Divorces are very common; one can scarcely meet with a middle-aged Dyak who has not had two and often three or more wives. Repudiation takes place for the slightest cause-personal dislike or disappointments, a sudden quarrel, bad dreams, discontent with the partner's powers of industry or labour, in fact, any excuse. In fact, marriage is a business of partnership for the purpose of having children, dividing labour, and by means of their offspring providing for old age. It is therefore entered into and dissolved almost at pleasure. The causes are innumerable, but incompatibility of temper is perhaps the most common; when they are tired of each other they do not say so, but put the fault upon an unfavourable dream or a bad omen-either of which is allowed to be a legitimate cause for separation."-St John.

+ Side by side with this state of things, which is practically one of free love, a licensed immorality exists among the natives, and there are several brothels or houses of assignation in the village of Mūs, population $53^{\circ}$ ! 
influential of the parents; when older, they exercise an individual choice.* $^{*}$

From the nature of the marriage, the woman as often divorces her husband as vice versâ.

The natives as a race are monogamous, but now and again polygamy is found to occur. It is practised, however, only by the chiefs and more wealthy men, who live in their own houses, and can afford to domicile their wives in separate dwellings.t

Cases of adultery are punished by a fine, but there is no established amount. The village elders consult together as to what the seducer shall be mulcted of, and generally decide on a certain number of pigs, which are cut up and distributed among the community.+

There seems to be no objection to a girl having as many lovers as she likes before marriage, and altogether the state when entered upon is one that presses very lightly on the people. There are few unwritten laws on the subject, and public opinion is of hardly any weight. $\S$

Courtship, like marriage, is merely a variation of the Malayan custom of nocturnal visiting, much simplified, however, by the absence of any ceremonies to mark its change into a more stable relationship.

When a man desires to marry a girl, he contracts a friendship

* Cf. A Naturalist in North Celebes, S. I. Hickson, p. 197.- "The rajah of Morong, in the Talant Islands, told me, that in case of a divorce the children go 'where they do not cry.'" P. 288 - "In some cases, the children, when the parents are divorced, can choose the family to which they will afterwards belong."

+ Yassan of Kachal possessed three houses and three wives. Offandi, headman of Mūs, had two wives, and knew of others similarly situated. "I got two wives now. I no want more than two wives one time; plenty trouble. Before I have other wives; when young, I go with _-."

"Generally speaking, the native (of Sarawak) is content with a single wife; only wealthy men and chiefs have sometimes two or three."-Schwaner.

$\ddagger$ This is the common practice of the Nicobarese. The fault of one is punished for the benefit of all, and the person directly injured receives little actual compensation. The custom is one that does not encourage litigiousness.

$\S$ The late "Davy Jones" of Kar Nicobar lived with two women who were sisters of each other; his neighbours looked on with much disapproval, but no one ventured to interfere. 
with her family, assists her in her daily work, and sleeps for a time in whatever house she may occupy. During the night he seeks the girl, who will be sleeping among others, and by blowing on the burning end of a cigarette he obtains light enough to discriminate. The efforts of the man to embrace and caress her the girl withstands vigorously with blows and scratches, so that his face and chest are often torn and covered with blood. So things continue for several nights perhaps, the man suffering patiently the while, until, if she is willing to take him as a husband, she yields herself. This is their nuptials, and concludes the marriage.* Thenceforth, the man holds to his wife's house rather than his own family's, but often the parents will learn nothing for some time. $\uparrow$

* "Among the Battas no marriage ceremonies take place; rich men and rajahs only regale the village by killing a buffalo or hog." -Featherman.

† (a) Cf. St John's Life in the Forest of the Far East.- " Besides the ordinary attentions which a young man (of the Sarawak Dyaks) is able to pay the girl he desires to make his wife, as helping her in her work, and carrying home her load of vegetables, as well as making her presents, there is a peculiar testimony of regard that is worthy of note. About nine or ten at night, when the family is supposed to be asleep within the mosquito curtains in the private apartment, the lover quietly slips back the bolt by which the door is fastened on the inside, and enters the room on tip-toe. He goes to the curtains of his beloved, gently awakes her, and she, on hearing who it is, rises at once, and they sit conversing together and making arrangements for the future, in the dark, over a plentiful supply of sireh leaf and betel-nut, which it is the gentleman's duty to provide. If, when awoke, the young lady arises and accepts the prepared betel-nut, happy is the lover, for his suit is in a fair way to prosper; but, if on the other hand, she rises and says, 'Be good enough to blow up the fire,' or 'to light the lamp,' then his hopes are at an end, for that is the usual form of dismissal. Of course if this kind of nocturnal visit is frequently repeated, the parents do not fail to discover it, although it is a point of honour among them to take no notice of their visitor ; and if they approve of him, matters take their course, but if not, they use their influence with their daughter to ensure the utterance of the fatal "Please blow up the fire."

(b) "Customs of the Minahassers," Hickson's Celebes, p. 272.- "Two young people meet at the mapalus (communal gatherings for work, followed by a feast), and over the feasting and singing become interested in one another, and fall in love. Then follows the courtship, which is not supposed to be open and above-board, but is, nominally at least, carried on in secret. It consists in nocturnal visits of the young man to the young woman's house, visits which although frequently attended by immorality, are not necessarily so, and are often perfectly decorous and formal.

"The young woman prepares a mat for her lover, and after dark he comes 
Sometimes the girl makes the path of courtship less easy, by changing her sleeping-hut from night to night. This difficulty the lover generally overcomes by employing small boys to follow her about and inform him of her resting-place.

Occasionally the man, following the girl home at night after a dance, etc., will meet with an attempt at resistance on the part of the other women dwelling there, when he essays to enter the house she has chosen.*

A man wishing to escape the consequences of marriage, and thinking he was unrecognised in the darkness by others during his intercourse with the girl, will nearly always be identified by some of the women present. If he refuses to carry out his share of the contract, a council is called of the principal men of his village, and they fine him so many pigs, which form the material for a general feast.

In the northern islands, the "Town Halls" in the Elpanams are the property of the community in general, for they are the work of the whole village. The products of the forest are common to all, but it is now necessary to obtain the headman's permission before occupying a piece of land near the village, to build a house or make a garden on.

Everything which the village as a whole makes or purchases, as the Elpanam houses or Chaura canoes, is common property, but the result of individual work belongs to the individual. Plantations, coconuts, $\nmid$ canoes, and houses, are private possessions, liable, however, to family claims founded on common family work.

to visit her. The parents are, of course, aware that their daughter is receiving a visitor, and are indeed proud that she should be thus so sought after; but at the same time they warn her to be cautious. The lover departs again before daybreak, in order that there may be no gossip in the village about their engagement until all is settled. These visits extend orer some weeks, and at last one morning he remains until the day has broken, as a sign that the engagement may be formally announced."

* Cf. Malay custom during the marriage ceremony, of the bride's female friends trying to prevent the entrance of the bridegroom and his companions.

+ In some places in the south it is said that coconut plantations are held in common by all in the village. 
Both sexes inherit, and property is generally divided equally among the heirs.

There is in Kar Nicobar a method of guarding property termed takoia, which at first is liable to be taken for a case of tabu or pomali. Posts and sticks, decorated with coloured rags and coconut husks, are erected near gardens, plantations, etc. They have no superstitious significance whatever, and only act as a kind of notice of title, warning all and sundry that the surroundings are private property. Anyone discovered stealing the same is fined, i.e., the usual pigs are confiscated to feast the community.*

The village headman and his deputy are a recent institution of the authorities to simplify the procedure of controlling the natives. The opinion of the village is generally taken on the question, and, if approved of, their nominees are invested with a certificate, a flag, and a suit of clothes, presented yearly.

The headmen can command no obedience, and enforce no laws; they work only by persuasion ; and, with the more influential men, deliberate on vexed questions, and impose fines, which seem always paid. Such fines do not accrue to the benefit of the injured party, but of the community, who enjoy a feast as the result, in which the culprit himself takes part.

As the headman now stands, he is the successor of the village "captain" or presiding elder, who had no other functions but to represent the community on the arrival of ships, and to regulate barter. His office and title were instituted by the natives when relations with European vessels became frequent, in order that they might have some representative to correspond to the commanding officer.

* "With regard to takoia, there is an observance of tabu when a death occurs. The coconut and pandanus plantation of the deceased is banned, the fruit being allowed to drop and germinate where it lies. The trees are marked by having coconut fronds fastened round their trunks, so no one, even a stranger, can appropriate the fruit through ignorance. As in the case of a large plantation it would be too great a task to mark each tree in this way, only the most conspicuous trees along the boundary are so distinguished, as this suffices to indicate that all within the boundary are included in the tabu."-E. H. Man. 
Before this epoch, everybody seems to have been on a footing of complete social equality, as, with the exceptions above-noted, is the case to-day.

Everyone, even children, is his own master; but persons who have been abroad, by virtue of their experience, are respected and have some authority, as also have the aged and wealthy. But there is no one who has power to exercise control over even a single village, save in the way of carrying out popular ideas.

A "primitive form of socialism exists. Chiefs are unknown. Certain individuals, by force of character ... have more influence than others ... but this influence seems to be at best but slight, and each person is obedient to himself alone, or to some unwritten code of public opinion "*-really the essence of the whole system.

The position of women is, and always has been, in no way inferior to that of the other sex. They take their full share in the formation of public opinion, discuss publicly with the men matters of general interest to the village, and their opinions receive due attention before a decision is arrived at. In fact, they are consulted on every matter, and the henpecked husband is of no extraordinary rarity in the Nicobars.

In Kar Nicobar, where the villages are divided into groups of several houses, a woman occasionally succeeds her late husband as sub-chief, on account of the knowledge she may possess of the regulations in vogue, the property and customs of her neighbours.

Women take a fair share in the day's work. They do the cooking, and the whole family eats together; the men build the houses, canoes, etc.; both sexes may be seen working in company in the plantations, fishing on the reefs, and paddling the canoes.

It is only the women in Chaura who manufacture pottery; but as the art is a monopoly, they must be looked on as rather privileged than otherwise.

In fine, there is no actual division of labour, but all assist in whatever has to be done, from their earliest years. Although * Dr Guillemard on "The Papuans," Australasia, vol. ii., 1894. 
scarcely any obedience seems due from children to their parents, most of the ordinary tasks of life are undertaken by young people of both sexes, and much deference is paid to age, especially when it is combined with wealth.

The domestic animals of the Nicobarese are swine, cats, fowls, and dogs, the latter generally of the pariah variety; but now and again in the southern islands a mongrel chow is met with, a cross between the chow and some animal brought thither by the Chinese junks. All are the descendants of introduced species. They are fed on little else but coconut, and support life on this and the results of their own foraging. Pigeons, parrots, and monkeys are occasionally to be seen in captivity, but the natives have not attempted to systematically utilise the megapode; all the laying-places near the villages are, however, known, and periodically overhauled for eggs.*

Weapons, in the strict sense of the word, do not exist now among the Nicobarese; they possess no shields, swords, clubs, or spears for warlike purposes only. The Burmese dáo, their most common implement - obtained from the ship-traders - is used for everyday purposes and for house-building, agriculture, canoe-fitting, etc., while the spears and harpoons used for pigkilling, cattle-hunting, and fishing are nearly all constructed by attaching a suitable haft to the variously shaped heads which are made locally. A fishing spear of native make is of the many-pronged wooden type (Mal., s'rempang) common throughout the East-a bunch of diverging barbed skewers spliced into a haft with lashings of cord or rattan.

The Shom Pen manufacture a javelin or dart, which is used indiscriminately for warfare or the chase as occasion may require; it is made of a single piece of heavy wood, and is possibly the

* The only place where the domestication of the megapode is recorded is the island of Savo in the Solomons. Here the birds may be seen sitting quietly on the fences about the villages, and the laying-grounds are regularly portioned out amongst the inhabitants.-Vide Among the Man-eaters, by Jolın Gaggin; London, Fisher Unwin. 
same kind of implement as was in general use among the Nicobarese before the introduction of iron heads.*

Fifty and more years ago, the natives obtained numbers of muskets-of which they were much afraid_-by barter with European traders; but recently the Indian Government has prohibited the

8.

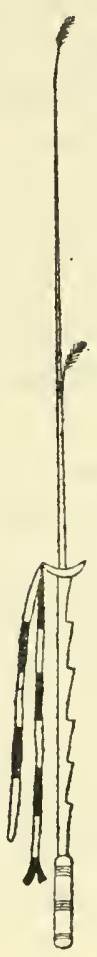

2.

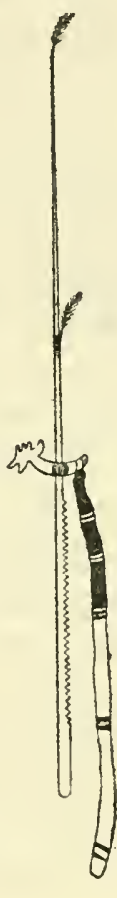

3.
9.

10.

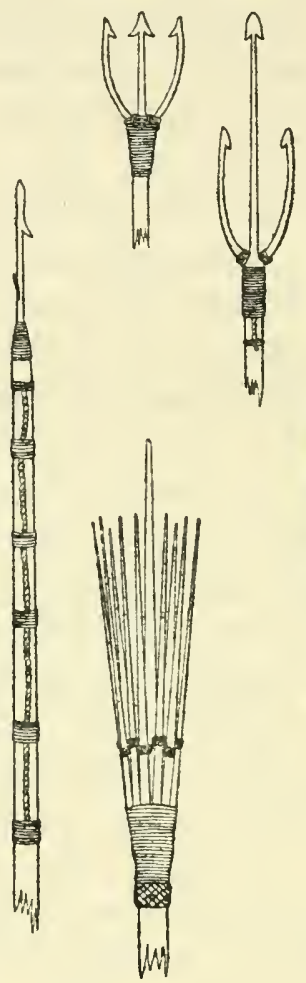

5.

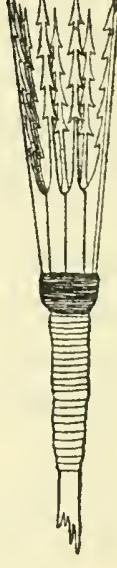

6.
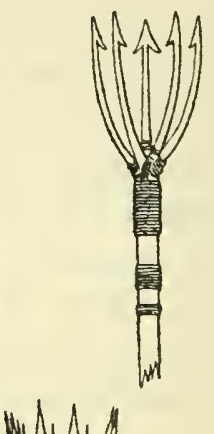

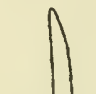

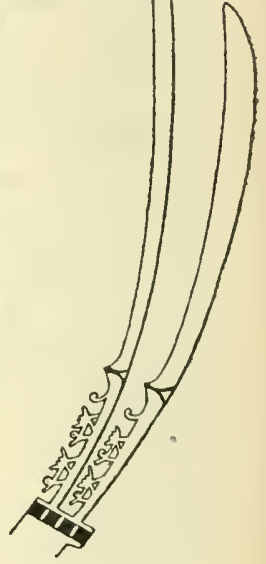

7 .

1, Shom Peń Spear (Great Nicobar). 2 and 3, "Hanoi cha," Canoe Decorations for bow, stern, and outrigger (Kar Nicobar). 4, Turtle Spear. 5 and 6, Wooden Fishing Spears. 7, Omamental Canoe Stern-piece, "Misoka ap" (Kar Nicobar). 8, 9, and I0, Iron Fishing Spears.

possession of these weapons, and whenever any are discovered they are immediately confiscated.

* "Their favourite weapons are javelins, which they throw fifty yards; they often poison the point with a subtle drug."-Chopard, J. I. A., I847.

"Lances with points of iron or hardened wood."-Scherzer, Cruise of the Novara, 1858 ; and see p. $28 \mathrm{I}$. 
In common with the other Malayan peoples, they do not seriously employ the bow and arrow. Crossbows are in use among them for shooting birds, but it is evident that such implements are not the invention of the natives. The stock is fashioned like a gun-butt, and the arrow rests in a groove running along the top of the fore-end, and is kept in position by means of three half-hoop pegs of brass wire. The bow is perfectly round in section, tapering towards the ends, and the release is of the string and peg varicty, hitching over the top of the trigger. The arrows, which are unfeathered and half the diameter of a lead pencil, have for point a sharpened nail attached by a wrapping of sheet-tin.

These bows have either been copied from the weapons of the early voyagers, or, more probably, have been introduced by the Burmese, amongst whom and the Karens there exists an article almost exactly similar.

Tools of European model are now common, and for fashioning canoes, houses, etc., imported axes, saws, adzes, planes, and spokeshaves are used, in addition to the dáo.

The latter is never fitted with a handle, and from constant use of it thus, thick ridges of skin and corns form on the inside of the natives' hands. It is found that the bare tang is very convenient for picking up coconuts; for retaining the weapon when up in the palm trees, by sticking it into the bark, thus leaving both hands free; for punching two holes in the opposite sides of a nut, through which the water may be extracted by suction; and for many other purposes.

The Nicobarese rarely use nets for fishing. Besides occasionally employing small casting nets purchased from traders, - the construction of which they never themselves attempt-they make and use a primitive net trap, which is baited and held a foot or two below the surface by the fisherman, who, on seeing a fish nibbling at the bait, promptly raises the trap, thereby catching the fish in the netting.

The fish are obtained either by hook and line (imported), or by spearing by day or at night with the aid of blazing 
torches of coconut leaf. Open-meshed traps of rattan, of various sizes and shapes, with funnel-shaped mouth leading towards the interior, are in common use, and are sunk in the sea-bottom in suitable places. They also construct weirs of coconut leaves (Tanánga-Kar Nicobar; Kan-Sháng-Nankauri), by means of which large quantities of fish are generally caught. These are employed only during the dry season when the sea is fairly calm.

Finally, the narcotic property possessed by the seeds of Barringtonia speciosa* is made use of ; for, in pools and confined waters, the addition of a small quantity of a paste, made of the mashed kernels, acts like "tuba," causing all the fish present to become insensible and rise to the surface, where they may be collected at leisure.

Turtle are common about the islands, and many skulls are to be met with in the houses of the natives, by whom they are used for the expulsion of demons. They are captured when floating on the sea by means of a harpoon with a skewer-shaped iron head, which, when fast in the shell, detaches from the shaft and remains connected by a short piece of cord only.

Large quantities of fish are often caught, when the weather is favourable, by means of the kan-shang, traps, etc., and, consequently, at times the natives live largely on fish. The staples of food throughout the year are coconuts and pandanus fruit, with bananas, yams, and occasionally other fruits and vegetables in small quantities. Fowls and pork can only be afforded now and then. Rice is used to a small extent, and is one of the articles for which the natives barter coconuts.

The fruit of the pandanus, which is an egg-shaped mass frequently attaining a diameter of 18 inches, consists of a

* Cf. "The large quadrangular nut is a 'common object of the sea-shore' in the Malay Islands, and is much used by the natives to catch fish. The fruit is pounded and thrown into the water, and the fish, rising to the surface in a stupefied condition, are easily secured."-P. 188, Cruise of the Marchesa, by F. H. H. Guillemard ; London, John Murray, 1889.

Also used for the same purpose by natives of the Solomons.-Vide H. B. Guppy's Solomon Islands; London, Swan, Sonnenschein. 
cluster of fibrous drupes, the tops of which are sliced off as soon as gathered. Thus treated, it can be preserved for some weeks.

When preparing it for eating, these divisions are separated from the central core and placed in a pot over a layer of bainboos or a grating, ${ }^{*}$ below which there is a little water; above them are laid yams, or whatever may be suitably cooked by that process, and the whole is then covered with leaves and steamed for some hours. $\dagger$

The pulpy matter that it contains is then scraped out with a shell while the drupe is held on a heavy slab of wood, and then the bristly fibres with which the nutritious portion is intermixed are extracted from the latter by drawing threads of a sort of bass through the pasty mass resulting. Thus is obtained a smooth dough, of a yellowish colour and somewhat sweet taste, that has been likened in flavour to apple-marmalade. A portion of this (kow-en), with some grated coconut, and sometimes a piece of chicken or pork, constitutes the usual meal.

This food is often made up into leaf-covered bundles, in which state it acquires a distinctive, though not unpleasant, odour, and can be kept a long time.

The fibrous drupe, after treatment as above, is commonly used as a foot-brush + at many of the islands, for which purpose it is kept near the top of the hut-ladder for those entering the hut.

The principal beverages are the water of the green unripe coconut, and toddy, made by fermenting the sap of the coco palm, which is regularly bled at the crown into bamboo receptacles. The toddy is largely manufactured, and as it is no more intoxicating than strong ale, much has to be consumed before drunkenness results. Ordinary water is scarcely ever taken, and its use is almost entirely restricted to cooking.

* Vide item 2 of plate facing p. 94.

+ In some of the islands a pot-cover is made by sewing together a special kind of leaf with long slips of rattan, until a pad quite an inch in thickness is obtained.

+ In many islands of the Pacific Ocean-Marshalls, Gilbert and Kingsmills, the Carolines, Union, and Ellice, and in New Guinea-the pandanus fruit is used as a food, especially in times of scarcity, but in general the kernel only is eaten, and the inner end of the drupes gnawed off. 
For the last few years the authorities at Port Blair have attempted to inculcate in the natives a liking for tea, the taste for which they have fostered by presenting the headmen with quantities of the leaf, in the hope that it will, if it become popular, somewhat minimise the prevalent consumption of toddy, which, when largely indulged in, cannot but have a bad effect on the general health of the people.

Toddy, however, does not stand alone as an intoxicant: nearly everywhere one comes across the black, square bottles in which gin is conveyed to all parts of the world: occasionally brandy is inquired for, but on all the islands there is a demand for rum, and this seems to have been the favourite drink since it was introduced to the natives by British captains bartering for coconuts in the early part of the last century. At present, however, Chinese traders are the only smugglers, and the spirit they introduce, samshu, runs only occasional risk of confiscation, as the trade of the junks is for the most part in places seldom visited by the occasional patrolling steamer.

Tobacco is used by everyone-men, women, and childrenboth for chewing and smoking: the native cigarette is a very crude affair, composed of a small quantity of the weed and a large amount of a certain dried leaf. The tobacco finding most favour is of Chinese and Javanese manufacture, and cigars are much appreciated.

Betel-chewing is universal, and the quid-which undoubtedly acts as a stimulant-consists of areca-nut, lime, and the sireh leaf only, without the addition of gambier. The teeth of the Nicobarese are both large and prominent, and the continuous use of betel and tobacco stains them a brown and black colour that is much admired.

In person, the natives, although generally clean, are less particular than tropical races as a rule: there are none of the fenced-in wells (panchurans, or bathing-screens) on the stream banks that one sees near all the villages of the Malays, but an occasional bath is taken by pouring the contents of a dozen 


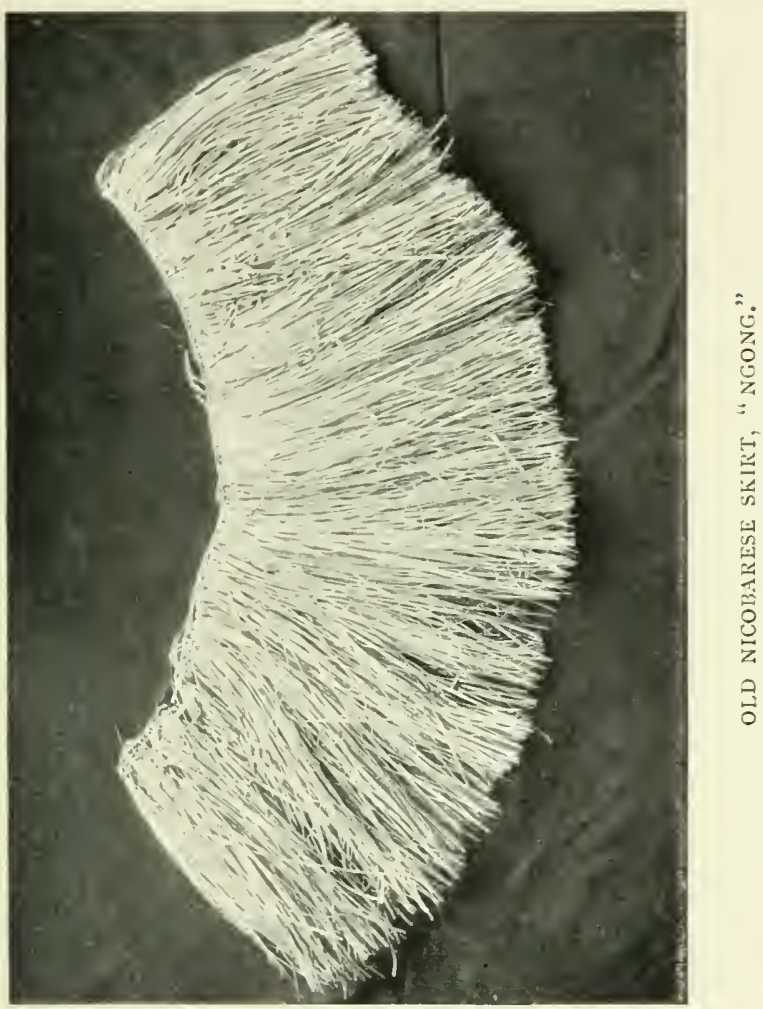



coconut shells over the body. Clothing gets a rinse in the sea at intervals by way of cleansing.

At the present time the everyday dress is of red cotton, but for the first half and more of the last century the fashion ran all in blue. On ordinary occasions men wear a long strip of cotton, gencrally red, passing round the thighs and between the legs,* and women drape a fathom or two of cotton about the waist by twisting the ends together; but for other times there are cotton draperies, sarongs, Chinese coats and trousers, and also European garments, which, from top-hats to shirts, are in great demand. $\dagger$

In the north a chaplet of areca palm spathe with loose ends (tá-chöla) is much worn, and the ear-lobes are pierced to retain short plugs of bamboo, half an inch in diameter, inlaid with silver and with silver pendants. From Kamorta southward the common head-dress is a similar chaplet of pandanus leaf (shanóang), or a coloured handkerchief or circlet of calico, and there is a plain ear-distender, one inch or more in diameter and three long, often shaped like a wedge: this is replaced on festive occasions by a large rosette of red and white cotton.

Other ornaments are bangles and anklets, made by twisting thick silver wire about the limb, and belts and necklaces made of rupees or smaller coins. Rings are worn, either of silver or shell.

Face and chest are sometimes covered with vermilion or saffron paint, but the natives do not employ any form of tattoo or scarification.

Hair is usually worn short by both sexes, but there is a more or less distinctive style or fashion at all the islands. On the occasion of a sudden or violent death at a village all its in-

* Referred to in these pages as kissat, neng, or $T$ bandage, for want of a more accurate expression.

+ For the dress used at various periods, refer to the authorities quoted in other chapters. The earliest clothing-apart from ornamental cords and string bracelets, etc., as are still used by the Andamanese-seems to have been, for the men a strip of bark cloth, and for the women a short petticoat of grass or coco-palm leaf (ngong). 
habitants are required to shave their heads, and the women their eyebrows as well.* Mourning for a relative is indicated in like manner as well as by other observances. With infants the head is often shaved for a time, and for the next few years the hair is kept short, in which way it is also worn by all ages and sexes. Boys as a rule have their heads cropped.

Fairly long hair is worn by many, but in no case is it ever permitted to grow below the shoulders; at that point it is cut across horizontally, and then, when bushy, the hair presents much the appearance represented in Assyrian and Egyptian. records.

The Nicobarese possess no musical instrument of their own invention, but very occasionally some individual attempts to produce, without much success, a copy of something he has seen in the hands of foreigners-a violin, guitar, etc.

Two instruments are, however, in use among them: one, a seven-holed flageolet, which is Burmese, and the other, the danang, borrowed from the Indian "sitar," has three frets, a string of cane, and two sound-holes. $\dagger$ "It is a hollowed bamboo, about $2 \frac{1}{2}$ feet long and 3 inches in diameter, along the outside of which there is stretched from end to end a single string, made of the threads of a split rattan, and the place under the string is hollowed, to prevent it from touching. This instrument is played upon in the same way as a guitar" while rested on the knee.+

With the exception of dancing, singing, and feasting, there are hardly any organised amusements. The exact forms of the dances vary, but for special occasions new figures and songs are composed and assiduously practised. In the north-ivest, challenges for canoe races, or processions rather, circulate amongst the Kar Nicobar villages, and are taken part in by twenty or thirty men a-side. The large canoes are decorated,

* The idea being that the demon who caused the death may fail to recognise the survivors.

+ M. V. Portman, Jour. Royal Asiatic Soc., 1888.

$\ddagger$ G. Hamilton, Asiatic Researches, vol. ii. 
and the course is a long one - several miles along the coast from village to village. As the men sing at the top of their voices throughout the race, they are generally exhausted at the finish. The pace is not remarkable, and the canoes keep abreast throughout, neither seeming to mind which comes in first.

Wrestling is a favourite pursuit of the boys. There is no science or cunning displayed, and the rounds are very short, one or the other combatant going down at once.

Pig processions are a pastime indulged in by young men. A pig is tied beneath a pole, and, with one of their number seated astride of it, is borne, with songs, about the village by a party of youths in the evening.

In such villages as are situated near the calmer waters of harbours, little children amuse themselves by sailing models of canoes and junks.

The Nicobarese have no writing or pictography, and their attempts at ornamental work on articles of general utility are confined to the finials of the houses, the stem and stern posts of their canoes, and a little decorative carving on their wooden dishes.* Nevertheless, in the charms and talismans connected with their superstitious cult they betray a certain artistic ability, and their pictures, screens, and figures of birds, men, and animals, show not only good powers of observation, but a capacity and skill of no mean order, in interpreting and reproducing whatever may present itself to them.

As concerns metals, it appears that 200 years ago Jesuit missionaries discovered tin on Great Nicobar. Having regard to the proximity of the rich deposits of this metal in Sumatra and the Malayan Peninsula, it seems not improbable that the statement will some day be verified. At Kar Nicobar small quantities of iron pyrites are found. The art of working in iron is almost confined to Chaura, where the mercilutas and the best spear-heads are manufactured. The latter are, however, made at the other islands as well. Of weaving they have no knowledge, * Cf. "Dyak dishes," in Headhunters of Borneo, plate 19. 
and prior to the introduction of cotton and cloth garments they clothed themselves in tapa or cloth made of the beaten bark of a tree at present believed to be the Ficus brevicuspis, also with girdles of split coconut leaves.

They are, however, expert basketmakers, and many-shaped baskets for various purposes are manufactured in different patterns of mesh, entirely out of the strips of rattan, or of the bark of the Maranta dichotoma.

What the sago is to the Papuan, the pandanus is to the Nicobarese, and its luxuriant natural growth renders unnecessary any extensive agricultural labour on his part. The other great support of life - the coconut - once planted, thrives without further attention, and for the rest, his fruits, bananas, and yams, require but the slightest amount of cultivation. The implement used in all cases seems to be the dáo only.

The islands produce no artificial material, and no raw merchandise is imported. Among themselves the natives trade in little more than pottery and canoes, and the only stores or bazaars are kept by foreigners who barter with the inhabitants. Coconuts, betel-nuts, rattan, mother-o'-pearl shells, trepang, and edible birds' nests, are the only trade commodities. The two latter are of minor importance, and are collected directly by the traders; the rattan comes from Great Nicobar only. Ambergris, for which the Nicobars were most noted in the Middle Ages, is still found, principally in the vicinity of Nankauri Harbour, and sold to traders.

All traders visiting the Nicobars have to obtain, either from Port Blair or from one of the local Government Agents, a license, at a cost of I rupee per man of the crew, which grants them "permission to visit ... for the purpose of trade during the present north-east monsoon season, on the condition that no person who may proceed thither by the vessel shall be permitted to remain behind . . . after her departure."

Disagreements between the traders and natives are frequent, and, for the most part, seem due to the dishonesty and high-handed behaviour of the former. They get the natives into their debt 


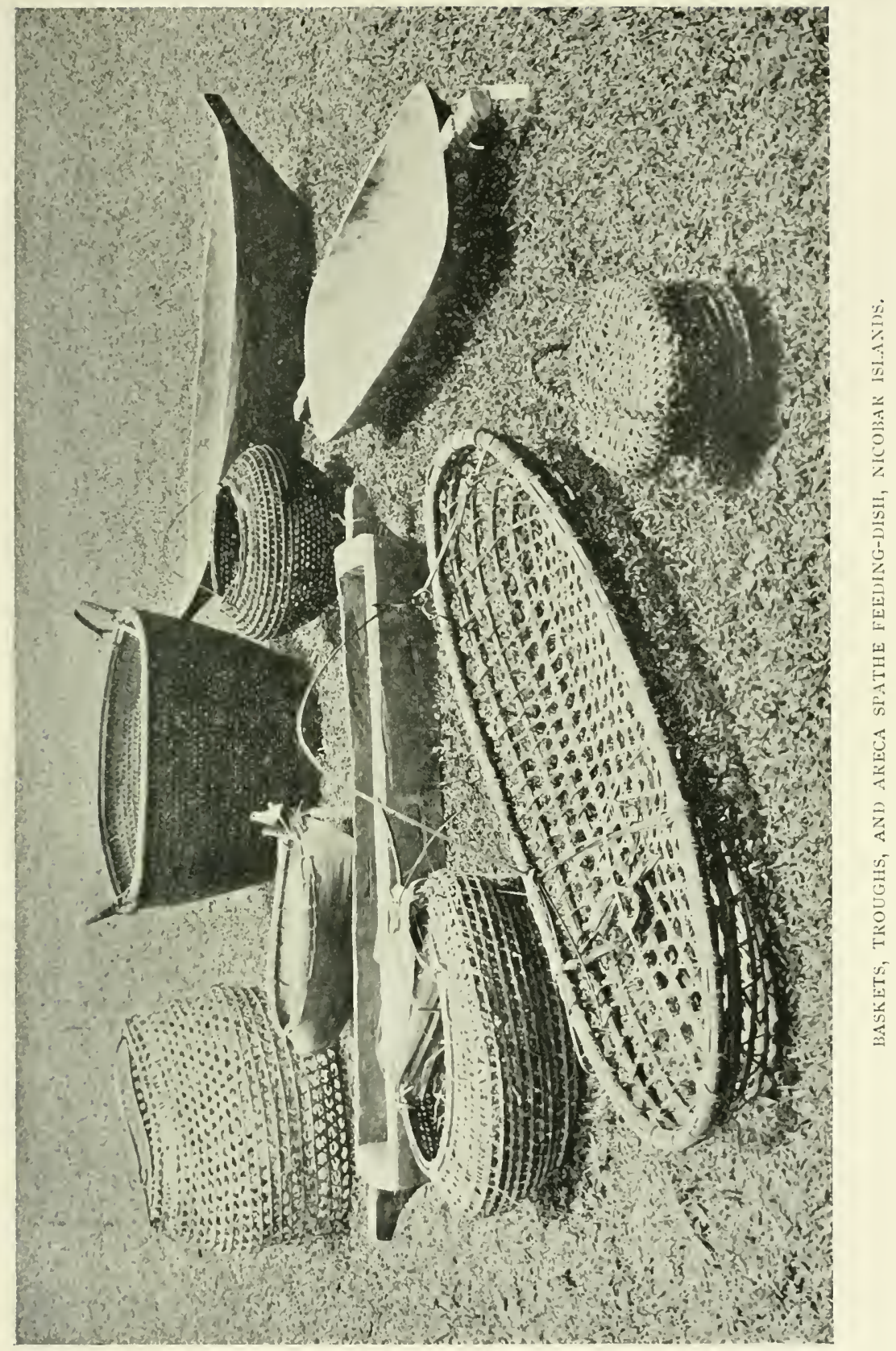



- often forcing them to accept things they do not require - falsify accounts, and even resort at times to acts of violence for which they have incurred punishment at Port Blair.

The merchants arrive in various kinds of vessels, from large barquentines, brigs, brigantines, and schooners, to the baglas of the Indians and Burmese kallus of 20 or 30 tons. These come mostly from Calcutta, Bombay, Negapatam, and Moulmein. The Chinese, of course, come in their national junks, viâ Singapore, Acheen, or Penang.

Trade is always carried on by barter; coconuts are the standard of value, and although dollars and rupees change hands, they are employed by the natives more as ornaments than mediums of exchange.

The annual production of coconuts is believed to reach at the lowest estimate, I5,000,000; about one-third of which are exported and the remainder consumed and planted.

Except in the northern islands, there are very few paths, and those merely tracks through grass and jungle; local transport and intervillage communication at the central and southern islands are largely carried on by canoe. 


\section{CHAPTER IV}

DAMPIER'S SOJOURN IN GREAT NICOBAR, AND VOYAGE THENCE TO ACHEEN IN A CANOE

I Do not think any excuse is needed for here giving in full Dampier's narrative of his experiences on Great Nicobar, and of his voyage thence to Acheen in a native canoe.

His "Voyages" are but little read nowadays; and not only are the chapters extracted of much interest in themselves, but they contain a careful record of his observations on the natives and their life and customs that, in spite of changes, is fairly accurate even for a description of things at the present day, with which it may be compared.

Dampier's account of the Nicobars is by far the most full that we have of the islands in past times, but I have nowhere, in any reference to them, seen attention drawn to his adventures in their neighbourhood. His voyage in the canoe was also a very interesting as well as a somewhat bold undertaking, for there are times in the south-west monsoon when it is by no means pleasant to be caught in a small open boat on that stretch of sea, where, too, the currents run very strongly.

The fever which prostrated himself and companions on their arrival in Sumatra was doubtless aggravated by exposure in the canoe, but was in all probability contracted during their sojourn in Great Nicobar, for all who spend any length of time on shore there seem certain to suffer from it.*

* (a) Of thirty individuals of the Galathea's crew engaged in an exploring expedition up the Galathea River, and caught one night in a rain-storm 
The privateer Cygnet of London, Captain Swan, originally fitted out to trade in the South Seas, in which Dampier made that part of his voyage round the world, extending from Realejo in Western Nicaragua to the Nicobars, had left the north-west coast of Australia on March 12, I688, and anchored nowhere until she reached the islands where he was permitted to quit her.

Since Captain Swan had been left ashore at Mindanao and his place taken by Read, it had been Dampier's continual desire to part from the vessel, and he explains in his narrative the reasons for the captain's objection to his desertion.

"... The 25th day of April 1688 we crossed the equator, still coasting to the northward, between the island Sumatra and a range of small islands lying 14 or 15 leagues off it. . .

"The 29th we saw a sail to the north of us, which we chased, but it being little wind, we did not come up with her till the 3oth day. Then, being within a league of her, Captain Read went in a canoe and took her, and brought her aboard. She was a prau with four men in her, belonging to Achin, whither she was bound. She came from one of those coconut islands that we passed by, and was laden with coconuts and with coconut oil. Captain Read ordered his men to take aboard all the nuts, and as much of the oil as he thought convenient, and then cut a hole in the bottom of the prau and turned her loose, keeping the men prisoners.

"It was not for the lucre of the cargo that Captain Read took

which compelled them to remain in the forest wringing wet, no fewer than twenty-one fell ill of fever, which ultimately proved fatal in four cases.-Vide Corvetten Galathea's Jordourseiling, 1852.

(b) During a stay of thirty-two days amongst the islands, the frigate Novara, with a crew of 320 men, had six cases of fever, but, when in the Straits of Malacca, fifteen more developed the same illness. All recorered, and those of the company who had never set foot on shore, furnished the largest contingent.-Vide Cruise of the Novara, 1858 .

(c) Of the five from the Terrapin who ascended the Galathea River and spent a night in the interior of the island, each was down with malaria either during the voyage to, or after arrival at, Singapore. 
this boat, but to hinder me and some others from going ashore, for he knew that we were ready to make our escapes, if an opportunity presented itself; and he thought that, by abusing and robbing the natives, we should be afraid to trust ourselves amongst them. But yet this proceeding of his turned to our greater advantage, as shall be declared hereafter.

"May the Ist, we ran down by the north-west end of the island Sumatra, within 7 or 8 leagues of the shore. All this west side of Sumatra which we thus coasted along, our Englishmen at Fort St George call the west coast simply, without adding the name Sumatra. The prisoners who were taken the day before showed us the islands that lie off Achin Harbour, and the channels through which ships go in; and told us also that there was an English factory at Achin. I wished myself there, but was forced to wait with patience till my time was come.

"We were now directing our course towards the Nicobar Islands, intending there to clean the ship's bottom in order to make her sail well.

"The fourth day, in the evening, we had sight of one of the Nicobar Islands. The southermost of them lie about 40 leagues N.N.W. from the N.W. end of the island Sumatra. The most southerly of them is Nicobar itself, but all the cluster of islands lying south of the Andaman Islands are called by our seamen the Nicobar Islands.

"The inhabitants of these islands have no certain converse with any nation, but as ships pass by them they will come aboard in their praus and offer their commodities to sale, never inquiring of what nation they are; for all white people are alike to them. Their chiefest commodities are ambergris and fruits.

"Ambergris is often found by the native Indians of these islands, who know it very well; as also know how to cheat ignorant strangers with a certain mixture like it. Several of our men bought such of them for a small purchase. Captain Weldon also about this time touched at some of these islands 
where we lay, and I saw a great deal of such ambergris that one of his men bought there; but it was not good, having no smell at all. Yet I saw some there very good and fragrant.

"At that island* where Captain Weldon was there were two friars, sent thither to convert the Indians. One of them came away with Captain Weldon; the other remained there still. He that came away with Captain Weldon gave a very good character to the inhabitants of that island, viz., that they were very honest, civil, harmless people; that they were not addicted to quarrelling, theft, or murder; that they did marry, or at least live as man and wife, one man with one woman, never changing till death made the separation; that they were punctual and honest in performing their bargains; and that they were inclined to receive the Christian religion. This relation I had afterwards from the mouth of a priest at Tonquin who told me that he received this information by a letter from the friar that Captain Weldon brought away from thence." $\dagger$

But, to proceed:- " The 5th day of May we ran down on the west side of the island Nicobar properly so-called, and anchored at the N.W. end of it, in a small bay, in 8 fathoms water, not half a mile from the shore. The body of this island is in $7^{\circ} 30^{\prime}$ N. lat. + It is about 12 leagues long, and 3 or 4 broad. The south end of it is pretty high, with steep cliffs against the sea; the rest of the island is low, flat, and even. $\S$ The mould of it is black and deep, and it is very well watered with small running streams. It produceth abundance of tall trees, fit for any uses; for the whole bulk of it seems to be but one entire grove. But that which adds most to its beauty off at sea, are the many spots

* Nankauri (?)

† Dalrymple, in his Oriental Repertory, states, that Captain Veldon surveyed the Nicobars in I687, and sent the survey, together with a history of the islands, by a Spanish priest to the East India Company. It does not appear to have been ever printed.

$\ddagger$ The parallel of $7^{\circ} \mathrm{N}$. lat. bisects the island.

$\$$ In this sentence of his description, Dampier's observations are incorrect. 
of coconut trees which grow round it in every small bay. The bays are half a mile or a mile long, more or less, and these bays are intercepted or divided from each other with as many little rocky points of woodland.

"As the coconut trees do thus grow in groves, fronting to the sea, in the bays, so there is another sort of fruit-tree in the bays, bordering on the back side of the coco trees, farther from the sea. It is called by the natives a melory tree.* This tree is as big as our large apple trees, and as high. It hath a blackish $\dagger$ rind and a pretty broad leaf. The fruit is as big as the breadfruit + at Guam, or a large penny loaf. It is shaped like a pear, and hath a pretty tough smooth rind of a light-green colour. The inside of the fruit is in substance much like an apple, but full of small strings as big as brown thread. I did never see of these trees anywhere but here.

"The natives of this island are tall, well-limbed men; pretty long visaged, with black eyes; their noses middle-proportioned, and the whole symmetry of their faces agreeing very well. Their hair is black and lank, and their skins of a dark copper colour. The women have no hair on their eyebrows. I do believe it is plucked up by the roots, for the men had hair growing on their eyebrows as other people.

"The men go all naked; only a long, narrow piece of cloth or sash, which, going round their waists, and thence down between their thighs, is brought up behind and tucked-in at that part which goes about the waist. The women have a kind of a short petticoat, reaching from their waists to their knees.

"Their language was different from any that I ever heard before; yet they had some few Malayan words, and some of them had a word or two of Portuguese, which, probably, they

* "Larum." If they called it so, the name was probably acquired from Portuguese visitors.

+ Always greyish-white.

+ This is the true bread-fruit (Artocarpus incisa), which does not grow in the Nicobars, and with which the fruit of the pandanus is nominally confounded by the English-speaking natives and by several of those Europeans who have visited the Archipelago. 
might learn aboard of their ships passing by this place; for when these men see a sail, they do presently go aboard of them in their canoes. I did not perceive any form of religion that they had; they had neither temple or idol, nor any manner of outward veneration to any deity, that I did see.

"They inhabit all round the island by the seaside, in the bays, there being four or five houses, more or less in each bay. Their houses are built on posts, as the Mindanayans. They are small, low, and of a square form. There is but one room in each house, and this room is about 8 feet from the ground; and from thence the roof is raised about 8 feet higher. But instead of a sharp ridge, the top is exceeding neatly arched with small rafters about the bigness of a man's arm, bent round like a half-moon, and very curiously thatched with palmetto leaves.*

"They live under no government that I could perceive, for they seem to be equal, without any distinction; every man ruling in his own house. Their plantations are only those coconut trees which grow by the seaside, there being no cleared land farther in on the island; for I observed that when past the fruit-trees, there were no paths to be seen going into the woods. The greatest use which they make of their coco-trees is to draw toddy from them, of which they are very fond.

"The melory trees seem to grow wild. They have great earthen pots to boil the melory fruit in, which will hold 12 or I4 gallons. These pots they fill with the fruit, and, putting in a little water, they cover the mouth of the pot with leaves to keep the steam while it boils. When the fruit is soft, they peel off the rind and the pulp from the strings, with a flat stick made like a knife, and then make it up into great lumps as big as a Holland cheese, and then it will keep six or seven days. It looks yellow, and tastes well, and is their chiefest food; for they have no yams, potatoes, rice nor plantains (except a very few), yet they have a few small hogs, and a very few p. I24.

* This type of house is still built. See photograph taken at Pulo Milo, 
cocks and hens like ours. The men employ themselves in fishing, but I did not see much fish that they got; every house hath at least two or three canoes belonging to it, which they draw up ashore.

"The canoes that they go fishing in are sharp at both ends, and both the sides and the bottom are very thin and smooth. They are shaped somewhat like the praus at Guam, with one side flattish and the other with a pretty big belly; and they have small slight outlayers* on one side. Being thus thin and light, they are better managed with oars than with sails: yet they sail well enough, and are steered with a paddle. There commonly go twenty or thirty men in one of these canoes; and seldom fewer than nine or ten. Their oars are short, and they do not paddle, but row with them as we do. $\dagger$ The benches they sit on when they row'are made of split bamboos laid across, and so near together that they look like a deck. The bamboos lie movable: so that when any go in to row they take up a bamboo in the place where they would sit, and lay it by to make room for their legs. The canoes of those of the rest of these islands were like those of Nicobar, and probably they were alike in other things; for we saw no difference at all in the natives of them who came hither while we were here.

"But, to proceed with our affairs: it was, as I said before, the $5^{\text {th }}$ day of May, about ten in the morning, when we anchored at this island. Captain Read immediately ordered his men to heel the ship, in order to clean her, which was done this day and the next. All the water-vessels were filled; they intended to go to sea at night, for the winds being yet at N.N.E., the captain was in hopes to get over to Cape Comorin before the wind shifted. Otherwise it would have been somewhat difficult for him to get thither, because the westerly monsoon was not at hand.

"I thought now was my time to make my escape, by getting

* Outriggers.

+ Nowadays they invariably paddle, and have no oars. 
leave, if possible, to stay here: for it seemed not very feasible to do it by stealth, and I had no reason to despair of getting leave, this being a place where my stay could, probably, do the crew no harm, should I design it. Indeed, one reason that put me on the thoughts of staying at this particular place, besides the present opportunity of leaving Captain Read, which I did always intend to do as soon as I could, was that I had here also a prospect of advancing a profitable trade for ambergris with these people, and of gaining a considerable fortune to myself. For in a short time I might have learned their language, and by accustoming myself to row with them in their praus or canoesespecially by conforming myself to their customs and manners of living-should have seen how they got their ambergris, and have known what quantities they got, and the time of the year when it most is found. And then afterwards I thought it would be easy for me to have transported myself from thence, either in some ship that passed that way, whether English, Dutch or Portuguese, or else to have gotten one of the young men of the island to have gone with me in one of their canoes to Achin, and there to have furnished myself with such commodities as I found most coveted by them, and therewith, at my return, to have bought their ambergris.

"I had, till this time, made no open show of going ashore here; but now, the water being filled and the ship in readiness to sail, I desired Captain Read to set me ashore on this island. He, supposing that I could not go ashore in a place less frequented by ships than this, gave me leave; which possibly he would have refused to have done if he thought I should have gotten from hence in any short time, for fear of my giving an account of him to the English or Dutch. I soon got up my chest and bedding, and immediately got some to row me ashore, for fear lest his mind should change again.

"The canoe that brought me ashore landed me on a small sandy bay, where there were two houses, but no person in them. For the inhabitants were removed to some other house, probably for fear of us; because the ship was close by: and yet both 
men and women came aboard the ship without any sign of fear. IVhen our ship's canoe was going aboard again, they met the owner of the houses coming ashore in his boat. He made a great many signs to them to fetch me off again, but they would not understand him. Then he came to me, and offered his boat to carry me off, but I refused it. Then he made signs to me to go up into the house, and, according as I did understand him by his signs, and a few Malayan words that he used, he intimated that somewhat would come out of the woods in the night, when I was asleep, and kill me, meaning, probably, some wild beast. Then I carried my chest and clothes up into the house.

"I had not been ashore an hour before Captain Teat and one John Damerel, with three or four men more, came to fetch me aboard again. They need not have sent an armed possé for me, for had they but sent the cabin-boy ashore for me, I would not have denied going aboard. For though I could have hid myself in the woods, yet then they would have abused, or have killed, some of the natives, purposely to incense them against me. I told them, therefore, that I was ready to go with them, and went aboard with all my things.

"When I came aboard, I found the ship in an uproar; for there were three men more, who, taking courage by my example, desired leave also to accompany me. One of these was the surgeon, $\mathrm{Mr}$ Coppinger, the other was $\mathrm{Mr}$ Robert Hall, and one named Ambrose-I have forgot his surname. These men had always harboured the same designs as I had. The two last were not much opposed, but Captain Read and his crew would not part with the surgeon. At last the surgeon leaped into the canoe, and, taking up my gun, swore he would go ashore, and that if any man did oppose it, he would shoot him. But John Oliver, who was the quarter-master, leaped into the canoe, taking hold of him, took away the gun, and with the help of two or three more, they dragged him again into the ship.

"Then Mr Hall, and Ambrose, and I were again sent ashore; and one of the men that rowed us ashore stole an axe and gave 
it to us, knowing it was a good commodity with the Indians. It was now dark, therefore we lighted a candle, and I, being the oldest stander in our new country, conducted them into one of the houses, where we did presently hang up our hammocks. We had scarce done this before the canoe came ashore again, and brought the four Malayan men belonging to Achin (which we took in the prau we took off Sumatra), and the Portuguese that came to our ship out of the Siam junk at Pulo Condore: the crew having no occasion for these, being leaving the Malayan parts where the Portuguese spark served as an interpreter; and not fearing now that the Achinese could be serviceable to us in bringing us over to their country, 40 leagues off; not imagining we durst make such an attempt; as, indeed, it was a bold one. Now we were men enough to defend ourselves against the natives of the island, if they should prove our enemies; though if none of these men had come ashore to me, I should not have feared any danger. Nay, perhaps less, because I should have been cautious of giving any offence to the natives: and I am of the opinion that there are no people in the world so barbarous as to kill a single person that falls accidentally into their hands, or comes to live among them, except they have been injured by some outrage or violence committed against them. Yet, even then, or afterwards, if a man could but preserve his life from their first rage, and come to treat with them (which is the hardest thing, because their way is usually to abscond, and rushing suddenly on their enemy, to kill him unawares), one might by some slight, insinuate oneself into their favours again. Especially. by showing some toy or knack that they did never see before, which any European that hath seen the world might soon contrive to amuse them withal: as might be done generally with a little fire struck with a flint and steel. ...

"As for these Nicobar people, I found them affable enough, and therefore I did not fear them; but I did not much care whether I had gotten any more company or no.

"But, however, I was very well satisfied, and the rather because we were now men enough to row ourselves over to 
the island Sumatra; and accordingly we presently consulted how to purchase a canoe from the natives.

"It was a fine clear moonlight night in which we were left ashore, therefore we walked in the sandy bay to watch when the ship would weigh and be gone, not thinking ourselves secure in our new gotten liberty till then. About eleven or twelve o'clock we saw her under sail, and then we returned to our chamber, and so to sleep; this was the 6th of May.

"The next morning betimes, our landlord with four or five of his friends came to see his new guests, and was somewhat surprised to see so many of us, for he knew of no more than myself. Yet he seemed to be very well pleased, and entertained us with a large calabash of toddy which he brought with him. Before he went away again (for wheresoever we came they left their houses to us, but whether out of fear or superstition I know not) we bought a canoe of his for an axe, and we did presently put our chests and clothes in it, designing to go to the south end of the island, and be there till the monsoon shifted, which we expected every day.

"When our things were stowed away, we with the Achinese entered with joy into our new frigate, and launched off from the shore. We were no sooner off but our canoe overset, bottom upwards. We preserved our lives well enough by swimming, and dragged also our chests and clothes ashore; but all our things were wet. I had nothing of value but my journal and some drafts of land of my own taking, which I much prized, and which I had hitherto carefully preserved: Mr Hall had also such another cargo of books and drafts, which were now like to perish. But we presently opened our chests and took out our books, which, with much ado, we did afterwards dry; but some of our drafts that lay loose in our chests were spoiled.

"We lay here afterwards three days, making great fires to dry our books. The Achinese in the meantime fixed our canoe with outlayers on each side; and they also cut a good mast for her, and made a substantial sail with mats. 
"The canoe being now very well fixed, and our books and clothes dry, we launched out the second time, and rowed towards the east side of the island, leaving many islands to the north of us. The Indians of the island accompanied us with eight or ten canoes against our desire; for we thought that these men would make provision dearer at that side of the island we were going to, by giving an account what rates we gave for it at the place from whence we came, which was owing to the ships being there, for the ship's crew were not so thrifty in bargaining (as they seldom are) as single persons or a few men might be apt to be who would keep to one bargain. Therefore, to hinder them from going with us, Mr Hall scared one canoe's crew by firing a shot over them; they all leaped overboard and cried out, but seeing us row away they got into their canoe again and rowed after us.

"The firing of that gun made all the inhabitants of the island to be our enemies. For presently after this we put ashore at a bay where were four houses and a great many canoes; but they all went away, and came near to us no more for several days. We had then a great loaf of melory, which was our constant food; and if we had a mind to coconuts or toddy, our Malayans of Achin would climb the trees and fetch as many nuts as we would have, and a good pot of toddy every morning. Thus we lived till our melory was almost spent; being still in hopes that the natives would come to us, and sell it as they had formerly done. But they came not to us; nay, they opposed us wherever we came, and after shaking their lances at us, made all the show of hatred that they could invent.

"At last, when we saw that they stood in opposition to us, we resolved to use force to get some of their food, if we could not get it other ways. With this resolution, we went in our canoe to a small bay on the north part of the island, because it was smooth water there, and good landing; but on the other side, the wind being yet on that quarter, we could not land without jeopardy of oversetting our canoe, and wetting our 
arms, and then we must have lain at the mercy of our enemies, who stood, 200 or 300 men in every bay where they saw us coming, to keep us off.*

"When we set out we rowed directly to the north end, and presently were followed by seven or eight of their canoes. They, keeping at a distance, rowed away faster than we did, and got to the bay before us; and there, with about twenty more canoes full of men, they all landed and stood to hinder us from landing. But we rowed in within roo yards of them. Then we lay still, and I took up my gun and presented at them, at which they all fell down flat on the ground. But I turned myself about, and to show that we did not intend to harm them, I fired my gun off to sea, so that they might see the shot graze on the water. As soon as my gun was loaded again, we rowed gently in; at which some of them withdrew. The rest, standing up, did still cut and hew the air, making signs of their hatred; till I once more frightened them with my gun, and discharged it as before. Then more of them sneaked away, leaving only five or six men on the bay. Then we rowed in again, and Mr Hall, taking his sword in his hand, leaped ashore; and I stood ready with my gun to fire at the Indians if they had injured him, but they did not stir, till he came to them, and saluted them.

"He shook them by the hand, and by such signs of friendship as he made, the peace was concluded, ratified, and confirmed by all that were present; and others that were gone were again called back, and they all very joyfully accepted of a peace. This became universal all over the island, to the great joy of the inhabitants. There was no ringing of bells, nor bonfires made, for that is not the custom here, but gladness appeared in their countenances, for now they could go out and fish again without fear of being taken. This peace was not more welcome to them than to us; for now the inhabitants brought their melory again to us, which we bought for old rags and

* This is probably an exaggeration, but there is no doubt that the island carried then a far greater population than it does at the present. 
small strips of cloth as broad as the palm of one's hand. I did not see above five or six hens, for they have but few on the island. At some places we saw some small hogs, which we could have bought of them reasonably; but we would not offend our Achinese friends, who were Mahometans.

"We stayed here two or three days, and then rowed towards the south end of the island, keeping on the east side, and we were kindly received by the natives wherever we came. When we arrived at the south end of the island, we fitted ourselves with melory and water. We bought three or four loaves of melory, and about twelve large coconut shells that had all kernel taken out, yet were preserved whole, except only a small hole at one end; and all these held for us about $3 \frac{1}{2}$ gallons of water. $\mathrm{WVe}$ bought also two or three bamboos that held about 4 or 5 gallons more. This was our sea-store.

"We now designed to go to Achin, a town on the N.W. end of the island Sumatra, distant from hence about 40 leagues, bearing S.S.E. IVe only waited for the western monsoon, which we had expected a great while, and now it seemed to be at hand; for the clouds began to hang their heads to the eastward, and at last moved gently that way, and though the wind was still at east, yet this was an infallible sign that the western monsoon was nigh.

(Ch. xviii.).- "It was the 15 th day of May I688, about four o'clock in the afternoon, when we left Nicobar Island, directing our course towards Achin, being eight men of us in company, viz., three English, four Malayans who were born at Achin, and the mongrel Portuguese.

"Our vessel, the Nicobar canoe, was not one of the biggest, nor of the least size. She was much about the burthen of one of our London wherries below Bridge, and built sharp at both ends, like the forepart of a wherry. She was deeper than a wherry, but not so broad, and was so thin and light that when empty four men could launch her or hale her ashore on a sandy bay. We had a good substantial mast, and a mat sail, and good outlayers lashed very fast and firm on each side the 
vessel, being made of strong poles. So that while these continued firm, the vessel could not overset, which she would easily have done without them, and with them too, had they not been made very strong; and we were therefore much beholden to our Achinese companions for this contrivance.

"These men were none of them so sensible of the danger as $\mathrm{Mr}$ Hall and myself, for they all confided so much in us, that they did not so much as scruple anything we did approve of. Neither was Mr Hall so well provided as I was, for before we left the ship, I had purposely consulted our draft of the East Indies (which we had but one in the ship), and out of that I had written in my pocket-book an account of the bearing and distance of all the Malacca coast, and that of Sumatra, Pegu, and all Siam, and also brought away with me a pocket compass for my direction in any enterprise that I should undertake.

"The weather at our setting out was very fair, clear, and hot. The wind was still at S.E., a very small breeze, just fanning the air, and the clouds were moving gently from west to east, which gave us hopes that the winds were either at west already abroad at sea, or would be so in a very short time. IVe took this opportunity of fair weather, being in hopes to accomplish our voyage to Achin before the western monsoon was set in strong, knowing that we should have very blusterous weather after this fair weather, especially at the first-coming of the western monsoon.

"We rowed, therefore, away to the southward, supposing that when we were clear from the island we should have a true wind, as we call it; for the land hales the wind; and we often find the wind at sea different from what it is near the shore. We rowed with four oars, taking our time. Mr Hall and I steered also by turns, for none of the rest were capable of it. IVe rowed the first afternoon and the night ensuing about i 2 leagues by my judgment. Our course was S.S.E.; but the I 6 th day, in the morning, when the sun was an hour high, we saw the island whence we came, bearing N.W. by N. Therefore 


\section{DAMPIER'S SOJOURN IN GREA'T NICOBAR 269}

I found we had gone a point more to the east than I intended, for which reason we steered $\mathrm{S}$. by $\mathrm{E}$.

"In the afternoon at four o'clock we had a gentle breeze at W.S.W., which continued so till nine, all which time we laid down our oars, and steered away S.S.E. I was then at the helm, and I found by the ripplings of the sea that there was a strong current against us. It made a great noise that might be heard half a mile. At nine o'clock it fell calm, and so continued till ten. Then the wind sprung up again, and blew a fresh breeze all night.

"The 17th day, in the morning, we looked out for the island Sumatra, supposing that we were now within 20 leagues of it, and the distance from Nicobar to Achin is 40 leagues. But we looked in vain for the island Sumatra, for, turning ourselves about we saw, to our grief, Nicobar Island lying W.N.W., and not above 8 leagues distant. By this it was visible that we had met a very strong current against us in the night. But the wind freshened on us, and we made the best use of it while the weather continued fair. At noon we had an observation of the sun; my lat. was $6^{\circ} 55^{\prime}$, and Mr Hall's was $7^{\circ} \mathrm{N}$.

"The ISth day the wind freshened on us again, and the sky began to be clouded. It was indifferent clear till noon, and we thought to have had an observation; but we were hindered by the clouds that came on the face of the sun when it came on the meridian. This oftens happens, that we are disappointed of making observations by the sun's being clouded at noon, though it shines clear both before and after, especially in places near the sun: and this obscuring of the sun at noon is commonly sudden and unexpected, and for about half an hour or more.

"We had then also a very ill passage (presage?), by a great circle about the sun (five or six times the diameter of it), which seldom appears but storms of wind, or much rain, ensue. Such circles about the moon are more frequent, but of less import. We do commonly take great notice of these that are about the sun, observing if there be any breach in the circle, and in what quarter the breach is; for from thence we commonly find the greatest 
stress of the wind will come. I must confess that I was a little anxious at the sight of the circle, and wished heartily that we were near some land. Yet I showed no sign of it to discourage my consorts, but made a virtue of necessity, and put a good countenance on the matter.

"I told Mr Hall that if the wind became too strong and violent, as I feared it would, it being even then very strong, we must of necessity steer away before the wind and sea till better weather presented; and that as the winds were now, we should, instead of about 20 leagues to Achin, be driven 60 or 70 to the coast of Cudda or Queda (Kedah) a kingdom and town and harbour of trade on the coast of Malacca.

"The winds, therefore, bearing very hard, we rolled up the foot of our sail on a pole fastened to it, and settled our yard within 3 feet of the canoe sides, so that we had now but a small sail; yet it was still too big considering the winds, for the wind being on our broadside, pressed her down very much, though supported by her outlayers, in so much that the poles of the outlayers going from the sides of the vessel bent as if they would break; and should they have broken, our overturning and perishing had been inevitable. Besides, the sea increasing, would soon have filled the sea this way. Yet thus we made a shift to bear up with the side of the vessel against the wind for a while; but the wind still increasing about one o'clock in the afternoon, we put right away before wind and sea, continuing to run thus all the afternoon and part of the night ensuing. The wind continued increasing all the afternoon, and the sea still swelled higher, and often broke, but did us no damage; for the ends of the vessel being very narrow, he that steered received and broke the sea on his back, and so kept it from coming in so much as to endanger the vessel: though much water would come in, which we were forced to keep heaving out continually. And by this time we saw it was well we had altered our course, every wave would else have filled and sunk us, taking the side of the vessel; and though our outlayers were well lashed down to the canoe's bottom with 
rattans, yet they must probably have yielded to such a sea as this, when even before they were plunged under water, and bent like twigs.

"The evening of this I 8th day was very dismal. The sky looked very black, being covered with dark clouds; the wind blew hard, and the seas ran high. The sea was already roaring in a white foam about us; a dark night coming on, and no land in sight to shelter us, and our little ark in danger to be swallowed by every wave; and what was worst of all, none of us thought ourselves prepared for another world. The reader may better guess than I can express, the confusion that we were all in. I had been in many eminent dangers before now, some of which I have already related, but the worst of them all was a play-game in comparison with this. I must confess I was in great conflicts of mind at this time. Other dangers came not upon me with such a leisurely and dreadful solemnity. A sudden skirmish or engagement or so was nothing when one's blood was up, and pushed forward with eager expectations. But here I had a lingering view of approaching death, and little or no hopes of escaping it; and I must confess that my courage, which I had hitherto kept up, failed me here; and I made very sad reflections of my former life, and looked back with horror and detestation on actions which before I disliked, and I now trembled at the remembrance of. I had long before this repented me of that roving course of life, but never with such concern as now. I did also call to mind many miraculous acts of God's providence towards me in the whole course of my life, of which kind I believe few men have met with the like. For all these I returned thanks in a peculiar manner, and this once more desired God's assistance, and composed my mind as well as I could in the hopes of it; and, as the event showed, I was not disappointed of my hopes.

"Submitting ourselves, therefore, to God's good providence, and taking all care we could to preserve our lives, Mr Hall and I took turns to steer, and the rest took turns to heave out the water, and thus we provided to spend the most doleful 
night I ever was in. About ten o'clock it began to thunder, lighten, and rain; but the rain was very welcome to us, having drank up all the water we brought from the island.

"The wind at first blew harder than before, but within half an hour it abated and become more moderate, and the sea also assuaged of its fury; and then by a lighted match, of which we kept a piece burning on purpose, we looked on our compass to see how we steered, and found our course to be still east. We had no occasion to look on the compass before, for we steered right before the wind, which if it shifted we had been obliged to have altered our course accordingly. But now it being abated, we found our vessel lively enough, with that small sail which was then aboard, to hale our former course S.S.E., which accordingly we did, being now in hopes again to get to the island Sumatra.

"But about two o'clock in the morning of the Igth day, we had another gust of wind, with much thunder, lightning, and rain, which lasted till day, and obliged us to put before the wind again, steering thus for several hours. It was very dark, and the hard rain soaked us so thoroughly that we had not one dry thread about us. The rain chilled us extremely: for any fresh water is much colder than that of the sea. For even in the coldest climates the sea is warm, and in the hottest climates the rain is cold and unwholesome for man's body. In this wet starveling plight we spent the tedious night. Never did poor mariners on a lee-shore more earnestly long for the dawning light than we did now. At length the day appeared, but with such dark black clouds near the horizon, that the first glimpse of the dawn appeared 30 or 40 degrees high, which was dreadful enough: for it is a common saying among seamen, and true, as I have experienced, that a high dawn will have high winds, and a low dawn small winds.

"We continued our course still east, before wind and sea, till about eight o'clock in the morning of the Igth day; and then one of our Malayan friends cried out, Pulo Way. Mr Hall and Ambrose and I thought the fellow had said Pull away! an 
expression usual among English seamen when they are rowing. And we wondered what he meant by it, till we saw him point to his consorts; and then we looking that way, saw land appearing, like an island, and all our Malayan friends said it was an island at the N.W. end of Sumatra, called Way, for Pulo Way is the island Way. We who were dropping with wet, cold, and hungry, were all overjoyed at the sight of the land, and presently marked its bearing. It bore south, and the wind was still at west, a strong gale, but the sea did not run so high as in the night. Therefore we trimmed our small sail no bigger than an apron, and steered with it. Now our outlayers did us a great kindness again, for although we had but a small sail, yet the wind was strong and pressed down our vessel's side very much. But being supported by the outlayers, we could brook it well enough, which otherwise we could not have done.

"About noon we saw more land beneath the supposed Pulo Way, and steering towards it, before night we saw the coast of Sumatra, and found the errors of our Achinese; for the high land that we first saw, which then appeared like an island, was not Pulo IVay, but a great high mountain on the island Sumatra, called by the English the Golden Mountain. Our wind continued till about seven o'clock at night, then it abated, and at ten o'clock it died away; and then we stuck to our oars again, though all of us quite tired with our former fatigues and hardships.

"The next morning, being the 2oth day, we saw all the low land plain, and judged ourselves not above 8 leagues off. About eight o'clock in the morning we had the wind again at west, a fresh gale, and steering in still for the shore, at five o'clock in the afternoon we run to the mouth of a river on the island Sumatra, called Passange Jonca (Pasangan River).* It is 34 leagues to the eastward of Achin and 6 leagues to the west of Diamond Point, which makes with three angles of a rhombus, and is low land.

* The Pasangan River has two mouths, of which the western is named Jangka. 
"Our Malayans were very well acquainted here, and carried us to a small fishing village within a mile of the river's mouth, called also by the name of the River Passange Jonca.* The hardships of this voyage, with the scorching heat of the sun at our first setting-out, and the cold rain, with our continuing wet for the last two days, cast us all into fevers, so that now we were not able to help each other, nor so much as to get our canoe up to the village; but our Malayans got some of the townsmen to bring her up. ... The Malayans that accompanied us from Nicobar separated themselves from us now, living at one end of the house by themselves, for they were Mahometans, as all those of the kingdom of Achin are; and though during our passage by the sea together we made them be content to drink their water out of the same coco-shell as us, yet being now no longer under that necessity, they again took up their accustomed niceness and reservedness. They all lay sick, and as their sickness increased, one of them threatened us that if any of them died, the rest would kill us for having brought them this voyage; yet I question whether they would have attempted it, or the country people have suffered it. We made a shift to dress our own food, for none of these people, though they were very kind in giving us anything that we wanted, would yet come near us to assist us in dressing our victuals. Nay, they would not touch anything that we used. We had all fevers, and therefore took turns to dress victuals according as we had strength to do it, or stomachs to eat it. I found my fever to increase, and my head so distempered that I could scarce stand; therefore I whetted and sharpened my penknife in order to let myself blood, but I could not, for my knife was too blunt.

"We stayed here ten or twelve days, in hopes to recover our health, but finding no amendment, we desired to go to Achin. ... The natives ... provided a large prau to carry us thither, we not being able to manage our own canoe. Besides, before this, three of our Malayan comrades were gone very sick * Kampong Jangka, on the left bank of the river of that name. 


\section{DAMPIER'S SOJOURN IN GREA'T NCOBAR 275}

into the country, and only one of them and the P'ortuguese remained with us, accompanying us to Achin, and they both as sick as we. ...

"Three days after our arrival here (Achin) our Portuguese died of a fever. What became of our Malayans I know not. Ambrose lived not long after; $\mathrm{Mr}$ Hall also was so weak that I did not think he would recover. I was the best, but still very sick of a fever, and little likely to live. Therefore Mr Driscol (an Irishman, and a resident in the factory which our East India Company had there then) and some other Englishmen persuaded me to take some purging physic of a Malayan doctor. I took their advice, being willing to get ease; but after three doses (each a large calabash of nasty stuff), finding no amendment, I thought to desist from my physic, but was persuaded to take one dose more, which I did, and it wrought so violently that I thought it would have ended my days. It working so quick with me... and my strength being almost spent, I even threw myself down once for all. ... I thought my Malayan doctor, whom they so much commended, would have killed me outright. I continued extraordinary weak for some days after his drenching me thus; but my fever left me for above a week, after which it returned upon me again for a twelvemonth, and a flux with it." 


\section{CHAPTER V}

\section{AN OLD ACCOUNT OF KAR NICOBAR}

IN 1778 Kar Nicobar was visited by Dr I. G. Koenig, a Swede, and pupil of Linnæus. He spent many years in India, both as doctor to the Danish missionaries at Tranquebar, and as naturalist to the Nabob of Arcot. After visiting different parts of India and Ceylon, he started on an expedition to Siam and Malacca, and as his account of the voyage will be but little known to English readers, I have extracted from it such portions as deal generally with the island, leaving out a quantity of botanical matter.

A translation of all Koenig's diaries was made for the Straits Branch of the Royal Asiatic Society, and appears in Nos. 26 and 27 of its Journals.

The account commences with the starting of the ship Bristol from Madras on August 8, 1778, on its way to Siam.

"August 3 I, I778.-At 9 o'clock, land was discovered from the mast. The sails were set and the course directed straight towards the land. A quarter of an hour later, we could distinguish the land from the fore deck; it rose before us like smoke, and seemed to be high and hilly.

"As we approached the land, we could from time to time distinguish some white, sparkling spots, especially close to the summit of the mountain; we took them to be chalk stone, but as we came nearer, we saw that they were a peculiar kind of fields interspersed with green. 
"Our captain knew this country very well: it was the first of the Nequebar* islands, which is called 'Kare Nequebar.' He therefore ordered the ship to be steered towards its north-eastern coast, in such manner as not to come too near a stony bank stretching far into the sea. The more we approached the land, the more agreeable it seemed to the eye, on account of the pleasant change of wood with green fields, and trees standing in thin rows between them. There was such perpetual change of scenery, that it was almost impossible to believe this island to be inhabited by uncivilized people. One field was specially conspicuous. It reached in a slope down to the sea, and there was bordered by a row of thinly planted trees, the waves beating against it with great violence; in all other parts the sea was bordered by thick trees like by a wall. After this we passed another side of the island pretty closely, this coast not being dangerous at all, and at the same time we came behind the wind. The ship cast anchor a quarter of a German mile from the shore, the water being fifteen fathoms deep. It was then 3 o'clock in the afternoon.

"The country seemed to be level and flat for about one German mile, and was thickly overgrown with trees down to the seashore. There were some semicircular openings hewn out, in which one could perceive several houses with thatched roofs.

"We had scarcely cast anchor, when some of the natives of Necquebar came in their canoes; they arrived rowing in silence. Their canoes were long, narrow, and pointed; they were hewn out of trees, the best of them having a thin staff, about $I \frac{1}{2}$ man's height, right in front, at the end of which was fastened a little flag, by means of diametrical pieces of wood; the flag, however, was not movable, and stood out straight in front. There were two bamboos tied to the top of the canoe, about I foot apart from each other, $\dagger$ and at one side there was a kind of wing fastened to the same, for the purpose of preventing the canoe from being overset.

"This wing was made of two bamboo sticks as long as the * Nicobar.

† Planksheers (?) 
eighth part of the whole length of the boat, and to these were tied two other bamboo sticks, which stood out at the two ends; they were twice as long as the width of the boat, and at the end of these cross sticks another bamboo was fastened, running parallel with the boat, and standing out as much at the front part, as long as the pointed end of the canoe. The smaller boats all had this arrangement, only they had no staff for the flag. There were more than eight men rowing the big boats. Their oars were lancet-shaped as far as the middle, and had a protruding sharp-cornered point. They were thin and smooth, about 6 inches wide, the handle was round and short, their whole length being about 4 feet; they were made of a sort of brownish red wood.

"Those of the natives that came on board were mostly young, except their captain, who was rather old; he had received a name from a European captain, who frequently came hither, viz., Makintosh.

"Their figure is very much like that of the Malays; they had round heads thickly covered with short coarse hair, a large forehead, round small brown eyes, a flat nose, thick lips and large faces, big teeth red with betel, and thin black beards; they were of a light brown colour. Their shoulders were large, and they seemed to be muscular, their veins were more prominent than is commonly the case with the black, their calves were very much developed, but they were all only of medium stature. Their clothing consisted of a piece of coarse blue linen, about three fingers wide, which was wound several times round the lower part of their body and taken up between the legs; some of them wore old straw hats. At first sight the expression of their face seemed to be wild, but one soon lost that impression; they showed few signs of any passion, smiled in drawing their lips up on one side, and when they felt offended they walked away without any sign of anger. The principal articles they brought with them were coconuts. Some of them had little square boxes, the biggest of them being one foot long; they were made from the sheaths of the young leaves 
of the chamorops, ${ }^{*}$ and they contained many varieties of ambert for sale. There were some pieces of one or two drachms weight, and they were wrapped in leaves, among them one kind very much resembling benzoin but not having the same odour. As much as I could make out from the interpreter, this piece, like all the other pieces, had been thrown on shore by the sea; it seemed to have been burnt at one end. $\neq_{+}^{+}$The payment for these articles was mostly made in tobacco or blue linen. My curiosity and longing to see the country were very great, but the time passed with necessary arrangements in reference to the ship and also in talking to the natives of Nacquebar. At last, at 4 o'clock the captain ordered the boat to be put out, and I set out for the shore, feeling very glad and happy. But on nearing the land we perceived a strong breaking of the waves against the shore. We chose a little bay, which seemed to have sandy banks, because it was guarded on both sides by high cliffs. A big wave seized the boat and threw it with great violence against the shore; a second bigger wave followed, which filled the boat, broke one of the oars, and some parts of the boat itself, besides terrifying us greatly. I did not want to wait for the third wave to come, but jumped down into the water, which reached up to my waist, in order to escape a greater danger, and all I had taken with me was soaked.

"The shore was rather steep in the beginning, and there were many little bays, covered with a whitish-yellow sand. The above-mentioned stone cliffs consisted of grey coarse chalkstone. Here and there big pieces of different kinds of corals had been thrown up by the sea, among them one kind which had the appearance of many knife-blades grown together.

* Probably a Licuala.

+ Ambergris (?)

+ "Ambergris, which is a waxy concretion formed in the intestine of the sperm-whale, is occasionally found on the shores of the Nicobar Islands. At times the carcase of a whale has been found ashore, and on examination a valuable quantity (several hundred rupees worth) of ambergris has been thus obtained."-E. H. Man. 
I do not remember having seen any of this kind before. Higher up on the shore there were innumerable varieties of blue, black, red, brown, and white corals, among them also the so-called 'red organ.' I also found a peculiar kind of very coarse sponge, and many kinds of shells were thrown up very high; many of them had been thrown into the woods for some little distance. The whole shore was not of a man's height, and it almost immediately sloped down again towards the wood... .

“... As it grew dark I went to one of the hamlets where about twenty houses, most of them with pointed thatched roofs, stood on piles. The principal houses, three in number, were placed in the middle, but each separate from the other. They were built on piles about Io to 12 inches thick, and more than a man's height. Some of them had 24 to 30 of these piles; they were bamboo, and one side was open, where a bench hung by ropes, large enough to allow two people to sit upon, and so low, that their feet when sitting would touch the ground. The roof of the real dwelling-house was in some cases angularly pointed, in others rounder; very few showed a long ridge. The access was gained by means of a narrow well-made bamboo ladder, through a square hole, which was wide enough to afford admission for a full-grown man; the floor consisted of broad sawn planks of unequal length supported by the cross beams; these beams in their turn resting on the above-mentioned piles. The big houses were divided into storeys, the lower one being as high as two men, the upper one was lower and more like a barn.

"Round about on the principal rafters, there were some bamboo sticks hardly as thick as the thumb fastened across. This looked very nice; but there were no windows at all, nor any to replace them, but the light came only through the holes serving them for door, therefore it was very dark. All their household implements were standing round about, mostly tied to the bamboo; that which could not be kept in this manner had been put into small boxes, which were one foot long, half a foot wide, and hardly half a foot high, and were provided 
with lids, which were made, as I have already said before, from the partitions sheaths of the young chamorops leaves. These little boxes had been tied to a bamboo, which was fastened right across the room, and was therefore at some distance from the roof.

"There was great cleanliness as regards the floor, and the air also was very pure, not the faintest disagreeable odour could be detected. The upper storey consisted only of bamboo sticks, they were thin, not tied together, and resting on the cross beams; they had turned somewhat brown through the smoke of the lamps, but I could not see that they kept any provisions there, and on the whole they do not collect many provisions. I saw some piles erected near some of the houses, they were more than man's height, two cross piles were fastened to them, and here they stewed some yam roots in the open air. They had no gardens, their houses and also their outhouses stood among Carica papaya. Their weapons consisted of small lances somewhat shaped like pikes, which were made of smooth round sticks about as thick as a finger and three yards long.* I saw some of them return with these kind of weapons. They had been in the wood to fetch provisions for one or two days. I did not see any fishing implements.

"There were two ships there, one of them an English threemaster, the second one lying further south with two masts, it was a French ship. They were both loading coconuts, which they bought here very cheaply in order to take them to Pegu, and to sell them there with great profit.

"Their women have almost the same appearance as their men, being strong and muscular, but most of them had their hair shorn off. Their clothing consisted of a blue cloth wound round their loins, or they wore an apron made of leaves, which was cut in strips hardly one line wide, and reached down to the knees; they were plaited together at the top and hung round their bodies in layers almost two inches thick. These strips 
seemed to have been taken from the borassi or chamœrops. Some grown-up girls I saw here as well, their hair was cut off below the ear and hung loosely round their head.

"However many people I saw here of different sex, I did not come across any whom I could have termed old. The only exception was a woman, apparently about fifty years old. The shortness of my stay here prevented me to make further researches and inquiries, which besides would have been very difficult considering the language and utter simplicity of the natives. As far as I could observe they were very vague in their ideas as regards years, months, weeks, days, and hours.

"Near one of the large houses I saw some piles; they were about ten inches thick, square, and two and a half feet high. At the upper end they had two holes, meeting in the middle like a cross; through them were plaited many coloured ribbons both of linen and of cloth, presenting the appearance of streamers ; at their end there was a stick about as high as a man, at the end of this a piece of white linen was fastened of about two inches wide, looking like a flag; all this was surrounded by a sort of conical figure of the sheaths of the chamœrops, so that only in front a little piece of the streamers was to be seen. I made inquiries as to these things, and they told me they were monuments for the dead, and that lately three persons had died in this house. I saw some more of the same kind of stakes which were already old, but there was not one near every house.

"I saw some persons of both sexes wearing green fringes, and I inquired why they were in this manner distinguished from the others; as much as I could learn from my interpreter these were those who had held their feast of love. This is always celebrated in the woods, never anywhere else, and as a sign of this joy they wore these fringes; they were really made from long pisang* leaves split through the middle and fringed crossways. They are first worn round their neck, then across their shoulders, and at last round their loins. 
"My attention was attracted by a continual murmuring; I inquired into its cause. It was the singing of some women, who wanted to cure another of her headache. This afforded me at the same time the opportunity of seeing the interior of their houses. I was admitted and allowed to mount, and I found the invalid sitting on her feet, some of the women lying near her, and four standing before her; one of them held something in her hand, which was supposed to be some article for fumigating; I could, however, neither see nor smell it. Their whole song consisted of one tone, which was taken first at a very high pitch, but by repeating it so often they slowly sank to the lowest notes, then they paused, and one of them commenced again very high, and the others chimed in until they' had again arrived at the lowest notes. They kept on singing in this way as long as I was there, which, however, was not very long, because it soon grew dark. I felt the invalid's forehead, which was a little warmer than ordinarily and covered with weak perspiration. Her hands were also hot, and her pulse quicker than usual, which symptoms might point to a cold in a body inclined to laziness.

"The number of children that I met here was not large either, and was far smaller than what I had seen on the coast in villages of equal size. I saw very few animals here; they kept some pigs near their houses, and the pork is said to be of very good taste here, because they feed the pigs on coconuts. There were also some small hens here, and a female dog, very much like the pariah dogs, which I had seen on the coast, and probably it was brought from there, only it seemed to have shorter legs than the ordinary kind... .

"... As it grew dark I left the country, where I should have liked to stay for some days, but I feared we might not get safely through the high waves. A cicada sang in the wood in a strange manner-for me it was a sad song. In the dark evening I picked up a little piece of seaweed which had been thrown on shore. We were luckier than we had feared to be as regards the starting from shore, which we left after having 
explored the country for one hour and a half. After one hour's journey both ways, we arrived on board at 7 o'clock.

"September 1st.-Early this morning the anchors were hoisted, but hardly had we left the land when a storm, combined with heavy showers of rain, arose. The atmosphere was misty, and one of these stormy showers was so violent and sudden that we almost perished. A new top-sail was torn to pieces, the waves at the same time were uncommonly high, and the whole sea like in a thunderstorm. I thanked God that I succeeded in arranging the specimens which I had gathered on my journey." 


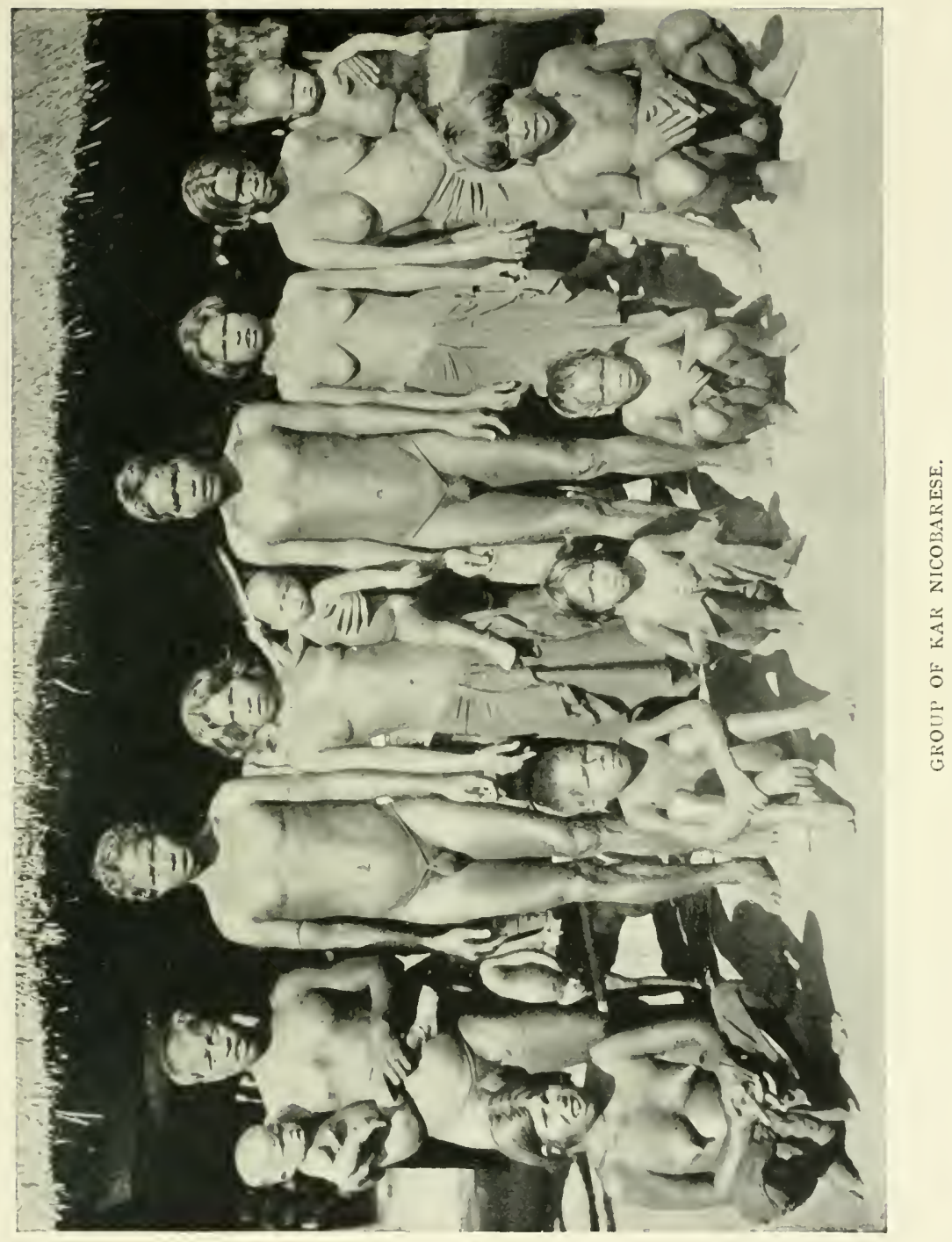





\section{CHAPTER VI}

\section{SOME CUSTOMS OF THE KAR NICOBARESE}

The Feast of Exhumation-A Scene in the Graveyard-"Katap-hang""Kiala"-"Enwan-n'gi"-Fish Charms-Canoe Offerings-"Ramal" "Gnunota" - Converse with the Dead - "Kewi-apa" - "Maya""Yintovna Siya"-Exorcism-"Tanangla"-Other Ceremonies - The "Sano-kuv"-The "Mafai"-The "Tamiluana"-Mafai CeremoniesBurial-Mourning-Burial Scenes-The Origin of Village GardensDestruction of Gardens-Eclipses-Canoe-buying-Dances-Quarrels"Amok" - Wizardry - Wizard Murders - Suicides - Land Sale and Tenure-Dislike to Strangers-Cross-bow Accidents-Canoe VoyagesCommercial Occupations-Tallies.

Amongst the Kar Nicobarese there are far more customs and ceremonies than I could ascertain during a short visit, but in the following pages an attempt has been made to chronicle all those that came to my knowledge. Many of them were elicited by questioning $\mathrm{Mr} \mathrm{V}$. Solomon, the Government Agent on the island, but still more are extracted from his diaries as printed in the Supplements of the Andaman and Nicobar Gazette. For the accuracy, therefore, of much of this chapter, $\mathrm{Mr}$ Solomon is responsible.

Of all the observances, customs, and ceremonies of Nicobarese life, that of Kana Awn, where the bones of the dead are exhumed, is perhaps the most important. Literally it is called $K a-a l$-awnfeast of pigs' flesh.

It is a very laborious and costly festival, commemorated every third or fourth year, with much ceremony commingled of joy and sorrow.

All the islanders cannot observe it at one limited period, nor 285 
can the people of one whole village do so conjointly with each other. If a few families of a village commemorate the feast during one year, other families will undertake it at some other convenient year, which will be at a time when their stores are abundant, and after sufficient delay for the bones of their deceased to become denuded of flesh.

The festival is conducted with much expenditure and demonstration, and differs slightly in each village.

It consists of a course of ceremonies continuing from one full moon to another, and commences as follows :-

About ten months prior to the occasion, all the people of a village consult together to fix the festival month, and then inform the rest of the villages, and obtain their promise of assistance. They next send messengers to give notice to all the villages of the island of their intentions, and bear preliminary invitations (mahaukaré). Of these there are two kinds-general and special. The general invitation is given to friends and relatives, that they may join them in the feast and help in various respects. The special invitation is sent by one family of the commemorators of the ceremony to the people of a whole village, that the hosts may give a performance in their house on the occasion. If ten families of a village commemorate the feast, they would invite the people of ten distant villages for this purpose, while those of three adjacent villages would be invited generally.

Their first duty, after sending out invitations, is to make a $\tilde{n} \alpha^{\prime}-$ kopáh (feast for the dead). Some well-carved wooden poles, fifty or sixty feet in height, with cross battens, are prepared and planted in the ground at Elpanam, and in the village in front of the houses of the commemorators. On these the people hang up varieties of yams and plantains; bundles of sireh leaf; bunches of coconuts, areca-nuts, pandanus, fruit, cheroots, and other eatables to which they are accustomed; in all, about fifty kinds. Below the posts they place teakwood boxes containing new clothes and jewels; bottles of toddy and earthen pots from Chaura, all fenced in carefully. These arrangements are decorated from top to bottom with flags, etc., until they look like Indian processional 
cars. This work is the occupation of about thirty men for three months. From the day the $\tilde{u} a-k o p a t h$ is commenced, the natives are restricted from killing pigs in the village.

On these occasions they take great pains in repairing their cooking huts, erecting new ones, and in making new roads and paths up to the boundaries of their village in every direction. The open ground at Elpanam and the graveyard are also cleared and kept tidy, and in the meanwhile they make every effort to secure sufficient quantities of provisions for the festival. A month before this begins some more ña-kopáhs, similar to the above, are prepared with fresh eatables, which, however, are not set out until a week before the feast. When this is done, final invitations ( $m i-n g a-l a)$ are sent to all the guests.

Besides this, a week before the opening day kare-yeng-chón (headstones of graves) are made in the following manner:-A well-shaped, round $\log$ of wood, about 3 feet long and 9 inches in diameter, having two through holes crossing each other near one end, is prepared and kept in readiness. At the approach of the feast a number of men and women together adorn it by rolling round it a piece of white calico and fringing it with red or blue cloth. Four large soup-ladles are fastened to the holes and to the middle of the log, a cross-shaped iron pike, about 6 feet long, called meráhta, ornamented with many spoons, forks and soup-ladles, ${ }^{*}$ is fixed. To it also are attached toys, dolls, and fancy weapons, with other curiosities, which all add to the gorgeous appearance of the object. Some families keep this in the newly-erected cookhouse, others in the open yard. They particularly take the guests and friends to see it in order to show that they are wealthy.

The men then construct, for temporary use, two or three long bamboo cages, with separate enclosures, so that a dozen pigs may be put in each cage. One is built underneath, and the others in front of the house.

* This same iron rod is used in the rainy season as a means for the prevention of thunder and lightning. 
Meanwhile, the canoes are decorated, filled with many kinds of provisions, and drawn up in front of the houses.

All this is done with the help of friends from neighbouring villages, who, neglecting their own affairs, willingly come and assist, even bringing with them food sufficient for their needs until the close of the festival.

After all these preparations are completed, there commences the preliminary ceremony called Vani pati (house decoration), which takes place a day before the festival. The interiors of the houses are decorated profusely with coco-palm leaves, goian (Arum) plants, and flags. Bunches of tender coconuts, areca-nuts and plantains are tied all about the posts of the house outside, that the guests may partake at pleasure. Several pieces of chintz, red cloth, and calico are hung from strings in the interior, and beneath the house as well, and the meráhta, with the ornamented canoes, are placed on either side of the ná-kopáh. The bamboo pig-pens are also decorated, and when all this is completed they kill a pig, sprinkle the blood over all as a sacrifice, and dance and sing around the house, with their guests, for the first time.

Now comes the first act. On the festival evening the people bring, with songs, numbers of pigs from their jungle piggeries, and placing them in the cages, dance before them. Those animals put in the cage beneath the house are merely for exhibition, as a proof of wealth, though, at the same time, they are dedicated to a future festival. In the cages outside are left those pigs that are to be slaughtered for the present occasion, and there is yet another cage in which are confined those brought to them by their friends as a festive gift.

Kiriam Hetpat (dancing in bright light) is the second and chief festival. By eight or nine in the evening, the village is filled with almost the whole of the islanders; a group of one village in one house. The special and general guests assemble in gangs in their respective quarters.

The men are adorned with new loin-cloths of various kinds and colours, with the tá-chökla, or chaplet, and tasses-necklaces made of silver coins. 
The women wear necklaces, "ear-distenders," bangles-made by twisting silver wire round arm and leg-and strings of silver coins as head ornaments. A pair of red Madras handkerchiefs, or two yards of red cloth and two of Chinese blue, stitched together, are worn as the principal garment.

Some come already dressed, others bring their attire with them, and don it on the spot.

The special guests bring ten or a dozen pigs of moderate size, as presents to those by whom they are invited. (Here it may be said that the people, although well acquainted in general, never call each other friends promiscuously. Whoever contributes a gift during this festival to another, is alone his true friend. There is a regular agreement about this, and special invitations for any occasion are only given by turns.) The women bring with them baskets of prepared food-pandanus bread, boiled yams, rice-and with this, and with pork presented by the hosts, they refresh themselves during the night.

Dancing and singing then take place. The men give their performance first, and when they are fatigued, they make way for the women, and so it goes on, turn and turn about. The former in their dance go through various motions of sitting, rising, bending, and jumping, but the women only attempt a series of steps.* This proceeding continues in the compound of each festival party throughout the night.

In the morning, while dancing still continues, there are brought forward some strong wooden cages, about 4 feet long and 3 feet in height and breadth-some in shape like a palanquin, and some dome-shaped like the houses. These cages are gaily decorated with flags, chintz, and gilt jewellery. On the top of each a platform with curtains is prepared, and on either side stout bamboo poles are fastened. A huge long-tusked boar adorned with jewellery is placed in each cage, and a man, woman, and boy, seat themselves on the platform with a quantity of plantains and betel-nut.

* These dances are practised by the guests from the time they receire the first intimation. 
When everything is ready, new red loin-cloth and tá-chöklas are supplied to the guests. Then the cages, with the pigs inside, and with the people upon them, are carried round from house to house in a procession, with singing and dancing, each borne by about forty men or women. Those who are not able to construct a cage, carry, as a substitute, long bamboos, across which the pig, with bound legs, is fastened. As they proceed, betel-nuts and plantains are distributed by those on the cages. In this way they march round the village, and return to the starting-point, via Elpanam, the teams of women as they stagger along with their heavy burden giving rise to much amusement.

When the procession is over the natives release the pigs in the cars, as well as nearly all the others, detaining only those that are to be slaughtered on that day for the guests. Then after felling the poles of the $\tilde{n} a-k o p a ́ k$ by cutting them with an axe, 6 feet above the ground, they scatter the food in the jungle and fence the site. The canoes and other articles are broken to pieces and thrown away, and only the meráhta, or iron pike, is preserved, with its decorations, to be made use of later.

Next comes Henglhawa, meaning "In return." A dozen or more pigs of ordinary size are distributed by the inviting party to the group of performers. These may kill and eat them on the spot, or take them away to their homes. This present is made in place of giving a feast. The dancing party who receive it would, according to their own numbers, kill a few of the pigs, cut them into pieces, and distribute the flesh among the families of their group. They roast the pieces, eat as much as they like, and take the remaining portions away with them. The pigs that are not killed will also be taken to their village, and will be there reserved for some public occasion. As a rule, the people who receive the present must be ready to give away a similar one in their turn when the same festival occurs in their village.

The spectacle of these people as they depart, men, women, young and old, each with a load of roasted pork cither fastened 
to long sticks, strung on cords, or packed in baskets, affords further amusement.

The general guests-the people of the nearest villageswill remain till the close of the feast to assist the hosts, and to give further performances of dancing and singing every night. They take their share of the food with the commemorators.

With their help the amusements are renewed, and on the following morning the big pigs, which were carried in procession, are slaughtered and cut into long strips, some of which, generally the spinal portions, are suspended at the entrance of the houses, as offerings to the evil spirits, and are there allowed to remain until the next celebration of Kana-Awn. Several pieces will also be distributed to friends and relatives.

Before these pigs are killed it is customary for young men to wrestle with them, and many of them are often so severely gored by the long tusks of the animals that they have to be carried away in litters.

This portion of the festival is called Yeng Awn-the great boar-for each of the animals which are dedicated to the purpose is looked on as a sacred creature, and is offered as a sacrifice in token of the last head of the family who died.

From the remaining portions of pork they separate the fatty part and prepare lard from it by pounding it in a wooden mortar and boiling it down in an earthen vessel. This lard is preserved in coconut shells and eaten with meals like butter. A few shellsfull are presented to those of their friends who have assisted them. This portion of the ceremony is called Wanaka Kuv (making lard), and with the immediately preceding stage lasts for four or five days. Then commences the ceremony of Kisu ta el pati, during which all the decorations of the houses are removed, and dancing and singing take place inside. This is done in order to purify the house.

Next, the practice of Tanang alah (prevention) takes place; and throughout the day the people busy themselves covering the houses and huts in Elpanam with green coco-palm leaves, to prevent pollution by the disinterred bones of next day's proceed- 
ings. They take their supper in Elpanam, and dance there all night.

At this point, the climax of the whole is reached in Anila Kopáh, or Ula Kopál (digging the graves). The women, children, and others stand at a distance from the graveyard, and one or two of the adults belonging to each of the houses commemorating, open the respective graves, remove the bones, and throw them in an adjoining bush called Tam n'gi Kopáh*-burial-place of bones (ossuary). But they replace in the graves the skulls of respected people or heads of families, and after refilling the holes with earth, place over them the new kuimitila or kare-yeng-chón (headstones). Before the skulls are replaced, however, they are sprinkled with the blood of fowls and young pigs.

The men who break open the graves are termed takkuwi (polluted) and when all is over they bathe in the sea, and then spend the night in the "house of pollution," after a period of feasting and dance in the Elpanam, called Kiriam Anill (digging dance).

Two or three days later the coco-palm leaves are removed from the houses at Elpanam, and another performance is held called Kiriam-nga-rit-roi-ta-oka (dance for clearing up coconut rubbish). Next morning sports and a little wrestling take place.

Finally, the people invite some of the mafais of adjacent villages to give a performance, and entertain them with gifts and feasting. This ceremony is called Afai tapoia, or Mafai tapira-grand mafai dance. When it is concluded some other village is challenged to a canoe race, and a dance and feast follow. With this ends the festival of Kana Awn.

When everything is over they carefully gather together the jawbones of the pigs that have been killed in every house, fasten them to a long rattan, and hang them up in the public building at Elpanam. In this way a comparison is made between past and present wealth, and proof is afforded of the splendour of

* Called also Kofentć-place of pollution. The natives have a horror of this spot, which nothing will induce them to visit at night. 
a ceremony that impoverishes many of the hosts for years to come.

The following is an account of the ceremony of Anila, or Ula Kopál, as it was actually carried out in the village of Lapáti on the east coast of Kar Nicobar. It was preceded by the usual festival of Kana Awn.

Of the tukkuwis (polluted ones) who were engaged in digging the graves, the men wore white loin cloths and the women petticoats of a similar colour. The graveyard was thickly screened by coco-palm leaves.

All the big houses in Elpanam, and the cooking huts in the village, were so thickly covered with leaves that no breeze could penetrate. A wall of palm leaves and four temporary huts were erected in each corner, that the takkuwis might take refreshment. Several pieces of white calico and Turkey red cloth were kept in these houses for wrapping up the bones. Those graves to be left untouched were covered with white cloth and neatly decorated.

Whilst each grave was being opened one of the tamiluanas stood at the head and fanned it with a bunch of "devil-expelling" leaves, and another man kept in readiness a palm-spathe and piece of white calico. When the grave-digger took out the skull it was cleaned by hand, carefully rolled in the calico, and placed in the spathe; all the other bones were then collected in the same spathe, which was taken away and placed over large yams scattered below the "deadhouse," where it was wrapped and bound with red and white calico. About fifty graves were opened, and the bones similarly treated. A few bundles were reinterred, but the others were taken away to a place called Kofenté (place of pollution), where they were opened, the bones thrown away and the cloth torn to rags.

After this the grave-diggers went to the sea and washed their hands and legs, and a few bathed entirely.

The following is an account of the observance of Katap-hang, or lighting the Elpanam. 
For several days a number of young men and women are engaged in cleaning out Elpanam. During this process they are not allowed to touch eatables meant for others, nor may they enter the village, as they are considered polluted while at work. When it is over the women collect all the coconut husks they can obtain, and arrange them in lines about the Elpanam and round the houses in it.*

The nuts are set fire to after sunset, and the people pass the night in singing and dancing, in several groups, lighted by the fires. Whenever they feel tired they eat, the proper food for the occasion being land-crabs, which have been collected during the previous week.

A spittoon of palm leaf is placed in the centre of each group, and into it go all the cheroot ends and betel-nut quids, to prevent pollution of the ground of Elpanam, which is now purified and fit for the habitation of spirits.

During the dancing the men cover their loins with a wrapping of plantain leaf, which makes them look like women. The women run about all night keeping the coconut shells alight.

About five o'clock in the morning the performance comes to an end, and then a number of women sweep out Elpanam, collecting the ashes and other rubbish, which are thrown into the sea. The men, with much excitement, take the outriggers from the canoes, and placing some of these under the Elpanam houses, bear others to the village, covering all with palm leaves. All portable property, pots, etc., is taken out of the houses in Elpanam, and, closing the doors, the people march away to the village (only the sick and one or two attendants, and those who dug the last grave, are left behind).

* The above is the Müs proceeding; at Lapáti there is more elaboration. The spacious square of Elpanam is thoroughly cleared, and the huts and fences of the traders dismantled, a separate place in the jungle being given them. In the centre of Elpanam an iron spike (meráhta) is fixed and covered with leaves. Then the tamiluanas, adorned with silver and garlands, arrive in procession, and suddenly pulling up the pike, throw it into the sea. After washing their feet they come back to the dances.

This ceremony is by way of augury as to the prospects for the ensuing season. 
Silence has now to be observed for a month; no fire or light may be seen, and no cheroot smoked in the place: women and children are interdicted from entering, but should they be compelled to do so, they must make no noise, and if at night, must leave their light at the entrance.

The people can give no account of the origin of this observance. Some allude to "custom," and others say that it is because so many spirits visit the place at this season.

Thirty days after the festival concludes, a great feast is given to the spirits, and they are sent back to the jungle.

Canoes are kept beneath the houses for several months, until the festival of Kiala, or fetching food, when they are brought to the beach at Elpanam, caulked, and made ready for use.

On the day of Kiala the men are out all day, with hook and line, fishing. When they return in the evening with their catch, each immediately offers as a sacrifice to the canoe a mixture of chopped fish and other materials, which are made into a paste and applied to the vessel. The fish they have caught are skewered on bamboo and roasted. Those unable to go during the day set out at night with torches prepared for the occasion.

Next day is Anoi-ila, a holiday, and in the morning all assemble in the houses at Elpanam and partake collectively of the roasted fish with other things. Then they sleep till evening, and do no work.

A day following closely is called Enwan-n'gi (fishing again for the children). As a rule, the fish caught on the first expedition is all consumed at the general banquet, but this is taken to the houses and eaten there. A holiday again follows.

To attract fish to their shores it is customary for the villages to erect on the beach at Elpanam, when the sea is calm, a number of long bamboos decorated with leaves, etc. This practice is called Ma-ya-kuv-ka-ma-ka-Papa is going this way to fetch fish. The poles remain for four days, and after they are removed, the large canoes obtained at Chaura are fed ( $\mathrm{Ngya}$ $a p$ ), and fowls are offered to them in sacrifice. 
Sacrifice is generally offered to these canoes thrice in each month-on seeing the new moon, at full moon, and on the waning of the moon.

A ceremony called Ramal is held in honour of the safe return of the canoes that periodically make the customary voyages to Chaura for pottery. It consists of feasting, dancing, and singing, as do most of the Nicobarese observances. These songs and dances are composed some time before the events and carefully practised during the interval.

The ceremony of Gmunota is held on behalf of those drowned during this annual voyage to Chaura, and is practised, instead of burial and the ceremony of Kana Aron, on occasions when the bodies are not available.

The death of a Nicobarese when absent is regarded with much greater concern than when such an event takes place at home. This is quite in accordance with European feeling.

A belief that the Chaura men are great exponents of zuizardry is deeply rooted throughout the group. One of the Mus canoes having been lost on the return from that island, the tamiluanas told the people that the Chaura men had a grudge against the people of Mūs, which, however, they did not like to satisfy in the island, but caused the visitors to be destroyed while at sea, by means of the black art, through which a tempest was raised during their return voyage.

The tamiluanas possess the power of conversing with the spirits of the dead, and they informed the village that they had seen this deceased party, who stated that they had perished from hunger, and now wanted meals.

Mūs, therefore, was ordered to offer sacrifice, and accordingly the people contributed spoons, forks, clothes, and silver wire, besides killing pigs and preparing meals in each house.

After the sacrifice (Gnunota) had been made the tamiluanas gave out that all the souls were satisfied with the meals and other things, but that "Davy Jones," the leader of the unfortunate party, was displeased with the offering!

Feasts are partaken of, and sacrifices made in the grave- 
yard, in honour of deceased ancestors, whose spirits sometimes reveal themselves to the tamiluanas. These occasions are called Ma-la-hal.

A series of festivals indulged in begins with a day called Kewi$a p a$. On this day, the people of Mins clear a portion of the jungle in the interior, and decorate the spot with palm leaves, bringing from it Siya-the devil-to Elpanam. All the houses at Elpanam, and the space there, are decorated. The people of Arong (a neighbouring village) and $M \bar{u}$ s then go there and take part in a performance lasting all night, for which they have practised during the past month Other villages come as spectators and guests. The next morning there is a feast, at which special materials are pigs and jungle crabs. When it is over, a wrestling match closes the ceremony.

On the third and following days, all the people, and those of the neighbouring villages, are engaged in preparing for the feast of Kial, to which many villages come as guests.

The day preceding the feast of Kial is called $M T u-n u n g-r e n$, or "day of preparation." Poles are brought from the jungle, tied round the houses at Elpanam, and covered with tender palm leaves, while new cooking places are prepared below each house. The interior of the houses and the compounds are decorated. From sunrise till dark the women are busy preparing kusuhu, a confection of yams, green and ripe plantains, coconut, and oil ; and meanwhile, the men sing songs in honour of the large canoes, which, kept for the past month in the interior, are brought to Elpanam, immersed in the sea, and decorated.

Next day is the day of Kial, or "taking food." From morning till night the people are engaged in feasting their guests, in dining together in groups, and in sending to their friends and neighbours kusuhu, pork and fowls.

At midday a cry of supplication is heard from each building"Let our house be always supplied with abundance of food; let us have many edible gifts from other villages; let there come new women to our village; let us be happy." 
This day is one of much rejoicing, for the natives consider the kusuhu one of their greatest delicacies.

Next day is called Anoi-ila-day of rest for the people.

Then, the eighth after Kewi-apa, comes the day $H a-c h u$, on which they take back the devil to the jungle with more ceremony. Having returned from this, they engage in a hunt, with the aid of dogs, for jungle pigs.

The day following is Anoi-ila; on the next, a second pig hunt takes place; and finally, one more "day of rest" ends the festival.

Maya, or Vani-el-kui, means "top decoration," and for this, long green bamboos are brought from the jungle and encircled with leaves from top to bottom. They are then fixed round the graveyard at Elpanam, to the accompaniment of ceremonies led by the tamiluanas, with spirit exorcising paraphernalia.

During the three days following, the people prepare two large rafts, of canoe shape, and equip them with sails of palm leaf, dry palm leaf torches, and bunches of "devil-expelling" leaves. This work is done by the young men and women, the tamiluanas and other elderly people being engaged, meanwhile, in singing by turns, through night and day, in one of the houses at Elpanam. The tamiluanas frequently come down and walk along the beach with their exorcising rods, and forbid the devil to enter the village.

The fourth day is called Yintorna Siya-expelling the devil by sails. In the evening, the whole of the village assembles at Elpanam with bunches of "devil-expelling" leaves, the women with baskets of ashes in addition.

A number of men, with an escort of tamiluanas, carry one of the floats to the sea, on the right side of the cemetery, and propel it some distance from the shore; when they return, another body of men despatches the other craft from the left side of the graveyard. The bearers, on reaching shore, are supplied with bundles of leaves, and as soon as the vessels reach deep water, the women throw ashes from the shore, and the whole crowd shouts, "Fly away, devil, fly away, never come again." Then all the decorated 
bamboos are removed, one after another, and all the leaves thrown into the sea; from each bamboo, as it is taken down, the devil is expelled.

Should the canoes sail off toward Chaura, much rejoicing is occasioned. One seems to contain an evil, the other a benignant spirit. The latter may possibly return and inform the tamiluanas that the devil has reached Chaura, and in token of this, there will be found near the graveyard a new Chaura pot, a chicken, a paddle, or similar objects.

If this occurs, there is a day of rejoicing, called Amhai, when pigs and fowls are offered as a sacrifice to the conquering spirit, and a grand feast and dance take place at night.

This is an annual ceremony, commemorated in turn by all the village, but unfortunately, as with their other customs and ceremonies, the islanders, whose knowledge of their origin is limited, can give no clear reason for its inception, although there must be a perfectly adequate one, and state only that they do it because it is "custom."

Festivals called Maya and Inturga are also commemorated to drive the jungle devils into the sea.

One of the most effectual means of exorcising devils is by fanning with leaves. The Mūs racing canoe, having returned to the village soon after a death had taken place there, was not received in the usual manner. Two elderly men who were on the beach, waiting, ran down before the canoe could touch the shore, and hurriedly brushed it, and the men in it, with brooms. They then brought the canoe ashore, and fanned it with coco-palm leaves, so that the dead man's ghost might not take possession.

When the north-east monsoon sets in, the sea is very rough on the east coast, and many people become seriously ill, the result being that there are always a greater number of deaths than usual in that part of the island.

All the villages there situated accordingly take in hand the process of Tanangla, which signifies "support" or "prevention." In this, they fence Elpanam with palm leaves, and festoon 
the houses and pathways with various kinds of shrubs and grasses. They also prepare huge images in human form, by twisting palm leaves round logs of wood, and place these about their houses.

An old man lost his teeth, and to celebrate the fact, gave a great feast to a large body of people who came to it from other villages. The giver was adorned with silver wire from head to foot, and made to sit in a kantéra (mafai's chair) in honour of his departed grinders.

A man was bitten by a snake, with serious consequences. When he recovered, he invited his friends to a feast, and performed the ceremony of Ke luing alaa, which consisted in waving a lighted palm-leaf torch round his head.

The natives apparently possess the right to assume various social distinctions at will.

There is a class of men termed Sanokuv which numbers many individuals in its ranks. Sanokw seems to mean a bashful or delicate person.

These men will not eat any food cooked by others, neither will they use well-water, nor partake of pigs and chickens reared in the village, as they consider these unclean. The water they require they obtain either from a jungle stream, or by collecting rain. They will not drink toddy made from trees near the village, but draw it from distant palms. Everything is partaken of from special vessels; toddy is sucked from a bamboo through a reed, of which the mouth-end is capped with a larger as soon as the drink is finished. They are, however, willing to accept bread, biscuits, and rum from others, but the latter is drunk from a new coconut shell, and never from a glass.

The whole proceeding seems to be a variant of the Hindu institution of caste.

The Mafai is another peculiarity of the Nicobar social organisation.

The Kar Nicobarese take great interest in the creation of mafais, and in conducting mafai performances. They give much of their property, time, and labour to a mafai, and look on him as 
somewhat sacred. He is a man who, recovering from a serious illness, decides to do no work for some time to come; in fact, he continues to be an invalid, and henceforth neither obtains nor cooks food, but is supported by the community.

The word mak means "sir," and is used to indicate one who is a superior, and is employed as a term of respect towards men and women of some age: the chief of a village, the head of a family, or parents, are styled mah. Fai means "inspired." Mafai therefore means "an inspired man," i.e., a seer.

A person may at the first stage of his recovery from a severe and long-standing illness, or an attack of delirium, inform his relatives that he has received a revelation, and therefore desires to become a mafai. This is communicated to the tamiluanas, and they, as well as other elderly people of the village, assemble in his house, and after making a formal examination, pronounce the verdict, tafuknu chuat-"sunken eyes."

A preliminary ceremony is then performed, called Hanata"adorning the invalid." They spread round his couch "devilcxpelling" leaves from $M a l$, and decorate the cane wall of the house, at his side, with festoons, tassels, beads, wire, garlands, etc., placing near him spoons, forks, and other electro-plated ware, with a few bottles of toddy.

They twist silver wire about his neck, arms, and legs, and adorn him with necklaces, tassels, breastplate, and armlets, made of silver coins, and then place him in a large decorated chair with a Chinese straw hat on his head. A silver-handled stick (sceptre of the tumiluana) and a small dagger to kill the devil are given him, together with a bottle of toddy, furnished with a hollow reed to suck the liquid through.

He is now proclaimed a mafai, and information is sent to his friends and relatives in other villages, who all come with presents to see the holy man.

From this time forward, until he is thoroughly recovered, the people of his village, with other friends and relatives, provide his food and other necessaries by turns. This they do on a liberal scale. 
There is a performance every night in the village, lasting till midnight, during which he sits on a chair in the midst of the ring of dancers, whom sometimes he may join. This exercise is to increase his strength, and he is freely supplied with toddy, as it is considered a tonic.

From time to time his neighbours take him, sometimes spontaneously and sometimes by invitation, from house to house and village to village, in procession, and give performances. Ai-yu- $x$ kare is one of these, and means "going to a feast adorned with jewels."

He never walks, but is always carried in a kantéra (chair), which in shape resembles a palanquin, covered with chintz and decorated with spoons, forks, and soup-ladles. The chair is borne by a dozen strong men. The spectacle of a returning mafai and his party is extremely comical, for, besides being fatigued by the night's exertions, every one is completely intoxicated.

The people venerate the mafai exceedingly, and take him at midnight to the sick, that he may heal them by touch or by shampooing, when he pretends to extract gravel and stones from the bodies of the invalids.

So matters continue until the mafai considers himself strong enough to work for his living, when, with the approval of the tamiluanas, he resigns his mafai-ship in a final ceremony called Luinj-lare Mafai-undressing the mafai.

The same man may eventually become a tamiluana (one who chases devils), or he may become Yom Ap and Yom Elpanam, i.e., "Grandfather or Guardian of Chaura canoes, and Guardian of Elpanam."

The mafai is a peg on which many festivals and customs are hung. The following ceremony is one as occasionally carried out in the village of Mūs. It is called Amutna Kuv-revealing to the invalid.

The tamiluanas of the village decorate themselves and go to a place called $\mathrm{Mal}$, outside the village, and there clear a certain spot in the midst of thick bush. They take with them a few yards of red cloth, a cage containing a score of fowls, a 
basket of pork, and other things, and hide all under different bushes at some distance from the cleared spot.

To it, with a number of followers, they lead the mafai in procession, and a dance with singing is held.

While the party in general is dancing, the tamiluanas take the mafai apart to one of the bushes and point out to him one of the concealed articles, telling him that it is a gift miraculously sent him by a deceased relative. All then return and join the dancing party. This action is repeated until all the articles are pointed out to the mafai.

The red cloth is then torn into strips and distributed to the men for loin cloths, and all the other objects are taken to the mafai's house, while afterwards the people renew the singing and dancing for the whole night.

The site in Mal the people consider to be something like Hades, and they believe that the spirits of the dead, immediately after life is ended, take up their abode in it. Consequently they never approach it on ordinary occasions, nor do they gather coconuts from the place, though the palms grow there thickly.

When a person becomes ill, or when it is desired to expel the devil from anyone, the tamiluanas first resort there to consult with their household spirits, or familiars, and to obtain "devil-expelling" leaves.

In the event of their attempts failing, they go to another spot in distant jungle called Passa (a former settlement of the Mūs people), where they suppose the souls of their ancestors sojourn.

The burial ceremony is peculiar, and the whole motif of it seems to be that if the corpse return to the village the ghost will be able to accompany it and haunt the place.

If a death should occur in the village proper, the natives, after conveying the corpse to the "deadhouse" in Elpanam, for fear of the spirit, barricade themselves for a time in their houses, and keep fires burning before the doors.

When a Kar Nicobarese becomes moribund he is taken to the "deadhouse," or "house of pollution," and there left to die, 
with bunches of "devil-exorcising" leaves about his bed. After the end has come, all friends bring a piece of cotton, in which the corpse is swathed subsequent to being washed in coconut water. It is then lifted by two men and, while kept in an upright position, lowered down the ladder and delivered to a number of friends waiting below, who try to prevent its burial. These, with the intention of returning it to the house occupied in life, attempt to bear it towards the village, but the movement is opposed by the rest of the community, who are in the majority. Much struggling takes place about the corpse, and it is very roughly handled, but at length it is forced towards the burial-ground and flung violently into the grave. Sucking pigs and fowls are then killed, and after blood from them is sprinkled over the body, are placed beneath the arms and legs.* The grave is then filled up, and on the third day is decorated, and marked by three bamboos, to which young coconuts are fastened for the purpose of engrossing the attention of the ghost. The house of mourning is also covered with young coco-palm leaves and sprinkled with sacrificial pigs' blood.

After the deatl of a person, houses, canoes, and the ground about the village are covered with palm leaves to prevent the ghost from entering.

Theoretically, all the possessions of the deceased are destroyed, $\uparrow$ but the practice is now confined to personal property, as spoons, dáos, clothes. Some of his pigs are killed, a few coco palms cut down, and on rare occasions his house is burnt, or unroofed and left deserted. What remains goes to the children.

* The reason for these proceedings given to Captain Gardner by the natives in 185 I was, "because they do thus in England," for so several captains had told them!

+ "Amongst the Arafuras (Aru Islands) the treatment of their dead betrays in the greatest degree their uncivilised condition, and the uncertainty which exists among them as to their future state. When a man dies all his relations assemble and destroy all the goods he may have collected during his life, even the gongs are broken to pieces and thrown away. In their villages I met with several heaps of porcelain plates and basins, the property of deceased individuals, the survivors entertaining an idea that they have no right to make use of them."-Kolff's Voyage of the Dourga, p. 166. 
There is no belief in a future state, but it is thought that, for a time, the ghost will haunt the vicinity.

For some days after a death the tamiluanas institute ceremonies for the purpose of expelling the ghost from the village.

Tall bamboos, festooned with palm leaves and cotton, are erected on the shore at Elpanam, and the tamiluanas take their place beneath. After scattering stones and ashes, they run about, uttering a mouse-like squeak the while, until they capture the spirit and imprison it in a bunch of leaves. Several men then grasp the bunch, and placing in it a small figure, made in human likeness of coco-palm leaf, twist up the whole, and throw it into the sea.

From time to time villages go through ceremonials somewhat similar, for the purpose of expelling such devils as may be haunting the place.

Shaving the head is sometimes indulged in as a sign of mourning, together with frequent bathing and abstinence from work. A man will also change his name to show grief at the loss of a friend, and will take another title if it comes to his knowledge that a namesake, even a comparative stranger, is dead.*

It was customary for widows to have one of their fingers cut off, and if they refused to submit to the operation, the posts and doorway of their houses were gashed and notched. $\dagger$

Accounts of two interments which differed somewhat from the usual practice may be worth giving here.

The first is that of "Distant," headman of Sáwi, who was buried with much pomp.

The corpse was dressed in a good suit of English clothes, and silver wire was wound about it from head to feet. This was because he was once a mafai, and the usual ceremony of

* In the matter of names, a Kar Nicobarese tries to please everyone with whom he is acquainted. There is often his own native appellation, an English one, another by which he is known to the Indian traders, and a fourth under which he does business with the Burmese!

† G. Hamilton, Asiatic Researches, vol. ii. 
Luinj-lare (renunciation of the character) had not been performed. Upon the wire, thirty-two pairs of spoons and forks were placed crosswise. Necklaces made of two-anna pieces (240 to each, and two dollars) were attached to head and neck, and the body was wrapped in forty yards of red cloth.

The corpse was then borne in procession by twenty-four men and women to the house of the relatives (contrary to custom), and was then taken to the graveyard. Two very large and four ordinary pigs were burnt alive as a sacrifice, and seven pigs and eight chickens were buried with the body after their blood had been sprinkled over the corpse.

The following night, the ceremony of Fota Elmot (wiping away tears) was performed, on which occasion fifty pigs and twenty fowls were slaughtered to feed the guests, and thirtytwo pairs of spoons and forks, necklaces of silver coin and wire, and teakwood boxes full of the dead man's property, were broken up and thrown into the sea.

Again, on the eighth day, the final mourning ceremony was gone through, when, in honour of the thirteen villages of the island, thirteen pairs of spoons and forks, and sundry other articles, were destroyed, and the guests were entertained at a feast of equal munificence to that they had shortly before taken part in.

The second case is that of a man, nearly one hundred years old, who owned a third part of the village of Lapáti.

The body was neatly wrapped in cloths under a curtain in the "deadhouse." A sort of open coffin, about 7 feet long and 4 feet wide, was made, and six thick green canes were fastened to it, three to the head and three to the foot, each cane about 50 yards long.

When all was ready the coffin was drawn into the "deadhouse" up a sloping plank, and when the corpse had been placed within, two women got in and lay on either side the body, embracing it with their arms. When the coffin was lowered to the ground two big men also laid themselves down in it.

The large Elpanam was filled with a crowd of about a 
thousand people, young and old, from other villages. Of these, a hundred from the southern and a hundred from the northern villages seized the long canes at either end, and dragged the coffin up and down in competition until the canes were broken, when, the grave being dug, the body was buried.

This ceremony is performed only when those of the highest repute are interred.

Once in every five years the villages in turn remove all their pigs, and keep them in sties in the jungle. The surroundings of the village are then offered to the public for cultivating fruit and vegetables, and the people from other villages arrive and make gardens, which are open; there is no need for fencing, since there are no pigs to cause damage.

The reason for all this is that after demolishing the $\tilde{n} \dot{\alpha}$ kopail (sacrifice to the dead), during the festival of Kana Awn, the yams and other vegetables and fruit with which they are loaded are scattered about the houses, and grow abundantly; to obtain some profit from this unplanned result this custom has been introduced.

The people in general have their large vegetable plantations at a distance, but for immediate use there are some smaller gardens near the village. The tamiluanas informed the people that in consequence of the flourishing condition of these latter, the devils were angry, and might cause the island to be drowned by a deluge, and that to save themselves they should uproot part of the plants. Accordingly, the greater portion of the yams and other vegetables were destroyed; some of the people doing it willingly, others with discontent.

The Kar Nicobarese seem to hold much the same belief with regard to an eclipse as do the Chinese and some of the peoples of India.

They think the moon is actually being swallowed by a serpent, and throughout the night both young and old refrain from sleep, and occupy themselves in driving the serpent away. Providing themselves with tins and planks, they beat them, causing 
a tremendous din, and shout, "Alas! alas! do not devour it, let the moon alone and go away."

In the buying and selling of the larger canoes the natives of Chaura act as middlemen - seeming to possess a monoply of intermediation in this business as they do of pottery making.*

The canoes are not made at Chaura; there are no suitable trees on that small island to construct them from. The Chaura people obtain them - very cheaply - from the central groups (where many are made, and where others, obtained from the southern group, are also sold), and sell them again to the Kar Nicobarese, making four or five times in the transaction what they themselves pay.

"As the Kar Nicobarese are timid, and allow themselves to be bullied by the natives of Chaura, who assume an overbearing manner towards them, as well as towards their southern neighbours-all of whom are dependent on them for pots, which cannot be made at any of the other islands-the feeling predominant among the Kar Nicobarese as regards the people of Chaura is one of fear, and they evince every desire to avoid incurring their ill-will and resentment," $\ddagger$ even to the point of submitting to be flagrantly cheated in their canoe barter! The extortionate price

* This monoply is due to their geographical position. The Kar Nicobarese find it as much as they dare venture to do, to go so far as Chaura for their large canoes and pots. As it is, many lives are lost at sea. (In I 899 at least 29 were drowned in returning from this island, and more recently 12 or 13 were similarly lost.) Chaura is situated midway between Kar Nicobar and Nankauri Harbour and Kamorta, where the principal purchases are made by the Chaura people.

† "I was present on a certain occasion at Müs . . . having brought Tanamara with me from Nankauri. In strolling through the village we caught sight of a fine large canoe, which he recognised as having been sold by him to a certain native of Chaura. Offandi proved to be the owner, and he, on being questioned, said that he had bought it from the same man. On further enquiry it was found, that while the Chaura middleman had promised to give 25 rupees in kind to Tanamara (only part of which had yet been paid), he would not let Offandi have it till he had delivered to him a long list of articles (e.g. cloth, spoons, tobacco, etc.), which, on being totalled up, were found to amount to about 105 rupees in value."-E. H. Man.

$\ddagger$ E. H. Man. 
they have to pay may have something to do with the high value the Kar Nicobarese set on their large canoes.

The business of purchasing these is accompanied by its peculiar ceremonies. In an instance at Mūs, after busy bargaining for pots and a large canoe, the Chaura people, in the evening, feasted, each man in his friend's house, and then at midnight assembled at the Elpanam, with the chief men of Mūs, and amused themselves singing songs in turn, and partaking of betelnut and toddy. There they got through the preliminaries to purchasing the canoe, and the articles intended as its price were exhibited. After the bargain was closed the Mūs people returned to the village, leaving the Chaura men at the house in Elpanam.

The articles agreed on were handed over.

Next evening a great feast was given to the people of Chaura by those of Mủs; in each house a young pig was killed for the purpose. At night all the people assembled in a house in Elpanam, and after dining, amused themselves singing songs by turns.

The Chaura people then left the island in the canoe they had sold, for it is the custom to do this, and bring the canoe back on a later occasion. They were provisioned for the voyage by the village of Mūs.

The dances of the Kar Nicobarese are always held at the open ground of Elpanam. With a mafai, a fire, or a trophy of spoons and forks as a centre, the people form large circles, or parts of circles, according to their number, and move slowly round to left and to right. The sexes dance separately, the one ring within the other, or join the ends of their chains to form one large circle, but form up very compactly, each person grasping his neighbour's shoulder with outstretched arms intertwined. The dance is somewhat monotonous, and consists of two or three steps sideways, and a pause, with a stamp with the foot or a swing of the body, and then the same movement in the reverse direction, and so on, over and over again, to the accompaniment of the performer's songs.*

* "In the morning dances commenced in the open air. Two immense 
The refreshments partaken of are coconuts, tobacco, and toddy. The latter is supplied in large quantities, and gives rise to much intoxication, which, however, only seems to result in increased friendliness and a drunken sleep.

When a quarrel takes place the participators often seek revenge in destroying each other's coconut trees, but in severe cases a man will probably burn his own house down. Possibly this is done on the supposition that the enemy will suffer more from self-reproach at having been the cause of the destruction than from any other form of punishment he could undergo. Or possibly it is a mild instance of a peculiar form of "amok," to a variation of which curious psychological state the Nicobarese are undoubtedly subject on occasions when they consider themselves injured. Several instances that have been recorded of kindred occurrences will perhaps best illustrate this conduct and idiosyncrasy.

I. A man named Kuhangta purchased some things from the traders on the responsibility of another named Tumilo. As the traders pressed Tumilo for immediate payment, he urged Kuhangta to settle the matter with coconuts forthwith. Kuhangta was enraged at this, and killed several of his own pigs, and also set fire to his own house. He threatened, in addition, to kill any one who approached, and kept a dá in hand for that purpose. Lorenzo therefore went to the owner of a gun and begged that Kuhangta might be killed. This

circles of men and women were formed, linked hand in hand, one circle within the other. The dance continued for hours, accompanied by a monotonous chant. Sometimes the two circles moved in opposite directions, or expanded to their utmost stretch and contracted again by advancing towards the centre. In posturing they kept time with the singing, all turning to right and then to left, raising their arms or letting them fall together. The inner circle knelt on the left knee, placing their heads to the ground, but still holding each other, while the outer circle, also hand-in-hand, stepped over them and became the inner one. This was frequently repeated, and in this and other movements the dance consisted. The circles consisted of about 200 people each." - "A Visit to Car Nicobar, 1851," by Captain Gardner, Singapore Review, vol. ii. 
request was not granted, and, in the end, the headmen of various villages succeeded in reconciling the two, and obtained from Kuhangta a promise of good behaviour. Such cases, however, do not always end so tamely as in this instance.

2. "About noon, Offandi, the headman of Mūs, came to my hut with a paddle in his hand which he was trying to break, muttering at the same time, 'I am a very rich man. All this land and everything in it is mine. You were a very poor man, and I gave you land, gardens, houses, and many other things. You now call me a liar, and so I am angry, and am going to dig up a grave.' He repeated this over and over again, and would not say anything else. I was quite puzzled, and could not understand what he meant. I asked him if he was angry with me, and he said, 'Yes, I am angry, and there is another man.'

"While this was going on, his wife and a number of men and other women came running after him from the village. As soon as he saw the crowd, he hastily broke the paddle in my hut and ran off with the handle to the burial-ground, and began to dig at the grave of his late father.

"The crowd ran off to the burial-ground, caught hold of him, and tried to drag him out of the place. A regular struggle commenced, and the women began to cry out, some, 'We fear, we fear,' others, 'Don't pollute us.' The Burmese and other traders looked on from a distance with great surprise.

"As the matter began to grow serious, I went across and ordered Offandi in a commanding tone to leave the place and come away at once. He came away quietly enough to my hut, and the crowd with him. After some inquiry, he said that 'Friend of England' had insulted him, and, therefore, he wanted to open the grave of his (Offandi's) father and throw the bones into the sea, adding, "This man was a very poor man once. My dead father patronised and gave him land, garden, and everything, but now he calls my father a liar, and so he must be punished.' I then sent word to all the chief men of the village, and told them to come over to my place that night.

"Accordingly, at about seven o'clock, all the people, including the parties of the dispute and the Kahokachan (village judge), assembled, and as this was a family quarrel, I asked the judge 
to investigate the case, and settle the matter according to their own customs. A good deal of argument then took place between Offandi and 'Friend of England,' the crowd, acting as jurors, gave their opinion, and at last the judge made a long speech, in which he pointed out the faults of both parties, and ended the case by ordering them to be reconciled. 'Friend of England' apologised to Offandi, admitting his bad language, and the latter forgave him, everybody departing quite satisfied.

"The origin of the affair was that Offandi and 'Friend of England,' with a few others, jointly cleared a spot in the jungle to make a garden. 'David Jones,' a cousin of the former's and a junior partner in the concern, wished to plant only coconut shoots, a plan to which 'Friend of England' raised an objection, as he wanted to grow only yams and other eatables. Offandi tried to intercede on behalf of 'David Jones,' on the plea that the land was given him by his deceased father, and therefore he was at liberty to plant what he liked in the allotment. Then it appeared that 'Friend of England' said, 'Your father was a liar.' Being enraged by this, Offandi rejoined, 'Shall I dig up the bones of my father and throw them into the sea?'-a very great indignity and bad omen to the party causing it. "Friend of England ' replied, 'Yes, you had better,' and hence the trouble." *

The cases of "amok" that occur among the Malayan peoples are, as often as not, the outcome of ill-health and long-continued brooding over some imaginary or trifling insult. Similar occurrences happen from time to time among the Nicobarese, and as they are an almost exact parallel, they possibly afford material proof as to the Malayan affinities of these people.

Sam-tat-yon was always a loafer who obtained his food gratis from the traders at Malacca, and slept in any bazaar he could. At dawn one morning, Osman-an old man - a servant of Yusuf Hussain, got up from his bed and went to the beach, and while returning to his hut, saw Sam-tat-yon coming out of it with an axe in his hand.

Osman called out to Ali Hussain and Yusuf Hussain (both foreign traders) and told them what he had seen, and Sam-tat-yon, 
hearing this, dropped the axe, and with a small American knife, kept for husking coconuts, attempted to kill both Ali and Yusuf. They, however, got beneath the floor of the hut and made their escape, the former with a slight wound.

Sam-tat-yon then fell upon old Osman and slew him with the knife.

He next went up to some Burmans who were gambling, and dispersed them, after doing one of them some slight injury. Samtat-yon then ran off to the village of Perka.

At Perka, there were sleeping in a house his brother-a man named Kichyeti,-one Chestu Chulia, and some women and children.

Sam-tat-yon entered, closed the door, and stabbing his brother first in the chest and then in the abdomen, killed him. At the first cry of Kichyeti, Chestu Chulia and the others got up, and giving the alarm, tried to snatch away the knife. Some women from a neighbouring house then came and helped to arrest the murderer, whose own wife - one of those arriving to rescue Chestu Chulia-was wounded in the struggle.

The populace not unnaturally wanted to kill Sam-tat-yon on the spot, but they were prevailed upon to keep him for trial. Not being accustomed to guarding prisoners, and not liking to keep him in any of their houses, lest they should become polluted, they prepared a strong wooden cage, similar to those made for pigs that are to be slaughtered, and left the man in it with his hands tied.

(The Nicobarese fear the presence of a desperado, and are too ignorant to know how to guard him, and for these reasons they always kill the men of whom they entertain fear.)

After three or four days of the cage, Sam-tat-yon became quite subdued, and answered any inquiries about the occurrence. He fully admitted his behaviour, but attributed no cause to it. He simply said that he had been unwell for the last month, and could not take his meals properly, that he was unable to drink coconut milk, but lived upon warm water, and that he had not slept for several nights. In such a state of health he lost his 
senses, and therefore committed the crime. He stated that the Mussulman who was killed by him was not an enemy, but on the other hand, he and all the traders were his friends. Regarding his brother, he said that he had been kind to him.

The proceedings of a man who wishes to obtain a name as a wizard are rather curious. He will, for instance, frequent pig wallows, and, sitting in the mud, collect the bristles left there by the pigs when cooling themselves; or again, he visits the graveyard at night and disturbs the graves. He generally lives by himself in the jungle, doing no work, but stealing pigs, chickens, and coconuts from others. Having made a reputation for witchcraft, he is held in much fear by the community, but to balance this advantage, if they consider themselves injured by his practices, it is not impossible that they may some day combine and murder him.

Besides ridding themselves of an unpleasant neighbour, it would seem that they also hope by such an action to cause the destruction of an evilly-disposed spirit.

I. "Tham Koi, son of Katha, having beaten a countryman to death in Chaura, made the following statement: 'Kanunla, a menluana (medicine man) and sorcerer, is addicted to sodomy and theft. He bewitched my father, who became very ill. I sent for Kanunla to come and shampoo my father, who gradually got worse. I became enraged with the menluana, and waited until he got on the ladder of my hut, when I struck him on the left side of the neck, so that he fell down. I went down and struck him again thrice, and he died. I then went and told my neighbours Kamrang Piko, Okio, Cher, and Tachoi what I had done, and asked them to help me remove the corpse, which we took in a canoe and threw into the sea. Kanunla did not make a noise. No one knew of this at the time because it was in the evening, and very dark. The villagers knew of it on the following morning.'" - Diary of Mr Obed Elias.

2. Tekwa was the adopted son of Iskol's father, and was always living in Iskol's house. Eventually he became a thief, 
and robbed the people of their fowls and pigs, and he was supposed to be a "devil-man" or wizard.

It happened that a man named Sutro died after suffering a long time from dysentery and consumption, and it was supposed by Iskol and his friends that Tekwa was the cause of this death. Tekwa perceived this, and hid himself in a place called Hat-Own; but three clays later, Iskol and his friends, Natla, Sundran, and Nawi, after consulting together, brought him thence to a place called Ranai, where, after giving him toddy, they killed him by strangling him with a rope, subsequent to breaking his joints at the knees and elbows.

The same night they buried the corpse in Kofenté (the place of pollution), near the graveyard, and a day or two later, killed a couple of pigs as a ransom or sacrifice.

The reason for these murders-or popular sentences, - when not because of witchcraft, seems to be somewhat obscure, but can possibly be found in a general dislike for the victim, or for some act or event with which he is associated.

A woman of Kenuaka had been shot to death with arrows by her fellow-villagers. She was suffering badly from secondary syphilis, and was very poorly off, but the reason given as the immediate cause of her death was the untimely delivery of a still-born child. The body was buried in the usual manner, and everybody contributed cloth to wrap the corpse in, ircording to custom.

A double murder took place in the village of Perka, whose headman was named Kan-nyána. The victims, who were detested by the village, were put to death because of their misconduct. Six men participated in the affair, but as there was no idea among the natives that they should be punished, no one could be brought to point them out to the Agent. The testimony of witnesses showed the light in which they were regarded. Tamikal, wife of one of the deceased, stated:- "On a certain night, while I was sitting at the entrance of my house, my husband was angry with me, and attempted to thrash me. I cried aloud. Then, suddenly, a lot of men, armed with sticks, came into the house and com- 
menced to beat the dead man. I was afraid and ran away, and cannot say what happened further, nor could I recognise any of the assailants. I am glad, however, that the two men were killed, for they were wicked men."

Kokali, son of one of the deceased, seconded the statements of his mother, and said, "I am glad that they were killed; they were very bad men ; the village now enjoys peace."

The culprits were finally apprehended, and one of them, Ringangmareng, grasping a stick, cried in great anger, "Why do you call me here? I am the man who killed those wicked villains with the very stick I have now in my hand. Do you wish to handcuff me and carry me to Port Blair? Do so if you like, but you must not take mah"- - pointing to the chief Kan-nyána.

(The Nicobarese possess much affection for their chiefs, and also value their tamiluanas highly. When one of the latter was being taken to Port Blair because of misconduct, the headman of his village entreated that two other men might be substituted for the "doctor.")

Suicide is not recognised as an institution of Nicobarese life, but cases of it do occur somewhat occasionally.

Pin-re-ta was a good man, very rich, and had no wife nor any enemies, and therefore his fellow-villagers could show no cause for the occurrence. One day, his servant-boy, who was sleeping in the cookhouse, was aroused by a noise as of a pig being beaten. Going down the ladder to see what was happening, he noticed that the pig-sty was in flames, and that a pig had been killed, and then he saw Pin-re-ta, who, standing below the cookhouse, axe in hand, threatened to murder him. The boy ran off to the jungle, where people were making a garden; and they, returning with him, found that Pin-re-ta, after setting fire to both his houses, had thrown himself into the flames, and was burnt to death.

While the negotiations were going on for the plot of land on which the Schoolhouse and Agent's bungalow stand, it was 
found that in buying land in Kar Nicobar, the bargain must be made with the chief, as overlord of all the land in the village, but that he, on his part, is bound to share the proceeds with all who are interested in it.

The price fixed on for the piece in question (about $8 \frac{1}{4}$ acres) was:-twelve black suits, one piece of red cloth, six bags rice, twenty packets Chinese tobacco, and twelve bottles rum.

These things were distributed amongst the people of the village by the headman, Offandi, who retained nothing for himself; but for some time subsequently he was in bad odour for having given up the land to the Government, and for a iong period the Agency was looked on with much disfavour.

The Kar Nicobarese have a deeply rooted aversion to the settlement of strangers in their midst, and more than once have expelled from their island intruding missionaries. Nowadays, great discontent is caused by the traders leaving agents to carry on business during the south-west monsoon, when the weather is not suitable for vessels to remain amongst these islands.

The habit the natives have of using their crossbows in the immediate neighbourhood of the villages is sometimes productive of fatal accidents. Two men were shooting at Sáwi, and one of them having shot at a bird and missed, the arrow in falling pierced the chest of his friend, who had run forward to recover it. Several similar mischances have occurred recently in Mūs; in the latest, a lad named Sinkin shot at a bird, and his arrow, glancing from a tree, struck a man, $\mathrm{Ka} \mathrm{Noe}$, and entered his side, causing a serious, but not fatal, wound.

The not infrequent mishaps that occur on the annual canoe voyages undertaken by the Kar Nicobarese to Chaura have much to do with the stationary condition of the population of the island. Canoes containing thirty to forty men are regularly sent out by the villages of the island, and when they meet with bad weather a total loss is not an uncommon occurrence.

During the months of October, November, and December- 
the first half of the north-east monsoon-or fine season, the people of Kar Nicobar live a busy life.

At first they are engaged in husking the coconuts which are to be exported to Calcutta and Moulmein. The wages they obtain for this work are the value of 100 nuts for husking I000 nuts. They are generally paid in cloth, or two-anna bits, which are utilised by manufacture into head-or neck-ornaments.

Next they are employed in landing the goods of the Burmese kopra-makers, and in carrying the same to their villages, for as no ships can anchor on the north-east coast during the season, everything has to be transported by the natives. The people of Mūs carry the things of those traders who own stores in their villages; in like manner the villagers of Malacca go to Sáwi Bay, and carry the goods of those Burmans who dwell amongst them. They are remunerated according to the following scale:-

For carrying a 3-maund bag of rice-

(a) From Hog Point (N.-IW. of Sáwi Bay)

China tobacco. $\quad$ Rice.

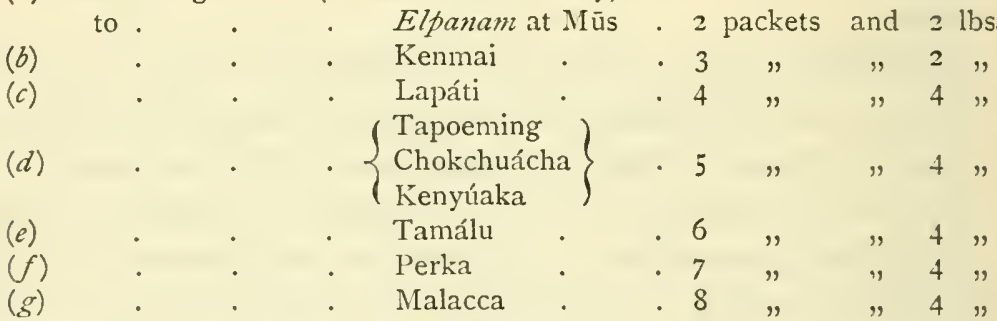

It costs a trader about 30 rupees to transport one cartload of goods from Müs to Malacca.

When this work is done, the Nicobarese are employed in erecting huts, to serve the traders as bazaars. Each hut is built by contract by one man with the help of friends, and on its completion the owner has to give the contractor 14 to 20 yards of red cloth, a Burmese betel-box and a dáo, and besides this, has to supply the men with food until the work is finished.

After the hut has been built, the natives proceed to make a fence round a small compound, in order to prevent pigs from 
destroying the stores of kopra. For this they are remunerated separately.

While some are thus engaged, others take passages in such of the trading vessels as go to Kamorta and other islands, in order to assist in husking coconuts and making kopra, work for which they receive one nut in ten. These opportunities are much desired by the natives, since they are at liberty to take home with them any number of Chaura pots, rattans, bamboos, paddles, and canoes; and masters of trading boats are glad to employ the Kar Nicobarese, for the people of the other islands are too indolent to collect and prepare the nuts, but sell them on the trees.

While the men are so occupied, the women and children are busy helping the traders to make kopra, and for this service they are fed twice daily, and receive presents at the termination of the work.

Careful accounts are kept by the Nicobarese of their transactions in coconuts, by means of a tally-stick (kenrāta kuk, Kar Nicobar), on which all the nuts that pass from them to the traders are registered by various kinds of notches.

A regular account is kept of the months, so that festivals may be held in proper season, and a daily account is kept of a child's age until the time arrives for piercing its ears, an operation taking place soon after the first year.

Note.-Since this chapter was printed, I have learned that the Anthropological Society has made use of V. Solomon's diaries in a paper appearing in their Journal for July 1902. It is perhaps well to say here that neither the Society nor myself was aware that the same material was about to be a subject for publication elsewhere.-C. B. K. 


\section{CHAPTER VII}

\section{FAUNA OF THE ANDAMANS AND NICOBARS}

PREvious to entering into any details of the fauna of the Andamans and Nicobars, a glance at the depths of the surrounding ocean is interesting, and to a great extent explanatory of the peculiarities occurring in both groups: it is well known that the soundings of the adjacent seas clearly indicate the extent of time during which masses of land have been isolated, and the facts of this case seem to fully explain the variation and numerous peculiarities of the local fauna.

Preparis Island is situated at the tail of a 100 -fathom (to be more particular, 50-fathom) bank projecting from the Arakan Yoma Peninsula. It is continental in its fauna, and possesses monkeys and squirrels.

Between it and the Cocos Islands is a depth of 150 fathoms.

The Andaman group, from Cocos to Little Andaman (except the South Sentinel, which is isolated), all stand on a roo-fathom bank (actually 50 fathoms).

All these are connected by a 200 -fathom line with the Arakan Yoma Peninsula.

Narkondam and Barren Island both rise from a sea approaching 1000 fathoms in depth.

The Andamans and Nicobars are separated by a channel with depths of 600 fathoms.

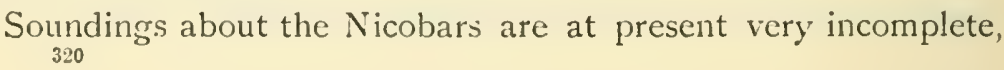


but the Archipelago seems capable of division into two groups, each standing on a roo-fathom bank.

The northern of these consists of the compactly-situated central islands, and possibly Kar Nicobar, and is separated from the southern (Great and Little Nicobar and the adjacent islets, all perhaps surrounded by a 50-fathom line) by a channel with approximate depths of 200 fathoms.

The Nicobars stand at the termination of a 1000 -fathom bank, projecting from the Arakan Yoma Peninsula, and from thence also curving east and south towards Sumatra, thus enclosing a long tongue of deep sea, over 1000 fathoms deep, that is connected with the Indian Ocean by the channel separating them from Sumatra.

This deep sea that surrounds the islands everywhere but on the north, shows that, so far as need be taken into account for present purposes, they have never been connected with the Malay Peninsula or Sumatra-a condition that is further shown by the almost total absence of any members of the Malayan faunaalthough they may at one time have been a prolongation of the Arakan Hills.

"It cannot, however, be asserted that this latter theory of connection derives, prima facie, much support from a consideration of their fauna; and if they ever were in uninterrupted communication with the Arakan Hills it must apparently have been at an immensely distant period, for not only are all the most characteristic species of the Arakan Hills, as we now find them, absent from the islands, but the latter exhibit a great number of distinct and peculiar forms, constituting, where the ornis is concerned, considerably more than one-third the number known." - Hume, Stray Feathers, vol. ii.

From the above details, it is to be inferred that not only have the Nicobars-if ever in connection with the mainlandbeen longest separated, but that they have also been disconnected among themselves for a great extent of time. At a later period the Andamans were cut off from the continent, and 
the process by which they have been broken up into islands isexcept in the cases of Narkondam and Barren Island-comparatively recent. This theory is fully borne out by the greatly localised nature of the fauna, nearly every island possessing its own peculiar species of terrestrial mammals.

\section{Mammals.}

The mammalian fauna of the Andamans and Nicobars is now known to consist of 35 positively identified species, I sub-species, and 4 others whose status is still doubtful.

Of this total of 40 animals, I 9 are found in the former (if we leave out a dugong, which, though at present reported from the Andamans, will certainly be found to occur in the Nicobars), 22 in the latter. Only two species are common to both groups, and both these are bats-Pteropus nicobaricus, a wide-flying species found also in the Malay Peninsula and Java, and P. vampyrusof which further knowledge will doubtless show that each group possesses its own variety.

To the Andamans 12 species are peculiar, the others being Mus musculus; Felis chaus, whose identification is doubtful; 4 bats; and a monkey, Macacus coinimus, in all probability introduced.

The Nicobars possess 14 peculiar species and I sub-species, and the remaining members are Mus alexandrimus, and 6 bats.

Not only is the peculiarity marked among the terrestrial, but among the winged animals, which form so large a part of the fauna; also, of the 7 bats occurring in the Andamans, 3 are endemic, while the same is the case with 5 of the II in the Nicobars.

Thus it is to be noted that in the Andamans all the II terrestrial mammals-except $M$. musculus, $M$. coininus (introduced?) and the doubtful F. chaus-are peculiar, and also 3 out of 7 bats; while in the Nicobars, only I species-M. alexandrinus -of Io terrestrial is other than endemic, and of the II bats 5 (nearly half) are peculiar. Remarkable as is the state of things 
with regard to the terrestrial, it is equally notable where the flying mammals are concerned.

The most noteworthy features of the fauna are the preponderance of bats ( 16 species) and rats (1 3 species)-which together constitute nearly three-fourths of the total number of mammals known to occur in the islands-and the absence of practically all representatives of the ungulates, squirrels, carnivores, and flying lemurs, which are characteristic of the surrounding regions and abound on other islands at equal distance from the mainland. From the Malayan islands where these occur they differ in that "they are surrounded by water of relatively great depth, while the others lie within the 50-fathom line. This paucity of mammalian life cannot be regarded as due to an unfavourable environment, since all the natural conditions on both Andamans and Nicobars are perfectly suited to the support of a rich and varied fauna"; yet so great is it that it appears safe to assume that these, "contrary to the case with the shallow-water islands, were isolated at a time when the mammals now characteristic of the mainland did not exist there." In fact, we are almost driven to conclude that they never were at any time a portion of the continent, but were formerly only far nearer to it, far larger and far more compactly situated-a hypothesis that is further supported by an investigation of the birds appertaining to them.

"As yet no species have been discovered whose origin may be referred to the remote period of a land connection: such mammals as are now known are evidently of very recent origin, as in scarcely an instance has their differentiation progressed further than in the case of members of the same genera found on islands lying in shallow water. The question at once arises, therefore, as to the means by which they have arrived where they now are. Flights from the mainland would readily account for the distribution of the bats; but the presence of the other mammals seems impossible to explain otherwise than through the agency of man. With the single exception of Tupai nicobarica, ${ }^{*}$ all are types well known to

* "It is worthy of note that this animal differs more conspicuously from its congeners than is the case with any of the other mammals." But even it- 


\section{FAUNA OF ANDAMANS AND NICOBARS}

be closely associated with man throughout the Malayan region. Moreover, the period of time necessary to the development of the peculiarities of the native Andamanese would undoubtedly be ample to allow the formation of any of the species known from either group of islands, since in a biologic sense it has been vastly longer to the smaller, more rapidly breeding, animals than to man. The introduction, intentional or otherwise, of a pig, a monikey, a palm-civet, two or three species of rats, a shrew, and perhaps also a tree-shrew, at about the time when the various islands were peopled by their present human inhabitants, would amply account for the existence of the present mammal fauna with its striking peculiarities."

The following tabular summary shows the distribution of the fauna among the islands. (The letter $\mathrm{A}$ indicates material obtained by $\mathrm{Dr}$ Abbott, the letter $\mathrm{R}$ a previous record; an asterisk denotes occurrence beyond the Andamans and Nicobars; doubtful species have a note of interrogation placed against them; and those in italics have been described as new from the collections made during the cruise of the Terrapin):-

were it indigenous and not a stray introduction-one would expect to find on others of the islands (such as Kachal) similar in surface and vegetation to Great and Little Nicobar. It no doubt was established in these two last before they became disunited, as sufficient time has elapsed for a distinct variation to occur, while the far greater depth of sea between them and Kachal would indicate a separation anterior to the arrival of the species. 


\section{Synopsis of the Mammalian Fauna of the Andaman and Nicobar Islands.*}

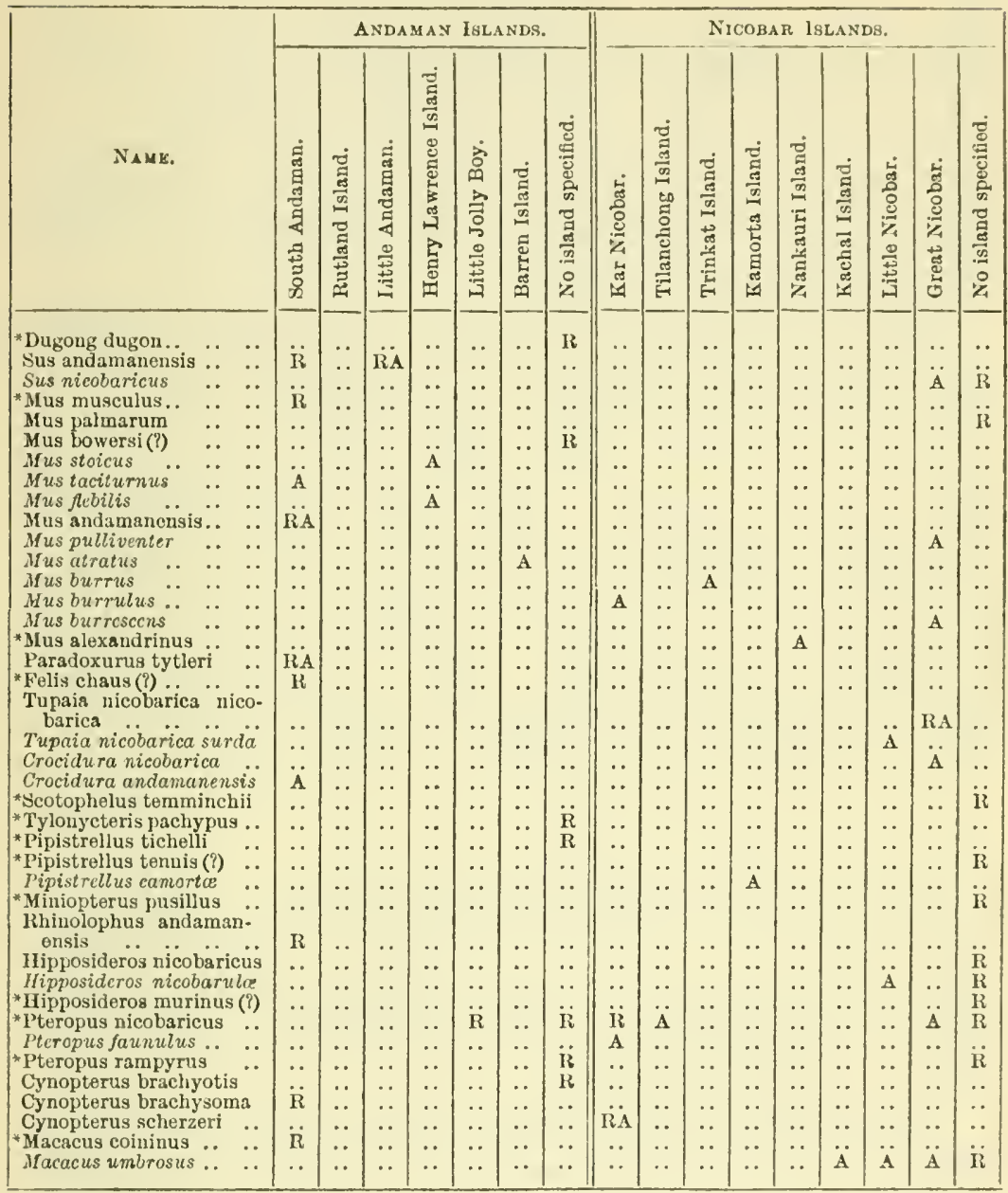

* This table and the foregoing quotations, are from the paper on the "Mammals of the Andaman and Nicobar Islands," by Mr Gerrit S. Miller, vol xxiv, Proceedings of the National Museum, U.S.A. 


\section{Birds.}

The birds of the Andamans and Nicobars have always been better known than the mammals, particularly since $\mathrm{Mr} \mathrm{A}$. O. Hume, with a number of collectors, made a cruise round the islands in a steamer in 1873 , which resulted in the discovery of many new species, and a careful analysis of the avifauna.

In spite of what is to be expected from their position, the islands derive the bulk of their species from the distant Indian region, while the Indo-Burmese and Indo-Malayan regions are represented to a far less degree.

One of the most striking features is the extreme paucity of rasorial birds-peafowl, junglefowl, pheasants, partridges, or any of the natural genera into which these divide, and which are all well represented in the Arakan Hills. The next point is the highly specialised character of the ornis, for, excluding waders and swimmers, more than a third of the species are peculiar to the islands; while still more remarkable is the extent to which it is localised in the several groups between which is nowhere a break of more than 80 miles. Even more noteworthy are the details: for instance, the Andaman Hypothymis, which, as a rule, is a very distinct form, is replaced in the Nicobars by one which, although not precisely identical with the Indian form, is far more closely allied to this than the Andaman Tytleri. Each group has its distinct harrier eagle, red-cheeked paroquet, oriole, sunbird, and bulbul. Two woodpeckers are peculiar to the Andamans, but neither extends to the Cocos or Nicobars. The latter group possesses three distinct but closely allied species of Astur, each confined to separate islands.

So far as the species not peculiar to the islands are concerned, the influence of the Indian sub-region has vastly predominated; and if we look to the genera the preponderance is still more marked, and thus it seems difficult to avoid the conclusion that the ornis has altogether a very far stronger affinity with that of the Indian region than with those of either the Indo-Burmese or the Indo-Malayan. Yet this involves great difficulties, for 
if we take Port Blair as a centre we shall find that its average distance in all directions north and east from Tenasserim (where the Indo-Malayan fauna predominates), and north of this from the Indo-Burmese sub-region, is less than half its distance from the nearest point of the Indian sub-region.

That so many of the characteristic birds of the Arakan Hills, especially the Rasores, should be entirely wanting, we may partly account for by the supposition that the mountains and the chain of islands never were continuous, and that the same agency that raised the Arakan Hills only raised portions of their continuation above the sea-level, so that, therefore, the islands have never been connected with Pegu. If, however, the groups first appeared and have ever since remained as detached islands, it is inconceivable how the great bulk of the work of colonisation should have gone on from a region so distant while so little should have been done from others less than half as far away.

Colonisation in no ordinary sense, however, can explain these facts. But the case of Sumatra, which, although only 80 miles distant from Great Nicobar, and itself the first link of a great chain, teems right up to Acheen Head with species unknown to the Nicobars, is perfectly comprehensible in the light of our knowledge of the deep sea existing between it and these latter islands.*

* The presence of a megapode in the Nicobars, a genus that occurs also in the Indo-Malayan region, is the most interesting feature of the islands' avifauna. Dr A. R. IVallace says, in The Distribution of Animals: "The Megapodidx are highly characteristic of the Australian region . . . only sending two species beyond its limits ( $M$. cumingi and $M$. lowi in the Philippine and North-West Borneo Islands), and another in the Nicobar Islands, separated by about 1800 miles from its nearest ally in Lombok. The Philippine species offers little diff. culty, for these birds are found on the smallest islands and sandbanks, and can evidently pass over a few miles of sea with ease; but the Nicobar bird is a very different case, because none of the numerous intervening islands offer a single example of the family. Instead of being a well-marked or differentiated form, as we should expect to find if its remote and isolated habitat were due to natural causes, it so nearly resembles some of the closely allied species from the Moluccas and New Guinea, that had it been found with them it would not have been thought specifically distinct. I therefore believe that it is probably an introduction by the Malays (Dr Guillemard states that this bird is often seen 


\section{FAUNA OF ANDAMANS AND NICOBARS}

If we conclude that the avifauna of the islands of the Bengal Sea is essentially Indian and not Indo-Burmese and Indo-Malayan, we must accept the fact with the qualification that we find it here in a most imperfect and mutilated form, lacking more or less entirely a large proportion of its characteristic genera, many of which are the strongest and most widely distributed, and to which the climate would appear in every way congenial.*

\section{List of Birds occurring in the Andamans and Nicobars. $\dagger$}

(A. denotes occurrence in the Andamans, N. in the Nicobars.)

Corvus macrorhyncus, Wagl. A.

Dendrocitta bayleyi, Tytler A.

Zosterops palpebrosa, Temm. A. N.

Irena puella, Lath. . . A.

Otocompsa emeria, Linn. A. N.

Iole nicobarica, Moore . N.

Micropus fusciflavescens, Hume

Dicrurus annectens, Hodgs.

D. leucogenys, Wald. . .

Dissemuroides andamanensis, Tytler . . . A

D. dicruriformis, Hume a A.

D. paradiseus, Linn. . . A. N.

Locustella certhiola, Pall. . A. N.

L. lanceolata, Temm. . A.

Cisticola cursitans, Frankl. N.

Arundinax ædon, Blyth . A. N.

Phylloscopus fuscatus, Blyth
Acanthopneuste magnirostris, Blyth . . . . A.

A. borealis, Blas. . . A.

A. lugubris, Blyth . . A.

A. tennilipes, Swinhoe - N.

Horornis pallidipes, Blanf. . A.

Lanius cristatus, Linn. A.

L. lucionensis, Linn. . . A. N.

Pericrocrotus andamanensis,

Tytler . . . A.

P. peregrinus, Linn. . . A.

P. cinereus, Lafr. . . A.

Campophaga terat, Bodd. . N.

Grauculus macii, Less. . A.

G. dobsoni, Ball . . . A.

Artamus leucogaster, Val. . A.

Oriolus macrurus, Blyth - A.

O. andamanensis, Tytler . A.

O. melanocephalus, Linn. . A.

in captivity in Malaysia), and that, owing to the absence of enemies and general suitability of conditions, it has thriven in the islands, and has become slightly differentiated from the parent stock."

The megapode also occurs on the Cocos Islands, but not on the Andamans intervening between these and the Nicobars. This may be explained either by the fact that it may formerly have existed on the Andamans, where it has been exterminated by the carnivorous palm-civet common in that group, or that, owing to the hostility of the natives, voyagers were deterred from stopping there and thus causing the introduction of the bird, a course they would be the less persuaded to attempt in that there were no coconuts to attract them?

* Vide A. O. Hume, Stray Feathers, vols. ii. and iv.

+ From A. L. Butler's "Birds of the Andamans and Nicobars," Proc. Bombay Nat. Hist. Soc., vols. xii. and xiii. 
Eulabes intermedia, Hay - A. N Calornis chalybeus, Horsf. . A. N. Pastor roseus, Linn. . . A. Sturnia andamanensis, Tytler A. S. erythropygia, Blyth . N. Agropsar sturninus, Pall. . N. Acridotheres tristis, Linn. . A. N. Muscitrea griseola, Blyth . A. Anthipes olivaceus(?), Hume A. Alseonax latirostris, Raffl. . A. Terpsiphone nicobarica, Oates A. N. Hypothymis azurea, Bodd. . N. H. tytleri, Beaven . . A. Pratincola maura, Pall. . A. Cyanecula suecica, Linn. . A. Copsycus saularis, Linn. . A. Cittincola albiventris, Blyth A. Merula obscura, Gemel. . A. Geocichla sibirica, Pall. . A. G. albigularis, Blyth . . N. G. andamanensis, Wald. . A. Petrophila solitaria, Mull. . A. N. Urolonga semistriata, Hume N. U. fumigata, Wald. . . A. Passer domesticus, Linn. . A. Emberiza pusilla, Pall. . A. E. aureola, Pall. . . . N. Hirundo rustica, Linn. . A. N. H. javanica, Sparmm. . A. Motacilla leucopsis, Gould . A. M. melanope, Pall.

M. borealis, Sundev. . M. flava, Linn. Liminodromus indicus, Anthus richardi, Vieill

A. cervinus, Pall. Æthopyga nicobarica, Hume Arachnechthra andamanica, Hume

Dicæum virescens, Hume .

Dendrocopus andamanensis, Blyth Thriponax hodgii, Blyth . A. Eurystomus orientalis, Linn. A. Merops philippinus, Linn. . N. Melittophagus swinhoii, Hume A. Alcedo ispida, Linn. . . A. N. A. beaveni, Wald. . . A. $\mathrm{N}$. A. A. A. A. . N.
Ceyx tridactyla, Pall. . A. N. Pelargopsis leucocephala, Gm. N. P. guarial, Pearson . . A. Halcyon saturatior, Hume A. H. pileata, Bodd. A. N. H. davisoni, Sharpe . . A. H. occipitalis, Blyth . . N. Calliacyon liliacina, Swains. A. N. Rhytidoceros narkondami, Hume . . . A. Cypselus apus, Linn. . . A. C. subfurcatus, Blyth . . A. Chætura indica, Hume . A. Collocalia innominata, Hume A. C. francica, Gmel. - . A. N. C. inexpectata, Hume . N. C. linchii, Horsf. and M. . A. N. Caprimulgus andamanensis, Hume

A.

Lyncornis cerviniceps (?), Gould

A.

Cuculus canorus, Linn. . A.

C. saturatus, Hodgs. . A. N.

C. micropterus, Gould . A.

Chrysococcyx xanthorynchus, Horsf.

A. N.

C. maculatus, Gmel. A. N. Eudynamus honorata, Linn. A. N. Centropus euryceros, Hay . N. (?) C. andamanensis, Tytler . A.

A. N. Palæornis magnirostris, Ball A. A. N. P. fasciatus, Müll. . . A. A. N. P. caniceps, Blyth . . N. A. N. P. erythrogenys, Blyth . N. A. P. tytleri, Hume . . A.

A. N. Loriculus vernalis, Sparmm. A. (N.?)
Strix flammea, Linn. . . A.

Syrnium sp.(?)seloputo, Horsf. A. (N.?) Ketupa sp. (?) javanensis (?), Less.

A.

Scops nicobarica, Hume . N.

S. balli, Hume - . . A.

Ninox affinis, Tytler . . A. N.

N. obscura, Hume . . A. N.

N. scrutulata, Raffl. . . N.

Spizaëtus andamanensis,

Hume . . . A.

Spilornis davisoni, Hume A. N. 
S. minimus, Hume . . N.

S. elgini, Tytler . . . A.

Haliætus leucogaster, Gmel. A. N.

Milvus govinda, Sykes . . A.

Circus cineraceus, Montagu A.

C. æruginosus, Linn. . . A.

Astur solœensis, Horsf. . N.

A. butleri, Gurney . . N.

Accipiter nisus, Blanf. . A.

A. virgatus, Reinw. . . A. N.

Falco peregrinus, Linn. . A. N.

Tinnunculus alandarius, Gmel.

Microhierax latifrons, Sharpe

Osmotreron chloroptera, Blyth

Carpophaga ænea, Linn.

C. insularis, Blyth .

Myristicivora bicolor, Scop.

Calœnas nicobarica, Linn. .

Chalcophaps indica, Linn. .

Alsocomus palumboides, Hume

Turtur tigrinus, Temm.

T. cambayensis, Gm. .

Enopopelia tranquebarica, Herm.

Macropygia rufipennis, Blyth

Excalfactoria chinensis, Linn.

Francolinus pondicerianus, Gm.

Megapodius nicobaricus, Blyth

Turnix albiventris, Hume Hypotœnidia obscuria, Hume Porzana pusilla, Pall. . . A

Rallina canningi, Tytler . A.

Amaurornis phœnicurus, Penn.

Gallicrex cinerea, $\mathrm{Gm}$. . A

Esacus magnirostris, Geoffr. A.

Dromas ardeola, Y'aykull . A. N.

Glareola orientalis, Leach . A. N.

Strepsilas interpres, Linn. . A. N.

Microsarcops cinereus, Blyth

Charadrius fulvus, Gm.

Squatarola helvetica, Linn. . A.

Egialitis geoffroyi, Wagl. . A. N
E. mongolica, . . . A. N.

Æ. vereda, Gould . . A.

Æ. dubia, Scop. . . . A.

Numenius arquata, Linn. . A. N.

N. phæopus, Linn. . . A. N.

Terekia cinerea, Güldenst. . A.

Totanus hypoleucus, Linn. . A. N.

T. glareola, Gm. . . A

T. ochropus, Linn. . . A.

T. calidris, Linn. . . . A.

T. glottis, Linn. . . . N.

Tringa ruficollis, Pall. . . A. N.

T. suminuta, Middend. . A. (?)

T. crassirostris, Temm. and Schl.

A.

T. subarquata, Güldenst. . A. N.

T. platyrhyncha, Temm. . A.

Gallinago cœlestis, Frenzel A.

G. stenura, Kuhl . . . A. N.

G. gallinula, Linn. . . A.

Hydrochelidon leucoptera, Meisner and Schinz. . A.

Sterna anglica, Mont. . . A.

S. dougalli, Mont. . . A.

S. media, Horsf. . • . A. N.

S. melanauchen, Temm. . A. N.

S. anæstheta, Scop. . . A.

Anous stolidus, Linn. . . A.

A. leucocapillus, Gould . A.

Pelecanus philippinus, Gm. A. N.

Phaëthon indicus, Hume . A.

P. flavirostris . . A.

P. rubicauda, Bodd. . . N.

Oceanites oceanus, Kuht (?) A.

Ardea manillensis, Sharpe . A. N.

Herodias intermedia, Wagl. A. N.

H. gazetta, Linn. . . A. (N.?)

Bubulcus coromandus, Bodd. A.

Lepterodius sacer, Gm. . A. N.

Ardeola grayi, Sykes . . A.

A. bacchus, Bonap. . . A.

Buteroides javanica, Horsf. A. N.

Nycticorax griseus, Linn. . N.

Goisakius melanolophus, Raffl.

N.

Ardetta sinensis, Gm. . . A. N.

A. cinnamomea, Gm. . A. N.

Dendrocygna javanica, Horsf. A. N. 
Nettopus coromandelianus, Gm. .
Nettium crecca, Linn.

N. albigulare, Hume
A. N.

A.

The following new additions should now be made to the above to complete the known list of Andaman and Nicobar avifauna :-

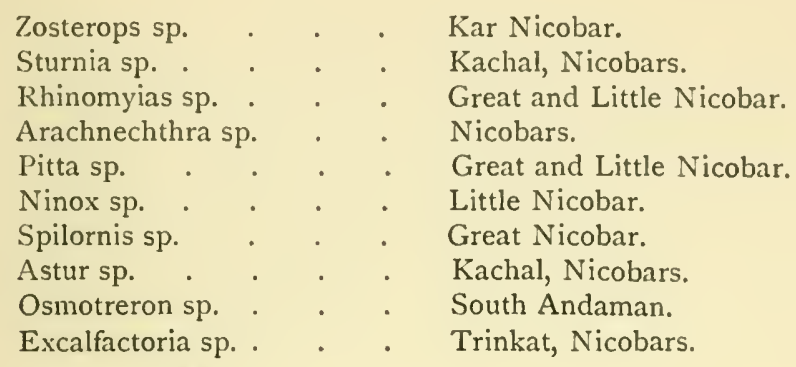



A P P E N D I C E S 



\section{A P P E N D I A}

\section{AVERAGE WIND AND WEATHER IN THE ANDAMANS}

October . Variable wind and weather; water-spouts.

November . The first half of the month the same as October, afterwards N.E. monsoon and little rain. A cyclone is almost certain to occur in November.

December . Fresh N.E. monsoon; fairly cool.

January . Cool and pleasant ; N.E. winds; nights sometimes foggy.

February . Cool and pleasant ; very clear ; light airs.

March . Hot by day, cool nights, light airs; occasional haze.

April . Very hot ; calm and hazy.

May S.W. monsoon sets in about the $15^{\text {th. }}$

June $\quad$ S.IV. monsoon; cool, squally.

$\left.\begin{array}{l}\text { July } \\ \text { August }\end{array}\right\}$ Do. do. do.

September . Rain every day, S.W. winds. 


\section{A P PENDIX B}

\section{PRINCIPAL FOREST TREES OF THE ANDAMANS}

\section{DILLENIACEE-}

Dillenia aurea, $S m$.

D. parviflora, Griff.

D. pentagyna, $R$.

\section{ANONACEE-}

Polyalthia Jenkinsii, Bth.

P. macrophylla, $H$. $f$.

Alfonsea ventricosa, $H$. $f$.

\section{POLyGaleE-}

Xanthophyllum glaucum, Wall.

HYPERICINEE-

Cratoxylum formosum, Bth. \& $H$. $f$.

\section{GUTTIFERE-}

Garcinia speciosa, Wall.

G. Cowa, $R$.

G. xanthochymus, $H k$. $f$.

Calophyllum spectabile, Willd.

C. inophyllum, $L$.

Mesua ferrea, $L$.

\section{DIPTEROCARPEE-}

Dipterocarpus turbinatus, Gaertn.

D. pilosus, $R$.

D. alatus, $R$.

D. Griffithii, Miq.

\section{MALVACEæ-}

Bombax malabaricum, D. C.

B. insigne, Wall.

Eriodendron anfractuosum, $D . C$.

\section{STERCULIACEE-}

Sterculia fotida, $L$.

S. villosa, $R$.

S. parviflora, $R$.

S. colorata, $R$.

S. alata, $R$.

S. campanulata, IVall.

Heritiera littoralis, Dry.

H. Fomes, Buch.

Buettneria aspera, Col.

\section{TILIACEE-}

Elæocarpus Helferi, $K z$.

\section{RUTACEA-}

Murraya exotica, $L$.

Aegle Marmelos, Cor.

OCHNACEA-

Ochna Wallichii, $\mathrm{Pl}$.
BurseraceE-

Garuga pinnata, $R$.

Canarium euphyllum, $K z$.

C. coccineo-bracteatum, $K z$.

MeliaceE-

Chisocheton grandiflorus, $K z$.

Amoora Rohituka, $W$. \& $A$.

A. cucullata, $R$.

Walsura hypoleuca, $K z$.

W. villosa, Wall.

W. robusta, $R$.

Carapa moluccensis, Lamk.

Cedrela Toona, $R$.

CelastrineA-

Salacia prinoides, D.C.

RHAMNEE-

Zizyphus Jujuba, Lamk.

Z. EEnoplia, Mill.

Z. rugosa, Lamk.

\section{SAPINDACEA-}

Erioglossum edule, $B$ l.

Cupania Lessertiana, Camb.

Pometia tomentosa, $K z$.

Harpullia cupanoides, $R$.

ANACARDIACEE-

Mangifera sylvatica, $R$.

Bonea burmanica, Griff.

Odina Wodier, $R$.

Parishia insignis, Hk.f.

Semecarpus heterophylla, $B l$.

Spondias mangifera, Willd.

Dracontomelum mangiferum, $B l$.

\section{LEGUMINOSE-}

Erythrina indica, Lamk.

Dalbergia latifolia, $R$.

Pterocarpus indicus, Willd.

Pongamia glabra, Vent.

Peltophorum ferrugineum, Bth.

Cassia Fistula, $L$.

C. renigera, Wall.

Cynometra ramiflora, $L$.

Afzelia retusa, $K z$.

A. bijuga, A. Gray.

A. palembanica, Baker.

Adenanthera pavonina, $L$.

Albizzia Lebbek, Bth.

A. stipulata, Boiv. 


\section{ROSACEE-}

Prunus martabanica, Wall.

\section{SAXIFRAGACEE-}

Polyosma integrifolia, $B l$.

\section{RHIZOPHOREÆ-}

Rhizophora mucronata, Lamk.

R. conjugata, $L$.

Ceriops Candolleana, Arn.

Bruguiera gymnorhiza, Lamk.

B. parviflora, $W$. \& $A$.

\section{COMBRETACEE-}

Terminalia procera, $R$.

T. Catappa, $L$.

T. bialata, $K z$.

Lumnitzera racemosa, Willd. Gyrocarpus Jacquini, $R$.

\section{MYRTACEE-}

Eugenia javanica, Lamk.

E. claviflora, $R$.

E. leptantha, $W g t$.

E. jambolana, Lamk.

Barringtonia speciosa, Forst.

B. racemosa, $B l$.

Careya arborea, $R$.

Planchonia littoralis, Vau.

\section{MELASTOMACEE-}

Memecylon pauciflorum, $B l$.

\section{LYTHRACEE-}

Pemphis acidula, Forst.

Lagerstroemia calyculata, $K z$.

L. hypoleuca, $K z$.

Duabanga sonneratioides, Ham.

Sonneratia acida, $L$. $f$.

S. alba, Sm.

\section{DATISCACEE-}

Tetrameles nudiflora, $R . B r$.

\section{RUBIACEA-}

Mussaenda macrophylla, Wall.

M. frondosa, $L$.

Randia densifiora, Bth.

R. exaltata, Griff.

Gardenia turgida, $R$.

Scyphiphora hydrophyllacea, Gertn.

Guettarda speciosa, $L$.

Timonius Jambosella, Thw.

Morinda citrifolia, $L$.
Goodenovieæ-

Scævola Kœnigii, $V h l$.

PlumbagineÆ-

Ægialitis rotundifolia, $R$.

MYRSINEÆ-

Mæsa andamanica, $K z$.

M. ramentacea, $D$. $C$.

Ægiceras majus, Gcertn.

\section{SAPOTACEÆ-}

Bassia caloneura, $K z$.

Mimusops Elengi, $L$.

M. littoralis, $K z$.

M. hexandra, $R$.

\section{EBenaceE-}

Diospyros pilulosa, Wall.

D. Kurzii, Hiern.

D. oleifolia, Wall.

\section{APOCYNACEE-}

Ochrosia borbonica, Gmel.

Cerbera Odollam, Gertn.

Alstonia Kurzii, $H$. $k$ f.

\section{LOGANIACEE-}

Fagræa racemosa, Jack.

F. fragrans, $R$.

BORAGINEE-

Ehretia lævis, $R$.

\section{BIGNONIACEE-}

Oroxylum indicum, Vent.

Dolichandrone Rheedii, Seem.

Heterophragma adenophyllum, Seem.

Pajanelia Rheedii, D.C.

VERBENACEE-

Premna integrifolia, $L$.

Gmelina arborea, $L$.

Avicennia officinalis, $L$.

NyCTAGINEÆ-

Pisonia alba, Span.

P. excelsa, $B l$.

\section{MYRISTICEE-}

Myristica andamanica, $H k$. $f$.

M. Irya, Gartn.

M. glaucescens, $H k . f$.

M. laurina, $B l$. 
LAURINEE-

Cryptocarya andamanica, $H k . f$.

Dehaasia Kurzii, King.

D. elongata, $B l$.

Cinnamomum obtusifolium, Nees.

Litsæa sebifera, Pers.

Hernandia peltata, Meis.

\section{EUPHORBIACEE-}

Briedelia tomentosa, $\mathrm{Bl}$.

Cleistanthus myrianthus, $K z$.

Glochidion calocarpum, $K z$.

G. andamanicum, $K z$.

Hemicyclia andamanica, $K z$.

Cyclostemon macrophyllum, $B l$.

Aporosa villosula, $K z$.

A. Roxburghii, Biall.

A. martabanicum, Presh.

Baccaurea sapida, $M$. Arg.

Mallotus Kurzii, $H k$. $f$.

M. acuminatus, $M$. Arg.

M. andamanicus, $H k$. $f$.

M. philippinensis, M. Arg.

Cleidion javanicum, $B l$.

C. nitidum, Thw.

Macaranga indica, $W g t$.

M. Tanarius, $M$. Arg.

Homonoia riparia, Lour.

Excœcaria Agallocha, $L$.

\section{URTICACEE-}

Celtis Wightii, $P l$.

Trema amboinensis, $B l$.

Gironniera subæqualis, $P l$.

G. lucida, $K z$.

Ficus gibbosa, $B l$.

F. altissima, $B l$.

$F$. glaberrima, $B l$.

$F$. indica, $L$.

F. Benjamina, $L$.
URTICACEE-Continued-

$F$. retusa, $L$.

F. Tjakela, Borm.

F. callosa, Willd.

Artocarpus Chaplasha, $R$.

A. Lakoocha, $R$.

\section{SALICINEÆ-}

Salix tetrasperma, $R$.

\section{CONIFERE-}

Podocarpus neriifolia, Don.

\section{CYCADACEE-}

Cycas Rumphii, Miq.

\section{PALMEE-}

Areca triandra, $R$.

Pinanga Manii, Becc.

P. Kuhlii, $B l$.

Caryota mitis, Lour.

Nipa fruticans, $W u r m b$.

Phœenix paludosa, $R$.

Corypha macropoda, $K z$.

Licuala peltata, $R$.

L. spinosa, Wurmb.

Calamus longisetus, Griff.

C. andamanicus, $K z$.

C. palustris, Griff.

\section{PANDANEE-}

Pandanus andamanensium, $K z$.

P. fascicularis, Lam.

P. Leram, Jones.

\section{GRAMINEE-}

Bambusa schizostachyoides, $K z$.

Oxytenanthera nigrociliata, Munro.

Dinachloa Tjankorreh, Büse. 


\section{NOTES ON THE PRODUCE OF THE ANDAMANESE FORESTS}

The following is a list of some of the more useful and valuable woods :-

\begin{tabular}{|c|c|c|c|c|c|c|c|}
\hline $\begin{array}{l}\text { Padouk } \\
\text { Koko. } \\
\text { Chuglam, I } \\
\text { Marble wo }\end{array}$ & $\begin{array}{l}\dot{\text { Black }} \\
\text { od }\end{array}$ & & . & $\cdot \dot{1}$ & $\begin{array}{l}\text { Pterocarpus Indicus } \\
\text { Albizzia Lebbek } \\
\text { Myristica Irya } \\
\text { Diospyros Kurzii : }\end{array}$ & $\dot{\bullet}$ & For furniture. \\
\hline $\begin{array}{l}\text { Padouk } \\
\text { Gangaw } \\
\text { Toung-peir } \\
\text { Pyimma } \\
\text { Thingan } \\
\text { Lakuch } \\
\text { Thitmin } \\
\text { Gurjan } \\
\text { Mohwa }\end{array}$ & 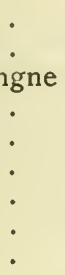 & $\begin{array}{l}\dot{5} \\
\dot{5} \\
\dot{5} \\
\dot{.}\end{array}$ & $\begin{array}{l}\dot{.} \\
\dot{.} \\
\dot{.} \\
\dot{.} \\
\dot{.} \\
\dot{.}\end{array}$ & $\begin{array}{l}\cdot \\
\dot{\cdot} \\
\dot{\cdot} \\
\dot{\cdot} \\
\dot{.} \\
\dot{\cdot}\end{array}$ & $\begin{array}{l}\text { Pterocarpus Indicus } \\
\text { Mesua ferrea. } \\
\text { Artocarpus Chaplasha } \\
\text { Lagerstrœenia hypoleuca } \\
\text { Hopea odorata } \\
\text { Artocarpus Lakucha } \\
\text { Podocarpus bracteata } \\
\text { Dipterocarpus sp. } \\
\text { Mimusops littoralis }\end{array}$ & $\begin{array}{l}\dot{.} \\
\dot{a} \\
\dot{.} \\
\dot{.}\end{array}$ & For building. \\
\hline $\begin{array}{l}\text { Bombway } \\
\text { Gangaw } \\
\text { Mohwa } \\
\text { Pyimma } \\
\text { Lakuch } \\
\text { Gurjan } \\
\text { Thingan }\end{array}$ & $\begin{array}{l}\dot{.} \\
\dot{.} \\
\dot{.} \\
\dot{.}\end{array}$ & $\begin{array}{l}\dot{.} \\
\dot{5} \\
\dot{.} \\
\dot{.}\end{array}$ & $\begin{array}{l}\dot{.} \\
\dot{.} \\
\dot{.} \\
\dot{.}\end{array}$ & $\begin{array}{l}\cdot \\
\cdot \\
\cdot \\
\cdot \\
\cdot \\
\cdot\end{array}$ & $\begin{array}{l}\text { Careya arborea } \\
\text { Mesua ferrea. } \\
\text { Mimusops littoralis } \\
\text { Lagerstrœmia hypoleuca } \\
\text { Artocarpus Lakucha } \\
\text { Dipterocarpus sp. . } \\
\text { Hopea odorata }\end{array}$ & $\begin{array}{l}\dot{.} \\
\dot{a} \\
\dot{.}\end{array}$ & $\begin{array}{l}\text { Probably useful for } \\
\text { paving-blocks. }\end{array}$ \\
\hline $\begin{array}{l}\text { Gurjan } \\
\text { Didu . } \\
\text { Toung-peir } \\
\text { Thitmin } \\
\text { And numer }\end{array}$ & igne & $\dot{\dot{b}}$ & $\begin{array}{l}\dot{\cdot} \\
\dot{*} \\
\text { woods }\end{array}$ & $\dot{\text {. }}$ & $\begin{array}{l}\text { Dipterocarpus sp. } \\
\text { Bombax insigne } \\
\text { Artocarpus Chaplasha } \\
\text { Podocarpus bracteata } \\
\text { Barringtonia sp. . }\end{array}$ & & $\begin{array}{l}\text { For tea - boxes, } \\
\text { indigo boxes, } \\
\text { and packing- } \\
\text { cases. }\end{array}$ \\
\hline $\begin{array}{l}\text { Padouk } \\
\text { Pyimma } \\
\text { Thingan }\end{array}$ & $\dot{\cdot} \cdot$ & $\dot{.}$ & $\dot{\dot{v}}$ & & $\begin{array}{l}\text { Pterocarpus Indicus } \\
\text { Lagerstrœmia hypoleuc: } \\
\text { Hopea odorata }\end{array}$ & & $\begin{array}{l}\text { For gun-carriages } \\
\text { and carriage } \\
\text { work. }\end{array}$ \\
\hline $\begin{array}{l}\text { Padouk } \\
\text { Gangaw }\end{array}$ & $\dot{\cdot}$ & $\dot{r}$ & & & $\begin{array}{l}\text { Pterocarpus Indicus } \\
\text { Mesua ferrea. }\end{array}$ & & For shafts. \\
\hline $\begin{array}{l}\text { Lakuch } \\
\text { Thitmin }\end{array}$ & . & & & & $\begin{array}{l}\text { Artocarpus Lakucha } \\
\text { Podocarpus bracteata }\end{array}$ & & \multirow{2}{*}{$\begin{array}{l}\text { Probably useful } \\
\text { for oars. } \\
\text { In place of box- } \\
\text { wood. }\end{array}$} \\
\hline Satin wood & & . & . & & Murraya exotica & & \\
\hline Mangrove & • & . & . & . & sp. . & $\cdot\}$ & For firewood. \\
\hline
\end{tabular}

The Madras and Bombay Government gun-carriage factories are supplied with Andamanese timber, which, so far, is understood to have given them satisfaction. Such timber has been sent to Roorkee for the Military Gymnasium, as being the best suited in India for its purposes. The Indian Marine 
Department also takes it regularly. Andamanese timber has also been supplied to Woolwich Arsenal. These facts show that Andamanese timber is of value to such establishments as gun-carriage factories, arsenals, gymnasia, and shipbuilding yards.

For various reasons, most of the Andamanese timbers will probably be found to be best marketable in a converted form. It is believed that such converted timbers will be found useful for six large trades at least, viz., paving wood-blocks, gun-stocks, pianoforte manufacture, furniture, organ buildingfor which Padouk is pre-eminently suitable-and electric light and telephone fittings. If Gurjan should turn out, as is believed to be probable, to be of use for paving wood-blocks, then the supply would be very large.

Two forms of converted timbers may be specially noticed as probably marketable in large quantities, viz., railway sleepers, and tea shooks. It is believed that there are several timbers which would stand the strain of railway traffic ; and as regards tea shooks, Gurjan is used for this purpose in some mills in Assam, and of this particular wood there is an unlimited supply all over the Andamans, which could probably be delivered locally at a price which would enable it to compete well in Indian markets with other timbers used for teaboxes.

The supply of mangrove billets for firewood, at points where it can be easily and cheaply shipped, is very large in the Andamans, and it is thought possible that a very profitable and lasting Indian trade might be established in firewood.

At present, no trade exists at all in gurjan oil, and, as above stated, the supply of Gurjan trees is unlimited. It is believed that the supply of Gurjan in India has largely been worked out, therefore that in the Andamans should become valuable. A small quantity of gurjan oil is extracted in the Settlement and used chiefly for mixing with earth oil for application to shingle roofs. The uses to which this oil is put are so many that the possibility of a profitable trade in the Andamanese supply seems to be beyond question.

For the construction of houses, bridges, and jetties, the following species are chiefly used in the Settlement:-

Padouk.-Posts, trusses, purlins, common rafters, battens, floor and wall planking, shingles, doors, and windows.

Koko.-Joists, common rafters, battens, fillets, floor-planking, doors, and windows.

White Chuglam.-Floor and ceiling planking.

Pyimma.-Posts, joists, common rafters, purlins, frames, floor and wall planking, shingles.

Lakuch and Mowha.-Posts, girders, beans, and purlins.

Gangaw.-Posts, girders of bridges, 3-inch planking over sluices, and sluice-gates.

Thitmin.-Inside walling and jambs, shelves, and any light work.

In boat-building the following species are used by the Marine Department :-

Padouk.-Hull planks, keel, stem and stern posts, ribs of large boats, and thwarts. 
White Chuglan.-Oars.

Pyimma.-Thwarts.

Thitmin.-Masts and spars.

Chooi.-Ribs of small boats.

For furniture, Padouk and Koko are chiefly used. Didu is the only species utilised for the manufacture of tea-boxes at Port Blair. Bark for tanning purposes is obtained from various species of Mangrove and from Terminalia procera. Mangrove also gives the most suitable wood for use in the furnaces of the Settlement steam-launches.

Firewood for ordinary purposes is obtained from all hard-wood species other than those in demand for timber.

Gurjan oil is obtained from three species of Dipterocarpus. The tapping operations extend from Ist January to zoth April. The daily outturn averages 7 lbs. per man, the greatest flow of oil taking place in the month of March. The mixture used for steeping house-shingles consists of $3 \mathrm{lbs}$. of gurjan oil to I lb. of earth oil and $\mathrm{I} \mathrm{lb}$. of Alford's metallic paint.

The minor produce of the Andamans comprises several useful species of bamboo and cane, used in house-building and in the construction of furniture, rattan roots for walking-sticks, and two species of palm (Nipa fruticans and Licuala peltata), the leaves of which are used for thatching.

The inner bark of Sterculia villosa is used for making ropes for timberdragging purposes.

With regard to the capabilities of the forests for export purposes, there is an abundance of mature and over-mature Padouk throughout the Andamans. Gurjan oil trees, Gangawe (the Assam "I ronwood"), suitable for sleepers, and Didu, suitable for tea-box planking, are extremely abundant. For the extraction of these species labour alone is required.

The forests are situated, in most cases, on the coast, or on or near to navigable creeks leading to the sea, and are capable of easy and economical working.-Andaman and Nicobar Gazette. 


\section{A P PENDIX D}

\section{CENSUS, ANDAMAN ISLANDS, I90I}

ANDAMANESE

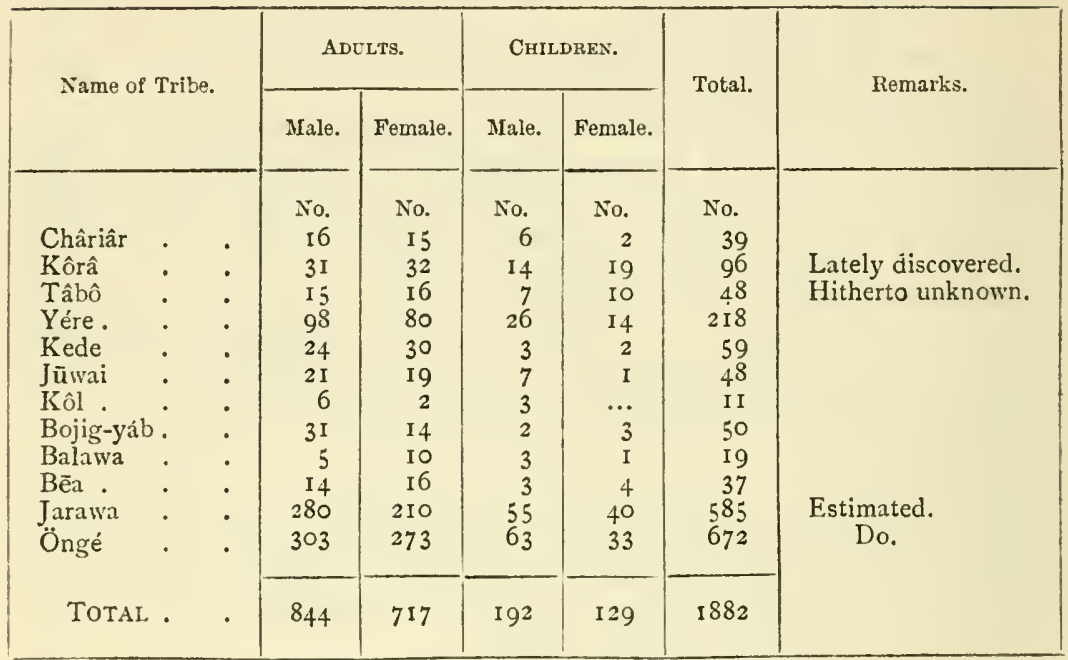

The number of children among the Andamanese is probably understated. The census operations have brought to light a new tribe, the Tâbô of North Andaman, and have proved the recently discovered Kôrâ tribe to be compara. tively numerous. In explanation of the small numbers of the newly discovered Tâbô tribe, the census party were informed that when a contagious disease was recently introduced among the Tâbôs by the Châriâr or Kôrâ tribes of the coast, they proceeded to kill off all those attacked until very few of the tribe were left.-Supp., And. and Nic. Gazette, March 2, I901.

The foreign residents number 16,106 (viz., 4102 free and 12,004 convict), who are all located at or near Port Blair; but as the amount is arrived at by deducting the Andamanese and the natives of the Nicobars from the total population of the two groups, allowance must be made for inaccuracy due to estimation only of the Jarawas, Öngés, and Shom Pen.

Average height of men . $4 \mathrm{ft}$. IO $\frac{3}{4}$ ins. Average height of women . $4 \mathrm{ft} .7 \frac{1}{4}$ ins. Average weight , . $\quad 98 \frac{1}{8}$ lbs. Average weight , . $93 \frac{1}{4}$ lbs.

Maximum . Men. . $5 \mathrm{ft} .4 \frac{1}{4}$ ins. Maximum . Nomen. $4 \mathrm{ft} .1 \mathrm{I} \frac{1}{2} \mathrm{ins}$.

Minimum . . . $4,55^{3} "$ Minimum . . $4 " 4$ "

-E. H. Man, Andaman Islanders. 


\section{A P PEN DIX E}

\section{GOVERNMENT SCHOOLS, PORT BLAIR}

The daily average number of pupils on the rolls of the Settlement schools for 1900 was $229-190$ boys and 39 girls. The daily percentage of attendance was about 92 of both sexes.

Of the former attending the schools, 133 were the children of free persons and ex-convicts, and the remainder were of convict parentage. With the exception of 6 , all the girls were of the latter class.

Inquiry shows that the percentage of boys attending the schools, born of free parents, is about 36 to the 20 born of convict parents, who remove their sons from school immediately the compulsory limit of age (I2 years) is passed.

The number of schools in the Settlement is seven, and the teaching staff consists of-six vernacular masters, including a gymnastic instructor, one assistant English master, fifteen vernacular assistant teachers and monitors, five sewing masters and mistresses, one carpenter, and a blacksmith.

The highest class in the English is the fifth, and in the vernacular school the sixth, in which mensuration and transliteration from Urdu into Roman characters are taught. The curriculum adopted is that in vogue in the Punjab. All vernacular education, as well as instruction, in the Industrial School is granted free of charge, but a fee of I rupee per month is imposed on those who are taught English.

There were 82 boys in the Industrial School learning both carpenter's and blacksmith's work, and the earnings during nine months amounted to Rs. 56. It is proposed to teach boys who are not strong enough for the above trades the use of the sewing-machine, with a view to turning them into tailors.

The girls do not make much progress in their literary studies, but their work in the sewing classes is more satisfactory. The reason for this is that free persons and ex-convicts do not send their girls to school, and convict parents withdraw their daughters as soon as they reach their tenth year. Efforts are made to overcome the prejudices of the parents, but without success. There are many difficulties in this matter with regard to native children, and at present it can only be hoped that by degrees prejudices will gradually break down, and the girls be allowed to make a better start in life than they are at present given. 
In Port Blair the locally born of both sexes may be fairly described, as a whole, as astonishingly wicked. Their delight is to do mischief, and to worry each other and their elders in an ingenious variety of underhand and crooked ways, including the perverse and fruitless lawsuit. It is very much better that their minds should be turned on athletic sports and games, while they can still join in them, than on such matters as these ; and hence grounds for cricket and football with all requisites have been granted, and a gymnastic instructor has been obtained for teaching the boys. It is believed that satisfactory progress is made, and that much benefit will be derived from the lately established gymnasium, in which 100 boys are (I90I) being trained.

\section{A P P E N D I X F}

\section{MEASUREMENTS OF SOME NATIVES OF LITTLE ANDAMAN MET AT RUTLAND ISLAND}

A

Height. . . $64 \frac{3}{4}$ inches.

Fathom . . $66 \frac{5}{8}$,

Chest. . . $33 \frac{1}{2}$,

Length of Hand . . $7 \frac{5}{8}$ "

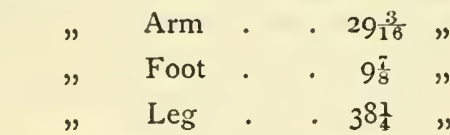

Girth of Thigh . . $18 \frac{7}{8}$,

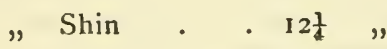

"Forearm . $10 \frac{1}{8}$,

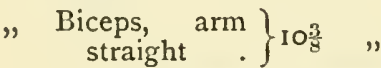

B

$63 \frac{1}{4}$ inches.

$64 \frac{3}{8}$

3 I $\frac{5}{3}$,

$7 \frac{1}{4}$,

$28 \frac{1}{2}$

$9 \frac{1}{2}$,

$36 \frac{3}{4}$,

$17 \frac{1}{8}$

I I $\frac{3}{8}$,

$9 \frac{1}{2} \quad$ "

$9 \frac{5}{8}$,
C 62 inches.

63 ,

$31 \frac{3}{3}$,

$6 \frac{1}{2}$,

28 "

$.9 \frac{1}{8}$

$35 \frac{3}{4}$,

I $8 \frac{1}{2}$,

I $\frac{0}{16}$ "

$9 \frac{7}{8} "$

9! 


\section{A P P E N DIX G}

PRINCIPAL FLORA OF THE NICOBARS

DiLLENIACEE.

Dillenia pilosa, $K z$. . . Little Nicobar . Interior.

ANONACEE.

Anona muricata, $L$. . . Around villages . Cultivated.

A. squamosa, $L$. . . . D Do. . Do.

BIXINEE.

Bixa Orellana, $L . \quad$. $\quad$. $\quad$. Malacca village . Do.

Flacourtia sepiaria, Roxb. : Nancowry : Interior.

GUTTIFERE.

Garcinia speciosa, Wall. . . Northern islands . Do.

Calophyllum spectabile, Willd. Little Nicobar : Do.

C. inophyllum, $L$. . . . Northern islands : Beach forest.

DipterocarpeE.

Hopea odorata, Roxb. . . Menchal . . . Interior.

Malvaces.

Hibiscus tiliaceus, $L . \quad$. $\quad$. All islands $\quad$. . Beach forest.

Thespesia populnea, Corr. . Do. . D Do.

Gossipium sp. . . . Malacca . . Cultivated.

Kydia calycina, Roxb. : : Northern islands : Interior.

STERCUliace $/$.

Sterculia campanulata, Wall. . Teressa . . . . Do.

S. villosa, Roxb. . . . Little Nicobar . Do.

S. rubiginosa, Vent. . . . Car Nicobar . . Do.

Heritiera littoralis, Dryand. . All islands . . Beach forest.

Pterospermun acerifolium, Willd. Little Nicobar . Interior.

RUTACEE.

Paramignya citrifolia, Hf. $\quad$ - Car Nicobar, Little Do.

Citrus medica, $L . \quad$. . Villages . : . Cultivated.

C. decumana, Willd. $\quad$. Do. $\quad$. . Do.

Egle Marmelos, Correa. : Do. : : Do.

\section{BURSERACE£.}

Canarium euphyllum, $K z$. . . Teressa . . . Interior.

MELIACE.

Carapa moluccensis, Lamk. - Little Nicobar . Maritime swamp.

C. obovota, Bl. . . . Do. Do.

Amoora Ganggo, Miq. : : Do. 
Celastrinee.

Salacia prinoides, D.C. . . Little Nicobar . Interior.

RHAMNEÆ.

Zizyphus subquinquenerva, Miq. Little Nicobar . Do.

ANIPELIDEÆ.

Vitis pedata, $V h l$.

Leea grandifolia, $K$

L. sambucina, $L$
Little Nicobar

Do. and Nancowry

Do.
Do.

Interior \& beach forest. Do.

\section{ANACARDIACEÆ.}

Mangifera sylvatica, Roxb.

- Teressa

Odina Wodier, Roxb. Nancowry

Semecarpus heterophyllus, $B l$. . All islands

Parishia insignis, $H k$. $f$.

Teressa

LEGUMINOSÆ.

Abrus precatorius, $L$.

Erythrina indica, $L$. .

Flemingia strobilifera, $A$ it.

Derris scandens, Bth.

\section{Pongamia glabra, Vent.}

Peltoforum ferrugineum, $\operatorname{Vog}$.

Cæsalpinia nuga, Ait.

Afzelia lijuga, A. Gray.

C. Bonducella, Roxb.

Tamarindus indica, $L$.

Entada scandens, Bth.

Albizzia stipulata, Boiv.

Adenanthera pavonina, $L$.

Pithecolobium sp.

Desmodium sp.
Malacca village

Little Nicobar

Car Nicobar, Nancowry .

Little Nicobar

All islands

Nancowry

All islands

Do.

Car Nicobar.

Little Nicobar

Nancowry

Little Nicobar

Do.

Do.
Beach forest.

Beach forest and man-

Cultivated.

Interior.

- Do. on border of grass

- Interior.

- Beach forest.

\section{RHIZOPHOREE.}

Rhizophora mucronata, Lmk. . Little Nicobar

R. conjugata, $L$.

Bruguiera gymnorhiza, Lam.

Carallia sp. (?)

Do.

Do.

Car Nicobar . . Interior.

\section{COMBRETACEE.}

Terminalia Catappa, $L$

T. sp. (procera ?)

All islands

Do. .

Pulo Milo

Car Nicobar

Combretum sp.

Lumnitzera racemosa, Willd.

\section{MYRTACEE.}

Eugenia Javanica, Lamk. .

Barringtonia speciosa, Forst. . Do. racemosa, $D . C$. Do. acutangula, Gertn. Psidium guava, Raddi.
All islands

Do.

Car Nicobar : . Interior.

Do.
Cultivated.

Interior.

Do.

Do.

Do. [grove swamp.

Do. Do.

Mangrove swamp.

Do.

Do.

and in- 


\section{MelastomaceE.}

Melastoma malabathricum, $L$. . Car Nicobar . . Interior.

\section{PASSIFLOREE.}

Carica papaya, $L$. . . . Villages . . . Cultivated.

\section{RUBIACEE.}

Pavetta indica, $L . \quad$. . . Little Nicobar . Beach forest.

Guettarda speciosa, $\dot{L}$. : : All islands . : Do.

\section{SAPOTACEE.}

Mimusops littoralis, Kz. . . All islands . . Do. on rocky coasts.

APOCYNACE.

Fagræa racemosa, Jack. . . Nancowry, Little Interior.

Cerbera Odollam, Ham. . . Car Nicobar, Little Beach forest.

Ochrosia salubris, Mig. . . Car Nicobar, Little Do.

Alstonia scholaris, R. Br. . Car Nicobar : : Interior.

\section{CONVOLVULACEE.}

Ipomæa biloba, Forsk. . . All islands . . Sea beach.

SOLANEE.

Solanum torvum, $S w . \quad$. . Car Nicobar . . Village lands

\section{BigNONIACE,E.}

Spathodea Rheedii, Wall. . Little Nicobar, Nan- Beach forest. cowry .

\section{VERBENACEE.}

Clerodendron inerme, $L$. . . Nancowry . . Interior, neargrass land.

Callicarpa longifolia, Lamk. . Car Nicobar . . Interior.

\section{BORAGINEÆ.}

Cordia subcordata, Lamk.

C. Myxa, $L$.

Tournefortia argentea, $L$.

- All islands

Lar Nicobar

- Little Nicobar
- Beach forest.

- Inland.

- Beach forest.

\section{LAURACE.}

Cinnamomum obtusifolium, N.E. Little Niccbar, Nan- Interior.

Cassytha filiformis, $L$

Hernandia peltata, Meissn.

$$
\text { cowry }
$$

Little Nicobar

Car Nicobar and other islands
Do.

Beach forest.

\section{ELAAGNACEÆ.}

Elæagnus latifolia, $L . \quad$. . Car Nicobar and Interior. other islands 


\section{MYRISTICACEE.}

Myristica Irya, Gertn. . . Little Nicobar, Nan- Interior. cowry

\section{EUPHORBIACEE.}

Croton argyratus, $B l$.

- Nancowry

Macaranga Tanarius, Mïll. Arg. $\begin{aligned} & \text { Nancowry } \quad \text { Teressa . : : Beach forest. } \\ & \text { Mach }\end{aligned}$

Mallotus philippinensis, $D . C$. .

Ricinus communis, $L$.
Interior.

Villages . : Cultivated.

\section{URTICACEE.}

Artocarpus integrifolia, $L . \quad$. Villages . . . Cultivated.

A. Chaplasha, Roxb. . . . Nancowry . . Interior.

A. Lakoocha, D. C. • . . Do. . . Do.

Ficus bengalensis, $L . \quad$. All islands $: \quad$. Beach forest.

PiPeracee.

Chavica Betle, Miq. . . . All islands . . Beach forest, and culti[vated.

CASUARINEe.

Casuarina equisetifolia, Forst. . All islands . . Beach forest(claybluffs).

CONIFERE.

Podocarpus cracteata, $B l$. . . Camorta . . . Interior.

CyCadacee.

Cycas Rumphii, Miq. . . Car Nicobar, Nan- Beach and interior cowry, Little Nic- [forests. obar

PALMÆ.

Nipa fruticans, Wurmb. . . Little Nicobar . Maritime swamp.

Cocos nucifera, $L$. . . . All islands . . Beach forest.

Areca Catechu, $L$. . $\quad$ Do. - . Interior and cultivated.

Ptychoraphis augusta, $L$. . . Do. . . Interior.

Calamus gracilis, Roxb. . . Little Nicobar . Do.

Bentinckia Nicobarica, Becc.

Pandanes.

Pandanus Larum, Jones . . All islands . . Beach forest.

P. odoratissimus, $L . F$. $\quad$. $\quad$ Do. $\quad$ : $\quad$ Do.

P. furcatus, Roxb. . . . Teressa . . . Interior.

AROIDEE.

Colocasia indica, $L$. . . . Villages . . . Cultivated.

Pothos scandens, $L$. . . . Little Nicobar : Interior.

\section{SCitaminee.}

Amomun Fenzlii, Kz. . . Little Nicobar . Do 
ORCHIDEA.

Dendrobium anceps, Sw. . Little Nicobar . Interior.

Vanda Teres, Ldl. . . . Do. Do.

Saccolabium obliquum, Ldl. : $\quad$ Do. : . $\quad$ Do.

Phalenopsis cornu-cervi, $\mathrm{Bl}$. . Do. . . Do.

AMARYLLIDEE.

Crinum asiaticum, L. . . Villages . . . Cultivated and in beach

LILIACEE.

[forest.

Smilax polyacantha, Wall. . Nancowry, Little Interior.

Flagellaria indica, $L . \quad$. Nancowry $\quad \cdot \quad \cdot \quad$ Do.

Graminere.

Saccharum spontaneum, L. . Northern islands . Grass heaths.

Imperata arundinacea, $C y r$. . Do. Do.

Dinachloa andamanica, $K z$. . All islands . . Interior.

Dendrocalamus Brandisii, $K z$. .

FiLices.

Gleichenia dichotoma, Willd. . Teressa . . . Grass heaths.

Gl. sp. . . . . . Little Nicobar . Interior.

Acrostichum scandens, $J$. Sm. . Car Nicobar, etc. . Do.

A. aureum, L. . . . . All islands . . Beach forest.

Polypodium adnascens, $S w$. . Northern islands, Everywhere.

P. quercifolium, L. . $\quad$. $\quad$ Do. ${ }^{\cdot}$ Do.

-Supp., And. and Nic. Gazette, May 1897. 


\section{A P PENDIX H}

\section{CENSUS, NICOBAR ISLANDS}

\begin{tabular}{|c|c|c|c|c|c|c|c|c|c|c|c|c|}
\hline \multirow{2}{*}{\multicolumn{2}{|c|}{ Islands. }} & \multicolumn{8}{|c|}{1901.} & \multicolumn{3}{|c|}{1886.} \\
\hline & & 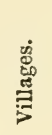 & 苟 & $\sum_{\frac{\pi}{2}}^{2}$ & $\begin{array}{l}\text { हूँ } \\
\text { हूँ } \\
\text { है }\end{array}$ & 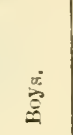 & 它 & $\begin{array}{l}\text { त्ञ } \\
\text { हैं }\end{array}$ & 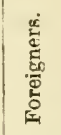 & 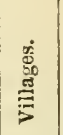 & 总 & 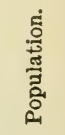 \\
\hline Car Nicobar & & I 3 & 748 & I I 26 & 999 & 704 & 622 & 3451 & 181 & 13 & $\ldots$ & 3500 \\
\hline Chowra. & . & 6 & 130 & 172 & 178 & 100 & 72 & 522 & $\ldots$ & 5 & 94 & 690 \\
\hline Teressa. & & I I & I 2 & 179 & 165 & I5 8 & 122 & 624 & $\ldots$ & 8 & 109 & 571 \\
\hline Bompoka & & 2 & 18 & 29 & 25 & 16 & 8 & 78 & $\ldots$ & 2 & 15 & 86 \\
\hline Camorta. & . & 30 & 98 & 170 & 164 & 85 & 69 & 488 & 7 & 26 & 106 & 359 \\
\hline Nancowry & . & 13 & 48 & 93 & 86 & 24 & $2 \mathrm{I}$ & 224 & 7 & I 4 & 78 & 222 \\
\hline Trinkat & . & 4 & 25 & 42 & 39 & 12 & 9 & 102 & I & 8 & 34 & 85 \\
\hline Kachal . & & 34 & 64 & 104 & 109 & $3 \mathrm{I}$ & 37 & $28 I$ & I & 37 & 66 & 183 \\
\hline $\begin{array}{l}\text { Great Nicobar } \\
\text { Little Nicobar }\end{array}$ & $\dot{r}$ and & I 5 & 25 & $4^{2}$ & 35 & 6 & 4 & 87 & I & 23 & 45 & 138 \\
\hline Pulo Milo & & I5 & $2 \mathrm{I}$ & 25 & 24 & 7 & II & 67 & I & I9 & 27 & 74 \\
\hline Condul . & . & 3 & 8 & 14 & I4 & 5 & 5 & 38 & I & 3 & 8 & 27 \\
\hline Total & - & 146 & I 297 & 1996 & 1838 & I I 48 & 980 & 5962 & 201 & 158 & $\ldots$ & 5935 \\
\hline
\end{tabular}

From these figures it appears that, on the whole, the population has remained fairly stationary since the last census. With regard to Chowra, I am inclined to believe that the decrease is due not only to the fact that many of the natives have migrated to Camorta and other islands of the group, but to the number of the children now on the island having been understated to the enumerators. Much of the increase shown in the central group and Teressa is attributable to immigration, and very probably also to incorrect information having been furnished to the enumerators, either at this census or the last one. As to the Shom Pen, it is still impossible to ascertain their numbers.-E. H. Man-Supp., And. and Nic. Gazette, March 2, I901. 


\section{A P P E D I X I}

\section{TRADE ARTICLES AND THEIR VALUE IN THE NICOBARS}

List of the principal articles imported by the traders for sale to the Kar Nicobarese :-

Nickel-silver soup-ladle

\section{" \\ long spoon}

"

"

$"$

",

Tumblers

table spoon and fork dessert spoon and fork tea spoon and small fork mustard spoon
Price in Coconuts.
500 pairs.
$500 "$,
$500 "$
$300 "$,
$120 "$
$200 "$

20-40 pairs, according to size. $60-80$," " " " $40-80$ " " , 40-80 " ", ", 40-80 ", " ", $40-80$ " " , 24 pairs. 12 " $12 "$ 40 " $100 "$ $1200 "$ 1600 ", 800,

\section{$\begin{array}{llll}\text { Chinese black cloth, I piece } & \text { - } & \text { - } & 600 \text { " } \\ \text { Madras handkerchiefs, I piece } & \text {. } & \text { - } & 800-2000 \text { pairs. }\end{array}$ \\ $\begin{array}{llll}\text { Chinese black cloth, I piece } & \text { - } & \text { - } & 600 \text { " } \\ \text { Madras handkerchiefs, I piece } & \text {. } & \text { - } & 800-2000 \text { pairs. }\end{array}$}

Fancy coloured chintz and saris " Bombay handkerchiefs

Rice ( $\mathrm{I}$ bag of 2 maunds, Calcutta). ," (I bag of 3 maunds, Burma) Chattis and pots

American knives

Burmese dros " clasp

Table knives.

Two-anna pieces

Rupee

Wooden and tin clothes-boxes, looking-glasses, sugar, camphor, Epsom salts, Eno's fruit salt, turpentine, castor oil, cabin biscuits, etc. 


\section{A P P E N I X J}

\section{PRESENTS AND BARTER}

Articles found to be in demand during the cruise of the Terrapin :ANDAMANS-

Red cotton (salu), clay pipes, leaf tobacco, matches, rice, sugar, axe-heads, parangs, iron wire and scraps, files, long nails.

NICOBARS-

Northern.

Cigars, cigarettes.

Chinese and Javanese tobacco.

Matches.

Dried Fish.

Turpentine, quinine, camphor, castor oil, scent, essential oils, plaster.

Silver (?) wire.

Red cotton.

Cotton handkerchiefs.

Old silk hats.

Old clothes.

Biscuits and crusts.

\section{Central.}

Cigarettes.

Chinese and Javanese tobacco.

Matches.

Dried fish.

Turpentine, quinine, camphor, castor oil, scent, essential oils, plaster.

Silver (?) wire, soupladles.

Red cotton.

Cotton handkerchiefs.

Silk hats, Malay caps.

Old clothes.

Rice.
Southern Islands,

Cigarettes.

Chinese and Javanese tobacco.

Matches.

Turpentine, quinine, camphor, castor oil, scent, essential oils, plaster.

Silver (?) wire.

Red cotton.

Cotton handkerchiefs.

Malay caps.

Chinese cotton coats and trousers, sarongs. Rice.

Parangs, knives, axes, beads, needles, thread, soap, old shoes. 


\section{APPENDIX K}

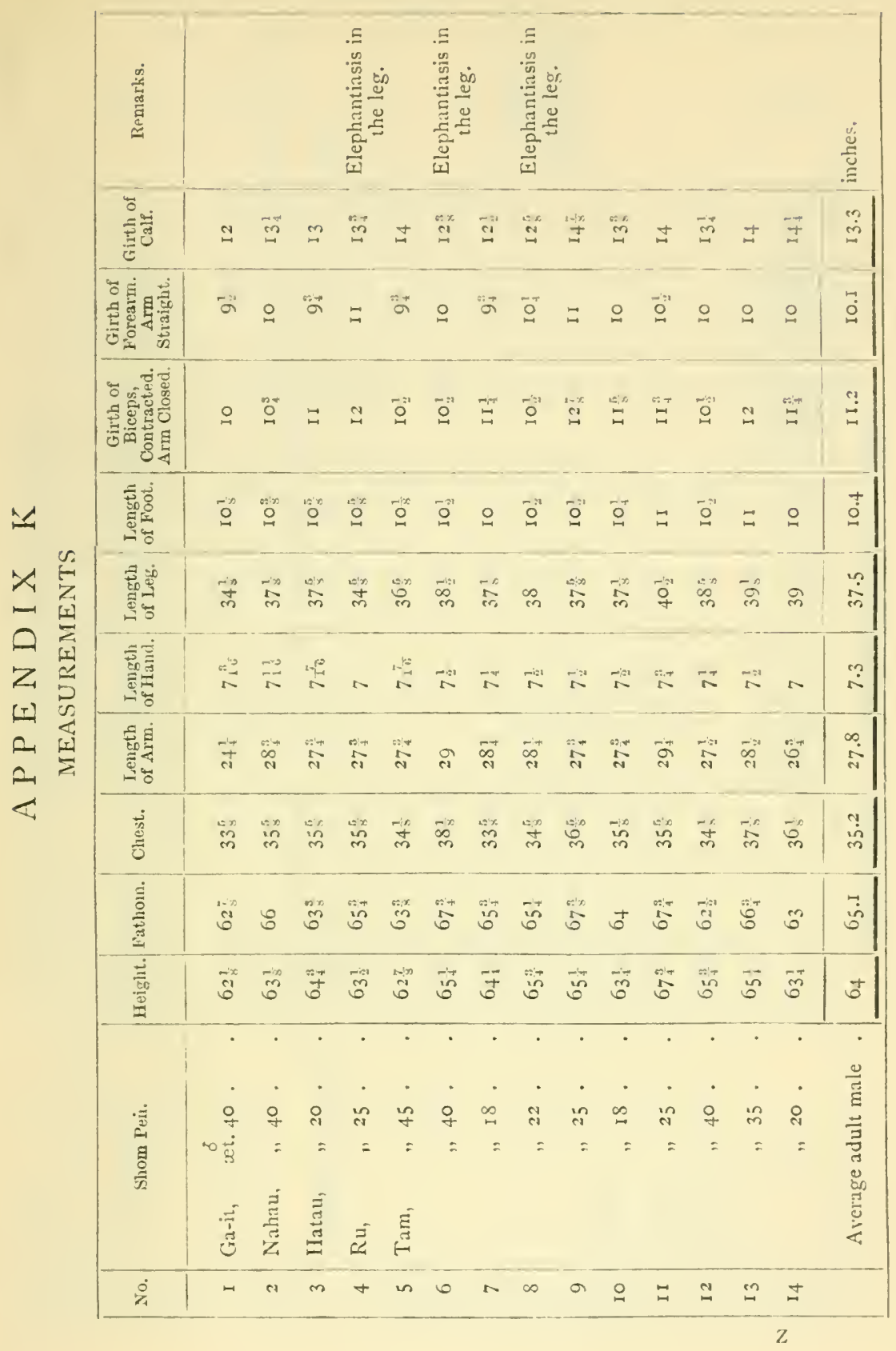




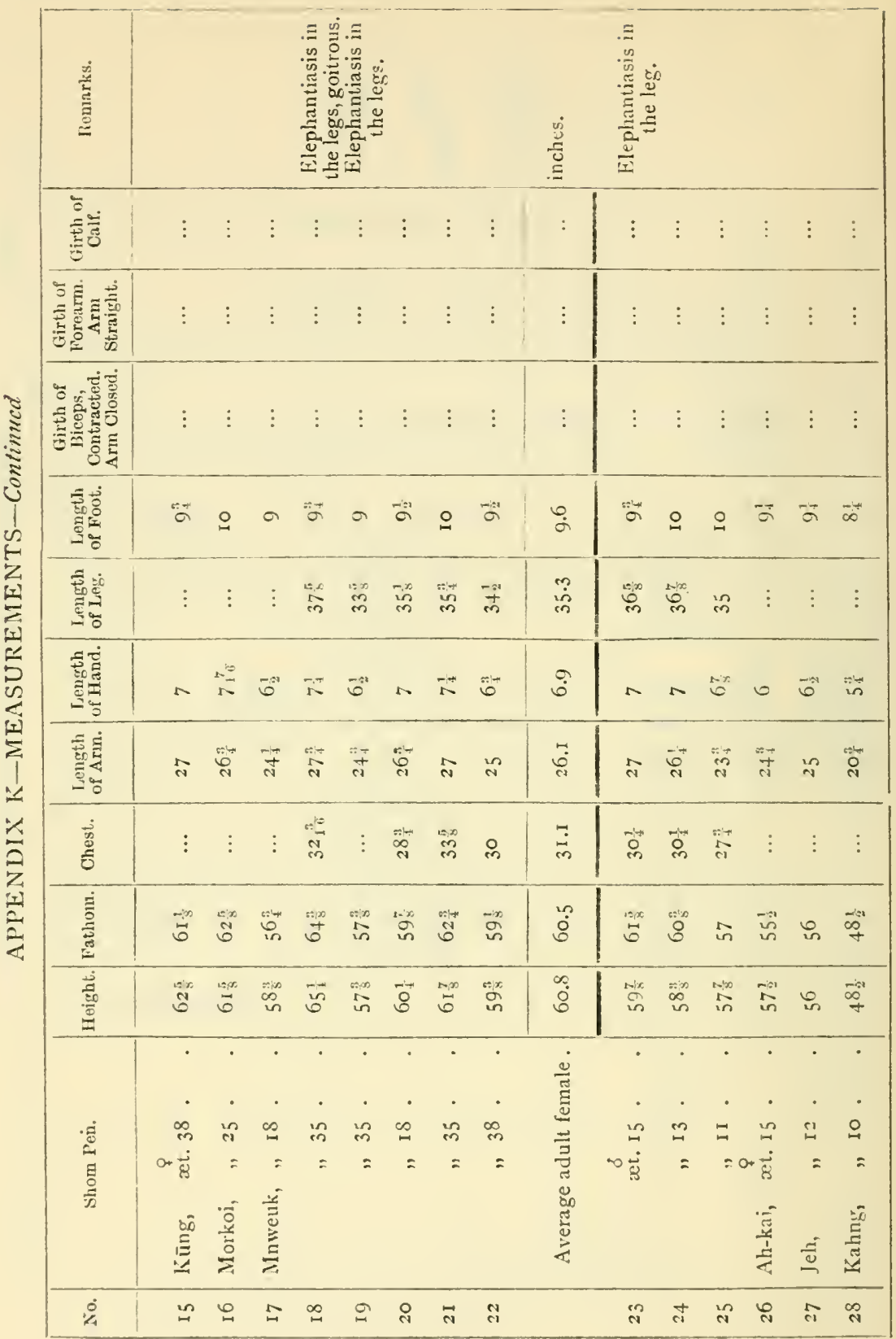




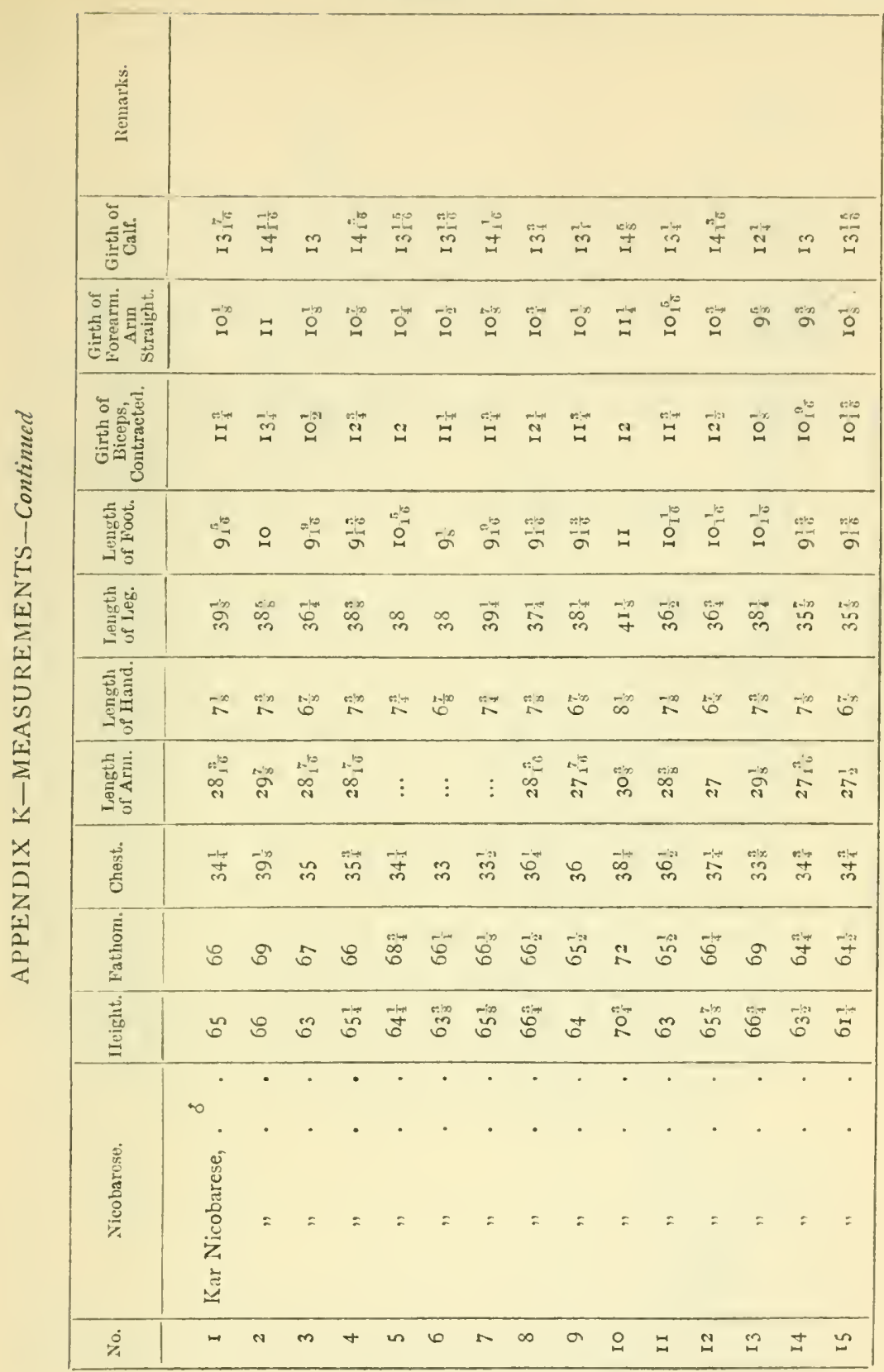




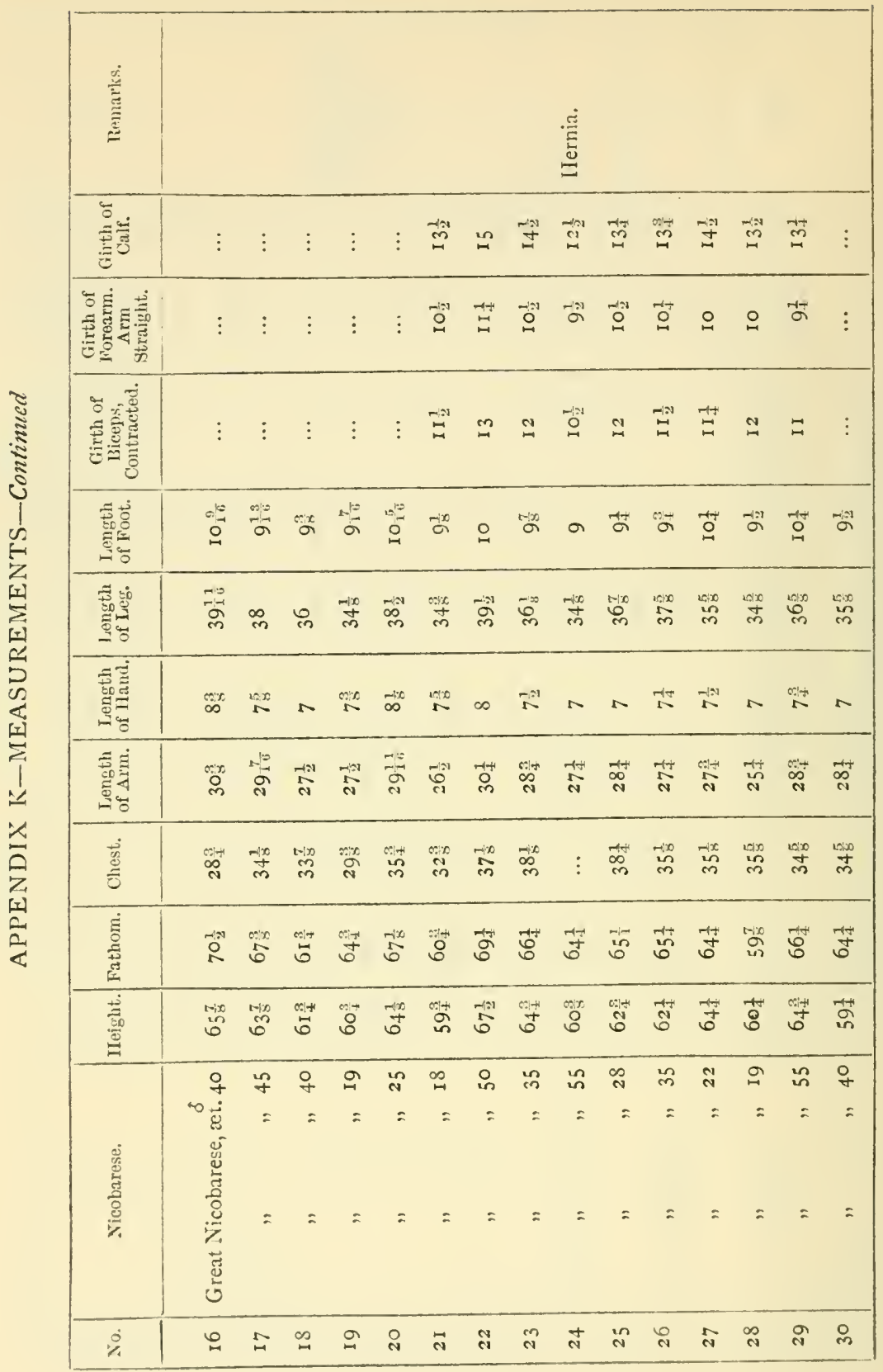




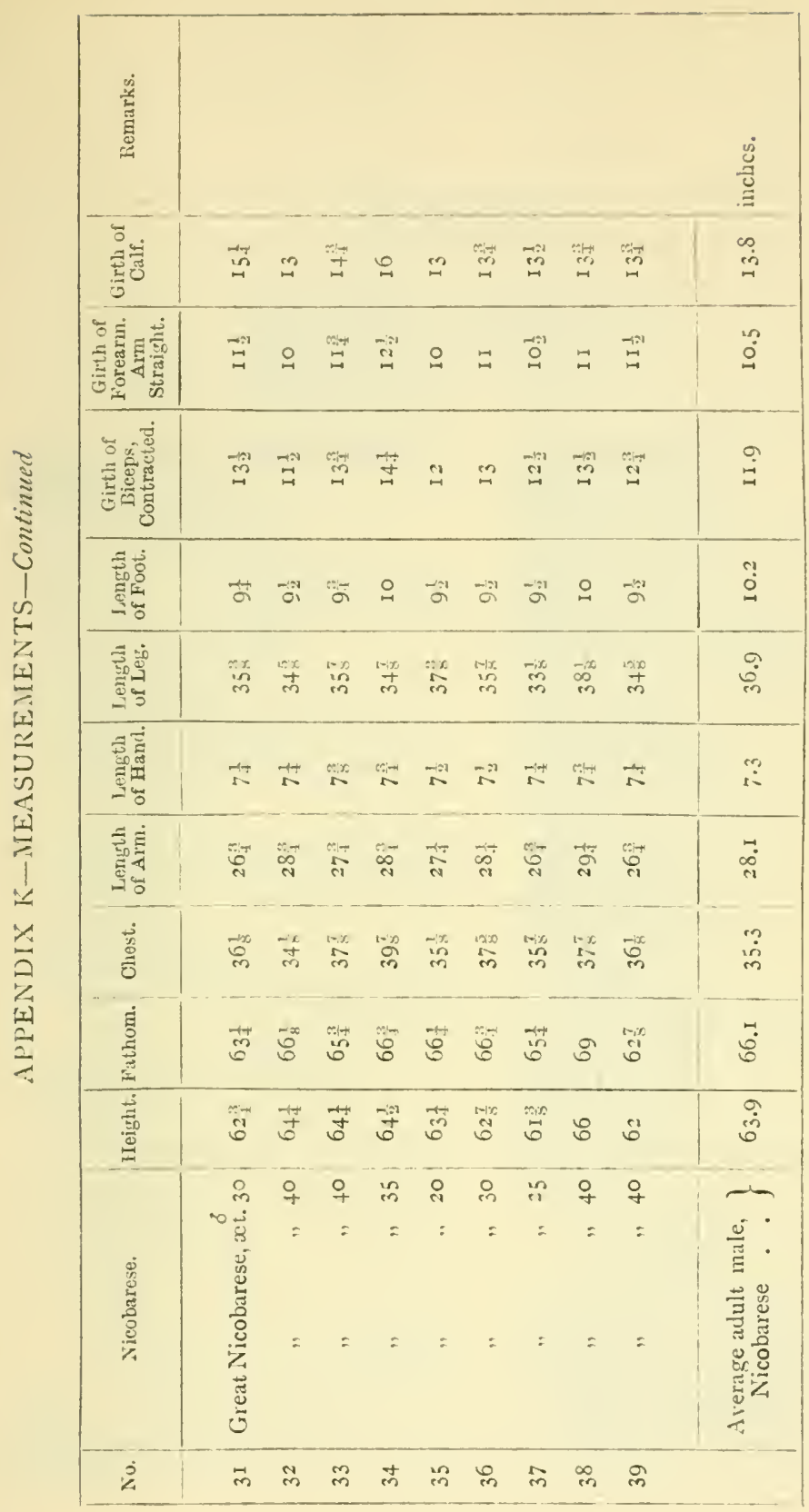





\title{
I N DE X
}

\author{
A. = "Andamanese" or "Andaman Islands" \\ $\mathrm{N}$. = "Nicobarese" or "Nicobar lslands" \\ K.N. = "Kar Nicobarese" or "Kar Nicobar" \\ S.P. = "Shom Pen"
}

Aborigines of the Andaman Islands, the

Seclusion, 173,184

Remote migration, $\mathbf{1} 8_{4}$

Predatory voyages, $2 I_{5}^{5}$

Kitchen-middens, I $8+$

Aborigines of the Nicobar Islands, the

Inhabitants of Nicobars two distinct ethnical groups, 215

The Shom Pen, $215-220$

Derivation, $215-217$

Population, 215

Hostility to Nicobarese, $76,215,220$

Appenrance, 217,218

Measurements of some Shom Pen,, 353,354

Disposition, 220

Language, 220

Comparison of some Shom Pen and Nicobarese words, 155

Diseases, 220

Headmen, 2 r 9

Position of women, 220

Respective occcupations of the sexes, 220

Rattan collecting, 219,220

Dress and ornaments, 219

Huts, 2 I 8

Gardens, 2 I 8

Domestic animals, 2 r 9

IVater-supply, 220

Trade, 2 I9

Cultivations, 218

Manufactures, 219

Cloth, 2 I9

Spears, 219, 243, 244

Baskets, 219

Cooking-vessel, 2 I9

A possible origin of pottery, 219 . see "Grent Nicobar"

Adoption, custom of, $\mathrm{N} ., 8_{4}$

Ai-ru-a-kare, K.N., 302

Aka-Balawa, tribe of, A., I $7,3 t^{2}$ 359
Ambergris, N., 252, 279

Amhai, K.N., 299

Amok, causes of, 312

Instances of, N, 3 I2

Amusements, Port Blair, A., 20

Amusements, N., $25 \mathrm{I}$

Amutna Kun', K.N., 302, 303

Anchorages. See under names of islands

Andaman, Great. See "Great Andaman"

Andaman Islands, the, 168

Position, I 67

Relationship, I67, 168, I7 I, 321, 327

Soundings, 168,320

Coral banks, I 70

Area, I68

Geology, I 74, I 75, I 76

Minerals, 176

Subsidence, 176

Volcanic action, 174

Earthquakes, I 76

Climate, I73

Rainfall, I73

Temperature, 173

Cyclones, I 74

Average wind and weather, 335

Scenery, I 70

Mountains, I69

Harbours, I 7 I

Flora, I 7 I, 172

Principal forest trees, $336-33 \mathrm{~S}$

Fauna

Birds, 326-328

List of, occurring in the Andamans, 328-33I

Mammals, 322-324

Synopsis of mammalian fauna, 325

History, $176-184$

Origin of the name Andaman, 176

First known reference, $I 77$

Chinese records, 177

Accounts of Arab travellers (A.D. 871 ), I 77 
Andaman Islands-continued

History, Accounts of Mlarco Polo (thirteenth century), I 77

Master Cæsar Frederike (sixteenth century), I 78

Dr Gemelli (seventeenth century), I 78

Captain Alexander Hamilton (eighteenth century), I79, I 80

Hon. East India Company's expeditions, 180

Establishment of a Penal Settlement (I789), I 80

Transfer of the Penal Settiement (I 792), 180

Colonel Syme's report (I795), I 8 I

Abandonment of Settlement (I796), I 8 I

Nineteenth century details, I 8 I

Attempt at colonisation (I8+9), I8I, I 82

Dr Mlouat's Commission (1857), I 83

Re-establishment of Penal Settlement, 183

Andamans formed in a Commissionership with Nicobars (187 I), I 84

Natural products, I 72, I 99, 34I

List of the more useful and valuable woods, 339

Cultivations, I $72,198,200$

Industries, I 7 I, I 72, I $98,199,200$, $339,340,341$

Exports, I 99, 339, 340

The Penal System, I93-199

Population, I 92

Foreign residents, 342

Census (I 901), 342

(For inhabitants, see "The Andamanese." See also "The Archipelago," "Barren Island," "The Cinques," "Great Andaman," "Little Andaman," "Narkondam," "Port Blair," "Rutland Island," "South Andaman.")

Andaman, Little. See "Little Andaman" Andaman, South. See "South Andaman" Andaman Strait, I68, I69

Andamanese, the

Aborigines, seclusion of, I 73, I 84

Remote migration, 184

Kitchen-middens, 184

Predatory voyages, 2 I 5

Tribal division, I9O, 192, 342

Hostility, I90-192

The Andamanese as enemies, 34

Effects of contact with civilisation, 192 Education, 187

Average duration of life, 187

Infant mortality, 192

Diseases, 40, I87
Andamanese, the-continued

Appearance, I 85, I 86

Average height, $34^{2}$

Weight, 342

Measurements of some Andamanese, 344

Disposition, 187

Dress, I 88

Dialects, I 86

Grammar, I86

Weapons and implements, I 84,189

Huts, 46

Food, Igo

Position of women, 187

Customs, I87, I88

Belief in spirits, I 88

Credence in wizardry, 188

Christian traditions, 189

Musical instrument, 189

Specimens of songs, 189

Manufactures, I 89

Articles found to be in demand for presents and barter, $35^{2}$

(Sce "Aka-Balawa," "Jarawas" "Önges," and under "Port Blair")

Anoi-ila, K.N., 295

Anúla Kopáh, K.N., 292

Account of this ceremony as carried out at Lapáti, K.N., 293

Archipelago, the (Andaman Islands)

General topography, I5

Aka-Balawa, tribe of, I 7

Birds, 16, I7

Rats, I7

Area. See under names of islands

Arrows, A., 24, 25, 33, 34, 42 ; N., 245

Arts, N., 25 I

Austin Strait, A., I68

BABIES, mode of carrying, A., 24

Banian trees, N., I22

- Barren Island

Relationship, I 74

Eievation, 169

General topography, 10-13

Anchorage, II

Landing-place, II

Hot spring, I I

Interior of the crater, 12,13

Eruptive cone, I 2

- Volcanic activity, 13, I4

Lava, I 2

Goats, I 2

Rats, I4

Crabs, 14

Fish, 14

Birds, I4

Barter, articles found to be in demand for presents, etc., A.N., 352

Baskets, A., 33; K.N., 48 ; S.P., 219 
Bat camp, a (Pleropus nicolaricus), N., I 33

Bats (Hipposideros nicobarula), I 26, I 27

Fruit (Pteropus nicobaricus), 70, I33, I 34

Attempt to rear young, 134 . See "Mammals," and under names of islands

Batti Malv, N., 66

Beach formation, A., 37

Belief concerning Chaura pots, N., 107 ; eclipses, N., 307

In evil spirits, N., 123

In spirits, A., 188

Beliefs, superstitious, N., 231-23+

Bench seats, N., 52

Beresford Chamel, N., 72, 73

Betel chewing, N., 49, 2.8 Effect of, 147

Ouids, 2 I9, 248

Beverages, N., 247

Birds, A., N., 326-33r. See also under names of islands

Bird's Nest Cape, A., 29

Bird's nests, edible, A., 29

Blyth's dove (Macropygin ruffennis), N. I I I

Body decoration, A., 24, 32, 34, 39; N., 249

Bompoka

General topography, 103, 105

Area, I05

Population, 105

Witter, 105

Plantations, 105

Native legend concerning formation of, 105

Natives of, compared with Kar Nicobarese, $\mathrm{IO}_{4}$

Hamilton's account of the Somerera Islands, I05

Botanic appearance, general, N., Iog, 207

Bows, A., 24, 25, 33, 34, 42; N., $2+5$

British possession, marks of, N., 97

British punitive expedition, N., 93

Buffalo, N., 99

Building materials, Nicobars rich in, 205

Bulbul, crested, A., 35

Bumila creek, A., 38

Burial ceremonies. See "Kar Nicobarese ceremonies and observances"

Burial customs, N., I I 3 , I 24

Butterflies, N., I 26

CAMPING out in Great Nicobar, $16 \hat{3}$

Canoe building, N., I6o

Decoration, N., 79

Masts, N., 79

Outrigger, N., 54

Paddles, N., 54

Sails, N., 79
Canoe building-continued

Buying, ceremonies accompanying, N., 309

Mishaps, N., 308, 317

Sequel to the loss of a Mũs, 296

Reception of the Mũs racing, after a death in the village, 299

Processions, N., 25 I

Offerings, N., 295, 296

Canoes, A., 41 ; N., 53, 54, 60, 79

Custom of feeding, N., 85

Chaura natives middlemen in buying and selling, 308

"Captains," N., 58

Casuarina Bay, N., I $44, I_{4}$ ), 15 I

Cattle, semi-wild, N., 47, 74, 75

Caves, Little Nicobar, I 26, I 27

Cellular jail, A., 21. See "Viper Jail," "The Andamanese l'enal System"

Cemetery, Kamorta, N., 95

Census, A., $3+2 ; \mathrm{N}, 350$

Ceremonial, decay of, N., I24

Ceremonies and observances. See "Kar Nicobarese ceremonies and observances," "The Andamanese," and "The Nicobarese"

Chang-ngeh, N., I6 I

Character of the locally - born young generation at Port Blair, A., $3+4$

Charms, N., 83,85 , I I6, I 24 , I 32, I 43

Chaura, Io6

Termed Sombrero, 106

Hamilton's Account of the Somerera Islands, 105

Area, 106

Population, 106

Decrease of, 350

Anchorage, 106

Trade, 106

Monopolies, 107, 308

Pots, I08

Process of making, 107, 108

Nicobarese belief concerning, I07

Pottery kiln, 108

Natives, 106, 308

Believed to be exponents of wizardry, $2 y 6$

Feeling of Kar Nicobarese towards, 308

Middlemen in canoe buying and selling, 308

Door mats, 106

Fruit, 106

Extortion of Chaura middlemen, 308

Children, position of, N., $2+2$

Chital, N., I00

Chitt, N., 56

Christian traditions, A., 189

Cinques, the

General topography, 36, 37

Geology, I 75 
Cinques, the-continued

Anchorage, 36

Beach formation, 37

Effect of S.W. monsoon, 37

Native camp, 37

Hut, 37

Civilisation, effects of contact with, A., I92

Cleanliness. N., 248

Climate, A., I73; N., 205, 205

Cloth, Shom Pen, I +5, I 46,2 I9

Coal, N., 204

Cocktail, a new, $S_{9}$

Coconut oil, mode of extracting, 52 Toddy, 247

Coconuts, mode of obtaining, 139

Carrying, 139

Opening, 63

Coco palms, legendary origin of, $N$., 230

Peculiarity of, N., I 28

Absence of, in Andamans, 172

Cocos Islands, I 72

History of an attempt at colonisation, I 81, I 82

Coiffure. See under names of islands

Colonel Temple, C.C., at Port Blair, A., 2 I

Commercial occupations, K.N., 318, 3 I9

Communication with Andamans, 200

Communication and transport, local, $\mathrm{N}$., 253

Convict Settlement on Kamorta, traces of the old, N., 95

Convicts. See "Port Blair" and "The Andamanese Penal System "

Cooking-vessel, Shom Peñ, I48, 2 I 9

A possible origin of pottery, 2 I9

Coral, N., 80

Banks, A, r70; N., 201

Reefs, 16

Courtship, N., 238-240

Crabs, A., I 4 ; N., 55, 62, 70, 129

Crater, interior of the, Barren Island, 12, I3

Creeks, mangrove, N., 80

Crocodile, N., 69

Crossbow accidents, K.N., 3 I 7

Crows, A., I 7

Cuckoo (Centropus andamanensis), A., I6

Cultivations. See under names of islands

Customs. See under names of islands

Cyclones, A., I $74 ;$ N., 2 c6

DAGMAR River, N., I49, I53

Dalrymple Bank, I7o

Dampier's sojourn on Great Nicobar. 212

Dampier's voyage from Great Nicobar to Acheen in a canoe, 254

Dampier's "Voyages," extract concerning his escape from the privateer $C_{y}$ gnet of London, 255, 256, 260-262

Concerning his sojourn in Great Nicobar, $263-267$
Dampier's "Voyages"-continued

Concerning his voyage from Great Nicobar to Acheen, 267-27;

Concerning the Nicobars and inhabitants generally, 256,257

Concerning Great Nicobar and inhabitants, $257-267$

Dance music, N., 87

Dances, Nankauri, 87

Kar Nicobar, 289, 309

Dead, converse with the, K.N., 296

Death Ceremony, Kachal, i i6

Similar Malay custom, i i 6

Among the Arafurns, 304

De Röepstorff, F. H., murder of, 96

Dérishi, cf. Hentá, N., I 6

"Deril expelling," N., 64

"Deril-expelling" leaves, 303

"Devils, scare-," N., 83, 85, I 24

Dialects. See "Langunge"

Diseases. A., 40, 187 ; N., I59, 235 ; S.P., I $45,152,220$

Disinterment customs, N., 5 I. See "Exhumation"

Dislike to strangers, K.N., 3 I 7

Divorce, N., 237

Dog-hobble, S.P., 144

Domeat, 154

Domestic animals, N., 219,243 ; S.P., 219 Feeding, 79

Domestic pigeons, K.N., 47

Door mats, Chaura, 106

Drainage, Great Andaman, 169

Dress. See under names of islands

Dring Harbour, N., 98

Drongo, black racquet-tailed (Dissemuroites andamanensis), A., 30

Duncan Passage, the, A., 36

EARTHQUAKES, A., I76; N., 205

Felt at Kar Nicobar, 205

Eclipses, belief concerning, N., 307 Custom during, 307

Education, effects of, on Andamanese, I 87 ; on Nicobarese, $57,59,89$

Eggs, megapodes', N., 70

Electro-plate possessed by Nicobarese, 8 I Prices given for, $8 \mathrm{I}$

Elevation, possible result of, N., 73

Elpanam, N., 50, 240

Elton, Captain, drowned at Trinkat, Sambelong, 154

Empress Peak, I 20

Enwan-ng'i, K.N., 295

Eruptive cone on Barren Island, I2

Expedition Ilarbour, 98

Reputed headquarters of piratical savages, 98

Exhumation ccremonies, account of, N., 82, 83. See "Disinterment"

Exports, A., I99, 339, 340 
Falna, A.N., 322-33I. Sce also under names of islands

Feasts, K.N., 50

Festival, a, N., 86-88

Preparations for a, $80,81,86$

Interior of a house prepared for, 8 I

Fever invariably contracted in Great Nicobar, I I 2, 254, 255

Fish, A., I4; N., I16, I 36, I 37

Fishing, N., 55 , I I $6,136,137,245,246$

Traps, 245,246

Weirs, 246

Flags, native, N., 80

Flat rock, I 70

Flattening the occiput, custom of, $N$., 226

Floods, ceremonies to subrlue, $N$, $5 I$

Flora, A., I 7 I, I 72 ; N., 207, 208, 345-349

Principal forest trees of the Andamans, 336-338. And see under names of islands

Flycatcher, Nicobar, N., 74, I35.

Food supply. See under names of islands

Foot-brush, N., 247

Ford's Peak, A., I69

Foreign residents, A., 342

Forest hawk (Astur bulleri), N., 62 ; (Astur soloensis), N., I 28

Fota elmot, K.N., 306

Frank Thompson, N., 57

"Friend of England," N., 52, 55-57, 3 II, 3 I 2

Fruit, N., 49, 64, 9I, I06

Fuel, K.N., 48

Galathea River, N., I6I-I64

Ganges Harbour, N., I 36, I 37, 205

Gardens, K.N., 307

Origin of, 307

Destruction of, 307

Shom Peñ, 2 I 8

Geology, A., I74-I 76; N., 202-204

Gmenota, K.N., 296

Goats, Barren Island, I2

Goverument agency clearing, K.N., 47, 54

Government settlement. See Port Blair

History of, I80, I8I, I 83

Government schools, Port Blair, 343, 344

Great Andaman

General topography, I68, I69, I70

Mountains, I69

Saddle Hill, I69

Drainage, 169

Harbours, I 7 I

Straits dividing, I68, I69. See also "South Andaman," "Rutland Island," "Port Blair," "Port Cornwallis"

Great Nicobar, I 4 I

Area, I4I

Mountains, I I

Rivers, I 42
Great Nicobar-continued

Peculiarity of coco palms, I $2 \mathrm{~S}$

Water, I52

Malaria, II 2, 254, 255

Population, coastal, I42

Shom Peri, I 42

Dialect, I 2 I

Trade, 143

Prices, 143

Dampier's "loyages," cxtract concerning Great Nicobar and inhabitants, 257267

Great Nicobar (North Coast)

General topography; 133-138, 205

Land subsidence, 13 ${ }^{6}, 137$

Ganges Harbour, 1 36, I 37, 205

Anchornge, 132

Up a creek, I 33

Mount Thuillicr, 138, I4 I

Jubilee River, I 38

Water, I35, I 37,139

Traces of Shom Peir, I $34,136,137$

Fauna

Birds, I 35-1 37

Water birds, 138

Sunbirds' nests, 133

Mammals, I $35-138$

A bat camp, 133

Fruit bats, 133, 134

Attempt to reatr young bats, $\mathbf{I} 3+$

Fish, I $36-137$

Fishing, I 36-I 37

Turtle, 138

Great Nicobar (W'est Coast)

General topography; I4I, I42, I 44

Pulo Kunyi, I42, I43, I45, I46

Harbour, I 42

Anchorage, I 42

Inhabitants, I 42 , I 43

Decline of population, I 49

Charm, I 43

Casuarina Bay, I44, I49, I 1

Mudfish, I 49

Dagmar River, I 49 , I 53

Kópenhéat, I 50

Anchorage, I 53

Pulo Nyur, I 50

Anchorage, I50

Decline of population, 150

Water, I 5 I

Morass, I 5 I

Birds, I 43 , I44, I 51

Fauna, I44, I 50

Young monkeys, I53

Shom Pein, I 43, I45-I48, I5O, I 52

Appearance, $145-147$

Elephantiasis, I 45,152

Effect of betel-chewing, I47

Dress and ornaments, 145

Camp, I 49, I5I

Village, I4t, I45 
Great Nicobar (West Coast)—contmued Shom Pen, Huts, I +5

Food supply, I 48

Dog-hobble, 144

Spears, $1+6$

Cloth, I $45, I_{4} 6$

Cooking-vessel, I 48

Mode of cooking pandanus, I 49

Great Nicobar (IVest and South Coasts)

General topography, I 56, I 58, 160

Native topographical names compared with chart and trade names, I 55

Growth of land, 157

Anchorage, 156

Pulo Babi, 156 , 157

Harbour, 156

Water, 156

Chang-ngeh, I6I

South Bay, 160

Galathea River, I6I-16+

Fauna, I62

Birds, I57, I60, I6 I

Monkeys, 166

Population, I 57

Inhabitants, I 57 , I 55-I 5 S

Domeat, I 54

Servitude, 157

Shom Pen, 155, I 59

Village, I 58, I 59

Huts, I58, I62

Dress, 159

Marriage, I 58

Ringworm, I 59

Canoe building, I6o

Mode of climbing trees, I57

Barter, 160

Supplies, 165

Water, I65

Guides, native, N., 57,58

Gunboat tours, 28

\section{Ha-chu, K.N., 298}

Hamilton's, Captain Alexander, account of the Andamans, I 79, I 80

References to the Nicobars, 102, I05, I 21,2 I 2,2 I 5

Hanata, K.N. 301

Harbours, A., I71. And see under names of islands

Headmen, N., 24I ; S.P., 219

Regard for, K.N., 316

Height, average, A., 342

Helfer, Murder of Dr, I 81

Henghawa, K.N., 290

Hentá, cf. Déüshi, N., 77, 85

Henta-koi, N., 77

Herons, N., 69

History, A., 176-184. For details, see under "Andaman Islands"

History, N., I 77-I 79, 208-2I4. For details, see under "Nicobar Islands"
Hog-deer, A., $2 S$

Homes for Andamanese at Haddo, 23-25

Homfray Strait, A., 169

Hostility of Andamanese, 190-192

Shom Peri, 215, 220

Hot spring on Barren Island, II

House, custom of feeding the, N., 85

"House of pollution," K.N., 5I, 304

Houses. See under names of islands

Maternity, K.N., 5 I

Hume, A. O., cruise round the Andamans and Nicobars, 326

Huts. See under names of islands

IMPLEMENTS and Weapons, A., I 84 , I 89 ; N., $243-245$

Industries, A., I 7 I, 172, I 98-200, 339-341

Port Blair, 22, I98-200, 3.t0, 34I ; N., $25 \mathrm{I}, 252$

Infant mortality, A., I 92

Inhabitants. See under names of islands

Interment of a headman of Sáwi, account of, 305,306

Interment of a man of repute of Lapati, account of, 306, 307

Inturga, K.N., 299

Invisible Bank, I 7o

lsle of Man, N., 72

JAIL, Cellular, A., 2 I

Viper, a visit to, 26

Inhabitants of, $25-27$

Employments in, 26-27

Punishment at, 27. See the Andamanese Penal System

Theel, N., 69, 74

Jubilee River, N, 138

Jakuns of Johore, the, $2 \mathrm{I} 7$

Jarawas, the, A., 190-192, $3 t^{2}$

An encounter with, I9I

KACHAL

General topography, I09, IIO, II 4 , II 7

Evidence of growth of land, IIO

Geology, II 7

Area, II 7

Population, iI 7

IVest Bay, Iog, I10, 113

Anchorage, I09

The reef, II 3

Lagoon, II

Water, II 7

Birds, I IO, II I, II 3

Vaterbirds, I IO

Monkeys, II 4

Megapodes, II 3

Fish, II 6

Native fishing, I 6

Ol-kolo-kwák, I IO I I 2, I I 3

Kanaia, I I 3

Houses, I I 2 
Kachal-continued

Natives, I09, III, II

Dress and ornaments, Iog, II 5

Yassan, III, II 6

Déushi, II6

Charms, I16

Supplies, I17

Medicine, II 5

A death ceremony, II 6

Burial customs, I 13

Ixamorta

General topography, 72, 97, 98, 99, 100, IOI

Population, I02

Peculiarity of flora, roI

Traces of the old convict settlement on, 95

The cemetery, 95

Murder of De Röepstorff (1 \$83), 96

Mount Edgecombe, 98

Expedition Harbour, 98

Reputed headquarters of piratical savages, 98

Dring Harbour, 98

Olta-möit, village of, 98

Natives, 99, 100

Dress, 100

Tattooing, a case of, 100

Birds, 97, 99, 100

Teal, 97

Buffalo, 99

Bats, 99

Chital, 100

Sambhar, 100

Supplies, I I I

Hamilton's description of the Central group, 102

Kana awn, K.N., 285-292

Kunaia, N., 79, I 13

Kantéra, K.N., 302

Kareau, N., 85, 86

Kare-yeng-chón, K.N., 287

Kallu, 224

Kar Nicobar

General topography, 45, 46, 6r, 64, 65

Kœnig's account of Kar Nicobar (1778), $276,277,279$

Geology, 46, 64

Earthquakes felt at, 205

Tide-race, 45

Landing, 46, 60, 61

Sảwi Bay, 46

Swell in, 55

Landing at, 55

Population, $6 ;$

Flora, 53, 6I, 62, 64

Fruit, 49,64

Coconuts, 62

Water, 65

Timber, 53, 54
Kar Nicobar-continued

Fiana

Birds, 53,62

Mammals, 62

Fishing, 55

Crabs, 55,62

Supplies, 65

Government agency clearing, 47,54

"Temple Villa," 47

Mission school, 59

Missionary endeavour, 57,63

V. Solomon, 46,63 Pupils, 57, 59

Mūs village, $47,49,50,51$

Population, 47

l3uildings, $50,5 \mathrm{I}$

Elpanam, 50, 240

Maternity houses, 5 I

Talik n' ${ }^{\prime} i, 5 \mathrm{I}$

"House of pollution," 51, 307

Houses, 46-49

Plantations, 49,64

Kofenté, 292

$\mathrm{Mal}, 302,303$

"Devil-expelling" lenves, 303

I'assa, 303

Kar Nicobarese, the, $46,49,5 I, 54,57-59$, $60,61,65$

Measurements of some, 355

Offandi, 49, 50, 54, 3II 312

"Friend of England," 52, 55-57, 3 I I, 3 I 2

"Little John," 58, 225

Frank Thompson, 57

Kar Nicobar boys, 59, 60

$V$. Solomon's pupils, 57,59

Educated natives, 57,59

Native guides, 57,58

A travelled Nicobarese, 54

Life of Kar Nicobarese, 65

Names, 305

Nicknames, 59

Dress, 49, 52, 61

Tá-chökln, 49

Betel-chewing, 49

Domestic pigeons, 47

Pigs, 50

Utensils, etc., 48

Fuel, 48

Baskets, 48

Canoes, 53, 54, 60

Outrigger, 54

Paddles, 54

Oilpress, 52

Mode of extracting coconut oil, 52

Bench seats, 52

Commercial occupations, 318,319

Barter, 56, 60

Cost of transporting goods, 318

Staples of wealth, 50

Mode of comparing past and present wealth, 292 
Kar Nicobarese, the-cominued

Effect of N.E. monsoon, 299

Canoe mishaps, 308, 3 I 7

Crossbow accidents, 317

A Kar Nicobarese tradition, 215

Gardens, 307

Origin of, 307

Destruction of, 307

Quarrels. instances of, 3IO-3I 2

Mode of revenging, 3 Io

Amok, instances of, 312

Causes of, 3 I 2

Vizard murders, 3 I 4

Instances of, $3 I+3 I_{5}$

Instances of murder as punishment, 3 I 5

Instance of suicide, 316

Dislike to strangers, 3 I 7

Land sale and tenure, 3 I 7

Instance of, 3 I 7

Takoia, 24 I

Tallies

Tally of commercial transactions, 319

Of the months, 3 I 9

Of a child's age, 3 I 9

Social and other distinctions

Social status, 6 I

The Mafai, 300-302

The Sanokur', 300

The Tamilumna, 302, 316

The Takkuri, 292

Yom Ap, 302

Yom Elpanain, 302

Headmen, 316

Vizardry, 3 I 4

Mode of obtaining reputation for, $3 \mathrm{I} 4$

Ceremonies and observances

Kana Awn (feast of exhumation), $28_{5}$ 292

$\tilde{N} a-K o p d h$ (feast for the dead), 286,287

Kare-yeng-chon (headstones of graves), 287

Vanipati (house decoration), 288

Kiriam Hepat (dancing in bright light), $288,28 \mathrm{~g}$

Henghawa (in return), 290

Yeng Awn (the great hoar), 29 I

Wanaka Kuv (making lard), 29 I

Kisu-ta-el-pati, 29 I

Tanang alah (prevention), 291

Auila Kopih (digging the graves), 292

K'iriam Antila (digging dance), 292

Kiriam-nga-rit-roi-ta-oka (dance for clearing up coconut rubbish), 292

Mafai tupira (grand Mafai dance), 292

Anila Kopih, account of this ceremony as carried out at Lapáti, 293
Kar Nicobarese, the-continued

Katap-hang (lighting the Elpanam), 294,295

Kiala (fetching food), 295

Anoi-ila (a holiday), 295

Envern-nigi (fishing again for the children), 295

$M a-y a-k u v-k a-m a-k a$ (papa is going this way to fetch fish), 295

Ramal, 296

Gnunota, 296

$M a-l a-h a l, 297$

Kevi-apa, 297, 298

Mu-neng-ren (day of preparation), 297

Kial (taking food), 297

Ha-chu, 298

Maya (top decoration), 298, 299

Yintorná Siya (expelling the devil by sails), 298, 299

Amhai, 299

Inturga, 299

Tanangla (support), 299, 300

Ke luinj alaa, 300

Mafai, creation of, 301

Hanata (adorning tlie invalid), 3OI

Mafai performances, 302

Ai-yut-n-kare (going to a feast adorned with jewels), 302

Luinj-lare Mafai (undressing the .Mafai), 302

Amutni $K u r^{\prime}$ (revealing to the invalid), 302,303

Burial ceremonies, 303-305

Account of interment of headman of Sáwi, 305, 306

Fota Elmot (wiping away tears), 306

Account of interment of a man of repute at Lapáti, 306, 307

Mourning, 305

Converse with the dead, 296

Instance of ceremonies accompanying canoe buying, 309

Sequel to the loss of a Müs canoe, 296

Reception of Mūs racing-calloe after a death in the village, 299

Canoe offerings, 295,296

Celebration of loss of teeth, 300

Custom during eclipses, 307

Belief concerning, 307

Disinterment customs, 5 I

"Devil expelling," 64

Tamiluana ceremonies to subdue floo's, 51

Feasts, 50

Dances, 289,309

Ceremonial accessories

Kantera, 302

K"usuhu, 297, 298

Merahta, 287

"Devil-expelling" leaves, 303

Katap-hang, K.N., 294, 295 
Kar Nicobarese, the-contimued

Ké huinj alaa, K.N., 300

Kewi-apa, K.N., 297, 298

Kial, K.N., 297

Kiala, K.N., 295

Kingfisher $(P$. lencocephala), N., I26; (Ceyx tridactyla), N., I 35 ; (Halcyon saturatior). A., 35

Kingfisher's eyes a specific for sleeplessness, 76

K'iriam anúla, K.N., 292

Kiriam Hepat, K.N., 288, 289

Kiriam-nga-rit-roi-ta-oka, K.N., 292

Kisu-ta-el-pati, K.N., 29 i

Koenig, Dr 1. J., 21 3, 276; account of Kar Nicobar (1 778$), 276-284$

Kofenté, K.N., 292

Kondul

General topography, I 3 I, I 32

Anchorage, I3I

Tide-rip, 131

Population, I3I

Village, 132

Houses, I 32

Plantation, 132

Charms, 132

Natives, 132

Boys, 139

Supplies, I 32, I 39

Kópenhéat, N., 150

Anchorage at, 153

Kusuhu, K.N., 297, 298

Kwang-tung Strait, A., 15, 16

LagooN, N., IIO

Lamp, N., SI

Land, growth of, N., I10, 157

Sale and tenure, K.N.. 317

Subsidence, N., I 36,$137 ;$ A., I 76

Landing-places. See under names of islands

Language, A., I86; N., I $21,228,229$; S.P., 220

Conparison of some Shom Peir and Nicobarese words, 155

Lava, Barren Island, 12

Legend concerning formation of Bompoka, native, I05

Illustrative of unpleasant qualities of pandanus, II 2

Legends of origin, native, N., 229

Life, average duration of, $\mathrm{A}$., 187

Linguists, Nicobarese, $55,58,75$, II 2

Little Andaman

General topography, $38,45,169$, 170

Effect of S.W. monsoon, 45

Geology, I 76

Bumila Creek, 38

Natives, $37-40,42$

Appearance, 39

Dress and ornaments, 39
Little Andiman-continued

Natives, body decoration, 39

Coiffure, to

Tools, 4 I

Bows and arrows, 42

Huts, 40,41

Citnoe, 4 I

Diseases, 40

Pig, 43

"Little John," N., 58, 225

Little Nicobar

General topography, I18, 120, I2 I, 125 , I26. I 27, I 31

Geology, I 20

Population (including Niio), I 20

Area, I 20

Harbour, I19, 125

Anchorage, II 9

Site for a settlement, 12 I, I 25

IVater, 126

Flora, I 20, 125

Peculiarity of coco palms, 128

Banian trees, 122

Course of a river, 125,126

Mount Deoban, 120

Empress Peak, I 20

A deserted village, I2 I

Caves, 126,127

Bats, I 26, 127

Swifts, I26, 127

Nests, 126, 127

Monkeys, I22, I 28, 129

Crabs, 129

Tupais, 122

Megapodes, 12 I

Pig, I 22

Butterflies, 126

Birds, II $1, I 21,122,127,128,130$

Water bircs, 126

Natives, II 9

Hamilton's account of the natives of the Southern Group, I 2 I

Mortality, I19, 123

Reputed c:u1ses, I 23

Dress, II 9

Dialect, I 2 I

Belief in evil spirits, 123

Charms and "scare-devils," I 2 f

Burial custom, 124

Decay of ceremonial, I24

Lizards (Gonyocephalus humeii), N., 67, 63

Luinj-lare Mafai, K.N., 302

Luxuries, native, N., 227

Macpherson Strait, A., 29

Mafai, the, K.N., 300-302

Creation of, $30 \mathrm{I}$

Performances, 302

Mafai tapira, 292

Mafai, Luinj-lare, 302

Jaharani Peak, N., 67 
"Making Christmas," N., 80

Mal, K.N., 302, 303

Malacca, N., 78

Ma-la-hal, K.N., 297

Malaria, N., i I 2, 205, 254, 255

Mammals, A.N., 322-325. And see under names of islands

Man, Mr E. H., 75

Isle of, 72

Mangrove creeks, N., 80

Mlanufactures, A., I 89 ; S.P., 219

Nlarriage, N., I $58,235-237$

Maternity houses, K.N., 5 I

May'a, K.N., $29 S-299$

$M a-y^{\prime} a-k u v-k a-m a-k a$. K.N., 295

Mayo, murder of Lord, 22, 23

Measurements of some Andamanese, $3+4$

Average height, $34^{2}$

Vieight, 342

Measurements of some Shom Pen, 353, 354 Great Nicobarese, 356,357

Kar Nicobarese, 355

Medicine, N., I I 5,235

Megapodes, ‥ 68-70, 74, 77, II 3 , I2I, 327,328

Eggs, 70

Mounds, 68-70

Laying-places watched by Nicobarese, $2+3$

Menchàl, I 27

Area, I 27

Flora, 127

Geology, 127

Menluanas, N., I 16,232

Ceremonies, 233

Meráhta, K.N., 287

Meröe, N., I 18

Metals, N., 25 I

Military force, Port Blair, 27

Minerals, A., I 76 ; N., 205

Mission School, Kar Nicobar, 59

Relics of old Moravian, N., 83

Missionary endeavour, N., 63, 257. See under "Nicobar Islands"-History.

Monkey's, N., II 4, I 22, I28, I29, I 50, I66 Young, 153

Monopolies, N., 107, 308

Monsoon, effect of S.IV., Andamans, 37, 45 N.E., Kar Nicobar, 299

Monsoons, N., 206

Mortality, N., I I9, 123 Infant, A., I92

Mount Deoban, N., I20

Edgecombe, N., 98

Harriet, A., 19, I69

Thuillier, N., I 38 , I 4 I

Mountain range, a submerged, 170

Mountains, A., I69; N., I4I

Mourning customs, N., 250, 305

Mludfish, N., $1+9$

Mu-nung-ren, K.N., 297
Murder, wizard, K.N., 314, 3I5

As punishment, K.N., 3 I 5

Of L.ord Mayo, 22, 23

Of Dr Helfer, I 8 I

Of F. H. de Röepstorff, 96

Of Captain Owen, 212

Mũs village. See "Kar Nicobar"

Music, the Nicobarese dance-, 87

Nusical instrument, A., I 89 Instruments used by Nicobarese, 87,250

Muskets prohibited, N., $24+$

Nii-kopáh, K.N., 286, 287

Names, K.N., 305. See "Nicknames"

Names, native topographical, I 20

Compared with chart and trade names, Great Nicobar, 155

Nankauri

General topography, 90, 109

Temperature, 206

Rainfall, 206

Geology, 90

Area, 90

Population, 91

-Harbour, 78, 98, 202

Settlement at, 2 It

Neglected by its possessors, 202

Malacca, 78

Spiteful Bay, 78

Anchorage, 78

Coral, 80

Village, 78

Landing-place, 79

Kanaia, 79

Houses, 79

Relics of old Moravian mission, $8 \mathbf{3}$

The headman's village, 83

Houses, 83,84

Mangrove creeks, so

Florn, 90

Fruit, 9I

Fauna, 90

Whimbrel, 80

Supplies, 9I

IVater, 91

Tanamara, $75,86,88,89$, Ior

Family, $8+, 88,89$

House, interior and contents, 84,85

Karcau, 85,86

Hentri, 85

Charms, talismans, and "scare-devils," 83,85

Native flags, 80

Electro-plate possessed by natives, $\mathrm{SI}$

Lamp, 8I

Preparation for a festival, 80, 8I, 86

"Making Christmas," 80

Interior of a house prepared for a festival, 8 I

A festival, $86,87,88$

Dancing, 87 
Nankauri-continued

Dress and ormaments, $75,81,86,87$

Canoe, 79

Masts, 79

Sails, 79

Decoration, 79

Feeding domestic animals, 79

The house, canoes, etc., 85

Custom of adoption, 84

Exhumation, 82

Account of exhumation ceremonies, 82, 83

Offerings for the dead, 84

Piracy in the Nicobars, 91-94

British punitive expedition, 93

Narcotics, N., 248

-Narkondam, A., Io, I69, I74

Natives. See under names of islands-"The Andamanese," "The Nicobarese," "The Aborigines of the Nicobar Islands"

Navigation in the Tropics, 29

Chinese, 138

Nests, edible birds', A., 29

Sunbirds' (Arachnechthra), I 33

Swifts', N., I 26, I 27

Ngong, N, 229

Nicknames, K.N., 59. See "Names"

Nicobarese, the

Evolution, 22 I-225

Native legends of origin, 229

Appearance, 225-227

Custom of flattening the occiput, 226

Measurements of some Great Nicobarese, 356,357

Measurements of some Kar Nicobarese, 355

Character, 227,228

Results of education. 89

Language, 228, 229

Comparison of some Nicobarese and Shoin Pen words, I55

Nicobarese linguists, $55,58,75, \mathrm{II} 2$

Social state, 6I, 242

Headmen, $24 \mathbf{I}$

Position of women, $2+2$

Children, $2+2$

Courtship, $238-240$

Marriage, 235-237

Polygamy, 238

Divorce, 237

Property, 240

Method of guarding, 24I

Takiaia (Kar Nicobar), 241

Diseases, 235

Medicine, 235

System of punishments, $230,238,241$

Superstitious beliefs, $231-2 \hat{3} 4$

Talismans, 23I

Henta $, 77,85$

Hentá-koi, 77
Nicobarese, the-continued

Superstitious beliefs, Ĺareau, 85-86

Tamiluanas, 232

Menluanas, 116, 232, 233

Cleanlincss, 248

Dress and ornaments, 229, 249

Body painting, 249

Tí-chökla, 49, 229, 249

Nong, 229

Coiffure, 249, 250

Betel chewing, 49, 248

Quids, 248

Use of tobacco, 248

Stimulants, 248

Coconut toddy, 247

Narcotics, 248

Bererages, 247

Native luxuries, 227

Food, 246

Pandanus fruit, 246,252

Mode of preparing, 247

"Town halls," 240

Amusements

Canoe processions, $25 \mathrm{I}$

Pig processions, 25I

Wrestling, $25 \mathrm{I}$

Musical instruments, 87,250

The Nicobarese dance-music, 87

Domestic animals, 243

Fishing, 245, 246

Traps, 245

Weirs, 246

Weapons, 243-245

Tools, 243,245

Foot brush, 247

Terms of salutation, 228

Custom when travelling, 228

Mourning custom, 250

Arts, 25I

Appreciation of anatomical detail, 85

Industries, 25I, 252

Metals, 25I

Cultivations, 252

Monopolies, 107

Trade commodities, 252

License, 252

Inland, 252

Traders, 252, 253

List of principal articles inported by, for sale to the Kar Nicobarese, 351

Articles found to be in demand for presents and barter, 352

l.ocal communication and transport, 253

Coconuts, 253

Turtle, 246

Mode of capturing, 246

Use of skull, 246

Dampier's account of the Nicobarese, 256,257 . See also under "Bompoka," "Chaura," "Great Nico- 
Nicobarese, the-continued

bar," "Kachal," "Kamorta," "Kar Nicobar," "Kondul," "Little Nicobar," "Nankauri," "Pulo Milo," "Teressa," and "Shom Pen"

Nicobar, Great. See "Great Nicobal"

Nicobar Islands, the, 201

Position, I67, 20I

Relationship, 32 I, 327

Soundings, $32 \mathrm{I}$

Coral banks, 201

Area, 201

Geology, 202-204

Minerals, 205

Coal, 204

Earthquakes, 205

Climate, 205, 206

Rainfall, 206

Temperature, 206

Monsoons, 206

Cyclone, 206

General botanic appearance, 207

Botanical division, 109

Flora, 207, 208 Fauna

Principal flora of the Nicobars, $345-349$

Birds, 326-328

List of, occurring in the Nicobars, 328-331

Mammals, $322 \cdot 324$

Synopsis of mammalian fauna, $\mathbf{3 2 5}$

History, I 77-I 79, 208-2I 4

Nicobars known to Arab navigators, 208

First probable reference, 208

Chinese records, 208

Account of an Arab trader (A.D. 851), 208

Rashuddin, 209

Marco Polo (thirteenth century), 209

Friar Oderic (fourteenth century), 209

Master Cæsar Frederike (sixteenth century), 209

Barbosa, 210

Captain John Davis (sixteenth century), 210

Officers of Sir J. Lancaster (sixteenth century), 2 Io

Sir James Lancaster (seventeenth century), 211,212

Kœping (eighteenth century), 212

Dampier's sojourn, 212. See "Dampier"

Murder of Captain Owen, 2 I 2

Hamilton's references, 102, 105, I 21 , 212,215

Jesuit attempt at settlement, 2 I 2

Danish colony founded ( 1756 ), 2 I 3

Settlement by Moravians (I766), 2 I 3

Konig's account, 213. Sce "Konig"
Nicobar Islands-continued

History, Commercial expedition, 213

New Moravian settlement (1779), 213

English traders from India begin to visit the islands (nineteenth cen. tury), 213

Pastor Rosen's mission (I83I), 21 3, 2 I4

Catholic mission, 214

Mackay's voyage in search of coal (I845), 2 I 4

Galathea expedition (I846), 214

Voyage of the Novara (1858), 214

Islands taken possession of by the Indian Government (1869), 214

British official possession ( $\mathrm{ISO}_{\mathrm{S}}$ ), $2 \mathrm{I}_{4}$

Settlement at Nankauri Harbour, 214

Nicobars and Andamans affiliated, 214

Marks of British possession, 97

Account of piracy in, 91-94

Missionary endeavour, 63,257 . See also under "History"

Natural products of commercial value, 207,208

Nicobars rich in building materials, 205

Malaria, I12, 205, 25+, 255

Population, 202, 350

Decrease of, $76,97,149,150,350$

Trade residents, 202

Census, 350

Water, 152

Native Topographical names, 120

Compared with chart and trade names, Great Nicobar, I55. See "Bompoka," "Chaura," "Great Nicobar," "Kachal," "Kamorta," "Kar Nicobar," "Kondul," "Little Nicobar," "Menchal," "Nankauri," "Pulo Milo," "Teressa," "Tilanchong," "Trinkat"

Nicobar, Kar. See "Kar Nicobar"

Nicobar, Little. See "Little Nicobar"

Novara Bay, N., 67

Occiput, custom of flattening the, N., 226

Occupations, commercial, K.N., 3IS, 3I9

Of the sexes, respective, S.P., 220

Offandi, N., 49, 50, 54, 3II 312

Offerings, canoe, K.N., 295, 296

For the dead, N., 84

Oil press, K.N., 52

Ol-kolo-kwak, N., IIO, I I 2, I I 3

Olta-möit, N., 98

Önges, A., I90, I92, 342. See under "Rutland Island" and "Little Andaman"

Ornaments, personal. Sie under names of islands

Owen, wreck and death of Captain (1708), N., 70, 7I, 212 
PADDles, N., 54

Pandanus fruit, N., 246, 252

Mode of preparing, $2+7$ Cooking, S.P., I 49

Pandanus, unpleasant qualities of, 1 I 2

Legend illustrative of, I I 2

Parrots, A., 17; (Paleornis canicips), N. I 28

Passa, cf. Mal, K.N., 303

Pathmaking, Is

Penal System, the Andamanese, I93-199. See also under "Port Blair"

Photography, trials of, 32

Pig (Sus andamanensis), A., 43 ; (Sus nicobaricus), N., I 37

Mode of preparing, for a feast, I0o

Processions, N., $25 \mathrm{I}$

Pigeons, Nicobar, 68, I 35

Pigeons, fruit (Carpophaga insularis), N., 62,68 .

Piracy in the Nicobars, account of, 9I-94

Plantations, N., 49, 64, 7 I, 105, 132

Police surveillance, $\Lambda$., 19

Polygamy, N., 238

Population. See under names of islands and "Census."

Decrease of, N., 76, 97, I 49, I 50 , 350

Port Blair

Ross lsland, I9, 20

The Government Settlement, I9, 20, 21 History of, I80, I 81,183

Colonel Temple, C.C., at, 2 I

Military force, 27

Police surveillance, 19

Gunboat tours, 28

Communication, 200

Temperature, I 73

Rainfall, 173

Government schools, 343 Gymnasium, 344

Amusements, 20

The Penal System, 193-9

Viper Island, 25, 26

Jail, a visit to, 26

Cellular, 21

Inhabitants of, $25,26,27$

Employments in, 26, 27

Punishment, 27

Convicts, 20, 26, 27

Hospital convalescents, 23

The harbour, 19, 21-25

Brickfields, 22

Lime kilns, 22

Phœnix Bay shipyard, 22

Mount Harriet, I 9, I69

Hopetoun, settlement of, 22

Chatham Island, sawmills, 23

Hospital convalescents at, 23

Navy Bay tei-gardens, 25

Industries, 22, I98, I 99, 200, 340, 34I
Port Blair-continued

Cultivations, 200

Character of the locally-born young generation, 344

Haddo, Homes for the Andamanese, 23, 24,25

Andamanese at, 24, 25

Appearance, 24

Dress, 24

Ornaments, 24, 25

Skin decorations, 24

Coiffure, 24

Bows and arrows, 24, 25

Mode of carrying babies, 24

Port Cornwallis, Government Settlement transferred to, 180, 181

Rendezzous at, in 1824, I 81

Port registers, 75

Pots, Chaura, N., I08

Nicobarese belief concerning, 107

Process of making, 107, 108

Pottery, a possible origin of, 2 I 9

Kiln, Chaura, I08

Manufacture, monopoly of, 107

Preparis Island, 320

Presents, articles found to be in demand for, A., N., 352

Products, natural, A., 172, 199, 341. See "WToods"

Of commercial value, N., 207, 208

Property, N., 240

Method of guarding, 24I

Pulo Babi. See "Great Nicobar"

Pulo Kunyi. See "Great Nicobar"

Pulo Milo, 123

Area, 123

Village, 123

Houses, I 23

Natives, 123

Pulo Nyur. See "Great Nicobar"

Punishment at Viper Jail, 27

System of, N., 230, 238, 24I

Instances of murder as, K.N., 3 I5

QUARREI.S, instances of, K.N., 3IO-3I2

Mode of Revenging, 3 Io

Rainfali, A., I73; N., 206

Ramal, K.N., 296

Rats (Mus atratus), A., I4. See also under names of islands and "Mammals"

Rattan collecting, N., 219, 220

Rhinomyias, N., 122

River, course of a, Little Nicobar, 125, 126

Dagmar, I49, I 53

Galathea, I 6 I-I 64

Jubilee, I 38

Rivers, Great Nicobar, 142

Ross Island. See "Port Blair"

Rowing, Chinese, I40 
Rutland Island

A part of Great Andaman, 168

General topography, 29

Geology, I75

Ford's Peak, r69

Landing-place, 30

Village, 32

Huts, 32

Jungle, 30

Birds, 30

Önge visitors, 30-33

Appearance, 3 I

Dress, 32

Body ornamentation, 32-34

Coiffure, 34

Utensils, 33

Bows and arrows, 33, 34

Mode of stringing, 34

Food, 33

Saddle Hill, 169

St George's Channel, I 3 I

Salutation, terms of, N., 228

Sambhar, N., Ioo

Samshu smuggling, N., 248. See "Spirit traffic"

Sanokuv, the, K.N., 300

Sáwi Bay. See "Kar Nicobar"

Scenery, A., I 70

School, mission, K.N., 59

Schools, Government, Port Blair, 343, 344

Servitude, N., 157

Settlement, the Government, A. See "Port Blair"

Site for a, N., I 2 I, I 25

Sharks, edible, 9

Shrew (Crocidura nicobarica), N., I 38

Shom Pen, the. See "The aborigines of the Nicobar Islands," and "Great Nicobar"

Sir John Lawrence Island, wrecks on, I8 I

Skin decoration, A., 24. See "Body decoration"

Social state, N., 6r, 242

And other distinctions, K.N., see "Kar Nicobarese social and other distinctions"

Solomon, V., K.N., 46, 63

Sombrero Channel, i 8

Tides in, II 8

Island, I06

Somerera lslands, Hamilton's account of the, 105

Songs, specimens of, A., 189

Soundings, A., I68, 320; N., 321

South Andaman

General topography, 28, 29

Macpherson Strait, 29

Anchorage, 29

Landing-place, 29

Birds' Nest Cape, 29

Edible birds' nests, 29
South Andaman-continued

Native camping-place, 29

Hut, 29

Water, 35

Hog-deer, 28

Birds, 34, 35

Mammals, 35

South Bay, I6o

Spears, N., 243; S.P., 2 19, 243, 244

Spirit traffic, roo. See "Samshu smuggling "

Spirits, belief in, A., I 88

Evil, N., I 23

Spiteful Bay. See under "Nankauri"

Spring, hot, Barren Island, I I

Squalls, tropic, IO, I 37

Stimulants, N., 248

Subsidence, A., I76; K.N., I36, I 37

Suicide, instance of, N., 316

Sunbird, Andaman, 35; (Aethopy'ga nicobarica), N., 127, 143

Superstitious beliefs, N., 23I-234

Supplies. See under names of islands

Surveillance, police, A., I9

Swifts (Collocalia linchii), N., I26, I27

Nests, 126, I 27

Tá-chökla, N., 49, 229, 249

Takkuwis, K.N., 292

Takoia, K.N., 24I

Talaings, 223,224

Talik-n'si, K.N., $5 \mathrm{r}$

Talismans, N., 83, 85, $23 \mathrm{I}$

Tallies, K.N.

Of commercial transactions, 319

Of the months, 319

Of a child's age, 3 I9

Tamils, 216

Tamiluanas, N., 232, 302

Ceremonies, $5 \mathrm{r}$

Regard for, 316

Tanamara, $75,86,88,89$, Ior

Family, 84, 88, 89

House, interior and contents of, 84,85

Tanang alah, K.N., 291

Tanangla, K.N., 299, 300

Tattooing, a case of, N., roo

Teal, attempt to foster taste for, N., 248

Teeth, celebration of loss of, K.N., 300

Temperature, A., I 73; N., 206

Temple, Colonel, C.C., at Port Blair, 2 r

"Temple Villa," K.N., 47

Teressa

General topography, 103, 104

Area, 10.4

Geology, 104

Flora, 104

Tobacco fields, 104

Population, I05

Natives compared with Kar Nicobarese, 10.4 


\section{Teressa-continued}

Hamilton's account of the Somerera Islands, 105

Terrapin Bay, N., 67

Thrush (Geocichla alligularis), N., 74

Tide-rips, N., 45, I 3 I

Tilanchong

General topography, $66,67,68,69,72$, I09

Area, 67

Anchorages, 67

Maharani Peak, 67

Novara Bay, 67

Terrapin Bay, 67

Jheel, 69

Herons, 69

Crocodile, 69

Water, 67

Plantations, 7I

Kamortan visitors, 7 I

Lizards, 67,68

Fruit bat, 70

Megapodes, 68, 69, 70

Mounds, 68,70

Eggs, 70

Birds, 68

Crabs, 70

Foul ground off, 72

Wreck of Captain Owen ( 1708 ), 70

Timber, K.N., 53, 54. See "Woods"

Tobacco, use of, $\mathrm{N} ., 2+8$

Fields, N., IO4

Tools, A., 4I ; N., 2+3, 245

Topography, general. See under names of islands

"Town halls," N., $2+0$

Trade, N., I 43, 252

Commodities, N., 253

Prices, N., I 43 , I 54

Residents, N., 202

Shom Peni, 2 I9

Chaura, 106

Traders, N., 252, 253

Chinese, i 2

Malay, I54

Articles imported by, for sale to Kar Nicobarese, 35 I

Tradition, a Kar Nicobarese, 215

Traditions, Christian, A., I 89

Transport, local, N., 253

Transporting goods, cost of, K.N., 3I 8

Trapping, I5

Traps, fishing, N., 245

Travelling, custom when, N., 228

Trees, principal forest, A., $336-33 \mathrm{~S}$

Mode of climbing, N., I 57

Banian, N., I 22

Urostigma, N., 62

Tribal division, A., I90, 192, $3+2$

Trinkat

General topography, 73, 74. 75
Trinkat-conlinued

Possible results of elevation, 73

A deserted village, $73,74,76,77$

Huts, 73

Hut, contents of $a, 77$

Jheel, 74

Water birds, 74

Megapodes, 74,77

Cattle, semi-wild, $47,74,75$

Birds, 74

Rats, 77

Tupaia nicolarica, 136 ; N. 122

Tupaia nicoliarica surda, N., I 22

Turtle, N., I $38,2.46$

Mode of capturing, 246

Skull, use of, 246

Urostigma trees, N., 62

Utensils, Önge, 33

Kar Nicobarese, 48

l'ani pati, K.N., 288

Villages. See under names of islands

Viper Island, 25, 26

Jail. See "Jail"

Volcanic activity, A., I 3, I4, I 74

WAI.KER Island, I6I

Waraka Kuv, K.N., 29 I

Water. See under names of islands

Water birds. See "Birds," and under names of islands

Wealth, staples of, K.N., 50

Comparison of past and present, 292

Weapons and implements, A., I 84, I 89 ; N., 2+3-245. See "Bows," "Arrows," "Spears"

Weight, a verage Andamanese, 342

Weirs, fishing, N., 246

West Bay. See under "Kachal"

Whale, killer, II 9

Wind and weather, a erage, A., 335

Wizard murders, K.N., 3I 4,315

Wizardry, credence in, A., I 88

Chaura natives believed to be exponents of, 296

Kar Nicobar, 314

Mode of obtaining reputation for, $3 \mathrm{I}_{4}$

Women, position of, A., 187 ; N., 242 ; S.P., 220

Woods, list of the more useful and valuable, A., 339

Worthington, William, 91, 92

Wreck and death of Captain Owen, 70, 7I, 2 I 2

Wrecks on Sir John Lawrence Island, I S I

Wrestling, N., 25 I

YASSAN, N., III, II 6

Yeng Awn, K.N., $29 \mathrm{I}$

Yintorna Siya, K.N., 298, 299

Iom Ap, K.N., 302

Yom Elpanam, K.N., 302 
Printed by Oliver and Boyd Edinburgh 





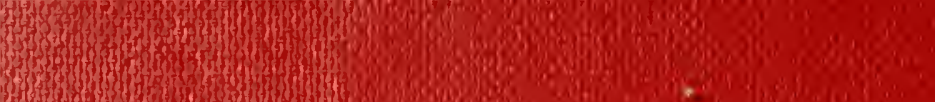

